\begin{tabular}{|l|l|}
\hline $\begin{array}{l}\text { 2. To: (Receiving Organization) } \\
\text { R.J. Murkowski, Retrieval } \\
\text { Programs }\end{array}$ & $\begin{array}{l}\text { 3. From: (Originating Organization) } \\
\text { Retrieval Design Projects }\end{array}$ \\
\hline $\begin{array}{l}\text { 5. Proj./Prog./Dept./Div.: } \\
\text { Waste Mangement }\end{array}$ & $\begin{array}{l}\text { 6. Design Authority/ offign Apent/Cog/7 } \\
\text { Engr.: }\end{array}$ \\
$\begin{array}{l}\text { 8. Originator Remarks: } \\
\text { Initial Transmittal for Approval }\end{array}$
\end{tabular}

11. Receiver Remarks:
11A. Design Basel ine Document?
[] Yes [X] No
4. Related EDT NO.:

$N / A$

7. Purchase Order No.:

N/A

9. Equip./Component No.:

$\mathrm{N} / \mathrm{A}$

10. Systen/Bldg./Facility:

$N / A$

12. Major Assm. Dwg. No.:

$N / A$

13. Permit/Permit Application No.: $N / A$

14. Required Response Date:

N/A

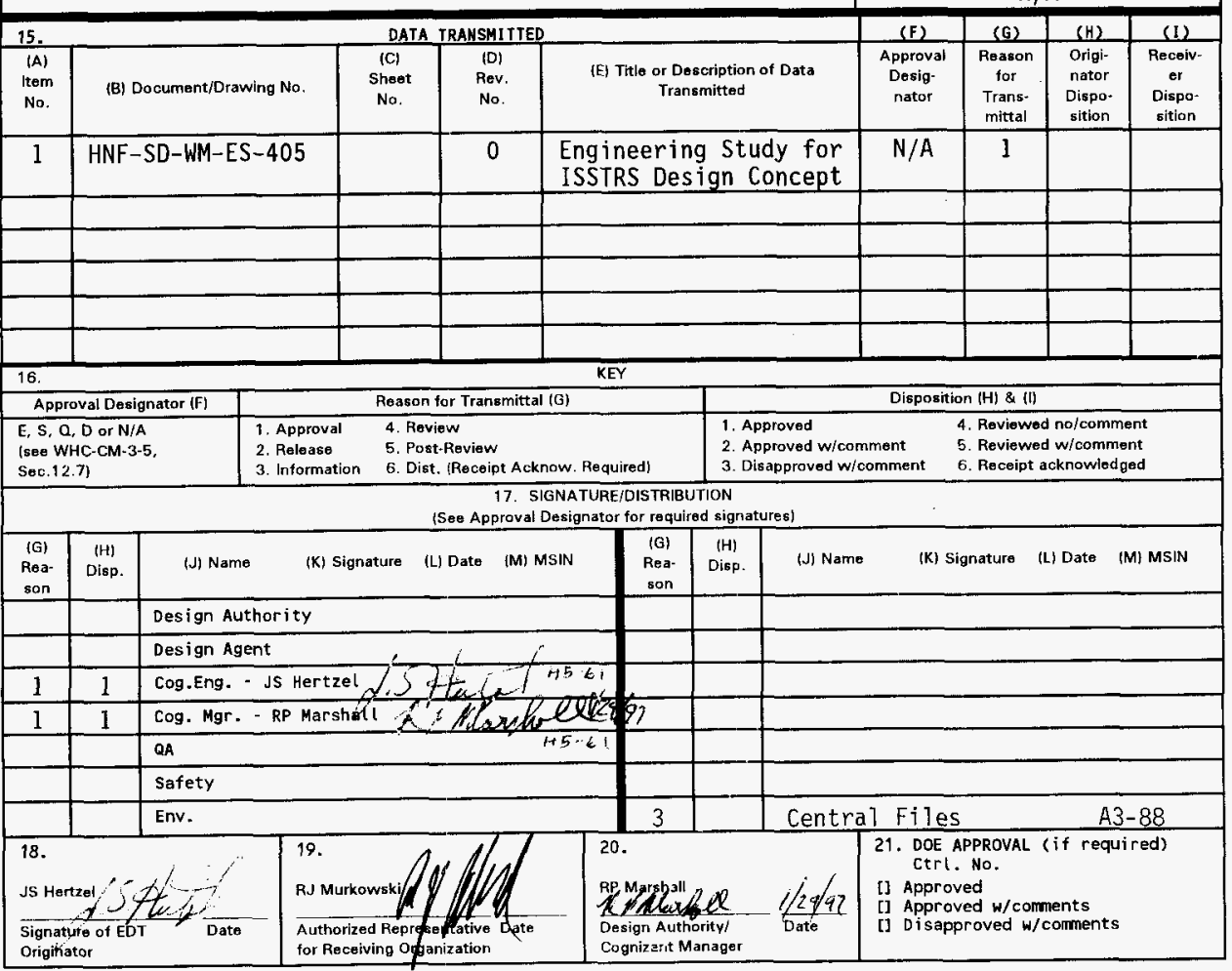

BD-7400-172-2 (05/96) GEF097 


\title{
Engineering Study for ISSTRS Design Concept
}

\section{J. S. Hertzel}

Numatec Hanford Company, Richland, WA 99352

U.S. Department of Energy Contract DE-AC06-87RL10930

\author{
EDT/ECN: $617647 \quad$ UC: 721 \\ Org Code: 8C420 Charge Code: D2CB1 \\ B\&R Code: EW3130010 Total Pages: $40 \mathrm{H} 397 \mathrm{fa}$
}

Key Words: ISSTRS, Design, Conceptual, Retrieval, Tanks, Sluicing

Abstract: This engineering study consists of a collection of draft documents of the Initial Single She11 Tank Retrieval System (ISSTRS) $90 \%$ Conceptual Design Report (CDR). This package includes the following:

- ISSTRS Project Design Concept (includes Project Cost Estimate and Implementation Schedule)

- ISSTRS Trade Studies

1. Retrieval Facility Cooling Requirements

2. Equipment Re-usability between Project $W-320$ and Tank $241-\mathrm{C}-103$ and $241-\mathrm{C}-105$

3. Sluice Line Options

4. Options for the Locations of Tanks AX-103 and A-102 HVAC Equipment

- Drawings - Sixty-five Sheets

- Risk Management Plan

- Interface Control Document

- Requirements Traceability Report

- Project Design Specification

TRADEMARK DISCLAIMER. Reference herein to any specific commercial product, process, or service by trade name, trademark, manufacturer, or otherwise, does not necessarily constitute or imply its endorsement, recommendation, or favoring by the United States Government or any agency thereof or its contractors or subcontractors.

Printed in the United States of America. To obtain copies of this document, contact: WHC/BCS Document Control Services, P.O. Box 1970, Mailstop H6-08, Richland WA 99352, Phone (509) 372-2420; Fax (509) 376-4989.
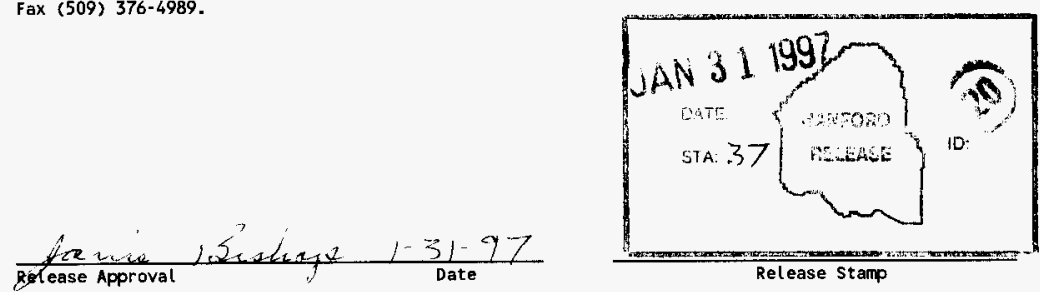

\section{Approved for Public Release}


November 1, 1996

Mr. Jeffrey S. Hertzel

Numatec Hanford Company

PO BOX 1300, MSIN H5-61

Richland, WA 99352

Subject: "Conceptual Design Package for the Initial Single Shell Tank Retrieval System (ISSTRS), $90 \%$ Conceptual Design Review" under TWRS Contract TJJ-SBW-387700, Line Item 702, Conceptual Design for the Initial Single Shell Tank Retrieval System

Dear Mr. Hertzel,

Los Alamos Technical Associates, Inc., is pleased to transmit the attached Conceptual Design Package for the Initial Single Shell Tank Retrieval System (ISSTRS), 90\% Conceptual Design Review, as agreed to under the above referenced task order.

The package includes the following:

- ISSTRS Project Design Concept (includes Project Cost Estimate and Implementation Scheduie)

- ISSTRS Trade Studies:

1. Retrieval Facility Cooling Requirements

2. Equipment Re-usability between Project W-320 and Tanks 241-C-103 and 241-C-105

3. Sluice Line Options

4. Options for the Location of Tanks AX-103 and A-102 HVAC Equipment

- Drawings (listing attached)

- Risk Management Plan

- Interface Control Document

- Requirements Traceability Report

- Project Design Specification

Questions and requests for additional information should be directed to myself or. Don Scott at LATA.

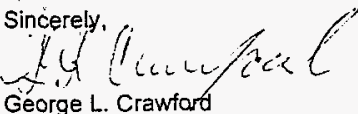

Géorge L. Crawford

Program Manager

TWRS

Enclosure: $\quad$ ISSTRS 90\% Conceptual Design Review

cc: - R. Finke (w/o.attachments)

J. Fleming (w/o attachments)

G.Crawtord/LATA (w/o attachments)

D. ScottlLATA (w/o attachments)

R. Tooze/BNFL (w/o attachments)

WT702 Project File (with attachments) 
ISSTRS Conceptual Design Drawing List

\begin{tabular}{|c|c|c|c|c|}
\hline DRAWING NUMBER & CADFLLENUMBER & \multicolumn{2}{|c|}{ SH OF SH } & \multirow{2}{*}{$\frac{\text { TITLE }}{\text { ISSTRS DRAWING LIST }}$} \\
\hline SK-2-300503 & $\mathrm{X} 300503 \mathrm{~A}$ & 1 & 1 & \\
\hline SK-2-300464 & $\mathrm{X} 300464 \mathrm{~A}$ & 1 & 1 & PROCESS LOGIC DIAGRAM \\
\hline SK-2-300465 & $\mathrm{X} 300465 \mathrm{~A}$ & I & 1 & VENTILATION FLOWSHEET \\
\hline SK-2-300466 & $\mathrm{X} 300466 \mathrm{~A}$ & 1 & 1 & ENGINEERING FLOW DIAGRAM \\
\hline SK-2-300467 & $\mathrm{X} 300467 \mathrm{~A}$ & 1 & 1 & HVAC FLOW DIAGRAM \\
\hline SK-2-300468 & $\mathrm{X} 300468 \mathrm{~A}$ & 1 & 1 & ELECTRICAL ONE-LINE DIAGRAM \\
\hline SK-2-300469 & $\mathrm{X} 300469 \mathrm{~A}$ & I & 1 & CIVIL SITE PLAN \\
\hline SK-2-300470 & $\mathrm{X} 300470 \mathrm{~A}$ & 1 & 4 & P\&ID TYPICAL SINGLE SHELL TANK \\
\hline SK-2-300470 & $\mathrm{X} 300470 \mathrm{~B}$ & 2 & 4 & P\&ID TYPICAL SINGLE SHELL TANK \\
\hline SK-2-300470 & $\mathrm{X} 300470 \mathrm{C}$ & 3 & 4 & P\&ID TYPICAL SINGLE SHELL TANK \\
\hline SK-2-300470 & $\mathrm{X} 300470 \mathrm{D}$ & 4 & 4 & P\&ID TYPICAL SINGLE SHELL TANK \\
\hline SK-2-300471 & $\mathrm{X} 300471 \mathrm{~A}$ & I & 3 & P\&ID 241-AN-105 \\
\hline SK-2-300471 & $\mathrm{X} 300471 \mathrm{~B}$ & 2 & 3 & P\&ID 241-AN-105 \\
\hline SK-2-30047I & $\mathrm{X} 300471 \mathrm{C}$ & 3 & 3 & P\&ID 241-AN-105 \\
\hline SK-2-300472 & $\mathrm{X} 300472 \mathrm{~A}$ & 1 & 1 & HYDRAULIC DIAGRAM A-102/AN-105 \\
\hline SK-2-300473 & $\mathrm{X} 300473 \mathrm{~A}$ & 1 & 1 & HYDRAULIC DIAGRAM AX-103/AN-105 \\
\hline SK-2-300474 & $\mathrm{X} 300474 \mathrm{~A}$ & 1 & 1 & HYDRAULIC DIAGRAM C-105/AN-105 \\
\hline SK-2-300475 & $\mathrm{X} 300475 \mathrm{~A}$ & 1 & 1 & HYDRAULIC DIAGRAM C-103/AN-105 \\
\hline SK-2-300476 & $\mathrm{X} 300476 \mathrm{~A}$ & 1 & 1 & ELECTRICAL SITE PLAN \\
\hline SK-2-300477 & $\mathrm{X} 300477 \mathrm{~A}$ & 1 & 4 & $\begin{array}{l}\text { INTERFARM TRANSFER SYSTEM } \\
\text { PLAN \& PROFILE }\end{array}$ \\
\hline SK-2-300477 & $\mathrm{X} 300477 \mathrm{~B}$ & 2 & 4 & $\begin{array}{l}\text { INTERFARM TRANSFER SYSTEM } \\
\text { PLAN \& PROFILE }\end{array}$ \\
\hline SK-2-300477 & $\mathrm{X} 300477 \mathrm{C}$ & 3 & 4 & $\begin{array}{l}\text { INTERFARM TRANSFER SYSTEM } \\
\text { PLAN \& PROFILE }\end{array}$ \\
\hline SK-2-300477 & $\mathrm{X} 300477 \mathrm{D}$ & 4 & 4 & $\begin{array}{l}\text { INTERFARM TRANSFER SYSTEM } \\
\text { PLAN \& PROFILE }\end{array}$ \\
\hline SK-2-300478 & $\mathrm{X} 300478 \mathrm{~A}$ & 1 & 3 & PIPING LAYOUT C-103 \& C-105/W320 \\
\hline SK-2-300478 & X300478B & 2 & 3 & PIPING LAYOUT AX-103/W320 \\
\hline SK-2-300478 & $\mathrm{X} 300478 \mathrm{C}$ & 3 & 3 & PIPING LAYOUT A-102/W320 \\
\hline SK-2-300479 & $\mathrm{X} 300478 \mathrm{~A}$ & 1 & 1 & PIPING LAYOUT AN-105/W320 \\
\hline SK-2-300480 & $\mathrm{X} 300480 \mathrm{~A}$ & 1 & 4 & HVAC P\&ID \\
\hline SK-2-300480 & X300480B & 2 & 4 & HVAC P\&ID \\
\hline SK-2-300480 & $\mathrm{X} 300480 \mathrm{C}$ & 3 & 4 & HVAC P\&ID \\
\hline SK-2-300480 & $\mathrm{X} 300480 \mathrm{D}$ & 4 & 4 & HVAC P\&ID \\
\hline SK-2-300481 & $\mathrm{X} 300481 \mathrm{~A}$ & 1 & 1 & TYPICAL SST PUMP ARRANGEMENT \\
\hline SK-2-300482 & $\mathrm{X} 300482 \mathrm{~A}$ & ] & 1 & TYPICAL SST SLUICER ARRANGEMENT \\
\hline SK-2-300483 & $\mathrm{X} 300483 \mathrm{~A}$ & 1 & 1 & 241-AN-105 PUMP/DISTRIBUTOR \\
\hline ARRANGEMENT & & & & \\
\hline SK-2-300484 & $\mathrm{X} 300484 \mathrm{~A}$ & 1 & 1 & HVAC PROCESS BUILDING PLAN \& SECTIONS \\
\hline SK-2-300485 & $\mathrm{X} 300485 \mathrm{~A}$ & 1 & $\mathbf{l}$ & P\&ID EQUIPMENT IDENTIFICATION \\
\hline SK-2-300486 & $\mathrm{X} 300486 \mathrm{~A}$ & 1 & 1 & HVAC EXHAUST SKID LAYOUT \\
\hline SK-2-300487 & $\mathrm{X} 300487 \mathrm{~A}$ & 1 & 2 & 241-C-03A PUMP PIT ARRANGEMENT \\
\hline SK-2-300487 & $\mathrm{X} 300487 \mathrm{~B}$ & 2 & 2 & 241-C-03A PUMP PIT ARRANGEMENT \\
\hline SK-2-300488 & $\mathrm{X} 300488 \mathrm{~A}$ & 1 & 2 & 241-C-05A PUMP PIT ARRANGEMENT \\
\hline SK-2-300488 & $\mathrm{X} 300488 \mathrm{~B}$ & 2 & 2 & 241-C-05A PUMP PIT ARRANGEMENT \\
\hline
\end{tabular}


309 Bradley Blvd. / Richland, WA 99352 / Telephone (509) 946-8100 / FAX (509) 946-8700

\section{ISSTRS Conceptual Design Drawing List (Continued)}

\begin{tabular}{|c|c|c|c|c|}
\hline DRAWING NUMBER & CADFILE NUMBER & \multicolumn{2}{|c|}{$\underline{\text { SH OF SH }}$} & TITLE \\
\hline SK-2-300489 & $\mathrm{X} 300489 \mathrm{~A}$ & 1 & 2 & 241-AN-05A PUMP PIT ARRANGEMENT \\
\hline SK-2-300489 & $\mathrm{X} 300489 \mathrm{~B}$ & 2 & 2 & 241-AN-05A PUMP PIT ARRANGEMENT \\
\hline SK-2-300490 & X300490A & 1 & 1 & 24I-AN-05A CENTRAL PUMP PIT \\
\hline SK-2-300491 & $\mathrm{X} 300491 \mathrm{~A}$ & 1 & 1 & 241-AX-03A SLUICE PIT ARRANGEMENT \\
\hline SK-2-300492 & X300492A & 1 & 1 & P\&ID LEGEND \\
\hline SK-2-300493 & X300493A & 1 & 2 & 241-C-05C SLUICE PIT ARRANGEMENT \\
\hline SK-2-300493 & X300493B & 2 & 2 & 241-C-05C SLUICE PIT ARRANGEMENT \\
\hline SK-2-300494 & $\mathrm{X} 300494 \mathrm{~A}$ & 1 & 2 & 241-C-03C SLUICE PIT ARRANGEMENT \\
\hline SK-2-300494 & $\mathrm{X} 300494 \mathrm{~B}$ & 2 & 2 & 241-C-03C SLUICE PIT ARRANGEMENT \\
\hline SK-2-300495 & $\mathrm{X} 300495 \mathrm{~A}$ & 1 & 2 & 241-A-02A PUMP PIT ARRANGEMENT \\
\hline SK-2-300495 & X300495B & 2 & 2 & 241-A-02A PUMP PIT ARRANGEMENT \\
\hline SK-2-300496 & $\mathrm{X} 300496 \mathrm{~A}$ & $\overline{1}$ & 2 & 241-A-02B PUMP PIT ARRANGEMENT \\
\hline SK-2-300496 & $\mathrm{X} 300496 \mathrm{~B}$ & 2 & 2 & 241-A-02B PUMP PIT ARRANGEMENT \\
\hline SK-2-300497 & $\mathrm{X} 300497 \mathrm{~A}$ & 1 & 2 & 241-A-02C RECIEVER PIT ARRANGEMENT \\
\hline SK-2-300497 & X300497B & 2 & 2 & 241-A-02C RECIEVER PIT ARRANGEMENT \\
\hline SK-2-300498 & $\mathrm{X} 300498 \mathrm{~A}$ & I & 2 & 241-AX-03D PUMP PIT ARRANGEMENT \\
\hline SK-2-300498 & $\times 300498 \mathrm{~B}$ & 2 & 2 & 241-AX-03D PUMP PIT ARRANGEMENT \\
\hline SK-2-300499 & X300499A & 1 & 2 & 241-AX-03C PUMP PIT ARRANGEMENT \\
\hline SK-2-300499 & X300499B & 2 & 2 & 241-AX-03C PUMP PIT ARRANGEMENT \\
\hline SK-2-300500 & $\mathrm{X} 300500 \mathrm{~A}$ & 1 & 2 & 241-AX-03B PUMP PIT ARRANGEMENT \\
\hline SK-2-300500 & $\mathrm{X} 300500 \mathrm{~B}$ & 2 & 2 & 241-AX-03B PUMP PIT ARRANGEMENT \\
\hline SK-2-300501 & $\mathrm{X} 300501 \mathrm{~A}$ & 1 & 2 & 241-C-03B RECIEVER PIT ARRANGEMENT \\
\hline $\mathrm{SK}-2-30050 \mathrm{I}$ & X300501A & 2 & 2 & 241-C-03B RECIEVER PIT ARRANGEMENT \\
\hline SK-2-300502 & $\mathrm{X} 300502 \mathrm{~A}$ & 1 & 2 & 241-C-05B RECIEVER PIT ARRANGEMENT \\
\hline SK-2-300502 & $\mathrm{X} 300502 \mathrm{~A}$ & 2 & 2 & 241-C-05B RECIEVER PIT ARRANGEMENT \\
\hline
\end{tabular}




\title{
PROJECT DESIGN CONCEPT
}

\section{INITIAL SINGLE-SHELL TANK RETRIEVAL SYSTEM WASTE RECOVERY SLUICING SYSTEM}

\author{
Review Copy
}

Prepared By:

LOS ALAMOS TECHNICAL ASSOCIATES, INC.

Richland, WA

Under Purchase Order TJJ-SBW-387700

November 1996

$$
\text { oiva }
$$


HNF-SD-WM-ES-405Rev. 0

This page left intentionally blank. 
Approved by:
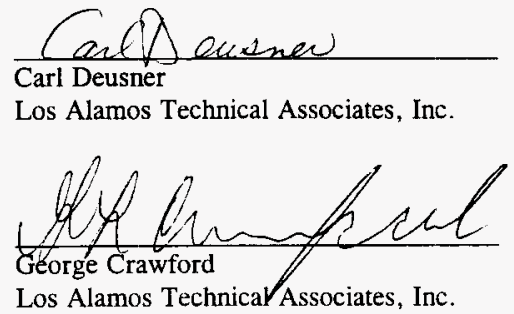
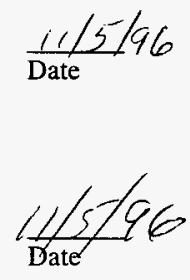

avia 


\section{CONTENTS}

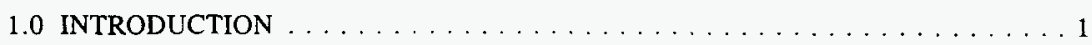

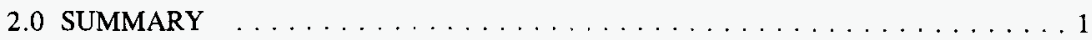

2.1 EQUIPMENT DESCRIPTION $\ldots \ldots \ldots \ldots \ldots \ldots \ldots \ldots \ldots$

2.1.1 Equipment Located Within Tank Farm Fences . . . . . . . . . . 3

2.1.2 Equipment Located Outside the Tank Farm Fence . . . . . . . . . 4

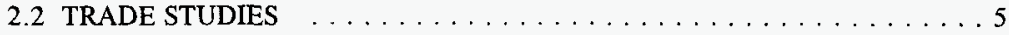

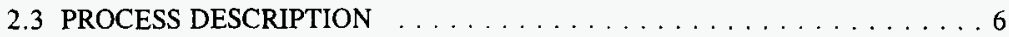

2.3.1 Startup and Normal Operation $\ldots \ldots \ldots \ldots \ldots \ldots \ldots$

2.3.2 Normal Shutdown . . . . . . . . . . . . . . . 6

2.3.3 Emergency Shutdown . . . . . . . . . . . . . . . 6

2.4 INSTRUMENTATION AND ALARMS $\ldots \ldots \ldots \ldots \ldots \ldots \ldots \ldots$

2.4.1 Sluice and Supernatant Pumps . . . . . . . . . . . . . 6

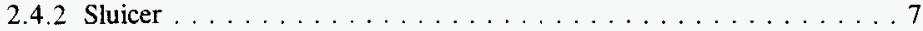

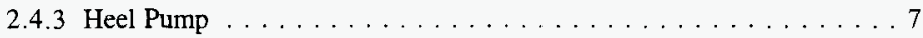

2.4.4 Leak Detection System $\ldots \ldots \ldots \ldots \ldots \ldots \ldots \ldots \ldots \ldots$

2.4 .5 Seal Loops $\ldots \ldots \ldots \ldots \ldots \ldots \ldots \ldots \ldots \ldots \ldots \ldots$

2.4.6 Transfer System Interlocks . . . . . . . . . . . . . . 8

2.4.7 Ventilation System for Process Building $\ldots \ldots \ldots \ldots \ldots$

2.4.8 HEPA System Cooled Chiller Skid $\ldots \ldots \ldots \ldots \ldots \ldots \ldots .8$

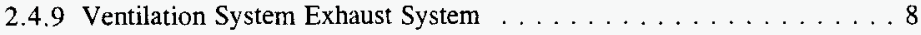

2.4.10 Single-Shell Tank Farm Sluicing Control Station . . . . . . . 9

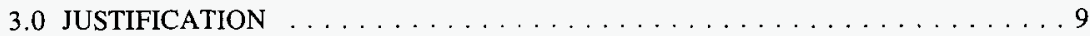

4.0 DESCRIPTION PROJECT SCOPE FOR TANKS 241-C-103 AND 241-C-105 . . . 9

4.1 IMPROVEMENTS TO LAND $\ldots \ldots \ldots \ldots \ldots \ldots \ldots \ldots \ldots$

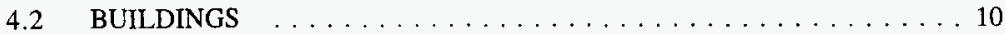

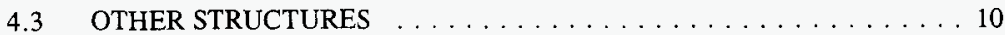

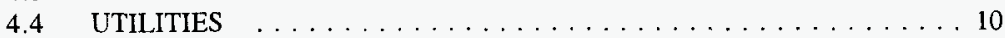

4.5 SPECIAL EQUIPMENT AND PROCESS SYSTEMS $\ldots \ldots \ldots \ldots \ldots$

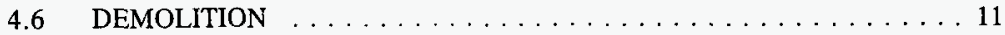

5.0 DESCRIPTION OF PROJECT SCOPE FOR TANK 241 -AX-103 $\ldots \ldots \ldots \ldots 11$

5.1 IMPROVEMENTS TO LAND $\ldots \ldots \ldots \ldots \ldots \ldots \ldots \ldots \ldots \ldots$

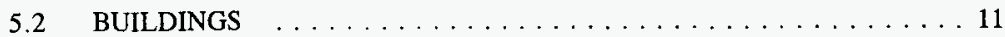

5.3 OTHER STRUCTURES $\ldots \ldots \ldots \ldots \ldots \ldots \ldots \ldots \ldots \ldots \ldots$

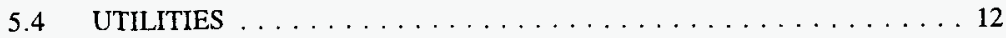

5.5 SPECIAL EQUIPMENT AND PROCESS SYSTEM $\ldots \ldots \ldots \ldots \ldots 12$

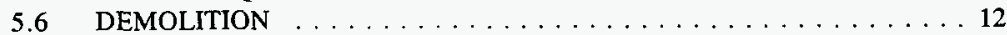




\section{CONTENTS (Continued)}

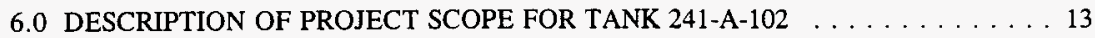

6.1 IMPROVEMENTS TO LAND $\ldots \ldots \ldots \ldots \ldots \ldots \ldots \ldots \ldots$

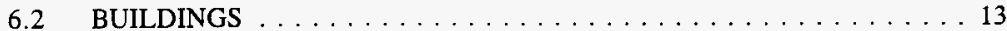

6.3 OTHER STRUCTURES $\ldots \ldots \ldots \ldots \ldots \ldots \ldots \ldots \ldots \ldots$

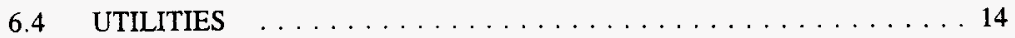

6.5 SPECIAL EQUIPMENT AND PROCESS SYSTEM $\ldots \ldots \ldots \ldots \ldots 14$

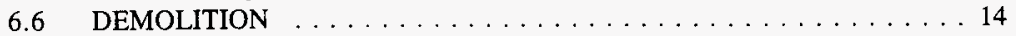

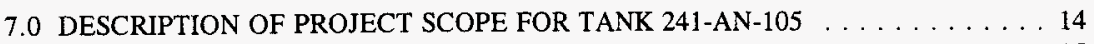

7.1 IMPROVEMENTS TO LAND $\ldots \ldots \ldots \ldots \ldots \ldots \ldots \ldots \ldots$

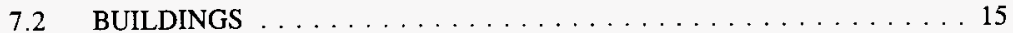

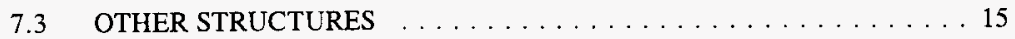

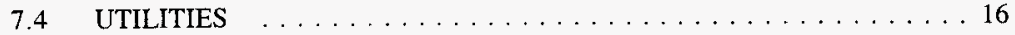

7.5 SPECIAL EQUIPMENT AND PROCESS SYSTEM $\ldots \ldots \ldots \ldots \ldots 16$

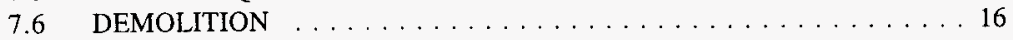

8.0 REQUIREMENTS TRACEABILITY $\ldots \ldots \ldots \ldots \ldots \ldots \ldots \ldots \ldots \ldots \ldots \ldots \ldots \ldots \ldots$

9.0 IDENTIFICATION AND ANALYSIS OF UNCERTAINTIES . . . . . . . 17

10.0 REFERENCES $\ldots \ldots \ldots \ldots \ldots \ldots \ldots \ldots \ldots \ldots \ldots \ldots \ldots \ldots \ldots \ldots \ldots \ldots$

APPENDIX A $\quad$ COST ESTIMATE $\ldots \ldots \ldots \ldots \ldots \ldots \ldots \ldots \ldots \ldots \ldots \ldots$

APPENDIX B WORK SCHEDULE $\ldots \ldots \ldots \ldots \ldots \ldots \ldots \ldots \ldots$ B-1

\section{LIST OF TABLES}

2-1. ISSTRS Sluice Tank Description $\ldots \ldots \ldots \ldots \ldots \ldots \ldots \ldots \ldots \ldots \ldots \ldots$ 


\section{LIST OF TERMS}

CCTV Closed-circuit television

DST Double-shell tank

HEME High-efficiency mist eliminator

HEMF High-efficiency metal filter

HEPA High-efficiency particulate air

HVAC Heating, ventilating, and air conditioning

IBD Interface Block Diagrams

ISSTRS Initial Single-Shell Tank Retrieval System

LATA Los Alamos Technical Associates

SST Single-shell tank

PDRD Preliminary Design Requirements Document

PICD Project Interface Control Documents

TWRS Tank Waste Remediation System

WRSS Waste Recovery Sluicing System 
HNF-SD-WM-ES-405 Rev. 0

Review Copy

November 6, 1996

This page left intentionally blank. 


\subsection{INTRODUCTION}

Underground tanks have been used at the Hanford Site since the 1940's to store radioactive waste, a by-product of processing spent nuclear fuel for recovery of plutonium, uranium, and neptunium. There are 149 single-shell tanks (SSTs) and 28 double-shell tanks. The SSTs are grouped in 12 tank farms, consisting of four to 18 tanks each, located in the 200 East and 200 West Areas. No waste has been added to the SSTs since 1980. Waste volumes in the SSTs vary as do the mechanical properties and consistency of the waste (ranging from pumpable liquid, to sludge and hard salt cake). The waste contains both chemically hazardous and radioactive constituents. The overall objective of the Initial Single-Shell Tank Retrieval System (ISSTRS) is to design, fabricate, and install the retrieval systems, waste transfer lines, tank HVAC systems, and infrastructure necessary to begin waste retrieval operations from four SSTs. The conceptual design of the systems and equipment for ISSTRS is based upon existing Project W-320 (tank 241-C-106) waste retrieval design.

This report contains the conceptual design information for the ISSTRS Waste Recovery Sluicing System (WRSS), which will retrieve the waste contents of four SSTs. The ISSTRS Project Cost Estimate and Conceptual Schedule are presented in Appendix A and B, respectively. The purpose of this document is describe the scope of ISSTRS as described in Krieg (1996).

\subsection{SUMMARY}

The ISSTRS WRSS will retrieve the waste contents of tanks 241-A-102, 241-AX-103, 241-C103 , and 241-C-105 with a continuous sluicing process (the contents of the tanks are summarized in Table 2-1). This process uses hydraulic pressure to loosen the sludge and form a slurry. The slurry is then pumped out of the tank being sluiced and transported up to 1,800 $\mathrm{ft}$ to the designated double-shell tank (DST) receiver (241-AN-105). After the slurry is deposited in the receiver tank, the solids will settle out. The clarified liquid (supernate) in tank 241-AN-105 will then be pumped back to the tank being sluiced to provide the spray stream for continuing the closed loop process.

The ISSTRS scope of work includes the design, procurement, and installation of the following items:

- Site preparation and tank modifications for the installation of equipment.

- New sluice and slurry lines, two valve pits, and a pump pit in AN Tank Farm.

- Utilities for retrieval operations (electrical power, water, telecommunications, etc.). 
Table 2-1. ISSTRS Sluice Tank Description.

\begin{tabular}{|c|c|c|c|c|c|c|}
\hline \multirow[b]{2}{*}{ rank: } & \multirow[b]{2}{*}{$\begin{array}{l}\text { Capacily } \\
\text { (kgal) }\end{array}$} & \multirow[b]{2}{*}{ Waste type } & \multicolumn{4}{|c|}{ Waste Volume } \\
\hline & & & $\begin{array}{c}\text { Supernate } \\
\text { rolume } \\
\text { (kgali). }\end{array}$ & $\begin{array}{l}\text { Slodge } \\
\text { roluine } \\
\text { (ggal) }\end{array}$ & $\begin{array}{l}\text { Salt } \\
\text { cake } \\
\text { rolime } \\
\text { (Gigan }\end{array}$ & $\begin{array}{l}\text { Touth } \\
\text { waste } \\
\text { roline } \\
\text { grgall }\end{array}$ \\
\hline 241-A-102 & 1,000 & $\begin{array}{l}\text { Double-shell } \\
\text { slurry feed }\end{array}$ & 4 & 15 & 22 & 41 \\
\hline 241-AX-103 & 1,000 & $\begin{array}{l}\text { Concentrated } \\
\text { complexant }\end{array}$ & 0 & 2 & 110 & 112 \\
\hline 241-C-103 & 530 & Noncomplexed & 133 & 62 & 0 & 195 \\
\hline $241-C-105$ & 530 & Noncomplexed & 2 & 132 & 0 & 134 \\
\hline
\end{tabular}

Note:

Data are from Hanlon (1996).

- Air and water process building with air compressor and backflow preventer.

- Control room that includes functions to monitor and control the retrieval system.

- Instrumentation to measure the physical and flow characteristics of the waste and to monitor leak detection.

- Air polishing process building with heat exchanger, moisture separator heating coil, high-efficiency mist eliminator (HEME), high-efficiency metal filter (HEMF), high-efficiency particulate air (HEPA) filters and, possibly, volatile organic compound adsorber.

- Chiller system to maintain and process temperatures within the sluice tank to acceptable levels.

- Nitrogen rack for booster pumps secondary seal protection.

- Tandem pumps to return supernate, under pressure, to the SST via the sluicer assembly.

- Tandem pumps to remove slurry from the SST. 
- $\quad$ Sluicer assembly and nozzle.

- Hydraulic power pack for sluicer operation.

- Remotely controlled winch to position the sluice and slurry pumps.

- Closed-circuit television camera (CCTV) system to monitor the sluicing operation.

- Flush capability for both transfer pumps and transfer piping.

- Heel pump for terminal tank cleanout removal of excess supernate from SST.

\subsection{EQUIPMENT DESCRIPTION}

\subsubsection{Equipment Located Within Tank Farm Fences}

The system design includes two pairs of identical pumps mounted in series, one pair is to be located in the slurry (sluiced) tank (241-A-102, 241-AX-103, 241-C-103, or 241-C-105) and the second pair is to be located in the receiver (supernatant) tank (241-AN-105). Within the tank to be sluiced, one pump ( $40 \mathrm{hp}$ ) is positioned within the tank at the slurry surface and functions as a supply pump to a booster pump $(250 \mathrm{hp})$ located in the tank riser pit. These tandem pumps move the slurry to the receiver tank. Within the receiver (supernate) tank the second pair of pumps is arranged in a similar manner to provide the hydraulic pressure for the sluicing of the slurry tank.

The adjustable flow rate of the 250-hp supernate and slurry pumps maintains a flow dependent on the sluice and slurry solids concentration in the transfer lines. The slurry/booster pumps and pipe-in-pipe transfer line are designed to handle up to $30 \%$ wt. solids loading, and direct the slurry into tank 241-AN-105 through a sludge distributor. The supernate/booster pumps and pipe-in-pipe transfer line are designed for a 10\% wt. solids loading (Estey 1996). Normal flow velocity for the 4-in. transfer lines is about $10 \mathrm{ft} / \mathrm{s}$. Two parallel transfer lines, typically about one-third mile in length, will be used. The sluice flow is ejected through a 1-in. nozzle with a design $180 \mathrm{psig}$ pressure drop. Terminal slurry tank clean out requires a 3.5 -hp heel pump.

A remotely operated CCTV camera is also located within the dome space of the slurry tank to monitor the slurry supply pump and sluicing nozzle position. The articulated CCTV is equipped with lens washing capacity and a zoom lens.

During the sluicing campaign, ventilation of the tank dome space will be required for emission, temperature control and CCTV visual clarity. Typical existing tank ventilation 
consists of a passive P-trap and/or active fan HEPA filtration. During sluicing operation the disruptive forces of the sluicing nozzle will atomize the slurry, which would exceed the existing capacity of passive traps and the active HEPA filtration. Consequently, an air polishing facility upstream of the HEPA filters must be provided for each tank being sluiced (May 1996). This process building removes excessive vapor prior to the final filtration, and recirculates dried and heated air back to the slurry tank for fog reduction. Reduced air pressure in the tank dome space created by the HEPA exhaust fans draw vapors and aerosols from the SST. All extracted air is chilled by passing it through a heat exchanger. A flow diverter routes a major portion of the air steam through a moisture separator and a $30 \mathrm{~kW}$ heating coil prior to recirculation to the slurry tank. This dehumidified air will reduce or prevent fog in the dome space. The remainder of the air is routed through a HEME and HEMF before being funneled through the HEPA filters to atmospheric discharge. All liquid extracted by the separators, heaters, eliminators, and filters is routed back to the slurry tank.

Differences in tank elevations could result in siphoning of supernate or slurry upon system shutdown. Consequently the penetrations to the receiver tank and slurry tanks will incorporate engineering features to prevent this undesired flow.

\subsubsection{Equipment Located Outside the Tank Farm Fence}

Most equipment located outside the tank farm fence line provide facilities or utilities necessary for tank sluicing. The largest single structure is the mobile office used as a control room. This facility will provide operator control for modification and monitoring of system conditions. The CCTV will provide monitoring of 40-hp slurry pump elevation, feed stock being introduced into the pump, and azimuth/elevation of the sluicing nozzle. Other conditions that will be monitored include slurry density, flow rate, viscosity, temperature, slurry/supernatant level, and pressure.

Smaller equipment located outside the fence line includes an air and water building. This building contains the air compressor and backflow preventer that provide control of remote valves and service water for a variety of functions. Included in this category are the transformer and motor control center for supplying 480-volt power to the variable speed pump motor controllers. A nitrogen rack for secondary protection on pump seals, and a chiller skid, for cooling of tank dome discharge air, are also included. 


\subsection{TRADE STUDIES}

Four trade studies were conducted to analyze 1) the re-usability of equipment installed as part of Project W-320 (tank 241-C-106 sluicing), 2) pipeline routing options, 3) HVAC system requirements, and 4) A/AX HVAC equipment options.

A study titled Re-usability of Equipment Installed Under Project W-320 Sluicing of Tank C-106 For Tanks $C-103$ and $C-105$ (LATA 1996c) concluded that most equipment used in the sluicing of tank 241-C-106 could be re-used for ISSTRS. However, all equipment would require functional testing and the hydraulic system would require rebuilding. Nonreusable equipment included individual jumpers, in-tank masts and pumps, and most equipment installed in riser pits.

A trade study, titled Sluice Line Options (LATA 1996d), identified pipeline routing options and recommended one for additional study. The scope of options considered within the study included use of the existing waste transfer system, proposed new construction, or any combination of both.

This study concluded that approximately two-thirds of the existing Project W-320 pipelines could be re-used for ISSTRS. The northern third of Project W-320 lines could be re-used for C Farm tanks with the waste routed to a new valve pit just inside the west fence of AN Tank Farm. New lines and valve pits would be installed to retrieve the tanks in AX and A Farms, which will tie into the southern end of Project W-320 lines. The proposed routing avoids low spots that could trap waste in off-normal shutdowns or from primary pipe leakages. The existing infrastructure could not accommodate the required flow rate because these lines are 2 and 3 inches in diameter. Routing is illustrated in the "ISSTRS Civil Site Plan" (SK-2300469).

A study of HVAC requirements, Retrieval Facility Cooling Requirements (LATA 1996b) was conducted. The study recommended that similar capacity HVAC equipment installed for Project W-320 be installed for the sluicing of the four ISSTRS tanks.

A study, Options for Location of AX-103 and A-103 HVAC Equipment (LATA 1996a) examined options for positioning equipment in either AX or A Tank Farm to support both tanks, or building two HVAC skids. It found the most cost effective solution to be building two skids-one for each tank farm. 


\subsection{PROCESS DESCRIPTION}

\subsubsection{Startup and Normal Operation}

The sluicer nozzle in slurry tanks (241-A-102, 241-AX-103, 241-C-103, or 241-C-105) is maintained at a fixed elevation but can be aimed (both elevation and azimuth) via hydraulics. Using CCTV, the sluicing nozzle will be aimed near the base of the $40 \mathrm{hp}$ slurry supply pump. The supernatant pumps (located in 241-AN-105) will then be energized. Using the hydraulic force of the supernatant discharged through a nozzle, a series of channels will be cut in the sludge surface to direct flow to the 40 hp slurry pump. When a sufficient pool has developed the slurry supply and booster pumps will be energized to transfer the slurry to the receiver tank (241-AN-105). Dispersion is provided as the slurry enters the receiver tank by a distributor at a fixed elevation near the tank bottom. The solids will settle out of the slurry the resulting supernate is pumped back to the sluicer nozzle and the process repeated. Winches will position the pumps in both the sluice and receiver tanks as required by tank level changes.

\subsubsection{Normal Shutdown}

It is anticipated that the sluicing of each tank will be a continuous operation ( 24 hours a day, 7 days a week), and will continue until the contents have been transferred to tank 241-AN-105. An orderly shut down at the conclusion of sluicing consists of final flush of piping and pumps for contamination reduction.

\subsubsection{Emergency Shutdown}

Emergency shutdown will occur under a limited number of conditions. A partial listing includes a seismic event, plugged line, equipment failure, detectable slurry or supernatant leak, motor overheating, or loss of HVAC. System design features for a emergency shutdown include the rapid depressurization of lines followed by a gravity drain with the engineered antisiphon protection. Waste from A or AX Tank Farms will drain by gravity to tank AN-105 and waste from $C$ Tank Farm will drain back to the source tank.

\subsection{INSTRUMENTATION AND ALARMS}

\subsubsection{Sluice and Supernatant Pumps}

Local controls and indicators for the two submersible sluice and supernatant pumps, and the two sluice and supernatant booster pumps are provided at the motor control center and the 
variable speed drive cabinet at the electrical equipment skid. Pump discharge pressure and volumetric flow will be provided for operator information. The submersible pumps will have moisture detectors in the motor. Additional monitoring of pump motor speed, current, and voltage, as well as motor bearing, bearing oil, and stator temperatures, will be furnished for all four pumps.

A remotely operated winch will be provided for the two submersible pumps in the SST and DST to accommodate liquid level changes in the receiver and sluice tanks. The winch will have upper and lower limit switches, alarms, and panel mounted annunciators to alert operators of potential damage to the pump and/or winch mechanism.

\subsubsection{Sluicer}

Controls will be provided to confine the sluicing stream to a specific location in the tank. Manual and semi-automatic positioning will provide directional control of the sluicer.

Hydraulic cylinders will provide azimuth and elevation control.

\subsubsection{Heel Pump}

Local controls and indicators for the submersible heel pump will be provided at the motor control center in the electrical equipment skid. Pump volumetric flow will be provided for operator information.

\subsubsection{Leak Detection System}

Leak detection sensors for ISSTRS are provided on the slurry and supernatant transfer line piping encasements where they enter the riser pits. Leak detection sensors are also provided in each pump and sluicing pit used during the retrieval process. These sensors will provide signals to alarm on the Tank Monitoring and Control System. Any leaks in the riser pits would drain into the tank below.

\subsubsection{Seal Loops}

Redundant seal loops will be provided to prevent tank over or under pressurization. The seal loops will relieve the differential pressure to maintain the structural integrity of the SST. A level gauge will monitor the fluid level in each seal loop. 


\subsubsection{Transfer System Interlocks}

Seismic detectors at each tank will automatically shut down the transfer system at the onset of a seismic event. High temperatures in the seismic detection cabinets will shut down the motor control centers that power the slurry and sluice pumps. The $(250 \mathrm{hp})$ slurry and sluice booster pumps are automatically shut down on low suction pressure after a time delay of 1 second, motor stator winding high temperature, or high bearing temperature. The $(40 \mathrm{hp})$ submersible pumps are automatically shut down on motor stator winding, high bearing temperature, or moisture detection.

\subsubsection{Ventilation System for Process Building}

Instrumentation will be provided to monitor the condenser air stream differential pressure, air stream inlet/outlet temperature, heating coil outlet temperature, recirculation fan differential pressure, and fan motor current. Instrumentation will also be provided for monitoring the HEME and HEMF differential pressure and the HEME outlet temperature. Position switches will indicate the HEMF flush water and/or blow-down air inlet valve and drain valve positions at the control station.

The heating coil outlet temperature will be regulated by a controller that senses the outlet temperature. The heating coil will be equipped with an internal high-high temperature cutout and a manual cutout switch. Alarms will alert the operator to abnormal situations.

\subsubsection{HEPA System Cooled Chiller Skid}

The air-cooled chiller skid will be started and stopped manually. It is controlled by a factoryinstalled temperature controller provided in the chiller discharge line. A common trouble alarm indicates failure of associated equipment at the control station. A pressure sensor in the circulation pump discharge line will sense the failure of the primary pump and start the standby pump.

\subsubsection{Ventilation System Exhaust System}

The exhaust system will consist of an electric heater, two HEPA filters with test sections, a volatile organic compound adsorber (if required), a variable speed exhaust fan, and an exhaust stack. The ventilation and exhaust monitoring system include a continuous air monitor, an air record sampler, sample flow controls, vacuum pump failure controls, and associated alarms. The instrumentation provided for this system will monitor the heating coil inlet and outlet temperatures, HEPA filter differential pressures, and exhaust fan inlet temperature indications and alarms. The heater increases the air stream temperature to reduce the relative humidity. A sensor on the heating coil outlet will control the outlet temperature. An internal high-high 
temperature switch and a manual cutout switch will also be included. Alarms will alert the operator to abnormal situations.

The exhaust fan will be controlled by a solid state variable speed drive that will vary the input frequency and voltage to achieve the desired fan speed. The drive will provide "soft start" and will have a minimum three-cycle "ride through" in case of momentary power interruptions. Exhaust fan controls will be available locally and at the control station.

\subsubsection{Single-Shell Tank Farm Sluicing Control Station}

All controls necessary to operate the waste transfer for sluice tanks 241-C-105 and 241-C-106 and receiver tank 241-AN-105 will be conducted at a modified control station installed by Project W-320. Waste transfer from SSTs located in the AX and A Farms will be conducted from a control station adjacent to each farm.

\subsection{JUSTIFICATION}

Bases of the Tank Waste Remediation System mission include retrieval of SST waste to permit closure of the tanks. The primary function of ISSTRS is to provide a tank farm demonstration for retrieval of selected SSTs. The fourth amendment to the Hanford Federal Facility

Agreement and Compliance Order (Ecology et al. 1994) specifies milestones that form the justification and bases for ISSTRS. These milestones include M-45-04A "Complete Conceptual Design for the Initial SST Retrieval Systems by April 30, 1997," M-45-04-T02 "Complete Design for the Initial SST Retrieval Systems by December 31, 2000," and M-4505-T03 "Provide Initial Single-Shell Tank Retrieval System by November 30, 2003."

\subsection{DESCRIPTION PROJECT SCOPE FOR TANKS 241-C-103 AND 241-C-105}

This section describes the installation of sluicing and support equipment for two adjacent tanks, tanks 241-C-103 and 241-C-105. Ancillary equipment and support facilities installed under Project W-320 will be used on this sequential terminal clean-out, with a number of minor modifications. 


\subsection{IMPROVEMENTS TO LAND}

Tanks 241-C-103 and 241-C-105 will require excavation for modification of existing riser pits, 241-C-03A and 241-C-05A respectively, for core drilling and new slurry and supernatant piping tie-in.

Excavation for re-routing of process building liquid drain, new buried pipelines, electrical and instrumentation conduit will be required.

\subsection{BUILDINGS}

\section{Architectural}

There will be no modification or additions to existing buildings.

\subsection{OTHER STRUCTURES}

1. Cover Blocks

Both tanks will require cover block replacement to provide slurry booster pump and sluicer clearance.

2. Riser Pits

Jumpers for slurry and supernate transfer will require fabrication and installation. Adapter rings for riser/booster pump connections will be required. The winches, sluicing assembly, and CCTV will be required for tanks 241-C103 and 241-C-105. Adapter rings for installation of heel pumps will also be required.

\subsection{UTILITIES}

Existing underground intra-farm utilities installed by Project W-320 will require extensions for tanks 241-C-103 and 241-C-105. This includes compressed air, hydraulic, water, and nitrogen gas.

\subsection{SPECIAL EQUIPMENT AND PROCESS SYSTEMS}

\section{Process Building}

The existing process building will require an extension of the inlet air supply duct (tank air outlet) and air recirculation duct to the tank being sluiced. Ducts will be above grade and additional duct supports will be required. 


\subsection{DEMOLITION}

Existing cover blocks will be removed, characterized, and excessed.

\subsection{DESCRIPTION OF PROJECT SCOPE FOR TANK 241-AX-103}

This section describes the installation of sluicing and support equipment for tank 241-AX-103. Some support facilities installed under Project W-320 will be duplicated with a number of minor modifications. However, extensive new fabrication will be required. The modifications and new fabrication are described below.

\subsection{IMPROVEMENTS TO LAND}

Tank 241-AX-103 will require riser pit modification for new supernatant and slurry line connections. Up to five riser pits may be required by ISSTRS.

Fence modification and inter-farm excavation are necessary for the $1,030 \mathrm{ft}$ of transfer piping with berm between slurry tank 241-AX-103 and receiver tank 241-AN-105. An underground valve pit will be located near the northwest corner of AY Tank Farm that will tie into existing W-320 transfer lines. (Identified as valve pit \#2 on Drawing SK-2-300469)

Excavation will be required for the new process building, new buried pipelines, new valve pits, and telecommunication signal and electrical conduit.

\subsection{BUILDINGS}

1. Architectural

The existing control room installed by Project W-320 will require duplication to support tank 241-AX-103 waste transfer.

The air and water service building, electrical equipment skids, seismic enclosures, chiller, and nitrogen bottle rack will be required.

\subsection{OTHER STRUCTURES}

1. Cover Blocks

Tank 241-AX-103 will require cover block replacement to provide slurry booster pump and sluicer clearance. 
2. Riser Pits

Jumpers for slurry and supernate transfer will require fabrication and installation. Adapter rings for riser/booster pump and heel pump connections will be required. The winches, CCTV, slurry and booster pumps, and sluicing assembly will require adaptation for tank 241-AX-103.

3. Process Building and Exhaust Skid A process building and exhaust skid will be modeled from Project W-320 design. Modification is required because tank 241-AX-103 has nearly twice the storage capacity of typical C Farm tanks.

4. Air Inlet Filters

A filter for inlet air for tank 241-AX-103 will be adapted from Project W-320.

The primary differences are riser design and location.

5. Hydraulic Power Pack Skid

A hydraulic power pack for sluicing nozzle articulation will be required. The power pack and drive assemble will be located inside the tank farm fence.

\subsection{UTILITIES}

1. Underground intra-farm utilities will be required for tank 241-AX-103. Included are compressed air, hydraulic, water, and nitrogen gas. Typically utilities will be extended from new buildings or structures outside the fence line.

2. Telecommunication signal and 480 -volt power will require extension from existing facilities.

\subsection{SPECIAL EQUIPMENT AND PROCESS SYSTEM}

No special equipment or process modification is required.

\subsection{DEMOLITION}

Existing cover blocks will be removed, characterized, and excessed. 


\subsection{DESCRIPTION OF PROJECT SCOPE FOR TANK 241-A-102}

This section describes the installation of sluicing and support equipment for tank 241-A-102. Some support facilities installed under Project W-320 will be duplicated with a number of minor modifications. However, extensive new fabrication will be required. The modifications and new fabrication are described below.

\subsection{IMPROVEMENTS TO LAND}

Tank 241-A-102 will require riser pit excavation for new supernatant and slurry line connections. Three to four riser pits will require modification.

Fence modification and inter-farm excavation are necessary for the $790 \mathrm{ft}$ of transfer piping with berm between slurry tank 241-A-102 and the underground valve pit located near the northwest corner of AY Tank Farm (identified in Section 5.1).

Excavation for a new process building, new buried pipelines, and telecommunication signal and electrical conduit will be required.

\subsection{BUILDINGS}

1. Architectural

The existing control room installed by Project W-320 will require duplication to support tank 241-A-102 waste transfer.

The air and water service building, electrical equipment skids, seismic enclosures, chiller, and nitrogen bottle rack will be required.

\subsection{OTHER STRUCTURES}

\section{Cover Blocks}

Tank 241-A-102 will require cover block replacement to provide slurry booster pump and sluicer clearance.

\section{Riser Pits}

Jumpers for slurry and supernate transfer will require fabrication and installation. Adapter rings for riser/booster pump and heel pump connections will be required. Winches, sluicing assembly, closed-circuit television and slurry and booster pumps will require adaptation for tank 241-A-102 
3. Process Building and Exhaust Skid

A process building and exhaust skid will be adapted or modeled from Project W-320 design. The existing design is sized for a tank with half the capacity of 241-A-102.

4. Air Inlet Filters

A filter for inlet air for tank 241-A-102 will be adapted from Project W-320. Riser design and location represent primary difference.

5. Hydraulic Power Pack Skid

A hydraulic power pack for sluicing nozzle articulation will be required. The power pack and drive assembly will be located inside the tank farm fence.

\subsection{UTILITIES}

1. Underground intra-farm utilities installed by Project W-320 will be duplicated for tank 241-A-102. Included are compressed air, hydraulic, water, and nitrogen gas. Typically utilities will be extended from new facilities located outside the fence.

2. Telecommunication signal and 480 -volt power will require extension from existing facilities.

\subsection{SPECIAL EQUIPMENT AND PROCESS SYSTEM}

No special equipment or process modification is required.

\subsection{DEMOLITION}

Existing cover blocks will be removed, characterized, and excessed

\subsection{DESCRIPTION OF PROJECT SCOPE FOR TANK 241-AN-105}

This section describes the installation of equipment for receiver tank 241-AN-105. Some support facilities installed under Project W-320 will be duplicated with minor modifications. However, extensive new fabrication will be required. The modifications and new fabrication are described below. 


\subsection{IMPROVEMENTS TO LAND}

Tank 241-AN-105 will require riser pit excavation for new supernatant and slurry line connections and a new pump pit for the supernatant booster pump. The new pump pit will be installed over existing risers.

Excavation will be required for the new valve pit just inside the west side of the AN Tank Farm fence.

Fence modification and inter-farm excavation are necessary for the $312 \mathrm{ft}$ of transfer piping with berm between the receiver tank, the new underground valve pit, and existing Project W-320 buried pipe.

Excavation will be required for new buried pipelines, and telecommunication signal and electrical conduit.

\subsection{BUILDINGS}

1. Architectural The existing control room installed under Project W-320 at the AY Tank Farm will require modification to support the transfer of tank 241-AN-105 waste.

The air and water service building, electrical equipment skids, seismic enclosures, and nitrogen bottle rack will be required.

The existing redundant fans combined with normal services fans will provide adequate exhaust. Failure to use both would require new air exhaust design and construction.

\subsection{OTHER STRUCTURES}

1. Cover Blocks and Pump Pit

A pump pit and cover blocks will be required for the supernatant booster pump.

2. Riser Pits

Jumpers for supernate transfer will require fabrication and installation. Adapter rings for riser/booster pump connections will be required. Winches, pumps and distributor assembly will require adaptation from Project W-320 for tank 241AN-105. 


\subsection{UTILITIES}

1. Underground intra-farm utilities installed by Project W-320 will require extensions for tank 241-AN-105. Included are compressed air, water, and nitrogen gas.

2. Telecommunication signal and 480 -volt power will require extension from existing facilities.

\subsection{SPECIAL EQUIPMENT AND PROCESS SYSTEM}

No special equipment or process modification is required.

\subsection{DEMOLITION}

Existing cover blocks will be removed, characterized, and excessed.

\subsection{REQUIREMENTS TRACEABILITY}

ISSTRS is only one part of TWRS. Within TWRS there are many functions to be fulfilled by architecture such as ISSTRS. There are 10 major functional subelements that make up the ISSTRS. The following titles describe the functions to be performed by ISSTRS. Each of these functions was developed into a set of design requirements which were given in the preliminary design requirements document (PDRD). They include the following:

a. Detect SST waste leakage during retrieval.

b. Monitor SST waste leakage during retrieval

c. Mitigate SST waste leakage during retrieval

d. Remove In-tank obstructions

e. Deploy retrieval system

f. Mobilize SST waste

g. Convey/transfer slurry waste

h. Ventilation and cooling

I. Monitor and control operations

j. Decontaminate equipment

The requirements traceability report is the method used to ensure all conceptual design applicable requirements and the closely associated constraints have been met. 
The traceability of each requirement is established through recording the system or subsystem that it has been assigned to, coupled with an explanation of how the requirement will be satisfied by the system or subsystem.

\subsection{IDENTIFICATION AND ANALYSIS OF UNCERTAINTIES}

\subsection{RISK MANAGEMENT PLAN}

The risk management plan is a systems engineering document that makes recommendations for managing risks associated with the conceptual design of the ISSTRS. Risk management involves planning, documenting, observing, and initiating actions that promote good decision making.

The risk management plan for the conceptual design for ISSTRS is a listing of the assumptions generated during conceptual design, the impact of those assumptions to the project if they are not correct, and a strategy to validate the correctness of the recommendations, as required.

\subsection{INTERFACE CONTROL DOCUMENT}

The interface control document is a systems engineering document that contains both interface block diagrams (IBD) and project interface control documents (PICD) for ISSTRS. The interfaces described in the IBDs and PICDs are primarily the pathway(s) for exchange of information or material(s) between ISSTRS and existing facilities. Examples of interfaces are utility connection(s), existing tank or pipe connection points, and other interfaces between system hardware/software elements belonging to ISSTRS, existing facilities and/or planned projects. Identification of these interfaces is of paramount importance to successful insertion and operation of ISSTRS into the tank farms, maintaining schedule, and controlling costs.

The process of interface negotiation and definition for ISSTRS is a continuous one, initiated in the PDRD. Due to the many states of development of the interfacing projects (ranging from existing tank farm operations to projects not yet in conceptual design), this document will continue to be updated throughout the detailed design stage.

Five methods were used to identify and define the interfaces for ISSTRS as follows:

a) Interfaces were identified during a review of the four trade studies that were performed as an initial step in the conceptual design.

b) Needed interfaces were identified and listed during the conceptual design phase.

c) Specific interfaces listed in the PDRD were included and expanded, if possible. 
d) A list of recent, existing and proposed projects was consulted for projects which would interface with ISSTRS.

e) A further level of detail of actual system element hardware and software interfaces was obtained from as-built records, design information from conceptual design reports, and interviews with knowledgeable personnel.

\subsection{REFERENCES}

Ecology, EPA, and DOE, 1994, Hanford Federal Facility Agreement and Consent Order, as amended, Washington State Department of Ecology, U. S. Environmental Protection Agency, and U. S. Department of Energy, Olympia, Washington.

Estey, S. D., 1996, Project W-320 Tank 241-C-106 Sluicing Process Flowsheet, WHC-SDW320-TI-002, Rev. 0, Westinghouse Hanford Company, Richland, Washington.

Hanlon, B.M., 1996, Tank Farm Surveillance and Waste Status Summary Report for Month Ending July 31, 1996, WHC-EP-0182-100, Westinghouse Hanford Company, Richland, Washington.

Hertzel, J. S., 1996, Preliminary Design Requirements Document for the Initial Single-Shell Tank Retrieval System, WHC-SD-WM-DRD-110, Rev. 0, Westinghouse Hanford Company, Richland, Washington.

Krieg, S. A., 1996, Statement of Work for the Conceptual Design for the Initial Single-Shell Tank Retrieval System, July 22, Rev. 1, Westinghouse Hanford Company, Richland, Washington.

LATA, 1996a, Initial Single-Shell Tank Retrieval System Trade Study: Options for the Location of Tank AX-103 and A-102 HVAC Equipment, Los Alamos Technical Associates, Richland, Washington.

LATA, 1996b, Initial Single-Shell Tank Retrieval System Trade Study: Retrieval Facility Cooling Requirements, Los Alamos Technical Associates, Richland, Washington.

LATA, 1996c, Initial Single-Shell Tank Retrieval System Trade Study: Equipment Re-usability Between Project W-320 and Tanks 241-C-103 and 241-C-105, Los Alamos Technical Associates, Richland, Washington.

LATA, 1996d, Initial Single-Shell Tank Retrieval System Trade Study: Sluice Line Options, Los Alamos Technical Associate, Richland, Washington. 
May, T. H., 1996, Tank 241-C-106 Waste Retrieval Sluicing System Operations Manual, WHC-SD-W320-TI-004, Rev. 0, Westinghouse Hanford Company, Richland, Washington. 


\section{APPENDIX A}

\section{COST ESTIMATE}


This page left intentionally blank. 


\section{ISSTRS Conceptual Design (90\% Design Review) Cost Estimate}

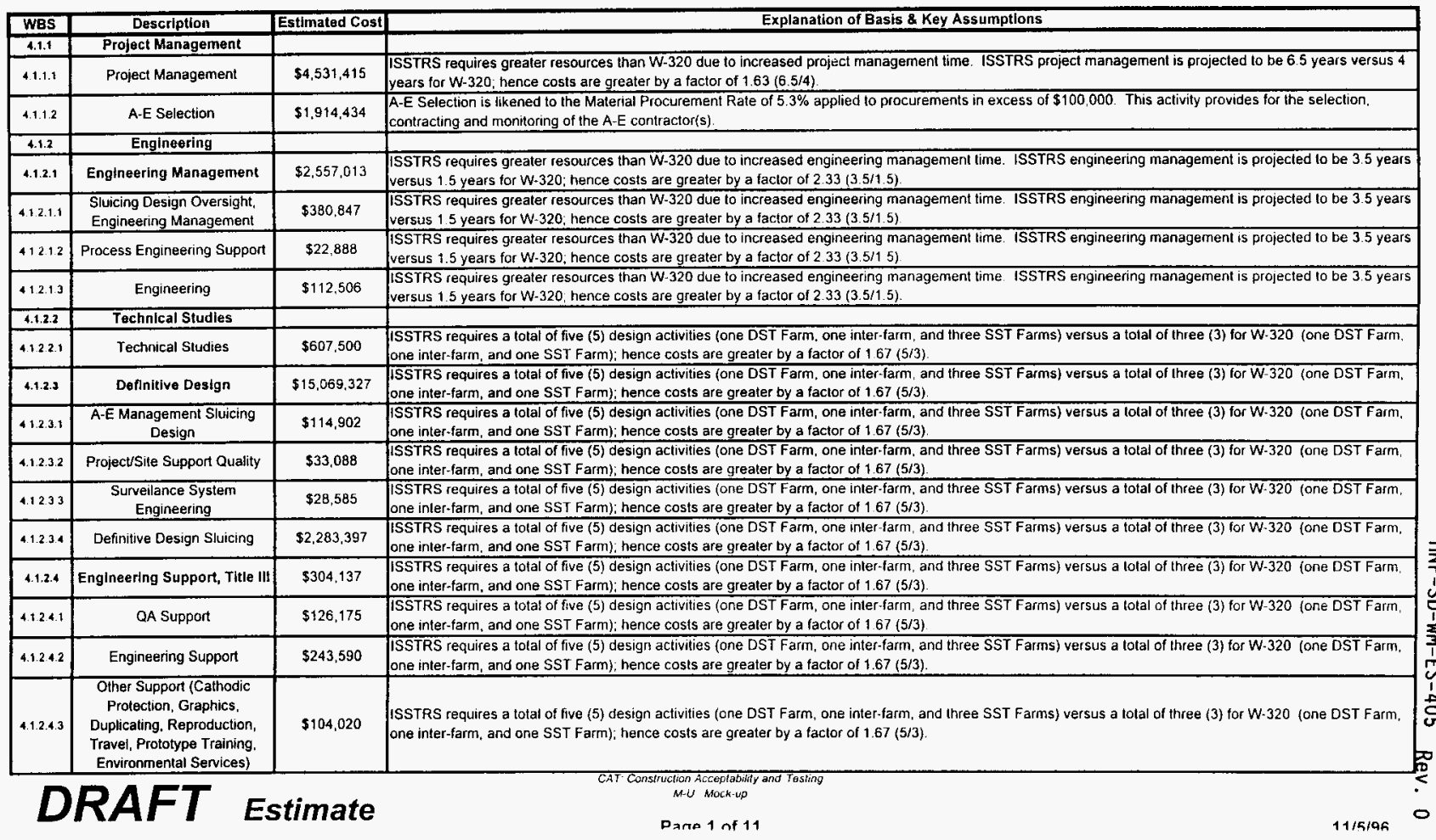




\section{ISSTRS Conceptual Design ( $90 \%$ Design Review) Cost Estimate}

\begin{tabular}{|c|c|c|c|}
\hline WBS & Descriptlon & Estimated Cost & Explanation of Basis \& Key Assumptions \\
\hline 4.1.2.4. & Process Support & $\$ 48,407$ & $\begin{array}{l}\text { ISSTRS requires a total of five (5) design aclivities (one DST Farm, one inter-farm, and three SST Farms) versus a total of three (3) for W-320 (One DST Farm, } \\
\text { one inter-farm, and one SST Farm); hence costs are greater by a factor of } 1.67(5 / 3) \text {. }\end{array}$ \\
\hline 4.1 .2 .4 & Independent Safety & $\$ 26,840$ & $\begin{array}{l}\text { ISSTRS requires a total of five (5) design activities (one DST Farm, one inter-farm, and three SST Farms) versus a total of three (3) for W-320 (one DST Farm, } \\
\text { one inter-farm, and one SST Farm), hence costs are greater by a factor of } 1.67(5 / 3) \text {. }\end{array}$ \\
\hline 4.1 .2 .46 & Engineering Inspection & $\$ 271.498$ & $\begin{array}{l}\text { ISSTRS requires a total of five (5) design activities (one DST Farm, one inter-farm, and three SST Farms) versus a total of three (3) for W-320 (one DST Farm, } \\
\text { one inter-farm, and one SST Farm); hence costs are grealer by a factor of } 1.67(5 / 3) \text {. }\end{array}$ \\
\hline 4.1 .2 .4 .7 & Sluicing Title III & $\$ 2,763,513$ & $\begin{array}{l}\text { ISSTRS requires a total of five (5) design activities (one DST Farm, one inter-farm, and three SST Farms) versus a total of three (3) for W-320 (one DST Farm, } \\
\text { one inter-farm, and one SST Farm); hence costs are greater by a factor of } 1.67(5 / 3) \text {. }\end{array}$ \\
\hline 4.1 .2 .4 & $\begin{array}{l}\text { Equipment Removal System } \\
\text { Title III }\end{array}$ & $\$ 169,578$ & $\begin{array}{l}\text { ISSTRS requires a total of five (5) design activities (one DST Farm, one inter-farm, and three SST Farms) versus a total of three (3) for W-320 (one DST Farm. } \\
\text { one inter-farm, and one SST Farm); hence costs are greater by a factor of } 1.67(5 / 3)\end{array}$ \\
\hline 4.1.2.5 & Equipment Removal Design & & \\
\hline 4.1.2.5.1 & Equipment Removal Design & $\$ 10,246,092$ & ISSTRS requires four (4) equipment removal designs versus one for W-320, hence ISSTRS costs are 4 times W-320. \\
\hline 4.1 .3 & CENRTC & & \\
\hline 4.1.3.2 & $\begin{array}{l}\text { CENRTC Des Ign - Design of } \\
\text { Capital Equipment which is } \\
\text { reused. Primarly Long } \\
\text { Length Contaminated } \\
\text { Equipment removal and } \\
\text { disposal equipment } \\
\end{array}$ & & \\
\hline 4.1 .32 .1 & CENRTC Definitive Design & $\$ 632,447$ & W-320 estimate used as is. No significant difference in scope. \\
\hline 4.132 .2 & $\begin{array}{l}\text { CENRTC Design Support, 2nd } \\
\text { Flexible Receiver }\end{array}$ & $\$ 77,600$ & W-320 estimate used as is. No significant difference in scope. \\
\hline 4.1.2.4 & $\begin{array}{l}\text { CENRTC Procurement - } \\
\text { Purchase of Capltal } \\
\text { Equlpment which is reused. } \\
\text { Primarily Long Length } \\
\text { Contaminated Equipment } \\
\text { removal and disposal } \\
\text { equipment }\end{array}$ & & \\
\hline 4.1.3.4.1 & CENTRC Procurement & $\$ 3,791,940$ & $\begin{array}{l}\text { ISSTRS requires four (4) procurements versus one for } W-320 \text {. An additionai two (2) procurements are estimated for contingency purposes; hence iSSTRS cosis } \\
\text { are six (6) times } W-320 \text {. }\end{array}$ \\
\hline
\end{tabular}




\section{ISSTRS Conceptual Design (90\% Design Review) Cost Estimate}

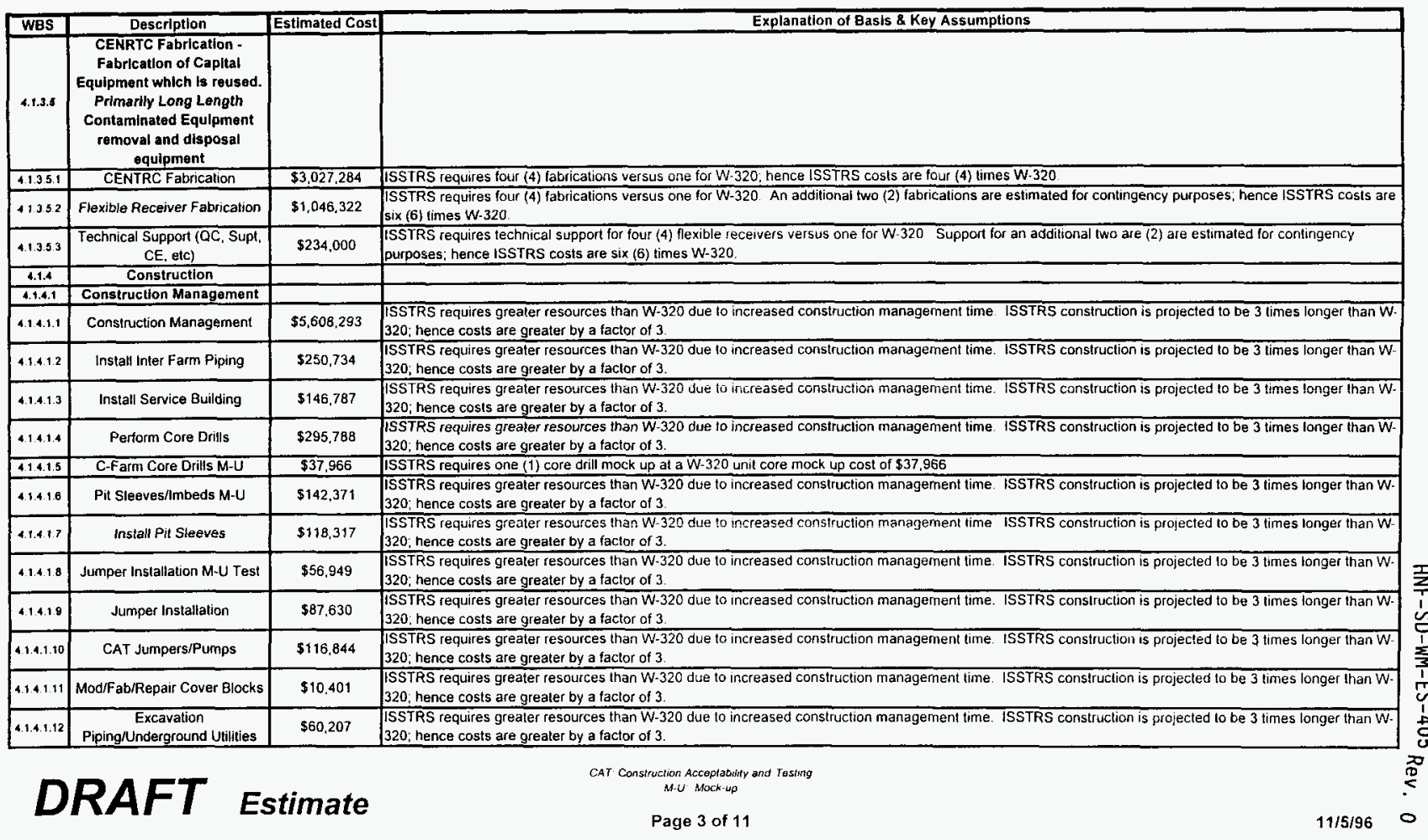




\section{ISSTRS Conceptual Design (90\% Design Review) Cost Estimate}

\begin{tabular}{|c|c|c|c|}
\hline WBS & Description & Estimated Cost & Explanation of Basis \& Key Assumptions \\
\hline 4.1 .4 .1 .13 & Installation of Encased Piping & $\$ 151,521$ & $\begin{array}{l}\text { ISSTRS requires greater resources than W-320 due to increased construction management time. ISSTRS construction is projected to be } 3 \text { times longer than W- } \\
320 \text {; hence costs are greater by a factor of } 3 \text {. }\end{array}$ \\
\hline 4.1.4.1.14 & CAT Encased Pipe & $\$ 32,115$ & $\begin{array}{l}\text { ISSTRS requires greater resources than W-320 oue to increased construction management time. ISSTRS construction is projected to be } 3 \text { times longer than W- } \\
320 \text {, hence costs are greater by a factor of } 3 \text {. }\end{array}$ \\
\hline 4.1 .41 .15 & CAT Utility Pipe & $\$ 32,115$ & $\begin{array}{l}\text { ISSTRS requires greater resources than W-320 due to increased construction management time. ISSTRS construction is projected to be } 3 \text { times longer than W- } \\
320 \text {; hence costs are greater by a factor of } 3 \text {. }\end{array}$ \\
\hline 4.4 .116 & Install Uijity Pipe & $\$ 107,733$ & $\begin{array}{l}\text { ISSTRS requires greater resources than W- } 320 \text { due to increased construction management time. ISSTRS construction is projected to be } 3 \text { times longer than W- } \\
320 \text {; hence costs are greater by a factor of } 3 \text {. }\end{array}$ \\
\hline 4.1 .117 & Install Instrumentation & $\$ 264,993$ & $\begin{array}{l}\text { ISSTRS requires greater resources than W-320 due to increased construction management lime. ISSTRS construction is projected to be } 3 \text { times longer than W- } \\
320 \text {; hence costs are greater by a factor of } 3 \text {. }\end{array}$ \\
\hline 41.4118 & Installation of In-Tank Imaging & $\$ 91.170$ & $\begin{array}{l}\text { SSTRS requires greater resources than W- } 320 \text { dive to increased construction management lime ISSTRS construction is projected to be } 3 \text { times longer than W- } \\
320 \text {; hence costs are greater by a factor of } 3 \text {. }\end{array}$ \\
\hline 41.4119 & Installation of Electrical & $\$ 211.614$ & $\begin{array}{l}\text { ISSTRS requires greater resources than W-320 due to increased construction management fime. ISSTRS construction is projected to be } 3 \text { times tonger than W- } \\
320 \text {, hence costs are greater by a factor of } 3 \text {. }\end{array}$ \\
\hline$|4.14120|$ & $\begin{array}{l}\text { Installation of Cathodic } \\
\text { Protection }\end{array}$ & $\$ 60.171$ & $\begin{array}{l}\text { ISSTRS requires greater resources than W-320 due to increased construction managernent time. ISSTRS construction is projected to be } 3 \text { times longer than W- } \\
320 \text {, hence costs are greater by a factor of } 3 \text {. }\end{array}$ \\
\hline 41.4 .21 & CAT Electrical & $\$ 32,622$ & $\begin{array}{l}\text { ISSTRS requires greater resources than W- } 320 \text { due to increased construction management time. ISSTRS construction is projecled to be } 3 \text { times tonger than W- } \\
320 \text {; nence costs are greater by a factor of } 3 \text {. }\end{array}$ \\
\hline$|41.1 .22|$ & $M-U$ Test Sluicing Equipment & $\$ 67,452$ & $\begin{array}{l}\text { ISSTRS requires greater resources than W-320 due to increa sed construction management time. ISSTRS construction is projected to be } 3 \text { times longer than W- } \\
\text { 320; hence costs are greater by a factor of } 3 \text {. }\end{array}$ \\
\hline 4.14 .123 & $\begin{array}{l}\text { Inslallation of Sluicing } \\
\text { Equipment }\end{array}$ & $\$ 109,119$ & $\begin{array}{l}\text { ISSTRS requires greater resources than W-320 due to increased construction management time. ISSTRS construction is projected to be } 3 \text { times longer than W- } \\
320 \text {; hence costs are greater by a factor of } 3 \text {. }\end{array}$ \\
\hline 4.1 .4 .124 & CAT Cathodic Protection & $\$ 32,622$ & $\begin{array}{l}\text { ISSTRS requires greater resources than W-320 due to increased construction management time. ISSTRS constiuction is ptojected to be } 3 \text { times longer than W- } \\
320, \text { nence costs are greater by a factor of } 3 \text {. }\end{array}$ \\
\hline 4.1 .125 & InstaHation of HVAC Chiller & $\$ 40,398$ & $\begin{array}{l}\text { ISSTRS requires greater resources than } W-320 \text { due to increased construction management time. ISSTRS construction is projected to be } 3 \text { times longer than W- } \\
320 ; \text { hence costs are greater by a factor of } 3 \text {. }\end{array}$ \\
\hline 4.1 .4 .126 & HVAC CAI & $\$ 64,236$ & $\begin{array}{l}\text { ISSTRS requires greater resources than W-320 due to increased construction management time. ISSTRS construction is projected to be } 3 \text { times longer than W- } \\
320 \text {; hence costs are greater by a factor of } 3 \text {. }\end{array}$ \\
\hline 4.1.4.1.27 & Installation of Process Skid & $\$ 67,335$ & $\begin{array}{l}\text { ISSTRS requires greater resources than } W-320 \text { due to increased construction management time ISSTRS construction is projected to be } 3 \text { fimes ionger than } W \text { - } \\
320 \text {, hence costs are greater by a factor of } 3 \text {. }\end{array}$ \\
\hline 4.1 .4 .126 & Installation of Exhaust System & $\$ 53,868$ & $\begin{array}{l}\text { ISSTRS requires greater resources than W-320 due to increased construction management time ISSTRS construction is projected to be } 3 \text { times longer than W- } \\
\text { 320; hence costs are greater by a factor of } 3 \text {. }\end{array}$ \\
\hline 40.4 .28 & instaltation of Mods for Air Intet & $\$ 32,331$ & $\begin{array}{l}\text { ISSTRS requires greater resources than W-320 due to increased construction management time. ISSTRS construction is projected to be } 3 \text { times longer than } W \text { - } \\
320 ; \text { hence costs are greater by a factor of } 3 \text {. }\end{array}$ \\
\hline 41.4 .1 .30 & Perform Core Drills & $\$ 69,174$ & $\begin{array}{l}\text { ISSTRS requires greater resources than W- } 320 \text { due to increased construction management time. ISSTRS construction is projected to be } 3 \text { times longer than W. } \\
320 ; \text { hence costs are greater by a factor of } 3 \text {. }\end{array}$ \\
\hline 4.1 .4 .1 .31 & Install Pit Sleeves/Embeds & $\$ 58,422$ & $\begin{array}{l}\text { ISSTRS requires greater resources than } W-320 \text { due to increased construction management time. ISSTRS construction is projected to be } 3 \text { times longer than } W \text { - } \\
320 \text {; hence costs are greater by a factor of } 3 \text {. }\end{array}$ \\
\hline
\end{tabular}




\section{ISSTRS Conceptual Design (90\% Design Review) Cost Estimate}

\begin{tabular}{|c|c|c|c|}
\hline WES & Description & Estimated Cost & Explanation of Basis \& Key Assumptions \\
\hline 4.1 .41 .32 & Jumper Installation & $\$ 116.844$ & $\begin{array}{l}\text { ISSTRS requires greater resources than W-320 due to increased construction management tirne. ISSTRS construction is projected to be } 3 \text { times longer than W- } \\
320 \text {; hence cosis are greater by a factor of } 3\end{array}$ \\
\hline 4.1 .1 .33 & Install Sluice Pump & $\$ 141.075$ & $\begin{array}{l}\text { ISSTRS requires greater resources than } W-320 \text { due to increased construction management time ISSTRS construclion is projected to be } 3 \text { times longer than } W \text { - } \\
\text { 320; hence costs are greater by a factor of } 3 \text {. }\end{array}$ \\
\hline 4.1 .4 .1 .34 & install Distributor & $\$ 141,075$ & $\begin{array}{l}\text { ISSTRS requires greater resources than W-320 due to increased construction management time ISSTRS construction is projecled to be } 3 \text { limes longer than } W \text { - } \\
320 \text {; hence costs are greater by a factor of } 3 \text {. }\end{array}$ \\
\hline$|41 .+1.35|$ & CAT Farm Pit Mods & $\$ 80,907$ & $\begin{array}{l}\text { ISSTRS requires greater resources than W- } 320 \text { due to increased construction management time. ISSTRS construclion is projected to be } 3 \text { times longer than } W \text { - } \\
320 ; \text { hence costs are greater by a factor of } 3 \text {. }\end{array}$ \\
\hline 4.1 .4 .1 .36 & Backfill Pits & $\$ 21,222$ & $\begin{array}{l}\text { ISSTRS requires greater resources than W-320 due to increased construction management time. ISSTRRS construction is projecled to be } 3 \text { limes longer than W- } \\
320 \text {; hence costs are grealer by a factor of } 3 \text {. }\end{array}$ \\
\hline 4.1 .1 .37 & Install New Cover Blocks & $\$ 20,226$ & $\begin{array}{l}\text { ISSTRS requires greater resources than W-320 due to increased consiruction management time. ISSTRS construction is projected to be } 3 \text { times longer than } W \text {. } \\
320 \text {, hence costs are greater by a factor of } 3\end{array}$ \\
\hline 4.1.1.1.38 & Fabrication of Misc. Pads & $\$ 26,196$ & $\begin{array}{l}\text { ISSTRS requires greater resources than W-320 due to increased construction management time. ISSTRS construction is projected to be } 3 \text { times tonger than W. } \\
320 \text {; hence costs are greater by a factor of } 3\end{array}$ \\
\hline 41.4 .1 .39 & $\begin{array}{c}\text { Excavate \& Backfil AN Farm } \\
\text { Piping } \\
\end{array}$ & $\$ 38,667$ & $\begin{array}{l}\text { ISSTRS requires greater resources than W-320 due to increased construction management time. ISSTRS construction is projected to be } 3 \text { times longer than W- } \\
\text { 320; hence costs are greater by a factor of } 3 \text {. }\end{array}$ \\
\hline 4.1 .4 .1 .40 & Install AN Encased Piping & $\$ 79,434$ & $\begin{array}{l}\text { ISSTRS requires greater resources than } W-320 \text { due to increased construction management tirne. ISSTRS construction is projected to be } 3 \text { limes longer than } W \text {. } \\
320 \text {, hence costs are greater by a factor of } 3 \text {. }\end{array}$ \\
\hline 4.1.1.1.41 & Backfill AN Piping & $\$ 9,666$ & $\begin{array}{l}\text { ISSTRS requires greater resources than W-320 due to increased construction management fime ISSTRS consiruction is projected to be } 3 \text { times longer than } W \text { - } \\
320 ; \text { hence costs are greater by a factor of } 3 \text {. }\end{array}$ \\
\hline 4.1 .1 .42 & CAT Utility Pipe & $\$ 0$ & W-320 estimate is zero. \\
\hline 4.1 .1 .43 & $\begin{array}{l}\text { CAT AN.Farm Encased } \\
\text { Pipeline }\end{array}$ & $\$ 59.574$ & $\begin{array}{l}\text { ISSTRS requires greater resources than W- } 320 \text { due to increased construction management time iSSTRS construction is projected to be } 3 \text { times longer than W- } \\
320 ; \text { hence costs are greater by a factor of } 3 \text {. }\end{array}$ \\
\hline 41.1 .44 & Electrical Installation & $\$ 259,452$ & $\begin{array}{l}\text { ISSTRS requires greater resources than W-320 due to increased construction management time ISSTRS construction is projected to be } 3 \text { times longer than W- } \\
320 \text {, hence costs are greater by a factor of } 3 \text {. }\end{array}$ \\
\hline 4.1 .41 .45 & CAT AN Electrical & $\$ 31,380$ & $\begin{array}{l}\text { ISSTRS requires greater resources than W-320 due to increased construction management time ISSTRS construction is projected to be } 3 \text { limes longer than W- } \\
320 \text {; nence costs are greater by a factor of } 3 \text {. }\end{array}$ \\
\hline 41.1 .46 & Install AN Instrumentation & $\$ 109,695$ & $\begin{array}{l}\text { SSTRS requifes greater resources than } W \text { - } 320 \text { due to increased construction management time. ISSTRS construction is projected to be } 3 \text { times longer than } W \text {. } \\
320 \text {; hence costs are greater by a factor of } 3 \text {. }\end{array}$ \\
\hline 4.1 .41 .47 & CAT AN instrumentation & $\$ 109.695$ & $\begin{array}{l}\text { ISSTRS requires greater resources than } W-320 \text { due to increased construction management time ISSTRS construction is projected to be } 3 \text { times longer than } W \text { - } \\
320 \text {, hence costs are greater by a factor of } 3 \text {. }\end{array}$ \\
\hline 4.1 .4 .1 .48 & Pit Decon Mock Up & $\$ 71,322$ & $\begin{array}{l}\text { ISSTRS requires greater resources than W-320 due to increased construction management time. ISSTRS construction is projected to be } 3 \text { limes ionger than W- } \\
320 \text {; hence costs are greater by a factor of } 3 \text {. }\end{array}$ \\
\hline 41.4 .1 .49 & $\begin{array}{l}\text { Pit Decon } \\
\text { (AX-103, C-103, C-105, A-102, } \\
\text { \& AN-105) }\end{array}$ & $\$ 681,818$ & Estimate based on W-320 SST unit pit decon cost $(\$ 41,958)$ for 15 SST pit decons and W-320 DST unit pit decon Cost $(\$ 52.448)$ for one pit decon \\
\hline+1.4 .150 & New Valve Pits (2) & $\$ 240,000$ & Estimate based on engineering judgement using $10 \%$ of modification cost for each new valve pit \\
\hline 4.1.4.1.51 & New Pump Pits on AN-105 & $\$ 150.000$ & Estimate based on engineering judgement using $10 \%$ of modification cost for new pump pit. \\
\hline
\end{tabular}




\section{ISSTRS Conceptual Design (90\% Design Review) Cost Estimate}

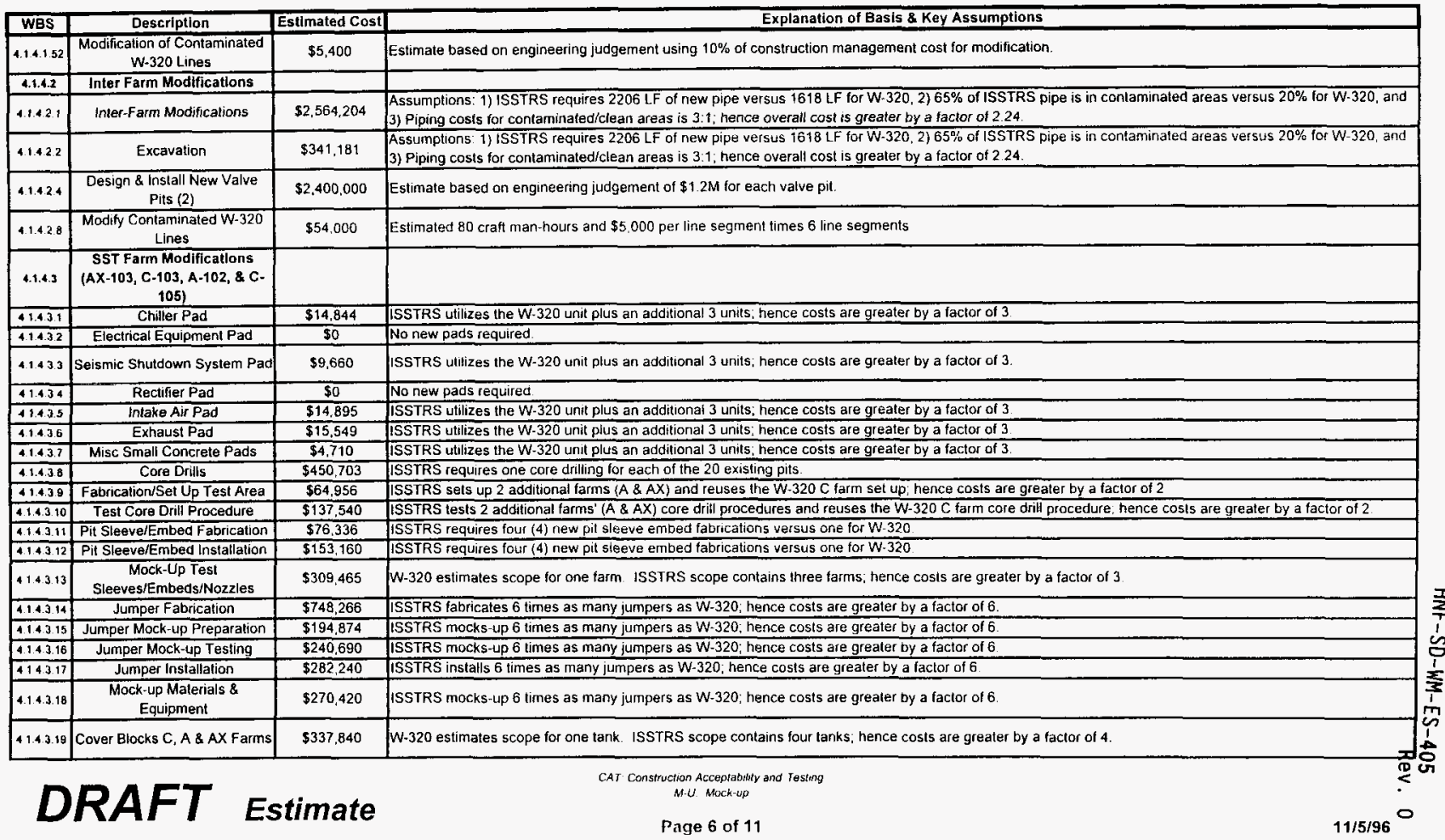




\section{ISSTRS Conceptual Design (90\% Design Review) Cost Estimate}

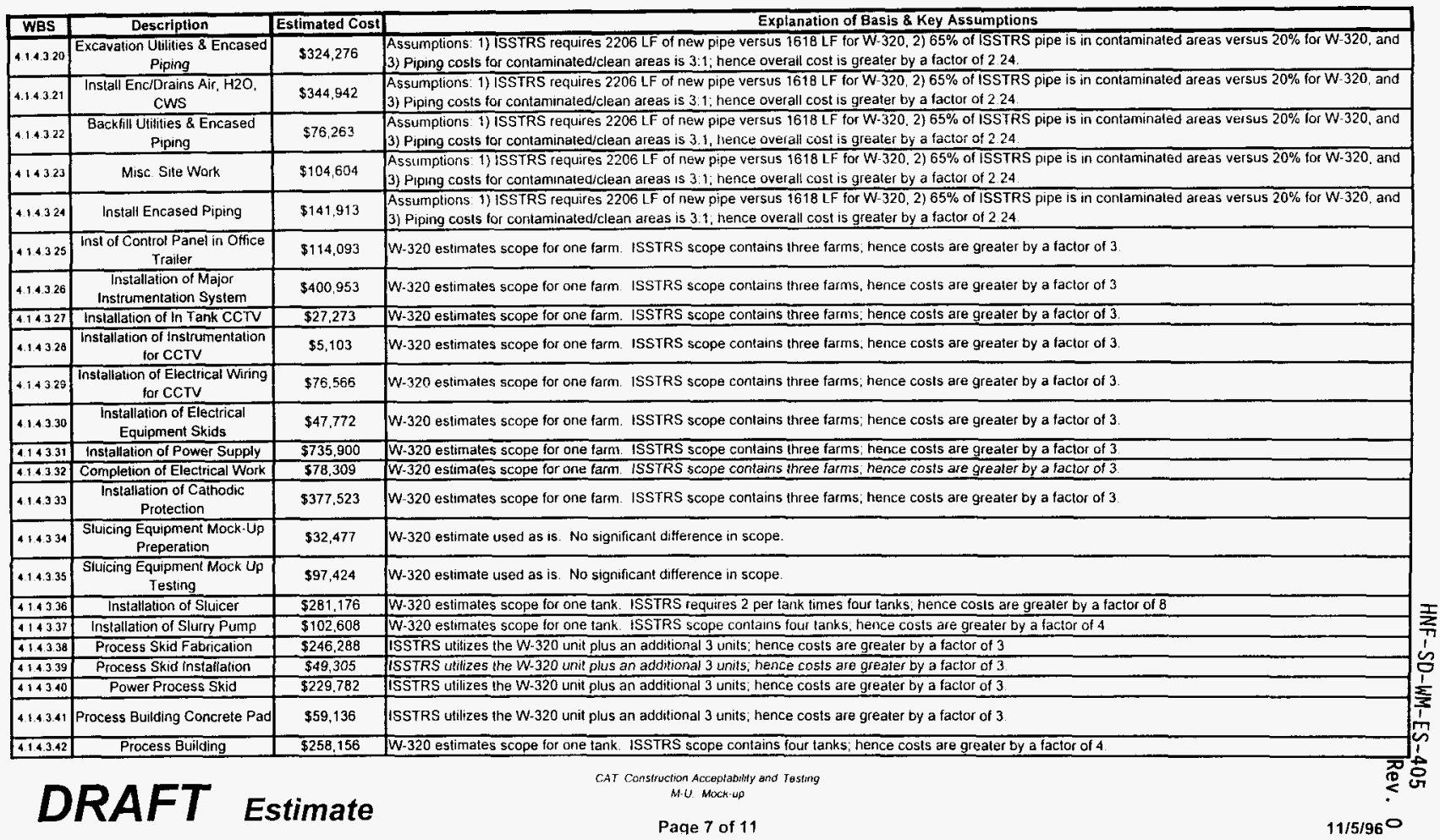




\section{ISSTRS Conceptual Design (90\% Design Review) Cost Estimate}

\begin{tabular}{|c|c|c|c|}
\hline WBS & Description & Estimated Cos! & Explanation of Basis \& Key Assumptions \\
\hline 4.1 .4 .3 .43 & Ventilation \& Exhaust System & $\$ 545,562$ & $\begin{array}{l}\text { ISSTRS utilizes the W-320 unit plus an additional } 3 \text { units; hence costs are greater by a factor of } 3 \text {, and a } 15 \% \text { allowance is made for the increased size of the } \\
\text { moisture monitor, heating coil and recirculation fan for the } 1,000,000 \text { gallon tanks. }\end{array}$ \\
\hline 4.1.4.3.44 & Installation of Chiller Skid & $\$ 30,234$ & ISSTRS utilizes the $W-320$ unil pius an additional 3 units nence costs are greater by a factor of 3 . \\
\hline 4143.45 & Support Area & $\$ 577,941$ & ISSTRS utifizes the $W-320$ urit plus an additional 3 units, hence costs are greater by a factor of 3 . \\
\hline 4.14346 & Heel Pump & $\$ 20.000$ & ISSTRS requires heel pumps for four lanks; an engineering assessment is that these pumps can be obtained for approximately $\$ 5,000$ each \\
\hline 4.1.4.4 & DST (AN-105) Modilications & & \\
\hline 41.44 & Fabrication of Misc Pads & $\$ 68,759$ & W-320 estimale used as is. No signilicant difference in scope from W-320. \\
\hline 11442 & Core Drills & $\$ 147.781$ & W-320 estimate used as is No significant difference in scope from W- 320 . \\
\hline 4.1 .443 & $\begin{array}{l}\text { Pil Sleeves/Embeds } \\
\text { Fabrication }\end{array}$ & $\$ 10,037$ & W-320 estimate used as is. No significant difference in scope from W-320 \\
\hline 4.1.4.4. & $\begin{array}{l}\text { Pit Sleeves/Embeds } \\
\text { Installation }\end{array}$ & $\$ 6,366$ & W-320 estimate used as is. No significant difference in scope from W- 320 . \\
\hline 4.1.4.4.5 & Jumper Fabrication & $\$ 205,742$ & W-320 estimate used as is and jumper assumed non-retis able. No significant difference in scope from W-320. \\
\hline .1446 & Jumper Installation & $\$ 305,412$ & W-320 estimate used as is No significant difference in scope from W-320. \\
\hline 4.1 .447 & Backfill Pits & $\$ 3,246$ & W-320 estimate used as is. No significant difference in scape from W-320. \\
\hline 4.1 .48 & Fabricate New Cover Blocks & $\$ 39.798$ & $W-320$ estimate used as is. No significant difference in scope from W-320. \\
\hline 4144.9 & Install New Cover Blocks & $\$ 10,034$ & W-320 estimale used as is. No significant difference in scope from W-320. \\
\hline 4.1 .4 .10 & Excavation for Encased Piping & $\$ 36,081$ & W-320 estimate used as is. No significant difference in scope from W-320. \\
\hline 4.4 .4 .12 & $\begin{array}{l}\text { Instaliation of Distribution } \\
\text { Panel }\end{array}$ & $\$ 26,503$ & W-320 estimate used as is. No significant difference in scope from W-320. \\
\hline 4.1 .4 .4 .13 & $\begin{array}{l}\text { Installation of Seismic } \\
\text { Shutdown Switch }\end{array}$ & $\$ 4,604$ & W-320 estimate used as is. No significant difference in scope from W-320. \\
\hline 4.14 .14 & Installation of Power & $\$ 111,727$ & $W$-320 estimate used as is. No significant difference in scope from W-320 \\
\hline $4.1+4.15$ & Complete Misc Electrical Work & $\$ 1,022$ & $W-320$ estimate used as is. No significant difference in scope from W-320. \\
\hline 4.14 .4 .16 & Install Cathodic Protection & $\$ 1,830$ & W-320 estimale used as is. No significant difference in scope from W-320. \\
\hline 4.1.4.4.17 & $\begin{array}{l}\text { Install Insirument House \& } \\
\text { Associated Instrumentation }\end{array}$ & $\$ 48,714$ & W-320 estimate used as is. No significant difference in scope from W-320. \\
\hline 4.1.4.1.18 & Support Area & $\$ 94,212$ & $W-320$ eslimate used as is No significant difference in scope from $W-320$ \\
\hline 4.1.4.19 & $\begin{array}{c}\text { Fabricate \& Install New Pump } \\
\text { Pit for AN-105 }\end{array}$ & $\$ 1,500,000$ & Estimate based on engineering judgement. \\
\hline 4.1 .4 .20 & AN-105 HVAC Modifications & $\$ 15,000$ & Estimate based on engineering judgement. \\
\hline 4.1.4.6 & Expense Procurement & & \\
\hline 4.1.4.5.1 & $\begin{array}{l}\text { Technical Support to } \\
\text { Procurement }\end{array}$ & $\$ 579,148$ & ISSTRS procurement time is projected to be double of that of W-320; hence costs are twice those of W-320. \\
\hline
\end{tabular}




\section{ISSTRS Conceptual Design (90\% Design Review) Cost Estimate}

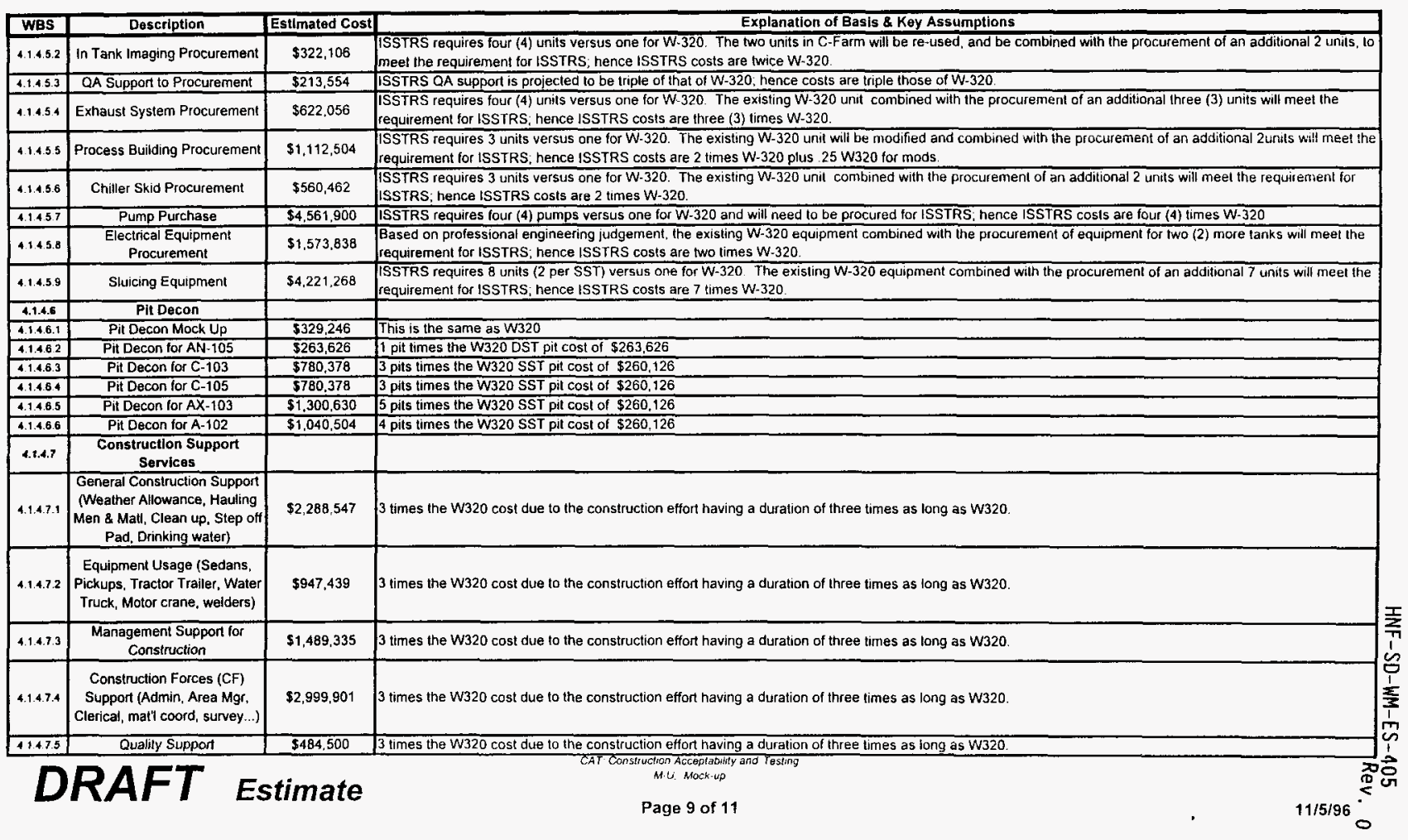




\section{ISSTRS Conceptual Design (90\% Design Review) Cost Estimate}

\begin{tabular}{|c|c|c|c|}
\hline WBS & Description & Estimated cost & Explanation of Basis \& Key Assumptions \\
\hline 4.1.4.4 & $\begin{array}{l}\text { Equipment Removal } \\
\text { Construction }\end{array}$ & & \\
\hline 4.1.4.8.1 & Equipment Removal & $\$ 20,524,535$ & ISSTRS has 5 tanks while W320 has two. This is the $W 320$ cost time $5 / 2$. \\
\hline 41.8 .2 & D\&D of Removed Equipment & $\$ 100,000$ & This estimate is based upon an engineering iudgement of $\$ 20,000$ per tank. \\
\hline 6.1 .5 & Other Project Costs & & \\
\hline 4.1.5.1 & Startup Administration & & \\
\hline 41511 & Startup Adminsitration & $\$ 6,551,992$ & ISSTRS has 4 new SST to DST systems. W320 has one SST to DST system. This cost is W320 times 4 \\
\hline 41512 & Ouality Assurance Support & $\$ 585,968$ & ISSTRS has 4 new SST to DST systems, W320 has one SST to DST system. This cost is W320 times 4. \\
\hline 4.1.5.2. & Startup Support & & \\
\hline 4.1 .522 & $\begin{array}{l}\text { Slartup Testing Maintenance } \\
\text { Craft Support }\end{array}$ & $\$ 469,994$ & ISSTRS has 4 new SST to DST systems; W320 has one SST to DST system. This cost is W320 times 4 . \\
\hline 41523 & Health Physics Support & $\$ 687,482$ & ISSTRS has 4 new SST to DST systems. W320 has one SST to DST system. This cost is W320 times 4 \\
\hline 11.5 .24 & Tank Farm Operations Suppont & $\$ 469,994$ & ISSTRS has 4 new SST to DST systems; W320 has one SST to DST system. This cost is W320 times 4. \\
\hline 4.1 .5 .2 .5 & Independent Safety Support & $\$ 281,438$ & ISSTRS has 4 new SST to DST systems: W320 has one SST to DST system. This cost is W320 times 4 \\
\hline 4.1 .5 .3 & Startup Testing & & \\
\hline 4.1.5.3.1 & Prepare \& Perform OTPs & $\$ 2,580,343$ & Assumes the $\mathrm{W} 320$ cost on the 1 st startup and a $20 \%$ improvenient on each successive slartup due to leaming improvements \\
\hline 1.6.3.2 & $\begin{array}{l}\text { Tank Farm Operating } \\
\text { Documents }\end{array}$ & $\$ 611,929$ & Assumes the $\mathrm{W} 320$ cost on the $1 \mathrm{st}$ startup and a $20 \%$ improvement on each successive startup due to learning improvernents. \\
\hline 4.1.5.4 & Startup Readiness Review & & \\
\hline 4.1.5.1.1 & ORR Documentation & $\$ 3,998,695$ & $\begin{array}{l}\text { Assumes the W320 ORR cost times two (because the W320 ORR overran by a } 2: 1 \text { factor). Successive ORRs are equal to W320 because of experience gained } \\
\text { from the } 1 \text { st ORR. }\end{array}$ \\
\hline 4.1 .6 & Safety \& Environmental & & \\
\hline 4.1.6.1 & Environmental Management & & \\
\hline 4.16 .1 & Environmental Management & $\$ 327,600$ & 6 years $\times 1$ person $\times 50 \%$ time $=5.460 \mathrm{~m}$-hrs $\quad \times \$ 60$ per hour \\
\hline 4.1.6.2 & Safety Management & & \\
\hline 41.6 .2 .1 & Safety Management & $\$ 327,600$ & 6 years $\times 1$ person $\times 50 \%$ time $=5,460 \mathrm{~m}$-hrs \\
\hline 4.1.6.3 & Safety & & \\
\hline 4.163 .1 & $\begin{array}{l}\text { Prepare Final Safety } \\
\text { Assesment }\end{array}$ & $\$ 2,921,512$ & Uses W320 estimate but with a 1.5 complexity factor due to the larger size of the total project scope. \\
\hline 4.1.6.3.2 & $\begin{array}{l}\text { Review Final Safely } \\
\text { Assesment }\end{array}$ & $\$ 143,740$ & Uses W320 estimate but with a 1.5 complexity factor due to the larger size of the total project scope. \\
\hline 4.16 .3 .3 & SEAC ReView SASSEL & $\$ 18,193$ & Uses W320 estimate but with a 1.5 complexity factor due to the larger size of the total projecl scope. \\
\hline
\end{tabular}




\section{ISSTRS Conceptual Design (90\% Design Review) Cost Estimate}

\begin{tabular}{|c|c|c|c|}
\hline WBS & Description & Estlmated Cost & Explanation of Basis \& Key Assumptions \\
\hline 4.16.34 & DOE-RL Review of SA & $\$ 37,510$ & Uses W320 estimate but with a 1.5 complexity factor due to the larger size of the total project scope. \\
\hline 4.16.4 & NEPA & & \\
\hline 4.1.6.4.1 & NEPA & $\$ 500,000$ & Basic NEPA effort is the same as W320, but an allowance is included for a complete environmental assessment. \\
\hline 4.1.6.6 & RCRA & & \\
\hline 4.16.5.1 & RCRA & $\$ 273,000$ & Assumes 1 person for 2.5 years at full time $=4.550 \mathrm{~m}$-hrs. @ $\$ 60$ per $m$-hr. \\
\hline 4.1.6.8 & CAA & & \\
\hline 4.1.8.6.1 & CAA Technical Services & $\$ 165,716$ & Uses same values as the $W 320$ estimate. \\
\hline 41.6 .82 & Review CAA & $\$ 2.476$ & Uses same values as the $W 320$ estimate. \\
\hline 4.1 .6 .8 .3 & Outside Agency Review & $\$ 2.476$ & Uses same values as the W320 estimate. \\
\hline 4.1 .6 .6 .4 & Permit Preparation & $\$ 3,354$ & Uses same values as the W320 estimate. \\
\hline \multicolumn{3}{|c|}{ ISSTRS Conceptual Design (90\%) Estlmate Total: } & $\$ 147,441,635$ \\
\hline \multicolumn{3}{|c|}{ Contingency (per Table 7-1 of DOE-RLIO 5700.3; @20\%): } & $\$ 29,488,327$ \\
\hline \multirow{2}{*}{\multicolumn{2}{|c|}{$\begin{array}{l}\text { (W320 was done in FY95; thls } \\
\text { eutumate is escalated to constant } \\
\text { FYg7 dotlars e } 2.7 \% \text { per year) }\end{array}$}} & Total: & $\$ 176,929,963$ \\
\hline & & w/ Escalation: & $\$ 186,613,163$ \\
\hline
\end{tabular}

\section{DRAFT Estimate}




\section{APPENDIX B}

\section{WORK SCHEDULE}


This page left intentionally blank. 


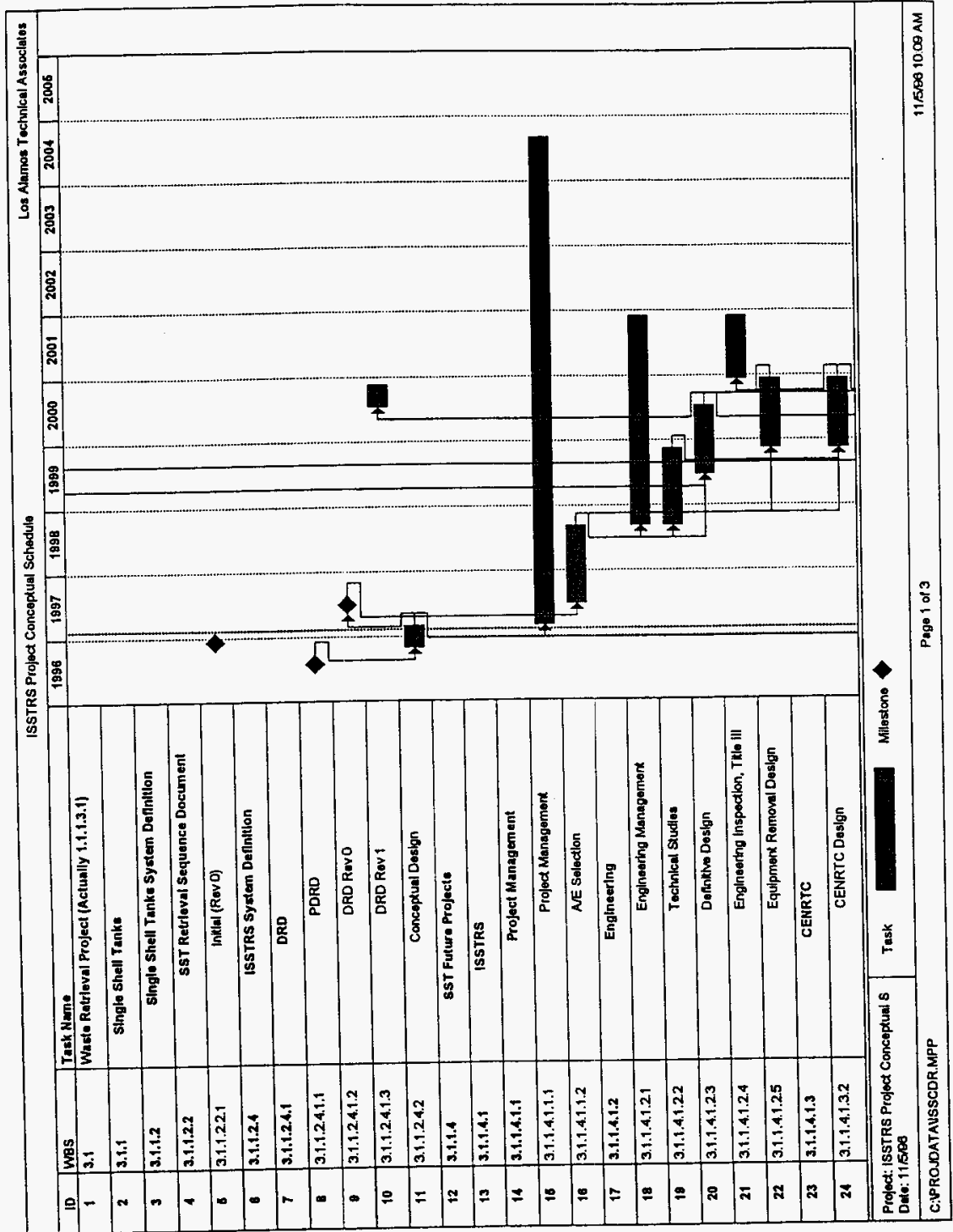

B-3 


\begin{tabular}{|c|c|c|c|c|c|c|c|c|c|c|c|c|c|}
\hline \multicolumn{10}{|c|}{ ISSTRS Project Concoptual Schodulo } & \multicolumn{4}{|c|}{ Los Alemos Technical Associates } \\
\hline ID. & was & \multicolumn{2}{|l|}{ Task Name } & 1998 & 1997 & 1998 & 1999 & \begin{tabular}{|l|l|}
2000 & 2001 \\
\end{tabular} & 2002 & 2003 & 2004 & 2005 & \\
\hline 28 & 3.1.1.4.1.3.4 & \multicolumn{2}{|r|}{ CENRTC Procurement } & & & & & & & & & & \\
\hline 26 & 3.1 .1 .4 .1 .3 .5 & \multicolumn{2}{|r|}{ CENRTC Fubricetion } & & & & & & & & & & \\
\hline 27 & 3.1.1.4.1.4 & \multicolumn{2}{|r|}{ Constructlon } & & & & & & & & & & \\
\hline 28 & 3.1 .1 .4 .1 .4 .1 & \multicolumn{2}{|r|}{ Construction Managoment } & & & & & & & & & & \\
\hline 29 & 3.1 .1 .4 .1 .4 .2 & \multicolumn{2}{|r|}{ Inter Farm Modificutions } & & & & & & & & & & \\
\hline 30 & 3.1.1.4.1.4.3 & \multicolumn{2}{|r|}{ SST Farm ModIneatione } & & & & & & & & & & \\
\hline 31 & 3.1 .1 .4 .1 .4 .3 .1 & \multicolumn{2}{|r|}{$A x-100$} & & & & & & & & & & \\
\hline 32 & 3.1 .1 .4 .1 .4 .3 .2 & \multicolumn{2}{|r|}{ C. 100} & & & & & & & & & & \\
\hline 33 & 3.1.1.4.1.4.3.3 & \multicolumn{2}{|r|}{ A-102 } & & & & & & & & & & \\
\hline 34 & 3.1 .1 .4 .1 .4 .3 .4 & \multicolumn{2}{|r|}{ C-105 } & & & & & & & & & & \\
\hline 36 & 3.1 .1 .4 .1 .4 .4 & \multicolumn{2}{|r|}{ DST (AN Farm \& AN-106) Modfica } & & & & & & & & & & \\
\hline 36 & 3.1.1.4.1.4.5 & \multicolumn{2}{|r|}{ Expenso Procurements } & & & & & & & & & & \\
\hline 37 & 3.1.1.4.1.4.6 & \multicolumn{2}{|r|}{ PR Docon } & & & & & 2 & & & & & \\
\hline 38 & 3.1.1.4. 1.4.7 & \multicolumn{2}{|r|}{ Construction Support Servces } & & & & & 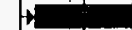 & & & & & \\
\hline 39 & $\overline{3.1 .1 .4 .1 .4 .8}$ & \multicolumn{2}{|r|}{ Equipment Removal Construction } & & & & & & & & & & \\
\hline 40 & 3.1 .1 .4 .1 .6 & \multicolumn{2}{|r|}{ Other Project Costs } & & & & & & & & & & \\
\hline 41 & 3.1 .1 .4 .1 .5 .1 & \multicolumn{2}{|r|}{ Startup Administration } & & & & & & & & & & \\
\hline 12 & 3.1 .1 .4 .1 .5 .2 & \multicolumn{2}{|r|}{ Startup Support } & & & & & & & & & & \\
\hline 43 & 3.1.1.4.1.6.3 & \multicolumn{2}{|r|}{ Sturtup Testlng } & & & & & & & & & & \\
\hline 44 & $3.1,1.4 .1 .5 .3 .1$ & \multicolumn{2}{|r|}{ Ax-100 } & & & & & & & & & & \\
\hline 46 & 3.1 .1 .4 .1 .5 .3 .2 & \multicolumn{2}{|r|}{ C. 100} & & & & & & & & & & \\
\hline 48 & 3.1 .1 .4 .1 .5 .3 .3 & \multicolumn{2}{|r|}{ A-102 } & & & & & & & & & & \\
\hline 17 & 3.1 .1 .4 .1 .5 .3 .4 & \multicolumn{2}{|r|}{ C-106 } & & & & & & & & & & \\
\hline 48 & 3.1 .1 .4 .1 .6 .4 & \multicolumn{2}{|r|}{ Startup Readlnese Revlew } & & & & & & & & & & \\
\hline $\begin{array}{l}\text { Projoc } \\
\text { Deto: }\end{array}$ & $\begin{array}{l}\text { ISSTRS Project C } \\
15 D 0\end{array}$ & Conceptuat 8 & Tnsk & & & & & & & & & & \\
\hline \multicolumn{4}{|c|}{ C:PROJDATAVSSCOR.MPP } & & 1. 2013 & & & & & & & $1 / 5061$ & D AM \\
\hline
\end{tabular}




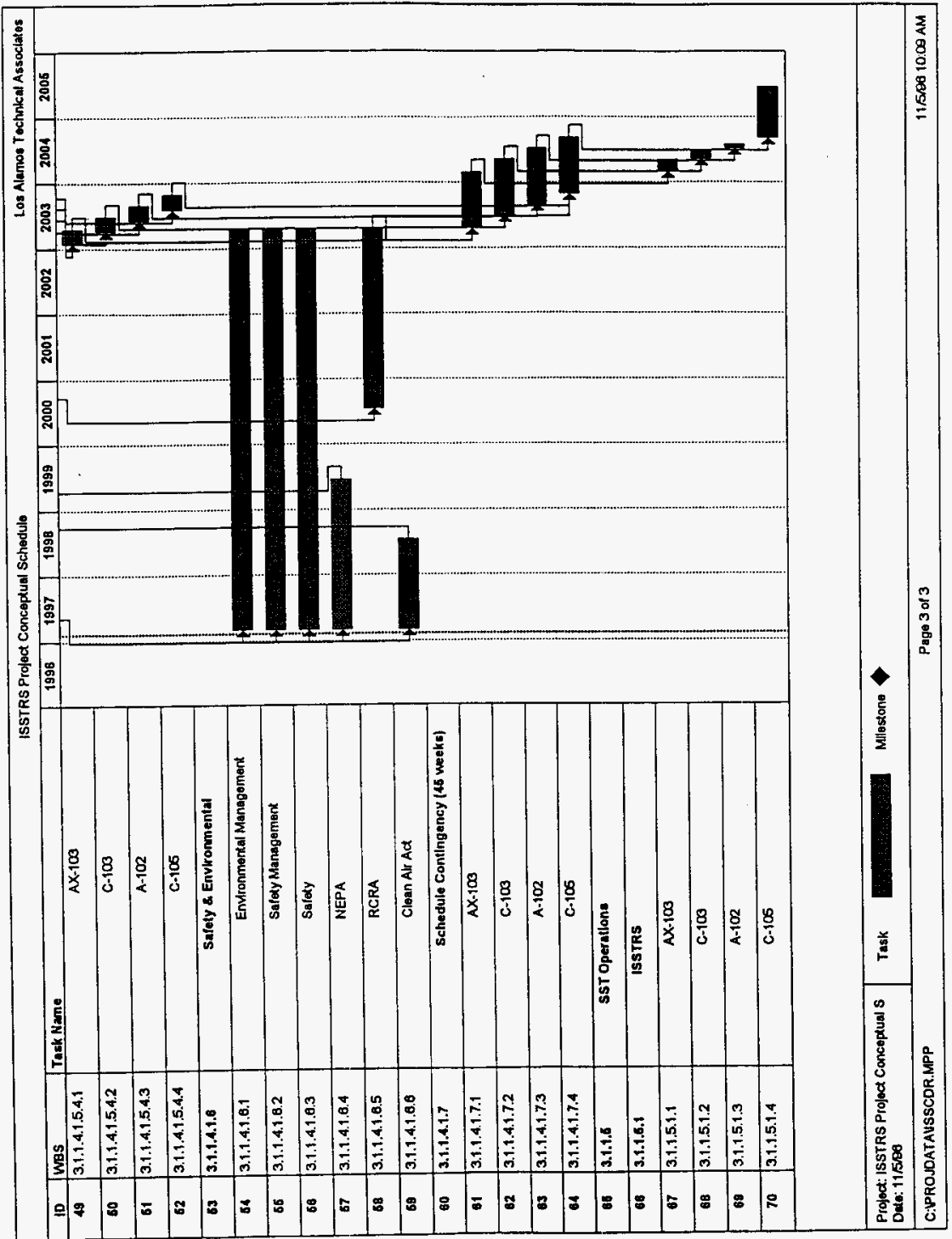


Rev. 0

\title{
PROJECT DESIGN SPECIFICATIONS FOR THE INITIAL SINGLE-SHELL TANK RETRIEVAL SYSTEM
}

\author{
Review Copy
}

Prepared By:

LOS ALAMOS TECHNICAL ASSOCIATES, INC.

Richland, WA

November 1996 
Approved by:
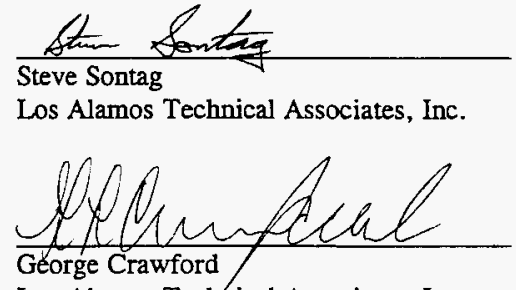

Los Alamos Technical Associates, Inc.
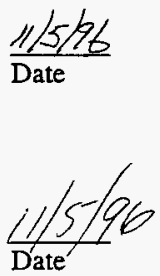


\section{CONTENTS}

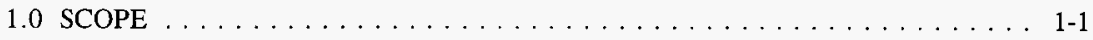

1.1 IDENTIFICATION . . . . . . . . . . . . . . . . 1-1

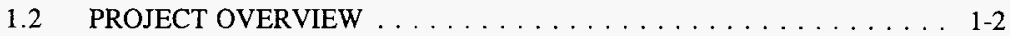

1.3 DOCUMENT OVERVIEW $\ldots \ldots \ldots \ldots \ldots \ldots \ldots \ldots \ldots \ldots$

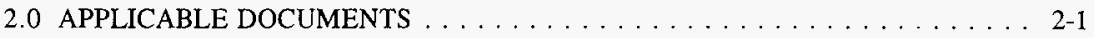

2.1 GOVERNMENT DOCUMENTS . . . . . . . . . . . 2-1

2.1.1 Hanford Site Documents/Other . . . . . . . . . . . . . . 2-4

2.2 NON-GOVERNMENT DOCUMENTS $\ldots \ldots \ldots \ldots \ldots \ldots \ldots . . \ldots . \ldots$

2.2.1 Information Documents: Process Flowsheet . . . . . . . 2-5

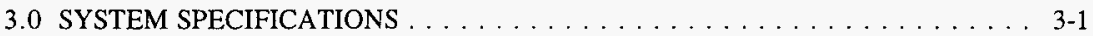

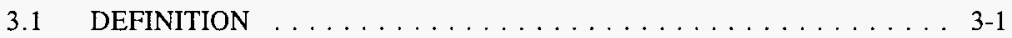

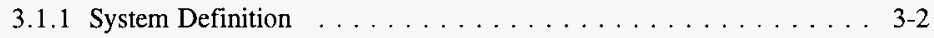

3.2 CHARACTERISTICS . . . . . . . . . . . . . . . 3-7

3.2.1 Performance Characteristics . . . . . . . . . . . . 3-8

3.2 .2 System Relationships $\ldots \ldots \ldots \ldots \ldots \ldots \ldots \ldots \ldots . . \ldots \ldots .31$

3.2 .3 External Interfaces . . . . . . . . . . . . . . . 3-32

3.2.4 Physical Characteristics . . . . . . . . . . . . . . .37

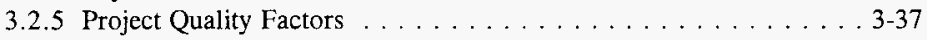

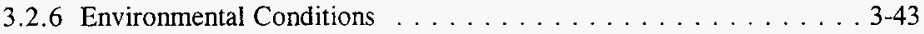

3.2 .7 Transportability . . . . . . . . . . . . . . . . 3-45

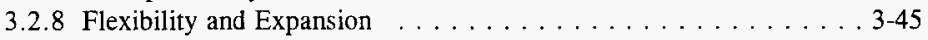

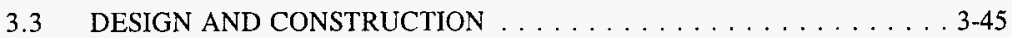

3.3.1 Materials, Processes and Design Practices . . . . . . . 3-45

3.3.2 Radiation . . . . . . . . . . . . . . . . 3-53

3.3.3 Nameplates and Product Marking . . . . . . . . . . . 3-55

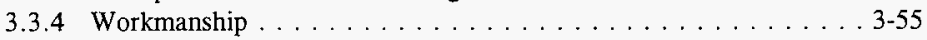

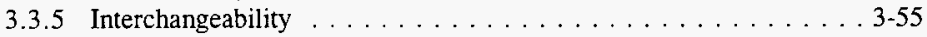

3.3 .6 Safety . . . . . . . . . . . . . . . . . . . . . .

3.3.7 Human Engineering . . . . . . . . . . . . . . . . . . . . .

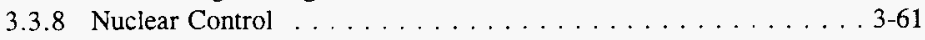

3.3 .9 Security . . . . . . . . . . . . . . . . . . 3-61

3.3.10 Government Furnished Property Usage . . . . . . . . . . . 3-61

3.3.11 Computer Resource Reserve Capacity . . . . . . . . . . . 3-61

3.4 INFORMATION . . . . . . . . . . . . . . . . 3-63 


\section{CONTENTS (Continued)}

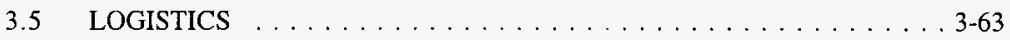

3.5.1 Maintenance . . . . . . . . . . . . . . . . 3-63

3.5.2 Waste Handling, Storage and Disposal . . . . . . . . . 3-64

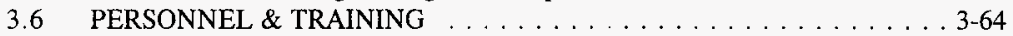

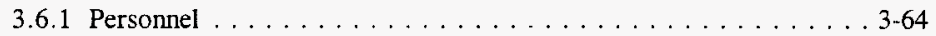

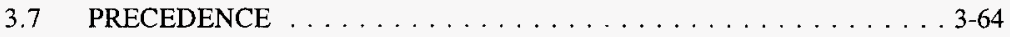

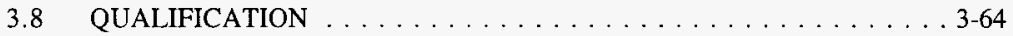

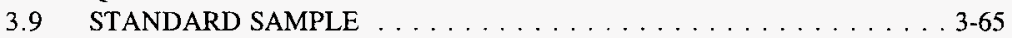

3.10 PREPRODUCTION SAMPLE, PERIODIC PRODUCTION

SAMPLE, PILOT LOT $\ldots \ldots \ldots \ldots \ldots \ldots \ldots \ldots \ldots \ldots$

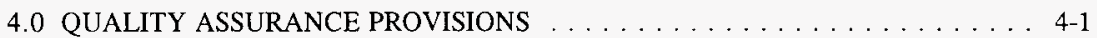

4.1 ACCESS FOR INSPECTION $\ldots \ldots \ldots \ldots \ldots \ldots \ldots \ldots \ldots$ 4-1

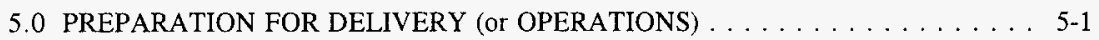

APPENDIX A $\quad$ SINGLE SHELL TANK INVENTORIES . . . . . . . A-1 


\section{LIST OF TABLES}

1-1. Selected Tri-Party Agreement Milestones . . . . . . . . . . . . . . 1-2

2-1. Applicable Constraint Documents . . . . . . . . . . . . . . . . . . 2-1

2-2. Westinghouse Hanford Company Documents and Other Applicable Codes . . . . 2-4

2-3. Supporting Documents . . . . . . . . . . . . . . . . . . . 2-5

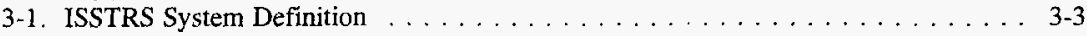

3-2. Maximum Soil Depth/Live Loads Above Tanks . . . . . . . . . . . . . . . . . . 3-9

3-3. Maximum Soil Depth/Live Loads Above Tanks Double-Shell Waste

Storage Tanks (241-AY, AZ Tank Farms) . . . . . . . . . . . . . . . . . 3-9

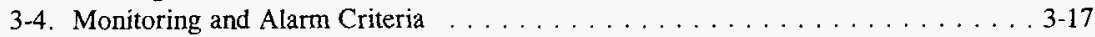

3-5. Shield Design Criteria . . . . . . . . . . . . . . . . . . . . . 3-40

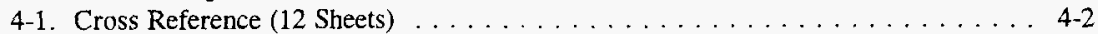

A-1. Single-Shell Tank 241-C-105 (2 Sheets). . . . . . . . . . . . . . A-2

A-2. Single-Shell Tank 241-C-103 (2 Sheets). . . . . . . . . . . . . A A-4

A-3. Single-Shell Tank 241-AX-103 (2 Sheets) . . . . . . . . . . . . A A-6 


\section{LIST OF TERMS}

\section{Acronyms}

ACTR

ALARA

ANSI

AWP

BACT

BACRT

CC

CFR

CP

DC

DCG

DIL

DOE

DST

DQO

EDE

EEM

EIS

ETF

HEPA

HLW

HSRCM

HVAC

ISSTRS

LERF

LLW

NEHRP

NRC

OSD

PNL

ppm

PSD

PSO

QAPP

RACT

RAEP

RCRA

RL

SSC
Acquire Commercial Technology for Retrieval

As Low As Reasonably Achievable

American National Standards Institute

Air and Water Permit

Best Available Control Technology

Best Available Radionuclide Control Technology

Complexant Concentrate

Code of Federal Regulations

Concentrated Phosphate Waste

Dilute Complexant Waste

Derived Concentration Guide

Drainable Interstitial Liquid

U.S. Department of Energy

Double-Shell Tank

Data Quality Objectives

Effective Dose Equivalent

Environmental Emission Management

Environmental Impact Statement

Effluent Treatment Facilities

High Efficiency Particulate Air

High Level Waste

Hanford Site Radiological Control Manual

Heating, Ventilating and Air Conditioning

Initial Single-Shell Tank Retrieval System

Liquid Effluent Retention Facility

Low Level Waste

National Earthquake Hazards Reduction Program

Nuclear Regulatory Commission

Operating Specification Document

Pacific National Laboratory

Parts per Million

Prevention of Significant Deterioration

Plant Safety Officer

Quality Assurance Program Plan

Reasonable Available Control Technology

Radionuclide Air Emission Program

Resource Conservation and Recovery Act of 1976

Richland Operations Office

Structures, systems and components 


\section{LIST OF TERMS (Continued)}

SpG

SST

SWDP

TBD

TGA

TCO

TOX

TPA

TRU

TWRS

USQ

WAC

WHC

WPS

WRS

WTS
Specific Gravity

Single-shell Tank

State Waste Discharge Permit

To Be Determined

Thermo Gravimetric Analysis

Total Organic Carbon

Total Organic Halogen

Tri-Party Agreement

Transuranic

Tank Waste Remediation System

Unreviewed Safety Question.

Washington State administrative Code

Westinghouse Hanford Company

Waste Pretreatment Storage

Waste Retrieval System

Waste Tank Storage 


\subsection{SCOPE}

A Project Design Specification (PDS) is the final requirements document following after the functions and requirements, technical requirements specification, and the design requirements document. The purpose of the PDS is to define the functions, requirements and architecture of the sub-systems and component elements that will comprise the project. The PDS, in coordination with the Conceptual Design drawings, defines the project understanding to this design stage and will be used as the basis for all future project work. Anticipated future work would include competitive bidding for final design and final design.

The Initial Single-Shell Tank Retrieval System (ISSTRS) supports the Tank Waste Remediation System (TWRS) retrieve waste functions, and specifically provides a tank farm demonstration for retrieval of waste from selected SSTs. Both saltcake and sludge retrieval will be demonstrated.

Conceptual design of ISSTRS provides a technical basis, physical concept, schedule and conceptual level cost for the project Design Configuration Baseline (DCBL) as described in the TWRS System Engineering Management Plan (SEMP) and supplemented by the ISSTRS Project SEMP. The ISSTRS project objective is to design. fabricate, and install waste retrieval systems, waste transfer lines, tank HVAC systems and infrastructure necessary to begin waste retrieval operations in the first Single-Shell Tank Farm by November, 2003.

The tank farms in the 200 West and 200 East areas at the Hanford site were installed to receive high level liquid waste from nuclear fuel processing and the production of special nuclear materials. Subsequent operations have resulted in mixing of wastes between tanks, volume reduction of the liquid with a corresponding increase in the solids content and physical isolation of some of the tanks. A total of 149 single-shell tanks (SSTs) were built between 1943 and 1964 and are clustered in rectangular arrays of 2 to 18 tanks called tank farms. No wastes have been added to any SST since 1980. There are 28 double-shell tanks (DSTs) arranged in tank farms of 2 to 8 tanks each, which were built between 1971 and 1986 . DSTs still receive waste on an as needed basis. The four SSTs specified for retrieval under ISSTRS are 241-A-102, 241-AX-103, 241-C-103, and 241-C-105 whose wastes are to be transferred to the DST 241-AN-105.

\subsection{IDENTIFICATION}

PROGRAM: TWRS, Remove Limited SST Waste (TWRS Function No. 4.2.2.1.4)

PROIECT: ISSTRS (Project XXX) 


\section{MISSION:}

- Satisfy the M-45-04 series of the Tri-Part Agreement milestones,

- Provide the initial retreival portion of the farm demonstration step of defining the limit of technlogy as defined in Figure 1, Attachment 1, TPA Change Form M-4593-01, approved $1 / 25 / 95$, and

- Demonstrate the feasibility of sluicing as applied by Project W-320 for saltcake retreival.

REFERENCE: ISSTRS Task Mission Analysis Report, WHC-SD-WM-MAR-009, Rev. 1.

\subsection{PROJECT OVERVIEW}

The fourth amendment to the Hanford Federal Facility Agreement and Compliance Order (Tri-Party Agreement) and U.S. Department of Energy (DOE) policy decision form the bases for the Tank Waste Remediation System (TWRS) mission. The bases includes: (1) retrieval and closure of both single shell, double-shell, miscellaneous underground tank waste, (2) disposal of immobilized Low Level Waste (LLW) onsite, (3) disposal of immobilized High Level Waste (HLW) offsite, (4) separation of immobilized transuranic wastes. The Hanford Federal Facility Agreement and Compliance Order (Tri-Party Agreement) specifies milestones which form the bases for ISSTRS as shown in Tables 1-1. Compliance with the Tri-Party Agreement to fulfill the commitment to complete retrieval of SST waste will be accomplished by a successful saltcake retrieval demonstration by ISSTRS.

Table 1-1. Selected Tri-Party Agreement Milestones.

\begin{tabular}{|l|l|l|}
\hline \multicolumn{1}{|c|}{$\begin{array}{l}\text { Milestone } \\
\text { Number }\end{array}$} & \multicolumn{1}{|c|}{ Title } \\
M-45-04A & $\begin{array}{l}\text { Complete conceptual design for the initial SST } \\
\text { retrieval systems. }\end{array}$ & April 30,1997 \\
\hline M-45-04-T02 & $\begin{array}{l}\text { Complete design for the initial SST retrieval } \\
\text { systems. }\end{array}$ & December 31, 2000 \\
\hline M-45-04-T03 & $\begin{array}{l}\text { Complete construction for the initial SST retrieval } \\
\text { systems. }\end{array}$ & June 30, 2003 \\
\hline M-45-05-T01 & $\begin{array}{l}\text { Provide initial single-shell tank retrieval system. } \\
\text { Complete construction and related testing of the } \\
\text { initial SST retrieval systems. This milestone will } \\
\text { provide retrieval systems for an entire single-shell } \\
\text { tank farm or an equivalent number of tanks. }\end{array}$ & November 30, 2003 \\
\hline
\end{tabular}


Table 1-1. Selected Tri-Party Agreement Milestones.

\begin{tabular}{|l|l|l|}
\hline \multicolumn{1}{|c|}{$\begin{array}{c}\text { Milestone } \\
\text { Number }\end{array}$} & \multicolumn{1}{|c|}{ Title } & Date \\
\hline M-45-08-T02 & $\begin{array}{l}\text { Establish the criteria through stakeholder, } \\
\text { participation and ecology approval for: (1) } \\
\text { Determining allowable leakage volumes, and (2) } \\
\text { Acceptable leak monitoring/detection and } \\
\text { mitigation measures necessary to permit sluicing } \\
\text { operations. Consistent with authorities granted by } \\
\text { EPA and the state under its delegated hazardous } \\
\text { waste management program, ecology will have } \\
\text { final authority in determining acceptable criteria for } \\
\text { this target activity, }\end{array}$ & April 30,1997 \\
\hline M-45-08A & $\begin{array}{l}\text { Complete systems design and operating strategy for } \\
\text { tank leak monitoring and mitigation for systems to } \\
\text { be used with initial retrieval systems for SSTs. }\end{array}$ & December 31, 2000 \\
\hline M-45-08B & $\begin{array}{l}\text { Complete demonstration and installation of leak } \\
\text { monitoring and mitigation systems for initial SST } \\
\text { retrieval. }\end{array}$ & June 30, 2003 \\
\hline $\begin{array}{l}\text { M-45-09A } \\
\text { through -09H }\end{array}$ & $\begin{array}{l}\text { Submit annual progress reports on the development } \\
\text { of waste tank leak monitoring/detection and } \\
\text { mitigation activities in support of M-45-08. } \\
\text { Reports will describe work accomplished under } \\
\text { M-45-08, technologies, applications, cost, } \\
\text { schedule, and technical data. Reports will also } \\
\text { evaluate demonstrations done by DOE and private } \\
\text { industry for applicability to SST retrieval and } \\
\text { provide recommendations for further testing for use } \\
\text { in retrieval operations. }\end{array}$ & $\begin{array}{l}\text { September 30, } \\
\text { September 30, 2003 to }\end{array}$ \\
\hline
\end{tabular}

The objective of the SST Retrieval is the retrieval of waste from Single Shell Tanks (SSTs) to permit the closure of these tanks in accordance with regulatory requirements. The regulatory requirement for SSTs is retrieval all but 30 or $360 \mathrm{ft}^{3}$ of waste from each tank.

Past Practice Sluicing alone mayl not accomplish the objective of retrieving SST waste. The Hanford Tank Initiative (HTI) is tasked with developing a variety of post-sluicing heel retreival technologies. 


\subsection{DOCUMENT OVERVIEW}

This PDS was developed from the Preliminary Design Requirements Document (PDRD)

Many documents have been reviewed and used in development of the ISSTRS Mission Analysis and Preliminary Design Requirements Document (PDRD). A major effort has been determination of the applicable requirements and constraints. Requirements are the characteristics that identify how well the system/subsystem/component needs to perform a function. The extent of which a function must be executed is generally measured in terms of quantity, quality, coverage, timeliness or safety. Constraints are limitations or restrictions that must be met. Constraints originate outside the project. Examples are national codes, state and federal regulations.

Supporting documents were also consulted for engineering drawing and specification standards, design loads, and military standards. One new constraint placed on ISSTRS was to modify the equipment, if applicable, for operation in a flammable gas waste storage tank. This means that requirements described in WHC-SD-WM-DGS-005, Rev. 0 must be met. 


\subsection{APPLICABLE DOCUMENTS}

The documents provided in the following Tables form a part of this specification to the extent specified. In the event of conflict between the documents referenced in the Tables and the contents of the specification, the contents of this specification shall be considered a superseding requirement.

\subsection{GOVERNMENT DOCUMENTS}

Federal government and Washington State regulations along with the DOE orders have been reviewed to determine constraints applicable to the design, construction, and operation of the ISSTRS to extent specified. To the extent specified, the references listed in Table 2-1 represent requirements imposed on the ISSTRS by sources external to the TWRS program.

Table 2-1. Applicable Constraint Documents (3 sheets).

\begin{tabular}{|l|l|}
\hline \multicolumn{1}{|c|}{ Document Identifier } & \\
\hline 10 CFR 61 & Licensing Requirement for Land Disposal of Radioactive Waste \\
\hline 10 CFR 830 & $\begin{array}{l}\text { Nuclear Safety Management, Subpart a, General Provisions, } \\
\text { Section 830.120, Quality Assurance Requirement }\end{array}$ \\
\hline 10 CFR 835 & Occupational Radiation Protection \\
\hline 20 CFR 1910 & Occupational Safety and Healthy Standards \\
\hline 20 CFR 1926 & Safety and Health Regulations for Construction \\
\hline 40 CFR 50 & $\begin{array}{l}\text { EPA Regulations on National Primary and Secondary Air } \\
\text { Quality Standards }\end{array}$ \\
\hline 40 CFR 52 & Approval and Promulgation of Implementation Plans. \\
\hline 40 CFR 61 & National Emission Standards for Hazardous Air Pollutants. \\
\hline 40 CFR 260 & Hazardous Waste Management System: General \\
\hline 40 CFR 262 & Standards Applicable to Generators of Hazardous Air Pollutants \\
\hline 40 CFR 264 & $\begin{array}{l}\text { Standards for Owners and Operators of Hazardous Waste } \\
\text { Treatment, Storage and Disposal Facilities }\end{array}$ \\
\hline 40 CFR 270 & $\begin{array}{l}\text { EPA Administered Permit Programs: The Hazardous Waste } \\
\text { Permit Program }\end{array}$ \\
\hline 40 CFR 280 & $\begin{array}{l}\text { Technical Standards and Corrective Action Requirements for } \\
\text { Owners and Operators of Underground Storage Tanks (UST) }\end{array}$ \\
\hline 40 CFR 300 & $\begin{array}{l}\text { National Oil and Hazardous Substances Pollution Contingency } \\
\text { Plan }\end{array}$ \\
\hline
\end{tabular}


Table 2-1. Applicable Constraint Documents (3 sheets).

\begin{tabular}{|c|c|}
\hline Document Identifier & 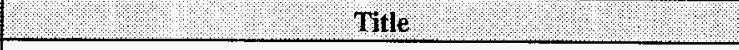 \\
\hline 40 CFR 302 & Designation, Reportable Quantities and Notification \\
\hline 42 USC 6901 & $\begin{array}{l}\text { Resource Conservation and Recovery Act of } 1975 \text { (RCRA) and } \\
\text { Hazardous and Solid Waste Amendments of } 1984 \text { (HSWA) }\end{array}$ \\
\hline DOE Order 1540.2 & $\begin{array}{l}\text { Hazardous Material Packaging for Transportation - } \\
\text { Administrative Procedures }\end{array}$ \\
\hline DOE Order $5000.3 \mathrm{~B}$ & Occurrence Reporting and Processing Operations Information \\
\hline DOE Order 5400.1 & General Environmental Protection Program \\
\hline DOE Order 5400.3 & Hazardous and Radioactive Protection Program \\
\hline DOE Order 5400.4 & $\begin{array}{l}\text { Comprehensive Environmental Response, Compensation, and } \\
\text { Liability Act Requirements }\end{array}$ \\
\hline $\begin{array}{l}\text { DOE Order } 5400.5 \\
(1990)\end{array}$ & Radiation Protection of the Public and the Environment \\
\hline DOE Order 5480.1B & $\begin{array}{l}\text { Environment, Safety, and Health Program for Department of } \\
\text { Energy Operations }\end{array}$ \\
\hline DOE Order $5480.1 \mathrm{E}$ & National Environmental Policy Act Compliance Program \\
\hline $\begin{array}{l}\text { DOE Order } 5480.3 \\
(1985)\end{array}$ & $\begin{array}{l}\text { Safety Requirement for the Packaging and Transportation of } \\
\text { Hazardous Materials, Hazardous Substances, and Hazardous } \\
\text { Waste }\end{array}$ \\
\hline $\begin{array}{l}\text { DOE Order } 5480.4 \\
(1984)\end{array}$ & $\begin{array}{l}\text { Environmental Protection, Safety, and Health Protection } \\
\text { Standards }\end{array}$ \\
\hline $\begin{array}{l}\text { DOE Order } 5480.6 \\
(1992)\end{array}$ & Radiological Control \\
\hline $\begin{array}{l}\text { DOE Order } 5480.7 \mathrm{~A} \\
(1987)\end{array}$ & Fire Protection \\
\hline $\begin{array}{l}\text { DOE Order } 5480.11 \\
(1988)\end{array}$ & Radiation Protection for Occupational Workers \\
\hline DOE Order 5480.19 & Conduct of Operations Requirements for DOE Facilities \\
\hline $\begin{array}{l}\text { DOE Order } 5480.20 \\
\text { (1991) }\end{array}$ & $\begin{array}{l}\text { Personnel Selection, Qualification, Training, and Staffing } \\
\text { Requirements at DOE Reactor and Non-Reactor Nuclear } \\
\text { Facilities }\end{array}$ \\
\hline DOE Order 5480.21 & Unreviewed Safety Questions \\
\hline DOE Order 5480.22 & Technical Safety Requirements \\
\hline DOE Order 5480.23 & Nuclear Safety Analysis Reports \\
\hline
\end{tabular}


Table 2-1. Applicable Constraint Documents (3 sheets).

\begin{tabular}{|c|c|}
\hline Document Identifier & Title \\
\hline $\begin{array}{l}\text { DOE Order } 5480.24 \\
(1992)\end{array}$ & Nuclear Criticality Safety \\
\hline DOE Order 5480.28 & Natural Phenomena Hazards Mitigation \\
\hline \begin{tabular}{|l|}
$\begin{array}{l}\text { DOE Order } 5483.1 \mathrm{~A} \\
(1983)\end{array}$ \\
\end{tabular} & $\begin{array}{l}\text { Occupational Safety and Health Program for DOE Contractor } \\
\text { Employees at Government-Owned Contractor-Operated Facilities }\end{array}$ \\
\hline DOE Order $5500.7 \mathrm{~B}$ & Emergency Operations Record Protection Program \\
\hline $\begin{array}{l}\text { DOE Order } 5820.2 \mathrm{~A} \\
(1993)\end{array}$ & Radioactive Waste Management \\
\hline $\begin{array}{l}\text { DOE Order } 6430.1 \mathrm{~A} \\
(1989)\end{array}$ & General Design Criteria \\
\hline DOE RL Order $5440.1 \mathrm{~A}$ & $\begin{array}{l}\text { Implementation of the National Environmental Policy Act at the } \\
\text { Richland Operations Office }\end{array}$ \\
\hline DOE RL Order $5480.1 \mathrm{~A}$ & $\begin{array}{l}\text { Environment, Safety, and Health Program for Department of } \\
\text { Energy Operations for Richland Operations }\end{array}$ \\
\hline NFPA $70(1993)$ & National Electric Code \\
\hline RCW 70.105 & Washington Hazardous Waste Management Act \\
\hline RLID 5480.7 & Fire Protection \\
\hline RLID $5480.2 \mathrm{~A}$ & Radioactive Waste Management \\
\hline RLID 5480.4C (1992) & $\begin{array}{l}\text { Environmental Protection, Safety, and Health Protection } \\
\text { Standards for RL } \\
\end{array}$ \\
\hline RLID 5480.11 (1991) & Radiation Protection for Occupational Workers \\
\hline $\begin{array}{l}\text { Tri-Party Agreement } \\
(1994)\end{array}$ & $\begin{array}{l}\text { Hanford Federal Facility Agreement and Consent Order } \\
\text { (Amendment 4) }\end{array}$ \\
\hline WAC $173-400$ & General Air Regulations \\
\hline WAC $173-401$ & Operating Permit Regulation \\
\hline WAC $173-460$ & Toxic Air Pollutants \\
\hline WAC $173-480$ & $\begin{array}{l}\text { Ambient Air Quality Standards and Emission Limits for } \\
\text { Radionuclides }\end{array}$ \\
\hline WAC $173-303$ & Dangerous Waste Regulations \\
\hline WAC $173-200$ & $\begin{array}{l}\text { Waste Quality Standards for Groundwater of the State of } \\
\text { Washington }\end{array}$ \\
\hline WAC $246-220$ & Radiation Protection - General Provision \\
\hline WAC $246-247$ & Radiation Protection - Air Emissions \\
\hline
\end{tabular}




\subsubsection{Hanford Site Documents/Other}

Selected DOE Orders and Federal Government and Washington State Regulations have been reviewed by the buyer to provide a consistent interpretation of the constraints for application at the Hanford Site. These constraints are represented in WHC Controlled manuals (CM). Also, the U.S. Department of Energy - Richland Field Office has prepared a collection of Hanford Site specific requirements and specifications.

\subsection{NON-GOVERNMENT DOCUMENTS}

Table 2-2 provides a list of non-government documents that contain requirements applicable to the ISSTRS.

Table 2-2. Westinghouse Hanford Company Documents and Other Applicable Codes (2 sheets).

\begin{tabular}{|l|l|}
\hline \multicolumn{1}{|c|}{ Document Identifier } & Title \\
\hline ASME & $\begin{array}{l}\text { Boiler and Pressure Vessel Codes, Section VIII, American } \\
\text { Society of Mechanical Engineers }\end{array}$ \\
\hline ANSI/ISA (1985) & Graphic Symbols for Process Displays \\
\hline ANSI/ISA (1991) & Instrument Loop Diagrams \\
\hline ANSI/ISA (1992) (R) & Binary Logic Diagrams for Process Operations \\
\hline ANSI/ISA (1994) & Instrumentation Symbols and Identification \\
\hline ASHRAE ISBN (1993) & $\begin{array}{l}\text { Heating Ventilation and Air-Conditioning for Department of } \\
\text { Energy Nuclear Facilities }\end{array}$ \\
\hline ASME (1989) & Quality Assurance Program Requirements for Nuclear Facilities \\
\hline HSCRM-1 & Hanford Site Radiological Control Manual \\
\hline WHC-CM-1-3 (1991) & Management Requirements and Procedures \\
\hline WHC-CM-2-14 (1993) & Hazardous Materials Packaging and Shipping \\
\hline WHC-CM-4-29 (1991) & Nuclear Criticility Safety Manual \\
\hline WHC-CM-4-46 & Non-reactor Facility Safety Analysis Manual \\
\hline WHC-CM-7-5 (1994) & Environmental Compliance \\
\hline WHC-EP-0063-4 (1993) & Hanford Site Solid Waste Acceptance Criteria \\
\hline OSD-T-151-00007, H-13 & $\begin{array}{l}\text { Operating Specifications for the 241-AN.AP, AW, AY, AZ \& } \\
\text { SY Tank farms }\end{array}$ \\
\hline OSD-T-151-00013, D-5 & Operating Specifications for Single-shell Waste Storage Tanks \\
\hline
\end{tabular}


Table 2-2. Westinghouse Hanford Company Documents and Other Applicable Codes (2 sheets).

\begin{tabular}{|l|l|}
\hline \multicolumn{1}{|c|}{ Document dentifier } & \multicolumn{1}{c|}{ Title } \\
\hline OSD-T-151-00017, D-5 & Operating Specifications for 24l-AY \& 241-AZ \\
\hline OSD-T-151-00030 & Operating Specification for Watch List Tanks \\
\hline WHC-IP-0842 & Tank Waste Remediation System Administration Manual \\
\hline $\begin{array}{l}\text { WHC-SD-WM-DRD-009, } \\
\text { Rev.0 }\end{array}$ & $\begin{array}{l}\text { Controlled, Clean, and Stable Preliminary Design Requirements } \\
\text { Document for Single Shell Tanks }\end{array}$ \\
\hline
\end{tabular}

Table 2-3. Supporting Documents.

\begin{tabular}{|l|l|}
\hline \multicolumn{1}{|c|}{ Standard Number and Title } \\
\hline WHC/BCSR/ICF KH and PNL & $\begin{array}{l}\text { Industry References (Standards, and National } \\
\text { Codes) }\end{array}$ \\
\hline WHC/BCSR/ICF KH & $\begin{array}{l}\text { ICF KH A/E Standard CG-DWG-01 } \\
\text { (Preparation and Control of Engineering and } \\
\text { Fabrication Drawings) }\end{array}$ \\
\hline WHC/BCSR/ICF KH & $\begin{array}{l}\text { WHC-CM-6-1, EP-1.2 (Preparation and } \\
\text { Control of Multi use Hanford Specifications) }\end{array}$ \\
\hline WHC/BCSR/ICF KH & Architectural-Civil \\
\hline \multicolumn{2}{|c|}{$\begin{array}{l}\text { DOE 6430.1A and ICF KH A/E STD, GC- } \\
\text { LOAD-01 (Design Loads for Facility) }\end{array}$} \\
\hline WHC/BCSR/ICF KH & $\begin{array}{l}\text { Mechanical } \\
\text { DOE 6430.1A and ICF KH A/E STD, }\end{array}$ \\
\hline
\end{tabular}

\subsubsection{Information Documents: Process Flowsheet}

A reference flowsheet has been developed for retrieval of Hanford Site tank wastes (Orme 1995). This flowsheet provides information on the expected retrieval of $100 \%^{1}$ of the tank waste.

'Eventually, waste will be retrieved from DSTs and SSTs to the extent required for closure. The closure requirements have not been fully specified. (Note: The TPA conditions for closure are that residues in 100 series tanks shall not exceed $360 \mathrm{ft}^{3}$ and in 200 series tanks shall not exceed $30 \mathrm{ft}^{3}$. If the retrieval technology is capable of better, then the limit of the technology may be revised. Further, decontamination of the tanks may be required to satisfy closure 
This approach does not account for retrieval inefficiencies and day-to-day variability, but establishes a conservative reference mass balance and overall throughput requirements. Section 3.2 . 1 contains the expected system performance requirements.

The TWRS flowsheet will be revised and updated periodically as additional data become available. Also, revisions to the RDS must be evaluated as the flowsheet is revised.

requirements). 


\subsection{SYSTEM SPECIFICATIONS}

\subsection{DEFINITION}

The primary function of ISSTRS is to provide a demonstration of retrieval of tank waste from an equivalent to a SST tank farm (i.e., preliminary tanks selection: 241-C-103, 241-A-102, 241-C-105, 241-AX-103, and 241-AN-105). Tanks contains saltcake and will be used to demonstrate saltcake retrieval. The retrieval demonstration shall remove sludge as well as saltcake from the selected tanks.

The demonstration goal of ISSTRS is to employ "past practice sluicing" as applied by Project W-320 (after the project was descoped). Maximum advantage will be taken from the designs and lessons learned from Project W-320, and subsequent 241-C-106 retrieval operations.

The ISSTRS supports the TWRS mission by accomplishing the TWRS retrieve waste function identified in Section 3.2.1 Performance Requirements. The TWRS that the ISSTRS interfaces with are identified in Section 3.2.3 External Interface Requirements. Function hierarchy diagrams displaying the hierarchial relationship of the ISSTRS Tank Farm Retrieval Demonstration to other TWRS functionality can be found in TWRS Systems Engineering Functions \& Requirements database.

The major sub-elements that makeup the ISSTRS are briefly described below but not in order of operation or need:

a. Detect SST Waste Leakage During Retrieval. The ISSTRS detect SST waste leakage during retrieval shall perform the leak detection. This function shall detect and confirm leakage from SSTs and ancillary components during retrieval activities.

b. Monitor SST Waste Leakage During Retrieval. The ISSTRS shall monitor SST waste leakage during retrieval. The waste leakage from retrieval activities shall be monitored during the pre-retrieval and post-retrieval activities to obtain data that will be used to determine information about the leakage.

c. Mitigate SST Waste Leakage During Retrieval. The ISSTRS shall mitigate SST waste leakage during retrieval. The activities shall include the operational, procedural, and administrative methods in conjunction with retrieval equipment used to mitigate leakage of SST waste during retrieval. This function shall assist in prevention and response to new leaks if they occur.

d. Remove In-Tank Obstructions. The ISSTRS shall remove the existing in-tank equipment and equipment that obstructs the retrieval activity. 
e. Deploy Retrieval System. The ISSTRS shall deploy the retrieval equipment/system which includes the installation of the equipment at the various tank interfaces.

f. Mobilize SST Waste. The ISSTRS mobilize system elements consists of a sluicer system that agitate waste into a slurry consistency for transfer to a designated DST storage facility. The sluicer will operate in the A, AX, and C tank farms sluice pits. The sluicer is a vertical design with its articulation point located at a one or more fixed elevation in the tank. The sluicer direction of aim is adjustable in both elevation and azimuth.

g. Convey/Transfer Slurry Waste. The ISSTRS conveys the waste with the slurry system which includes two pumps located in the pump pit. The system includes a booster pump, a transport system to transfer the slurry waste the distance between the two tanks at a desired flow rate, valve pits, diversion boxes, pump pits, and ancillary equipment (e.g., fittings, valves) required to route through or connect the transport system.

h. Ventilation and Cooling. The ISSTRS ventilation and cooling system shall cool the tank during the retrieval operation and maintain the appropriate negative pressure while discharging the decontaminated stream to the atmosphere. The system is a combination of exhaust and recirculation system. The recirculation portion of the system is used to provide the needed cooling. The exhaust portion of the system maintains the required pressure in the tank.

I. Monitor \& Control Operations. The ISSTRS monitoring and control system shall provide the structures, monitoring and instrumentation devices, and cabling required to properly supervise and operate the retrieval activities associated with ISSTRS.

j. Decontaminate Equipment. The ISSTRS decontamination equipment shall consist of activities that fully decontaminate the retrieval equipment to be decommissioned at a future date.

\subsubsection{System Definition}

ISSTRS consists of two pumping systems, the sluice and slurry pump systems; a sluicer system, a slurry distributor, and an HVAC system. The sluice and slurry system convey the waste from the SST tank and mobilizes the waste from the SSTs. The slurry distributor dispenses the waste into the tanks. The Tank sluicing HVAC system ventilates and maintains the tank pressure. 
Sluicing involves contacting the solid waste with the sluicing liquid to form a slurry which will be pumped directly to the designated DST tank farm for additional storage prior to processing. The select SSTs will be equipped with sluicers to mobilize the waste with decant liquid from the AN storage facility.

The elements that comprise ISSTRS are given in Table 3-1.

Table 3-1. ISSTRS System Definition (4 sheets).

\begin{tabular}{|c|c|}
\hline ISSTRS Giements for Tanks A 102, AX & Tank farn Facilities \\
\hline \multicolumn{2}{|l|}{ Instrumentation: } \\
\hline \multirow[t]{2}{*}{ Waste Storage Instrumentation } & $\begin{array}{l}\text { Designated DST storage tank equipment: } \\
\text { - Annulus leak detectors, Liquid Level, } \\
\text { and Continuous Air Monitors } \\
\text { - } \quad \text { Tank waste monitors } \\
\text { - Specific gravity, temperature, liquid } \\
\text { level, primary tank vapor space pressure } \\
\text { - } \quad \text { Pressure/vacuum monitoring } \\
\text { - } \quad \text { Leak Detection Pit leak detectors, high } \\
\text { level detectors, and alarms } \\
\text { - Tank waste high liquid level alarm } \\
\text { - Gaseous Effluent Monitoring System } \\
\text { - Primary Ventilation Exhaust System and } \\
\text { Stack within designated DST storage } \\
\text { tank. } \\
\text { Secondary tank equipment: } \\
\text { - Tank concrete structures thermocouple } \\
\text { tree monitors } \\
\text { Pressure/vacuum system }\end{array}$ \\
\hline & $\begin{array}{l}\text { SST retrieval tank equipment: } \\
-\quad \text { tank temperature: thermocouples } \\
\text { tank liquid-level: ENRAF, and manual } \\
\text { tapes } \\
\text { tank leak detection }\end{array}$ \\
\hline $\begin{array}{l}\text { Primary \& annulus ventilation radiation } \\
\text { system, and HEPA filter monitors }\end{array}$ & $\begin{array}{l}\text { Designated DST storage tank equipment: } \\
\text { - differential pressure } \\
\text { - } \text { exhaust temperature } \\
\text { - exhaust deferential pressure }\end{array}$ \\
\hline
\end{tabular}


Table 3-1. ISSTRS System Definition (4 sheets).

\begin{tabular}{|c|c|}
\hline 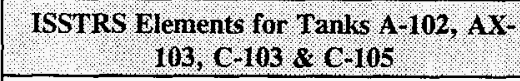 & Tank Farm Facilities \\
\hline & $\begin{array}{l}\text { SST Retrieval tank equipment: } \\
-\quad \text { exhaust radiation monitor } \\
-\quad \text { continuous air monitors and record } \\
\text { samplers }\end{array}$ \\
\hline Backup ventilation system & $\begin{array}{l}\text { Designated DST storage tank equipment: } \\
-\quad \text { Exhauster }\end{array}$ \\
\hline Waste Transfer Instrumentation & $\begin{array}{l}\text { Designated DST storage tank equipment: } \\
\text { - Primary and secondary intertank transfer } \\
\text { pipes } \\
\text { - } \quad \text { Waste transfer system pits } \\
\text { - Waste transfer system pit equipment } \\
\text { (e.g., pumps, valves, pipes, flanges, leak } \\
\text { detectors) }\end{array}$ \\
\hline \multirow[t]{2}{*}{ Compressed Air Instrumentation } & $\begin{array}{l}\text { Designated DST storage tank equipment: } \\
-\quad \text { process air } \\
-\quad \text { instrument air } \\
\end{array}$ \\
\hline & $\begin{array}{l}\text { SST Retrieval Equipment: } \\
-\quad \text { Air supply monitoring instrumentation }\end{array}$ \\
\hline Raw Water Instrumentation & $\begin{array}{l}\text { Designated DST storage tank equipment: } \\
-\quad \text { service pit } \\
-\quad \text { radiation detectors } \\
\end{array}$ \\
\hline Backup Power & $\begin{array}{l}\text { Designated DST storage tank equipment: } \\
-\quad \text { ventilation system } \\
-\quad \text { primary tank instrumentation }\end{array}$ \\
\hline Signal Routing and Display & $\begin{array}{l}\text { SST Retrieval Monitoring and Control Room } \\
\text { equipment: } \\
\text { - Control panels with monitoring and } \\
\text { control instruments } \\
\text { - Alarms to detect leakage, radiation, and } \\
\text { loss of ability. } \\
\text { - Alarms with visible indication and high- } \\
\text { intensity strobe indicators. } \\
\text { In-tank imaging with remote capabilities. }\end{array}$ \\
\hline
\end{tabular}


Table 3-1. ISSTRS System Definition (4 sheets).

\begin{tabular}{|c|c|}
\hline $\begin{array}{l}\text { ISSTRS Elements for Tanks A-102, AX- } \\
103, \mathrm{C}-103 \text { \& } \mathrm{C}-105\end{array}$ & Tank Farm Facilities \\
\hline Ventilation and Cooling & $\begin{array}{l}\text { Designated DST storage tank equipment: } \\
\text { - Primary ventilation } \\
\text { - deentrainers, condensers, heaters } \\
\text { - duct work } \\
\text { - seal loop } \\
\text { - exhaust fans } \\
\text { Existing underground annulus and } \\
\text { primary ducts } \\
\text { Backup ventilation system } \\
\text { - exhauster } \\
\text { - ventilation duct work } \\
\text { - Annulus ventilation system }\end{array}$ \\
\hline Ventilation Exhaust Radiation System & $\begin{array}{l}\text { Designated DST storage tank equipment: } \\
-\quad \text { Continuous air monitors } \\
-\quad \text { Record samplers }\end{array}$ \\
\hline Annulus Exhaust Radiation System & $\begin{array}{l}\text { Designated DST storage tank equipment: } \\
-\quad \text { Continuous air monitors } \\
-\quad \text { Record samplers }\end{array}$ \\
\hline Active Ventilation System & $\begin{array}{l}\text { SST retrieval tank equipment: } \\
\text { - } \quad \text { exhaust headers } \\
\text { - } \quad \text { exhaust fan, HEPA filters } \\
\text { - } \quad \text { Steam or electric preheaters } \\
-\quad \text { process condensate drain with seal pot } \\
-\quad \text { air inlet filters }\end{array}$ \\
\hline $\begin{array}{l}\text { Active Ventilation Exhaust Radiation } \\
\text { Monitoring System }\end{array}$ & $\begin{array}{l}\text { SST retrieval tank equipment: } \\
\text { - } \quad \text { Continuous air monitors } \\
\text { - } \quad \text { Record Samplers }\end{array}$ \\
\hline
\end{tabular}


Table 3-1. ISSTRS System Definition (4 sheets).

\begin{tabular}{|c|c|}
\hline $\begin{array}{l}\text { ISSTRS Elements for Tanks A-102, AX. } \\
\text { 103, C-103 \&, C-105. }\end{array}$ & Tank Farm Facilities \\
\hline Ventilation System & $\begin{array}{ll}\text { SST retrieval tank equipment: } \\
-\quad \text { process building skid } \\
-\quad \text { chiller skid } \\
-\quad \text { exhaust skid }\end{array}$ \\
\hline \multicolumn{2}{|l|}{ Waste Transfer Element: } \\
\hline Sluicing waste transfer system & $\begin{array}{l}\text { SST retrieval tank equipment: } \\
\text { - Seismic switch } \\
\text { - primary and secondary transfer pipes to } \\
\text { DST storage tank equipment: } \\
\text { - slurry distributor } \\
\text { - syphon distributor } \\
\text { - pit cover blocks } \\
\text {-seal loop } \\
\text { - waste transfer equipment (e.g., pumps, } \\
\text { valves, pipes, flanges) in pits } \\
\text {-raw water supply and transfer line flushing } \\
\text { system } \\
\text { - compressed air system }\end{array}$ \\
\hline
\end{tabular}


Table 3-1. ISSTRS System Definition (4 sheets).

\begin{tabular}{|c|c|}
\hline $\begin{array}{l}\text { ISSTRS Elements for Tanks A-102, AX- } \\
103, \mathrm{C}-103 \text { \& C-105. }\end{array}$ & Tank Farm Facilities: \\
\hline \multicolumn{2}{|l|}{ Electrical Distribution: } \\
\hline \multirow[t]{2}{*}{ AC Power } & $\begin{array}{l}\text { DST Storage Tank Equipment: } \\
\text { - Primary tank instrumentation } \\
\text { - Ventilation }\end{array}$ \\
\hline & $\begin{array}{l}\text { SST Retrieval Tank Equipment: } \\
\text { - Active Ventilation System } \\
\text { - Temperature Monitoring System } \\
\text { - Liquid Level Monitoring System } \\
\text { - Leak Detection Monitoring system }\end{array}$ \\
\hline \multicolumn{2}{|l|}{ Support Services: } \\
\hline \multirow[t]{2}{*}{ Compressed Air } & $\begin{array}{l}\text { SST Retrieval Tank Equipment: } \\
\text { - Air supply monitoring instrumentation } \\
\end{array}$ \\
\hline & $\begin{array}{l}\text { DST Storage Tank Equipment: } \\
\text { - Process Air } \\
\text { - Instrument Air }\end{array}$ \\
\hline \multirow[t]{2}{*}{ Raw Water } & $\begin{array}{l}\text { SST Retrieval Activities \& Transfer } \\
\text { Activities }\end{array}$ \\
\hline & DST Storage \& Transfer Activities \\
\hline Fire Protection System & $\begin{array}{l}\text { SST Retrieval Activities \& DST Storage } \\
\text { Activities }\end{array}$ \\
\hline Emergency Cooling System & $\begin{array}{l}\text { DST Storage Activities \& SST Retrieval } \\
\text { Activities }\end{array}$ \\
\hline Steam Supply & SST Retrieval \& DST Storage Activities \\
\hline
\end{tabular}

\subsection{CHARACTERISTICS}

ISSTRS shall have the following characteristics, design, construction, documentation, logistics, and quality assurance. 


\subsubsection{Performance Characteristics}

3.2.1.1 ISSTRS Tank Farm Retrieval Demonstration. The Initial Single-Shell Tank Retrieval System (ISSTRS) shall retrieve waste from four selected tanks (i.e., 241-A-102, 241AX-103, 241-C-103, and 241-C-105). The ISSTRS shall mobilize the tank waste, convey the slurry waste from the tank, transfer the slurry waste to the designated storage facility, the DST 241-AN-105, and recirculate decant liquid from the DST storage facility back to the SST subject to the retrieval activities. The ISSTRS shall include a saltcake retrieval demonstration from the selected tanks. The ISSTRS shall consists of a sluice and slurry system, a tank ventilation and cooling system, monitoring and control systems, leak detection during retrieval, and decontamination of equipment. The process flow activities consist of preparing the receiving DST liquid from the storage facility to the sluicer in the SST, sluicing the waste, pumping the waste to the designated DST storage facility. The operational activities shall include preparing the designated DST liquid, start-up and routine sluicing operations, sluicing completion evaluation, transfer to designated DST storage facility, material balance and leak detection, leak prevention and mitigation, monitoring and control instrumentation, and flushing and cleaning the ISSTRS and the transport system.

3.2.1.1.1 The ISSTRS Total Waste Volume. The ISSTRS shall have the capabilities to transport the retrieved waste at a maximum of $5 \mathrm{M} \mathrm{Na}$ and $10 \%$ weight percent solids. The expected ISSTRS retrieved waste volume shall be the existing (non-dilute) waste of $483 \mathrm{kgal}$ $\left(1.8 \times 10^{6} \mathrm{~L}\right)$ increased by the dilution with water using the molarity limit for sodium and the weight percent solids.

Quantity of Retrieved Tank Waste. ISSTRS shall retrieve tank waste with an estimated quantity of retrieved tank waste is $3.1 \mathrm{E}+05$ metric tons, based upon hydraulic retrieval methods.

\subsection{ISSTRS Productivity Rate. The ISSTRS shall have the capabilities of} hydraulically retrieving at the expected productivity rate $7.2 \mathrm{~m}^{3} /$ day of sludge or saltcake per day per sluicer system used. Expected productivity rate shall take into account overall system efficiencies, failures, replacement and maintenance.

SST Waste Retrieval Rate. ISSTRS shall determine its ability to retrieve tank waste in accordance with the needed SST waste retrieval rate which must average approximately 21 cubic meters per day of SST waste. This waste retrieval rate is a linear assumption, will vary over time, and does not include solutions (if any) added to mobilize the SST wastes. 
3.2.1.1.3 Tank-To-Tank Sluicing. ISSTRS shall implement tank-to-tank sluicing for the retrieval of the single shell tank farm demonstration. Tank-to-tank sluicing is preparing the designated DST facility liquid waste by adding caustic treated water and transferring it to the selected SST to be used by the sluicing nozzle(s) and pump(s) to agitate the tank waste into slurry waste. This slurry waste shall be transferred and dispersed into the designated DST facility. The solids suspended in the slurry shall be allowed to settle out. The adequately clarified supernatant shall be re-circulated back to the selected SST to continue or initiate the sluicing operations.

ISSTRS Recycled Decant Liquid for Retrieval. Decanted liquid from Tank AN-105 shall be used during processing of the ISSTRS retrieval tank wastes. This liquid includes caustic water that was used to initiate the retrieval activities and all flush water.

3.2.1.1.4 Single Shell Tank Selection. The M-45-04 series requires the completion of the conceptual design, design, and construction for the initial SST retrieval systems (ISSTRS). TPA milestone M-45-04-T01, "Provide initial single-shell tank retrieval system. Complete construction and related testing of the initial SST retrieval systems. This milestone will provide retrieval systems for an entire single-shell tank farm or an equivalent number of tanks." The preliminary selection for ISSTRS is four single shell tanks (i.e., preliminary tank selection 241-A-102, 241-AX-103, 241-C-103, 241-C-105, and 241-AN-105 from Initial Single Shell Retrieval System - Tank Selection) (Grenard 1996)

This tank selection is driven by WHC-SD-WM-RPT-229, Rev. 0 "Initial Retreival Sequence and Blending Strategy."

\subsection{Deploy Retrieval System}

The ISSTRS shall deploy and install the system equipment. Subordinate elements to this function shall be monitoring and controlling equipment (i.e., cranes, hoisting and rigging), interfacing with support services for electrical utilities, raw water, and etc.

Static Dome Loading. The static dome loading prior to and during mobilization shall not exceed the equivalent maximum depth of soil above the tanks measured at the center (crown) of the tank dome and the live load shall not exceed the maximum value as described in the table below in order to prevent structural damage to tank domes. 
Table 3-2. Maximum Soil Depth/Live Loads Above Tanks.

\begin{tabular}{|c|c|c|}
\hline Tank Description & $\begin{array}{c}\text { Maximum Soil Depth Above } \\
\text { Tank. }\end{array}$ & Live Load Marimum \\
\hline \multicolumn{2}{|c|}{ Single Shell Waste Storage Tanks (A, AX, B, BX, BY, C, S, SX, T, TX, TY and U) } \\
\hline 200 Series Tanks (20 ft. dia.) & $12 \mathrm{ft}$. & 50 tons \\
\hline 100 Series Tanks (75 ft. dia.) & $10 \mathrm{ft}$. & 100 tons \\
\hline
\end{tabular}

Table 3-3. Maximum Soil Depth/Live Loads Above Tanks Double-Shell Waste Storage Tanks (241-AY, AZ Tank Farms).

\begin{tabular}{|c|c|c|c|}
\hline Tank Description & Max. Soil Depth & Live Load & $\begin{array}{c}\text { Above Tank } \\
\text { Max. }\end{array}$ \\
\hline $\mathrm{AY}, \mathrm{AZ}$ & $7 \mathrm{ft}$ & $100 \mathrm{lb} / \mathrm{ft} 2$ uniform load & 50 tons conc. load \\
\hline
\end{tabular}

\subsection{Mobilize Waste}

The SST Waste Retrieval System shall mobilize the tank waste with supernate from the designated DST storage facility. The mobilization of the waste includes positioning the equipment at a determined level, equalizing the tank temperature, inducing a sluice stream aimed at agitating the area around the equipments in-take area. The accepted solids content shall be ensured in the fluid described as slurry waste. Continuous monitoring of slurry flow rate and pressure shall be achieved until slurry loading is acceptable.

The subordinate elements include controlling and monitoring SST waste chemical composition, percent solids content of the slurry waste, slurry flow rate and slurry pressure, waste transfer requirements applicable to transferring into a SST tank farm, the supernate recirculated from the DST storage facility, SST waste level, and SST flammable gas concentrations. The subelements include defining and initiating actions for mitigation / resolution of safety issues.

The discrete elements of the Mobilize Waste shall include a sluicing system, sluice and slurry pump systems, sluicer system, slurry distributors, in-tank hardware removal system, an analysis and waste transfer system.

Chemical Concentrations Limits. Waste sources shall not exceed the following nitrate, nitrite, and hydroxide concentrations limits. These limits shall be met prior to initiating waste transfers. ISSTRS shall achieve and verify these limits through sampling and laboratory analysis of the tank's contents prior to transfer.

The concentration limits prevent corrosion and stress corrosion cracking. Each waste storage facility and transfer system controls the ion concentration and composition of the waste to 
inhibit corrosion rates. A general corrosion requirement was derived with application to all waste storage facilities transferring waste. Transfer system systems interfacing with the waste sources must be capable of handling waste with this type of chemical composition and makeup.

Note: Square brackets [] signify the mean concentration in moles per liter (M).

For operating temperatures of the receiving tank $100 \mathrm{C}(212 \mathrm{~F})$ :

For [NO3-] 1.0M:

$0.010 \mathrm{M}[\mathrm{OH}-]$ 5.0M; and

$0.011 \mathrm{M}[\mathrm{NO} 2-] 5.5 \mathrm{M}$

For $1.0 \mathrm{M}<$ [NO3-] $3.0 \mathrm{M}$ :

$0.1 \mathrm{M} x$ [NO3-] [OH-] $<10 \mathrm{M}$; and

$[\mathrm{OH}-]+[\mathrm{NO} 2-] \geq 0.4 \times[\mathrm{NO} 3-]$

For $[\mathrm{NO} 3-]>3.0 \mathrm{M}$ :

$0.3 \mathrm{M}[\mathrm{OH}-]<10 \mathrm{M}$; and

$[\mathrm{OH}-]+[\mathrm{NO} 2-] \geq 1.2 \mathrm{M}$; and

[NO3-] $5.5 \mathrm{M}$

For tanks 102-AP, 104-AP and 106-AP the following limits shall apply:

For $[\mathrm{NO} 2-]<0.005 \mathrm{M}$ :

$0.001 \mathrm{M}[\mathrm{OH}-] \quad 0.02 \mathrm{M}$

Providing these conditions are met:

1) Only "Hanford Facility Wastes" (phosphate and/or sulfate decontamination wastes) may be added to tanks.

2) All liquids added to the tanks must be $<0.005 \mathrm{M}[\mathrm{NO} 2-]$.

3) Temperature $<50 \mathrm{C}(122 \mathrm{~F})$.

For normal operating temperature of the receiving tank $>100 \mathrm{C}(212 \mathrm{~F})$, if the same limits apply with the exception the $[\mathrm{OH}-]<4.0 \mathrm{M}$ in all cases, then the waste is acceptable.

\section{Tank Vapor Sampling}

The vapor space shall be sampled to verify it is below $20 \%$ of the LFL prior to in-tank work activities. If the flammable gas concentration is $>10 \%$ of the LFL, but $<20 \%$ of the LFL, a sample will be taken to the lab to determine the type of flammable gases present. The gas sampling shall include: Hydrogen, Nitrogen dioxide, Hydrogen cyanide, Hydrazine, Ammonia, and Organic.

All tanks with active ventilation shall have the ventilation systems operational during activities in, or on, the tank. Physical restraints shall be in place to prevent dropping objects into the 
tank. All objects inserted into or connected to objects in the tank for work to be done shall be electrically grounded.

Flammable Gases - Lower Flammability Limit. The flammable gases concentration shall be maintained less than or equal to $20 \%$ of the lower flammability limit (LFL) when potential spark operations are taking place within the tank.

Flammable Gases - Vapor Space Monitoring. The insertion, temporary use, and/or removal of electrically non conductive objects into the tank or vapor space shall require constant monitoring during movement of the object to verify the vapor space is less than $20 \%$ of the LFL. Constant monitoring shall mean use of installed monitors or every 15 minutes for portable monitors. Insertion or removal shall cease if the vapor space flammable gas concentration is $20 \%$ of the LFL.

Temperature - Tank Dome. Ventilation by the ISSTRS shall prevent the tanks from approaching the maximum tank dome temperature of $250^{\circ} \mathrm{F}$ for SSTs (OSD-T-151-00013, section 13.2.1.E). The maximum tank dome temperature is not specified for non-aging waste DSTs because the primary tank waste temperatures are limited to $180^{\circ} \mathrm{F}$ in AP Farm DSTs and $200^{\circ} \mathrm{F}$ in AN, AW, and SY Farm DSTs (non-aging waste DSTs). These waste temperature limits preclude dome vapor space from reaching the previously specified non-aging waste tank dome temperature limit of $250^{\circ} \mathrm{F}$.

\subsection{Convey and Transfer Waste}

The mobilized waste shall meet the acceptance criteria for the waste transport system and the receiving storage facility. The chemical concentration limits shall be the same as given in Section 3.2.1.1.6, preceding. Wastes to be removed from the tank shall include liquids, saltcake/sludge slurries.

The recirculated supernate liquid shall be transferred to the selected SSTs in order to mobilize the SST waste.

ISSTRS shall also include treatment/preparation of liquid, gaseous, and solid wastes generated as a result of the retrieved tank waste transfer activities in accordance with facilities criteria.

ISSTRS shall include preparing the waste transfer system, setting up the transfer route, contain waste, moving waste, cleaning liquid waste transfer system, and responding to abnormal conditions.

The discrete elements of the waste transfer system include monitor and control instrumentation for slurry transfer line flow rate and pressure, bulk liquid density, sluice stream percent solids, 
specific gravity, temperature, tank concrete structures temperature, liquid level, primary tank vapor space pressure, pressure/vacuum monitoring, leak detection pit leak detectors, and gaseous effluent monitoring system.

Cross-site Transfer Tank Operations Information. ISSTRS, in coordination with existing instrumentation shall provide information with respect to tank storage status, routing configurations, and other operational data required to perform cross-site transfers shall be utilized to perform operations in accordance with DOE 5480.19, Conduct of Operations.

Transfer System Flush. Following a waste transfer through a transfer pipeline, ISSTRS shall have the capability to flush the transfer pipeline with a volume of water that is equal to the transfer pipeline volume. Flushing the transfer system achieves the following objectives:

1) Removes the waste in the line.

2) Reduces radiation dose rates of the transfer system.

3) Eliminates the need for a compatibility assessment of the transfer system for a subsequent transfer.

4) Eliminates solids that may have precipitated from a previous waste transfer.

5) Avoids pluggage of the transfer line.

6) Enables corrosion control that provides reliability of the transfer system.

The primary tank waste temperature limits for each tank farm are limited to prevent excessive stress to the primary tank and vary depending on the particular DST in question.

Transfer System Temperature Ranges Operations Information. The waste storage facility shall transfer waste that does not exceed the temperature limits of at least $82.2^{\circ} \mathrm{C}\left(180^{\circ} \mathrm{F}\right)$ and up to $149^{\circ} \mathrm{C}\left(300^{\circ} \mathrm{F}\right)$. Maximum temperatures will vary based on the storage facility that the waste will be sent to.

The primary tank waste temperature limits for each tank are limited to prevent excessive stress to the primary tank and vary depending on the particular DST in question. It can be derived that the temperatures of the wastes to be transferred should not exceed these temperature limits.

Waste Characterization Data. For waste transfers made within the tank farms and transfers made to the tank farms from other sources, specific characterization data shall be required before the transfer is made. If the characterization data is not available, ISSTRS shall be capable of a sampling event, sampling regime and resultant analysis. Not every analyte is needed to make a transfer decision for a particular waste stream. Table 7-2 located in Data Quality Objectives for Tank Farms Waste Compatibility Program, shall be used to establish the specific data needs for the transfer event.

Emergency Capacity. For emergency situations involving liquid high-level waste, spare capacity with adequate heat dissipation capability shall be maintained to receive the largest volume of liquid contained in any one tank. Adequate transfer pipelines also shall be maintained in operational condition. Interconnected tank farms with adequate transfer 
capabilities and spare capacity may be considered as a single tank farm for purposes of this requirement.

Waste Volume Reduction. Technical and administrative controls shall be directed to reducing the gross volume of waste generated and/or the amount of radioactivity requiring disposal. Waste reduction efforts shall be based on the implementation of techniques such as process modification, process optimization, materials substitution, decontamination, assay of suspect waste, and new technology development. Volume reduction techniques, such as incineration, compaction, extraction, and shredding, shall be implemented wherever cost effective and practical. Treatment facilities shall be permitted by the appropriate regulatory authority.

Waste Segregation. Each DOE low-level waste generator shall separate uncontaminated waste from low-level waste to facilitate cost effective treatment and disposal.

Waste Minimization. Each DOE-low-level waste generator preparing a design for a new process or process change shall incorporate principles into the design that will minimize the generation of low-level waste.

Tank Capacity. The maximum storage capacity in an existing tank shall depend on the tank type. The waste level in the tanks shall be maintained between a maximum limit to prevent overfilling the tank and a minimum level to prevent bottom uplifting of the tanks steel liner.

Leak/Spill Control. The owner or operator must use appropriate controls and practices to prevent spills and overflows from tank or containment systems. These include at a minimum: (1) Spill prevention controls (e.g., check valves, dry disconnect couplings); (2) Overfill prevention controls (e.g., level sensing devices, high level alarms, automatic feed cutoff, or bypass to a standby tank); and (3) Maintenance of sufficient freeboard.

Hazardous Wastes or Treatment Reagents. Hazardous wastes or treatment reagents must not be placed in a tank system if they could cause the tank, its ancillary equipment, or the containment system to rupture, leak, corrode, or otherwise fail.

Transfer Leak Detection. Transfer system leak detection shall be verified as operable (not failed) before a transfer is initiated, or applicable diversion boxes/catch tanks shall be constantly surveyed with portable conductivity probes during the transfer.

\subsubsection{Detect, Monitor and Mitigate SST Waste Leakage}

Control Liquid Inventory Data. Engineering controls shall be incorporated to provide liquid volume inventory data and to prevent spills, leaks, and overflows from tanks or containment systems. Examples are level-sensing devices, liquid level alarms, and 
maintenance of sufficient freeboard. The high-level waste shall be stored at pressures lower than those of ancillary systems (e.g., cooling water).

Waste Volume Inventory Data. Engineered systems shall be incorporated to provide waste volume inventory data, consistent with the nature of the specific waste stored in singly contained tanks. Examples are surface level sensing devices and interstitial liquid level sensing devices.

Monitoring and Surveillance. Monitoring and surveillance capability shall exist to provide liquid volume, waste inventory data, and identification of failed containment.

Disposal Site Waste Treatment. Waste shall be treated by appropriate methods so that the disposal site can meet the performance objectives of the disposal site. (2) Waste treatment techniques such as, shredding and compaction to reduce volume and provide more stable waste forms shall be implemented as necessary to meet performance requirements. Use of waste treatment techniques to increase the life of the disposal facility and improve long-term facility performance, by improved site stability and reduction of infiltrating water, is required to the extent it is cost effective.

Hazardous Waste Container. ISSTRS shall comply with the requirements of hazardous waste containers; requirements for hazardous waste container liner material; handling and storing hazardous waste containers requirements; hazardous waste containers storage area and containment system; and incompatibility requirements for hazardous waste.

\subsection{Monitor SST Waste Leakage during Retrieval. ISSTRS shall design and} construct the system to monitor for SST waste leakage during retrieval. Detect leakage in the near-field zone by acquiring and evaluating the following data at least once each operating day:

- $\quad$ potential leakage conditions within the SST structure

- waste inventory in the retrieval system

- monitor changes in the size and location of existing contaminant plumes

Monitoring Leak Detection Capabilities. Monitoring and leak detection capability shall be incorporated in the engineering systems (e.g., liquid level sensing devices and alarms for high-level waste liquid systems) to provide rapid identification of failed containment, and measurement of abnormal temperatures. The following, at a minimum, shall be monitored; temperature; pressure; radioactivity in ventilation exhaust; and liquid effluent streams associated with high-level waste facilities. Where the possibility exists for the generation of flammable and explosive mixtures of gases, monitoring shall be conducted for those gases. For facilities storing liquid high-level waste, the following should also be monitored: liquid levels; sludge volume; tank chemistry: condensate and cooling water. 
Leak Detection Systems. Leak detection systems (e.g., conductivity probes) shall be designed and operated so that they will detect the failure of the primary containment boundary, the occurrence of waste release, or accumulated liquid in the secondary containment system.

Surveillance Capability. (a) Monitoring and surveillance capability shall exist to provide liquid volume, waste inventory data, and identification of failed equipment.

Discharge of Other Liquids. Liquid discharges, even though uncontaminated, are prohibited in inactive release areas to prevent the further spread of radionuclides previously deposited.

Periodic Waste Storage Assessment. A method for periodically assessing waste storage tank integrity (e.g., coupons, photographic inspections, leak detectors, liquid level devices) shall be established and documented.

Emergency Power. Electrical leak detection devices essential to safe operations shall be provided with backup power, as appropriate, to ensure operability under emergency conditions.

Detection of Released Radioactive Materials. (B) Upon detection of released radioactive materials, steps shall be taken to prevent further migration of the release to soil or surface water. Major contamination in the soil shall be removed or stabilized unless compliance with this requirement would cause greater harm to human health or the environment.

Environmental Monitoring. ISSTRS shall monitor leak during retrieval activities by satisfy satisfying the environmental monitoring requirement. The requirement states that operational or non-operational low-level waste treatment, storage, and disposal facility shall be monitored by an environmental monitoring program that conforms with DOE 5484.1 DOE 5400.1, Chapter IV , 5.b] and, at a minimum, meet the requirements of paragraph $3 \mathrm{~K}(2)$ through $3 \mathrm{~K}(4)$.

3.2.1.2.2 Mitigate SST Waste Leakage During SST Waste Retrieval. ISSTRS shall be capable of operational, procedural, and administrative methods to mitigate leakage of SST waste during the removal of SST waste. This specification shall be applicable to preventing new leaks from occurring and responding to new leaks if they do occur. ISSTRS shall be capable of operational, procedural, and administrative methods to mitigate leakage of SST waste during the removal of SST waste. This specification shall be applicable to preventing new leaks from occurring and responding to new leaks if they do occur.

ISSTRS shall implement the following requirements in the design and construction of the retrieval system. 
Maximum Contaminant Levels. ISSTRS shall mitigate leaks before the maximum contaminant levels for ${ }^{226} \mathrm{Ra},{ }^{228} \mathrm{Ra}$, and gross alpha particle radioactivity in community water systems are exceeded. The following are the maximum contaminant levels for ${ }^{226} \mathrm{Ra},{ }^{228} \mathrm{Ra}$, and gross alpha particle radioactivity: (a) Combined ${ }^{226} \mathrm{Ra}$ and ${ }^{228} \mathrm{Ra}-5 \mathrm{pCi} / 1$. (b) gross alpha particle activity (including ${ }^{226} \mathrm{Ra}$ but excluding radon and uranium) $-15 \mathrm{pCi} / \mathrm{L}$.

Beta Particles Maximum Contaminant Levels. Maximum contaminant levels for beta particle and photon radioactivity from man-made radionuclides in community water systems.

(a) The average annual concentration of beta particle and photon radioactivity from man-made radionuclides in drinking water shall not produce an annual dose equivalent to the total body or any internal organ greater than $4 \mathrm{mrem} /$ year.

Containment and detection of releases - [RESERVED].

\section{Response to leaks or spills - [RESERVED].}

Migration of Leaks. For tank systems in interim status from which there has been a leak, ISSTRS shall be capable of preventing further migration of the leak or spill to soils or surface water.

\section{Designation, Reportable Quantities, and Notification - [RESERVED]}

Environmental Surveillance. ISSTRS shall detect leaks of the SST waste by meeting the environmental surveillance requirement. The summarized requirement itemized these components of the requirement by requiring that environmental surveillance shall be conducted to monitor the effects onsite and offsite environmental and natural resources. Environmental surveillance shall be designed to satisfy one or more of the following program objectives: (a) Verify compliance with applicable environmental laws and regulations; (b) Verify compliance with environmental commitments; (c) Characterize and define trends in the physical, chemical and biological condition of environmental media; (d) Establish environmental baselines; (e) Provide a continuing assessment of pollution abatement programs; and (f) Identify and quantify new or existing environmental quality problems. Surveillance programs are likely to include one or more of the following: (a) Monitoring stations; (b) Sampling and analysis; and (c) Monitoring data record keeping.

Impact on Other Systems. The liquid effluents from DOE activities shall not cause private or public drinking water systems downstream of the facility discharge to exceed the drinking water radiological limits of 40 CFR 141.

Variance for Alternative Design and Operating Practices in the Prevention of Leaks. ISSTRS shall consider when necessary the variance for alternative design and operating practices to prevent leaks requirement. The requirement summarizes these components. The owner or operator may obtain a variance from the requirements of this subsection if the 
department finds, as a result of a demonstration by the owner or operator that alternative design and operating practices, together with location characteristics, will prevent the migration of any dangerous waste or dangerous constituents into the ground water, or surface water at least as effectively as secondary containment during the active life of the tank system or that in the event of a release that does migrate to ground water or surface water, no substantial present or potential hazard will be posed to human health or the environment.

\subsubsection{Ventilation \& Cooling System}

Functional Description: The ventilation and cooling system shall cool the tank, and maintain the tank vapor space at a negative pressure relative to atmosphere (i.e., confinement) for the selected retrieval SSTs storage facilities and the SST Waste Retrieval System. The system must be continuously operational during all sluicing activities. This system shall interface with architectural infrastructure of Waste Storage Facilities.

The subordinate functions shall be to 1) control and monitor the waste temperature in SSTs to prevent excessive stresses to the primary tank and structural degradation of the concrete shell during the retrieval activities 2) control and monitor vapor space pressure in SSTs to prevent over pressurization and under pressurization of the tank and to protect the tank against structural damage during to the retrieval activities, and 3) control and integrate the emission of radioactive and toxic airborne discharge to the atmosphere.

Included in the system are the selected structures, systems and components necessary to control and mitigate the collection of hazardous gases within the waste retrieval activities, the discharge of hazardous gaseous effluents to the environment, and the effects of excessive heat generation within the selected retrieval tanks.

The discrete elements of the SST Ventilation and Cooling system shall be to monitor and control instrumentation to measure the differential pressure indication and alarm for highefficiency particulate air and adsorption filtration units; detect failure of the tank pressure monitoring and tank ventilation system; provide the isokinetic sampling at the ventilation system exhaust stack; and maintain the emissions monitoring at ventilation exhaust stack to meet 40 CFR 61, "National Emission Standards for Hazardous Air Pollutants, " Subpart H, and referenced requirements.

Pressure Systems. The WRS shall provide the systems and equipment capable of maintaining a negative pressure in the SST and confining and filtering hazardous vapors and airborne radioactive particles.

The pressure in each tank vapor space relative to atmosphere shall be maintained:

a $\quad$ For tanks with $=>15$ inches WASTE maintain pressure $=>-15$ inches water gauge. 
b. For tanks with $<15$ but $=>6$ inches WASTE maintain pressure $>$ the negative of the WASTE height in inches water gauge.

c. For tanks with $<6$ inches WASTE maintain pressure $>-6$ inches water gauge.

Toxic Air Emissions (Hazardous Air Pollutants). The establishment and/or operation of a new toxic air pollutant source shall install and operate best available control technology for toxics (T-BACT) in accordance with WAC 173-460-060. In addition all sources of emissions, including reasonably available control technology (RACT) as defined under this regulation. It should be noted that NOC approval orders can also contain specifications for control technologies and other conditions for the proposed activity being approved by the agency.

Criteria pollutants are those pollutants subject to the Prevention of Significant Deterioration (PSD) program as enforced by the State of Washington Department of Ecology through WAS 173-400-141. If criteria pollutant(s) from TWRS activities approaches trigger levels specified under WAC 173-400 and 40 CFR 52 (as incorporated by reference) the information required for the PSD process would need to be included in an application to the agency.

Continuous Monitoring and Alarm Requirements. 1. Timeliness shall be considered when quantifying radionuclides in airborne emissions. The management responsible for the emissions shall determine whether potential offsite radiological impacts require continuous monitoring and alarm capability or if radionuclide record sampling and collection with periodic measurement (e.g., laboratory analysis) conducted according to requirements is sufficient to quantify the radionuclide emissions.

The determination of monitoring and alarm requirements shall be based upon criteria provided in Table 3-4, Monitoring and Alarm Criteria, which follows, and the explanation of those criteria in items 2,3 , and 4 following. The determination shall be documented in the appropriate facility effluent monitoring plan (FEMP), following the guidance for FEMP preparation in the DOE Order 5400.1 and A Guide for Preparing Hanford Site FEMPs, WHC-EP-0438-01.

The applicable FEMP shall also include a detailed description of any installed continuous monitoring and alarm systems. The design of the monitoring equipment required by this paragraph shall meet the intent of the guidance provided in the ANSI N13.1 and in Chapter 3.0, Section 3.5.8, of DOE/EH-0173T.

Table 3-4. Monitoring and Alarm Criteria.

\begin{tabular}{|l|l|l|}
\hline Category & Monitoring and Alarm Criteria \\
\hline & $\begin{array}{l}\text { Projected offsite effective } \\
\text { dose equivalent }\end{array}$ & Monitoring Requirement \\
\hline
\end{tabular}




\begin{tabular}{|l|l|l|}
\hline 1 & $>0.1 \mathrm{mrem} / \mathrm{yr}$ & $\begin{array}{l}\text { Continuous monitoring with } \\
\text { remote alarms (30 min. } \\
\text { checks) }\end{array}$ \\
\hline 2 & $0.01-0.1$ & $\begin{array}{l}\text { Continuous monitoring with } \\
\text { remote alarms (4 hr. checks) }\end{array}$ \\
\hline 3 & $<0.01 \mathrm{mrem} / \mathrm{yr}$ & $\begin{array}{l}\text { Continuous sampling if } \\
\text { required per DOE/EH-0173T } \\
\text { (Daily checks) }\end{array}$ \\
\hline
\end{tabular}

2. The theoretical annual emissions of radionuclides (used to calculate the projected offsite dose) are to include those expected from routine operations at maximum expected capacity combined with those expected from process upsets more likely than not to occur. The theoretical annual emissions are to include the further assumption that no pollution control equipment (e.g., final system of HEPA filters) is in place. The EDE estimate (projected offsite dose) must be calculated using an EPA-approved model. The results must either be approved by the Hanford Environmental Dose Overview Panel (HEDOP) or be based upon unit dose tables previously approved by HEDOP.

3. Those points of airborne radioactive emissions qualifying as Category 1 above shall have a remote alarm permanently installed in an area occupied (or visited and providing alarm checks) at least every 30 minutes.

4. Those points of airborne radioactive emissions qualifying as Category 2 above shall have a remote alarm permanently installed in an area occupied (or visited and providing alarm checks) at least every 4 hours.

5. Audible and visible indications shall be easily discernible to responsible personnel in continuously or frequently occupied areas described in items 3

and 4 , above. These continuous alarm requirements do not apply to emergency backup instruments such as continuous air monitors (CAM) when used during periods of continuous monitor downtime. During such downtime, an inspection of the backup instrument every two hours will be acceptable.

6. The monitoring systems described above shall be calibrated and maintained according to the requirements of DOE/EH-0173T, Chapter 3.0, Sections 3.3 and 3.5. System calibration for continuous monitoring systems shall be conducted before use, and any system shall be recalibrated any time it is subject to maintenance or modification that may affect equipment calibration. In addition, the system shall be recalibrated at least annually and routinely checked with known sources to determine that it is consistently functioning properly. To the extent allowable while still complying with the requirements of DOE/EH-0173T, calibration(s) 
should be performed in a manner consistent with manufacturer's instructions and specifications or engineering methods.

7. Continuous Monitoring Sensitivity.

a. Monitoring systems shall alarm at emission concentrations as low as possible without resulting in an excessive number of alarms due to normal fluctuations in background or normal fluctuations in emissions. The alarms are intended to provide timely warnings when the radionuclide concentration or content of emissions has increased significantly so that corrective actions are required to prevent their exceeding the discharge limits. The alarm settings for a specific facility may be selected by the cognizant engineer of the facility who has detailed knowledge of both its process design and its operating experience. Documentation of the various alarm settings and the bases for their selection shall be provided in the applicable FEMP.

b. Monitoring systems shall, as a minimum, have the capability to alarm at less than or equal to the time-integrated equivalent concentration equal to a 4-hour release at 5,000 times the DCG-public value, as noted in Appendix $\mathrm{C}$ of this manual.

8. Systems for monitoring specific radionuclides (including tritium, $\mathrm{C}-14$, radioiodine, or noble gases) shall follow the guidance of DOE/EH-0173T, Chapter 3.0, Section 3.5.8.

9. Continuous monitoring systems shall be powered from a source that has the same or equivalent emergency capability as the air mover for the effluent stream being monitored.

10. The detection portion of continuous emissions monitoring systems shall have the capability to be inspected daily and source-checked monthly with known sources to ensure it is consistently functioning properly.

a. Monitoring system downtime as a result of scheduled maintenance shall be limited to 8 hours in each 24-hour period unless prior approval is obtained from WHC EEM and WHC Occupational Health and Safety.

b. During periods of monitoring system maintenance or malfunction, the ability to ensure that the parameter concerned is analyzed at 2-hour intervals by using a temporary sampling method approved by WHC EEM shall be provided.

Ventilation Point of Discharge Radionuclide Release Control. Where active ventilation is required, systems shall be provided to maintain radionuclide releases at the point of discharge within the guidelines specified in applicable EH Orders for offsite concentrations and DOE $5480.1 \mathrm{~B}$ for onsite dose commitment considerations.

\section{Emission Filtration and Treatment.}


1. Particulate filtration.

a. High-efficiency particulate air (HEPA) filtration is required in all areas of facilities that contain radioactive materials in a dispersable form and in facilities, areas, or containment boundaries that contain unsealed, radioactive material. With WHC EEM concurrence, HEPA equivalent filters or process controls may be used in certain specialized installations. An installed HEPA or HEPA-equivalent filter shall have a leakage rate efficiency of 99.95 percent for removal of airborne particulate having a nominal median diameter less than 1 micrometer.

b. The number of exhaust filtration stages shall be sufficient to limit concentrations of airborne radioactive particulate released to the environment, during normal conditions and up to, but not including, design basis accident conditions. Determination of the number of exhaust filtration stages shall be performed in accordance with ANSI/ASME N509.

2. Radio-iodine treatment.

a. Stationary sources of airborne radioiodine shall use iodine removal systems (charcoal absorbers, silver reactors, etc.) of sufficient capability to ensure compliance with the limits.

b. Required charcoal adsorbent shall be located as near the source of radioiodine as practical and shall be located downstream of at least one stage of HEPA filtration or equivalent.

c. Charcoal adsorbent shall not be subjected to exhaust air containing per chlorates or other strong oxidizing agents.

\section{ALARA}

At a minimum, the control equipment of all emission units shall represent every reasonable effort to maintain radioactive materials in effluents to unrestricted areas ALARA. 


\section{Testing and Performance Criteria}

1. All airborne filtration systems used by WHC other than those built in place (e.g., sand filters) shall be efficiency tested (batch tested) using a DOE-approved test aerosol and according to the applicable approved procedure (e.g., HPS-157-M through -160). Testing of safety class item containment systems shall be conducted according to ANSI/ASME N510 requirements.

Basis: WHC best management practice. This requirement is an internal WHC quality assurance component of the air filtration requirements contained in this section.

2. Scheduling tests

a. On-line effluent filter systems shall have an in-place, WHC-approved particulate filtration efficiency test before initial startup and shall have the capability for repeat testing.

b. The downstream stage of a set of close-coupled, tandem air filters shall be tested each time the upstream filter stage is replaced.

3. Performance of tests.

a. Each filter stage required by 2.5.5.1 shall be tested individually.

b. Filter systems shall be leak tested in place at the operating flow rate utilizing a DOE-approved test aerosol.

c. The efficiency of a charcoal absorber or equivalent treatment installation shall be demonstrated by one of the following:

- Annual testing using I-131.

- Continued satisfactory service (e.g., demonstrable efficiencies of 99 percent or greater for absorber installations in facilities that routinely handle radio-iodine).

- $\quad$ Radioiodine concentrations less than limits of indicated by the stack charcoal cartridge method (or equivalent).

4. Filter in-place performance requirements.

a. Filter in-place leak test requirements: All filters required under 3.2.1.5 shall remove at least 99.95 percent of Hanford approved aerosol particles (HPS-157-M) with particle size ranges and median diameter less than 1 micrometer as specified by ASME/ANSI N510.

b. The HEPA filter cartridges shall capable of being replaced when continuous exposure rates exceed one R/h at six inches (as measured or extrapolated by WHC Occupational Health and Safety) or when the pressure drop across the filter exceeds five inches water gauge (w.g.). 
Flow Measurement Requirements. Each point of powered ventilation flow of radioactive air emissions (stack or vent), shall be capable of having its flow rate (i.e., effluent flow rate measurements) made using methods specified in Reference Method 2 of 40 CFR 60, Appendix A, for stacks and large vents. Reference Method $2 \mathrm{~A}$ or $2 \mathrm{C}$, Appendix A, shall be used for small vents.

Filter Efficiency: Single HEPA Filter System and Multiple HEPA Filter system for DSTs. Filter Efficiency: Single HEPA Filter System: $99.95 \%$ of particles between 0.1 um and $3.0 \mathrm{um}$, and of average size $0.5 \mathrm{um}$, are removed per filter. Multiple HEPA Filter System: $99.95 \%$ of particles between $0.1 \mathrm{um}$ and $3.0 \mathrm{um}$, and of average size $0.5 \mathrm{um}$, are removed per filter.

\section{Maximum Permissible Radionuclides Concentration in Gaseous Emissions.}

The maximum permissible concentration of radionuclides in gaseous emissions from the ventilation system shall be:

1) Annual Average Concentrations: Not to exceed 1 times the DCG-public value of WHC-CM-7-5, Appendix C, at point of release.*

2) Weekly Average Concentrations: Not to exceed 10 times the annual average ACV concentrations for that stack at point of release.*

3) Instantaneous Concentration: Not to exceed 5,000 times the DCG-public value of WHC-CM-7-5, Appendix C, averaged over any four hour period at point of release.

a. Exceptions

Stacks 296-A-17, 296-A-27, 296-A-29: Not to exceed 10 times the DCG value at point of release. (For other exceptions see compliance plans to WHC-CM-7-5.)

* Except for krypton-85: Not to exceed a combined release of $4 \mathrm{E}+06 \mathrm{Ci} / \mathrm{yr}$.

[OSD-T-151-00007, 7.3.1.E]

Record Sampling Requirements. 1. The 40 CFR 61, Subpart $\mathrm{H}$ criteria apply to any point of emissions that, if all pollution control equipment did not exist, could provide a maximum offsite exposure of greater than $0.1 \mathrm{mrem} /$ year EDE. The theoretical annual emissions are to include those expected from routine operations at maximum expected capacity and those expected from process upsets more likely than not to occur. The EDE estimate must be made using EPA-approved offsite dose models. The quality assurance requirements of 40 CFR 61 , Appendix D, Method 114, shall be addressed regarding the measurement of emissions.

2. Record sampling systems meeting WHC design criteria shall be provided for all airborne emissions that have the potential to exceed 10 percent of any DCG-public value on an annual average, as noted in Appendix $\mathrm{C}$ of this manual. "Record sampling" as used in this section means either a continuous record sampler or a continuous monitor that is used for determining actual emissions. All record sampling systems shall be checked daily to ensure the continuous sampling equipment is operational. 
For purposes of this section, an exhaust system is required to be record sampled if any feeder stream or any part of the exhaust upstream of the filtration system is contaminated in excess of 10 percent of the DCG-public value on an annual average.

It is the intent of this requirement to provide the means for accurate measurement of airborne emissions of radioactive materials to the environment. All new installation or removal of record sampling capability shall be documented in the applicable FEMP.

3. For any source of airborne emissions of radioactive materials for which any feeder stream or any part of the exhaust upstream of the filtration system contains airborne concentrations less than 10 percent of the DCG-public value on an annual average, periodic confirmatory measurements shall be made to verify the low emissions. The methods for such confirmatory measurement are not specified. Good engineering judgment should be used.

4. For emission points which meet the criteria of paragraph 2 , but not paragraph 1 , record sampling systems shall provide representative sampling. Standard error in proportional sampling flow rate shall not exceed applicable ranges referenced in DOE/EH-0173T, Chapter 3.0, Section 3.5. Standard error in any proportional sampling flow rate shall not exceed 20 percent on a continuous basis.

5. Each record sampled airborne emission release point shall have a unique identification number, and each record sampler shall have a unique number. WHC EEM shall be responsible for assigning and/or concurrence with these numbers.

6. For emission points which meet the criteria of paragraph 2, but not paragraph 1, sample probes shall withdraw a representative sample, be downstream of all emissions abatement systems, be configured to minimize sample loss in the sampling system, and be located as close as practical to the point of emission. The design of all sample system components shall follow guidance of the DOE/EH-0173T, Chapter 3.0, Section 3.5. Either Method 1 or $1 \mathrm{~A}$ of 40 CFR 60, Appendix A, is acceptable for selection of sample probe location dependent upon stack size applicability.

7. For emission points which meet the criteria of paragraph 2, but not paragraph 1, stack record air samples shall be collected according to the guidance in DOE/EH-0173T, Chapter 3.0, Section 3.5.6. The sample flow rate and sample time shall be sufficient to achieve the analytical requirements of item 9 following. Unless otherwise directed, the samples should be collected at minimum flow rate of 0.06 cubic meters/minute $(2 \mathrm{cfm})$ for a minimum of 1 week (168 hours running time). Any reduction in flow rate or sample collection period will cause a proportional decrease in the sample activity available for analysis.

The flow meter, or the flow volume totalizer when it is a part of the record sampling system, shall be routinely cleaned and calibrated. Unless extenuating circumstances dictate otherwise, this equipment shall be calibrated to within 10 percent of value at the normal operating flow rate at 95 percent confidence interval relative to a standard traceable to the National Institute 
of Standards and Technology (NIST), or other recognized standards organization. Such calibrations shall occur prior to installation and at least annually thereafter. The flow volume totalizer shall record total sample volume in units of cubic meters except when special arrangements are made with WHC EEM to use other volumetric units. Preventive maintenance on vacuum pumps shall be provided in accordance with the manufacturer's recommendations or maintenance procedures. The frequency shall be according to the manufacturer's recommendations or as determined by a documented evaluation of the system.

8. Record air sampling systems shall be calibrated when first installed and capable of recalibration. Calibration should be to the manufacturer's or cognizant engineer's specifications and applicable portions of ANSI 42.18 standards. If these requirements are not applicable, documentation shall be completed that specifies and justifies any deviations from the FEMP. Calibration should also consider sampling capabilities, physical and operating limits, and reliability. The following requirements also apply.

a. System calibration should include devices in the sample train (flow meter, pressure indicator, volume totalizer, flow alarm switch) necessary for the system to perform its intended function.

9. Determine that the type and frequency of effluent sampling shall be adequate to characterize effluent streams.

10. Record sampling system designs shall be reviewed and approved by WHC EEM prior to construction or modification. Record sampling systems should be installed to operate separately from monitoring systems.

10. Record sampling system designs shall be reviewed and approved by WHC EEM prior to construction or modification. Record sampling systems should be installed to operate separately from monitoring systems.

11. Record sampling system downtime.

a. Loss of emissions record sampling capabilities required by the provisions of this section shall be corrected as quickly and efficiently as practicable. Operations with the potential to contribute airborne radionuclide emissions shall be discontinued to the maximum extent compatible with safe operations if a WHC EEM-approved record sampling method is not operational within 8 hours and if continuous record sampling is not restored within 72 hours.

b. The loss of record sampling capabilities as a result of scheduled maintenance shall be limited to 8 hours during any 24 -hour period. This requirement does not preclude the use of alternative record sampling methods approved by WHC EEM. 
Tank Ventilation System - Filtration System. Tank ventilation system through which gaseous effluents are released to the environment shall adhere to the following filtration requirements: 
Variable

1. Gaseous Effluent Filtration

a. HEPA Filter Stages

b. Passive Ventilation

2. Filter Differential Pressure

a. First filter in a series

b. Other filter in a series

c. Total series of filters
Specifications

All tanks on active ventilators shall have two stages of High Efficiency Particulate Air (HEPA) filtration in the outlet stream.

Air inlets for active ventilation systems shall be HEPA filtered

All SSTs shall be passively ventilated using HEPA breather filters even if active ventilation is temporarily installed

Maximum 5.9 in. wg

Minimum 0.05 in. wg

Maximum 4.0 in. wg

Minimum 0.05 in. wg

Maximum 5.9 in. wg

Minimum 0.05 in. wg

Differential pressure is defined as the drop in pressure from the inlet to outlet of a filter (or series of filters)

3. HEPA Filter Temperature

4. HEPA Filter Testing and Efficiency

a. Efficiency

b. Testing Frequency
Maximum $200^{\circ} \mathrm{F}$

Minimum $99.95 \%$ for $0.3 \mathrm{~m}$ particles

The following conditions shall require that the filter system be aerosol tested:

1) System is low

2) System is moved

3) Filter(s) replaced

4) System has been off over 60 days

5) Every $12+-1$ month during use (maybe tested more often)

Discharge Radionuclides in Air. 1. The emission of radionuclides in air from the combined discharge of all WHC-managed facilities and all other facilities on the Hanford Site shall not exceed those amounts that would cause an effective dose equivalent (EDE) of $10 \mathrm{mrem} / \mathrm{year}$ to any member of the public during any 12 -month period. Doses due to $\mathrm{Rn}-220, \mathrm{Rn}-222$, and 
their respective decay products are excluded from these limits. Doses due to $\mathrm{Rn}-220, \mathrm{Rn}-222$, and their respective decay products are subject to DOE limits.

2. Individual airborne emissions shall not result in the annual average concentration at any ground-level ambient location or other occupied area exceeding any DCG-public value specified in Appendix A of this manual. Facilities shall enforce appropriate administrative controls that consider atmospheric conditions relative to operations for the purpose of ensuring compliance with this requirement.

\section{Noble Gases.}

a. The annual discharge of $\mathrm{Kr}-85$ from all 200 Area emissions units shall not exceed a combined release of $4 \mathrm{E}+06 \mathrm{Ci} / \mathrm{yr}$.

b. The discharge of radon (including thoron) and the resultant decay products shall be ALARA. The ALARA-based ACV limit for discharge of Rn-220 or Rn-222 from all WHC facilities combined should not exceed 5 E-06_Ci/ml on an annual average basis.

\subsubsection{Decontaminate ISSTRS Equipment}

ISSTRS shall decontaminate any existing equipment which must be removed and is suitable for re-use.

The ISSTRS equipment that has been contaminated with tank waste and /or radioactive materials and is suitable for re-use shall be designed for ease of decontamination. Used ISSTRS equipment will be characterized, inventoried, and dispositioned as reusable equipment, or waste.

Above ground, out-of-service contaminated equipment that is not reusable and is inaccessible or difficult to remove (based on the risk and cost involved) shall be sealable to prevent contamination spread.

All above- ground, out-of service contaminated equipment that is not reusable shall be designed for ease of inventory and disposal. Dispositioning in most cases will require characterizing the waste constituents, removing and packaging the equipment as waste, and designating the waste containers in accordance with WAC 173-303.

Reusable contaminated equipment shall be managed in accordance with as-low-as reasonablyachievable (ALARA) guidelines and the WAC 173-303 requirements relevant to the storage of dangerous wastes (Where appropriate). 


\subsubsection{Stabilize Retrieved Single Shell Tank.}

ISSTRS shall implement all applicable requirements to stabilizing the selected ISSTRS retrieval tanks. This includes intrusion prevention, safety assessments, corrective actions for mitigating and/or resolving the hazards to ensure stabilization is complete. ISSTRS shall provide an acceptable condition that is controlled, and stable environment for the retrieved SSTs. Controlled sub-elements shall be to repair/upgrade the active and passive systems to operable by the basis authorization documents; and provide remote monitoring capability. Stable sub-elements shall be to remove pumpable interstitial liquid from SSTs; comply with the interim stabilization criteria; and comply with intrusion prevention criteria.

Prevent Intrusion into ISSTRS Demonstration Tanks.. Intrusion Prevention shall include disconnecting and blanking or capping pipelines from tank systems, and disconnecting, capping and sealing applicable risers and pipelines per the following criteria listed in the Tank Waste Remediation System Administration Manual, WHC-IP-0842, Volume IV, Section 4.2:

- Risers terminating above-grade or less than $3 \mathrm{ft}$ below-grade shall be sealed; and

- Pits, cells, and vaults for tanks with riser/piping systems terminating in confined area shail have confinement covers installed and sealed.

Interim Stabilize the ISSTRS Demonstration Tanks. The ISSTRS demonstration tanks condition shail satisfy the acceptance criteria from the Tank Waste Remediation System Administration Manual, WHC-IP-0842, Volume IV, Section 4.1.

- Each tank contains less than 50,000 gallon of Drainable Interstitial Liquid, based on either a $45 \%$ porosity, or on the porosity determined during actual pumping;

- Each tank contains less than 5,000 gallon of supernatant; and

- The pumping rate has decreased to less than $0.05 \mathrm{gal} / \mathrm{min}$, or inflow in the saltwell screen has decreased to less than $0.05 \mathrm{gal} / \mathrm{min}$, and the tank has less than 50,000 gal of Drainable Interstitial Liquid remaining.

\subsubsection{Remove In-Tank Hardware}

Functional Description: The ISSTRS shall remove in-tank hardware described as solids (e.g., failed equipment, concrete, rocks, bricks, and etc.) as necessary to allow system operation. Solids shall be removed only to the extent necessary to prevent interference with the retrieval of 
other wastes or as required to allow completion of closure activities. The in-tank hardware (ITH) shall be retrieved by: locating the ITH: extracting the ITH; moving the ITH to a container.

Secondary Waste Handling, The design shall include waste handling and storage facilities for all secondary wastes (as opposed to retrieved waste) generated by the ISSTRS. Waste facilities shall provide for waste segregation, storage characterization, and shipping.

Solid Radioactive Waste Transfer. Transfer of solid radioactive waste to the Hanford Site Solid Waste program for dispositioning shall be in accordance with criteria specified in the Hanford Site Solid Waste Acceptance Criteria, WHC-EP-0063, DOE 1540.1 Material, Transportation and Traffic Management, and DOE 95-SWT-186 for on site shipment.

WHC-CM-7-5, Chapter 7, 6.5.2. Threshold doses and/or concentrations are established to define levels below which soil and included rubble do not require controls as site radioactive materials (see Tables 6.1 and 6.2 in WHC-CM-7-5, chapter 7).

Radioactive Waste Transuranic Radionuclides. Radioactive wastes with quantities of transuranic radionuclides in concentrations of $100 \mathrm{nCi} / \mathrm{g}$ of waste or less shall be considered to be low-level waste, and shall be managed according to the LLW requirements.

\section{Characterization of Low Level Waste. DOE5820.2A, Chapter III, 3.d}

d(1) Low-level waste shall be characterized with sufficient accuracy to permit proper segregation, treatment, storage, and disposal. This characterization shall ensure that, upon generation and after processing, the actual physical and chemical characteristics and major radionuclide content are recorded and known during all stages of the waste management process.

(2) Waste characterization data shall be recorded on a waste manifest and shall include:

(a) The physical and chemical characteristics of the waste.

(b) Volume of the waste (total of waste and any solidification or absorbent media).

(c) Weight of the waste (total of waste and any solidification or absorbent media).

(d) Major radionuclides and their concentrations.

(e) Packaging date, package weight, and external volume.

(3) The concentration of a radionuclide may be determined by direct methods or by indirect methods such as use of scaling factors which relate the inferred concentration of one radionuclide to another that is measured, or radionuclide material accountability, if there is reasonable assurance that the indirect methods can be correlated with actual measurements.

\subsubsection{System Relationships}

Relationships between the ISSTRS and other, interfacing systems are described below. This relationship is premised on the ISSTRS demonstrating the feasibility of sluicing as applied by Project W-320. The ISSTRS project will perform design, fabrication, and installation of a waste retrieval systems, waste transfer lines, HVAC systems, and infrastructure necessary to begin waste retrieval operations in the first Single-shell tank farm (Hertzel 1996). The 
ISSTRS shall accomplish the previously listed performance characteristics by itself or through the appropriate interface with other TWRS systems.

The ISSTRS shall obtain and assimilate information regarding the suitability and execution of retrieval operations. All raw materials (e.g., electricity, raw water, steam, and compressed air) associated with the ISSTRS shall be provided through interfacing with TWRS. The ISSTRS shall mobilize, retrieve, and convey the tank waste to the designated DST storage facility.

The ISSTRS shall feed back operations data affecting the tank storage and characterization requirements for tank waste retrieved. Solid waste resulting from the ISSTRS remove in-tank hardware operations shall be transferred to the Solid Waste Facility. The ISSTRS equipment once having fulfilled its function shall be decontaminated for re-use or disposal. The liquid waste resulting from flushing the transport system shall be transferred to the appropriate tank.

\subsubsection{External Interfaces}

3.2.3.1 Physical Descriptions. The physical interfaces described in this document are based on current ISSTRS scope. The ISSTRS scope is to achieve the goal of demonstrating the feasibility of sluicing as applied by Project W-320. Additional scope and modification of the contents of this section may be required.

3.2.3.1.1 ISSTRS Selected DST Receiving Storage Facility. The existing infrastructure (i.e., sluice, pump and distributor pit) which are located within the circumference of the tank dome shall interface with the ISSTRS. The physical interfaces are the risers which extends from the tank dome through the pit floor.

3.2.3.1.2 ISSTRS Selected SST Retrieval Tank's Sluice and Pump Pits. The sluice and pump pits are located below grade, and above the tank dome. The pits are located within the diameter of the SST. The pits shall contain the ISSTRS, specifically the sluicer system and slurry systems, and supporting motive forces architecture. The physical interface between the pit and the tank dome are riser configurations which includes a plated flange for connections.

3.2.3.1.3 ISSTRS and the Existing Waste Transfer System. The ISSTRS shall have the capabilities to transport the retrieved waste from the SST storage facility to the DST storage facility using portions of the existing waste transfer system. 
3.2.3.1.4 ISSTRS and the Existing Valve Pits/Diversion Boxes. The ISSTRS selected retrieval tank's valve pits/diversion boxes provide a central and common point where waste can be transferred out of the SSTs and a clarified sluice stream from the DST AN-105 can be returned. The physical interfaces are defined to be at the valve pit.

3.2.3.1.5 ISSTRS and Existing Power Systems. ISSTRS and associating retrieval components shall require electrical power to be provided. The physical interface is the transformer which takes utility power $(13.8 \mathrm{kV})$ and transforms it to a usable voltage level $(480 \mathrm{~V})$. ISSTRS shall provide the connection to the existing transformer(s) and the associating equipment required to provide 3 phase power.

3.2.3.1.6 ISSTRS and the Existing Raw Water System. The ISSTRS requires raw water to perform operational flushes of the ISSTRS and associating ancillary equipment. The physical interface shall be with the raw water system.

3.2.3.1.7 ISSTRS and the Existing Fire Protection. The ISSTRS requires fire protection to insure adequate fire protection. The physical interface is with the existing fire water system, and alarm systems and components.

3.2.3.1.8 Tank Operations Information. Characterization of waste requires tank operations information consisting of monitoring and surveillance data which includes: in-tank temperature measurements, pressure measurements, waste level measurements, photographs, emission monitoring data, data from specialty equipment, as well as information related to the structure of the tank and its safety status.

\subsection{Tank Operations Information Interface Requirements.}

Transfer System Temperature Ranges Operations. The waste storage facility shall transfer waste that does not exceed the temperature limits of at least $82.2^{\circ} \mathrm{C}\left(180^{\circ} \mathrm{F}\right)$ and up to $149^{\circ} \mathrm{C}$ $\left(300^{\circ} \mathrm{F}\right)$. Maximum temperatures will vary based on the storage facility that the waste will be sent to.

3.2.3.1.9 Input: Raw Materials for Retrieve SST Waste. Any material or services (e.g., steam, water, air, process chemicals, electricity) needed from outside TWRS for retrieving SST waste shall be provided by ISSTRS.

Corrosion Control. The chemistry of liquid high-level waste shall be adjusted to control corrosion within design limits for the storage system. 
Treatment Reagents. Treatment reagents shall not be placed in a tank system without proven effective mitigative action if they could cause the tank, its ancillary equipment, or the containment system to rupture, leak, or otherwise fail.

Waste Compatibility. ISSTRS waste compatibility shall adhere to the requirements cited in the Tank Farm Waste Transfer Compatibility Program, WHC-SD-WM-OCD-015, Rev.

3.2.3.1.10 ISSTRS Retrieved In-Tank Hardware (ITH). Pipe, equipment, and miscellaneous, non-radioactive or hazardous debris that has been installed in or put in an underground storage tank is termed ITH. Samples of ITH include, but are not limited to, instrument trees, air lifts, steam lances, level tapes, pumps, and rocks. This waste will be segregated, packaged, assayed, and certified for transfer to Hanford Solid Waste, for further treatment or disposal. This includes mixed and radioactive solid wastes.

ITH shall be classified according to its radionuclide and chemical composition prior to treatment, storage and disposal.

TRU Concentrations. Radioactive wastes with quantities of transuranic radionuclides in concentrations of $100 \mathrm{nCi} / \mathrm{g}$ of waste or less shall be considered to be low-level waste, and shall be managed according to the requirements of Chapter III of this Order DOE 5820.2A.

TRU Concentration Limits. The lower concentration limit for transuranic waste ( $>100$ $\mathrm{nCi} / \mathrm{g}$ of waste) shall apply to the contents of any single waste package at the time of assay.

TRU Waste Storage. Newly generated transuranic waste shall be placed in noncombustible packaging that meets DOT requirements. All Type A transuranic waste containers shall be equipped with a method to prevent pressure buildup. Acceptable pressure-relief devices include permeable gaskets, vent clips, and filtered vents.

Low Level Waste Characterization. Low-level waste shall be characterized with sufficient accuracy to permit proper segregation, treatment, storage, and disposal. This characterization shall ensure that, upon generation and after processing, the actual physical and chemical characteristics and major radionuclide content are recorded and known during all stages of the waste management process. Waste characterization data shall be recorded on a waste manifest, and shall include:

- The physical and chemical characteristics of the waste.

- Volume of the waste (total of waste and any solidification or absorbent media).

- Weight of the waste (total of waste and any solidification or absorbent media).

- Major radionuclides and their concentrations

- Packaging date, package weight, and external volume. 
The concentration of a radionuclide may be determined by direct methods or by indirect methods such as use of scaling factors which relate the inferred concentration of one radionuclide to another that is measured, or radionuclide material accountability, if there is reasonable assurance that the indirect methods can be correlated with actual measurements.

Solid Radioactive Waste Transfer. Transfer of solid radioactive waste to the Hanford Site Solid Waste program for dispositioning shall be in accordance with criteria specified in the Hanford Site Solid Waste Acceptance Criteria, WHC-EP-0063, DOE 1540.1 Material, Transportation and Traffic Management, and DOE 95-SWT-186 for on site shipment.

3.2.3.1.11 ISSTRS Treated Gaseous Effluents. Treated gaseous effluents that are discharged to the atmosphere shall comply with the following regulations.

Gaseous Emission Limits. Discharge of hazardous organics, nitrogen dioxide, lead, sulfur oxide/dioxide, particulates, carbon monoxide and ozone will not exceed the limits in 40 CFR 264.1032 (a) (1) or 40 CFR 50. Pressure relief devices shall comply with the control of emission requirements of 40CFR 264. 1054.

Discharge of toxic air pollutants shall be controlled in accordance with the requirements of WAC 173-460.

Toxic Air Emissions (Hazardous Air Pollutants). The establishment and/or operation of anew toxic air pollutant source shall install and operate best available control technology for toxics (T-BACT) in accordance with WAC 173-460-060.

General Regulations for Air Pollution Sources. The General Regulations for Air Pollution Sources, WAC 173-400 shall apply except for sections WAC 173-400-070 (Emission Standards for Certain Source Categories) and WAC 173-401-190 (Requirements for Nonattainment Areas).

Radioactive Air Emission Control. Discharge of radioactive air emission shall be controlled in accordance with the requirements of WAC 173-246.

Effective Dose Equivalent. ISSTRS shall meet this requirement as stated in WHC-CM-7-5, 2.5.2.1 (1-3) The requirements specify the effective dose equivalent for the emission of radionuclides in air from the combined discharge of all WHC-managed facilities and all other facilities on the Hanford Site. The basis is that DOE facilities are subject to the regulations of the EPA and specifically names 40 CFR 61 as the primary regulation for control of atmospheric emissions. Individual airborne emissions shall not result in the annual average concentration at any ground-level ambient location or other occupied area exceeding any DCG-public value. The third requirement of this section states the annual discharge for Noble 
Gases of $\mathrm{Kr}-85$, discharge of radon (including thoron) and the resultant decay products, and the discharge of $\mathrm{Rn}-220$ or $\mathrm{Rn}-222$ from all WHC facilities.

3.2.3.1.12 Output: ISSTRS Treated Liquid Effluents. Liquid effluents shall comply with the requirements of the State Waste Discharge Permit \#ST 4502 for 200 Area Treated Effluent Disposal Facility.

\subsection{ISSTRS Recycled Decant Liquid for Retrieval Interface Requirements}

HLW Constituents Limitations. No additives shall be allowed which would have a detrimental impact on the operation of the HLW immobilization process, interim storage operations, or the volume of immobilized HLW produced. Additionally, inclusion of nonradioactive constituents should be minimized to avoid impacting the volume of immobilized HLW produced. This requirement is based upon achieving the TWRS mission goals of cost effectiveness and minimizing HLW volume.

Recycle of Water for Tank Waste Retrieval and Pretreatment. Where feasible and cost effective, treated process condensate should be recycled for use in tank waste retrieval and pretreatment process activities. Alternative facility concepts will need to be evaluated to determine the feasibility and cost effectiveness for conducting recycle of process condensate.

3.2.3.1.14 ISSTRS Prepared Solid Waste. Solid waste generated from the retrieve/transfer ISSTRS Tank Farm Demonstration waste function shall be segregated, packaged, assayed, and certified for transfer to the Hanford Site Solid Waste Facility, for further treatment or disposal. This includes mixed, and radioactive solid wastes.

ISSTRS shall prepared solid waste in accordance with the following requirements.

40CFR264.13(a)(1).

40CFR268.41(b)

40CFR268.42(a)

TRU Concentration Limits - DOE5820.2A, Chapter II, 3.a(3)

LLW Characterization - DOE5820.2A, Chapter III, 3.d

Solid Radioactive Waste Transfer.

Threshold Doses and/or Concentrations - WHC-CM-7-5, Chapter 7, 6.5.2.

3.2.3.1.15 ISSTRS Excess Facilities. Facilities that have reached the end of their useful life or have no identifiable or planned programmatic use by the ISSTRS Tank Farm Retrieval Demonstration or Retrieve SST Waste function shall be transferred as excess facilities. 
Planning for facility decommissioning shall be initiated during the design phase for new facilities.

\subsubsection{Physical Characteristics}

3.2.4.1 Protective Coatings. The ISSTRS components and piping shall be constructed of or lined with materials that are compatible with the waste to be placed in the primary system. The system shall have sufficient strength and thickness to prevent failure owing to physical contact with the waste to which it is exposed, climatic conditions, and the stress of daily operation to the reliability requirements outlined in section 3.2.5.1.

\subsubsection{Land Use}

The 200 Area is a limited land use area. The ISSTRS shallbe sited on available land adjacent to the tank farms.

\subsubsection{Project Quality Factors}

This paragraph describes the requirements for the reliability, maintainability, availability, and other quality factors for the system.

3.2.5.1 Reliability. The ISSTRS design shall provide design features to enhance remote equipment reliability. Evaluation of equipment system failures must be provided to fully define equipment reliability.

3.2.5.1.1 Failure Mode and Effects. The ISSTRS design shall perform a qualitative Failure Mode, and Effects Analysis (FMEA) using MIL-STD-1692A as a guide. The FMEA will be prepared on the ISSTRS system and control system components.

3.2.5.1.2 Fault Tree Analysis. A qualitative Fault Tree Analysis (FTA) will be prepared using NUREG-0492 as a guide. This top level analysis shall be tailored to complement the FMEA.

3.2.5.2 Maintainability. Each facility shall use remote maintenance features and other appropriate techniques to maintain personnel radiation exposure as low as reasonably achievable. 
Remote Features. Each facility shall utilize remote maintenance features and other appropriate techniques to minimize personnel radiation exposure in accordance with DOE $5481.1 B$.

Power Loss. Upon loss and subsequent recovery of normal electrical power, high-level waste transfer equipment shall not have the capability to restart without active operator action.

Equipment Maintainability. The design of equipment shall incorporate the objective of efficient maintainability. The surveillance, testing, and maintenance of a system and its restoration to operational effectiveness shall be achieved at minimum cost with a minimum level of support services. UCRL 15673 shall be considered for system design.

Equipment Maintainability Factors. The design shall consider the maintainability factors peculiar to the specific equipment to be used in the facility. Facility design shall provide for routine maintenance, repair, or replacement of equipment subject to failure. The design of all process equipment shall include features to minimize self-contamination of the equipment, piping, and confinement areas. The design of process equipment shall also include features to minimize the spread of contamination out of local areas.

The ISSTRS design shall provide for routine maintenance, repair or replacement of equipment subject to failure. Remote maintenance, inspection and testing capabilities shall be incorporated where required in the design of the mechanism that are involved in movement, insertion, and retrieval of the sluicing nozzles, their control components, systems and equipment (DOE Order 6430.1 A, Section 1300-3.5).

3.2.5.3 Availability. The ISSTRS overall availability (e.g., operational availability) shall be sufficient to produce the required total retrieval rates over the designated life of the system. Reliability and maintainability analyses shall be conducted for each major equipment component development item to obtain availability predictions.

3.2.5.4 Operability and Maintainability. Four maintenance and operations (M\&O) categories shall be used to assist in evaluating the design of all facilities. Each facility shall utilize remote maintenance features and other appropriate techniques to minimize personnel radiation exposure in accordance with DOE 5481.1B, Chapter I, 3.b(2)(I).

Categories 1\&2 - Fully Remote Maintenance and operation/Remotely Operated and "No" Maintenance. Each system or portion of a system having radiation levels greater than $50 \mathrm{mrem} / \mathrm{hr}$ contact exposure shall be either (1) remotely maintained and operated or (2) designed to require no maintenance and be remotely operated. 
M\&O - Category 1 Definition: equipment and operational areas falling into this category have radiation levels higher than that which would allow full contact maintenance and operations. Selection of this category should be considered when operational practicalities and economics dictate the need for maintenance and replacement capabilities, while ALARA considerations restrict worker contact. Design for this category should minimize active components. The amount of remote handling equipment is dependent of the operations to be performed.

M\&O - Category 2 Definition: Equipment and operational areas falling into this category have radiation levels higher than that which would allow full contact maintenance and operations. Selection of this category should consider worker exposure as well as operational practicality and economics. Systems and equipment designed for the M\&O category have little external contamination potential because they are typically all-welded systems. Moving parts, wear surfaces, gaskets, and stress cycles (e.g. thermal) are minimized. The corrosion potential for all materials must be low and the flowsheet fully demonstrated with no potential for change. "No maintenance" facilities/areas have little or no remote handling equipment installed.

Category 3 - Limited Contact Maintenance and Operation. Each system or portion of a system having radiation levels greater than $0.1 \mathrm{mrem} / \mathrm{hr}$ to less than or equal to $50 \mathrm{mrem} / \mathrm{hr}$ shall be designed for limited contact maintenance and operation. Designs shall consider remote removal of radiation sources and decontamination prior to personnel entry.

M\&O - Category 3 Definition: "Equipment and operational areas falling onto this category have radiation levels higher than that which would allow full contact maintenance and operations. Selection of this category should consider occupational dose, operational practicality and economics which favor design for a limited amount of contact M\&O over design for fully remote $\mathrm{M} \& O$. Design for this category may include sealed sources in-cell that can be remotely removed with effective contamination control. Personnel entry is then allowed for contact maintenance."

Category 4 - Full Contact Maintenance and Operation. Each system or portion of a system having radiation levels less than or equal to $0.1 \mathrm{mrem} / \mathrm{hr}$ shall be designed for full contact maintenance and operation.

M\&O - Category 4 Definition: Full Contact Maintenance and Operation (Reference Appendix $\mathrm{H})$ "Equipment and operations falling into this category have levels of radiation and potential for contamination so low that the area may either be considered uncontrolled, such that fulltime access is allocated, or controlled, such that a maximum of $40 \mathrm{~h} /$ week of individual worker occupancy is permitted. This corresponds to "uncontrolled radiation areas" and "controlled radiation zone 1 areas". Additionally, levels of contamination are so low as to require no posting, consistent with he criteria presented in DOE 5480.6 
3.2.5.4.1 Operations and Maintenance Considerations. Operations and Maintenance (O\&M) design requirements relate specifically to the personnel-to-physical system interface. $O \& M$ qualities of design pertain to the ability of personnel to safely and efficiently interface with the physical system to perform the intended functions. A particular design solution/approach can either enhance, be neutral, or degrade O\&M as opposed to another solution/approach. This section defines and quantifies (as best possible) O\&M considerations to be used for design of the ISSTRS and is based on a philosophy of "good operating practices".

The ISSTRS design approach shall enhance operations and maintenance to the greatest extent practicable while fulfilling all other design requirements.

Factors such as life-cycle cost, radioactive waste minimization, and number of personnel and time required to perform plant functions shall be considered in the design. These design requirements need to be met or exceeded to enhance O\&M. Enhancements of O\&M can be further achieved by incorporation of design features and considerations such as the ones listed below.

Operations Considerations based on "Good Operating Practices" are cited from source document DOE 5480.19, Conduct of Operations Requirement for all DOE Facilities. The system shall be designed with operations considerations taken into account. Examples include the following:

- Modifications of SSTs and DSTs made by ISSTRS shall not preclude, or significantly add to the difficulty of accomplishing tank closure.

- The design of ISSTRs systems/subsystems shall be modular to the maximum extent practical. Equipment may be moved from tank to tank. Modular design also reduces exposure (ALARA) problems.

- Commercially available equipment and parts shall be used to the greatest extent practical.

- The ISSTRS shall provide a method to cool the pump/sluice pits as determined necessary by analysis.

- $\quad$ Equipment shall be positioned away from potential leaks of corrosive liquids. Where this is not practical, splash guards shall be provided to protect the equipment.

- A design analysis shall be prepared that considers loads seen throughout the entire product life cycle, including fabrication, storage, operation, and decommissioning. The analysis shall verify the structural integrity of the 
ISSTRS and that the proper margins of safety have been maintained in the design.

- The ISSTRS design shall preclude, as far as practical, the need for confined space entry during construction and operations.

- The materials used in the ISSTRS shall be (1) resistant to radiation, process solutions, acid and caustic vapors and solutions, and decontamination agents; (2) nonabsorbent, easily removable if not contamination resistant; and/or (3) oversized to permit partial destruction without affecting structural integrity.

- Rotating equipment, electrical components, and other high-maintenance items should be located outside radiation areas to the extent practical.

- The ISSTRS shall be designed such that the failure of any part or component will not preclude the safe removal of the equipment from the pits or tanks.

- Equipment should be designed for recovery from in-process failures. These criteria apply particularly to remotely operated in-tank equipment.

- $\quad$ Equipment shall be designed so no single failure of mechanical or electrical equipment can cause a loss of control resulting in an unrecoverable condition. Functions shall be provided that facilitate placement of the equipment in the appropriate position to establish a safe configuration during a faulted condition.

- I\&C: Instrument and power cable runs shall be housed in separate raceways within the tank farm for protection and for facilitating future modifications.

- I\&C: Instrumentation shall be designed for the intended service and shall be qualified for the environmental conditions in which it is required to function.

- I\&C: The instrumentation and monitoring systems shall be designed to alert the operator when failure has occurred.

- I\&C: Instrumentation and monitoring equipment systems shall be specified and designed to facilitate troubleshooting and replacement.

- I\&C: Where limit switches are used for equipment stops or position indication, the following guidelines should be observed. The limit switch shall be mounted in a stationary position with the actuator mounted to the movable member. The limit switch should be protected to preclude damage from inadvertent bumping. The positioning and configuration of the limit actuator shall prevent damage to the limit switch if overtravel, misalignment, or malfunction occurs. Failure detection circuitry or mechanical stops should be designed to protect equipment 
from overtravel caused by limit switch failures. Limit devices shall be adjustable with positive position locking hardware. Mounts and actuators shall have indexes for reference during limit switch adjustment or replacement. Enclosed units shall be used with secondary actuation and bellows-type seals.

- Electrical Systems: All electrical equipment or components shall be selected or protected to resist adverse affects of the environment in which they are installed. Electrical enclosures and junction boxes of the proper National Electrical Manufacturers Association rating and material shall be used to resist and protect internal components from the corrosive effects of moisture and chemicals.

- Electrical Systems: Stainless steel enclosures, junction boxes, and pull boxes shall only be used in a corrosive environment.

- Electrical Systems: Sensitive electrical/electronic devices should not be located in high-radiation areas. When such devices are located in high radiation areas, the devices shall be designed to withstand the demands of the environment and meet the design life requirements identified previously.

- Pneumatic Systems: Piping and valve arrangements shall be designed to preclude misrouting liquids outside of confinement boundaries due to incorrect valve settings.

- Pneumatic Systems: Equipment such as dip tubes, sample lines, transfer lines, and drains shall be designed to preclude the possibility of syphoning or backflow.

- Pneumatic Systems: All piping, regardless of safety class, shall be arranged for gravity flow wherever possible and sloped to drain.

- Pneumatic Systems: Process piping sizes shall be specified to minimize solids from accumulating.

- Pneumatic Systems: Valve and actuation design or selection shall consider the minimization of the accumulation of solids in crevices or water hammer caused by fast-closing valves.

- Pneumatic Systems: Adequate physical protection shall be provided for waste transfer lines, with consideration given to radiological exposure to personnel and damage by vehicles. 
3.2.5.4.2 Contaminated Equipment Maintenance. The ISSTRS shall be designed and constructed to meet the maintenance requirements of DOE Order 6430.1A, and the design requirements of DOE Order 4330.4A, Maintenance Management Program.

3.2.5.4.3 High Dose-Rate Areas Equipment Maintenance. The ISSTRS shall be designed to preclude the need for routine, hands-on maintenance in contaminated or high-dose-rate areas using the ALARA design principles, WHC-IP-1043, ALARA Program Manual.

3.2.5.4.4 Remote Maintenance Equipment. Provisions for remote replacement of system equipment that operates in a high-radiation area shall be made as required to meet ALARA criteria. The capability shall be provided to perform a preliminary decontamination, where practical, of equipment before repair or removal using ODE/EV/1830-T5, a Guide to Reducing Radiation Exposure to as Low as Reasonably Achievable (ALARA), and WHC-IP-1043, AL_ARA Program Manual.

\subsubsection{Environmental Conditions}

Temperature, pressure and humidity environments shall be based on the most severe postulated accident affecting the particular item. The postulated environment shall reflect an environment that considers both radiological composition (i.e., elements, isotropic, total radioactivity) and chemical composition (i.e., abrasives, acids, smoke, caustics, vapors) of all material physical forms likely to affect the equipment (DOE 6430.1A, Div. 1300-3.4.2).

Each system for ISSTRS shall be designed to meet the requirements for exposure to the following natural and induced environmental conditions:

3.2.6.1 Natural Environments. New facilities and systems functioning on the Hanford site shall withstand the environmental conditions specified below. Thermal effects of the soil shall be considered for the buried portions of the system.

Ambient Air Temperature Range:

Rate of Increase:

Rate of decrease:

Relative Humidity:

Mean annual precipitation

Maximum precipitation rate of change:

Blowing Dust \& Smoke

Visibility:

Frequency:
-6.67 to $48.89^{\circ} \mathrm{C}$ ( 20 to $120^{\circ} \mathrm{F}$ )

$3.34^{\circ} \mathrm{C}\left(26^{\circ} \mathrm{F}\right)$ per 20 minutes maximum $-4.45^{\circ} \mathrm{C}\left(24^{\circ} \mathrm{F}\right)$

5 to $100 \%$ (Rate of change is neglible)

$16 \mathrm{~cm}(6.3 \mathrm{in}$.)

$1.52 \mathrm{~cm} / \mathrm{hr}(0.6 \mathrm{in} . / \mathrm{hr})$

6 miles or less with sky completely

obscured

10 times per year, maximum 
Duration:

24 hrs. Per occurrence

Winds Gusts up to 80 miles per hour can be expected on site with the average wind speed in the 200 Area of $7.7 \mathrm{mph}$ in the WNW direction.

Frost Line:

36 inch

Solar Radiation:

Frequent exposure due to minimal cloud cover

Additional information on Hanford site weather conditions can be obtained from the Hanford Site vicinity weather bureau.

3.2.6.1.1 Ashfall. The ashfall requirements that shall be used for this project are located in DOE 6430.1A and ICF KH A/E Standard, GC-LOAD-01. The requirement for ashfall loading on a roof is $117 \mathrm{~kg} / \mathrm{m}^{2}\left(24 \mathrm{lb} / \mathrm{ft}^{2}\right)$, for Safety Class 1 structures, systems, components, and equipment. There are no additional loading requirements for ashfall for Safety Class 2, 3, and 4 items. Ashfall requirements for ventilation systems are to be determined.

\subsubsection{Induced Environments.}

3.2.6.2.1 Radiation and Chemical. Equipment installed in the tanks shall be capable of performing their intended function for the duration of their intended useful life with no adverse affects due to the radiological and chemical environment in the tanks. (DOE Order 6430.1A,)

3.2.6.2.2 Internal - Radionuclide. The ISSTRS Elements shall be capable of withstanding the liquid waste radionuclide concentrations ranges specified in Appendix A, Tables A-1 to A-4.

3.2.6.2.3 Internal - Waste Chemical Characteristics. The ISSTRS elements shall be capable of withstanding the liquid waste chemical composition ranges specified in Appendix A, Tables A-1 to A-4.

3.2.6.2.4 Internal - Waste Physical Properties. The ISSTRS elements shall be capable of withstanding slurry wastes and liquids with the physical characteristics ranges in Appendix A, Tables A-1 to A-4. 


\subsubsection{Transportability}

\subsubsection{Packaging and Marking of Materials for Transportation. The packaging,} marking, labeling, and placarding regulations of the Department of Transportation applicable to all shippers, are contained in 49 CFR parts 171-179. Noncompliance with these regulations carry both civil and criminal penalties. Reporting requirements for hazardous material incidents are those listed on page II-11 paragraph $7 \mathrm{~d}$.

Transportation of Hazardous Materials. Any system or component used to ship hazardous materials shall be designed to meet the requirements of WHC-CM-2-14.

\subsubsection{Flexibility and Expansion}

Flexibility is a major design requirement for all facilities except those with highly specialized functions. Even in those special facilities, however, the design shall, to the maximum extent practicable, provide sufficient flexibility to accommodate for programmatic changes or operational modifications.

\subsection{DESIGN AND CONSTRUCTION}

DOE Order 6430.1A provides general design criteria for the acquisition of the DOE Order 6430.1A shall be used for the design and construction of the ISSTRS. Additional specific requirements are identified in the following sections.

\subsubsection{Materials, Processes and Design Practices}

3.3.1.1 Facility Design and Shielding Criteria. Guidelines for radiological design are provided in Radiological Design Guide WHC-SD-GN-30011. The shielding design criteria in table 3-4 are summarized from Radiological Design Guide, Section 7.0, and shall be used to determine the shielding requirements of different areas in the ISSTRS Design. Shielding shall be designed to limit the total whole body dose to less than $5 \mathrm{mSv}$ per year. The source term used for shielding design will be provided by WHC. 
Table 3-5. Shield Design Criteria.

\begin{tabular}{|c|c|c|c|}
\hline Zone Category & $\begin{array}{l}\text { Acress Time } \\
\text { Allowed }\end{array}$ & Maximum (mSv/h) & Maximum (mrem/h) \\
\hline Uncontrolled Area & Full time & 0.0005 & 0.05 \\
\hline \multicolumn{4}{|l|}{ Controlled Area } \\
\hline 1 & Full time & 0.0025 & 0.25 \\
\hline 2 & Less than $1 \mathrm{~h} /$ day & 0.02 & 2.0 \\
\hline 3 & Less than $1 \mathrm{~h} /$ week & 0.1 & 10.0 \\
\hline 4 & Less than $10 \mathrm{~h} / \mathrm{yr}$ & 0.5 & 50.0 \\
\hline 5 & $\begin{array}{l}\text { No normal access } \\
\text { permitted }\end{array}$ & $>0.5$ & $>50.0$ \\
\hline
\end{tabular}

Note:

For design purposes, the dose from neutrons should be calculated by doubling the neutron quality factors (DOE Order 5480.1).

\section{Facility Design and Modification}

During the design of new facilities or modification of old facilities, the following objectives shall be adopted:

- Optimization methods shall be used to assure that occupational exposure is maintained ALARA in developing and justifying facility design and physical controls.

- The design objective for controlling personnel exposure from external sources of radiation in areas of continuous occupational occupancy (2000 hours per year) shall be to maintain exposure levels below an average of 0.5 mrem ( 5 microsieverts) per hour and as far below this average as is reasonably achievable. The design objectives for exposure rates for potential exposure to a radiological worker where occupancy differs from the above shall be ALARA.

- Regarding the control of airborne radioactive material, the design objective shall be, under normal conditions, to avoid releases to the workplace atmosphere and in any situation, to control the inhalation of such material by workers to levels that are ALARA; confinement and ventilation shall normally be used.

- The design or modification of a facility and the selection of materials shall include features that facilitate operations, maintenance, decontamination, and decommissioning. 
3.3.1.2 Support Devices. Design for supporting structures, housing modules, and services of the ISSTRS shall be in accordance with DOE Order 6430.1A. General Design Criteria.

3.3.1.3 Structural Supports. All structural system, components, and structures shall be designed, fabricated, inspected, and installed in accordance with the requirements of DOE Order 6430.1A.

3.3.1.4 Air Control for Contaminated Areas. The ISSTRS shall provide ventilation control (differential pressure) for confinement by directing air from uncontaminated areas, or areas of lower contamination, toward areas of higher contamination, and by high-efficiency particulate air filtration.

Nonradioactive Airborne Emissions. A notice of Construction application for the emission of toxic air pollutants and/or criteria pollutants will be required by Ecology (WAC 173-400, "General Regulations for Air Pollutants"). The preconstruction approval requires that BACT and T-BACT analyses be performed regardless of emission levels. The applicant must also demonstrate that (1) the facility complies with all applicable air quality standards, new source performance standards (NSPS), and NESHAP; (2) the task will not delay the attainment date or cause or contribute to a violation of any ambient air quality standard; and (3) the facility meets small-quantity emission levels or acceptable source impact levels, or performs a second-tier analysis.

3.3.1.5 Retrieval Construction and Operations Solid Waste. The ISSTRS shall be designed to comply with all onsite packaging and shipping requirements. All waste retrieval equipment shall eventually be disposed of as well as in-tank equipment that obstructs the retrieval activities. All waste generated shall be designated in accordance with WHC-EP-0063-1, Hanford Site Radioactive Solid Waste Acceptance Criteria, and WHC-CM-2-4, Hazardous Material Packaging and Shipping and shall meet waste acceptance requirements contained therein.

Minimized Waste Segregation. Waste generation shall be controlled, reduced, segregated, and minimized in accordance with DOE Order 5820.2A. Chapter III, 3.c.E.

Transfer of Radioactive Solid Waste. Transfer of solid radioactive waste to the Hanford Site Solid Waste program for dispositioning shall be in accordance with criteria specified in the Hanford Site Solid Waste Acceptance Criteria, WHC-EP-0063-4 and WHC-CM-2-12, Hazardous Materials Packaging and Shipping. The facility design shall be capable of segregating and packaging the categories of waste generated from the ISSTRS. Once separated, it is recommended the solid waste be packaged into $208-\mathrm{L}$ ( $55 \mathrm{gal})$ drums or boxes $(5 \mathrm{ft} \times 5 \mathrm{ft} \times 9$ $\mathrm{ft}$ ). The exterior of all waste packages must not be smearable above $220 \mathrm{dpm} / 100 \mathrm{~cm}^{2}$ for beta-gamma per WHC-EP-0063. 
3.3.1.6 Facility Fire Water System. Fire protection systems provided by ISSTRS shall be designed to meet the following requirements, as applicable:

- DOE Order 6430.1A, General Design Criteria, all sections

- DOE Order 5480.4, Environmental Protection, Safety, and Health Protection Standards, Attachment 2, "Mandatory ES\&H Standards," Section 2C, "Fire Protection".

- DOE Order 5480.7A, Fire Protection.

- DOE RLID 5480.7, Fire Protection.

- DOE/EV-0043, Standards on Fire Protection for Portable Structures.

- WHC-CM-4-41, Fire Protection Program Manual, Section 3.0, "Requirements".

- $\quad$ National Electrical Code (NFPA 1990a)

- National Fire Codes (NFPA 1990b)

The Fire Water System shall include all equipment necessary to provide a reliable source of fire water to TWRS complex facilities (e.g., storage tanks, pumps, hearers, and distribution piping, etc.). The fire water system shall be capable of providing service under all credible accident and emergency scenarios.

3.3.1.7 Fire Hazards Analysis. A fire hazards analysis (FHA) shall be provided for the project in accordance with DOE Order 5480.7A, Fire Protection. Recommendations in the FHA shall be incorporated into the design of the facility. The Fire scenarios in the safety analysis documentation shall be provided or validated by the FHA. The following documents provided the basis WHC-CM-4-41, Fire Protection Program Manual, Section 3.0, "Requirements," "Integration of Fire Hazards Analysis and Safety Analysis Report Requirements."

3.3.1.8 Power Systems. The electrical power systems shall be in accordance with DOE 6430.1A Division 16, NFPA 70 and ANSI C2 for primary uninterruptable, and emergency backup power.Backup Electrical Power System Definitions and Design Criteria shall be used to determine the proper definition of backup electrical power systems.

Other Electrical. The electrical system shall be accordance with DOE 6430.1 A Division 16, NFPA 70, and ANSI C2. 
Electrical Loads \& Operational Design Requirements. All systems shall comply with NFPA 70 and ANSI C2. Electrical systems shall be designed so that all components operate within their capacities for initial and projected loads. Preferred standard voltages in conformance with ANSI C84.1 shall be used, with a single-voltage level characteristic in any classification, to minimize stocks of spare equipment and to standardize operating and maintenance practices and procedures.

Electrical materials and equipment shall be UL- or FM-tested, with label attached, for the purpose intended, whenever such products are available. Where there are no UL- or FM-listed products of the type, testing and certification by another nationally recognized testing agency may be acceptable. Installation methods shall be in accordance with the manufacturer's instructions, with NFPA 70, and with other applicable requirements.

On-site acceptance testing shall be required for each major electrical system. Tests shall be specified to demonstrate that each function and important parameter is implemented. Specific criteria shall be included to determine pass/fail acceptance. Tests shall be performed in the presence of a government representative. Copies of all test results shall be submitted for approval.

Lighting Design and Construction Requirements. Lightning protection systems shall comply with NFPA 78. Lightning protection systems shall be considered for buildings containing facilities for the use, processing, and storage of radioactive, explosive, and similarly hazardous materials; for buildings over 50 feet in height; and for buildings containing valuable equipment. A risk assessment using the guide in Appendix I of NFPA 78 shall be made of these buildings to determine the risk of loss due to lightning. Electric power and communication services to all buildings and facilities and to underground power cables, where connected by overhead power distribution lines, shall have lightning and surge protection.

3.3.1.9 Containment System Design. All new high-level waste handling, transfer, and storage facilities (e.g., tanks, bins, pipelines, and capsules) shall be doubly contained.

Conditional Use for Singly Contained Pipelines. Singly contained pipelines may be used routinely for liquid waste that has a total radioactivity concentration of less than $0.05 \mathrm{Ci} / \mathrm{gal}(4.9$ $\mathrm{X} 10^{11} \mathrm{~Bq} / \mathrm{m}^{3}$ ). They may be used on a temporary basis for higher activity waste, if appropriate design and administrative controls are in place to mitigate adverse effects from a pipeline failure.

Secondary Containment System. Secondary containment system shall be capable of containing liquid that leak into them from the primary system and shall be equipped with transfer capability to retrieve the leaked liquid. Secondary containment systems for solidified high-level waste shall provide for physical isolation of the waste from the environment.

Secondary Containment System to Prevent Migration of Waste. The ISSTRS secondary containment system shall comply with the items below: 
Secondary containment systems must be:

- Designed, installed, and operated to prevent any migration of wastes or accumulated liquid out of the system to the soil, ground water, or surface water at any time during the use of the tank system; and

- Capable of detecting and collecting releases and accumulated liquids until the collected material is removed.

Minimum Requirements for Secondary Containment System. The ISSTRS system shall meet the minimum requirements for the system to have construction of the system to be lined with materials that are compatible with the waste(s) to be placed in the tank system and must have sufficient strength and thickness to prevent failure owing to pressure gradients (including static head and external hydrological forces). physical contact with the waste to which it is exposed. climatic conditions, and the stress of daily operations (including stresses from nearby vehicular traffic); foundation or base capable of providing support to the secondary containment system, resistance to pressure gradients above and below the system, and capable of preventing failure due to settlement, compression, or uplift; a leak-detection system that is designed and operated so that it will detect the failure of either the primary or secondary containment structure or the presence of any release of dangerous waste or accumulated liquid in the secondary containment system within twenty-four hours; and sloped or otherwise designed or operated to drain and remove liquids resulting from leaks, spills. or precipitation.

Ancillary Equipment Secondary Containment Requirement. ISSTRS shall comply with the ancillary equipment requirements for above ground piping, welded flanges, sealless and magnetic pumps, and pressurized systems.

- Ancillary equipment must be provided with secondary containment (e.g., trench, jacketing, double-walled piping) except for:

- Aboveground piping (exclusive of flanges, joints, valves, and other connections) that are visually inspected for leaks on a daily basis;

- Welded flanges, welded joints. and welded connections, that are visually inspected for leaks on a daily basis;

- Sealless or magnetic coupling pumps and sealless valves, that are visually inspected for leaks on a daily basis; and

- $\quad$ Pressurized aboveground piping systems with automatic shut-off devices (e.g., excess flow check valves, flow metering shutdown devices, loss of pressure actuated shut-off devices) that are visually inspected for leaks on a daily basis. 
Ancillary Equipment Support and Protection Requirements. ISSTRS shall support and protect in accordance with the requirement listed below to mitigate the excessive stresses caused from settlement, vibration, expansion, or contraction on ancillary equipment.

Ancillary equipment must be supported and protected against physical damage and excessive stress due to settlement, vibration, expansion, or contraction.

Note: The piping system installation procedures described in American Petroleum Institute (API) Publication 1615 (November 1979), "Installation of Underground Petroleum Storage Systems," or ANSI Standard B31.3, "Petroleum Refinery Piping," and ANSI Standard B31.4 "Liquid Petroleum Transportation Piping System," may be used, where applicable, as guidelines for proper installation of piping systems.

Secondary Containment for Hazardous Waste. ISSTRS shall comply with the hazardous waste requirements for secondary containment by meeting the itemized requirement of 40 CFR265.196(a-c). The summary of the requirement is that a tank system or secondary containment system from which there has been a leak or spill, or which is unfit for use, must be removed from service immediately, and the owner or operator must satisfy the following requirements: Cessation of use shall be accomplished by; prevention of flow or addition of wastes; removal of waste from tank system or secondary containment system; immediately conducting a visual inspection of the release; and containment of visible releases to the environment.

3.3.1.10 Corrosion Control. Underground storage tanks, and associating piping and ancillary equipment (e.g., piping, fittings, flanges, valves, and pumps used to distribute meter or control the flow regulated substances to or from any underground storage tank) shall be designed to have corrosion control. The following requirements outline corrosion control:

Corrosion Inspection. The owner or operator must provide the type and degree of corrosion protection recommended by an independent corrosion expert, or other corrosion protection if the department believes other corrosion protection is necessary to ensure the integrity of the tank system during use of the tank system. The installation of a corrosion protection system that is field fabricated must be supervised by an independent corrosion expert to ensure proper installation.

Factors for Potential Corrosion Sources. For new tank systems or components in which the external shell of a metal tank or any external metal component of the tank system will be in contact with the soil or with water, a determination by a corrosion expert of: Factors affecting the potential for corrosion. including but not limited to:

- Soil moisture content;

- Soil pH; (III) Soil sulfides level;

- Soil resistivity: 
- Structure to soil potential;

- Influence of nearby underground metal structures (e.g., piping);

- Existence of stray electric current;

- Existing corrosion-protection measures (e.g., coating, cathodic protection); and

The type and degree of external corrosion protection that are needed to ensure the integrity of the tank system during the use of the tank system or component, consisting of one or more of the following:

- Corrosion-resistant materials of construction such as special alloys, fiberglass reinforced plastic, etc.;

- Corrosion-resistant coating (such as epoxy, fiberglass, etc.,) with cathodic protection (e.g., impressed current or sacrificial anodes); and

- Electrical isolation devices such as insulating joints, flanges, etc.

Note: The practices described in the National Association of Corrosion Engineers (NACE) standard, "Recommended Practice (RP-02-85)--Control of External Corrosion on Metallic Buried, Partially Buried, or Submerged Liquid Storage Systems," and the American Petroleum Institute (API) Publication 1632, "Cathodic Protection of Underground Petroleum Storage Tanks and Piping Systems," may be used, where applicable, as guidelines in providing corrosion protection for tank systems.

Corrosion Assessment and Storage Integrity. A method for periodically assessing waste storage system integrity (e.g., coupons for corrosion testing, photographic and periscopic inspections, leak detectors, liquid level devices) shall be established, documented, and reported as required in the Waste Management Plan.

\subsubsection{Materials}

Secondary Containment Materials. The system secondary containment materials shall be compatible with waste(s).

Compatible Materials for Hazardous Waste Storage. The owner or operator must use a container made of or lined with materials which will not react with, and are otherwise compatible with, the hazardous waste to be stored, so that the ability of the container to contain the waste is not impaired.

Incompatible Waste and Materials. ISSTRS shall comply with the incompatible wastes, and or materials that line the container as outlined below. 
(a) Incompatible wastes, or incompatible wastes and materials, must not be placed in the same container, unless 40 CFR [Section] 264.17(b) is complied with.

(b) Hazardous waste must not be placed in an unwashed container that previously held an incompatible waste or material.

(c) A storage container holding a hazardous waste that is incompatible with any waste or other materials stored nearby in other containers, piles, open tanks, or surface impoundments must be separated from the other materials or protected from them by means of a dike, berm, wall, or other device.

3.3.1.12 Toxic Products and Formulations. The ISSTRS shall be designed without components or hardware which uses asbestos, Polychlorinated Biphenyl (PCBs), or ozone depleting chemicals.

Asbestos-Containing Materials. The system shall comply with 29 CFR 1910 during maintenance, repair, and demolition of DOE facilities.

\subsubsection{Radiation}

\section{DOE Sponsored Radiological Requirements}

The Radiological Health and Safety Policy provides the general framework for the conduct of radiological control activities throughout the DOE complex. Below the policy statement are both regulatory and contractual systems of basic requirements established through 10 CFR 835 , which is enforced through a regulatory system established in 10 CFR 820, and DOE Order 5480.11, which is enforced through contractual commitments. The requirements of the Rule are augmented by complementary guidance provided in Implementation Guides while the requirements of the Order are augmented by complementary guidance provided in the DOE Radiological Control Manual.

The Hanford Site Radiological Control Manual (HSRCM) has been developed through a cooperative effort between the DOE Richland Operations Office (RL) and the Hanford contractors. As required by Article 114.1, the HSRCM has been approved by the senior site executives of the Hanford contractors and provides the basis for consistent and uniform implementation of radiological control requirements for the Hanford Site.

Non-DOE Sponsored Radiological Requirements. For any Non-DOE sponsored work $10 \mathrm{CFR}$ $20.1201,10$ CFR 20.1301, 10 CFR 20.1601. 10 CFR 20.1602, 10 CFR 20.1603, 10 CFR 20.1701, 10 CFR 20.1702, 40 CFR 191, 40 CFR 192, and 40 CFR 193 are applicable. 
Accidental Public Exposure. DOE facilities will be designed, constructed, operated, and decommissioned to assure the protection of the public, workers, and the environment.

DOE has adopted two quantitative safety goals to limit the risks of fatalities associated with its nuclear operations. These goals are the same as those established for nuclear powerplants by the Nuclear Regulatory Commission (NRC) and, like the NRC goals, should be viewed as aiming points for performance. The goals are:

The risk to an average individual in the vicinity of a DOE nuclear facility for prompt fatalities that might result from accidents should not exceed one tenth of one percent $(0.1 \%)$ of the sum of prompt fatalities resulting from other accidents to which members of the population are generally exposed. For evaluation purposes, individuals are assumed to be located within one mile of the site boundary.

The risk to the population in the area of a DOE nuclear facility for cancer fatalities that might result from operations should not exceed one tenth of one percent $(0.1 \%)$ of the sum of all cancer fatality risks resulting from all other causes. For evaluation purposes, individuals are assumed to be located within 10 miles of the site boundary.

In striving to reach these goals, DOE nuclear facilities and activities shall be designed, constructed, operated, and decommissioned with: a) appropriate barriers to prevent or minimize potential radioactive releases; $b$ ) engineered safety features to minimize potential releases; and $c$ ) procedural controls to mitigate the effects of potential releases. These goals shall be addressed for both new and existing facilities. Proposed modifications to existing facilities to achieve these goals shall be prioritized along with other proposed modifications based on their safety significance. DOE shall pursue the evolution of additional potential safety goals for plant and co-located workers to support enhanced safe operations of its facilities.

Control of Access to High Radiation Areas. ISSTRS shall design the elements of the system that meet the requirements of the control of access to high radiation areas. The requirement summary includes the access requirements, control device for entry area, control device to energize an alarm, control and locked high radiation areas, electronic surveillance of entry, and control of entrance or access to areas with qualified personnel trained to take necessary precautions.

Radiation Exposure Rates in Controlled Workplace. Radiation exposure rates in controlled workplace areas should be reduced to as low as reasonably achievable levels by proper facility design and control. The primary means for maintaining exposures as low as reasonably achievable are to be through physical controls, e.g., confinement, ventilation, remote handling, and shielding. Administrative controls and procedural requirements are to be considered supplemental means to achieve control. The requirement summary includes design, optimization, external radiation exposure, internal radiation exposure, maintenance, decontamination, and decommissioning. 


\subsubsection{Nameplates and Product Marking}

Identification of Subparts Legibly Marked. Identification of disconnecting means and circuits. Each disconnecting means required by this subpart for motors and appliances shall be legibly marked to indicate its purpose, unless located and arranged so the purpose is evident. Each service, feeder, and branch circuit, at its disconnecting means or over current device, shall be legibly marked to indicate its purpose, unless located and arranged so the purpose is evident. These markings shall be of sufficient durability to withstand the environment involved.

Durability and Legibility of Labels. Equipment and any parts of that equipment to be used by personnel shall be identified with appropriate labels. The label shall indicate clearly and concisely the function and purpose of the item being labeled.

Permanent labels shall be attached to the specific component or equipment in such a manner that environmental conditions or usage by personnel will not remove or destroy the label.

Labeling shall be legible and conform to human visual capabilities and limitations in regard to physical characteristics such as letter and symbol size, contrast, font, simplicity, spacing and stroke width.

Specific guidelines for addressing labeling considerations are contained in NUREG 0700 , Section 6.6 and MIL- STD-1472D, Section 5.5.

\subsubsection{Workmanship}

The ISSTRS system elements shall conform to the workmanship standards specified in WHCCM-8-9, "Workmanship Standards".

\subsubsection{Interchangeability}

ISSTR system elements shall include interchangeability factors. These requirements are "To Be Determined." Interchangeability is required to allow, as much as is practical, for temporary use of parts/equipment until a replacement is procured, (i.e., use of a pipe fitting or electrical fitting) which may suffice until its replacement is obtained.

\subsubsection{Safety}

The policy of The buyer is to assure that all activities are strictly controlled, from design, to operation and maintenance, all components, system, and processes must meet safety and environmental requirements. Requirements and standards outlined in DOE 5480.4. 
Environmental Protection, Safety and Health Protection, applicable to system design shall be incorporated for safety.

Safety Analysis. A contractor, as designated in writing by the PSO, who is responsible for the design, construction, or operation of DOE nuclear facilities shall be required to perform a safety analysis that develops and evaluates the adequacy of the safety basis for each such facility.

Unreviewed Safety Questions. Perform all safety evaluations to determine whether a situation involves USQ. Prior to implementation of a proposed action, obtain PSO approval for situations determined to involve a USQ or a Technical Safety Requirements (TRS) change; and develop and implement procedures to govern the need for , and the performance of safety evaluations under this section.

Technical Safety Requirements. In accordance with this Order, a contractor responsible for the operation of a DOE nuclear facility shall prepare and submit the Technical Safety Requirements to the PSO for approval for the facility. The contractor shall operate the facility in accordance with the Technical Safety Requirements as approved by the PSO including any modification by the PSO.

Safety/Hazard Classification for Nuclear Facilities and Operations. Facilities that treat, store or dispose of hazardous (dangerous) waste and mixed waste (containing both hazardous and radioactive waste components) shall conform to DOE Order 5820.2A. Hazardous waste is regulated in accordance with the Resource Conservation and Recovery Act (RCRA) and the Washington Administrative Code (WAC) 173-303, Dangerous Waste Regulations.

\subsubsection{Fire Protection}

Fire Protection Program. A program in accordance with DOE5480.7A, Fire Protection, as required by the PSO or the Heads of Field Organizations and directed by the Contracting Officer shall be a part of ISSTRS. The fire protection program summary includes these requirements: 1) Provide and maintain a level of fire protection, 2) Provide and maintain a system to ensure that the requirements of the DOE fire protection program are documented and incorporated in the plans and specifications for all new facilities and for major modifications of existing facilities. 3) Assist DOE in coordinating fire safety assessments at those facilities included in the survey program, 4) Establish and maintain a list of facilities for fire protection assessment, 5) Conduct fire protection assessments of facilities, 6) Provide fire protection technical assistance to DOE, 7) Submit requests for exemptions and fire safety equivalencies for those facilities where compliance with specific program elements is not attainable and where an acceptable level of safety has been achieved, and 8) Maintain or have access to an adequate fire protection staff, including a qualified fire protection engineer(s).

Uniform Fire Codes. Containers holding reactive waste exhibiting a characteristic specified in WAC 173-303-090 (7)(a)(vi), (vii) or (viii) must be stored in a manner equivalent to the 
Uniform Fire Code's "American Table of Distances for Storage of Explosives," Table 77-201, 1979 edition or the version adopted by the local fire district. These requirements state. in part, "(b) The owner or operator shall design, operate, and maintain ignitable waste and reactive waste (other than a reactive waste which must meet (a) of this subsection) container storage in a manner equivalent with the Uniform Fire Code. Where no specific standard or requirements are specified in the Uniform Fire Code, or in existing state or local fire codes, applicable sections of the NFPA Pamphlet \# 30, "Flammable and Combustible Liquids Code," shall be used. The owner/operator shall also comply with the requirements of WAC 173-303-395 (1)(d).

\subsubsection{ALARA}

ALARA. In accordance with the recommendations of the Environmental Protection Agency, formerly the Federal Radiation Council, approved by the president of the United States of America, persons engaged in activities under licenses issued by the Washington state department of health pursuant to the Atomic Energy Act of 1954, as amended, shall, in addition to complying with the requirements set forth in chapter 246-221 WAC, make every reasonable effort to maintain radiation exposures, and releases of radioactive materials in effluents to unrestricted areas, as low as is reasonably achievable.

ALARA Design. The cost/benefit analysis used by The buyer is based on guidance provided in Health Physics Manual of Good Practices for Reducing Radiation Exposures to Levels That Are As Low As Reasonably Achievable, PNL-6577. This document is cited in DOE Order 5480.11 . Radiation Protection for Occupational Workers as providing useful information for implementing the requirements of the order.

The detriment associated with exposure to radiation is expressed in PNL-6577 as follows:

$\mathrm{X}=\mathrm{A}+\mathrm{B}$

where

$A=$ cost of a person-rem due to health detriment (\$)

$\mathrm{B}=$ cost of a person-rem due to nonhealth-related detriment $(\$)$

$\mathrm{X}=$ cost of a person-rem due to total detriment $(\$)$.

The minimum value of $\mathrm{A}$ accepted by The buyer is $\$ 2,500$.

A value for the B component is not assigned in PNL-6577, but is considered to be variable; the actual value depends on application. As applicable to Westinghouse Hanford, the value of B is considered to be a range from essentially zero dollars to an upper limit value dependent on application.

The maximum value for $B$ is limited in practical terms, to the cost of replacing the individual worker in the specific work force who has approached a preset limit. A specific evaluation of B 
for The buyer is developed in WHC-SA-1533-FP. The method used in this paper can be employed to develop quantitative values of $\mathrm{B}$ for other situations.

\subsubsection{Design for Safety}

Design Objectives. Design objectives for new facilities will assure protection of the public and operating personnel from hazards associated with normal high-level waste operations, accident conditions, and the effects of natural phenomena. Other objectives are compliance with DOE policies regarding nuclear safety, quality assurance, fire protection, pollution control, and safeguards and security protection for high-level waste and protection of essential operations from the effects of potential accidents.

Safety Analysis Reports. (2) Design Review for Existing Facilities. Uniform requirements for the preparation of safety analysis reports for high-level waste operations, detailed in DOE $5481.1 \mathrm{~B}$, include the review of existing operational facilities based on current technical criteria. When hazards are identified that should be eliminated, controlled, or mitigated, appropriate upgrading, actions in accordance with paragraph 3 a(1) above, shall be identified and implemented according to the requirements of DOE $5481.1 \mathrm{~B}$.

Worker Occupational Safety. TWRS activities shall conform to 29 CFR 1910 and DOE 5483.1 a Occupational Safety and Health Administration (OSHA) Program at Government owned contractor operated facilities.

Safety Class. ISSTRS shall satisfy the following safety class criteria for the identification of safety structures, systems and components (SSCs). These requirements shall be used for design and quality assurance.

1. Prevent or mitigate offsite public exposure in excess of 500 mrem ( $5 \mathrm{mSv}$ ) EDE.

2. Place or maintain an operating process in a safe condition that prevents or mitigates consequences to the public in excess 500 mrem EDE.

3. Monitor the release of radioactive materials to the environment during and after accidents where the monitor's output initiates Emergency Response Plan actions or operator actions to place the operating process in a safe condition per criterion 2 .

4. Maintain operating parameters within the TSRs or OSRs that protect the public per criteria 1 or 2 .

5. Maintain double contingency protection against an accidental nuclear criticality as defined in WHC-CM-4-29, Nuclear Criticality Safety.

6. Support the safety function of safety class structures, systems, and components (SSC). This includes control and monitoring functions (operating air, electrical power, instrumentation, etc.). See Notes 3 and 4. 
Safety Significant. ISSTRS shall satisfy the following safety class criteria for the identification of safety structures, systems and components (SSCs). These requirements shall be used for design and quality assurance.

1. Prevent or mitigate onsite exposure to radiological materials in excess of 5 rem $(50 \mathrm{mSv})$ EDE. See Notes 1 and 2.

2. Prevent or mitigate toxic chemical exposure to within the risk guidelines of WHC-CM-446, Chapter 7.0. Se notes 2 and 4.

3. Place or maintain an operating process in a safe condition that prevents or mitigates consequences that exceed criteria 6 or 7 .

4. Prevent or mitigate exposure in excess of 5 rem EDE or an airborne concentration of toxic material in excess of the applicable chemical ERPG-2 limit to facility operators who are relied on to achieve the safe condition of criteria 2 and 8 .

5. Monitor the release of radioactive and/or hazardous materials to the environment during and after accidents where the monitor's output initiates Emergency Response Plan actions or operator actions to place the operating process in a safe condition per criterion 8 .

6. Maintain operating parameters within the TSRs or OSRs that protect the onsite worker per criterion 6.

7. Provide defense-in-depth prevention or mitigation of an uncontrolled release of radioactive and/or hazardous material deemed significant. See Note 4.

8. Prevent or mitigate an acute fatality to a facility worker or serious injury to a group of workers, except where the SSCs are controlled through an implemented institutional safety or radiation protection program.

9. Support the safety function of a safety significant SSC. This includes control and monitoring functions (operating air, electrical power, instrumentation, etc.). See Notes 3 and 4 .

Maintenance Management Program. The Maintenance management program for all DOE property be consistent with this Order and that all DOE property be maintained in a manner which promotes operational safety, worker health, environmental protection and compliance, property preservation, and cost-effectiveness while meeting the programmatic mission.

Structures, systems, and components that are important to safe operation shall be subject to a maintenance program in order to meet or exceed their design requirements throughout their life.

Periodic inspection of structures, systems, components, and equipment be performed to determine deterioration or technical obsolescence which threaten performance and/or safety.

Warning and Annunciator. Warning and Annunciator Systems. An effective warning system shall alert personnel to a problem of abnormal condition and shall provide sufficient time to respond appropriately to the problem. General warning guidelines are found in MIL-STD-1472D, Section 5.3. For the special case of control room annunciators, see NUREG 0700 , Section 6.3. For auditory signals guidelines, see NUREG 0700, Section 6.2 . 
Emergency Lighting. Emergency lighting systems shall be provided as required by NFPA 101 . A control room emergency lighting system shall be automatically activated and immediately available for a stated minimum length of time on failure of the normal lighting system. The emergency lighting system for vital areas shall be an electronically independent system that is not degraded by failure of the normal lighting system. Control room emergency lighting levels shall be in accordance with NUREG 0700, Section 6.1.5.4.

Display Device. Displays shall provide only the information about system status and parameter values that is needed to meet task requirements in normal, abnormal and emergency situations. Status, rather than demand information, shall be displayed for important parameters. Displays shall indicate whether they reflect demand or actual values.

Each display device, including meters, CRTs, LCDs, consoles, and other electronic or mechanical media shall be formatted and designed to ensure that both the display and display content are readable, understandable, and accessible.

Failure of a display of any type shall be easily recognized and shall not affect equipment or system performance.

Where CRTs are used, rapid, error-free access to the information required for the task shall be accomplished by ensuring that system response to any query is less that 2 seconds and that user feedback to control action is less that 0.2 seconds or faster whenever possible.

More specific information regarding these requirements is contained in NUREG 0700 , Section 6.5, MIL-STD- 1472D, Section 5.2, and NUREG CR-2496.

\subsubsection{Human Engineering}

Human Dimension Consideration. Equipment that is to be used by personnel shall be designed or selected to accommodate their body dimensions. This equipment shall include control panels, work tables and counters, enclosures, seating, storage, and any other equipment designed for an operator. The design of equipment for personnel shall accommodate a wide variety of body dimensions. Generally, it is recommended that equipment dimensions accommodate the fifth to ninety-fifth percentile of the user population. For recommended data representing these percentiles, see NUREG 0700, Section 6.1, and MIL-STD-1472, Section 5.6. 


\subsubsection{Nuclear Control}

\subsubsection{Criticality}

Criticality Safety Program. The criticality safety program defined herein applies to all storing, retrieving, processing, transfer operations, transport and storage activities and waste form operations involving fissionable material quantities in excess of $3 \%$ of a minimum critical mass. Designs shall incorporate sufficient factors of safety to require at least two unlikely, independent, and concurrent changes in process conditions before a criticality accident is possible. Protection shall be provided by either (a) the control of two independent process parameters (which is the preferred approach, if practical) or (b) a system of multiple (at least two) controls of a single parameter. In all cases, no single credible failure shall result in the potential for a criticality accident. The basis for selecting one approach over another shall be fully documented. New criticality safety evaluations (CSEs) and major revisions to existing CSEs shall provide this documentation; existing CSEs are not required to be revised just to provide this documentation.

Nuclear Criticality Safety Considerations. Nuclear criticality safety considerations and controls shall be evaluated for normal operations and, before any significant operational changes are made, to protect against an uncontrolled nuclear criticality incident (e.g., dissolution of sludge for removal from tank).

\subsubsection{Security}

Safeguard and security system shall meet the requirements of DOE 470.1. Detailed requirements for personnel security activities, protection operations, information security, and materials control and accountability are set forth in the Orders listed below:

1) Program Management, DOE 0470 series

2) Personnel Security, DOE 0472 series

3) Protection Operations, DOE 5632 and DOE 0473 series

4) Materials Control and Accountability, DOE 5632 and DOE 0474

5) Information Security, DOE 5639 and DOE 0471 series

\subsubsection{Government Furnished Property Usage}

[RESERVED].

\subsubsection{Computer Resource Reserve Capacity}

[RESERVED]. 
This page intentionally left blank. 


\subsection{INFORMATION}

Records \& Document Control. Records, documents, and document control pertinent to design functions shall be in accordance with ASME-NQA-1-1994-IA, DOE 5500.7b, DOE-5480.CM, and ANSI/ANS-3.2-88.

Handling Procedures. The owner or operator of a new tank system must ensure that proper handling procedures are adhered to in order to prevent damage to the system during installation.

Conduct of Operations. It is the policy of the Department that the conduct of operations at DOE facilities be managed with a consistent and auditable set of requirements, standards, and responsibilities.

\section{$3.5 \quad$ LOGISTICS}

\subsubsection{Maintenance}

ISSTRS shall meet all applicable ALARA requirements from WHC-CM-4-1 1, ALARA Program Manual, and WHC-CM-4-10, Radiation Protection Manual, and shall make every effort to maintain radiation exposures, and releases of radioactive materials in effluents to unrestricted areas, as low as is reasonably achievable.

Equipment items which are in contact with waste, or in inaccessible areas such as the interior of the tank, will not be routinely/periodically maintained. These shall be designed for long life (relative to the service life), and shall be replaced during routine overhauls prior to failure. These will include: seals, elastomers, pumps, and waste property instrumentation. The items shall be designed to fail in a recoverable mode, so that replacement and decontamination of equipment can be done by remotely. The overhauls shall be performed after a retrieval campaign, when the equipment has been decontaminated to allow contact maintenance, and prior to installation for a new retrieval campaign. Equipment shall be reusable, decontaminatable, and/or replaceable.

Supply/Support. The system design shall use readily available parts and components.

\section{Spare Parts.}

\section{[RESERVED]}

Impact to Existing Facilities and Equipment. The equipment shall be designed to maintain Operating and Safety requirements during construction, testing, and normal operations. This includes maintaining proper confinement and ventilation during equipment insertion and removal from the tank, as well as ventilation system construction, testing and connection. 


\subsubsection{Waste Handling, Storage and Disposal}

Solid waste handling, storage and disposal shall be preformed in accordance with WHC CM-7-5, Section 7.0 .

\subsection{PERSONNEL \& TRAINING}

\subsubsection{Personnel}

Operator training and qualification standards shall be developed and an up-to-date record of training status shall be maintained.

System Design for Operating Qualified Personnel. The system shall be designed for operation by personnel possessing qualifications in accordance with DOE 5480.20 Chapter IV, and trained in accordance with Chapter I.

\subsection{PRECEDENCE}

The hierarchical relationship, top to bottom, among requirements specified in section 3 is provided in this section. This relationship among requirements specified in section 3 is as follows, except in those instances where Washington state has been granted regulatory authority by the U.S Government:

- Federal Laws (e.g., Code of Federal Regulations)

- Revised Code of Washington $(\mathrm{RCW})$ as specified in Washington Administrative Code

- Local Ordinances

- U.S. Department of Energy Orders and Secretary of Energy directives

- National Consensus Codes and Standards

- WHC control manuals, design standards, etc. not previously covered.

\subsection{QUALIFICATION}

[RESERVED]. 


\subsection{STANDARD SAMPLE}

[RESERVED].

3.10 PREPRODUCTION SAMPLE, PERIODIC PRODUCTION SAMPLE, PILOT LOT

[RESERVED]. 


\title{
4.0 QUALITY ASSURANCE PROVISIONS
}

This function shall adhere to the applicable requirements of 10 CFR 830, "Nuclear Safety Management, Subpart A, General Provisions, Section 830.120, Quality Assurance Requirements," Code of Federal Regulations. In accordance with these requirements, the project shall develop a project specific Quality Assurance Program Plan (QAPP) encompassing the following program elements as applicable to the project:

\author{
Program \\ Personnel Training and Qualifications \\ Quality Improvement \\ Documents and Records \\ Work Processes \\ Design \\ Procurement \\ Inspection And Acceptance Testing \\ Management Assessment \\ Independent Assessment.
}

The QAPP shall be submitted to DOE for approval.

All subcontractors providing services for the function, such as: architect and engineering (A-E) services, Construction Management (CM) services, and testing services in support of technology development shall be required to have or develop a QAPP compatible with the requirements of 10 CFR 830.120, as specific to the subcontractors area of responsibility. As long as the program is compatible with the above referenced requirements, it's bases can be founded in existing consensus standards, such as: ASME NQA-1, 10 CFR 50 Appendix B, and the ISO 9000 series. All subcontractor QAPPs shall be submitted to the WHC for review and concurrence.

Consistent with DOE Order $-5700.6 \mathrm{~B}$, high-level waste operations shall be conducted in accordance with applicable requirements of the American National Standards Institute/American Society of Mechanical Engineers Nuclear Quality Assurance-1 and other appropriate national consensus standards. (See Attachment 1, page 5, paragraph 48).

\subsection{ACCESS FOR INSPECTION}

ISSTRS shall provide access so that the owner or operator can inspect areas looking for leaks to the containment system caused by corrosion, deterioration, or other factors. 


\subsection{PREPARATION FOR DELIVERY (or OPERATIONS)}

[RESERVED] 


\section{APPENDIX A}

\section{SINGLE SHELL TANK INVENTORIES}


Table A-1. Single-Shell Tank 241-C-105 (2 Sheets).

\begin{tabular}{|c|c|c|c|}
\hline \multicolumn{4}{|c|}{ Solids Composite Inventory Estimate ${ }^{1}$} \\
\hline \multicolumn{4}{|l|}{ Physical Properties } \\
\hline Total Solid Waste & \multicolumn{3}{|c|}{$8.20 \mathrm{E}+05 \mathrm{~kg}(150 \mathrm{kgal})$} \\
\hline Heat Load & \multicolumn{3}{|c|}{$1.03 \mathrm{E}-02 \mathrm{~kW}(35 \mathrm{Btu} / \mathrm{hr})$} \\
\hline Bulk Density & \multicolumn{3}{|l|}{$1.44(\mathrm{~g} / \mathrm{cc})$} \\
\hline Void Fraction & \multicolumn{3}{|l|}{0.799} \\
\hline Water wt $\%$ & \multicolumn{3}{|l|}{70.4} \\
\hline TOC wt $\%$ & \multicolumn{3}{|l|}{0} \\
\hline Chemical Constituents & mole/L & ppm & kg. \\
\hline $\mathrm{Na}^{+1}$ & 2.04 & $3.26 \mathrm{E}+04$ & $2.67 \mathrm{E}+04$ \\
\hline $\mathrm{Al}^{+3}$ & 4.89 & $9.15 \mathrm{E}+04$ & $7.50 \mathrm{E}+04$ \\
\hline $\mathrm{Fe}^{+3}$ (total $\left.\mathrm{Fe}\right)$ & 0.970 & $3.75 \mathrm{E}+04$ & $3.08 \mathrm{E}+04$ \\
\hline $\mathrm{Cr}^{+3}$ & $6.46 \mathrm{E}-03$ & 233 & 191 \\
\hline $\mathrm{Bi}^{+3}$ & 0 & 0 & 0 \\
\hline $\mathrm{La}^{-3}$ & 0 & 0 & 0 \\
\hline $\mathrm{Ce}^{-3}$ & 0 & 0 & 0 \\
\hline $\mathrm{Zr}\left(\right.$ as $\left.\mathrm{ZrO}(\mathrm{OH})_{2}\right)$ & 0 & 0 & 0 \\
\hline $\mathrm{Pb}^{+2}$ & 0 & 0 & 0 \\
\hline $\mathrm{Ni}^{2}=$ & $5.66 \mathrm{E}-02$ & $2.10 \mathrm{E}+03$ & $1.72 \mathrm{E}+03$ \\
\hline $\mathrm{Sr}^{+2}$ & 0 & 0 & 0 \\
\hline $\mathrm{Mn}^{+4}$ & 0 & 0 & 0 \\
\hline $\mathrm{Ca}^{-2}$ & 0.107 & $2.98 \mathrm{E}+03$ & $2.44 \mathrm{E}+03$ \\
\hline $\mathrm{K}^{+1}$ & 0 & 0 & 0 \\
\hline $\mathrm{OH}^{-1}$ & 19.1 & $2.25 \mathrm{E}+05$ & $1.85 \mathrm{E}+05$ \\
\hline $\mathrm{NO}^{-1}$ & 0.763 & $3.28 \mathrm{E}+04$ & $2.69 \mathrm{E}+04$ \\
\hline $\mathrm{NO}_{2}^{-1}$ & 0.435 & $1.39 \mathrm{E}+04$ & $1.14 \mathrm{E}+04$ \\
\hline $\mathrm{CO}^{-2}$ & 0.120 & $5.00 \mathrm{E}+03$ & $4.10 \mathrm{E}+03$ \\
\hline $\mathrm{PO}_{4}^{-3}$ & $9.32 \mathrm{E}-02$ & 613 & 503 \\
\hline $\mathrm{SO}_{4}^{-2}$ & 0.101 & $6.70 \mathrm{E}+03$ & $5.49 \mathrm{E}+03$ \\
\hline $\mathrm{Si}\left(\right.$ as $\left.\mathrm{SiO}_{3}^{-2}\right)$ & $1.08 \mathrm{E}-02$ & 211 & 173 \\
\hline $\mathrm{F}^{1}$ & 0 & 0 & 0 \\
\hline $\mathrm{Cl}^{-1}$ & $1.48 \mathrm{E}-02$ & 364 & 298 \\
\hline
\end{tabular}


Table A-1. Single-Shell Tank 241-C-105 (2 Sheets).

\begin{tabular}{|l|l|l|l|}
\hline \multicolumn{4}{|c|}{ Solids Composite Inventory Estimate } \\
\hline $\mathrm{C}_{6} \mathrm{H}_{5} \mathrm{O}_{7}^{-3}$ & 0 & 0 & 0 \\
\hline EDTA $^{-4}$ & 0 & 0 & 0 \\
\hline
\end{tabular}


Table A-1. Single-Shell Tank 241-C-105 (2 Sheets).

\begin{tabular}{|c|c|c|c|}
\hline \multicolumn{4}{|c|}{ Solids Composite Inventory Estimate ${ }^{1}$} \\
\hline Chemical Constituents & mole/L & ppm & $\mathrm{kg}$ \\
\hline HEDTA $^{-3}$ & 0 & 0 & 0 \\
\hline $\mathrm{NTA}^{-3}$ & 0 & 0 & 0 \\
\hline glycolate $^{-1}$ & 0 & 0 & 0 \\
\hline acetate $^{-1}$ & 0 & 0 & 0 \\
\hline oxalate $^{-2}$ & 0 & 0 & 0 \\
\hline DBP & 0 & 0 & 0 \\
\hline $\mathrm{NPH}$ & 0 & 0 & 0 \\
\hline $\mathrm{CCl}_{4}$ & 0 & 0 & 0 \\
\hline hexone & 0 & 0 & 0 \\
\hline $\mathrm{Fe}(\mathrm{CN})_{6}^{-4}$ & 0 & 0 & 0 \\
\hline \multicolumn{4}{|l|}{ Radiological Constituents } \\
\hline $\mathrm{Pu}$ & & $0.798(\mu \mathrm{Ci} / \mathrm{g})$ & $10.9(\mathrm{~kg})$ \\
\hline U & $0.142(\mathrm{M})$ & $2.34 \mathrm{E}+04(\mu \mathrm{g} / \mathrm{g})$ & $1.92 \mathrm{E}+04(\mathrm{~kg})$ \\
\hline $\mathrm{Cs}$ & $1.77 \mathrm{E}-03(\mathrm{Ci} / \mathrm{L})$ & $1.23(\mu \mathrm{Ci} / \mathrm{g})$ & $1.01 \mathrm{E}+03(\mathrm{Ci})$ \\
\hline $\mathrm{Sr}$ & $1.47 \mathrm{E}-03(\mathrm{Ci} / \mathrm{L})$ & $1.02(\mu \mathrm{Ci} / \mathrm{g})$ & $835(\mathrm{Ci})$ \\
\hline
\end{tabular}

Note:

'Composite inventory excludes supernatant, diatomaccous earth, and cement.

Unknowns in tank inventory are assigned by Tank Layering Model (TLM). 
Table A-2. Single-Shell Tank 241-C-103 (2 Sheets).

\begin{tabular}{|c|c|c|c|}
\hline \multicolumn{4}{|c|}{ Solids Composite Inventory Estimate ${ }^{1}$} \\
\hline \multicolumn{4}{|l|}{ Physical Properties } \\
\hline Total Solid Waste & \multicolumn{3}{|c|}{$3.27 \mathrm{E}+05 \mathrm{~kg}(62 \mathrm{kgal})$} \\
\hline Heat Load & \multicolumn{3}{|c|}{$8.30 \mathrm{~kW}(2.83 \mathrm{E}+04 \mathrm{Btu} / \mathrm{hr})$} \\
\hline Bulk Density & \multicolumn{3}{|l|}{$1.39(\mathrm{~g} / \mathrm{cc})$} \\
\hline Void Fraction & \multicolumn{3}{|l|}{0.813} \\
\hline Water wt $\%$ & \multicolumn{3}{|l|}{70.4} \\
\hline TOC wt $\%$ & \multicolumn{3}{|l|}{0} \\
\hline Chemieal Constituents & moleh & ppm & 表 $\quad \mathrm{kg}$ \\
\hline $\mathrm{Na}^{+1}$ & 2.31 & $3.82 \mathrm{E}+04$ & $1.25 \mathrm{E}+04$ \\
\hline $\mathrm{Al}^{+3}$ & 3.59 & $6.96 \mathrm{E}+04$ & $2.27 \mathrm{E}+04$ \\
\hline $\mathrm{Fe}^{+3}($ total $\mathrm{Fe})$ & 1.17 & $4.70 \mathrm{E}+04$ & $1.54 \mathrm{E}+04$ \\
\hline $\mathrm{Cr}^{-3}$ & $6.54 \mathrm{E}-03$ & 244 & 79.8 \\
\hline $\mathrm{Bi}^{+3}$ & 0 & 0 & 0 \\
\hline $\mathrm{La}^{+3}$ & 0 & 0 & 0 \\
\hline $\mathrm{Ce}^{+3}$ & 0 & 0 & 0 \\
\hline $\mathrm{Zr}\left(\right.$ as $\left.\mathrm{ZrO}(\mathrm{OH})_{2}\right)$ & 0 & 0 & 0 \\
\hline $\mathrm{Pb}^{+2}$ & 0 & 0 & 0 \\
\hline $\mathrm{Ni}^{+2}$ & 6.963E-02 & $2.93 E+03$ & 959 \\
\hline $\mathrm{Sr}^{+2}$ & 0 & 0 & 0 \\
\hline $\mathrm{Mn}^{+4}$ & 0 & 0 & 0 \\
\hline $\mathrm{Ca}^{+2}$ & 0.140 & $4.02 \mathrm{E}+03$ & $1.31 \mathrm{E}+03$ \\
\hline $\mathrm{K}^{+1}$ & 0 & 0 & 0 \\
\hline $\mathrm{OH}^{-1}$ & 15.6 & $1.90 \mathrm{E}+05$ & $6.22 \mathrm{E}+04$ \\
\hline $\mathrm{NO}^{-1}$ & 0.584 & $2.60 \mathrm{E}+04$ & $8.50 \mathrm{E}+03$ \\
\hline $\mathrm{NO}_{2}^{-1}$ & 0.133 & $4.39+03$ & $1.43 \mathrm{E}+03$ \\
\hline $\mathrm{CO}^{-2}$ & 0.140 & $6.02 \mathrm{E}+03$ & $1.97 \mathrm{E}+03$ \\
\hline $\mathrm{PO}^{-3}$ & $6.86 \mathrm{E}-03$ & 468 & 153 \\
\hline $\mathrm{SO}_{4}^{-2}$ & $1.01 \mathrm{E}-02$ & 699 & 228 \\
\hline $\mathrm{Si}\left(\right.$ as $\left.\mathrm{SiO}_{3}{ }^{-2}\right)$ & 0.588 & 1.19E+04 & $3.88 \mathrm{E}+03$ \\
\hline$F^{\prime}$ & 0 & 0 & 0 \\
\hline $\mathrm{Cl}^{-1}$ & $1.26 \mathrm{E}-02$ & 321 & 105 \\
\hline
\end{tabular}


HNF-SD-WM-ES-405 Rev. 0

Table A-2. Single-Shell Tank 241-C-103 (2 Sheets).

Solids Composite Inventory Estimate ${ }^{1}$

\begin{tabular}{|l|l|l|l|}
\hline $\mathrm{C}_{6} \mathrm{H}_{5} \mathrm{O}_{7}^{-3}$ & 0 & 0 & 0 \\
\hline EDTA $^{-4}$ & 0 & 0 & 0 \\
\hline
\end{tabular}


Table A-2. Single-Shell Tank 241-C-103 (2 Sheets).

\begin{tabular}{|c|c|c|c|}
\hline \multicolumn{4}{|c|}{ Solids Composite Inventory Estimate } \\
\hline Chemical Constituents (Cont'd) & mole/L & $\mathrm{npm}$ & kg \\
\hline HEDTA $^{-3}$ & 0 & 0 & 0 \\
\hline $\mathrm{NTA}^{-3}$ & 0 & 0 & 0 \\
\hline glycolate $^{-1}$ & 0 & 0 & 0 \\
\hline acetate $^{-1}$ & 0 & 0 & 0 \\
\hline oxalate ${ }^{-2}$ & 0 & 0 & 0 \\
\hline DBP & 0 & 0 & 0 \\
\hline $\mathrm{NPH}$ & 0 & 0 & 0 \\
\hline $\mathrm{CCl}_{4}$ & 0 & 0 & 0 \\
\hline hexone & 0 & 0 & 0 \\
\hline $\mathrm{Fe}(\mathrm{CN})_{6}^{-4}$ & 0 & 0 & 0 \\
\hline \multicolumn{4}{|l|}{ Radiological Constituents } \\
\hline $\mathrm{Pu}$ & & $2.73(\mu \mathrm{Ci} / \mathrm{g})$ & $14.9(\mathrm{~kg})$ \\
\hline $\mathrm{U}$ & $0.127(\mathrm{M})$ & 2.17E+04 $(\mu \mathrm{g} / \mathrm{g})$ & $7.09 \mathrm{E}+03(\mathrm{~kg})$ \\
\hline Cs & $0.111(\mathrm{Ci} / \mathrm{L})$ & $79.6(\mu \mathrm{Ci} / \mathrm{g})$ & $2.60 \mathrm{E}+04(\mathrm{Ci})$ \\
\hline $\mathrm{Sr}$ & $5.18(\mathrm{Ci} / \mathrm{L})$ & $3.72 \mathrm{E}+03(\mu \mathrm{Ci} / \mathrm{g})$ & $1.21 \mathrm{E}+06(\mathrm{Ci})$ \\
\hline
\end{tabular}

Note:

Composite inventory excludes supernatant. diatomaccous earth. and cement. Unknowns in tank inventory are assigned by Tank Layering Model (TLM). 
Table A-3. Single-Shell Tank 24 I-AX-103 (2 Sheets).

\begin{tabular}{|c|c|c|c|}
\hline \multicolumn{4}{|c|}{ Solids Composite Inventory Estimate ${ }^{1}$} \\
\hline \multicolumn{4}{|l|}{ Physical Properties } \\
\hline Total Solid Waste & \multicolumn{3}{|c|}{$6.71 \mathrm{E}+05 \mathrm{~kg}(112 \mathrm{kgal})$} \\
\hline Heat Load & \multicolumn{3}{|c|}{$6.21 \mathrm{~kW}(2.12 \mathrm{E}+04 \mathrm{Btw} / \mathrm{hr})$} \\
\hline Bulk Density & \multicolumn{3}{|l|}{$1.58(\mathrm{~g} / \mathrm{cc})$} \\
\hline Void Fraction & \multicolumn{3}{|l|}{0.709} \\
\hline Water wt $\%$ & \multicolumn{3}{|l|}{42.9} \\
\hline TOC wt $\%$ & \multicolumn{3}{|l|}{0.309} \\
\hline Chemical Constituents & mole/L & 4,8 ppm & $\mathbf{k g}$ \\
\hline $\mathrm{Na}^{+1}$ & 10.4 & $1.51 \mathrm{E}+05$ & $1.02 E+05$ \\
\hline $\mathrm{Al}^{+3}$ & 1.19 & $2.03 E+04$ & $1.36 \mathrm{E}+04$ \\
\hline $\mathrm{Fe}^{-3}$ (total Fe) & 0.506 & $1.79 E+04$ & $1.20 \mathrm{E}+04$ \\
\hline $\mathrm{Cr}^{-3}$ & $2.22 \mathrm{E}-02$ & 729 & 489 \\
\hline $\mathrm{Bi}^{+3}$ & 7.37E-04 & 97.4 & 65.3 \\
\hline $\mathrm{La}^{+3}$ & 0 & 0 & 0 \\
\hline $\mathrm{Ce}^{+3}$ & 0 & 0 & 0 \\
\hline $\mathrm{Zr}\left(\right.$ as $\left.\mathrm{ZrO}(\mathrm{OH})_{2}\right)$ & $1.63 \mathrm{E}-03$ & 94.0 & 63.1 \\
\hline $\mathrm{Pb}^{+2}$ & $1.24 \mathrm{E}-04$ & 16.3 & 10.9 \\
\hline $\mathrm{Ni}^{+2}$ & $1.43 \mathrm{E}-02$ & 532 & 357 \\
\hline $\mathrm{Sr}^{+2}$ & $1.36 \mathrm{E}-04$ & 7.52 & 5.05 \\
\hline $\mathrm{Mn}^{+4}$ & $1.40 \mathrm{E}-03$ & 48.7 & 32.7 \\
\hline $\mathrm{Ca}^{-2}$ & $6.99 \mathrm{E}-02$ & $1.77 \mathrm{E}+03$ & $1.19 E+03$ \\
\hline $\mathrm{K}^{+1}$ & $3.63 \mathrm{E}-02$ & 897 & 602 \\
\hline $\mathrm{OH}^{-1}$ & 7.10 & $7.63 E+04$ & $5.12 \mathrm{E}+04$ \\
\hline $\mathrm{NO}^{-1}$ & 4.48 & $1.75 \mathrm{E}+05$ & $1.18 \mathrm{E}+05$ \\
\hline $\mathrm{NO}_{2}^{-1}$ & 1.20 & $3.50 \mathrm{E}+03$ & $2.35 \mathrm{E}+04$ \\
\hline $\mathrm{CO}^{-2}$ & 0.329 & $1.25 E+04$ & $8.36 \mathrm{E}+03$ \\
\hline $\mathrm{PO}^{-3}$ & $8.38 \mathrm{E}-02$ & $5.03 \mathrm{E}+03$ & $3.38 \mathrm{E}+03$ \\
\hline $\mathrm{SO}_{4}^{-2}$ & 0.823 & $4.99 \mathrm{E}+04$ & $3.35 E+04$ \\
\hline $\mathrm{Si}\left(\right.$ as $\left.\mathrm{SiO}_{3}^{-2}\right)$ & 0.302 & $5.36 \mathrm{E}+03$ & $3.60 \mathrm{E}+03$ \\
\hline$F^{\prime}$ & 0.109 & $1.31 E+03$ & 876 \\
\hline $\mathrm{Cl}^{-1}$ & $9.82 \mathrm{E}-02$ & $2.20 \mathrm{E}+03$ & $1.47 E+03$ \\
\hline
\end{tabular}


Table A-3. Single-Shell Tank 241-AX-103 (2 Sheets).

\begin{tabular}{|l|l|l|l|}
\hline \multicolumn{5}{|c|}{ Solids Composite Inventory Estimate } \\
\hline $\mathrm{C}_{6} \mathrm{H}_{5} \mathrm{O}_{7}^{-3}$ & $2.02 \mathrm{E}-02$ & $2.41 \mathrm{E}+03$ & $1.62 \mathrm{E}+03$ \\
\hline EDTA $^{-4}$ & $3.84 \mathrm{E}-03$ & 699 & 469 \\
\hline
\end{tabular}


Table A-3. Single-Shell Tank 241-AX-103 (2 Sheets).

\begin{tabular}{|c|c|c|c|}
\hline \multicolumn{4}{|c|}{ Solids Composite Inventory Estimate } \\
\hline Chemical Constituents (Cont'd) & mole/L & $\mathrm{ppm}$ & $\mathrm{kg}$ \\
\hline HEDTA $^{-3}$ & $1.72 \mathrm{E}-05$ & 2.98 & 2.00 \\
\hline $\mathrm{NTA}^{-3}$ & 0 & 0 & 0 \\
\hline glycolate $^{-1}$ & $7.79 \mathrm{E}-02$ & $3.69 \mathrm{E}+03$ & $2.48 \mathrm{E}+03$ \\
\hline acetate $^{-1}$ & $2.45 \mathrm{E}-02$ & 913 & 613 \\
\hline oxalate $^{-2}$ & 0 & 0 & 0 \\
\hline DBP & $3.59 \mathrm{E}-03$ & 604 & 405 \\
\hline $\mathrm{NPH}$ & 0 & 0 & 0 \\
\hline $\mathrm{CCl}_{4}$ & 0 & 0 & 0 \\
\hline hexone & 0 & 0 & 0 \\
\hline $\mathrm{Fe}(\mathrm{CN})_{6}^{-4}$ & 0 & 0 & 0 \\
\hline \multicolumn{4}{|l|}{ Radiological Constituents } \\
\hline $\mathrm{Pu}$ & & $0.167(\mu \mathrm{Ci} / \mathrm{g})$ & $1.86(\mathrm{~kg})$ \\
\hline $\mathrm{U}$ & 8.69E-02(M) & $1.31 \mathrm{E}+04(\mu \mathrm{g} / \mathrm{g})$ & $8.77 \mathrm{E}+03(\mathrm{~kg})$ \\
\hline $\mathrm{Cs}$ & $0.454(\mathrm{Ci} / \mathrm{L})$ & $287(\mu \mathrm{Ci} / \mathrm{g})$ & $1.93 \mathrm{E}+05(\mathrm{Ci})$ \\
\hline $\mathrm{Sr}$ & $1.86(\mathrm{Ci} / \mathrm{L})$ & $1.17 \mathrm{E}+03(\mu \mathrm{Ci} / \mathrm{g})$ & $7.88 \mathrm{E}+05(\mathrm{Ci})$ \\
\hline
\end{tabular}

Note:

'Composite inventory excludes supernatant. diatomaccous earth, and cement.

Unknowns in tank inventory are assigned by Tank Layering Model (TLM). 
Table A-4. Single-Shell Tank 241-A-102 (2 Sheets).

\begin{tabular}{|c|c|c|c|}
\hline \multicolumn{4}{|c|}{ Solids Composite Inventory Estimate } \\
\hline \multicolumn{4}{|l|}{ Physical Troperties } \\
\hline Total Solid Waste & \multicolumn{3}{|c|}{$2.11 \mathrm{E}+05 \mathrm{~kg}(37 \mathrm{kgal})$} \\
\hline Heat Load & \multicolumn{3}{|c|}{$0.870 \mathrm{~kW}(2.97 \mathrm{E}+03 \mathrm{Btu} / \mathrm{hr})$} \\
\hline Bulk Density & \multicolumn{3}{|l|}{$1.51(\mathrm{~g} / \mathrm{cc})$} \\
\hline Void Fraction & \multicolumn{3}{|l|}{0.874} \\
\hline Water wt $\%$ & \multicolumn{3}{|l|}{45.4} \\
\hline TOC wt\% & \multicolumn{3}{|l|}{0.758} \\
\hline Chemical Constituents & nolent & $\mathrm{ppm}$ & $\sqrt{1.1 .69}$ \\
\hline $\mathrm{Na}^{+1}$ & 10.1 & $1.54 \mathrm{E}+05$ & $3.25 \mathrm{E}+04$ \\
\hline $\mathrm{A} 1^{+3}$ & 1.49 & $2.67 \mathrm{E}+04$ & $5.64 \mathrm{E}+03$ \\
\hline $\mathrm{Fe}^{+3}$ (total Fe) & 6.99E-02 & $2.59 \mathrm{E}+03$ & 547 \\
\hline $\mathrm{Cr}^{+3}$ & 2.94E-02 & $1.01 \mathrm{E}+03$ & 214 \\
\hline $\mathrm{Bi}^{+3}$ & $9.50 \mathrm{E}-04$ & 132 & 27.8 \\
\hline $\mathrm{La}^{+3}$ & 0 & 0 & 0 \\
\hline $\mathrm{Ce}^{+3}$ & 0 & 0 & 0 \\
\hline $\mathrm{Zr}\left(\right.$ as $\left.\mathrm{ZrO}(\mathrm{OH})_{2}\right)$ & $2.11 \mathrm{E}-03$ & 127 & 26.9 \\
\hline $\mathrm{Pb}^{+2}$ & $1.59 \mathrm{E}-04$ & 21.9 & 4.62 \\
\hline $\mathrm{Ni}^{+2}$ & $5.87 \mathrm{E}-03$ & 229 & 48.3 \\
\hline $\mathrm{Sr}^{+2}$ & 0 & 0 & 0 \\
\hline $\mathrm{Mn}^{+4}$ & $1.58 \mathrm{E}-03$ & 57.6 & 12.2 \\
\hline $\mathrm{Ca}^{+2}$ & $5.39 \mathrm{E}-02$ & $1.43 \mathrm{E}+03$ & 302 \\
\hline $\mathrm{K}^{+1}$ & 4.49E-02 & $1.16 \mathrm{E}+03$ & 246 \\
\hline $\mathrm{OH}^{-1}$ & 6.64 & $7.47 \mathrm{E}+04$ & $1.58 \mathrm{E}+04$ \\
\hline $\mathrm{NO}_{3}^{-1}$ & 4.21 & $1.763 \mathrm{E}+05$ & $3.66 \mathrm{E}+04$ \\
\hline $\mathrm{NO}_{2}^{-1}$ & 1.53 & $4.67 \mathrm{E}+04$ & $9.88 \mathrm{E}+03$ \\
\hline $\mathrm{CO}^{-2}$ & 0.392 & $1.56 \mathrm{E}+05$ & $3.30 \mathrm{E}+03$ \\
\hline $\mathrm{PO}^{-3}$ & 0.108 & $6.77 \mathrm{E}+03$ & $1.43 \mathrm{E}+03$ \\
\hline $\mathrm{SO}^{-2}$ & 0.358 & $2.28 \mathrm{E}+04$ & $4.81 \mathrm{E}+03$ \\
\hline $\mathrm{Si}\left(\right.$ as $\left.\mathrm{SiO}_{3}^{-2}\right)$ & 0.152 & $2.84 \mathrm{E}+03$ & 600 \\
\hline $\mathrm{F}^{\prime}$ & 0.137 & $1.72 \mathrm{E}+03$ & 363 \\
\hline $\mathrm{Cl}^{-1}$ & 0.113 & $2.65 \mathrm{E}+03$ & 560 \\
\hline
\end{tabular}


Table A-4. Single-Shell Tank 241-A-102 (2 Sheets).

\begin{tabular}{|l|l|l|l|}
\hline \multicolumn{5}{|c|}{ Solids Composite Inventory Estimate } \\
\hline $\mathrm{C}_{6} \mathrm{H}_{5} \mathrm{O}_{7}{ }^{-3}$ & $3.01 \mathrm{E}-02$ & $3.77 \mathrm{E}+03$ & 798 \\
\hline $\mathrm{EDTA}^{-4}$ & $1.60 \mathrm{E}-02$ & $3.05 \mathrm{E}+03$ & 644 \\
\hline
\end{tabular}


Table A-4. Single-Shell Tank 241-A-102 (2 Sheets).

\begin{tabular}{|c|c|c|c|}
\hline \multicolumn{4}{|c|}{ Solids Composite Inventory Estimate } \\
\hline Chemical Constituents (Cont'd) & mole/L & ppm & $\mathrm{kg}$ \\
\hline $\mathrm{HEDTA}^{-3}$ & $2.22 \mathrm{E}-02$ & $4.02 E+03$ & 851 \\
\hline $\mathrm{NTA}^{-3}$ & 0 & 0 & 0 \\
\hline glycolate $^{-1}$ & 0.110 & $5.47 \mathrm{E}+03$ & $1.16 \mathrm{E}+03$ \\
\hline acetate $^{-1}$ & $3.13 \mathrm{E}-02$ & $1.22 \mathrm{E}+03$ & 259 \\
\hline oxalate $^{-2}$ & 0 & 0 & 0 \\
\hline DBP & $4.81 \mathrm{E}-03$ & 849 & 179 \\
\hline NPH & 0 & 0 & 0 \\
\hline $\mathrm{CCl}_{4}$ & 0 & 0 & 0 \\
\hline hexone & 0 & 0 & 0 \\
\hline $\mathrm{Fe}(\mathrm{CN})_{6}^{-4}$ & 0 & 0 & 0 \\
\hline \multicolumn{4}{|l|}{ Radiological Constituents } \\
\hline $\mathrm{Pu}$ & & $0.154(\mu \mathrm{Ci} / g)$ & $0.544(\mathrm{~kg})$ \\
\hline $\mathrm{U}$ & $1.07 \mathrm{E}-02(\mathrm{M})$ & $1.69 \mathrm{E}+03(\mu \mathrm{g} / \mathrm{g})$ & $358(\mathrm{~kg})$ \\
\hline $\mathrm{Cs}_{\mathrm{S}}$ & $0.606(\mathrm{Ci} / \mathrm{L})$ & $402(\mu \mathrm{Ci} / \mathrm{g})$ & $8.49 \mathrm{E}+04(\mathrm{Ci})$ \\
\hline Sr & $0.501\left(\mathrm{Ci} / \mathrm{I}_{2}\right)$ & $332(\mu \mathrm{Ci} / \mathrm{g})$ & $7.01 \mathrm{E}+04(\mathrm{Ci})$ \\
\hline
\end{tabular}

Note:

'Composite inventory excludes supernatant, diatomaccous earth. and cement.

Unknowns in tank inventory are assigned by Tank Layering Model (TLM). 


\title{
PROJECT INTERFACE CONTROL DOCUMENT FOR CONCEPTUAL DESIGN OF THE INITIAL SINGLE SHELL TANK RETRIEVAL SYSTEM
}

\author{
Review Copy
}

Prepared By:

LOS ALAMOS TECHNICAL ASSOCIATES, INC.

Richland, WA

Under Purchase Order TJJ-SBW-387700

November 1996

$$
\text { oic }
$$


HNF-SD-WM-ES-405 Rev, 0

This page intentionally left blank. 
Approved by:

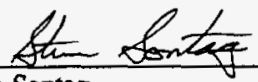

Steve Sontag

Los Alamos Technical Associates, Inc.

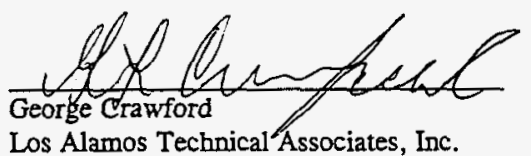
$\frac{11 / 5 / 96}{\text { Date }}$

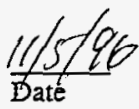


CONTENTS

1.0 Introduction and Scope $\ldots \ldots \ldots \ldots \ldots \ldots \ldots \ldots \ldots \ldots \ldots \ldots$

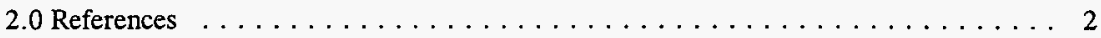

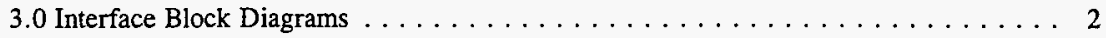

4.0 Project Interface Control Documents $\ldots \ldots \ldots \ldots \ldots \ldots \ldots \ldots$

5.0 Assumptions and Additional Areas of Work $\ldots \ldots \ldots \ldots \ldots \ldots \ldots$

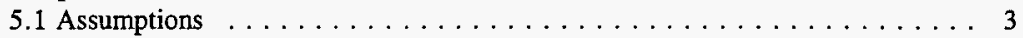

5.2 Additional Work $\ldots \ldots \ldots \ldots \ldots \ldots \ldots \ldots \ldots \ldots \ldots$

\section{APPENDICES}

APPENDIX A: INTERFACE BLOCK DIAGRAM $\ldots \ldots \ldots \ldots \ldots \ldots$ A-1

APPENDIX B: PROJECT INTERFACE CONTROL DOCUMENTS $\ldots \ldots \ldots \ldots$ B-1 


\section{LIST OF TERMS}

CCTV

DST

HEME

HEMF

HVAC

$I \& C$

IBD

ICWG

ISSTRS

PDRD

PICD

SEMP

SST

TMACS

TWRS
Closed-circuit television

Double-shell tank

High-efficiency mist eliminator

High-efficiency metal filter

Heating, ventilating, and air conditioning

Instrumentation \& Control

Interface Block Diagrams

Interface Control Working Group

Initial Single-Shell Tank Retrieval System

Preliminary Design Requirements Document

Project Interface Control Documents

System Engineering Management Plan

Single-Shell Tank

Tank Monitor and Control System

Tank Waste Remediation System 


\subsection{INTRODUCTION AND SCOPE}

This document contains Interface Block Diagrams (IBD) and Project Interface Control Documents (PICD) for the Initial Single-Shell Tank Retrieval System (ISSTRS). The interfaces described in the IBDs and PICDs are the physical interfaces between system hardware/software elements belonging to ISSTRS and either existing facilities or planned projects. Example interfaces include utility connections required for new equipment, instrumentation signals sent to an existing control room, and the existing flange of a tank riser. Identification of these interfaces is of paramount importance to successful insertion and operation of ISSTRS into the tank farms, maintaining schedule and controlling costs.

ISSTRS supports the Tank Waste Remediation System (TWRS) retrieve waste functions, and specifically provides a tank farm demonstration for retrieval of waste from selected single-shell tanks (SSTs). Both saltcake and sludge retrieval will be demonstrated.

Conceptual design of ISSTRS provides a conceptual level cost, schedule and technical basis for the project Design Configuration Baseline as described in the TWRS System Engineering Management Plan (SEMP) (Peck 1996) and supplemented by the ISSTRS Project SEMP, (Kreig 1996). The ISSTRS project objective is to design, fabricate, and install waste retrieval systems, waste transfer lines, tank HVAC systems and infrastructure necessary to begin waste retrieval operations in the first Single-Shell Tank Farm by November, 2003.

The tank farms in the 200 West and 200 East areas at the Hanford Site were installed to receive high level liquid waste from nuclear fuel processing and the production of special nuclear materials. Subsequent operations have resulted in mixing of wastes between tanks, volume reduction of the liquid with a corresponding increase in the solids content and physical isolation of some of the tanks. A total of 149 SSTs were built between 1943 and 1964 and are clustered in rectangular arrays of 2 to 18 tanks called tank farms. No wastes have been added to any SST since 1980. There are 28 double-shell tanks (DSTs) arranged in tank farms of 2 to 8 tanks each, which were built between 1971 and 1986. DSTs still receive waste on an as needed basis. The four SSTs specified for retrieval under ISSTRS are 241-A-102, 241-AX-103, 241-C-103, and $241-\mathrm{C}-105$ whose wastes are to be transferred to the DST 241-AN-105.

The process of interface negotiation and definition for ISSTRS is a continuous one, initiated in the Preliminary Design Requirements Document (PDRD). Due to the many states of development of the interfacing projects (ranging from existing tank farm operations to projects not yet in conceptual design), this document will to continue to be updated throughout the detailed design stage. In addition, there is the potential for decreasing project integration due to the age of Hanford facilities coupled with the number of existing and planned projects, which may increase fragmentation of all modifications that will be performed at a tank farm. 
Five methods were used to identify and define the interfaces for ISSTRS as follows:

a) Interfaces were identified during a review of the four Trade Studies that were performed as an initial step in the conceptual design. These studies were 1) equipment reuse from Project W-320,2) use of existing pipelines, 3) evaluation of transfer line routing options, and 4 ) air chiller need study.

b) Additional needed interfaces were identified and listed during the conceptual design phase by the engineers in each major work area.

c) Specific interfaces listed in the PDRD were included and expanded, if possible.

d) A list of recent, existing and proposed projects was consulted for projects which would interface with ISSTRS.

e) The combination of a), b), c), and d) served to identify the interface boundary of ISSTRS at a macro level. A further level of detail of actual system element hardware and software interfaces was obtained from as-built records, design information from Concept Design Reports, and interviews with knowledgeable personnel.

Continued development of the PICDs will continue through final design. Some working group must take ownership of the interfaces (and hence the documents defining them) to facilitate amicable and cost effective resolutions.

\subsection{REFERENCES}

Peck, 1996, Tank Waste Remediation System System Engineering Management Plan.

Krieg, 1996, Initial Single-Shell Tank Retrieval System SEMP.

Hertzel, 1996, Preliminary Design Requirements Document for ISSTRS.

\subsection{INTERFACE BLOCK DIAGRAMS}

The IBDs provide graphical representation of identified physical system element interfaces between ISSTRS and other project and non-project organizations identified to date. ISSTRS has 
been separated into five system elements of Electrical Power, Ventilation, Instrumentation and Control (I\&C), Mechanical and Process Engineering. Interfaces are identified for each element to existing equipment by a single line referenced to an individual PICD by reference. External project interfaces, either with existing equipment in the same physical area or with ISSTRS hardware/software, are also identified and referenced to an individual PICD.

Due to the limited size of ISSTRS, only one tank level IBD was needed and developed. This IBD is the lowest level of information which will be generated for ISSTRS and is directed at SSTs to identify the detailed tank equipment interfaces. Interfaces with equipment provided by other projects is also included to provide comprehensive coverage of tank equipment.

The IBD is presented in Appendix A.

\subsection{PROJECT INTERFACE CONTROL DOCUMENTS}

The purpose of the PICDs is to further highlight, describe and/or decompose each interface identified in the IBDs in increasing depth. Project external interfaces, shown in the IBD as just a single line, may be described in depth in the PICD. The descriptive depth of an interface in a PICD may be expanded through an iterative process as the design develops via interface meetings between ISSTRS, tank farms, and associated existing/planned projects.

The PICDs, like the IBDs, hold information at the tank equipment level-practical and detailed. These documents are likely to be the vehicle for projected level working group negotiations especially with advanced stage projects. The major elements of a PICD apply to ownership of the interfacing facility, the interface descriptions, related schedule of milestones, constraints and requirements, and associated issues. The PICDs are given in Appendix B.

\subsection{ASSUMPTIONS AND ADDITIONAL AREAS OF WORK}

The level of detail identified in both the IBD and PICDs will be expanded as ISSTRS progresses into the definitive design phase. It is anticipated that by the operational phase of ISSTRS, now scheduled for 2004, all of the current tank farm upgrade projects will have been completed and will then simply be part of tank farm operations. 


\subsection{ASSUMPTIONS}

A starting assumption was made that the four ISSTRS SSTs will meet the definition of controlled, clean, and stable as defined in WHC-SD-WM-728, Rev. 0. If they do not, the cost of ISSTRS construction and field operations will be adversely impacted. Further, following ISSTRS operations, the SSTs are to be returned to controlled, clean, and stable. It is also assumed that ISSTRS will do nothing to preclude or adversely impact that effort.

Another major assumption was that the needed risers for use during ISSTRS will be available and free of old equipment. The riser interfaces are listed in the PICDs, but the removal and disposal of interfering equipment; such as instrument trees, air lances, etc, including the costs, were taken to be outside of the current scope of ISSTRS.

In developing the details of ownership and physical interface definition of the IBDs the following assumptions were made.

1. Changes to the existing tank farm facilities by ISSTRS will be represented by an interface identifier to that item from ISSTRS system elements. The item will be tagged as being owned by ISSTRS.

2. Changes to the existing tank farm facilities by other projects will be represented by an interface identifier to that item from the associated project. The item will be tagged as being owned by that project.

3. Changes of hardware/software owned by other projects from ISSTRS will be represented by an interface identifier to that project and its elements.

4. Internal interfaces between system elements (e.g., I\&C changes that support Ventilation) are not uniquely identified.

5. Items are shown allocated to tank farms where they are physically located. The exception is for items whose true location bas not yet been fixed. These items have been assigned to farms that they functionally support.

6. Interfacing facilities that provide utility services are owned by the site operations but are retained on the IBD for completeness.

7. Projects that have been started or are presently on hold are identified and shown interfacing with the farm facilities and, where appropriate, ISSTRS. 


\subsection{ADDITIONAL WORK}

During the course of preparing the IBDs and PICDs, several additional requirements were identified. These requirements have not been previously compiled, so they have been listed here.

1. Tank status information shall be conveyed and in a compatible format for input into Hanford's Computer Automated Status System or similar central, tank data processing and storage system.

2. For Tank An-105 discharge of gaseous effluents shall be through the existing tank farm stack, if available. Physical connections shall be provided under ISSTRS. New exhaust stacks will be provided by ISSTRS for all four SSTs.

3. Connection(s) for discharge of aqueous waste shall be made to the 200 Area Treated Effluent Disposal Facility. All regulatory constraints (containment, monitoring, permitting, etc.) for the connection shall be met. 
This page intentionally left blank. 
APPENDIX A

INTERFACE BLOCK DIAGRAM 
This page intentionally left blank. 
APPENDIX B

PROJECT INTERFACE CONTROL DOCUMENTS 
ISSTRS-PICD--241A-102

\section{SECTION A}

\section{INTERFACE DESCRIPTION:}

This PICD contains conceptual interface data which has been identified in association with the subject facilities during conceptual design of ISSTRS.

These interface descriptions together with the Associated Issues (Section B) will be subject for review by the Interface Control Working Group (ICWG) which will be assembled specifically to address and resolve issues related to ISSTRS and in support of further development of the PICD and any forthcoming ICDs.

\section{$\underline{\text { SCOPE }}$}

The following Interface diagrams provide scoping data from which detailed lower level PICDs will be generated.

\begin{tabular}{|l|l|}
\hline \multicolumn{1}{|c|}{$\begin{array}{l}\text { ISSTRS } \\
\text { A-102 HVAC system }\end{array}$} & \multicolumn{1}{c|}{$\begin{array}{c}\text { TWRS } \\
\text { 200E Tank Farm Operations }\end{array}$} \\
\cline { 3 - 3 } & $\begin{array}{l}\text { Instrumentation } \\
\text { - Required monitoring and signals to TMACS }\end{array}$ \\
\hline $\begin{array}{l}\text { Electrical Power } \\
\text { - Power supply to equipment and instrumentation. }\end{array}$ \\
$\begin{array}{l}\text { Filtered Water } \\
\text { - Required filtered water to high-efficiency mist eliminator } \\
\text { (HEME) and high efficiency metal filter (HEMF). }\end{array}$ \\
\hline
\end{tabular}




\begin{tabular}{|c|l|l|}
\hline \multicolumn{1}{|c|}{$\begin{array}{c}\text { ISSTRS } \\
\text { A-102 Exhaust Stack }\end{array}$} & $\begin{array}{l}\text { Toxic Air Pollutant Concentration } \\
\text { Factor For Ground Level Release }\end{array}$ \\
\cline { 3 - 3 } & & $\begin{array}{l}\text { Concentration Factor of } 2.79 \mu \mathrm{g} / \mathrm{m}^{3} \text { per } \mathrm{g} / \mathrm{s} \text { for } 200 \text { East area } \\
\text { release location }\end{array}$ \\
\hline
\end{tabular}

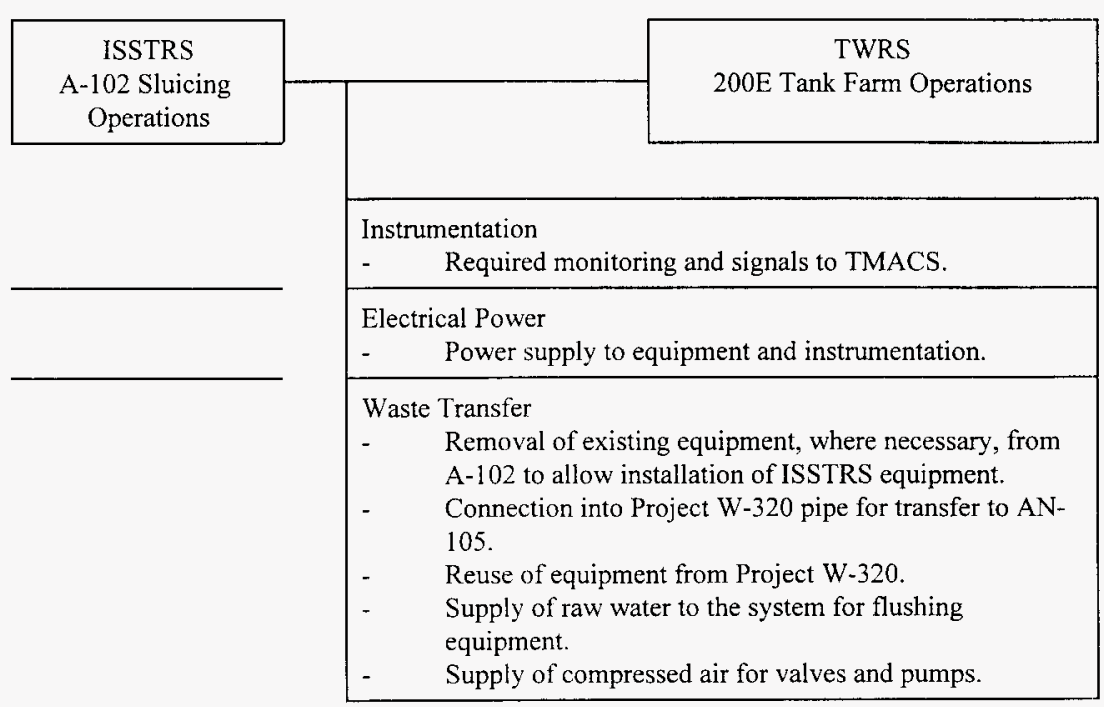




\begin{tabular}{|c|c|}
\hline \multirow{2}{*}{$\begin{array}{c}\text { ISSTRS } \\
\text { A-102 Piping System }\end{array}$} & \multirow[t]{2}{*}{ W-320\& TWRS } \\
\hline & \\
\hline & $\begin{array}{l}\text { A-102 Pits } \\
\text { - Required for sluicer, pumps, \& CCTV access } \\
\text { - Additional 4-in- } 6 \text { pipes installed in pits }\end{array}$ \\
\hline & $\begin{array}{l}\text { On-Farm piping (new) } \\
-4 \text {-in- } 6 \text { piping from existing pits to west fence then north to } A Y \\
\text { fence. }\end{array}$ \\
\hline & $\begin{array}{l}\text { Off-Farm piping (new) } \\
-4 \text {-in- } 6 \text { piping along Buffalo Ave outside AY fence. }\end{array}$ \\
\hline & $\begin{array}{l}\text { W-320 Tie-in } \\
\text { - New pipe is welded to southern end of existing W- } 320 \text { lines. }\end{array}$ \\
\hline
\end{tabular}




\section{ISSTRS-PICD-241A-102}

\section{$\underline{\text { SECTION B }}$}

\section{$1 \quad$ GENERAL}

ISSTRS is currently tasked with designing a system to demonstrate retrieval of both sludge and saltcake from a tank farm or equivalent number of tanks in support of the TriParty Agreement milestones: 45-M-04 Series. ISSTRS is to apply the systems and equipment constructed by $\mathrm{W}-320$ to four other SSTs, with modification or deviation only when required.

In addition, as ISSTRS develops further requirements may be identified. Any associated issues identified will be included in revision to this PICD.

2 NEW INSTALLATION

No issues currently identified.

3 OTHER

No issues currently identified. 


\section{PROJECT INTERFACE CONTROL DOCUMENT}

Initial Single-Shell Tank Retrieval System

PICD No: ISSTRS-PICD-A102

Date Initiated: $11 / 4 / 96$

PICD Title: A Tank Farm Interfaces

Revision:

Date:

\section{ICWG Concurrences:}

ISSTRS:

Proj. Definitions:

TWRS-Transition:

Operations:

Final Approval: Title:

Equipment Responsibility:

Interface Block Diagram:

ISSTRS-IBD

Subtier PICDs:

TBD

Related Schedule Milestone: TPA M-45-04 (ISSTRS), other TBD

Implementing ICDs:

(TBD)

ISSTRS-PICD--241AX-103

SECTION A

INTERFACE DESCRIPTION: 
This PICD contains conceptual interface data which has been identified in association with the subject facilities during conceptual design of ISSTRS.

These interface descriptions together with the Associated Issues (Section B) will be subject for review by the Interface Control Working Group (ICWG) which will be assembled specifically to address and resolve issues related to ISSTRS and in support of further development of the PICD and any forthcoming ICDs.

\section{SCOPE}

The following Interface diagrams provide scoping data from which detailed lower level PICDs will be generated.

\begin{tabular}{|l|l|}
\hline \multicolumn{1}{|c|}{$\begin{array}{l}\text { ISSTRS } \\
\text { AX-103 HVAC } \\
\text { system }\end{array}$} & \multicolumn{1}{c|}{$\begin{array}{c}\text { TWRS } \\
\text { 200E Tank Farm Operations }\end{array}$} \\
\cline { 2 - 3 } & $\begin{array}{l}\text { Instrumentation } \\
\text { - Required monitoring and signals to TMACS }\end{array}$ \\
\hline $\begin{array}{l}\text { Electrical Power } \\
\text { - Power supply to equipment and instrumentation. }\end{array}$ & $\begin{array}{l}\text { Filtered Water } \\
\text { - Required filtered water to high-efficiency mist eliminator } \\
\text { (HEME) and high efficiency metal filter (HEMF). }\end{array}$ \\
\hline
\end{tabular}

\begin{tabular}{|l|l|l|}
\hline \multicolumn{1}{|c|}{$\begin{array}{l}\text { ISSTRS } \\
\text { AX-103 Exhaust } \\
\text { Stack }\end{array}$} & $\begin{array}{l}\text { Toxic Air Pollutant Concentration } \\
\text { Factor For Ground Level Release }\end{array}$ \\
\cline { 3 - 3 } & & $\begin{array}{l}\text { Concentration Factor of } 2.79 \mu \mathrm{g} / \mathrm{m}^{3} \text { per } \mathrm{g} / \mathrm{s} \text { for } 200 \text { East area } \\
\text { release location }\end{array}$ \\
\hline
\end{tabular}

\begin{tabular}{|c|c|}
\hline ISSTRS & TWRS \\
\hline $\begin{array}{c}\text { AX-103 Sluicing } \\
\text { Operations }\end{array}$ & $200 \mathrm{E}$ Tank Farm Operations \\
\hline
\end{tabular}




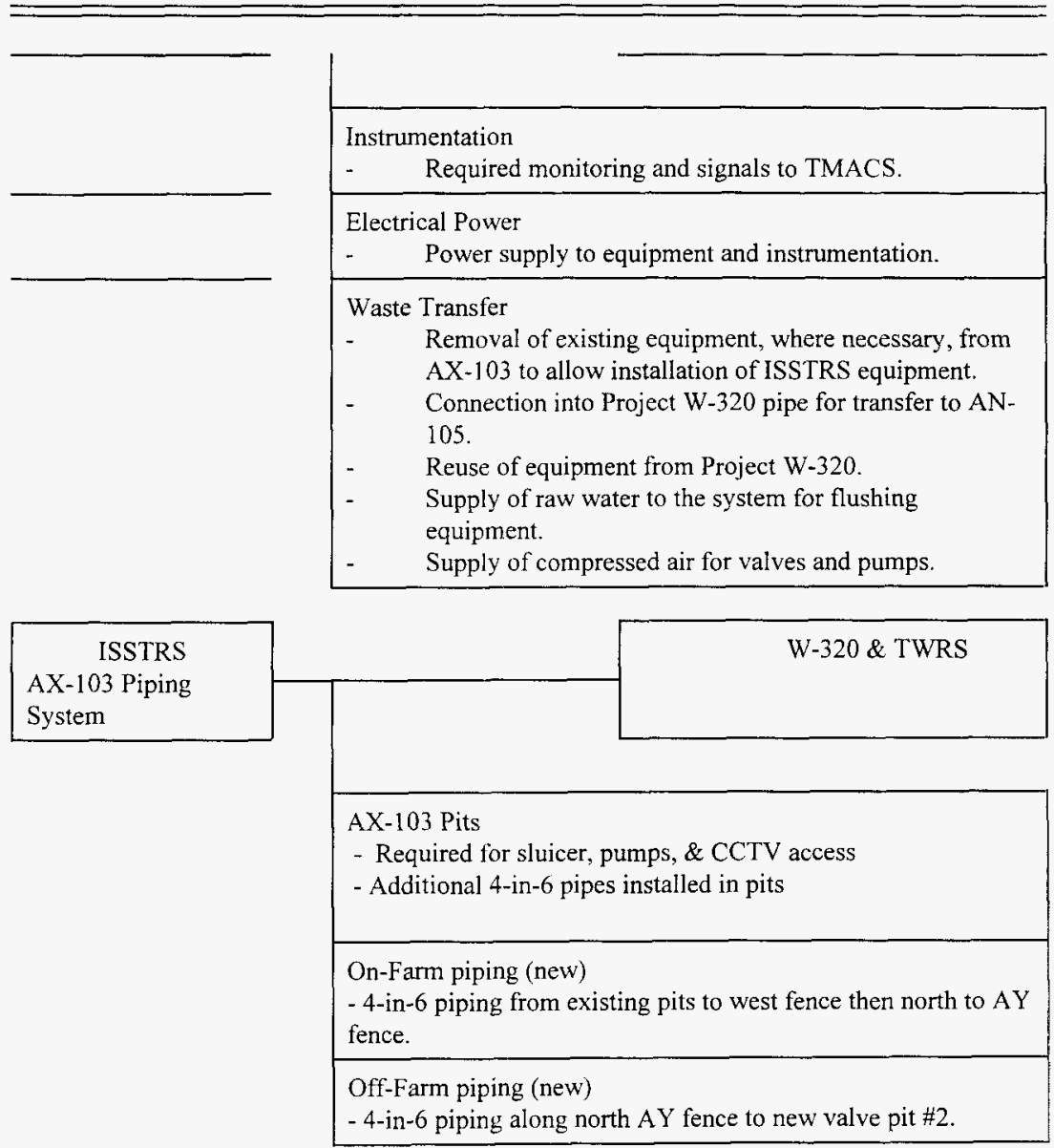




\section{ISSTRS-PICD-241AX-103}

\section{SECTION B}

\section{GENERAL}

ISSTRS is currently tasked with designing a system to demonstrate retrieval of both sludge and saltcake from a tank farm or equivalent number of tanks in support of the TriParty Agreement milestones: $45-\mathrm{M}-04$ Series. ISSTRS is to apply the systems and equipment constructed by W-320 to four other SSTs, with modification or deviation only when required.

In addition, as ISSTRS develops further requirements may be identified. Any associated issues identified will be included in revision to this PICD.

2 NEW INSTALLATION

No issues currently identified.

3 OTHER

No issues currently identified. 
ISSTRS-PICD-241AX-103

\section{PROJECT INTERFACE CONTROL DOCUMENT}

Initial Single-Shell Tank Retrieval System

PICD No: ISSTRS-PICD-AX103

Date Initiated: 11/4/96

PICD Title: AX Tank Farm Interfaces

Revision:

Date:

\section{ICWG Concurrences:}

ISSTRS

Proj. Definitions:

TWRS-Transition:

Operations:

Final Approval: Title:

Equipment Responsibility:

Interface Block Diagram:

ISSTRS-IBD

Subtier PICDs:

TBD

Related Schedule Milestone: TPA M-45-04 (ISSTRS), other TBD

Implementing ICDs:

(TBD)

ISSTRS-PICD--24IC-103

SECTION A

INTERFACE DESCRIPTION: 
This PICD contains conceptual interface data which has been identified in association with the subject facilities during conceptual design of ISSTRS.

These interface descriptions together with the Associated Issues (Section B) will be subject for review by the Interface Control Working Group (ICWG) which will be assembled specifically to address and resolve issues related to ISSTRS and in support of further development of the PICD and any forthcoming ICDs.

\section{SCOPE}

The following Interface diagrams provide scoping data from which detailed lower level PICDs will be generated.

\begin{tabular}{|l|l|}
\hline \multicolumn{1}{|c|}{$\begin{array}{l}\text { ISSTRS } \\
\text { C-103 HVAC system }\end{array}$} & \multicolumn{1}{c|}{$\begin{array}{c}\text { TWRS } \\
\text { 200E Tank Farm Operations }\end{array}$} \\
\cline { 2 - 3 } & $\begin{array}{l}\text { Instrumentation } \\
\text { - Required monitoring and signals to TMACS }\end{array}$ \\
\hline $\begin{array}{l}\text { Electrical Powers } \\
\text { - Power supply to equipment and instrumentation. }\end{array}$ \\
$\begin{array}{l}\text { Filtered Water } \\
\text { - Required filtered water to high-efficiency mist eliminator } \\
\text { (HEME) and high efficiency metal filter (HEMF). }\end{array}$ \\
\hline
\end{tabular}

\begin{tabular}{|l|l|l|}
\hline \multicolumn{2}{|c|}{$\begin{array}{c}\text { ISSTRS } \\
\text { C-103 Exhaust Stack }\end{array}$} & $\begin{array}{l}\text { Toxic Air Pollutant Concentration } \\
\text { Factor For Ground Level Release }\end{array}$ \\
\cline { 2 - 3 } & & $\begin{array}{l}\text { Concentration Factor of } 2.79 \mu \mathrm{g} / \mathrm{m}^{3} \text { per g/s for } 200 \text { East area } \\
\text { release location }\end{array}$ \\
\hline
\end{tabular}

\begin{tabular}{|c|c|c|}
\hline $\begin{array}{c}\text { ISSTRS } \\
\text { C-103 Sluicing } \\
\text { Operations }\end{array}$ & TWRS \\
\cline { 2 - 3 } & 200E Tank Farm Operations \\
\hline
\end{tabular}


Instrumentation

- $\quad$ Required monitoring and signals to TMACS.

Electrical Power

- Power supply to equipment and instrumentation.

Waste Transfer

- Removal of existing equipment, where necessary, from C-103 to allow installation of ISSTRS equipment. Connection into Project W-320 pipe for transfer to AN105.

Reuse of equipment from Project W-320.

Supply of raw water to the system for flushing equipment.

Supply of compressed air for valves and pumps.

\begin{tabular}{|c|l|}
\hline \multicolumn{1}{|c|}{$\begin{array}{c}\text { ISSTRS } \\
\text { C-103 Piping System }\end{array}$} & \\
\cline { 3 - 3 } & $\begin{array}{l}\text { C-103 Pits } \\
\text { - Required for sluicer, pumps, \& CCTV access } \\
\text { - Additional 4-in-6 pipes installed in pits }\end{array}$ \\
\hline $\begin{array}{l}\text { W-320 Tie-in TWRS } \\
\text { - New lines welded to W-320 lines NE of C-103 }\end{array}$ \\
\hline
\end{tabular}




\section{ISSTRS-PICD-241C-103}

\section{SECTION B}

\section{$1 \quad$ GENERAL}

ISSTRS is currently tasked with designing a system to demonstrate retrieval of both sludge and saltcake from a tank farm or equivalent number of tanks in support of the TriParty Agreement milestones: 45-M-04 Series. ISSTRS is to apply the systems and equipment constructed by W-320 to four other SSTs, with modification or deviation only when required.

In addition, as ISSTRS develops further requirements may be identified. Any associated issues identified will be included in revision to this PICD.

2 NEW INSTALLATION

No issues currently identified.

3 OTHER

No issues currently identified. 
ISSTRS-PICD-241C103

\section{PROJECT INTERFACE CONTROL DOCUMENT}

Initial Single-Shell Tank Retrieval System

PICD No: ISSTRS-PICD-C103

Date Initiated: $11 / 4 / 96$

PICD Title: C Tank Farm Interfaces

Revision:

Date:

ICWG Concurrences:

ISSTRS:

Proj. Definitions:

TWRS-Transition:

Operations:

Final Approval: Title:

Equipment Responsibility:

Interface Block Diagram:

ISSTRS-IBD

Subtier PICDs:

TBD

Related Schedule Milestone: TPA M-45-04 (ISSTRS), other TBD

Implementing ICDs:

(TBD)

ISSTRS-PICD--241C-105

\section{SECTIONA}

INTERFACE DESCRIPTION: 
This PICD contains conceptual interface data which has been identified in association with the subject facilities during conceptual design of ISSTRS.

These interface descriptions together with the Associated Issues (Section B) will be subject for review by the Interface Control Working Group (ICWG) which will be assembled specifically to address and resolve issues related to ISSTRS and in support of further development of the PICD and any forthcoming ICDs.

\section{$\underline{\text { SCOPE }}$}

The following Interface diagrams provide scoping data from which detailed lower level PICDs will be generated.

\begin{tabular}{|l|l|}
\hline \multicolumn{1}{c|}{$\begin{array}{l}\text { ISSTRS } \\
\text { C-105 HVAC system }\end{array}$} & \multicolumn{1}{c|}{$\begin{array}{c}\text { TWRS } \\
\text { 200E Tank Farm Operations }\end{array}$} \\
\cline { 3 - 3 } & $\begin{array}{l}\text { Instrumentation } \\
\text { - Required monitoring and signals to TMACS }\end{array}$ \\
\hline $\begin{array}{l}\text { Electrical Powers } \\
\text { - Power supply to equipment and instrumentation. }\end{array}$ \\
\hline $\begin{array}{l}\text { Filtered Water } \\
\text { - Required filtered water to high-efficiency mist eliminator } \\
\text { (HEME) and high efficiency metal filter (HEMF). }\end{array}$ \\
\hline
\end{tabular}

\begin{tabular}{|c|l|l|}
\hline $\begin{array}{c}\text { ISSTRS } \\
\text { C-105 Exhaust Stack }\end{array}$ & $\begin{array}{l}\text { Toxic Air Pollutant Concentration } \\
\text { Factor For Ground Level Release }\end{array}$ \\
\cline { 2 - 3 } & $\begin{array}{l}\text { Concentration Factor of } 2.79 \mu \mathrm{g} / \mathrm{m}^{3} \mathrm{per} \mathrm{g} / \mathrm{s} \text { for } 200 \text { East area } \\
\text { release location }\end{array}$ \\
\hline
\end{tabular}

\begin{tabular}{|c|c|c|}
\hline ISSTRS \\
$\begin{array}{c}\text { C-105 Sluicing } \\
\text { Operations }\end{array}$ & \multicolumn{2}{|c|}{ TWRS } \\
\cline { 2 - 3 } & & \\
\hline
\end{tabular}




\section{Instrumentation}

- $\quad$ Required monitoring and signals to TMACS.

\section{Electrical Power}

- Power supply to equipment and instrumentation.

Waste Transfer

- $\quad$ Removal of existing equipment, where necessary, from

C-105 to allow installation of ISSTRS equipment.

- Connection into Project W-320 pipe for transfer to AN105.

- $\quad$ Reuse of equipment from Project W-320.

- Supply of raw water to the system for flushing equipment.

- $\quad$ Supply of compressed air for valves and pumps.

\begin{tabular}{|l|l|}
\hline \multicolumn{1}{|c|}{$\begin{array}{c}\text { ISSTRS } \\
\text { C-105 Piping System }\end{array}$} & \\
\cline { 2 - 3 } & \\
\hline C-105 Pits \\
- Required for sluicer, pumps, \& CCTV access \\
- Additional 4-in-6 pipes installed in pits \\
\hline W-320 Tie-in TWRS \\
- New lines welded to W-320 lines east C-105 after retrieval of \\
C-103 \\
- C-103 stub is capped off \\
\hline
\end{tabular}


ISSTRS-PICD-24IC-105

SECTION B

1 GENERAL

ISSTRS is currently tasked with designing a system to demonstrate retrieval of both sludge and saltcake from a tank farm or equivalent number of tanks in support of the TriParty Agreement milestones: 45-M-04 Series. ISSTRS is to apply the systems and equipment constructed by W-320 to four other SSTs, with modification or deviation only when required.

In addition, as ISSTRS develops further requirements may be identified. Any associated issues identified will be included in revision to this PICD.

2 NEW INSTALLATION

No issues currently identified.

3 OTHER

No issues currently identified. 


\section{PROJECT INTERFACE CONTROL DOCUMENT}

Initial Single-Shell Tank Retrieval System

PICD No: ISSTRS-PICD-C105

Date Initiated: $11 / 4 / 96$

PICD Title: C Tank Farm Interfaces

Revision:

Date:

\section{ICWG Concurrences:}

ISSTRS:

Proj. Definitions:

TWRS-Transition:

Operations:

Final Approval: Title:

Equipment Responsibility:

Interface Block Diagram:

ISSTRS-IBD

Subtier PICDs:

TBD

Related Schedule Milestone: TPA M-45-04 (ISSTRS), other TBD

Implementing ICDs:

(TBD)

ISSTRS-PICD--241AN-105

SECTION A

INTERFACE DESCRIPTION: 
This PICD contains conceptual interface data which has been identified in association with the subject facilities during conceptual design of ISSTRS.

These interface descriptions together with the Associated Issues (Section B) will be subject for review by the Interface Control Working Group (ICWG) which will be assembled specifically to address and resolve issues related to ISSTRS and in support of further development of the PICD and any forthcoming ICDs.

\section{SCOPE}

The following Interface diagrams provide scoping data from which detailed lower level PICDs will be generated.

\begin{tabular}{|l|l|l|}
\hline \multicolumn{1}{|c|}{$\begin{array}{l}\text { ISSTRS } \\
\text { AN-105 Exhaust } \\
\text { Stack }\end{array}$} & $\begin{array}{l}\text { Toxic Air Pollutant Concentration } \\
\text { Factor For Ground Level Release }\end{array}$ \\
\cline { 2 - 3 } & $\begin{array}{l}\text { Concentration Factor of } 2.79 \mu \mathrm{g} / \mathrm{m}^{3} \text { per } \mathrm{g} / \mathrm{s} \text { for } 200 \text { East area } \\
\text { release location }\end{array}$ \\
\hline
\end{tabular}




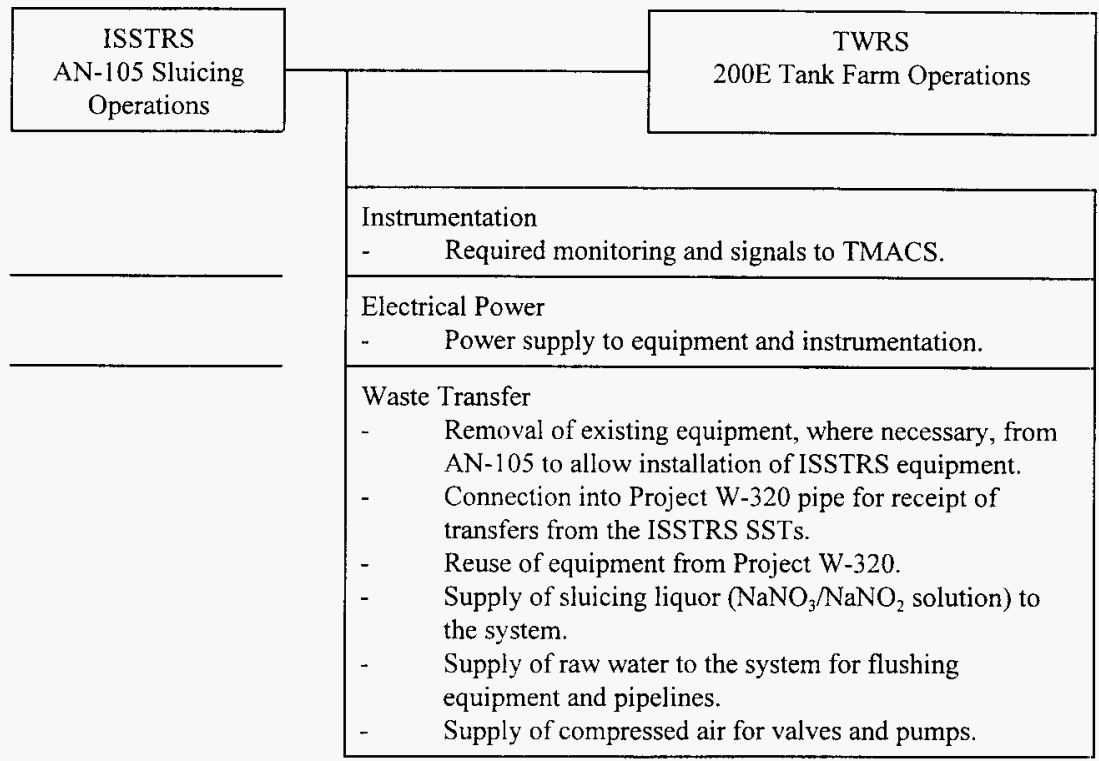

\begin{tabular}{|l|l|}
\hline \multicolumn{1}{|c|}{$\begin{array}{l}\text { ISSTRS } \\
\text { AN-105 Piping } \\
\text { Sysyem }\end{array}$} & \multicolumn{2}{|l|}{ TWRS } \\
& $\begin{array}{l}\text { New Pump Pit } \\
\text { - Sluicing pump location } \\
\text { - Origin of ISSTRS sluice line } \\
\text { - Pick-up through existing riser (5A or 5B) }\end{array}$ \\
\hline $\begin{array}{l}\text { Central Pump Pit } \\
\text { - Terminus of ISSTRS slurry line }\end{array}$ \\
\hline
\end{tabular}


ISSTRS-PICD-241AN-105

\section{$\underline{\text { SECTION B }}$}

1 GENERAL

ISSTRS is currently tasked with designing a system to demonstrate retrieval of both sludge and saltcake from a tank farm or equivalent number of tanks in support of the TriParty Agreement milestones: $45-\mathrm{M}-04$ Series. ISSTRS is to apply the systems and equipment constructed by W-320 to four other SSTs, with modification or deviation only when required.

In addition, as ISSTRS develops further requirements may be identified. Any associated issues identified will be included in revision to this PICD.

2 NEW INSTALLATION

No issues currently identified.

3 OTHER

No issues currently identified. 


\section{ISSTRS-PICD-AN105}

\section{PROJECT INTERFACE CONTROL DOCUMENT}

Initial Single-Shell Tank Retrieval System

PICD No: ISSTRS-PICD-ANI05

Date Initiated: $11 / 4 / 96$

PICD Title: AN Tank Farm Interfaces

Revision:

Date:

\section{ICWG Concurrences:}

ISSTRS:

Proj. Definitions:

TWRS-Transition:

Operations:

Final Approval: Title:

Equipment Responsibility:

Interface Block Diagram:

ISSTRS-IBD

Subtier PICDs:

TBD

Related Schedule Milestone: TPA M-45-04 (ISSTRS), other TBD

Implementing ICDs:

(TBD)

ISSTRS-PICD-NVP1

SECTION A

INTERFACE DESCRIPTION: 
This PICD contains conceptual interface data which has been identified in association with the subject facilities during conceptual design of ISSTRS.

These interface descriptions together with the Associated Issues (Section B) will be subject for review by the Interface Control Working Group (ICWG) which will be assembled specifically to address and resolve issues related to ISSTRS and in support of further development of the PICD and any forthcoming ICDs.

\section{$\underline{\text { SCOPE }}$}

The following Interface diagrams provide scoping data from which detailed lower level PICDs will be generated.

\begin{tabular}{|c|c|}
\hline \multirow{2}{*}{$\begin{array}{c}\text { ISSTRS } \\
\text { New valve pit \#1 }\end{array}$} & \multirow[t]{2}{*}{ W-320 } \\
\hline & \\
\hline & $\begin{array}{l}\text { Pipelines } \\
\text { - Inter-connects piping from } \mathrm{AX} / \mathrm{A} \text { and } \mathrm{C} \text { Farms with } \mathrm{AN}-105 .\end{array}$ \\
\hline & $\begin{array}{l}\text { Jumpers } \\
\text { - Inter-connects piping from AX, A and C Farms with new } \\
\text { pipelines to AN-105 }\end{array}$ \\
\hline
\end{tabular}




\section{ISSTRS-PICD-NVP1}

\section{SECTIONB}

\section{$1 \quad$ GENERAL}

ISSTRS is currently tasked with designing a system to demonstrate retrieval of both sludge and saltcake from a tank farm or equivalent number of tanks in support of the TriParty Agreement milestones: 45-M-04 Series. ISSTRS is to apply the systems and equipment constructed by W-320 to four other SSTs, with modification or deviation only when required.

In addition, as ISSTRS develops further requirements may be identified. Any associated issues identified will be included in revision to this PICD.

\section{NEW INSTALLATION}

New Valve Pit \#1 will be installed to connect A, AX and C Tank Farm piping with new piping to AN Tank Farm.

3 OTHER

No issues currently identified. 


\section{PROJECT INTERFACE CONTROL DOCUMENT}

Initial Single-Shell Tank Retrieval System

PICD No: ISSTRS-PICD-NVP1

Date Initiated: 11/4/96

PICD Title: New Valve At \#1

Revision:

Date:

\section{ICWG Concurrences:}

ISSTRS:

Proj. Definitions:

TWRS-Transition:

Operations:

Final Approval: Title:

Equipment Responsibility:

Interface Block Diagram:

ISSTRS-IBD

Subtier PICDs:

TBD

Related Schedule Milestone: TPA M-45-04 (ISSTRS), other TBD

Implementing ICDs:

(TBD)

ISSTRS-PICD-NVP2

SECTION A

INTERFACE DESCRIPTION: 
This PICD contains conceptual interface data which has been identified in association with the subject facilities during conceptual design of ISSTRS.

These interface descriptions together with the Associated Issues (Section B) will be subject for review by the Interface Control Working Group (ICWG) which will be assembled specifically to address and resolve issues related to ISSTRS and in support of further development of the PICD and any forthcoming ICDs.

\section{$\underline{\text { SCOPE }}$}

The following Interface diagrams provide scoping data from which detailed lower level PICDs will be generated.

\begin{tabular}{|l|l|}
\hline \multicolumn{1}{|c|}{\begin{tabular}{|l|} 
ISSTRS \\
New valve pit $\# 2$
\end{tabular}} & \multicolumn{1}{|c|}{ W-320 } \\
\cline { 3 - 3 } & $\begin{array}{l}\text { Pipelines } \\
\text { - Inter-connects piping from AX and A Farms with existing W- } \\
320 \text { lines. }\end{array}$ \\
\hline & $\begin{array}{l}\text { Jumpers } \\
\text { - Inter-connects piping from AX and A Farms with existing W- } \\
320 \text { lines as required for ISSTRS operation }\end{array}$ \\
\hline
\end{tabular}




\begin{tabular}{|c|c|c|}
\hline \multirow{2}{*}{$\begin{array}{l}\text { ISSTRS } \\
\text { C Farm to AN Farm } \\
\text { Piping System }\end{array}$} & & \multirow[t]{2}{*}{ W-320 \& TWRS } \\
\hline & & \\
\hline & \multicolumn{2}{|c|}{$\begin{array}{l}\text { Pipelines (new) } \\
\text { - Welded "T" connection to existing W-320 piping west of AN } \\
\text { Farm } \\
\text { - New 4-in-6 lines to new valve pit \#1 }\end{array}$} \\
\hline
\end{tabular}




\section{ISSTRS-PICD-NVP2}

\section{SECTION B}

\section{GENERAL}

ISSTRS is currently tasked with designing a system to demonstrate retrieval of both sludge and saltcake from a tank farm or equivalent number of tanks in support of the TriParty Agreement milestones: 45-M-04 Series. ISSTRS is to apply the systems and equipment constructed by W-320 to four other SSTs, with modification or deviation only when required.

In addition, as ISSTRS develops further requirements may be identified. Any associated issues identified will be included in revision to this PICD.

\section{NEW INSTALLATION}

New Valve Pit \#2 will be installed to connect A and AX Tank Farm piping with existing W-320 piping.

\section{OTHER}

No issues currently identified. 
HNF-SD-WM-ES-405 Rev. 0

Review Copy

November 6, 1996

ISSTRS-PICD-NVP2

PROJECT INTERFACE CONTROL DOCUMENT

lnitial Single-Shell Tank Retrieval System

PICD No: ISSTRS-PICD-NVP2

Date Initiated: $11 / 4 / 96$

PICD Title: New Vavle Pit $\$ 2$

Revision:

Date:

\section{ICWG Concurrences:}

ISSTRS:

Proj. Definitions:

TWRS-Transition:

Operations:

Final Approval: Title:

Equipment Responsibility:

Interface Block Diagram:

ISSTRS-IBD

Subtier PICDs:

TBD

Reiated Schedule Milestone: TPA M-45-04 (ISSTRS), other TBD

Implementing ICDs:

(TBD) 


\title{
RISK MANAGEMENT PLAN FOR CONCEPTUAL DESIGN OF THE INITIAL SINGLE SHELL TANK RETRIEVAL SYSTEM
}

\author{
Review Copy
}

Prepared By:

LOS ALAMOS TECHNICAL ASSOCIATES, INC.

Richland, WA

Under Purchase Order TJJ-SBW-38770 
This page intentionally left blank. 
Approved by:
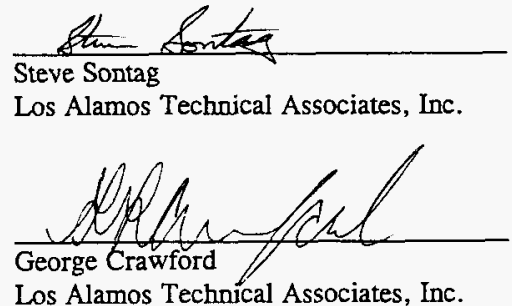
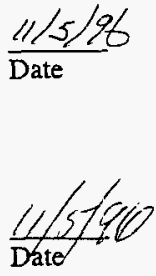


\section{CONTENTS}

1.0 Introduction and Scope $\ldots \ldots \ldots \ldots \ldots \ldots \ldots \ldots \ldots \ldots \ldots$

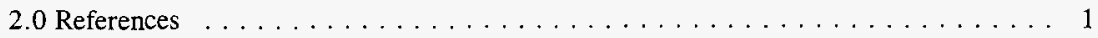

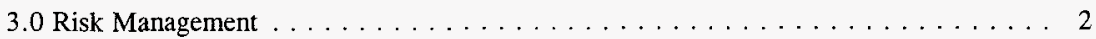

3.1 Method . . . . . . . . . . . . . . . . . . . 2

3.2 Assumptions, Impacts and Validation Strategy Recommendations $\ldots \ldots \ldots 2$

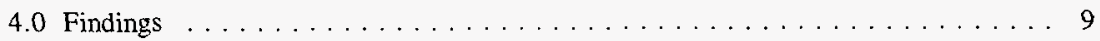

\section{LIST OF TABLES}

3-1 Civil Related Assumptions, Impacts and Validation Recommendations . . . . . . . 2

3-2 Electrical Related Assumptions, Impacts and Validation Recommendations . . . . . 5

3-3 HVAC Related Assumptions, Impacts and Validation Recommendations . . . . . 6

3-4 Process Systems Related Assumptions, Impacts and Validation

Recommendations . . . . . . . . . . . . . . . . . . . 7

3-5 Trade Study Generated Assumptions, Impacts and Validation Recommendations _. 8

\section{LIST OF TERMS}

DCBL Design Configuration Baseline

DST Double-Shell Tank

HVAC Heating, Ventilating, and Air Conditioning

ISSTRS Initial Single-Shell Tank Retrieval System

SEMP System Engineering Management Plan

SST Single-Shell Tank

TWRS Tank Waste Remediation System

VOC Volatile Organic Compound 
This page intentionally left blank. 


\subsection{Introduction and Scope}

This risk management plan makes recommendations for managing risks associated with the conceptual design of the Initial Single-Shell Tank Retrieval System (ISSTRS). Risk management involves planning, documenting, observing, and initiating actions that promote good decision making. The conceptual design provides a conceptual level cost, schedule and technical basis for the project Design Configuration Baseline (DCBL) as described in the Tank Waste Remediation System (TWRS) System Engineering Management Plan (SEMP) and supplemented by the ISSTRS Project SEMP. The ISSTRS project objective is to design, fabricate, and install waste retrieval systems, waste transfer lines, tank HVAC systems and infrastructure necessary to begin waste retrieval operations in the first Single-Shell Tank Farm by November, 2003.

ISSTRS supports the TWRS retrieve waste functions, and specifically provides a tank farm demonstration for retrieval of waste from selected SSTs. Both salt cake and sludge retrieval will be demonstrated.

The tank farms in the 200 West and 200 East areas at the Hanford site were installed to receive high level liquid waste from nuclear fuel processing and the production of special nuclear materials. Subsequent operations have resulted in mixing of wastes between tanks, volume reduction of the liquid with a corresponding increase in the solids content and physical isolation of some of the tanks. A total of 149 single-shell tanks (SSTs) were built between 1943 and 1964 and are clustered in rectangular arrays of 2 to 18 tanks called tank farms. No wastes have been added to any SST since 1980 . There are 28 double-shell tanks (DSTs) arranged in tank farms of 2 to 8 tanks each, which were built between 1971 and 1986. DSTs still receive waste on an as needed basis. The four SSTs specified for retrieval under ISSTRS are 241-A-102, 241-AX-103, 241-C-103, and 241-C-105 whose wastes are to be transferred to the DST 241-AN-105.

The risk management plan for the conceptual design for ISSTRS is a listing of the assumptions generated during conceptual design, impact of those assumptions to the project if they are not correct, and validation strategy recommendations as required.

\subsection{References}

Hertzel, 1996, Preliminary Design Requirements Document for ISSTRS.

Krieg, 1996, Initial Single-Shell Tank Retrieval System SEMP.

Peck, 1996, Tank Waste Remediation System System Engineering Management Plan. 


\subsection{Risk Management}

\subsection{Method}

The methodology used to establish the risk management strategy for the conceptual design of ISSTRS was to list each assumption, determine the impact to the project if the assumption is incorrect or must be otherwise changed, and identify, develop and implement the needed plans and actions (which may include responsibilities and status tracking).

\subsection{Assumptions, Impacts and Validation Strategy Recommendations.}

The following tables summarize the assumptions from the trade studies and other sources, impacts to the project, and recommendations for validating the assumptions.

Table 3-1. Civil Related Assumptions, Impacts and Validation Recommendations.

\begin{tabular}{|l|l|l|}
\hline \multicolumn{1}{|c|}{ Assumptions } & \multicolumn{1}{|c|}{ Impact if Incorrect } & Validation Recommendations \\
\hline $\begin{array}{l}\text { ISSTRS design pressure } \\
\text { is } 320 \text { psi at pump } \\
\text { discharge, same as W- } \\
320 .\end{array}$ & $\begin{array}{l}\text { Higher design pressure } \\
\text { requires recertification of } \\
\text { W-320 system. Lower } \\
\text { pressure will require smaller } \\
\text { pumps. }\end{array}$ & $\begin{array}{l}\text { Verify ISSTRS design } \\
\text { pressure. This can be verified } \\
\text { during the operation of the W- } \\
\text { 320 systems, currently } \\
\text { scheduled to begin operations } \\
\text { in Sept of 1997. }\end{array}$ \\
\hline Flow rate is 350 gpm. & $\begin{array}{l}\text { Higher flow rates require } \\
\text { larger pumps. Lower rates } \\
\text { will drop Reynold's number } \\
\text { below minimum required for } \\
\text { good solids suspension. }\end{array}$ & $\begin{array}{l}\text { Verify design flow rate. } \\
\text { Actual flows, and fluid } \\
\text { properties can be obtained } \\
\text { during W-320 operation, and } \\
\text { that data should be reflected in } \\
\text { the ISSTRS Definitive Design. }\end{array}$ \\
\hline $\begin{array}{l}\text { Primary piping is 4" } \\
\text { diameter. }\end{array}$ & $\begin{array}{l}\text { Smaller diameter will impact } \\
\text { flow rate, Re, velocity, etc. } \\
\text { which influences pump size, } \\
\text { jumper design, etc. }\end{array}$ & $\begin{array}{l}\text { Verify primary pipe size. } \\
\text { Actual flows, and fluid } \\
\text { properties can be obtained } \\
\text { during W-320 operation, and } \\
\text { that data should be reflected in } \\
\text { the ISSTRS Definitive Design. }\end{array}$ \\
\hline
\end{tabular}


Table 3-1. Civil Related Assumptions, Impacts and Validation Recommendations.

\begin{tabular}{|l|l|l|}
\hline \multicolumn{1}{|c|}{ Assumptions } & \multicolumn{1}{|c|}{ Impact if Incorrect } & Validation Recommendations \\
\hline $\begin{array}{l}\text { Necessary risers and pits } \\
\text { are available at all four } \\
\text { SSTs and the DST. }\end{array}$ & $\begin{array}{l}\text { Unable to install complete } \\
\text { ISSTRS system, and cost } \\
\text { estimate to remove and } \\
\text { dispose of existing } \\
\text { equipment may not be } \\
\text { adequate. }\end{array}$ & $\begin{array}{l}\text { Verify future plans for selected } \\
\text { riser, and pit availability. } \\
\text { This must include an interface } \\
\text { with Operations, clearly } \\
\text { agreeing to what risers, pits, } \\
\text { and routings are available at } \\
\text { the time of ISSTRS } \\
\text { construction and operation, as } \\
\text { well as specifics on any } \\
\text { existing equipment which must } \\
\text { be removed and disposed prior } \\
\text { to ISSTRS. This interface } \\
\text { should be fully defined prior to } \\
\text { definitive design, and } \\
\text { confirmed periodically } \\
\text { thereafter. }\end{array}$ \\
\hline $\begin{array}{l}\text { Shallow burial of ISSTRS } \\
\text { lines is acceptable. }\end{array}$ & $\begin{array}{l}\text { Increased construction costs, } \\
\text { especially hand excavation, } \\
\text { for deep burial in tank } \\
\text { farms. }\end{array}$ & $\begin{array}{l}\text { Confirm acceptability with } \\
\text { Operations prior to start of } \\
\text { definitive design. }\end{array}$ \\
\hline $\begin{array}{l}\text { Acceptable that Pump Pit } \\
\text { fences. }\end{array}$ & $\begin{array}{l}\text { Simultaneous retrieval will } \\
\text { require ISSTRS redesign } \\
\text { (jumpers, pipe \& pump } \\
\text { sizes, line routing). }\end{array}$ & $\begin{array}{l}\text { Current ISSTRS design concept } \\
\text { is consistent with WHC-SD- } \\
\text { WM-RPT-229 Rev 0, Initial } \\
\text { Retrieval Sequence and } \\
\text { Blending Strategy. Changes to } \\
\text { the Strategy could drive both } \\
\text { design concept and cost of } \\
\text { ISSTRS. }\end{array}$ \\
\hline be moved. & $\begin{array}{l}\text { Verify acceptability with } \\
\text { Operations prior to starting } \\
\text { Definitive Design. }\end{array}$ \\
\hline
\end{tabular}


Table 3-1. Civil Related Assumptions, Impacts and Validation Recommendations.

\begin{tabular}{|c|c|c|}
\hline Assumptions & Impact if Incorrect & Validation Recommendations \\
\hline $\begin{array}{l}\text { AN-105 inventory will be } \\
\text { managed to accommodate } \\
\text { retrieved SST waste (w/ } \\
\text { dilution). AN- } 105 \text { will } \\
\text { be emptied approx. } 3 \\
\text { times during course of } \\
\text { ISSTRS. }\end{array}$ & $\begin{array}{l}\text { ISSTRS cannot start, or } \\
\text { maintain operation if } \\
\text { sufficient space is not } \\
\text { available in the reliever } \\
\text { tank. }\end{array}$ & $\begin{array}{l}\text { Current ISSTRS design concept } \\
\text { is consistent with WHC-SD- } \\
\text { WM-RPT-229 Rev 0, Initial } \\
\text { Retrieval Sequence and } \\
\text { Blending Strategy. Changes to } \\
\text { the Strategy could drive both } \\
\text { design concept and cost of } \\
\text { ISSTRS. }\end{array}$ \\
\hline $\begin{array}{l}\text { Chemical adjustments to } \\
\text { sluice water made in AN- } \\
105 \text {. }\end{array}$ & $\begin{array}{l}\text { If chem adjustments are } \\
\text { required in the SSTs, } \\
\text { ISSTRS equip, redesign will } \\
\text { be required. }\end{array}$ & $\begin{array}{l}\text { Verify acceptability of } \\
\text { chemical addition into AN-105 } \\
\text { with Operations prior to } \\
\text { ISSTRS definitive design. }\end{array}$ \\
\hline $\begin{array}{l}\text { W-320 is complete \& it's } \\
\text { piping is available for re- } \\
\text { use. }\end{array}$ & $\begin{array}{l}\text { ISSTRS uses some of the W- } \\
320 \text { piping system. ISSTRS } \\
\text { will be impacted if C-106 } \\
\text { sluicing and HTI heel clean } \\
\text { out operations are not } \\
\text { complete prior to ISSTRS } \\
\text { construction. }\end{array}$ & $\begin{array}{l}\text { Validate } W-320 \text { completeness } \\
\text { and verify system integrity } \\
\text { prior to re-use. }\end{array}$ \\
\hline $\begin{array}{l}\text { Maximum waste } \\
\text { properties: } 1.5 \mathrm{SpGr}, 30 \\
\text { cps, } 30 \% \text { solids. }\end{array}$ & $\begin{array}{l}\text { Greater: will decrease } \mathrm{Re} \text {, } \\
\text { velocity, etc. } \\
\text { Less: smaller equip, pumps, } \\
\& \text { lines are possible. }\end{array}$ & Verify waste parameter values. \\
\hline $\begin{array}{l}\text { W-320 is complete \& it's } \\
\text { piping is certified for re- } \\
\text { use. ISSTRS concept } \\
\text { assumes re-use of some } \\
\text { of the W- } 320 \text { piping and } \\
\text { other systems. }\end{array}$ & $\begin{array}{l}\text { The W- } 320 \text { system was } \\
\text { designed for a service life of } \\
2 \text { years. ISSTRS concept } \\
\text { and costs will be impacted if } \\
\text { these systems are not } \\
\text { authorized for re-use. }\end{array}$ & $\begin{array}{l}\text { Prior to or early in definitive } \\
\text { design analysis must be } \\
\text { performed to verify that the } \\
\text { acceptable service life of the } \\
\text { reused systems can be extended } \\
\text { beyond the original } 2 \text { year } \\
\text { design life. }\end{array}$ \\
\hline
\end{tabular}


Table 3-2. Electrical Related Assumptions, Impacts and Validation Recommendations.

\begin{tabular}{|l|l|l|}
\hline \multicolumn{1}{|c|}{ Assumptions } & Impact(s) & Validation Recommendations \\
\hline $\begin{array}{l}\text { 480v power is available } \\
\text { Project W-320 } \\
\text { transformer bank. }\end{array}$ & $\begin{array}{l}\text { Power requirements would } \\
\text { have to be obtained } \\
\text { elsewhere (enlarge capacity } \\
\text { of existing transformer bank } \\
\text { or utilize other available C } \\
\text { Farm transformer bank). }\end{array}$ & $\begin{array}{l}\text { Coordinate with Hanford } \\
\text { Utilities to assure that the } \\
\text { currently available power does } \\
\text { not change prior to ISSTRS. }\end{array}$ \\
\hline $\begin{array}{l}\text { 480v power is available } \\
\text { at either of two existing } \\
\text { transformer banks at AN } \\
\text { Farm. }\end{array}$ & $\begin{array}{l}\text { Increase capacity of either } \\
\text { existing bank. }\end{array}$ & $\begin{array}{l}\text { Coordinate with Hanford } \\
\text { Utilities to assure that the } \\
\text { currently available power does } \\
\text { not change prior to ISSTRS. }\end{array}$ \\
\hline $\begin{array}{l}\text { 480v power is available } \\
\text { at existing transformer } \\
\text { bank at A, AX Farm. }\end{array}$ & $\begin{array}{l}\text { Increase capacity of existing } \\
\text { bank. }\end{array}$ & $\begin{array}{l}\text { Coordinate with Hanford } \\
\text { Utilities to assure that the } \\
\text { currently available power does } \\
\text { not change prior to ISSTRS. }\end{array}$ \\
\hline $\begin{array}{l}\text { Seismic shutdown } \\
\text { switches will be utilized. }\end{array}$ & $\begin{array}{l}\text { Areas of farms will have to } \\
\text { be analyzed and potentially } \\
\text { upgraded to be seismically } \\
\text { qualified. This could } \\
\text { impact concept, schedule, } \\
\text { and cost. }\end{array}$ & $\begin{array}{l}\text { Prepare trade study of seismic } \\
\text { switch and hardening tank } \\
\text { farm areas. }\end{array}$ \\
\hline
\end{tabular}


Table 3-3. HVAC Related Assumptions, Impacts and Validation Recommendations.

\begin{tabular}{|c|c|c|}
\hline Assumptions & Impact(s) & Validation Recommendations \\
\hline $\begin{array}{l}\text { For fog removal, it is } \\
\text { assumed that the amount } \\
\text { of moisture to be } \\
\text { removed from the } \\
\text { ISSTRS SSTs is the } \\
\text { same as for project W- } \\
320 \text { (241-C-106) and } \\
\text { that the airflow required } \\
\text { to remove the fog is } \\
\text { proportional to the tank } \\
\text { volume. }\end{array}$ & $\begin{array}{l}\text { Fog will form in the tanks } \\
\text { during sluicing operations } \\
\text { reduces visibility, thus } \\
\text { slowing production. }\end{array}$ & $\begin{array}{l}\text { Monitor fog formation during } \\
\text { project W-320 (241-C-106) } \\
\text { sluicing operations and } \\
\text { effectiveness of ventilation } \\
\text { system. }\end{array}$ \\
\hline $\begin{array}{l}\text { The exhaust airflow is } \\
\text { limited to the infiltration } \\
\text { airflow of } 230 \mathrm{scfm} \text { as is } \\
\text { currently design for W- } \\
320 \text {. }\end{array}$ & $\begin{array}{l}\text { Increased airflow may result } \\
\text { in the emission of } \\
\text { radionuclides no longer being } \\
\text { in accordance with WHC- } \\
\text { CM- } 4-11 \text { and Air Pollution } \\
\text { Control Regulations WAC } \\
173-4800 \text {. If an exhaust off- } \\
\text { gas flow higher than } 230 \\
\text { scfm is required, an } \\
\text { evaluation of the air } \\
\text { emissions associated with } \\
\text { sluicing tanks } 241-A-102 \text {, } \\
\text { AX-103, C- } 103 \text { \& C- } 105 \text { will } \\
\text { have to be performed. }\end{array}$ & $\begin{array}{l}\text { Confirm during W- } 320 \\
\text { operations that these low } \\
\text { exhaust flows are adequate, and } \\
\text { provide that information to } \\
\text { ISSTRS Definitive Design. }\end{array}$ \\
\hline $\begin{array}{l}\text { Minimum primary } \\
\text { airflow requirement for } \\
\text { DST } 241 \text {-AN-105 is } 500 \\
\text { scfm and is required to } \\
\text { remove energy inputs } \\
\text { from radiation sources } \\
\text { in the DST, energy } \\
\text { added by slurry pump, } \\
\text { and energy added by } \\
\text { sluicing pump. Air flow } \\
\text { will be obtained by use } \\
\text { of both regular and } \\
\text { spare exhauster. }\end{array}$ & $\begin{array}{l}\text { The HVAC system for DST } \\
241 \text {-AN tank farm would } \\
\text { need to be modified in order } \\
\text { to provide a minimum airflow } \\
\text { of } 500 \mathrm{scfm} \text { to primary tank } \\
\text { of AN-105 without use of } \\
\text { spare. }\end{array}$ & $\begin{array}{l}\text { Monitor heat removal from } \\
\text { AY-102 during Project W- } 320 \\
\text { (241-C-106) sluicing operations } \\
\text { to determine actual heat } \\
\text { removal requirements and } \\
\text { acceptability of using spare } \\
\text { exhauster. }\end{array}$ \\
\hline
\end{tabular}


Table 3-4. Process Systems Related Assumptions, Impacts and Validation Recommendations.

\begin{tabular}{|c|c|c|}
\hline Assumptions & Impact(s) & Validation Recommendations \\
\hline $\begin{array}{l}\text { The equipment presently in } \\
\text { risers identified for use by } \\
\text { ISSTRS will be removed } \\
\text { by others prior to } \\
\text { commencing the ISSTRS } \\
\text { construction. }\end{array}$ & $\begin{array}{l}\text { The equipment will have to } \\
\text { be removed prior to } \\
\text { ISSTRS construction, else, } \\
\text { new risers and pump pits } \\
\text { will have to be installed in } \\
\text { the tanks. }\end{array}$ & $\begin{array}{l}\text { Removal of in-tank hardware } \\
\text { be allocated asap to allow } \\
\text { design work to commence. }\end{array}$ \\
\hline $\begin{array}{l}\text { None of the miscellaneous } \\
\text { hardware debris believed to } \\
\text { be in the tanks will } \\
\text { interfere with the retrieval } \\
\text { process. }\end{array}$ & $\begin{array}{l}\text { The hardware debris could } \\
\text { damage the slurry pump. }\end{array}$ & $\begin{array}{l}\text { Review the performance of the } \\
\text { project } W-320 \text { pump to } \\
\text { determine if debris needs to be } \\
\text { removed from the tank. }\end{array}$ \\
\hline $\begin{array}{l}\text { A heel pump (a Flygt } \\
\text { submersible is the } \\
\text { recommended pump) is } \\
\text { required after the } \\
\text { completion of sluicing to } \\
\text { reduce the liquid level to } \\
\text { below the controlled, clean } \\
\text { and stable limits. }\end{array}$ & $\begin{array}{l}\text { A pump may not be needed } \\
\text { (Project W- } 320 \text { design does } \\
\text { not include a heel pump), } \\
\text { or, the selected pump may } \\
\text { not be able to remove the } \\
\text { liquor to such a low level } \\
\text { (potentially less than 2" } \\
\text { from the tank base). }\end{array}$ & $\begin{array}{l}\text { Review the performance of } \\
\text { project W-320. }\end{array}$ \\
\hline $\begin{array}{l}\text { The cost of running new } \\
\text { pipe routes in the Tank } \\
\text { Farms is } \$ 3,000 \text { per } \mathrm{ft} \text {. }\end{array}$ & $\begin{array}{l}\text { If the cost is significantly } \\
\text { different from this there } \\
\text { may be a need to further } \\
\text { review the pipe route } \\
\text { options presently adopted } \\
\text { by the project. }\end{array}$ & $\begin{array}{l}\text { Obtain actual cost information } \\
\text { from project W- } 320 \text { for the } \\
\text { running of new pipe routes. } \\
\text { Trade studies were based on } \\
\text { W-320 } 90 \% \text { estimated costs, as } \\
\text { only they were available. }\end{array}$ \\
\hline $\begin{array}{l}\text { A VOC adsorber is } \\
\text { required for the removal of } \\
\text { Dioxins and Furans from } \\
\text { the ventilation off-gas. }\end{array}$ & $\begin{array}{l}\text { If this assumption were } \\
\text { adopted, there would be a } \\
\text { cost increase for the } \\
\text { ISSTRS project, plus there } \\
\text { would be significant } \\
\text { implications for all other } \\
\text { tanks at Hanford which } \\
\text { contain Dioxins and } \\
\text { Furans. }\end{array}$ & $\begin{array}{l}\text { Perform a cost/benefit analysis } \\
\text { to determine if a VOC adsorber } \\
\text { can be justified. }\end{array}$ \\
\hline
\end{tabular}


Table 3-4. Process Systems Related Assumptions, Impacts and Validation Recommendations.

\begin{tabular}{|l|l|l|}
\hline \multicolumn{1}{|c|}{ Assumptions } & \multicolumn{1}{|c|}{ Impact(s) } & Validation Recommendations \\
\hline $\begin{array}{l}\text { No additional leak } \\
\text { detection methods will be } \\
\text { required other than those } \\
\text { presently installed and a } \\
\begin{array}{l}\text { similar system to that } \\
\text { planned for use on C-106. }\end{array}\end{array}$ & $\begin{array}{l}\text { If alternative leak detection } \\
\text { systems are required, there } \\
\text { will be significant cost } \\
\text { implications for the } \\
\text { project. }\end{array}$ & $\begin{array}{l}\text { Review the performance of } \\
\text { Project W-320. }\end{array}$ \\
\hline
\end{tabular}

Table 3-5. Trade Study Generated Assumptions, Impacts and Validation Recommendations.

\begin{tabular}{|l|l|l|}
\hline \multicolumn{1}{|c|}{ Assumptions } & \multicolumn{1}{|c|}{ Impact if Incorrect } & Validation Recommendations \\
\hline $\begin{array}{l}\text { Risers for sluicer and } \\
\text { pumps are the same size } \\
\text { and configuration in tanks } \\
\text { C-103 and C-105 as they } \\
\text { are for C-106. }\end{array}$ & $\begin{array}{l}\text { Installation of equipment } \\
\text { designed during Project W- } \\
\text { 321 would be delayed for } \\
\text { modification. }\end{array}$ & $\begin{array}{l}\text { Field verify prior to definitive } \\
\text { design. }\end{array}$ \\
\hline $\begin{array}{l}\text { Increasing regulatory } \\
\text { compliance between 1996 } \\
\text { and 2004 will not be } \\
\text { addressed. }\end{array}$ & $\begin{array}{l}\text { Equipment installed under } \\
\text { W-320 may not be } \\
\text { reusable. }\end{array}$ & $\begin{array}{l}\text { Mitigate by adopting an } \\
\text { aggressive schedule in } \\
\text { retrieving waste from SSTs. }\end{array}$ \\
\hline $\begin{array}{l}\text { Sluicer Hydraulic Power } \\
\text { Pack and Drive Assembly } \\
\text { will not be exercised for } \\
\text { eight years resulting in } \\
\text { hardened seals, corrosion, } \\
\text { and contaminated fluid. }\end{array}$ & $\begin{array}{l}\text { If allowed to deteriorate, } \\
\text { reuse is impacted resulting } \\
\text { in a cost impact to } \\
\text { ISSTRS. }\end{array}$ & $\begin{array}{l}\text { Periodic Maintenance which } \\
\text { cycles the equipment could } \\
\text { reduce deterioration. } \\
\text { Equipment should by inspected } \\
\text { prior to re-Lse, and project } \\
\text { planning should allow } \\
\text { contingency for rebuild or } \\
\text { replacement of equipment. }\end{array}$ \\
\hline
\end{tabular}




\subsection{Findings}

Recommendations for validation were grouped into two categories; verify design parameters and verify programmatic issues. Verification of design parameters such as operation pressure, flow rate, pipe size, specific gravity, etc is recommended prior to conceptual design approval. One identified design parameter which would be a "show stopper" for ISSTRS is if the risers and pits at the four SSTs and the DST are not available for use. However as conclusive verification can only be done by the operation of the W-320 retrieval systems, timing of information becomes critical. However, it is vital that these issues be resolved either before or very early in Definitive Design.

Initial verification of programmatic issues, such as master tank retrieval sequence, DST waste management, removal of in-tank hardware, and utility availability at the tank farms, should also be a part of the conceptual design review. Every identified programmatic issue is a potential "show stopper" as ISSTRS is designed to retrieve waste sequentially and not cocurrently, Tank AN-105 must have available free volume to receive the waste, in-tank hardware may prevent use of risers and pits or damage equipment, and power must be available at the tank farms. 


\section{REQUIREMENTS TRACEABILITY REPORT FOR CONCEPTUAL DESIGN OF THE INITLAL SINGLE SHELL TANK RETRIEVAL SYSTEM}

TANK WASTE REMEDIAITON SYSTEM

Prepared By:

LOS ALAMOS TECHNICAL ASSOCIATES, INC.

Richland, WA 
This page intentionally left blank. 
Approved by:
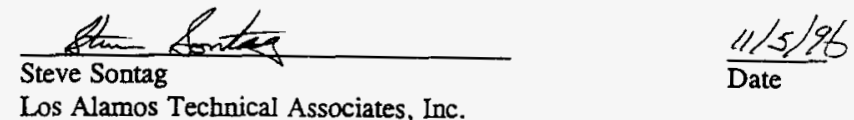

Los Alamos Technical Associates, Inc.
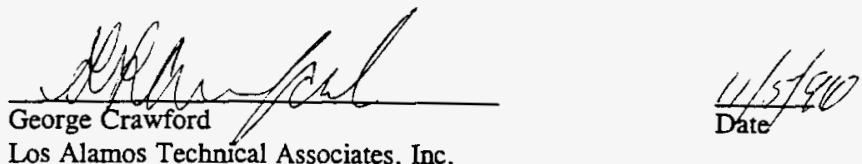

Los Alamos Technical Associates, Inc. 


\section{CONTENTS}

1.0 INTRODUCTION AND SCOPE $\ldots \ldots \ldots \ldots \ldots \ldots \ldots \ldots \ldots \ldots \ldots$

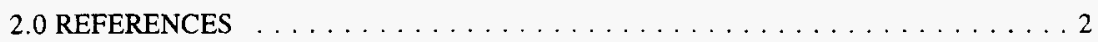

3.0 REQUIREMENTS TRACEABILITY $\ldots \ldots \ldots \ldots \ldots \ldots \ldots \ldots \ldots \ldots \ldots$

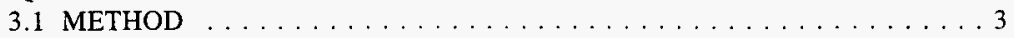

3.2 REQUIREMENTS, ASSIGNMENT AND EXPLANATION LISTINGS $\ldots \ldots 3$

\section{LIST OF TABLES}

Table 3-1. PDS Requirements, Assignments and Explanations (18 Sheets) . . . . . . . 4 


\subsection{INTRODUCTION AND SCOPE}

The Initial Single-Shell Tank Retrieval System (ISSTRS) supports the Tank Waste Remediation System (TWRS) retrieve waste functions, and specifically provides a tank farm demonstration for retrieval of waste from selected SSTs. Both saltcake and sludge retrieval will be demonstrated.

Conceptual design of ISSTRS provides a conceptual level cost, schedule and technical basis for the project Design Configuration Baseline (DCBL) as described in the TWRS System Engineering Management Plan (SEMP) and supplemented by the ISSTRS Project SEMP. The ISSTRS project objective is to design, fabricate, and install waste retrieval systems, waste transfer lines, tank HVAC systems and infrastructure necessary to begin waste retrieval operations in the first Single-Shell Tank Farm by November, 2003.

The tank farms in the 200 West and 200 East areas at the Hanford site were installed to receive high level liquid waste from nuclear fuel processing and the production of special nuclear materials. Subsequent operations have resuited in mixing of wastes between tanks, volume reduction of the liquid with a corresponding increase in the solids content and physical isolation of some of the tanks. A total of 149 single-shell tanks (SSTs) were built between 1943 and 1964 and are clustered in rectangular arrays of 2 to 18 tanks called tank farms. No wastes have been added to any SST since 1980. There are 28 double-shell tanks (DSTs) arranged in tank farms of 2 to 8 tanks each, which were built between 1971 and 1986. DSTs still receive waste on an as needed basis. The four SSTs specified for retrieval under ISSTRS are 241-A-102, 241-AX-103, 241-C-103, and 241-C-105 whose wastes are to be transferred to the DST 241-AN-105.

It should be noted that the ISSTRS Mission is to apply the $W^{\prime}-320$ systems and equipment to four other SSTs. The goal was to deviate from or modify the W-320 designs or equipment only when required by the new application. Therefore, the W-320 designs ability to optimize performance parameters or minimize cost was not explored in the ISSTRS conceptual design. If the W-320 design met or exceeded minimum performance requirements, it was adopted as is.

The ability of W-320 design to optimize operability or maintainability was not evaluated. It is assumed (dependent on schedule) that fabrication, construction, operation and maintenance lessons learned from W-320 experience will be documented and provided to the $\mathrm{A} / \mathrm{E}$ by the PHMC prior to definitive design. As the mission of ISSTRS is to demonstrate the performance of W-320 systems in other tanks, the performance of ISSTRS against requirements like dilution ratio, retrieval rate, and reliability can only be show through field service. Definitive design analysis should by performed to assure safety and indicate a reasonable chance of meeting those requirements. However it must be remembered that the mission can be met only by actual operational determination of the system's capability. 
There are ten major sub-elements that makeup the ISSTRS. The titles describe the functions to be performed which are part of the basis of the requirements in the Preliminary Design Requirements Document (PDRD).
a. Detect SST Waste Leakage During Retrieval.
b. Monitor SST Waste Leakage During Retrieval
c. Mitigate SST Waste Leakage During Retrieval
d. Remove In-Tank Obstructions
e. Deploy Retrieval System
f. Mobilize SST Waste
g. Convey/Transfer Slurry Waste
h. Ventilation and Cooling
i. Monitor and Control Operations
j. Decontaminate Equipment

Design requirements for ISSTRS are given in the PDRD. The PDRD was reviewed for requirements that were applicable for conceptual design. The applicable requirements were then listed in the Project Design Specifications (PDS). The traceability of each PDS requirement is established through recording the system or sub-system that it has been assigned to, coupled with an explanation of how the requirement will be satisfied by the system or sub-system.

\subsection{REFERENCES}

"Tank Waste Remediation System System Engineering Management Plan," Peck, 1996

"Initial Single-Shell Tank Retrieval System SEMP," Krieg, 1996

"Preliminary Design Requirements Document for ISSTRS," Hertzel, 1996 


\subsection{REQUIREMENTS TRACEABILITY}

\subsection{METHOD}

The methodology used to establish traceability of the requirements was to list each requirement in the PDS, determine which system, sub-system or combination of the two will accomplish each requirement and develop an explanation of how the system or sub-system will satisfy the requirement.

\subsection{REQUIREMENTS, ASSIGNMENTS, AND EXPLANATION LISTINGS}

Table 3-1 summarizes the requirements from the PDS, assigned system or sub-system, and explanations below. Reserved areas within the PDS have not been listed. 
Table 3-1. PDS Requirements, Assignments and Explanations (18 Sheets).

\begin{tabular}{|c|c|c|}
\hline PDS Requirement & $\begin{array}{c}\text { System or Sub-System } \\
\text { Assignment }\end{array}$ & Explanation of How Requirement is Satisfied \\
\hline $\begin{array}{l}\text { 3.2.1.1 Tank Farm Retrieval } \\
\text { Demonstration }\end{array}$ & All, including interfaces & $\begin{array}{l}\text { All systems acting in coordination will retrieve } \\
\text { wastes. }\end{array}$ \\
\hline 3.2.1.1.1 Total Waste Volume & I\&C, Sluicing Operations & $\begin{array}{l}\text { 1. Pumps shall be capable of transferring up to } \\
\text { and instrumentation shall be capable of } \\
\text { monitoring up to } 5 \mathrm{M} \text { sodium concentration } \\
\text { and } 10 \% \text { weight percent solids. } \\
\text { 2. Design lifetime and flow rate shall provide } \\
\text { retrieval of existing waste volume of } 1.8 \times 10^{6} \\
\mathrm{~L} \text { ( } 483 \mathrm{kgal} \text { ) after dilution to above limits; } \\
\text { alternately } 310,000 \text { tons. }\end{array}$ \\
\hline 3.2.1.1.2 Productivity Rate & I\&C, Sluicing Operations & $\begin{array}{l}\text { Pumps and I\&C shall be capable of retrieving } \\
\text { and confirming retrieval of } 7.2 \mathrm{~m}^{3} \text { per day of } \\
\text { SST waste. }\end{array}$ \\
\hline 3.2.1.1.3 Tank-to-Tank Sluicing & Sluicing Operations & $\begin{array}{l}\text { Pumps and piping have been designed to } \\
\text { convey slurry from each of the } 4 \text { SSTs to } \\
\text { DST AN-105 and return supernate from AN- } \\
105 \text { to each of the } 4 \text { SSTs. }\end{array}$ \\
\hline $\begin{array}{l}\text { 3.2.1.1.4 Single Shell Tank } \\
\text { Selection }\end{array}$ & Mission Analysis & $\begin{array}{l}\text { WHC-SD-WM-ES-367, Rev. } 0 \text { selected } 4 \\
\text { SSTs; A-102, AX-103, C-103 \& C-105. Also } \\
\text { overall retrieval tank selection, required rate } \\
\text { and DST receiver is governed by WHC-SD- } \\
\text { WM-RPT-229, Rev. 0, "Initial Retrieval } \\
\text { sequence and Blending Strategy" }\end{array}$ \\
\hline
\end{tabular}


Table 3-1. PDS Requirements, Assignments and Explanations (18 Sheets).

\begin{tabular}{|c|c|c|}
\hline PDS Requirement & $\begin{array}{c}\text { System or Sub-System } \\
\text { Assignment }\end{array}$ & Explanation of How Requirement is Satisfied \\
\hline $\begin{array}{l}\text { 3.2.1.1.5 Deploy Retrieval } \\
\text { System }\end{array}$ & All, including interfaces & $\begin{array}{l}\text { Submersible pumps, sluicer nozzle assembly, } \\
\text { jumpers, etc are designed for insertion into } \\
\text { tanks and connection to existing } \\
\text { facilities/piping without exceeding maximum } \\
\text { live loads onto tank domes. }\end{array}$ \\
\hline 3.2.1.1.6 Mobilize Waste & Sluicing Operations & $\begin{array}{l}\text { Sluicing nozzle assembly, CCTV, sluice and } \\
\text { slurry pump systems, slurry distributors, and } \\
\text { control and monitoring systems are designed } \\
\text { for controllable slurry formation and pickup. } \\
\text { Chemical concentration and environment, } \\
\text { tank vapor sampling for LFL and max. dome } \\
\text { temperature are known duties/limitations. }\end{array}$ \\
\hline $\begin{array}{l}\text { 3.2.1.1.7 Convey and Transfer } \\
\text { Waste }\end{array}$ & Sluicing Operations and Piping & $\begin{array}{l}\text { Mobilized slurry will be pumped from SSTs } \\
\text { to DST An-105, and supernate will be } \\
\text { returned for use in forming additional slurry. } \\
\text { Instrumentation will monitor important } \\
\text { parameters. }\end{array}$ \\
\hline $\begin{array}{l}\text { 3.2.1.2 Detect, Monitor and } \\
\text { Mitigate SST Waste Leakage }\end{array}$ & $\mathrm{I} \& \mathrm{C}$ & $\begin{array}{l}\text { Leak detectors, coupons, liquid level sensors, } \\
\text { and similar devices have been identified as } \\
\text { suitable methods. Detailed design will select } \\
\text { final method(s). In an emergency, slurry } \\
\text { transfer pump or heel pump would be used to } \\
\text { remove liquids from SST to a safe level. }\end{array}$ \\
\hline
\end{tabular}


Table 3-1. PDS Requirements, Assignments and Explanations (18 Sheets).

\begin{tabular}{|l|l|l|}
\hline PDS Requirement & \multicolumn{1}{|c|}{$\begin{array}{c}\text { System or Sub-System } \\
\text { Assignment }\end{array}$} & Explanation of How Requirement is Satisfied \\
\hline $\begin{array}{l}\text { 3.2.1.2.1 Monitor SST Waste } \\
\text { Leakage during Retrieval }\end{array}$ & I\&C & $\begin{array}{l}\text { Detection of leakage will be accomplished by } \\
\text { acquiring and evaluating data on potential } \\
\text { leakage conditions, waste inventory, and size } \\
\text { and location of existing contaminant plumes. } \\
\text { Emergency power for electrical leak detection } \\
\text { devices will be the responsibility of others } \\
\text { and is beyond the scope of conceptual design. }\end{array}$ \\
\hline $\begin{array}{l}\text { Leakage During SST Waste } \\
\text { Retrieval }\end{array}$ & I\&C, Sluicing Operations & $\begin{array}{l}\text { Detection of leaks will be the first step. } \\
\text { Mitigation will occur before maximum } \\
\text { contaminant levels are reached. In an } \\
\text { emergency, slurry transfer pump or heel } \\
\text { pump would be used to remove liquids from } \\
\text { SST to a safe level, pumping would be } \\
\text { stopped, or lines could be flushed. }\end{array}$ \\
\hline
\end{tabular}


Table 3-1. PDS Requirements, Assignments and Explanations (18 Sheets).

\begin{tabular}{|c|c|c|}
\hline PDS Requirement & $\begin{array}{c}\text { System or Sub-System } \\
\text { Assignment }\end{array}$ & Explanation of How Requirement is Satisfied \\
\hline $\begin{array}{l}\text { 3.2.1.3 Ventilation and Cooling } \\
\text { System }\end{array}$ & Ventilation System, I\&C & $\begin{array}{l}\text { Ventilation system fans will maintain required } \\
\text { negative pressures in tanks. Recirculation of } \\
\text { conditioned air plus the ability to induce } \\
\text { outside air flow into the tanks will maintain } \\
\text { the required temperature. All condensate } \\
\text { collected from the ventilation system will be } \\
\text { returned to the SST being sluiced. } \\
\text { Monitoring and alarm criteria for } \\
\text { radionuclides, particulates, and hazardous } \\
\text { materials have been listed for use in detailed } \\
\text { design (including max. concentrations, } \\
\text { sensitivities, efficiencies, testing, flow } \\
\text { measurement, record sampling, pressure drop } \\
\text { through HEPAs, ALARA for radiation } \\
\text { exposure, and allocation of Hanford Site } \\
\text { discharge amounts). }\end{array}$ \\
\hline $\begin{array}{l}\text { 3.2.1.4 Decontaminate ISSTRS } \\
\text { Equipment }\end{array}$ & $\begin{array}{l}\text { General Mechanical Design, } \\
\text { Sluicing Operations }\end{array}$ & $\begin{array}{l}\text { Designs to minimize contamination capture on } \\
\text { equipment and decontaminate equipment } \\
\text { during removal will be developed during } \\
\text { detailed design. Flushing after waste transfer } \\
\text { will perform some decontamination. }\end{array}$ \\
\hline $\begin{array}{l}\text { 3.2.1.5 Stabilize Retrieved Single } \\
\text { Shell Tank }\end{array}$ & Sluicing Operations & $\begin{array}{l}\text { A heel pump is an integral part of the design } \\
\text { and is to reduce the amount of liquid } \\
\text { remaining to less than } 5,000 \text { gallons. } \\
\text { Intrusion prevention details will be developed } \\
\text { during definitive design. }\end{array}$ \\
\hline
\end{tabular}


Table 3-1. PDS Requirements, Assignments and Explanations (18 Sheets).

\begin{tabular}{|c|c|c|}
\hline PDS Requirement & $\begin{array}{c}\text { System or Sub-System } \\
\text { Assignment }\end{array}$ & Explanation of How Requirement is Satisfied \\
\hline $\begin{array}{l}\text { 3.2.1.6 Remove In-Tank } \\
\text { Hardware }\end{array}$ & Secondary Waste Handling & $\begin{array}{l}\text { This will be the responsibility of others and is } \\
\text { not included in the present scope of work for } \\
\text { conceptual design. }\end{array}$ \\
\hline 3.2.2 System Relationship & All & $\begin{array}{l}\text { ISSTRS will accomplish the performance } \\
\text { characteristics by itself or through appropriate } \\
\text { interfaces with other TWRS systems. Tank } \\
\text { specific interface diagrams have been } \\
\text { prepared. }\end{array}$ \\
\hline 3.2.3 External Interfaces & All & $\begin{array}{l}\text { Physical and programmatic interfaces have } \\
\text { been identified and will be specifically } \\
\text { addressed during detailed design. Physical } \\
\text { interfaces include the AN-105 sluice, pump } \\
\text { and distributor pit, SST sluice and pump pits, } \\
\text { portions of W-320 transfer system, exiting } \\
\text { valve pits/diversion boxes, existing electrical } \\
\text { system, existing raw water system, existing } \\
\text { fire protection, tank operations information } \\
\text { supporting characterization and safety, and } \\
\text { input of raw materials for corrosion control or } \\
\text { treatment. Programmatic interfaces include } \\
\text { retrieved in-tank hardware characterization- } \\
\text { packaging-transfer, treated gaseous effluents, } \\
\text { treated liquid effluents, additive restrictions } \\
\text { into tanks, maximum recycle of process } \\
\text { condensates, and secondary waste } \\
\text { characterization-packaging-transfer. }\end{array}$ \\
\hline
\end{tabular}


Table 3-1. PDS Requirements, Assignments and Explanations (18 Sheets).

\begin{tabular}{|c|c|c|}
\hline PDS Requirement & $\begin{array}{c}\text { System or Sub-System } \\
\text { Assignment }\end{array}$ & Explanation of How Requirement is Satisfied \\
\hline 3.2.4 Physical Characteristics & Sluicing Operations, All & $\begin{array}{l}\text { Protective coatings, if used in detailed design } \\
\text { will be compatible to their service conditions } \\
\text { and will be specifically developed in } \\
\text { definitive design. }\end{array}$ \\
\hline \multicolumn{3}{|l|}{ 3.2.5 Project Quality Factors } \\
\hline 3.2.5.1 Reliability & All & $\begin{array}{l}\text { Actual reliability performance data of W-320 } \\
\text { equipment will be used in the definitive } \\
\text { design analysis process. Reliability of the } \\
\text { detailed design will be evaluated through } \\
\text { performance of a Failure Mode and Effects } \\
\text { Analysis and a complementing Fault Tree } \\
\text { Analysis. Both are to prepared to federal } \\
\text { guidelines, MIL-STD-1692A and NUREG- } \\
\text { 0492, respectively. }\end{array}$ \\
\hline 3.2.5.2 Maintainability & All & $\begin{array}{l}\text { Actual maintenance experience of W- } 320 \\
\text { systems will be a valuable input to definitive } \\
\text { design process. Efficient maintainability, } \\
\text { ALARA, remote maintenance features, and } \\
\text { routine maintenance for equipment subject to } \\
\text { failure are identified elements to be } \\
\text { incorporated into the detailed design. }\end{array}$ \\
\hline 3.2.5.3 Availability & All & $\begin{array}{l}\text { Actual availability experience of } W-320 \\
\text { systems will be a valuable input to definitive } \\
\text { design process. Operational availability of the } \\
\text { system will be sufficient to produce the } \\
\text { required total retrieval rates over the design } \\
\text { life of the system. }\end{array}$ \\
\hline
\end{tabular}




\begin{tabular}{|c|c|c|}
\hline PDS Requirement & $\begin{array}{c}\text { System or Sub-System } \\
\text { Assignment }\end{array}$ & Explanation of How Requirement is Satisfied \\
\hline $\begin{array}{l}\text { 3.2.5.4 Operability and } \\
\text { Maintainability }\end{array}$ & All & $\begin{array}{l}\text { Four maintenance and operations (O\&M) } \\
\text { categories have been developed based on } \\
\text { expected radiation levels which determine } \\
\text { whether O\&M should be remote, limited } \\
\text { contact or hands-on and will be addressed in } \\
\text { definitive design. }\end{array}$ \\
\hline $\begin{array}{l}\text { 3.2.5.4.1 Operations and } \\
\text { Maintenance Considerations }\end{array}$ & All & $\begin{array}{l}\text { Twenty six O\&M qualities for design } \\
\text { pertaining to the ability of personnel to safely } \\
\text { and efficiently operate and maintain the } \\
\text { system have been identified in the PDS for } \\
\text { use during detailed design. }\end{array}$ \\
\hline $\begin{array}{l}\text { 3.2.5.4.2 Contaminated } \\
\text { Equipment Maintenance }\end{array}$ & $\begin{array}{l}\text { Sluicing Operations, I\&C, } \\
\text { Ventilation }\end{array}$ & $\begin{array}{l}\text { Detailed design is to review and use } \\
\text { appropriate requirements from DOE Orders } \\
6430.1 \mathrm{~A} \text { and } 4330.4 \mathrm{~A} \text {. }\end{array}$ \\
\hline $\begin{array}{l}\text { 3.2.5.4.3 High Dose Rate Areas } \\
\text { Equipment Maintenance }\end{array}$ & $\begin{array}{l}\text { Sluicing Operations, I\&C, } \\
\text { Ventilation }\end{array}$ & $\begin{array}{l}\text { Detailed design is to use ALARA principles } \\
\text { to preclude routine, hands-on maintenance of } \\
\text { equipment that operates in a high-radiation } \\
\text { area. }\end{array}$ \\
\hline $\begin{array}{l}\text { 3.2.5.4.2 Remote Equipment } \\
\text { Maintenance }\end{array}$ & $\begin{array}{l}\text { Sluicing Operations, I\&C, } \\
\text { Ventilation }\end{array}$ & $\begin{array}{l}\text { Detailed design is to use remote replacement } \\
\text { of equipment that operates in a high-radiation } \\
\text { area. }\end{array}$ \\
\hline 3.2.6 Environmental Conditions & All & $\begin{array}{l}\text { Both natural and induced environmental } \\
\text { conditions have been identified in the PDS } \\
\text { for use during detailed design. }\end{array}$ \\
\hline
\end{tabular}


Table 3-1. PDS Requirements, Assignments and Explanations (18 Sheets).

\begin{tabular}{|c|c|c|}
\hline PDS Requirement & $\begin{array}{l}\text { System or Sub-System } \\
\text { Assignment }\end{array}$ & Explanation of How Requirement is Satisfied \\
\hline 3.2.6.1 Natural Environments & All & $\begin{array}{l}\text { Fourteen environmental conditions, from } \\
\text { temperature to volcanic ashfall loads, have } \\
\text { been listed in the PDS for use during detailed } \\
\text { design. }\end{array}$ \\
\hline 3.2.6.1 Induced Environments & All & $\begin{array}{l}\text { Chemical, physical and radionuclide } \\
\text { conditions based on best available tank } \\
\text { characterization have been listed in the PDS } \\
\text { for use during detailed design. }\end{array}$ \\
\hline 3.2.7 Transportability & All & $\begin{array}{l}\text { Compliance with DOT regulations for } \\
\text { packaging, labeling, placarding, and shipment } \\
\text { of hazardous materials have been identified as } \\
\text { applicable for any part which must be } \\
\text { transported. }\end{array}$ \\
\hline 3.2.8 Flexibility and Expansion & All & $\begin{array}{l}\text { Flexibility to accommodate programmatic or } \\
\text { operational changes has been identified as a } \\
\text { concern during detailed design. }\end{array}$ \\
\hline 3.3 Design and Construction & All & $\begin{array}{l}\text { DOE Order } 6430.1 \mathrm{~A} \text { has been identified as } \\
\text { the general design guide. }\end{array}$ \\
\hline
\end{tabular}


Table 3-1. PDS Requirements, Assignments and Explanations (18 Sheets).

\begin{tabular}{|c|c|c|}
\hline PDS Requirement & $\begin{array}{c}\text { System or Sub-System } \\
\text { Assignment }\end{array}$ & Explanation of How Requirement is Satisfied \\
\hline $\begin{array}{l}\text { 3.3.1 Materials, Processes and } \\
\text { Design Practices - Facility Design } \\
\text { \& Shielding, Support Devices, } \\
\text { Structural Support, Air Control, } \\
\text { Solid Waste Operation, Fire } \\
\text { Protection, Fire Hazards Analysis }\end{array}$ & All & $\begin{array}{l}\text { Radiation shielding is to designed to limit the } \\
\text { total body dose to } 5 \text { mSv/year. A radiological } \\
\text { design guideline for use during detailed } \\
\text { design has been identified. Facility design is } \\
\text { to overall conform to ALARA principles, } \\
\text { control airborne radioactive material releases } \\
\text { and facilitate O\&M, decontamination and } \\
\text { decommissioning. Supporting devices and } \\
\text { structural supports will be designed in } \\
\text { accordance with DOE Order } 6430.1 \text { A. Air } \\
\text { flow will be from areas of no contamination } \\
\text { toward areas of higher contamination to } \\
\text { provide confinement. Nonradioactive } \\
\text { airborne emissions will comply with WAC } \\
\text { 173-400. All secondary waste will comply } \\
\text { with onsite packaging and shipping } \\
\text { requirements, waste minimization, and } \\
\text { transfer to Hanford Solid Waste. Fire } \\
\text { protection system shall be accordance with } 5 \\
\text { DOE, } 1 \text { Hanford and } 2 \text { national fire } \\
\text { protection codes. A fire hazards analysis will } \\
\text { be performed with the recommendations } \\
\text { incorporated into the design. }\end{array}$ \\
\hline
\end{tabular}


Table 3-1. PDS Requirements, Assignments and Explanations (18 Sheets).

\begin{tabular}{|c|c|c|}
\hline PDS Requirement & $\begin{array}{c}\text { System or Sub-System } \\
\text { Assignment }\end{array}$ & Explanation of How Requirement is Satisfied \\
\hline $\begin{array}{l}\text { 3.3.1 (Continued) - Electrical, } \\
\text { Containment, Cathodic Protection, } \\
\text { Corrosion Control, Materials, } \\
\text { Toxic Products }\end{array}$ & All & $\begin{array}{l}\text { Electrical power, emergency power, and } \\
\text { uninterruptable power supply system will be } \\
\text { provided in accordance with DOE } 6430.1 \mathrm{~A} \text {, } \\
\text { ANSI C2, and NFPA } 70 \text {. Electrical loads } \\
\text { and operational design requirements will } \\
\text { comply with NFPA } 70 \text { and ANSI C2. } \\
\text { Electrical material or equipment will be UL- } \\
\text { or FM- tested. Double containment will be } \\
\text { used for all waste handling facilities unless a } \\
\text { temporary exemption has been made. } \\
\text { Secondary containment will be capable of } \\
\text { containing the liquid that may leak into them } \\
\text { and transferring the liquid to storage. Other } \\
\text { design requirements have been identified for } \\
\text { containment systems. Cathodic protection } \\
\text { will be used to prevent corrosion where } \\
\text { appropriate. Corrosion control will be } \\
\text { designed into the system by a corrosion expert } \\
\text { and use of corrosion resistant material. } \\
\text { Materials of construction will be compatible } \\
\text { with the waste it is to be in contact with and } \\
\text { incompatible wastes and materials will be } \\
\text { separated. Toxic products (asbestos, PCB, or } \\
\text { ozone depleting chemicals) will not be used in } \\
\text { the design. }\end{array}$ \\
\hline
\end{tabular}




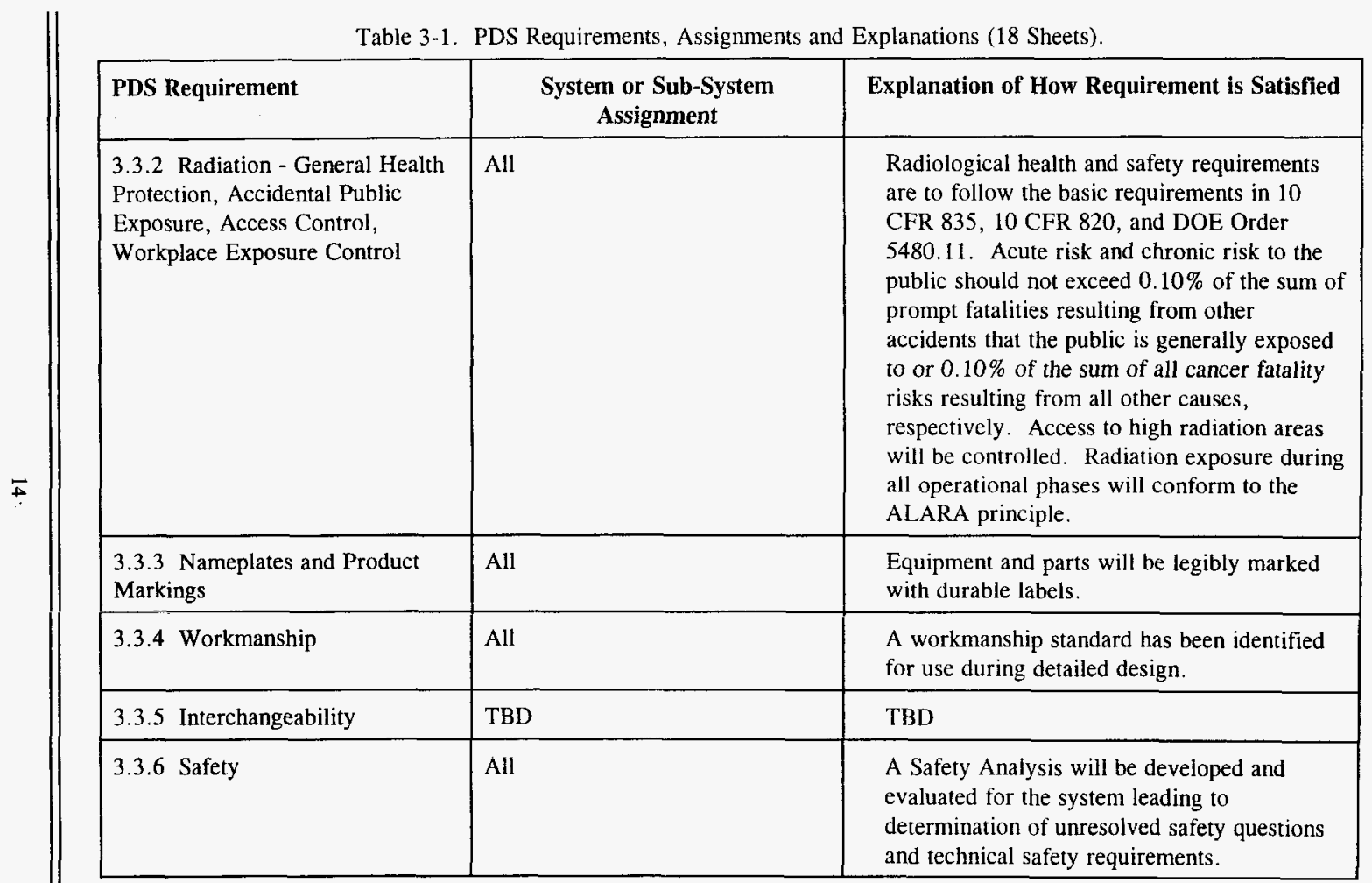




\begin{tabular}{|l|l|l|l|}
\hline \multicolumn{2}{||}{ Table 3-1. PDS Requirements, Assignments and Explanations (18 Sheets). } \\
\hline PDS Requirement & \multicolumn{1}{|c|}{$\begin{array}{c}\text { System or Sub-System } \\
\text { Assignment }\end{array}$} & Explanation of How Requirement is Satisfied \\
\hline 3.3 .6 .1 Fire Protection & All & $\begin{array}{l}\text { Detailed design will include provisions for a } \\
\text { fire protection program in accordance with } \\
\text { DOE Order 5480.7A and compliance with } \\
\text { WAC 173-303-395. Any reactive waste must } \\
\text { be stored in compliance with Uniform Fire } \\
\text { Code. }\end{array}$ \\
\hline 3.3 .6 .2 ALARA & All & $\begin{array}{l}\text { Work place and general exposure to radiation } \\
\text { and hazardous materials will be maintained as } \\
\text { low as reasonably achievable. Cost/benefit } \\
\text { analysis will use a minimum value of } \$ 2,500 \\
\text { per person-rem ranging to an upper limit } \\
\text { dependent on application. }\end{array}$ \\
\hline
\end{tabular}


Table 3-1. PDS Requirements, Assignments and Explanations (18 Sheets).

\begin{tabular}{|c|c|c|}
\hline PDS Requirement & $\begin{array}{c}\text { System or Sub-System } \\
\text { Assignment }\end{array}$ & Explanation of How Requirement is Satisfied \\
\hline 3.3.6.3 Design for Safety & All & $\begin{array}{l}\text { Protection of the public and operating } \\
\text { personnel will be part of the detailed design. } \\
\text { Identified hazards should be eliminated, } \\
\text { controlled or mitigated after preparation of a } \\
\text { safety analysis report. Safety class structures, } \\
\text { systems and components will be identified } \\
\text { within the detailed design for protection of } \\
\text { both onsite and offsite personnel. The } \\
\text { detailed design will comply with OSHA and } \\
\text { be compatible with a maintenance } \\
\text { management program. Warning and } \\
\text { annunciator systems will alert personnel in } \\
\text { time to respond appropriately. Emergency } \\
\text { lighting will be provided by NFPA } 101 \text { and } \\
\text { conform to NUREG } 0700 \text {. Display devices } \\
\text { will be readable,understandable, and } \\
\text { accessible during normal, abnormal and } \\
\text { emergency conditions. }\end{array}$ \\
\hline 3.3.7 Human Engineering & All & $\begin{array}{l}\text { Detailed design of equipment to be used by } \\
\text { personnel is to accommodate the fifth to } \\
\text { ninety-fifth percentile of the user population. }\end{array}$ \\
\hline 3.3.8 Nuclear Control & All & $\begin{array}{l}\text { Nuclear criticality safety considerations will } \\
\text { be evaluated for normal operations or before } \\
\text { significant operational changes are made. }\end{array}$ \\
\hline 3.3.9 Security & All & $\begin{array}{l}\text { Safeguard and security systems will conform } \\
\text { to DOE Order } 470.1 \text {. }\end{array}$ \\
\hline
\end{tabular}


Table 3-1. PDS Requirements, Assignments and Explanations (18 Sheets).

\begin{tabular}{|c|c|c|}
\hline PDS Requirement & $\begin{array}{c}\text { System or Sub-System } \\
\text { Assignment }\end{array}$ & Explanation of How Requirement is Satisfied \\
\hline 3.4 Information & All & $\begin{array}{l}\text { Records, documents and document control to } \\
\text { design will be in accordance with ASME- } \\
\text { NQA-1-1994-IA. }\end{array}$ \\
\hline 3.5 Logistics & All & $\begin{array}{l}\text { Maintenance will be in accordance with } \\
\text { ALARA principles with equipment which is } \\
\text { difficult to reach or inaccessible to be } \\
\text { designed for long life. System design will use } \\
\text { readily available parts and components. } \\
\text { Installation of new equipment will not } \\
\text { comprise existing equipment or system } \\
\text { operating and safety requirements. }\end{array}$ \\
\hline 3.6 Personnel and Training & All & $\begin{array}{l}\text { Detailed design will be for personnel trained } \\
\text { in accordance with DOE Order } 5480.20 \text {. }\end{array}$ \\
\hline 3.7 Precedence & All & $\begin{array}{l}\text { A hierarchical relationship of regulatory } \\
\text { documents has been determined for use in } \\
\text { detailed design. }\end{array}$ \\
\hline 4.0 Quality Assurance Provisions & All & $\begin{array}{l}\text { Design will develop a Quality Assurance } \\
\text { Program Plan in accordance with NQA-1, } 10 \\
\text { CFR } 50 \text { and ISO } 9000 \text {. Detailed design will } \\
\text { provide inspection access for leaks, corrosion, } \\
\text { deterioration and other factors. }\end{array}$ \\
\hline
\end{tabular}




\title{
INITIAL SINGLE-SHELL TANK RETRIEVAL SYSTEM TRADE STUDY: RETRIEVAL FACILITY COOLING REQUIREMENTS
}

\author{
Review Copy
}

Prepared By:

LOS ALAMOS TECHNICAL ASSOCIATES, INC.

Richland, WA

Under Purchase Order TJJ-SBW-387700

November 1996 
Document Title: Initial Single-Shell Tank Retrieval System Trade Study:

Retrieval Facility Cooling Requirements

Approved By:

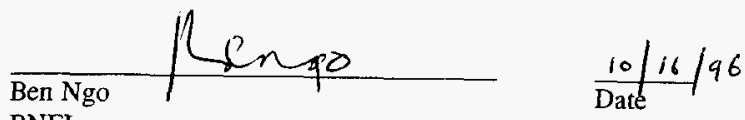

\section{BNFL}

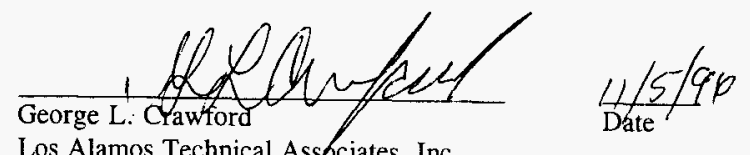

Los Alamos Technical Assbciates, Inc. 
November 6, 1996

This page left intentionally blank. 


\section{CONTENTS}

1.0 INTRODUCTION $\ldots \ldots \ldots \ldots \ldots \ldots \ldots \ldots \ldots \ldots \ldots \ldots \ldots \ldots \ldots \ldots \ldots \ldots$

2.0 CONSTRAINTS AND ASSUMPTIONS $\ldots \ldots \ldots \ldots \ldots \ldots \ldots \ldots$

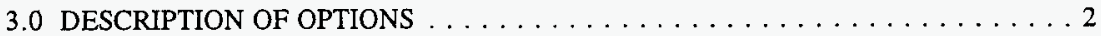

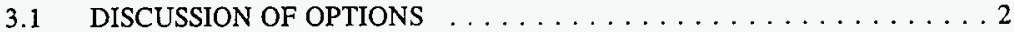

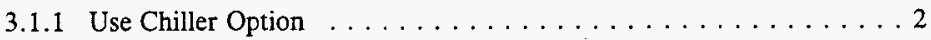

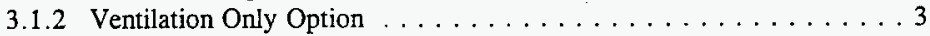

3.2 OVERALL SYSTEM DESCRIPTION $\ldots \ldots \ldots \ldots \ldots \ldots \ldots \ldots$

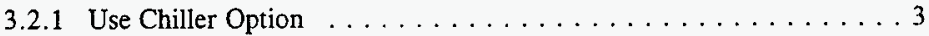

3.2 .2 Ventilation Only Option $\ldots \ldots \ldots \ldots \ldots \ldots \ldots \ldots$

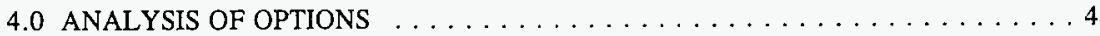

5.0 CONCLUSIONS AND RECOMMENDATIONS $\ldots \ldots \ldots \ldots \ldots \ldots$

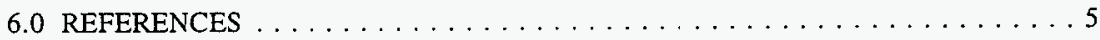

APPENDIX A HEAT REMOVAL CALCULATION $\ldots \ldots \ldots \ldots \ldots$ A-1

APPENDIX B INTAKE AIRFLOW CALCULATION

(NO CHILLER OPTION) $\ldots \ldots \ldots \ldots \ldots \ldots \ldots \ldots$ B-1

APPENDIX C REQUIRED AIRFLOWS CALCULATION ......... C-1

\section{LIST OF TERMS}

$\begin{array}{ll}\text { DST } & \text { Double-Shell Tank } \\ \text { HEME } & \text { High-Efficiency Mist Eliminator } \\ \text { HEMF } & \text { High-Efficiency Metal Filter } \\ \text { HEPA } & \text { High-Efficiency Particulate Air } \\ \text { HVAC } & \text { Heating, Ventilating, and Air Conditioning } \\ \text { ISSTRS } & \text { Initial Single-Shell Tank Retrieval System } \\ \text { SST } & \text { Single-Shell Tank } \\ \text { TAP } & \text { Total Airborne Pollution } \\ \text { VOC } & \text { Volatile Organic Compound }\end{array}$


This page left intentionally blank. 


\subsection{INTRODUCTION}

The Initial Single-Shell Tank Retrieval System (ISSTRS) consists of the equipment, hardware, procedures, and systems necessary to retrieve waste from four Hanford Site single-shell tanks (SSTs). High-level radioactive waste has been stored at the Hanford Site since the 1940's as a by-product of processing spent nuclear fuel. Waste volumes in the single-shell tanks vary as does the consistency of the waste (ranging from pumpable liquid, to sludge and hard salt cake). The overall objective of the ISSTRS Project is to design, fabricate, and install the retrieval systems, waste transfer lines, tank heating, ventilating, and air conditioning (HVAC) systems, and infrastructure necessary to begin waste retrieval operations in SSTs 241-A-102, AX-103, C-103, and C-105 for delivery to double-shell tank 241-AN-105. The conceptual design of the systems and equipment for ISSTRS is based upon existing Project W-320 (tank 241-C-106) waste retrieval system design.

The purpose of this study is to determine cooling requirements and hence, the need for a chiller in the HVAC system of the ISSTRS.

\subsection{CONSTRAINTS AND ASSUMPTIONS}

The temperatures of the ISSTRS SSTs and tank 241-AN-105 are not significantly different, hence there is no requirement to $\mathrm{cool}$ the waste prior to sluicing. While sluicing, the Waste Retrieval Sluicing System HVAC must be operating to perform the following functions:

- Maintain a negative pressure in the tank vapor space.

- Remove equipment-generated heat from the tank and dehumidify the recirculating air.

- Treat and then exhaust the offgas stream to the atmosphere through a stack.

- Reduce the formation of fog in the tank vapor space to improve visibility for the remote viewing camera.

- Provide continuous monitoring of offgas emissions. 


\subsection{DESCRIPTION OF OPTIONS}

There are two basic options for the HVAC design in order to comply with the above requirements. They are:

- Use a Chiller - This HVAC system is designed to recirculate air in the tank and uses the chiller to remove heat and dehumidify the recirculating vapor (see Appendixes $\mathrm{A}$ and $\mathrm{C}$ for the calculation to determine the chiller size).

- Ventilation Only - This HVAC system is designed to draw air into the tank to remove heat and moisture in the tank vapor space. The exhaust airflow would be sent through a filtration unit and then released to the atmosphere (see Appendixes $\mathrm{B}$ and $\mathrm{C}$ for the calculation of the required air quantity).

\subsection{DISCUSSION OF OPTIONS}

\subsubsection{Use Chiller Option}

For this option, it is assumed that the HVAC design would be the same as the Project W-320 design with the exception of the chiller size. The calculation to size the chiller for heat removal is included in Appendix A. The Microsoft Excel spreadsheet program is used to prepare this energy balance calculation. To determine the required recirculation air flow rate, a trial and error method was used and repeated until all energy flow into the tank was equal to all energy flow from the tank. The exhaust air flow rate is set equally to the assumed infiltration flow rate. All individual energy inputs and outputs are calculated as shown on spreadsheets. The chiller size is determined based upon the design air conditions leaving the tank at $95^{\circ} \mathrm{F} \mathrm{db}$ and $95^{\circ} \mathrm{F} \mathrm{wb}$, the air conditions exiting the recirculation condenser at $40{ }^{\circ} \mathrm{F}$ $\mathrm{db}$ and $40^{\circ} \mathrm{F}$ wb (May 1996), and the assumed minimum primary airflow requirement for DST 241-AN-105 of $500 \mathrm{scfm}$. This is assumed to be the same as the required airflow for tank 241-AY-102 (Conner 1996) and is required to remove energy inputs from radiation sources in tank 241-AY-102, energy added by the slurry pump, and energy added by the sluicing pump.

For fog removal, it is assumed that the amount of moisture need to be removed from the SST is the same as with Project W-320 and airflow required to remove fog is proportional to tank volume. The calculation to determine the required airflows and chiller size is included in Appendix C. 


\subsubsection{Ventilation Only Option}

The calculation to determine the required intake airflow for heat removal for the no chiller option is included in Appendix B. Again, the Microsoft Excel program is used to prepare this energy balance calculation. To determine the required intake airflow, a trial and error method was used and repeated until all energy flow into the tank was equal to energy flow from the tank.

For fog removal, it is assumed that the amount of moisture needed to be removed from the tank is the same as with Project W-320 and airflow required to remove fog is proportional to tank volume. The calculation to determine the required airflows is included in Appendix $C$.

\subsection{OVERALL SYSTEM DESCRIPTION}

\subsubsection{Use Chiller Option}

The HVAC system will remove and chill the SST vapors and recycle them back into the SST. A portion of the airflow will be sent through a high-efficiency mist eliminator (HEME), a high-efficiency metal filter (HEMF), two high-efficiency particulate air (HEPA) filters, and will be exhausted to atmosphere via a stack. About $1,090 \mathrm{scfm}$ will be drawn from tanks 241 C-103/C-105 and 2,200 scfm from tanks 241-A-102/AX-103, of which about 860 scfm for tanks $241-\mathrm{C}-103 / \mathrm{C}-105$ and $1,970 \mathrm{scfm}$ for tanks $241-\mathrm{A}-102 / \mathrm{AX}-103$ will be recycled back into the tanks and about $230 \mathrm{scfm}$ will be exhausted to atmosphere via a stack.

The recirculation system removes excess heat from the tank vapor space and dehumidifies the recirculating air. The recirculated air passes through a condenser to cool it from $95^{\circ} \mathrm{F}$ to 40 ${ }^{\circ} \mathrm{F}$ and condense moisture in the airstream. The condensate is returned to the tank. The air then passes through a heating coil to reheat it to $77^{\circ} \mathrm{F}$ and, hence, decrease the relative humidity of the airstream before it passes through the fan. This will reduce errosion of the fan and provide some fog suppression capability when returned to the tank.

The chiller skid contains an air-cooled chiller and a chilled water cooling system. The chilled water cooling system consists of a makeup storage tank, an air separator, circulation pumps, an expansion tank, and instruments for monitoring the closed-loop cooling system. The circulating fluid (chilled water) is a $46 \%$ propylene glycol/water solution, and is recirculated between the chiller and the condenser.

The exhaust skid directs offgases through a heating coil, volatile organic compound (VOC) adsorber (if required), two HEPA filters, and a fan. This skid also includes a stack and exhaust monitoring instruments. The exhaust ventilation system controls the pressure of the tank vapor space. 


\subsubsection{Ventilation Only Option}

About $1,170 \mathrm{sefm}$ of air from infiltration and system intake will be drawn into tanks 241-C$103 / \mathrm{C}-105$ and about $2,208 \mathrm{scfm}$ will be drawn into tanks $241-\mathrm{A}-102 / \mathrm{AX}-103$ to remove heat and moisture. It is assumed that the air enters the tank at summer design temperature $101{ }^{\circ} \mathrm{F}$ $\mathrm{db}, 68^{\circ} \mathrm{F}$ wb (KEH 1995). All airflow will be sent through a HEME, a HEMF, a heating coil, VOC adsorber (if required), two HEPA filters, and is exhausted to atmosphere via a stack. The exhaust ventilation system will control the pressure of the tank vapor space.

\subsection{ANALYSIS OF OPTIONS}

The Use Chiller Option and Ventilation Only Option each satisfy the heat and fog removal requirements for ISSTRS. However, the discharged radioactive offgas airflow to the atmosphere with the Ventilation Only Option will be very high compared to the Use Chiller Option. With the Use Chiller Option, the discharged radioactive offgas airflow is limited due to the infiltration flowrate limit of $230 \mathrm{scfm}$. The Ventilation Only Option discharged offgas airflows are approximately $1,170 \mathrm{scfm}$ and 2,208 scfm for tanks $241-\mathrm{C}-103 / \mathrm{C}-105$ and 241 -A$102 / \mathrm{AX}-103$, respectively. Also, under the Use Chiller Option, the condenser will cool the airstream to $40^{\circ} \mathrm{F}$. This will remove most of the moisture in the airstream and significant quantities of contaminants (McGrew 1994). An estimate of the Toxic Air Pollutant (TAP) emissions from the ISSTRS Project was performed by Stan Hill (Hill 1996). The assessment showed that with no condenser the Small Quantity Emission rate will be exceeded for dioxins/furans from tanks 241-C-103, C-105 and AX-103 with ventilation airflow as low as $270 \mathrm{cfm}$.

\subsection{CONCLUSIONS AND RECOMMENDATIONS}

The Use Chiller Option uses a chiller is used to remove heat and dehumidify the recirculating tank vapor. The chiller is estimated at about 40 tons. The airflow required to remove fog from tanks 241-A-102/AX-103 is estimated to be about 2,200 scfm, of which about 1,970 $\mathrm{scfm}$ will be recycled back into the tank and about $230 \mathrm{scfm}$ will be exhausted to the atmosphere via a stack. The airflow required to remove fog from tanks $241-\mathrm{C}-103 / \mathrm{C}-105$ is the same as for the Project W-320. The intake and infiltration airflow required by the Ventilation Only Option to remove heat and fog from an SST during the sluicing operation is estimated to be about $1,170 \mathrm{scfm}$ for tanks $241-\mathrm{C}-103 / \mathrm{C}-105,2,208 \mathrm{scfm}$ for tanks $241-\mathrm{A}$ $102 / \mathrm{AX}-103$ and all of the airflow will be exhausted to the atmosphere via a stack. 
If the HVAC system includes a chiller and keeps the exhaust airflow down below $270 \mathrm{cfm}$, the need for TAP removal equipment will be minimized and may not be needed at all. If the Ventilation Only Option were adopted, there would need to be TAP removal equipment for dioxins and furans and possibly many other TAPs. Also, because of the higher flow rates this equipment would be very large and expensive.

In conclusion, it is recommended that the ISSTRS HVAC design includes a chiller and a ventilation airflow proportional to the 241-C-106 airflow, based on tank volume.

\subsection{REFERENCES}

Conner, J. C., 1996,, An Analysis of Energy and Temperature Effects for Tank 24I-AY-102, WHC-SD-W320-TI-003, Rev. 0, Westinghouse Hanford Company, Richland, Washington.

Himmelblau, D. M., 1982, Basic Principles and Calculations in Chemical Engineering, Prentice-Hall, New-Yersey .

KEH, 1995, "Design Climate Data for Hanford Site," A/E Standard - Mechanical, GH-CLIM-01, Rev. 0, ICF Kaiser Hanford Company, Richland, Washington.

Hill, S., 1996, "Estimated Air Emissions Associated with Sluicing Tanks 241-A-102, AX-103, C-103 and C105," Internal Memo 01872-96-017, Westinghouse Hanford Company, Richland, Washington.

May, T. H., 1996, Tank 241-C-106 Waste Retrieval Sluicing Operation Manual, WHC-SDW320-TI-004, Rev. 0, Westinghouse Hanford Company, Richland, Washington.

McGrew, D. L., 1994, Double Shell Tank Ventilation Upgrades: Engineering Study For Project W-314, WHC-SD-WM-ES-284, Rev. 0, Westinghouse Hanford Company, Richland, Washington. 


\section{APPENDIX A}


This page left intentionally blank. 


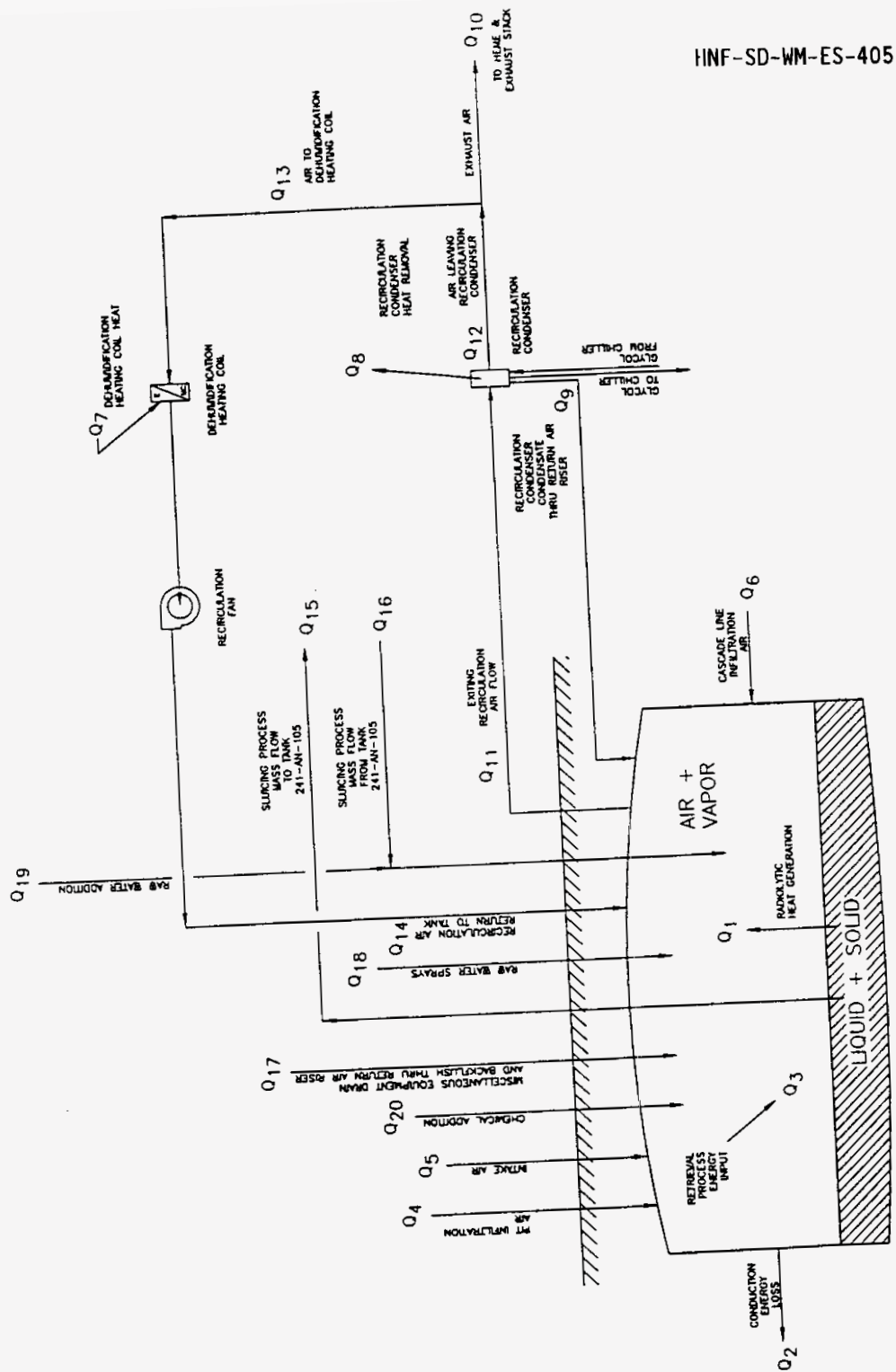

Rev. 0 


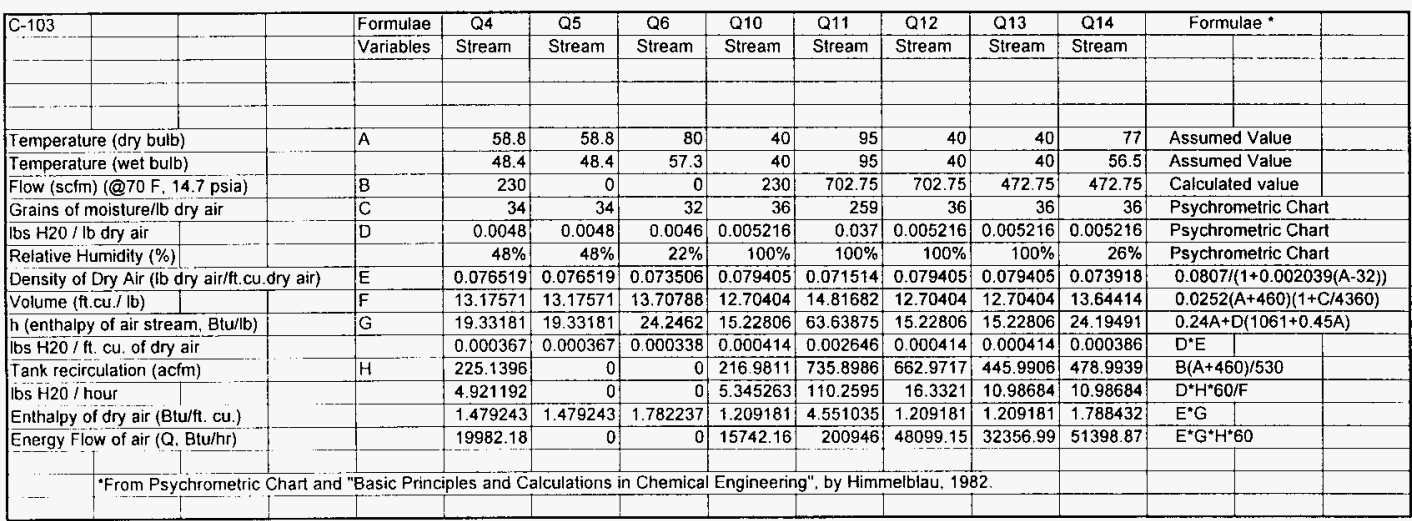




\begin{tabular}{|c|c|c|c|c|c|c|c|c|}
\hline$C-103$ & & & & & & & 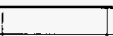 & \\
\hline ENER & ALCULATI & ONS: & & & & & & \\
\hline & & & & & & & & \\
\hline & & & & & & & & \\
\hline RADIC & IC HEAT TH & RANSFER ( & (Energy Flo & ow Q1 Btu/h & & $Q 1=$ & 47400 & Btu/hr \\
\hline Q1 is $i$ & ded radiolyt & ic heat trans & sfer for tank & $\mathrm{kC}$ - $103(28$ & $300 \mathrm{btu} / \mathrm{hr})$ & and $19100 \mathrm{t}$ & btu/hr for he & eat gain \\
\hline from $f$ & otor of recir & culation fan. & & & & & & \\
\hline & & & & & & & & \\
\hline HEAT & NSFER CO & NDUCTION & $\checkmark$ (Energy $F$ & Flow Q2) & & & & \\
\hline & & & & & & & & \\
\hline Tank & nts Temp. & & $Q$ conducti & $\operatorname{tion}(\mathrm{Q} 2)$ & & & & \\
\hline (See & imptions) & & 12000 & Btu/hr & & & & \\
\hline & & & & & & & & \\
\hline & & & & & & & & \\
\hline RETR & LPROCES & S ENERGY & INPUT (Er & nergy Flow & Q3 Btu/hr) & & & \\
\hline & & & & & & & & \\
\hline & Sluicing de & sign flowrate & & & & 350 & gpm & \\
\hline & One inch $n$ & ozzle exiting & g velocity: & & & 8547 & $\mathrm{fpm}(143 \mathrm{fp}$ & \\
\hline & Specific gre & avity & & & & 1.12 & & \\
\hline & Density of $y$ & water at 77 & & & & 62.23 & $1 \mathrm{bm} / \mathrm{cu} . \mathrm{ft}$ & \\
\hline & Density of & sluicing fluid & & & & 69.7 & $\mathrm{lbm} / \mathrm{cu} . \mathrm{ft}$ & \\
\hline & Volumetric & flow rate of & fluid: & & & 46.79 & $\mathrm{cu} . \mathrm{ft} . / \mathrm{min}$ & \\
\hline & Mass flow & rate: & & & & 3261 & $\mathrm{lbm} / \mathrm{min}$ & \\
\hline & Power (Kin & etic energy/ & (time) $=0.5$ & $m v^{\wedge} 2$ & & 79867 & Btu/hr & \\
\hline & & & & & & & & \\
\hline & Submersib & le Slurry pur & $\mathrm{mp}(4 \mathrm{OHP})$ & & & 12600 & Btu/hr & \\
\hline & & & & & & & & \\
\hline Q3 \& S & $r$ kinetic ent & ergy \& Subn & mersible Ŝl & urry pump e & energy): & 92467 & Btu/hr & \\
\hline & & & & & & & & \\
\hline & & & & & & & & \\
\hline HEAT & RECIRCUI & LATION CO & NDENSAT & TE (Q9) & & & & \\
\hline $\mathrm{H} 20 \mathrm{C}$ & ensing $=$ & \begin{tabular}{|c|}
93.92738 \\
\end{tabular} & lbs/hr & (from $95 \mathrm{~F}$ & to $40 \mathrm{~F}$ ) & & & \\
\hline Enthal & condensat & & 18.11 & Btu/lb & F) & & & \\
\hline$Q 9=1$ & Condensing & x Enthapy & of condens & sate & & & & \\
\hline$Q 9=$ & 1701.025 & Btu/hr & & & & & & \\
\hline & & & & & & & & \\
\hline & & & & & & & & \\
\hline HEAT & DEHUMID & IFICATION & COIL (Q7) & & & & & \\
\hline$Q 7=C$ & Q13 & & & & & & & \\
\hline$Q 7=$ & 19041.88 & Btu/hr & & & & & & \\
\hline & & & & & & & & \\
\hline & & & & & & & & \\
\hline HEAT & RECIRCU & LATION CO & ONDENSER & २(Q8): & $Q 8=011-$ & $Q 12-Q 9$ & & \\
\hline Q8= & 151145.8 & Btu/hr & & & & & & \\
\hline & & & & & & & & \\
\hline & & & & & & & & \\
\hline & & & & & & & & \\
\hline & & SUMMARY & OF ENER & GY FLOWS & & & & \\
\hline & & & & & & & & \\
\hline & & Energy Flov & & Btu/hr & & & & \\
\hline & & Q1 & & 47400 & & & & \\
\hline & & $\overline{Q 2}$ & & 12000 & & & & \\
\hline & & Q3 & & 92467 & & & & \\
\hline & & Q4 & & 19982.18 & & & & \\
\hline & & Q5 & & 0 & & & i & \\
\hline
\end{tabular}




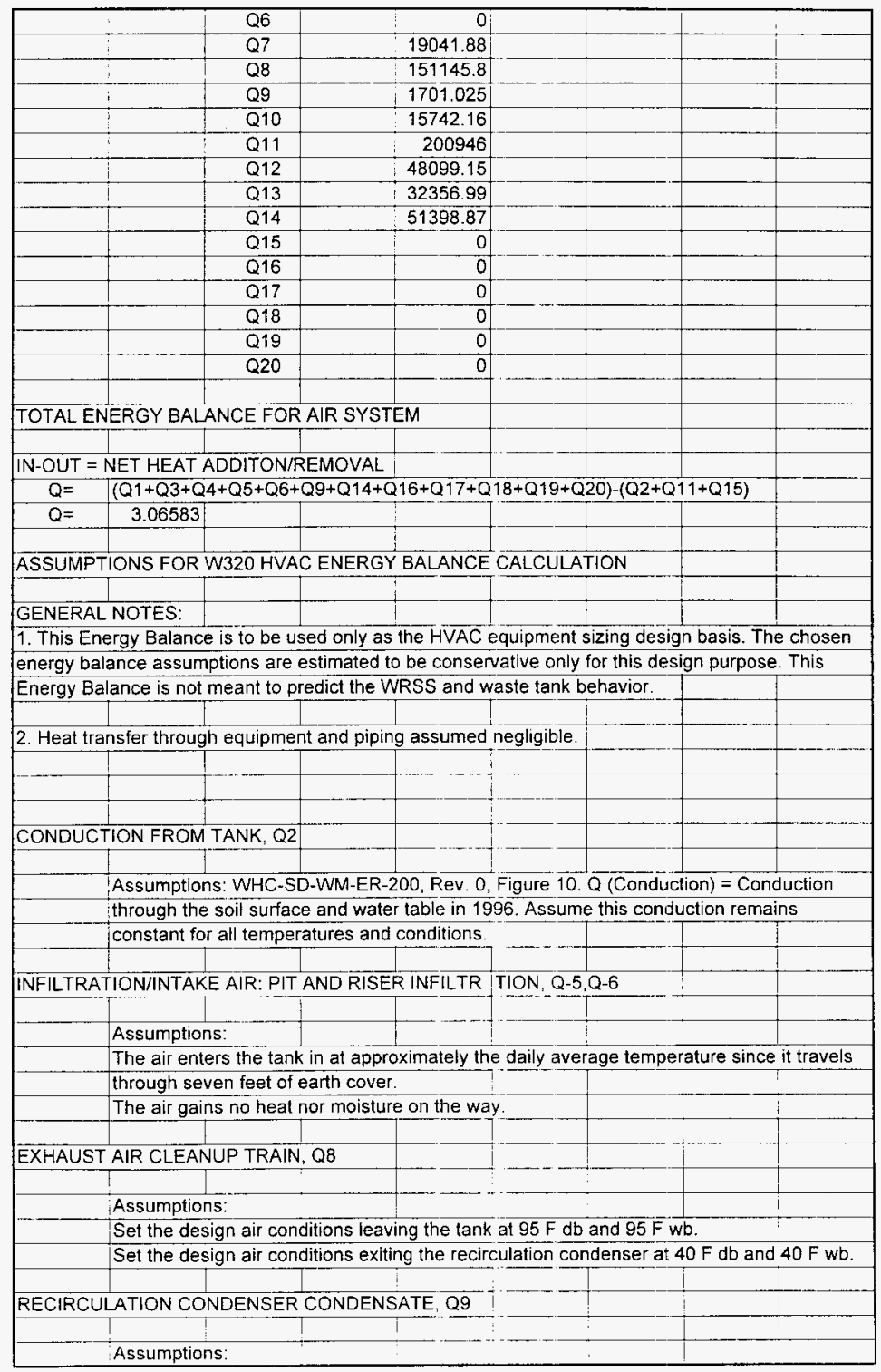




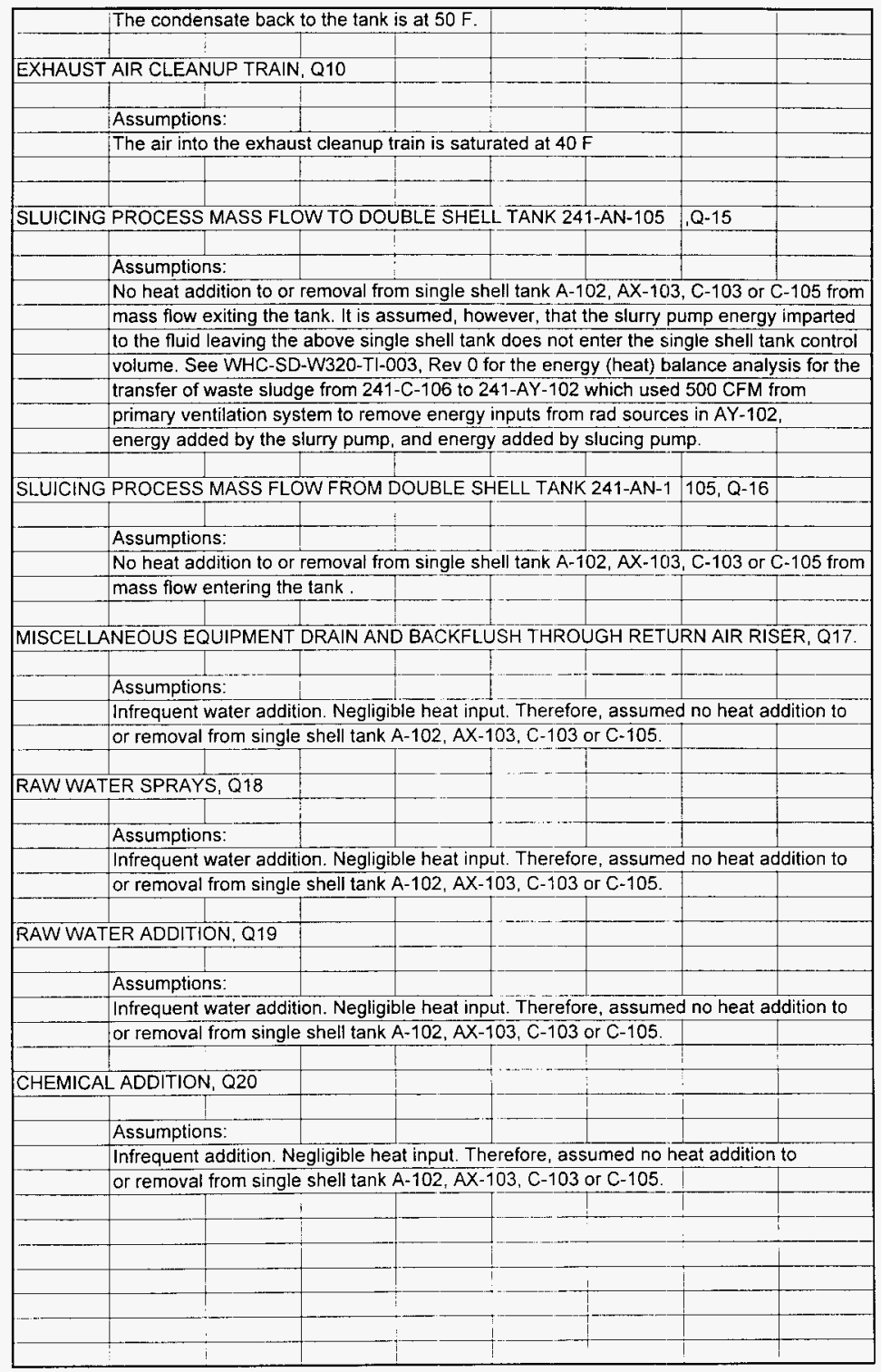




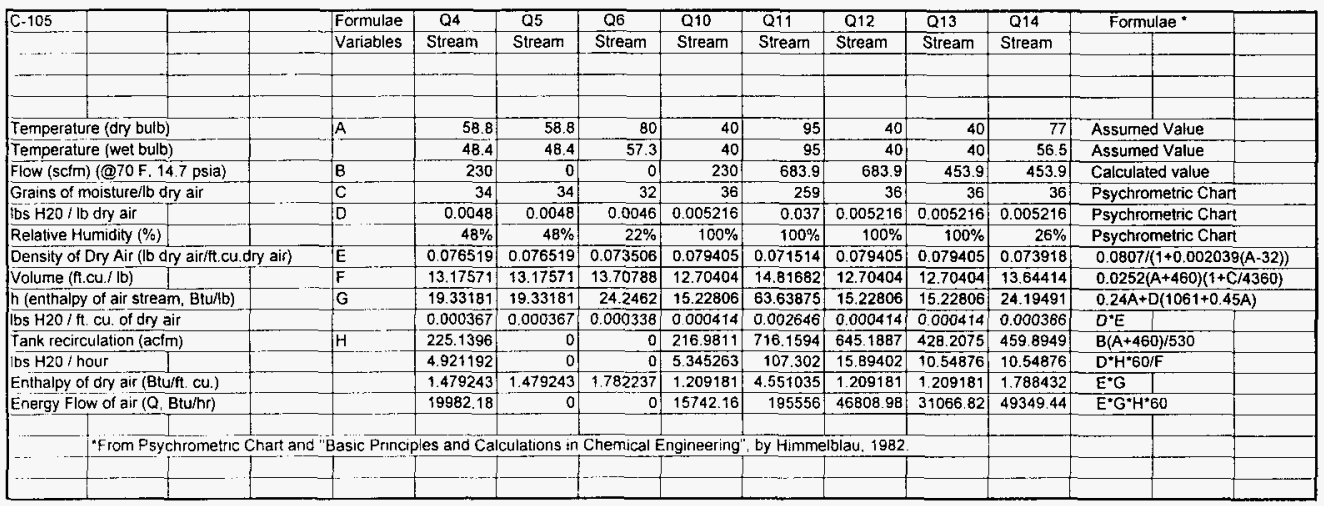




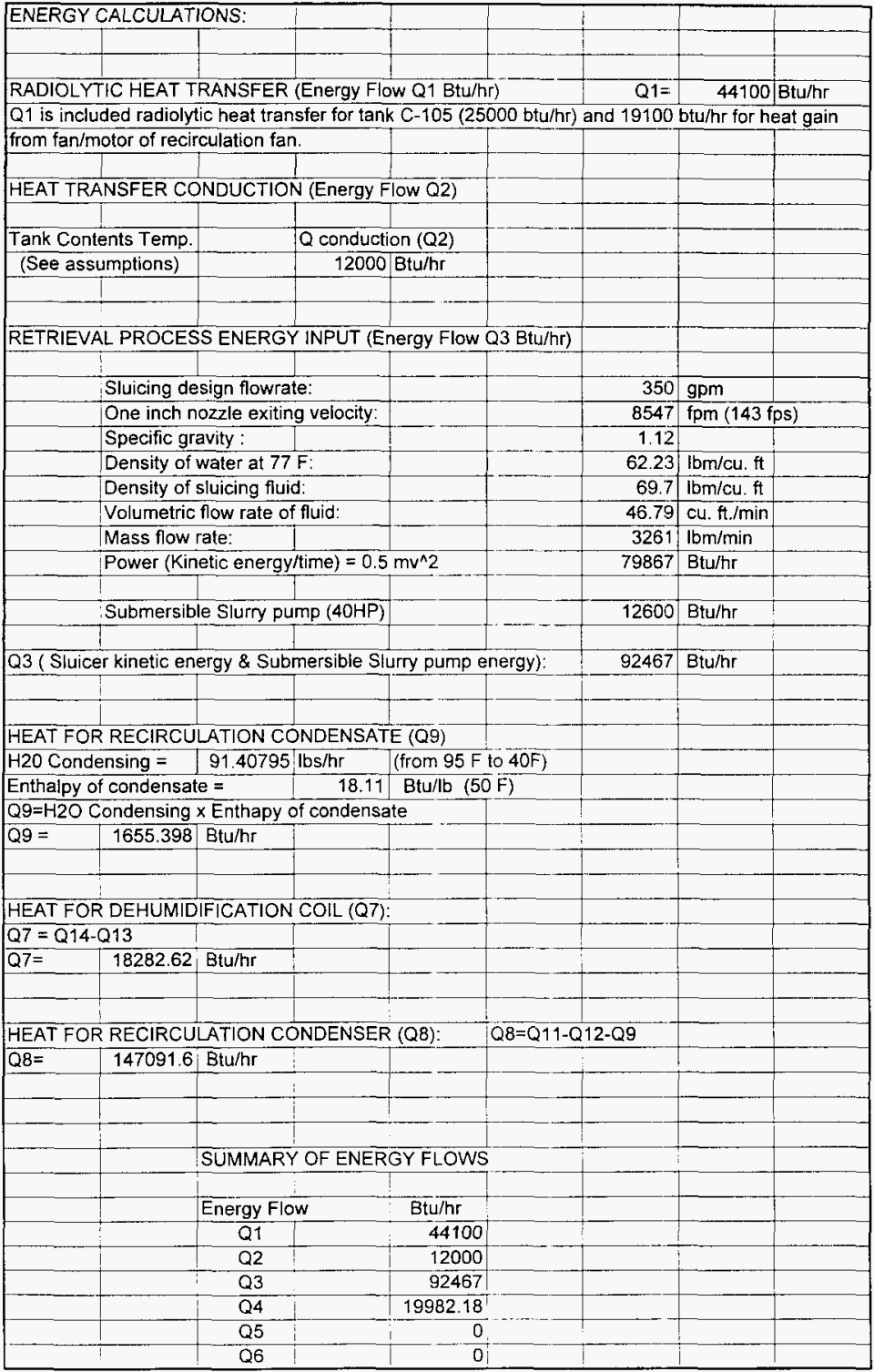


Rev. 0

\begin{tabular}{|c|c|c|c|c|c|}
\hline & & Q7 & 18282.62 & 1 & \\
\hline & & Q8 & 147091.6 & & \\
\hline & & Q9 & 1655.398 & & \\
\hline & & Q10 & 15742.16 & & \\
\hline & & Q11 & 195556 & & \\
\hline & & Q12 & 46808.98 & & \\
\hline & & Q13 & 31066.82 & & \\
\hline & & Q14 & 49349.44 & & \\
\hline & & Q15 & 0 & & \\
\hline & & Q16 & 0 & & \\
\hline & & $\overline{Q 17}$ & 0 & & \\
\hline & & Q18 & 0 & & \\
\hline & & Q19 & 0 & & \\
\hline & & Q20 & 0 & & \\
\hline \multicolumn{6}{|c|}{ TOTAL ENERGY BALANCE FOR AIR SYSTEM } \\
\hline & & & & & \\
\hline \multicolumn{6}{|c|}{ IN-OUT = NET HEAT ADDITON/REMOVAL } \\
\hline $\mathrm{Q}=$ & \multicolumn{4}{|c|}{$(\mathrm{Q} 1+\mathrm{Q} 3+\mathrm{Q} 4+\mathrm{Q} 5+\mathrm{Q} 6+\mathrm{Q} 9+\mathrm{Q} 14+\mathrm{Q} 16+\mathrm{Q} 17+\mathrm{Q} 18+\mathrm{Q} 19+\mathrm{Q} 20)-(\mathrm{Q} 2+\mathrm{Q} 11+\mathrm{Q} 15)$} & \\
\hline $\mathrm{Q}=$ & -1.97866 & & & & \\
\hline & & & & & \\
\hline
\end{tabular}




\begin{tabular}{|c|c|c|c|c|c|c|c|c|c|c|c|c|c|c|c|}
\hline $\mathrm{A}-102$ & & & & Formulae & Q4 & Q5 & Q6 & Q10 & Q11 & Q12 & Q13 & Q14 & Formu & dae" & \\
\hline & & & & Variables & Stream & Stream & Stream & Stream & Stream & Stream & Stream & Stream & & & \\
\hline & & & & & & & & & & & & & & & \\
\hline & & & & & & & & & & & & & & & \\
\hline & & & & & & & & & & & & & & & \\
\hline Temper & (dry bulb) & & & A & 58.8 & 58.8 & 80 & 40 & 95 : & 40 & 40 & 77 & Assumed & d Value & \\
\hline Temper & re (wet bulb & & & & $4 \overline{8} .4$ & 48.4 & 57.3 & 40 & 95 & 40 & 40 & 56.5 & Ássumed & d Value & \\
\hline Flow (so & (@70 F. 1 & $4.7 \mathrm{psia}$ & & $B$ & 230 & 0 & 0 & 230 & 557.9 & 557.9 & 327.9 & 327.9 & Calculate & ed value & \\
\hline Grains O & oisture/lb d & dry air & & $\underline{C}$ & 34 & 34 & 32 & 36 & 259 & 36 & 36 & 36 & Psychron & metric Cl & \\
\hline bs $\mathrm{H} 2 \mathrm{O}$ & dry air & & & $\bar{D}$ & 0.0048 & 0.0048 & 0.0046 & 0.005216 & 0.037 & 0.005216 & 0.005216 & 0.005216 & Psychron & metric C & \\
\hline Relative & umidity (\%) & & & & $48 \%$ & $48 \%$ & $22 \%$ & $100 \%$ & $100 \%$ & $100 \%$ & $100 \%$ & $26 \%$ & Psychror & metric C & \\
\hline Density & Dry Air (lb d & dry air/ft.cu. & dry air) & $E$ & 0.076519 & 0.076519 & 0.073506 & 0.079405 & 0.071514 & 0.079405 & 0.079405 & 0.073918 & $0.0807 / 1$ & $(1+0.002$ & $39(A-32))$ \\
\hline volume & $\mathrm{cu} / / \mathrm{lb})$ & & & $F$ & 13.17571 & 13.17571 & 13.70788 & 12.70404 & 14.81682 & 12.70404 & 12.70404 & 13.64414 & $0.0252(f$ & $A+460)($ & $\mathrm{C} / 4360)$ \\
\hline h (entha & of air strea & $\mathrm{am}, \mathrm{Btu} / \mathrm{hb})$ & & $G$ & $\overline{19.33} 181$ & 19.33181 & 24.2462 & 15.22806 & 63.63875 & 15.22806 & 15.22806 & 24.19491 & $0.24 A+D$ & $\mathrm{D}(1061+$ & 15A) \\
\hline Ibs $\mathrm{H} 20$ & cu. of dry & & & & 0.000367 & 0.000367 & 0.000338 & 0.000414 & 0.002646 & 0.000414 & 0.000414 & 0.000386 & $D^{*} E$ & & \\
\hline Tank re & ulation (acf & & & $\mathrm{H}$ & 225.1396 & 0 & 0 & 216.9811 & 584.216 & 526.3208 & 309.3396 & 332.2308 & $B(A+460$ & $0) / 530$ & \\
\hline lbs $\mathrm{H} 20$ & & & & & 4.921192 & 0 & 0 & 5.345263 & 87.53293 & 12.96575 & 7.620486 & 7.620486 & $\mathrm{D}^{*} \mathrm{H}^{*} 60 /$ & & \\
\hline Enthalp & dry air (Btu & u/tt cu. & & & 1.479243 & 1.479243 & 1.782237 & 1.209181 & 4.551035 & 1.209181 & 1.209181 & 1.788432 & $E^{*} G$ & & \\
\hline Energy & $w$ of air $(Q$. & Btu/hr) & & & 19982.18 & 0 & 0 & 15742.16 & 159527.3 & 38185.01 & 22442.85 & 35650.32 & $\mathrm{E}^{*} \mathrm{G}^{*} \mathrm{H}^{*} \mathrm{E}$ & & \\
\hline & & & & & & & & & & & & & & & \\
\hline & From Psy & chrometric & art a & Basic Pri & les and $\mathrm{Ca}$ & culations in & nChemical & Engineer & g", by Him & nelblau, 198 & & & & & \\
\hline
\end{tabular}




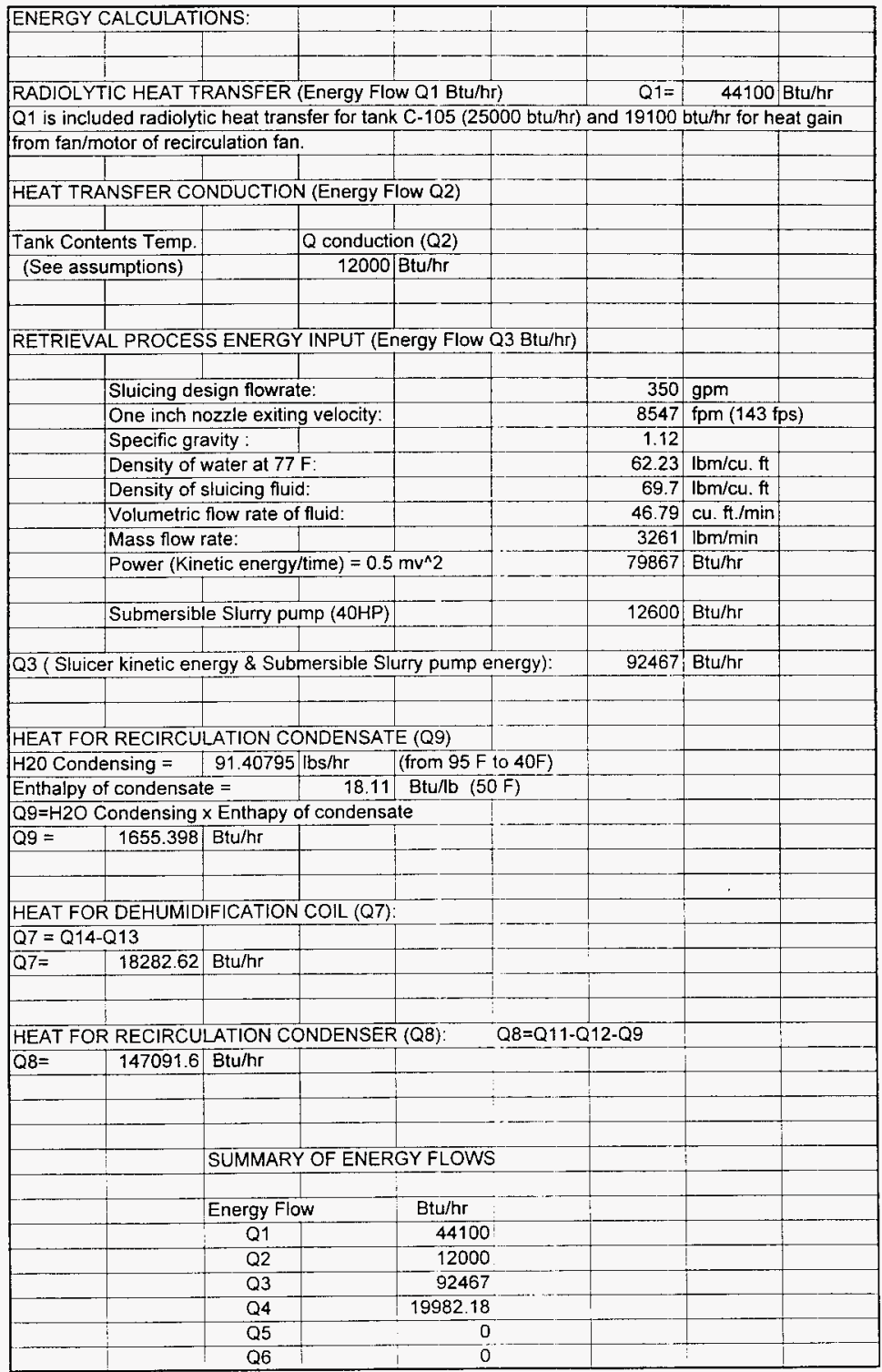




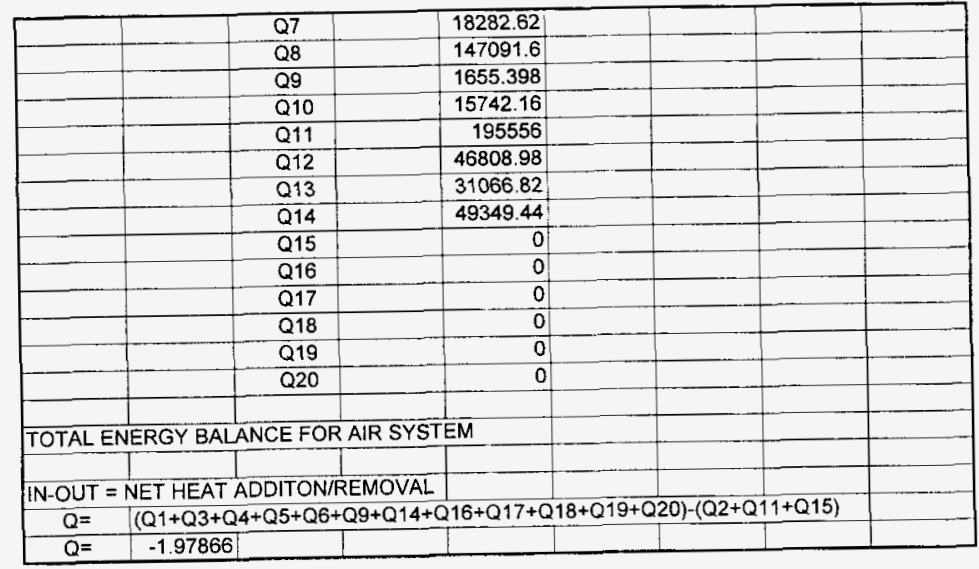




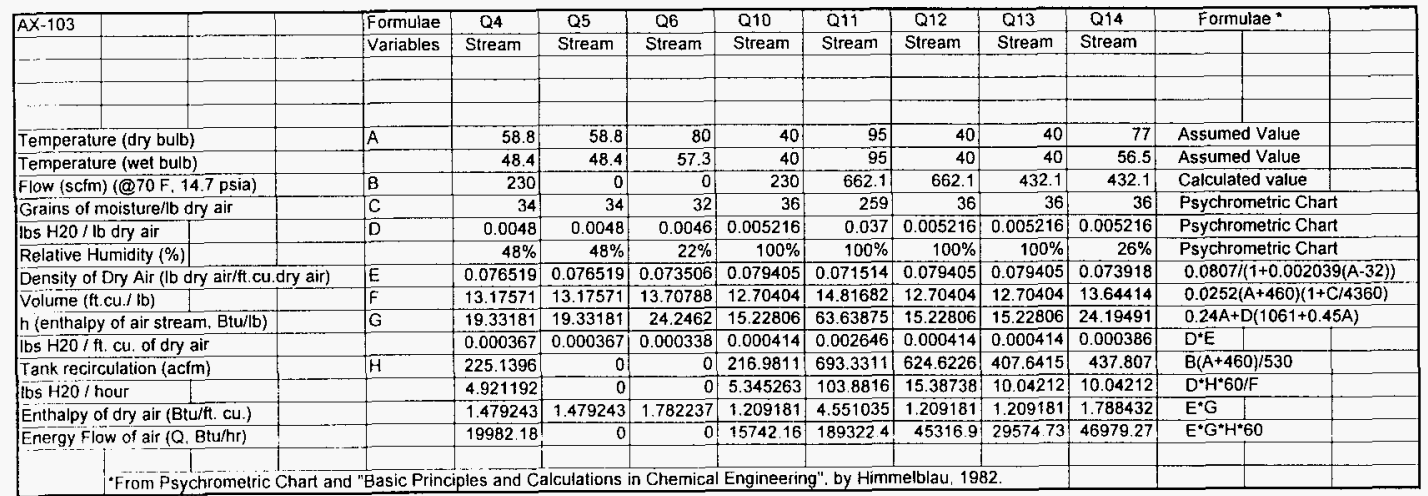




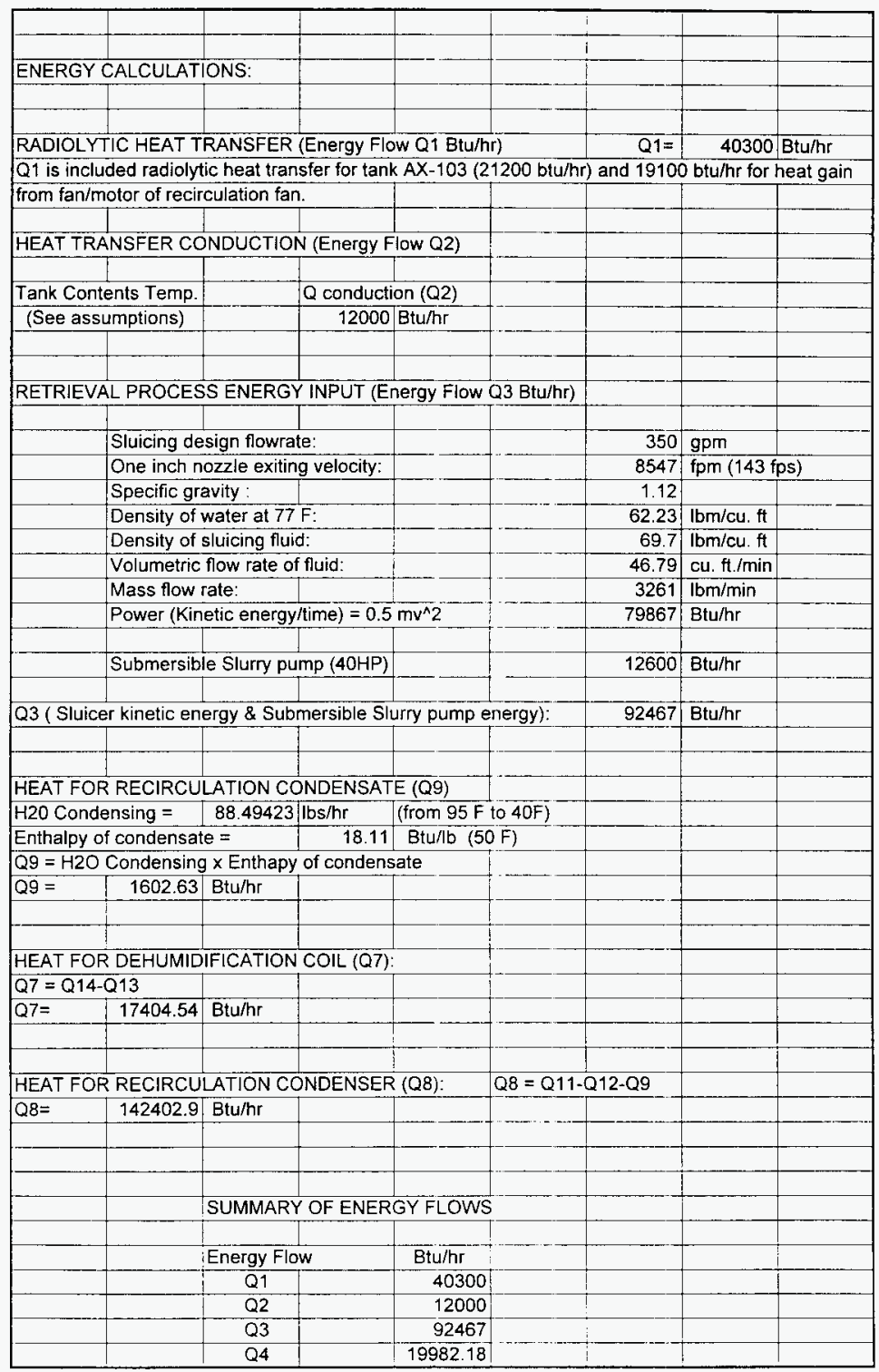




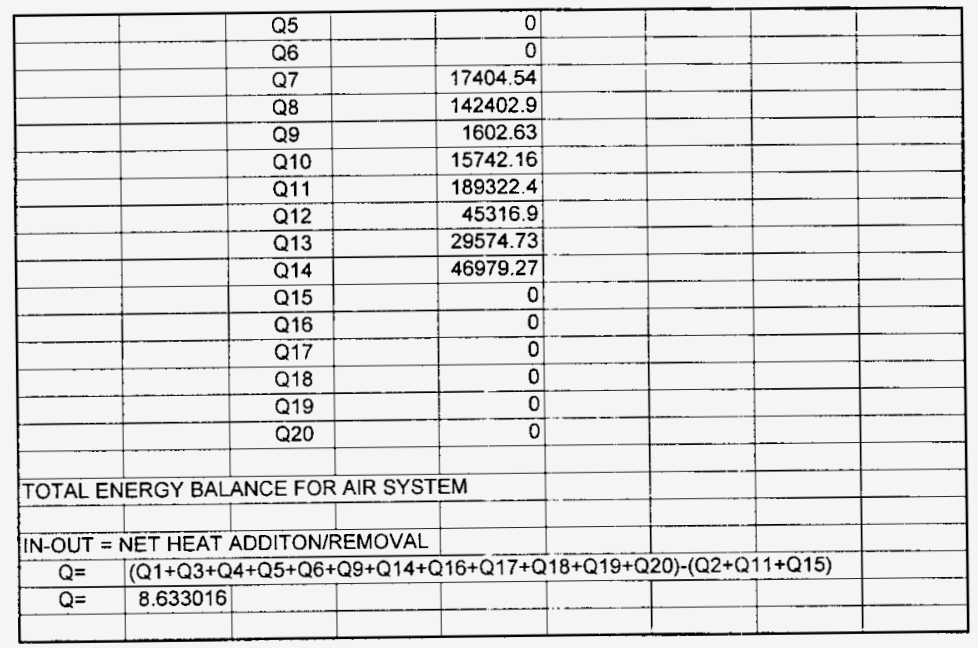


HNF-SD-WM-ES-405 Rev. 0

November 6, 1996

\section{APPENDIX B}


HNF-SD-WM-ES-405 Rev. 0

November 6, 1996

This page left intentionally blank. 


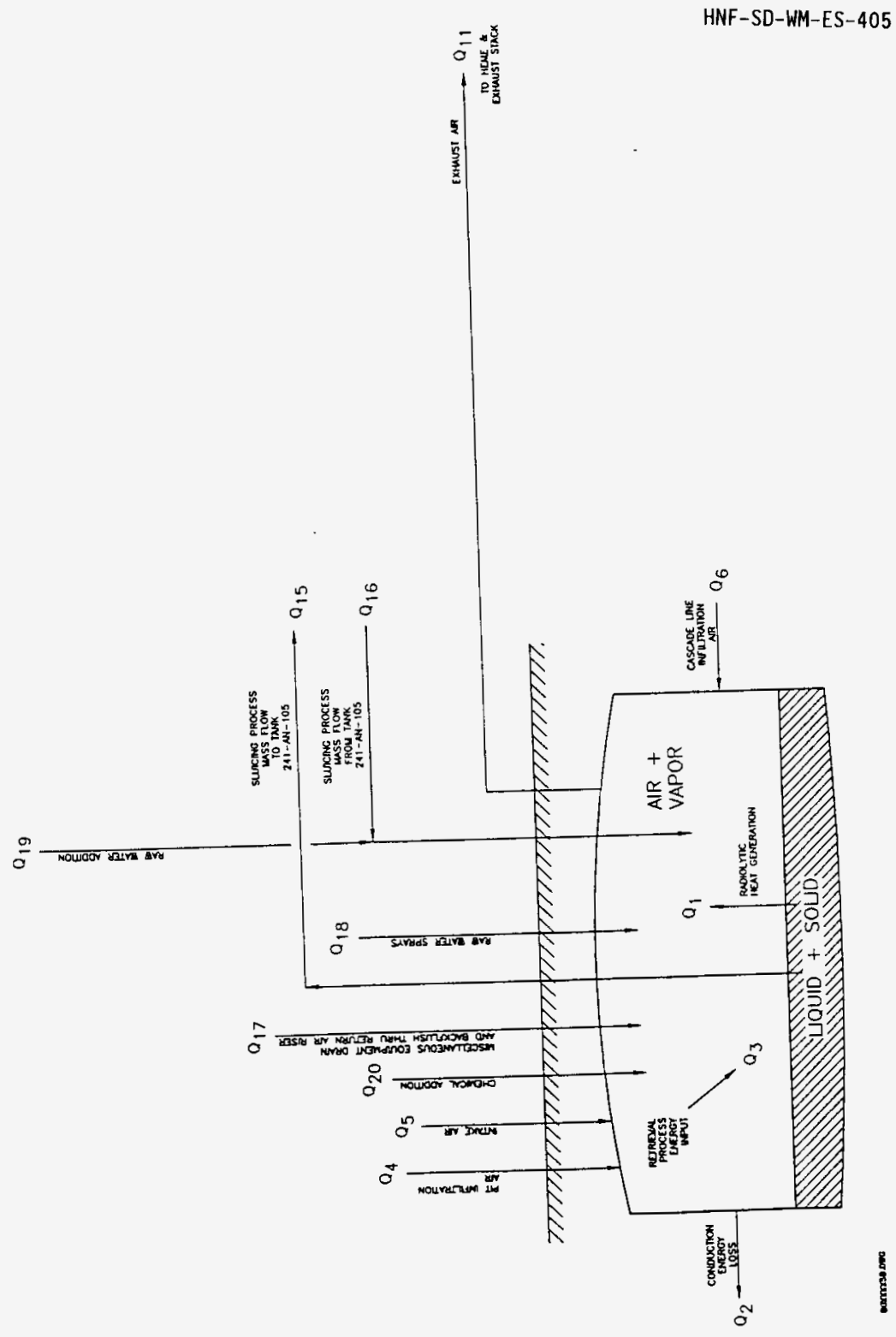

B. $3+$ 


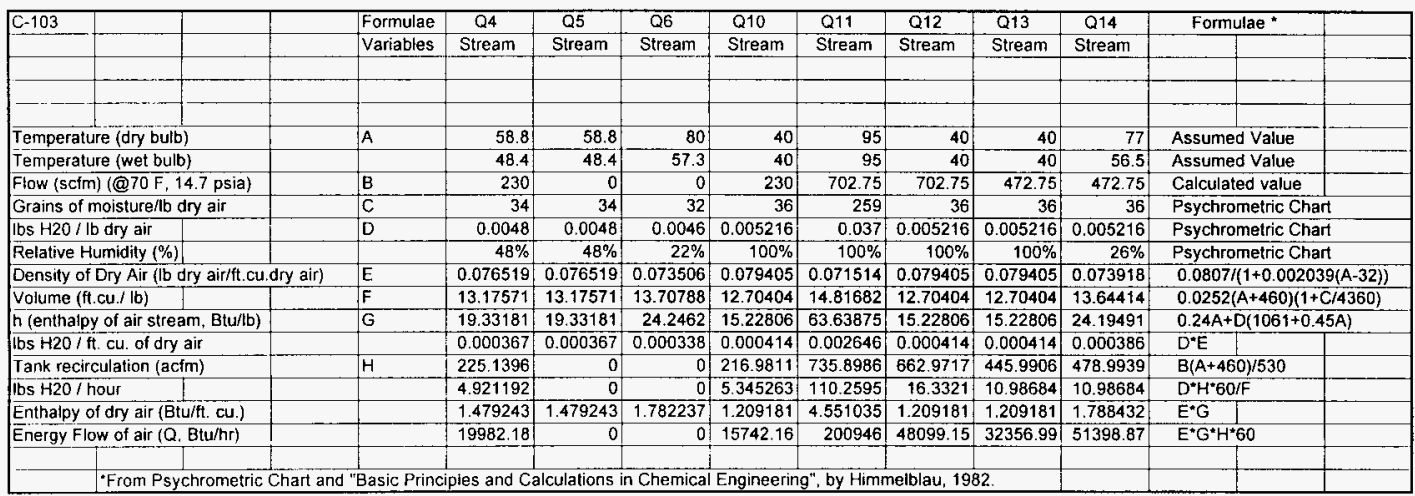




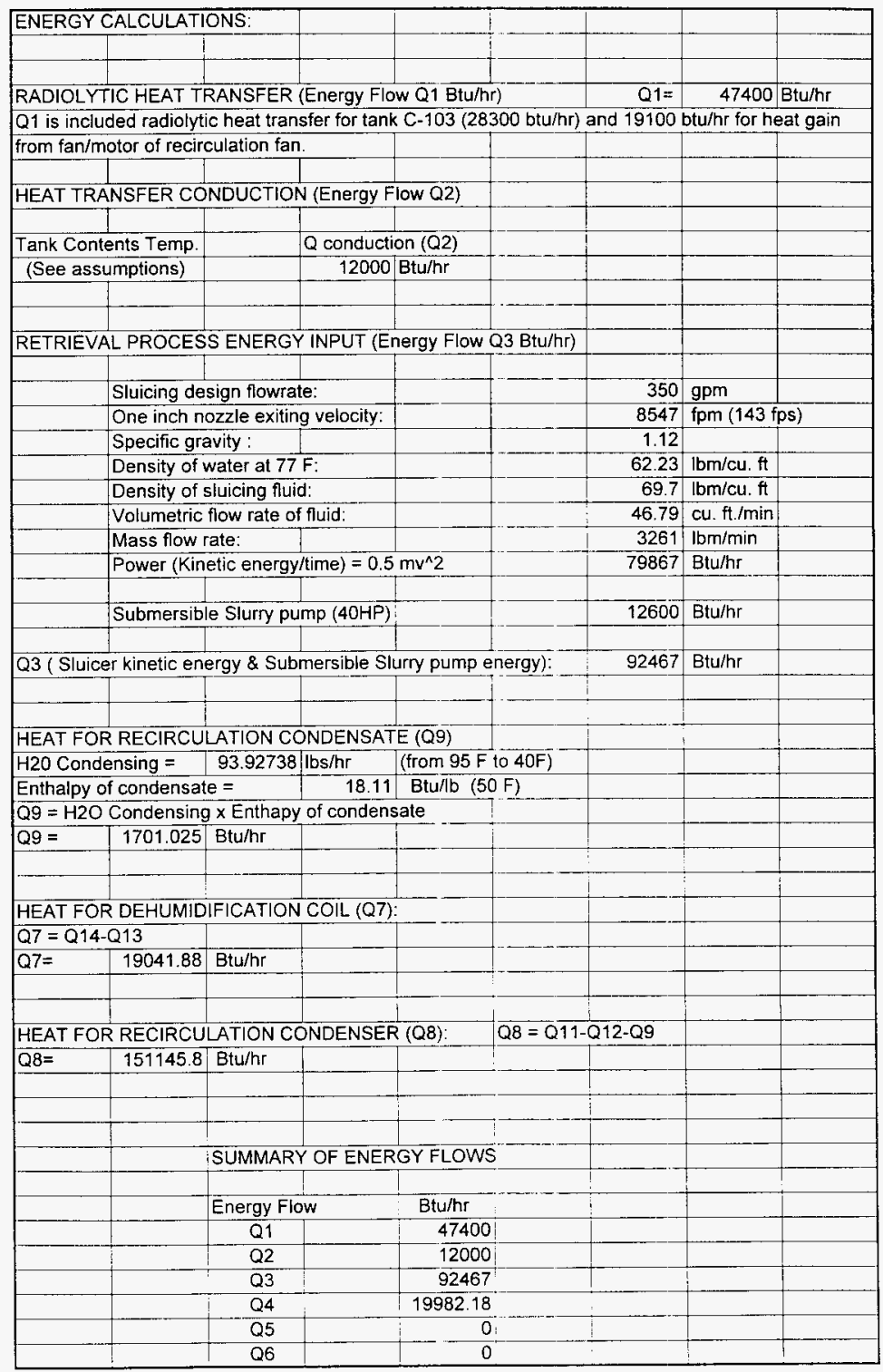


Rev. 0

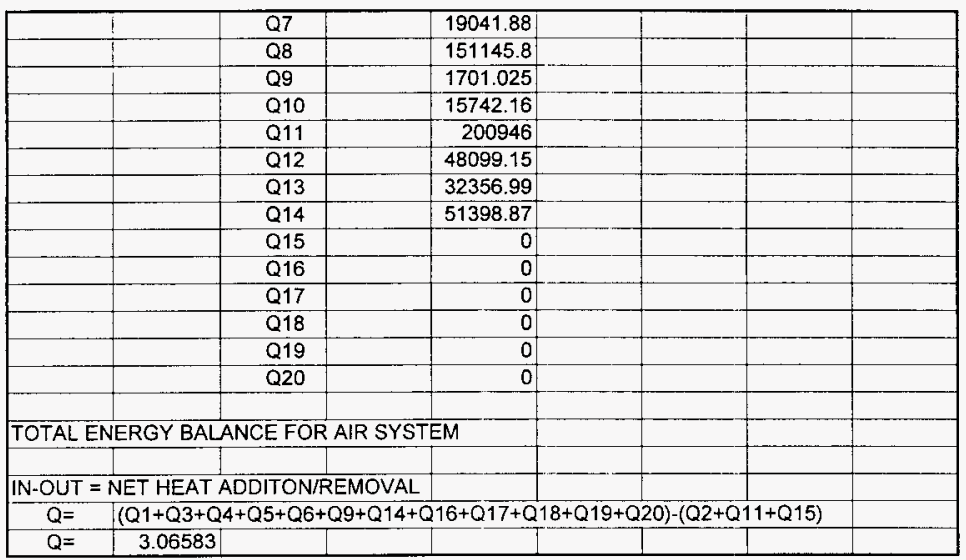




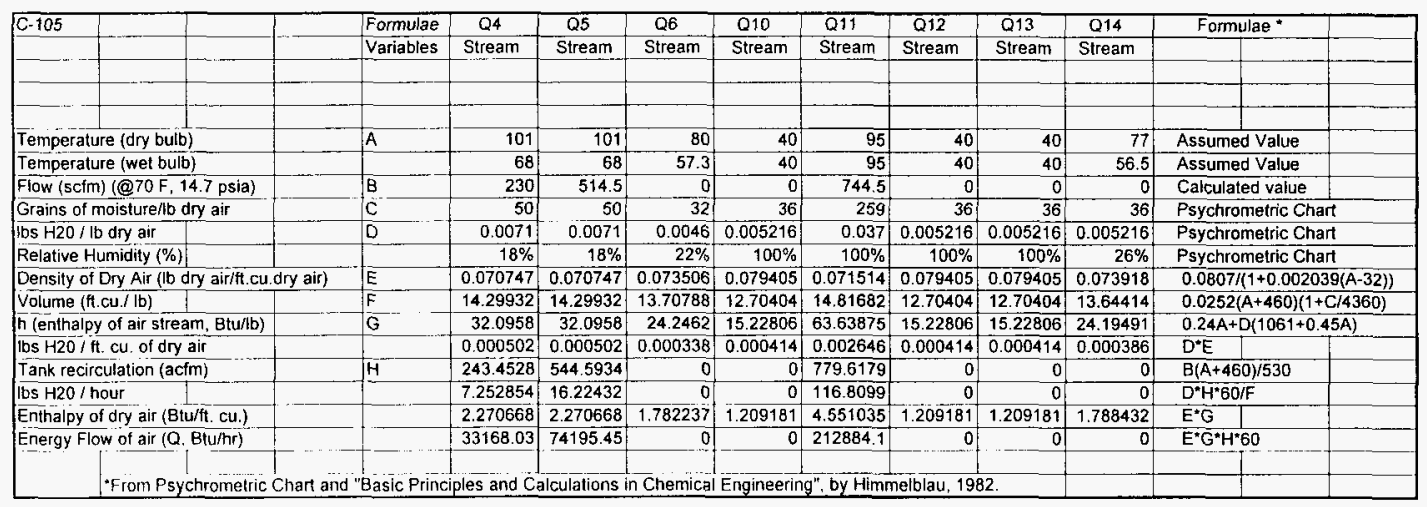




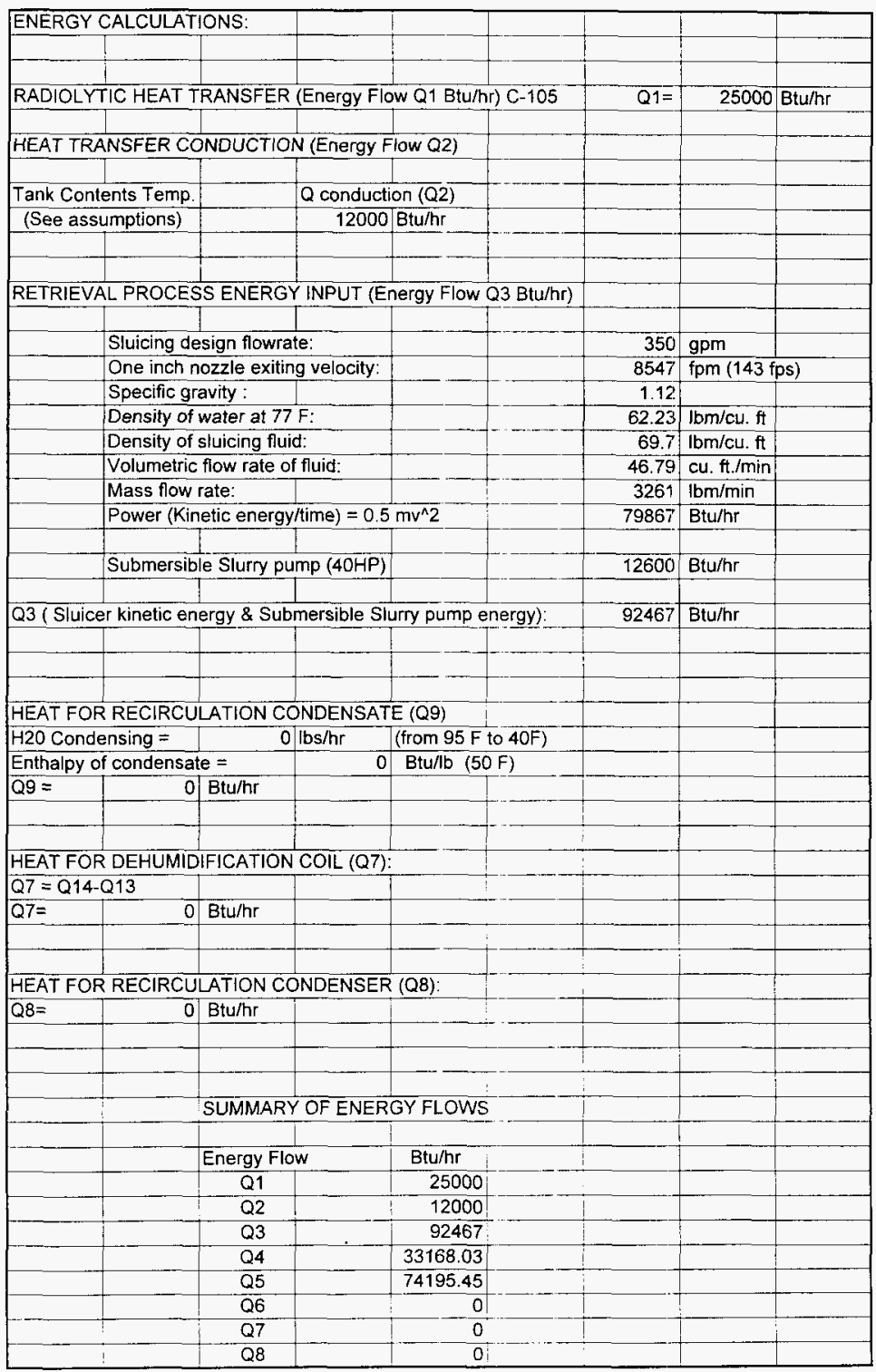




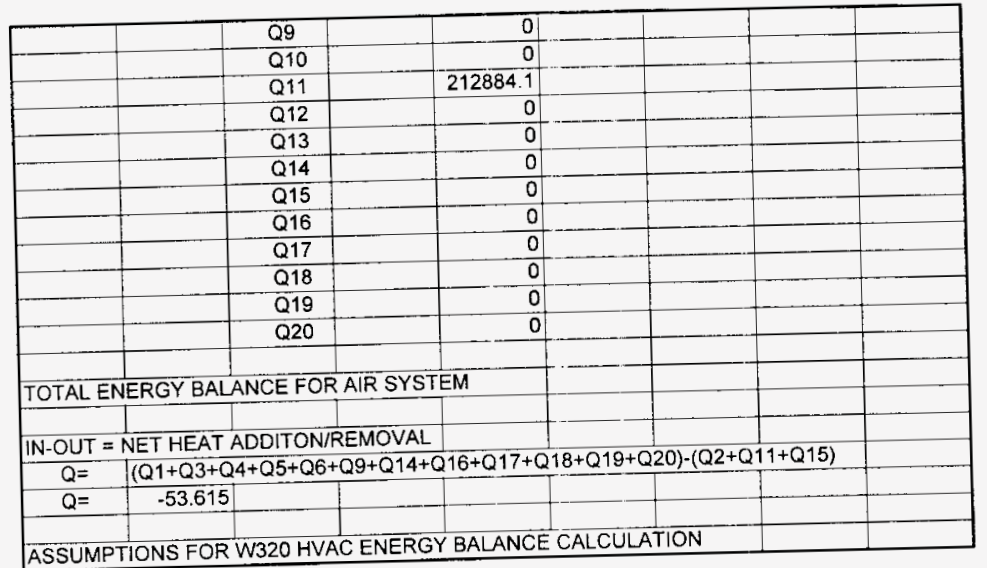




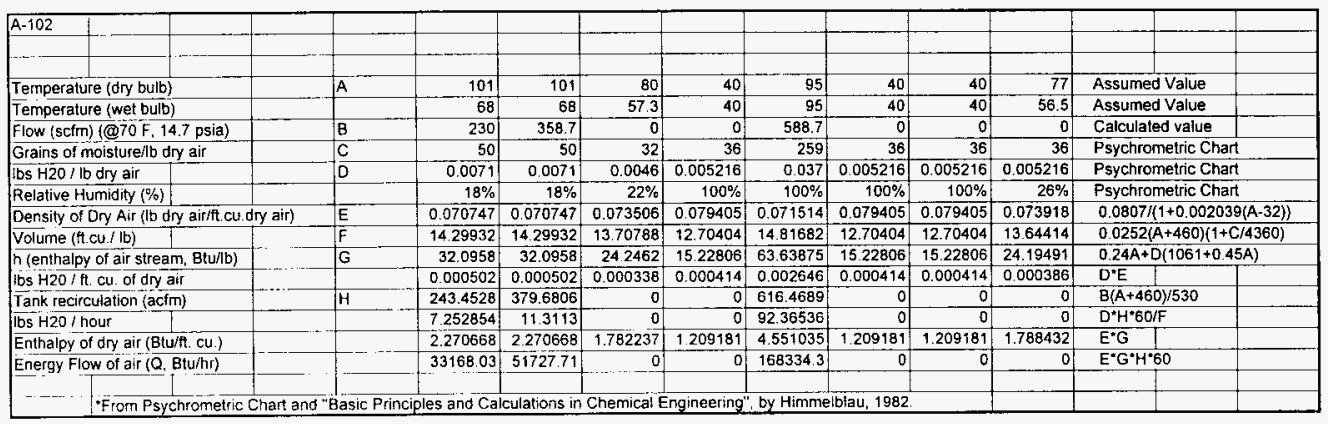




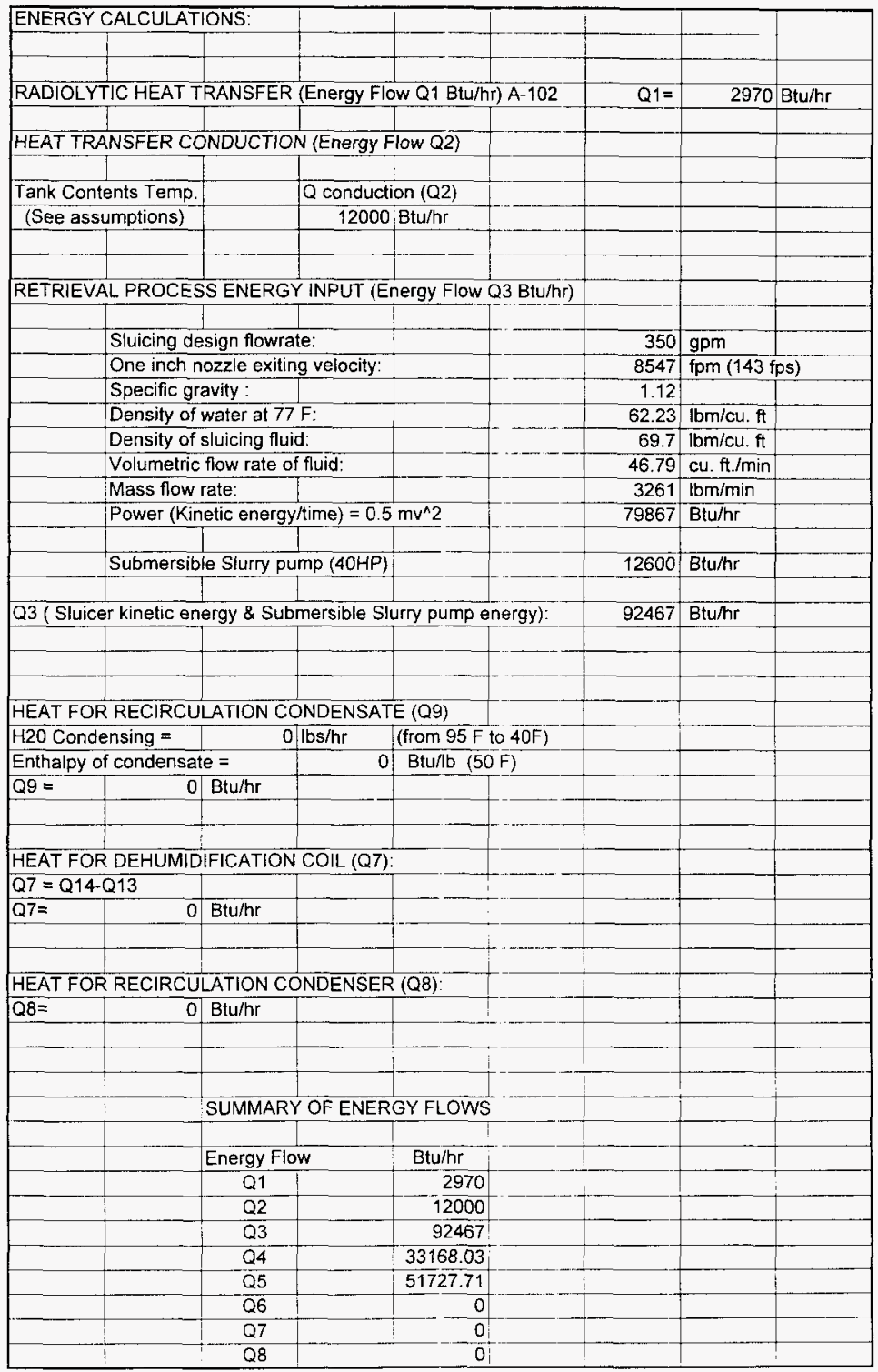




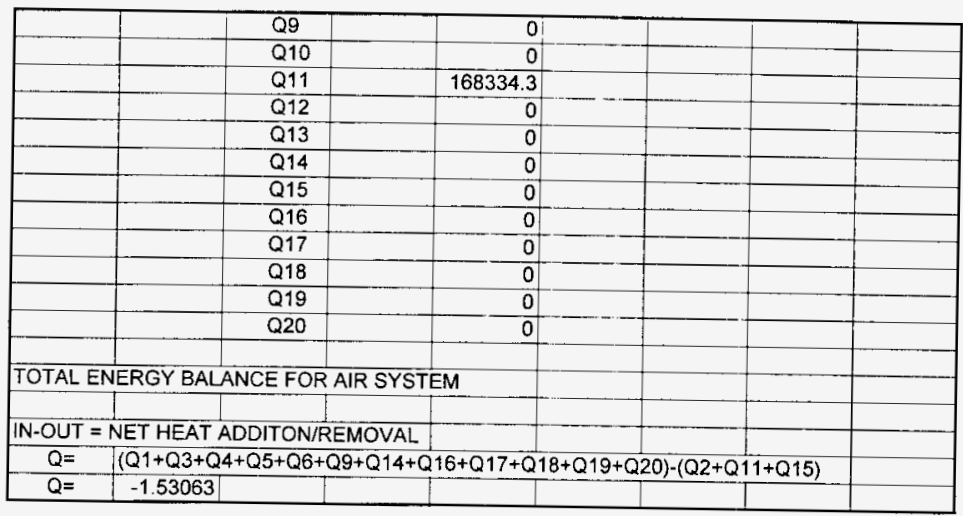




\begin{tabular}{|c|c|c|c|c|c|c|c|c|c|c|c|c|c|c|c|}
\hline$A X-103$ & & & & Farmulae & Q4 & Q5 & Q6 & Q10 & Q11 & Q12 & Q13 & Q14 & \multicolumn{2}{|c|}{ Formulae * } & \\
\hline & & & & Variables & Stream & Stream & Stream & Stream & Stream & Stream & Stream & Stream & & & \\
\hline & & & & & & & & & & & & & & & \\
\hline & & & & & & & & & & & & & & & \\
\hline & & & & & & & & & & & & & & & \\
\hline \multicolumn{3}{|c|}{ Temperature (dry bulb) } & & $A$ & 101 & 101 & 80 & 40 & 95 & 40 & 40 & 77 & \multicolumn{2}{|c|}{ Assumed Value } & \\
\hline \multicolumn{3}{|c|}{ Temperature (wet bulb) } & & & 68 & 68 & 57.3 & 40 & 95 & 40 & 40 & 56.5 & \multicolumn{2}{|c|}{ Assumed Value } & \\
\hline \multicolumn{3}{|c|}{ Flow (sctm) (@70 F, 14.7 psia) } & & $B$ & 230 & 487.3 & 0 & 0 & 717.3 & 0 & 0 & 0 & \multicolumn{2}{|c|}{ Calculated value } & \\
\hline \multicolumn{3}{|c|}{ Grains of moisture $/ \mathrm{b}$ dry air } & & $\mathrm{C}$ & 50 & 50 & 32 & 36 & $259 !$ & 36 & 36 & 36) & \multicolumn{3}{|c|}{ Psychrometric Chart } \\
\hline \multicolumn{3}{|c|}{ bs $\mathrm{H} 20$ / lb dry air } & & $\mathrm{D}$ & 0.0071 & 0.0071 & 0.0046 & 0.005216 & 0.037 & 0.005216 & 0.005216 & 0.005216 & \multicolumn{3}{|c|}{ Psychrometric Chart } \\
\hline \multicolumn{3}{|c|}{ Relative Humidity (\%) } & & & $18 \%$ & $18 \%$ & $22 \%$ & $100 \%$ & $100 \%$ & $100 \%$ & $100 \%$ & $26 \%$ & \multicolumn{3}{|c|}{ Psychrometric Chart } \\
\hline \multicolumn{4}{|c|}{ Density of Dry Air (lb dry air/tt.cu.dry air) } & $\mathrm{E}$ & 0.070747 & 0.070747 & 0.073506 & 0.079405 & 0.071514 & 0.079405 & 0.079405 & 0.073918 & \multicolumn{3}{|c|}{$0.0807 /(1+0.002039(A-32))$} \\
\hline \multicolumn{4}{|c|}{\begin{tabular}{|l|l|l|l|l} 
Volume $(\mathrm{ft} . \mathrm{cu} / \mathrm{ib})$ & \\
\end{tabular}} & $\mathrm{F}$ & 14.29932 & 14.29932 & 13.70788 & 12.70404 & 14.81682 & 12.70404 & 12.70404 & 13.64414 & \multicolumn{3}{|c|}{$0.0252(A+460)(1+C / 4360)$} \\
\hline \multicolumn{3}{|c|}{ h (enthalpy of air stream, Btu/lb) } & & $G$ & 32.0958 & 32.0958 & 24.2462 & 15.22806 & 63.63875 & 15.22806 & 15.22806 & 24.19491 & \multicolumn{3}{|c|}{$0.24 A+D(1061+0.45 A)$} \\
\hline \multirow{2}{*}{\multicolumn{3}{|c|}{$\begin{array}{l}\text { Ibs } \mathrm{H} 20 \text { / } \mathrm{ft} \text { cu. of dry air } \\
\text { Tank recirculation (acfm) }\end{array}$}} & & & 0.000502 & 0.000502 & 0.000338 & 0.000414 & 0.002646 & 0.000414 & 0.000414 & 0.000386 & $D^{*} E$ & & \\
\hline & & & & $\mathrm{H}$ & 243.4528 & 515.8025 & 0 & $0 \mid$ & 751.1349 & 0 & 0 & 0 & \multicolumn{2}{|c|}{$B(A+460) / 530$} & \\
\hline \multicolumn{3}{|c|}{ Ibs $\mathrm{H} 20 /$ hour } & & & 7.252854 & 15.36659 & 0 & 0 & 112.5423 & 0 & 0 & o. & \multicolumn{2}{|c|}{$\mathrm{D}^{*} \mathrm{H}^{* 60 / \mathrm{F}}$} & \\
\hline \multicolumn{3}{|c|}{ Enthalpy of dry air (Btu/ft. cu.) } & & & 2.270668 & 2.270668 & 1.782237 & 1.209181 & 4.551035 & 1.209181 & 1.209181 & 1.788432 & $E^{*} \bar{G}$ & & \\
\hline \multicolumn{3}{|c|}{ Energy Flow of air (Q, Btu/hr) } & & & 33168.03 & 70272.97 & 0 & 01 & 205106.5 & 0 & 0 & ol & \multicolumn{2}{|c|}{$E^{*} G^{*} H^{*} 60$} & \\
\hline & From Psy & chrometric & Chart an & Basic & ples and $\mathrm{Ca}$ & iculations ir & Chemical & Engineering & $\mathrm{g}^{\prime \prime}$, by Hin & nelblau, & & & & & \\
\hline
\end{tabular}

$\int_{\infty}^{\infty}$ 


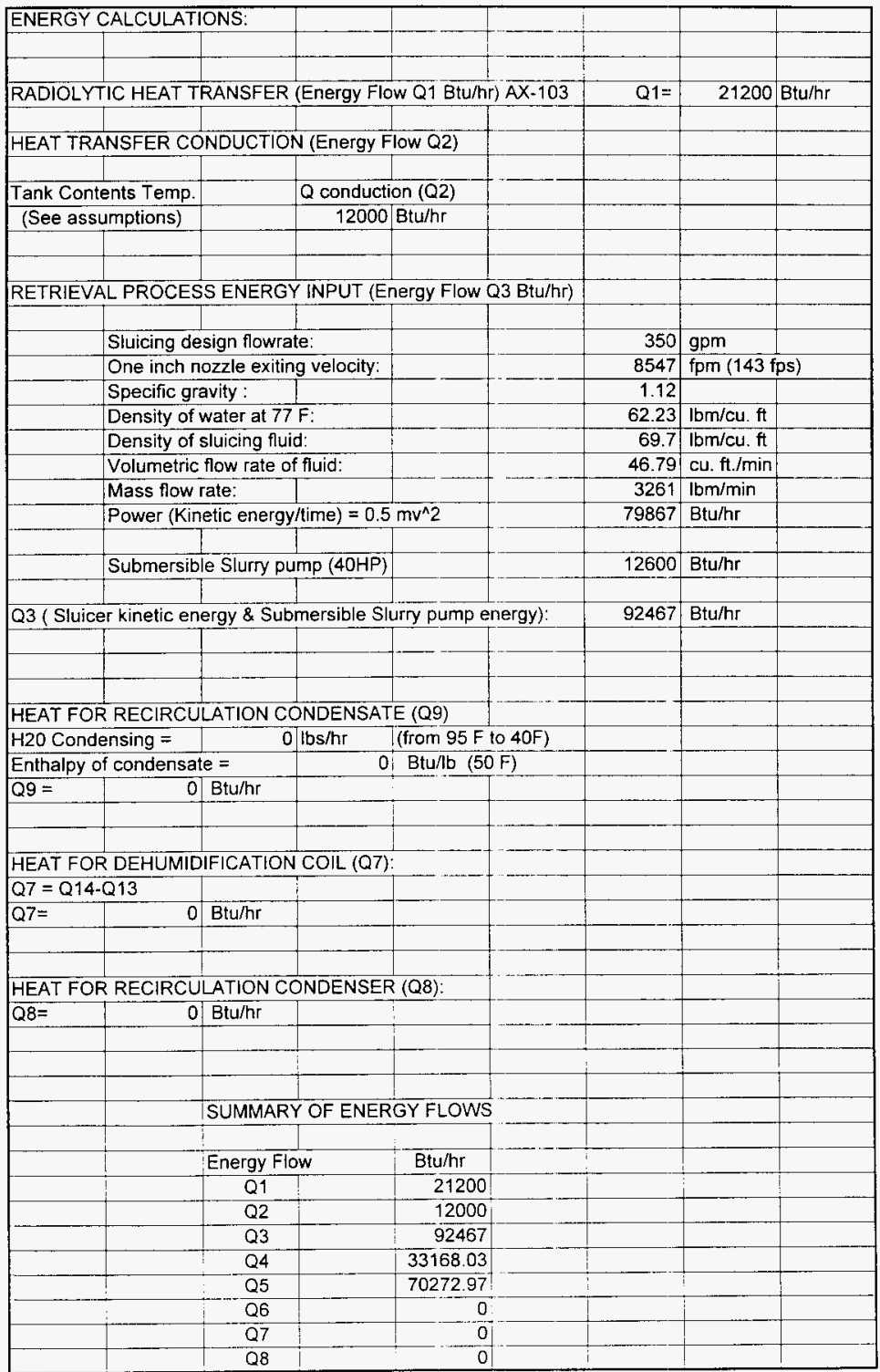


Sheet 1

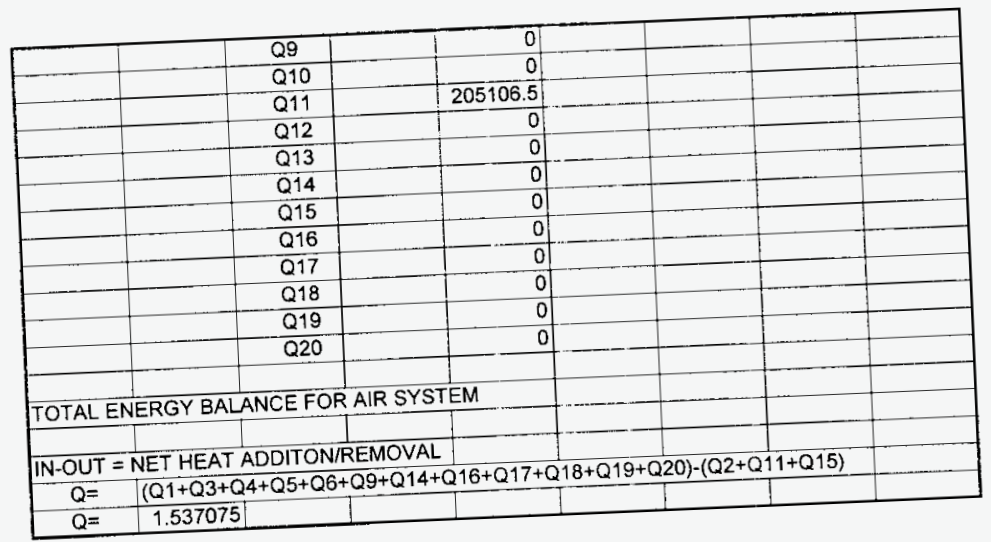




\section{APPENDIXC}


November 6, 1996

This page left intentionally blank. 


\section{FOG REMOVAL:}

The amount of moisture removal from the tank of project W320 (241-C-106) was estimated about $146.56 \mathrm{lb} / \mathrm{hr}$ ( $\mathrm{H} 2-81-8479)$. Assume same amount of moisture need to be removed from the tank by ventilation system ( without chiller) in order to remove the fog to be the same as project W320.

From attached calculation showed the air intake/infiltration required to remove fog for ventilation system is estimated about $1170 \mathrm{cfm}$ for same tank volume with C-106.

$241-\mathrm{C}-103,105$ or 106 tank volume is 530,000 gallons.

241-A-102 or AX-103 tank volume is $1,000,000$ gallons.

Assume the airflow required to remove fog is proportional to tank volume. The intake/infiltration airflow required for ventilation system to remove fog for tank A-102 or AX-103 is estimated as follows:

$(1,000,000 \times 1170) / 530,000=2208 \mathrm{CFM}$

The airflow required for chiller option to remove fog for tank A-102 or AX-103 is estimated about $2200 \mathrm{scfm}$ be drawn from the tank, of which about $1970 \mathrm{scfm}$ be recycled back into the tank and about $230 \mathrm{scfm}$ be exhausted to the atmosphere via a stack. The required chiller is estimated about 40 tons.

Note: Per Calculation W320-H-015, a percentage of water vapor that is condensed will be reentrained in the airstream. Therefore, a moisture separator shall be required for recirculation air. 
Rev. 0

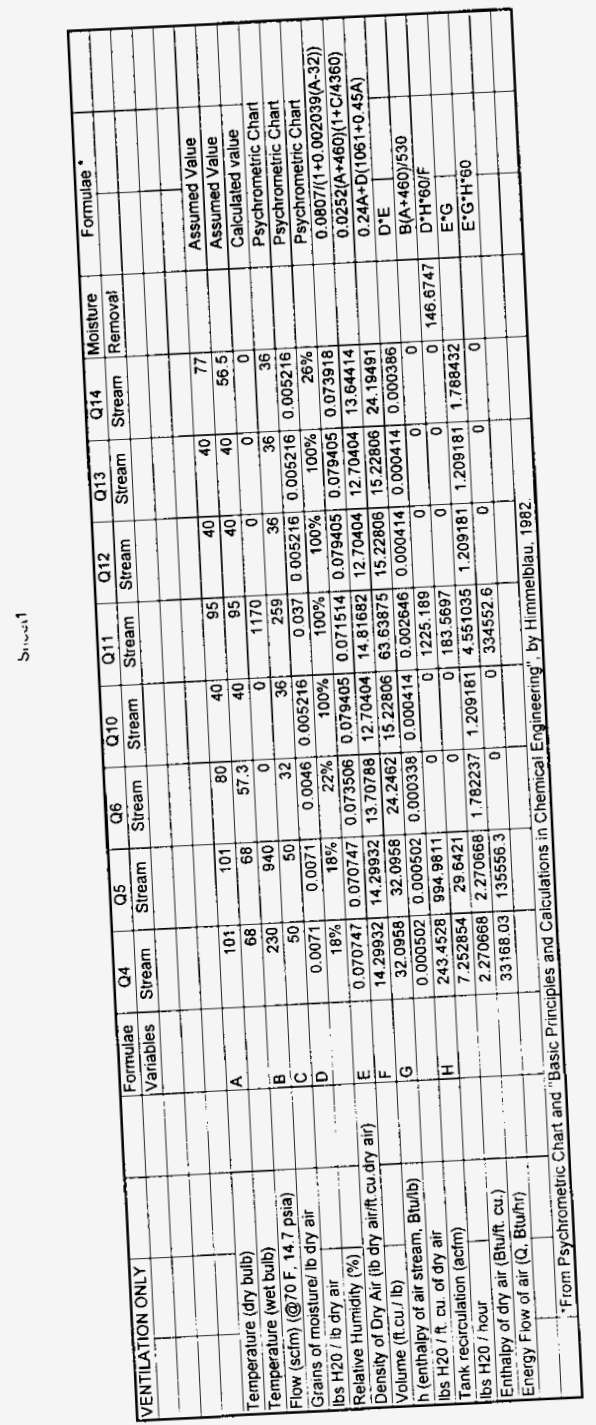


Rev. 0

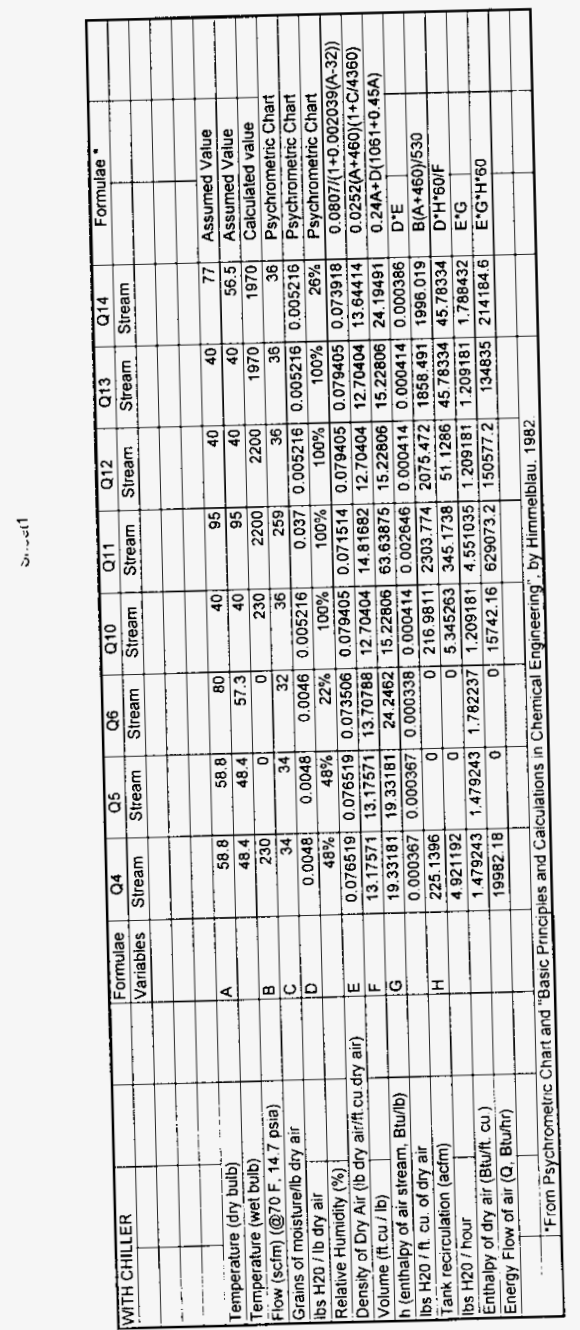




\begin{tabular}{|c|c|c|c|c|c|c|c|c|}
\hline \multicolumn{9}{|c|}{ ENERGY CALCULATIONS: } \\
\hline & & & & & & & & \\
\hline \multirow{2}{*}{\multicolumn{6}{|c|}{ RADIOLYTIC HEAT TRANSFER (Energy Flow Q1 Btu/hr) }} & & & \\
\hline \multirow{2}{*}{\multicolumn{9}{|c|}{ Q1 is included radiolytic heat transfer for tank C-103 (28300 btu/hr) and $19100 \mathrm{btu} / \mathrm{hr}$ for heat gain }} \\
\hline & & & & & & & & \\
\hline \multicolumn{9}{|c|}{ from fan/motor of recirculation fan. } \\
\hline \multicolumn{9}{|c|}{ HEAT TRANSFER CONDUCTION (Energy Flow Q2) } \\
\hline & & & & & & & & \\
\hline \multicolumn{2}{|c|}{ Tank Contents Temp. } & & \multicolumn{2}{|c|}{$Q$ conduction $(\mathrm{Q} 2)$} & & & & \\
\hline \multicolumn{2}{|c|}{ (See assumptions) } & & \multicolumn{2}{|c|}{$12000 / B t u / h r$} & & & & \\
\hline & & & & & & & & \\
\hline & & & & & & & & \\
\hline \multicolumn{9}{|c|}{ RETRIEVAL PROCESS ENERGY INPUT (Energy Flow $Q 3$ Btu/hr) } \\
\hline & & & & & & & & \\
\hline & \multicolumn{3}{|c|}{ Sluicing design flowrate: } & & & 350 & $\mathrm{gpm}$ & \\
\hline & \multicolumn{3}{|c|}{ One inch nozzle exiting velocity: } & & & 8547 & \multicolumn{2}{|c|}{ fpm (143 fps) } \\
\hline & \multicolumn{2}{|c|}{ Specific gravity: } & & & & 1.12 & & \\
\hline & \multicolumn{3}{|c|}{ Density of water at $77 \mathrm{~F}$ : } & & & 62.23 & $\mathrm{lbm} / \mathrm{cu} . \mathrm{ft}$ & \\
\hline & \multicolumn{3}{|c|}{ Density of sluicing fluid: } & & & 69.7 & $\mathrm{lbm} / \mathrm{cu} \cdot \mathrm{ft}$ & \\
\hline & \multicolumn{3}{|c|}{ Volumetric flow rate of fluid: } & & & 46.79 & cu. ft. $/ \mathrm{min}$ & \\
\hline & \multicolumn{2}{|c|}{ Mass flow rate: } & & & & 3261 & $\mathrm{lbm} / \mathrm{min}$ & \\
\hline & Power (Kin & etic energy & time $=0.5$ & $m v^{\wedge} 2$ & & 79867 & Btu/hr & \\
\hline & & & & & & & & \\
\hline & Submersibl & le Slurry pu & $\mathrm{mp}(40 \mathrm{HP})$ & & & 12600 & Btu/hr & \\
\hline & & & & & & & & \\
\hline Q31 & er kinetic en & ergy \& Sub & mersible Slu & ury pump en & fergy): & 92467 & Btu/hr & \\
\hline & & & & & & & & \\
\hline & & & & & & & & \\
\hline HEA & RECIRCU! & LATION CC & DNDENSATE & $E(Q 9)$ & & & & \\
\hline $\mathrm{H} 2 \mathrm{O}$ & ensing $=$ & 294.0452 & $\mathrm{lbs} / \mathrm{hr}$ & (from $95 \mathrm{~F}$ to & O40F) & & & \\
\hline Enthe & f condensat & $e=$ & 18.11 & Btu/lb $(50 \mathrm{~F}$ & & & & \\
\hline $\mathrm{Q9}=$ & Condensing & $\times$ Enthapy & of condens & ate & & & & \\
\hline$Q 9=$ & 5325.158 & Btu/hr & & & & & & \\
\hline & & & & & & & & \\
\hline & & & & & & & & \\
\hline $\mathrm{HEA}$ & R DEHUMID & IFICATION & COIL $(Q \bar{Q})$ & & & & & \\
\hline$Q 7=$ & Q13 & & & & & & & \\
\hline Q7= & 79349.56 & Btu/hr & & & & & & \\
\hline & & & & & & & & \\
\hline HEA & RECIRCU & LATION CO & DNDENSER & (Q8): & $\mathrm{Q} 8=\mathrm{Q} 11-\mathrm{C}$ & 212-Q9 & & \\
\hline Q8= & 473170.9 & Btu/hr & & & & & & \\
\hline & & & & & & & & \\
\hline & & & & & & & & \\
\hline & & & & & & & & \\
\hline & & SUMMARY & OF ENERC & GY FLOWS & & & & \\
\hline & & & & & & & & \\
\hline & & Energy Flo & & Btu/hr & & & & \\
\hline & & Q1 & & 47400 & & & & \\
\hline & & Q2 & & 12000 & & & & \\
\hline & & Q3 & & 92467 & & & & \\
\hline & & Q4 & & 19982.18 & & & & \\
\hline & & Q5 & & 0 & & & & \\
\hline & & Q6 & & 0 & & & & \\
\hline
\end{tabular}




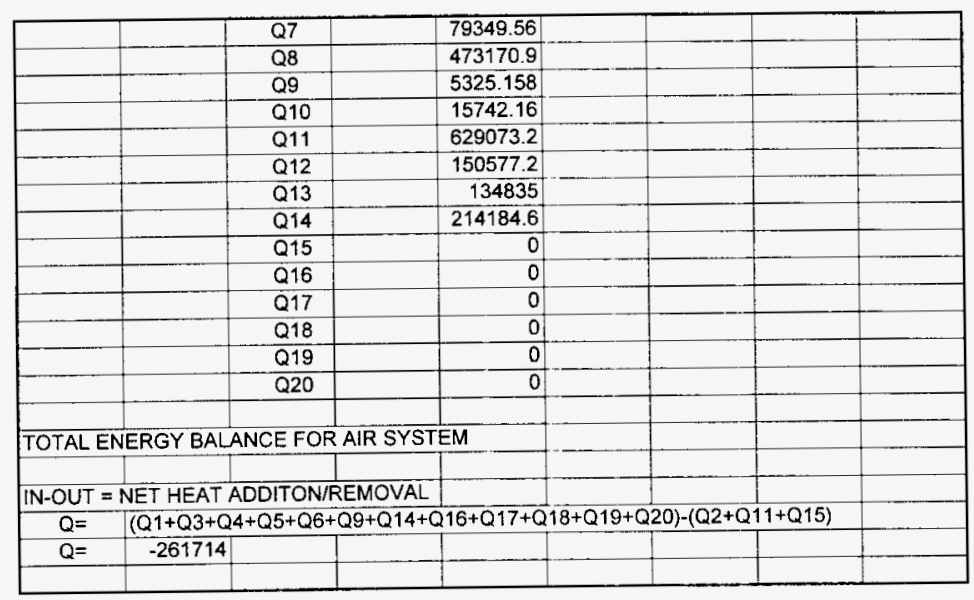




\title{
INITIAL SINGLE-SHELL TANK RETRIEVAL SYSTEM TRADE STUDY:
} EQUIPMENT RE-USABILITY BETWEEN PROJECT W-320 AND

\author{
TANKS 241-C-103 AND 241-C-105
}

\author{
Review Copy
}

Prepared By:

LOS ALAMOS TECHNICAL ASSOCIATES, INC.

Richland, WA

Under Purchase Order TJJ-SBW-387700

November 1996 
Approved by:

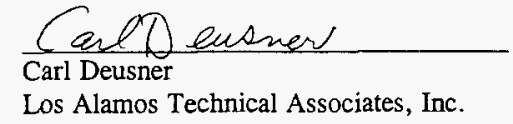

Los Alamos Technical Associates, Inc.
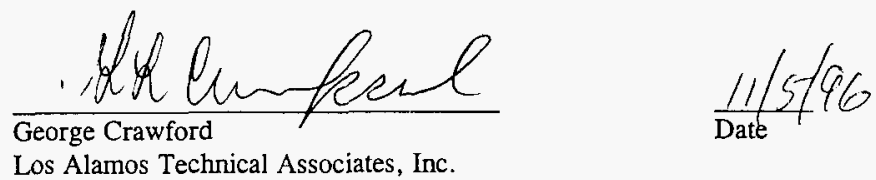

Los Alamos Technical Associates, Inc. 
HNF-SD-WM-ES-405 Rev. 0

This page left intentionally blank. 


\section{CONTENTS}

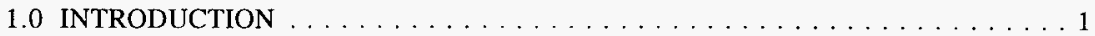

2.0 CONSTRAINTS AND ASSUMPTIONS $\ldots \ldots \ldots \ldots \ldots \ldots \ldots \ldots$

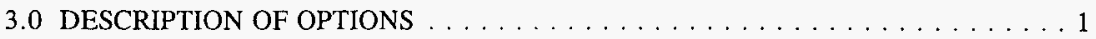

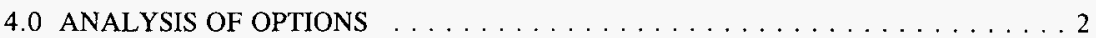

4.1 EQUIPMENT AVAILABLE FOR RE-USE $\ldots \ldots \ldots \ldots \ldots \ldots \ldots \ldots$

4.2 EQUIPMENT WITH POTENTIAL FOR RE-USE $\ldots \ldots \ldots \ldots \ldots \ldots$

4.3 EQUIPMENT WITH LOW POTENTIAL FOR RE-USE . . . . . . . . . 4

4.4 EQUIPMENT SUITABILITY PER DESIGN GUIDANCE DOCUMENT $\ldots .8$

5.0 CONCLUSIONS AND RECOMMENDATIONS $\ldots \ldots \ldots \ldots \ldots \ldots$

6.0 REFERENCES . . . . . . . . . . . . . . . . . . . 11

\section{LIST OF TABLES}

Table 1. Equipment Available for Re-use $\ldots \ldots \ldots \ldots \ldots \ldots \ldots \ldots \ldots \ldots \ldots \ldots \ldots$

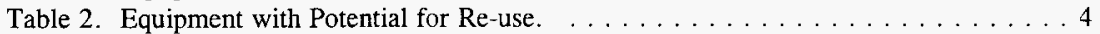

Table 3. Contaminated Equipment with Low Potential for Re-use. . . . . . . . . . . . . 5

Table 4. Cost Estimate for Equipment with Low Potential for Re-use . . . . . . . . . . . 7

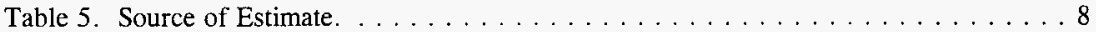

Table 6. Suspect Dome Intrusive and Waste Intrusive Equipment $\ldots \ldots \ldots \ldots \ldots$

\section{LIST OF TERMS}

ASTM American Society for Testing Materials

HEPA High-Efficiency Particulate Air

HVAC Heating, Ventilating, and Air Conditioning

ISSTRS Initial Single-Shell Tank Retrieval System

KEH Kaiser Engineers Hanford

SST Single-Shell Tank 
This page left intentionally blank. 


\subsection{INTRODUCTION}

The Initial Single-Shell Tank Retrieval System (ISSTRS) consists of the equipment, hardware, procedures, and systems necessary to retrieve waste from four Hanford Site single-shell tanks (SSTs). High-level radioactive waste has been stored at the Hanford Site since the 1940's as a by-product of processing spent nuclear fuel. Waste volumes in the SSTs vary as does the consistency of the waste (ranging from pumpable liquid, to sludge and hard salt cake). The overall objective of the ISSTRS Project is to design, fabricate, and install the retrieval systems, waste transfer lines, tank HVAC system, and infrastructure necessary to begin waste retrieval operations in SSTs A-102, AX-103, C-103, and C-105 for delivery to double-shell tank AN-105. The conceptual design of the systems and equipment for ISSTRS is based upon existing Project W-320 (tank C-106) waste retrieval system design.

This study examines options available for the re-utilization of equipment installed under Project W-320. Specifically examined was the re-use of process and utility equipment used in the sluicing of tank C-106 and the application of the same equipment in the sluicing of tanks C-103 and C-105. Equipment design flammability constraints, as identified in the Equipment Design Guidance Document for Flammable Gas Waste Storage Tank New Equipment (Smet 1996) were also examined.

\subsection{CONSTRAINTS AND ASSUMPTIONS}

This study assumes that tanks $\mathrm{C}-103$ and $\mathrm{C}-105$ will not be sluiced simultaneously and that tank contents and tank/riser design are compatible with equipment installed under Project W-320. In addition, the sluicing schedule identified in the Initial Retrieval Sequence and Blending Strategy (Penwell et al. 1996) and the design guidance identified in the Equipment Design Guidance Document for Flammable Gas Waste Storage Tank New Equipment (Smet 1996) would govern design and operation.

The efficiency of equipment re-use is dependent upon adopted schedules, the functionality of transferred equipment, and increasing regulatory compliance. As time progresses it is likely additional regulations will be adopted which, in turn, will increase complexity of the equipment transfer.

\subsection{DESCRIPTION OF OPTIONS}

Equipment available for re-use was divided into three broad location categories: 1) equipment outside the $\mathrm{C}$ Tank Farm fence, 2) equipment within the $\mathrm{C}$ Tank Farm fence, and 3) equipment in the tanks and riser pits. This study addresses the re-use of equipment for tanks C-103 and C-105, and is potentially applicable to additional C Farm tanks. 


\subsection{ANALYSIS OF OPTIONS}

\subsection{EQUIPMENT AVAILABLE FOR RE-USE}

Equipment available for re-use (Table 1) is typically located outside the C Tank Farm fence, considered radiological clean, and provides support or utilities for processes within the C Tank Farm. With the exception of the Sluicer Hydraulic Control (SHC-1361) and Drive Assembly, all identified equipment could be adapted for use at tanks C-103 or C-105 by extending underground wire, tubing, or pipe. The alternative would be relocation or duplication of existing equipment and facilities.

The sluicer hydraulic power pack and drive assembly are located within the $\mathrm{C}$ Tank Farm fence. The drive assembly is bolted to the sluice pit $241-\mathrm{C}-06$ cover block, with the power pack on a adjacent concrete pad. The drive assembly could be relocated, with minimum exposure and expense to tank C-103 or C-105. Relocation of the power pack would not be complex and would consist of new wiring and a concrete pad. The alternative of extending the hydraulic hoses above ground to a relocated drive assembly requires investigation for line losses and capacities. Under the proposed schedule, with eight years between equipment installation and re-use, it is anticipated that the weather exposed equipment would degrade. The hardening of pump seals, plugging of orifices, and corrosion would necessitate a complete hydraulic overhaul prior to return to service.

For equipment within the Available for Re-use category, the cost effective solution of extending utilities (air, water, power and signal) is weighed against the construction of new duplicate equipment. The cost for duplication of facilities, running of new services $\approx 700$ feet when compared to extending existing services $\approx 100$ feet, illustrates the effectiveness of equipment re-use.

Table 1. Equipment Available for Re-use (2 sheets).

\begin{tabular}{|l|l|l|}
\hline \multicolumn{1}{|c|}{ Equipment Description } & \multicolumn{1}{|c|}{ Drawing Number } & \multicolumn{1}{|c|}{ Location } \\
\hline $\begin{array}{l}\text { Sluicer Hydraulic Control } \\
\text { (power pack) SHC-1361 } \\
\text { and Sluicer Drive } \\
\text { Assembly }\end{array}$ & H-2-818559 Sh. 2 Zn E6 & $\begin{array}{l}\text { Existing equipment is located } \\
\text { outside sluice pit 241-C-06C, } \\
\text { but within the C Farm fence; } \\
\text { equipment could be moved or } \\
\text { modified. }\end{array}$ \\
\hline $\begin{array}{l}\text { In Tank Imaging System } \\
\text { Rack FCU-1361 }\end{array}$ & $\begin{array}{l}\text { H-2-818559 Sh. 3 Zn E6 } \\
\text { H-2-818592 }\end{array}$ & $\begin{array}{l}\text { Rack inside MO-211; } \\
\text { connections could be adapted to } \\
\text { other C Tank Farm tanks. }\end{array}$ \\
\hline
\end{tabular}


Table 1. Equipment Available for Re-use (2 sheets).

\begin{tabular}{|l|l|l|}
\hline \multicolumn{1}{|c|}{ Equipment Description } & \multicolumn{1}{|c|}{ Drawing Number } & \multicolumn{1}{|c|}{ Location } \\
\hline $\begin{array}{l}\text { Electrical Equipment Skid } \\
\text { 41-C-51 }\end{array}$ & $\begin{array}{l}\text { H-2-818559 Sh. 3 Zn E4 } \\
\text { H-2-818681 }\end{array}$ & $\begin{array}{l}\text { Located outside the C Farm } \\
\text { fence line; skid could be } \\
\text { modified to support addition } \\
\text { tanks. }\end{array}$ \\
\hline Operator Station MO-211 & H-2-81859 Sh. 3 Zn F1-8 & $\begin{array}{l}\text { Located outside the C Farm } \\
\text { fence; trailer could be modified } \\
\text { to support additional tanks. }\end{array}$ \\
\hline $\begin{array}{l}\text { Nitrogen Purge for Slurry } \\
\text { booster Pump P-1362 }\end{array}$ & H-2-818559 Sh. 5 Zn E6 & $\begin{array}{l}\text { Located outside C Farm fence } \\
\text { line; bottle rack could be } \\
\text { modified or moved to support } \\
\text { additional tanks. }\end{array}$ \\
\hline $\begin{array}{l}\text { Seismic Detection } \\
\text { Enclosure 241-C-51A and } \\
241-C-51 B\end{array}$ & $\begin{array}{l}\text { H-2-818559 Sh 1 } \\
\text { H-2-818679 Sh 3 }\end{array}$ & $\begin{array}{l}\text { Located outside the C Farm } \\
\text { fence and equipment could be } \\
\text { connected to addition tanks. }\end{array}$ \\
\hline $\begin{array}{l}\text { Air \& Water Service Bldg. } \\
241-C-73\end{array}$ & $\begin{array}{l}\text { H-2-818562 Sh 1 } \\
\text { H-2-818530 }\end{array}$ & $\begin{array}{l}\text { Building and equipment is } \\
\text { located outside the C Farm } \\
\text { fence; could be modified or } \\
\text { moved to support additional } \\
\text { tanks. }\end{array}$ \\
\hline $\begin{array}{l}\text { Air Chiller Skid System } \\
\text { R-1361 }\end{array}$ & $\begin{array}{l}\text { H-2-818561 Sh 2 } \\
\text { H-2-818483 }\end{array}$ & $\begin{array}{l}\text { Located outside the C Farm } \\
\text { fence; skid could be modified or } \\
\text { moved to support additional } \\
\text { tanks if required. }\end{array}$ \\
\hline $\begin{array}{l}\text { In-Tank Imaging CCTV- } \\
1361\end{array}$ & N/A & $\begin{array}{l}\text { Located within tank; remove } \\
\text { and re-use }\end{array}$ \\
\hline
\end{tabular}

\subsection{EQUIPMENT WITH POTENTIAL FOR RE-USE}

The equipment located above ground within the C Tank Farm fence is modular and has potential for re-use. This equipment is identified in Table 2. The air inlet cooling system, process building 241-C-91, and exhaust skid associated with tank C-106 could be adapted for use at tanks C-103 and C-105. The complexity of moving contaminated modular equipment within a tank farm should be minimized and the expense of relocation should always be compared with new construction, equipment modification, or schedule modification. Because of similar design it is anticipated that modification of tank C-106 modular equipment for tank $\mathrm{C}-103$ or $\mathrm{C}-105$ would be more cost effective than equipment relocation. 
The re-use of process building 241-C-91 for tank C-103 or C-105 cleanout could be accomplished cost effectively by routing the supply duct (V'T-1010) and recirculation lines to $\mathrm{C}$ Tank Farm tanks as required. A determination of the adequacy of the liquid/air handling capacity and radiation shielding would be necessary for the longer runs of pipe/duct. Utility services, compressed air, water, and power would remain relatively constant, although the rerouting of process drains at conclusion of tank C-106 sluicing would have to be addressed.

The Air Inlet Cooling System associated with tank C-106 as determined by a trade study titled Retrieval Facility Cooling Requirements (LATA 1996), will not be required for cleanout of tanks $\mathrm{C}-103$ or $\mathrm{C}-105$. The potential re-use of the cooling system would be dependent on conditions outside the scope of this document.

Re-use of the exhaust skid would be required for the cleanout of tanks C-103 or C-105 because it functions as an integral part of the HVAC exhaust system.

Table 2. Equipment with Potential for Re-use.

\begin{tabular}{|l|l|l|}
\hline \multicolumn{1}{|c|}{ Equipment Description } & \multicolumn{1}{|c|}{ Drawing Number } & \multicolumn{1}{c|}{ Location } \\
\hline Air Inlet Cooling System & $\begin{array}{l}\text { H-2-818561 Sh 1 } \\
\text { H-2-818470 Sh 2 }\end{array}$ & $\begin{array}{l}\text { Located within C Farm } \\
\text { fence; equipment could be } \\
\text { re-used or moved. }\end{array}$ \\
\hline Process Building 241-C-91 & $\begin{array}{l}\text { H-2-818561 Sh 3-5 } \\
\text { H-2-818482 Sh 1 }\end{array}$ & $\begin{array}{l}\text { Located within C Farm } \\
\text { fence; could be re-used at C- } \\
103 \text { or C-105. }\end{array}$ \\
\hline $\begin{array}{l}\text { Exhaust Skid, Flow Control } \\
\text { Module C-1, exhaust stack } \\
\text { 296-C-006 }\end{array}$ & $\begin{array}{l}\text { H-2-818561 Sh 7 } \\
\text { H-2-818674 Sh 4 }\end{array}$ & $\begin{array}{l}\text { Located within C Farm } \\
\text { fence; could be re-used. }\end{array}$ \\
\hline
\end{tabular}

\subsection{EQUIPMENT WITH LOW POTENTIAL FOR RE-USE}

Contaminated equipment with low potential for re-use is identified in Table 3. To determine cost effectiveness, four options were studied for the identified equipment used in the riser pits and tank intrusive activities. The options include the following: 1) Remove the equipment identified in Table 3 for storage, inventory, and re-use. 2) Remove equipment identified in Table 3, ship to burial, and fabricate new equipment from lessons learned for the next sluicing campaign. 3) Assume the targeted equipment could, without compromising principles identified in Tank Waste Remediation System Controlled, Clean, and Stable Functions and Endpoint Criteria for Single-Shell Tank Farms (Hull 1996) 6.1.2.b and c, remain in tank C106 until required for re-use in 2004. 4) Equipment identified in Table 3 is abandoned in tank $\mathrm{C}-106$ remaining in place during tank closure and new equipment is fabricated. 
Table 3. Contaminated Equipment with Low Potential for Re-use.

\begin{tabular}{|l|l|l|}
\hline \multicolumn{1}{|c|}{ Equipment Description } & \multicolumn{1}{|c|}{ Drawing Number } & \multicolumn{1}{|c|}{ Location/function } \\
\hline $\begin{array}{l}\text { Sluicer S-1361, 250-350 } \\
\text { gal/min }\end{array}$ & $\begin{array}{l}\text { Located inside tank C-106 } \\
\text { and sluicing pit 241-C-06C } \\
\text { H-2-818559 sh. 2 Zn. B6 } \\
\text { H-2-818549 }\end{array}$ & $\begin{array}{l}\text { Abandoned in place inside } \\
\text { tank C-106 due to } \\
\text { degradation and } \\
\text { contamination }\end{array}$ \\
\hline $\begin{array}{l}\text { All jumpers associated with } \\
\text { Sluice pit 241-C-06C and } \\
\text { Pump pit 241-C-06A }\end{array}$ & $\begin{array}{l}\text { H-2-818513, H-2-818515, } \\
\text { H-2-818516, H-2-818508, } \\
\text { and H-2-818505 }\end{array}$ & $\begin{array}{l}\text { Abandoned in place due to } \\
\text { contamination and unique } \\
\text { application }\end{array}$ \\
\hline $\begin{array}{l}\text { Submersible Slurry Pump and } \\
\text { Motor Assembly P-1361 40 } \\
\text { hp }\end{array}$ & $\begin{array}{l}\text { H-2-818559 sh. 3 Zn. B-3 } \\
\text { H-2-818495 }\end{array}$ & $\begin{array}{l}\text { Abandoned in place inside } \\
\text { tank C-106 due to } \\
\text { contamination and equipment } \\
\text { degradation. }\end{array}$ \\
\hline $\begin{array}{l}\text { Sump pumps P-1368 and } \\
\text { P-1363 }\end{array}$ & $\begin{array}{l}\text { H-2-818559 Sh 4, Zn B2 } \\
\text { H-2-818559 Sh 2, Zn C7 } \\
\text { H-2-818539 Sh 1 }\end{array}$ & $\begin{array}{l}\text { 1/3 hp pumps abandoned in } \\
\text { place in pits 241-C-06C and } \\
\text { 241-C-06A. }\end{array}$ \\
\hline $\begin{array}{l}\text { Winch W-1361 (level } \\
\text { adjustment for the Slurry } \\
\text { Pump) }\end{array}$ & H-2-818559 sh. 3 Zn. C-3 & $\begin{array}{l}\text { Abandoned in place inside } \\
\text { H-2-818496 pit 241-C-06A } \\
\text { due to contamination. }\end{array}$ \\
\hline $\begin{array}{l}\text { Slurry Booster Pump and } \\
\text { Motor Assembly P-1362 } \\
\text { 250 hp }\end{array}$ & $\begin{array}{l}\text { H-2-818559 Sh.4, Zn C8 } \\
\text { H-2-818524 }\end{array}$ & $\begin{array}{l}\text { Abandoned in place inside } \\
\text { pump pit 241-C-06A } \\
\text { due to contamination and } \\
\text { equipment degradation. }\end{array}$ \\
\hline
\end{tabular}

With options 1,2, and 3, similar activities and costs are required regardless of the choice. These include, but are not limited to, cover block removal, riser pit decontamination, equipment removal, transport, lifting/rigging, and packaging for disposal or storage. A drawback of options 1 and 3 is a high potential for radiation exposure with the storage (option 1 above ground, option 3 in tank $\mathrm{C}-106$ ), maintenance, and re-installation of contaminated equipment. An additional consideration for options 1 and 3 is the degradation of neoprene seals in swivel joints and the sluicer nozzle flex hose interior, and natural rubber of the flex hose exterior. Pump seizure and seal failure would also be concerns that would require the rebuild/repair of all elastomeric products prior to reinstallation. Failure to conduct a thorough rebuild could result in the additional expense of failure and replacement during the sluicing of tanks C-103 and C-105 in 2004.

Options 2 and 4 require the expense of new equipment fabrication. Option 4 would cost less than option 2 due to its lack of burial and equipment removal expenses. 
Cost estimates with pumps and the sluicer inside tank C-106 were prepared with installation and fabrication costs extracted from the Tank 241-C-106 Sluicing 90\% Preliminary Estimate (KEH 1995). Necessary assumptions for a rough order of magnitude cost estimate include

- Jumpers are unique for a specific riser pit and not reusable

- The re-use of $1 / 3$ horsepower sump pumps was neglected

- The removal costs of contaminated equipment equals two times the installation costs of clean equipment

- The installation costs of contaminated material equals three times the installation costs of clean equipment

- The decontamination costs of pumps and riser pits equal two times the decontamination costs of riser pits alone

- Burial costs of sluicer/pumps equal costs of installation

- Storage costs of sluicer/pumps equal two times the costs of burial

- Rebuilding costs of pumps/sluicer equal two times costs of storage.

The cost estimates are presented in Table 4. The location (estimate line number) of each activity in the tank C-106 estimate (KEH 1995) are shown in Table 5.

Comparing the cost estimates (based on the identified options) shows the most cost effective approach is to abandon in-tank and riser pit equipment in place and fabricate new equipment. For equipment transfer between tanks C-103 and C-104 in the year 2004 or 2005, option 3 could be exercised without rebuilding the equipment. 
Table 4. Cost Estimate for Equipment with Low Potential for Re-use

\begin{tabular}{|c|c|c|}
\hline Option & Activity & $\operatorname{Cost}^{1}$ \\
\hline \multirow[t]{6}{*}{ Option 1} & Decontaminate pumps/sluicer & $2 \mathrm{D}$ \\
\hline & Remove pumps/sluicer & $2 I$ \\
\hline & Store pump/sluicer & $2 \mathrm{I}$ \\
\hline & Rebuild pumps/sluicer & $4 \mathrm{I}$ \\
\hline & Install rebuilt equipment & $3 \mathrm{I}$ \\
\hline & Total & $111+2 \mathrm{D}=\$ 1,860,000$ \\
\hline \multirow[t]{6}{*}{ Option 2} & Decontaminate pumps/sluicer & $2 \mathrm{D}$ \\
\hline & Remove pumps/sluicer & $2 \mathrm{I}$ \\
\hline & Bury pump/sluicer & I \\
\hline & Fabricate new pumps/sluicer & Fab \\
\hline & Install new equipment & I \\
\hline & Total & $4 \mathrm{I}+2 \mathrm{D}+\mathrm{Fab}=\$ 2,930,000$ \\
\hline \multirow[t]{5}{*}{ Option 3} & Decontaminate pumps/sluicer & $2 \mathrm{D}$ \\
\hline & Remove pumps/sluicer & $2 \mathrm{I}$ \\
\hline & Rebuild old equipment & $4 \mathrm{I}$ \\
\hline & Install rebuilt equipment & $3 \mathrm{I}$ \\
\hline & Total & $9 \mathrm{I}+2 \mathrm{D}=\$ 1,740,000$ \\
\hline \multirow[t]{3}{*}{ Option 4} & Fabricate new pumps/sluicer & Fab \\
\hline & Install new equipment & I \\
\hline & Total & $\mathrm{Fab}+\mathrm{I}=\$ 1,550,000$ \\
\hline
\end{tabular}

Notes:

$\mathrm{D}=$ decontamination $=520+83=\$ 600,000$

$\mathrm{I}=$ installation $=35+26=\$ 60,000$

$\mathrm{Fab}=$ fabrication $=1,100+392=1,490,000$

'All dollar values rounded to the nearest thousand. 
Table 5. Source of Estimate.

\begin{tabular}{|l|l|l|}
\hline \multicolumn{1}{|c|}{ Activity } & \multicolumn{1}{|c|}{$\begin{array}{l}\text { KNH Estimate Line } \\
\text { Number }\end{array}$} & Cost $\$$ \$?: \\
\hline $\begin{array}{l}\text { Riser pits C-106 } \\
\text { decontamination technical } \\
\text { support }\end{array}$ & 416151 & $\$ 83,916$ \\
\hline $\begin{array}{l}\text { Riser pits C-106 } \\
\text { decontamination, material }\end{array}$ & 461510 & $\$ 520,252$ \\
\hline Sluicer installation & 434321 & $\$ 35,147$ \\
\hline $\begin{array}{l}\text { Sluicer and winches } \\
\text { fabrication (KEH identifies } \\
\text { two sluicers) }\end{array}$ & 454310 & $\$ 391,888$ \\
\hline Slurry pump installation & 434322 & $\$ 25,652$ \\
\hline Slurry pump fabrication & $45110 \mathrm{AB}$ & $\$ 1,140,475$ \\
\hline
\end{tabular}

\subsection{EQUIPMENT SUITABILITY PER DESIGN GUIDANCE DOCUMENT}

The Design Guidance document (Smet 1996) identifies 10 criteria for the design and installation of equipment associated with Flammable Gas Waste Storage Tanks. The location and application of the equipment is further categorized by Dome Intrusive, Non-Intrusive, and Waste Intrusive. A partial listing of design limiting conditions included materials, automatic shutdown, single point of failure, and gas purging.

A detailed survey of Dome Intrusive and Waste Intrusive equipment from the pre-descoped drawings, identified some suspect materials (these are listed in Table 6). 
Table 6. Suspect Dome Intrusive and Waste Intrusive Equipment (2 sheets)

\section{Items that May Not Be Suitable for Dome Inclisive Activities}

Sluicer Assembly

H-2-818551 sh. 3 Sluicer Assembly Material List.

Item 24, Grease Dow Corning No. 111.

Item 25, O-ring, Parker 2-318 V6874-75, 2-318=size, V=fluorocarbon, material composition unknown.

Item 27, Loctite 242.

Item 15-17, -2-818555 sh. 1 Actuating Rack

Notes 1, Packing \& O-ring Neoprene ASTM d2000

M286 407.

Note 1, Chrome Alloy Steel Balls.

Note 1, Carbon Steel.

Note 5, Dow Corning 3400A Bonded Lube.

Note 6, Chevron NRR Grease 159.

Item 18, H-2-818556 sh. 1, Hose

Hose Gates 3618-0225.

Item 19, H-2-90187, Pn 2 4" Male Nozzle (Drawing not available)

\section{In-Tank Imaging CCTV-1361}

No drawings available on the details of installation.

\section{Submersible Slurry Pump}

H-2-818495 Sh.1, Piping Pump Assembly, Material List.

Items 15-16 Shielding Plate, Detail shown on $\mathrm{H}-2-818498$ Sh. 1-3; insufficient detail to determine potential problems, pre-descoped drawings are not accurate but entire assembly could be made from 304L SST. No drawing of nozzle assembly $\mathbf{H}-2-90187$. 
Table 6. Suspect Dome Intrusive and Waste Intrusive Equipment (2 sheets)

\section{Items that May Not Be Suitable for Bome Space or Waste Intrusive Activities}

Submersible Slurry Pump

H-2-818495 Sh.1, Piping Pump Assembly, Material List.

Item 20, McMaster Carr $3458 \mathrm{~T} 850$ contains 302 SST, identified as $3458 \mathrm{~T} 85$ not $3458 \mathrm{~T} 850$.

Item 21, McMaster Carr 3473T84 Positive Wire Rope Fitting, Found SST 3473 T98 for $3 / 8$ in. rope but for $6 \times 19$ rope not $7 \times 19$ rope (per item 20) Item 7, H-2-818497 Pump Sheave and Details Sh. 1 \& 2.

Item 22 , No definition of what the electrical pump is.

Item 11,12, H-2-818442, Sh.1 Pipe Swivel.

O-Ring Neoprene ASTM D2000 M286 407.

Note 2, Chevron NRR grease 159.

Item 13,14 H-2-818444 Sh. 1 Hose Assembly

Gates 3618-0225.

\section{Items that May Not Be Suitable for Non-Tank Intrusive Activities}

Submersible Slurry Pump

H-2-818495 Sh.1, Piping Pump Assembly, Material List.

Item 8, H-2-818496 Pump Winch Assembly .

Item 62, weld stud, Nelson 101-010-003.

Notes:

It is inferred that alloying elements contained within a material are exempt from criteria 1 (no $\mathrm{Al}, \mathrm{Mg}$,

$\mathrm{Zn}$, \& Ti permitted); i.e., actuating rack, gear drive for sluicing nozzle is ATSM 1045, which has

$0.006 \%$ Al but is electroless nickel plated.

18-8 SST type 302 is acceptable.

\subsection{CONCLUSIONS AND RECOMMENDATIONS}

Review of the pre-descoped design indicates that with minor potential material exceptions, the intent of the design guide for flammable gas tanks (Smet 1996) was satisfied on Project W-320. However, the options are limited for re-use of equipment from Project W-320 under the proposed schedule. An attempt to re-use equipment for the cleanout of tanks C-103 and C-105 after seven years of inactivity following the scheduled cleanout of tank C-106 suggests serious equipment degradation may occur, technological or regulatory obsolescence notwithstanding. The best opportunity for equipment utilization would be a schedule modification to move or modify tank C-106 transfer equipment for re-use in the cleanout of 
tanks C-103 or C-105 immediately upon completion of tank C-106 cleanout. The relatively short duration for tank sluicing, coupled with a schedule modification would permit continuity of personnel (crafts and engineering), reduce design cost, and prevent equipment (lifting, rigging, and shielding) from being excessed. Assigning a value of one year per tank for design and one year per tank for equipment transfer for the terminal cleanout of tanks C-103 and $\mathrm{C}-105$ could be accomplished three to four years ahead of the published schedule.

\subsection{REFERENCES}

Penwel1, D.L., C.E. Grenard, and R.S. Wittman, 1996, Initial Retrieval Sequence and Blending Strategy, WHC-SD-WM-RPT-229, Rev. 0, Westinghouse Hanford Company, Richland, Washington.

Hull, K. A., 1996, Tank Waste Remediation System Controlled, Clean, and Stable Functions Endpoint Criteria for Single-Shell Tank Farms, WHC-SD-WM-TI-728, Rev. 0, Westinghouse Hanford Company, Richland, Washington.

KEH, 1995, Tank 241-C-106 Sluicing 90\% Preliminary Estimate, IEST Project Cost Summary, Kaiser Engineers Hanford, Richland, Washington.

LATA, 1996, Initial Single-Shell Tank Retrieval System Trade Study: Retrieval Facility Cooling Requirements, Los Alamos Technical Associates, Richland, Washington.

Smet, D.B., 1996, Equipment Design Guidance Document for Flammable Gas Waste Storage Tank New Equipment, WHC-SD-WM-DSG-005, Rev. 0, Westinghouse Hanford Company, Richland, Washington. 


\title{
INITIAL SINGLE-SHELL TANK RETRIEVAL SYSTEM TRADE STUDY: SLUICE LINE OPTIONS
}

\author{
Review Copy
}

Prepared By:

LOS ALAMOS TECHNICAL ASSOCIATES, INC.

Richland, WA

Under Purchase Order TJJ-SBW-387700

November 1996 
Approved by:
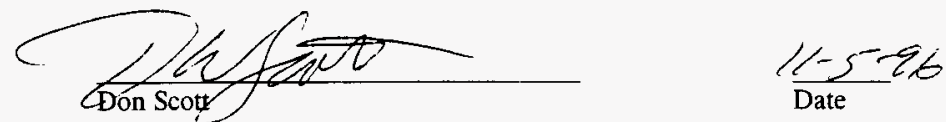

Los Alamos Technical Associates, Inc.
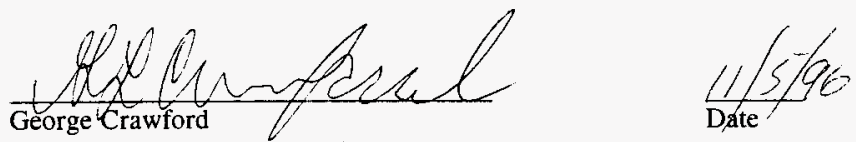

Los Alamos Technical Associates, Inc. 
HNF-SD-WM-ES 405

This page left intentionally blank. 


\section{CONTENTS}

1.0 INTRODUCTION $\ldots \ldots \ldots \ldots \ldots \ldots \ldots \ldots \ldots \ldots \ldots \ldots \ldots \ldots$

2.0 CONSTRAINTS AND ASSUMPTIONS $\ldots \ldots \ldots \ldots \ldots \ldots \ldots \ldots$

2.1 LEGAL/REGULATORY CONSTRAINTS $\ldots \ldots \ldots \ldots \ldots \ldots \ldots$

2.2 TANK FARM OPERATING CONSTRAINTS $\ldots \ldots \ldots \ldots \ldots \ldots \ldots$

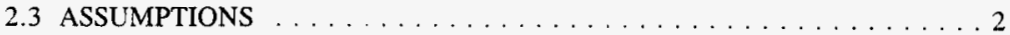

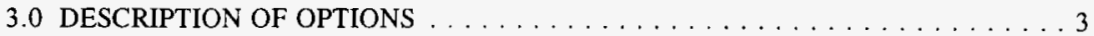

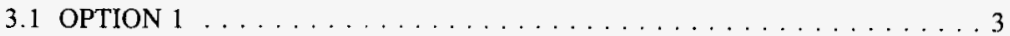

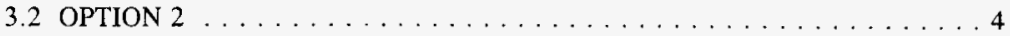

3.2 .1 C Tank Farm . . . . . . . . . . . . . . . . . 4

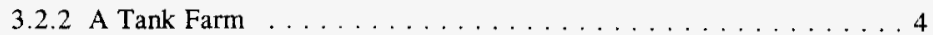

3.2 .3 AX Tank Farm . . . . . . . . . . . . . . . 4

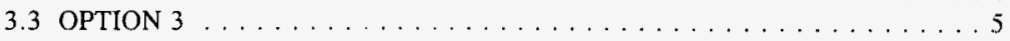

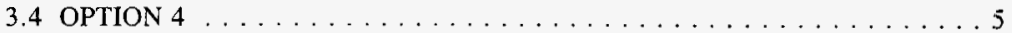

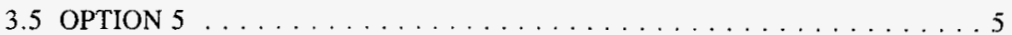

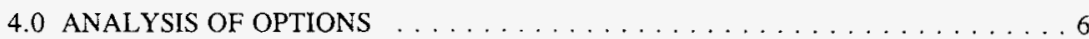

4.1 DISCUSSION OF OPTIONS $\ldots \ldots \ldots \ldots \ldots \ldots \ldots \ldots \ldots \ldots \ldots$

4.2 COST ANALYSIS OF OPTION $2 \ldots \ldots \ldots \ldots \ldots \ldots \ldots$

5.0 CONCLUSIONS AND RECOMMENDATIONS $\ldots \ldots \ldots \ldots \ldots$

6.0 REFERENCES . . . . . . . . . . . . . . . . 9

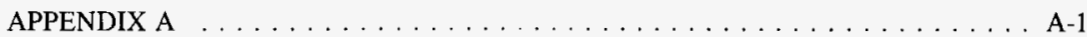

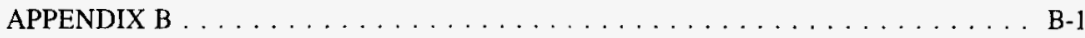

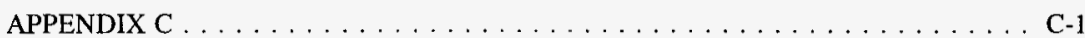

\section{LIST OF TABLES}

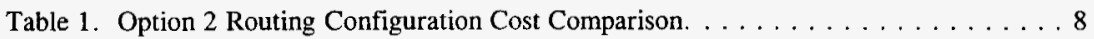




\section{LIST OF TERMS}

DST Double-Shell Tank

HVAC Heating, Ventilating, Air Conditioning

ISSTRS Initial Single-Shell Tank Retrieval System

RCRA Resource Conservation and Recovery Act

SST Single-Shell Tank 
HNF-SD-WM-ES-405 Rev. 0

This page left intentionally blank. 


\subsection{INTRODUCTION}

The Initial Single-Shell Tank Retrieval System (ISSTRS) consists of the equipment, hardware, procedures, and systems necessary to retrieve waste from four Hanford Site single-shell tanks (SSTs). High-level radioactive waste has been stored at the Hanford Site since the late 1940's as a by-product of processing spent nuclear fuel. Waste volumes in the single-shell tanks vary as does the consistency of the waste (ranging from pumpable liquid, to sludge and hard salt cake). The overall objective of the ISSTRS Project is to design, fabricate, and install the retrieval systems, waste transfer lines, tank HVAC systems, and infrastructure necessary to begin waste retrieval operations in four SSTs. The conceptual design of the systems and equipment for ISSTRS is based upon the existing Project W-320 (tank C-106) waste retrieval system design.

The purpose of this Trade Study is to identify pipeline routing options and recommend one for additional study, in support of the ISSTRS. The scope of this study includes both the existing waste transfer system and proposed new construction, or any combination of the two. This study combines two trade studies listed in the Work Plan for Conceptual Design of ISSTRS (LATA 1996); the first was to evaluate the sluice line routing options and the second was to evaluate the use of existing transfer lines.

The scope of ISSTRS includes the retrieval of waste from tanks C-103, C-105, A-102, and AX -103 and routing the contents of these tanks to double shell tank (DST) AN-105 (a summary of the current status of these tanks is shown in Appendix A, Table A-1). Because liquid from $\mathrm{AN}-105$ will be used as the sluicing fluid, a piping circuit is required to avoid a liquid inventory build-up in the SSTs. ISSTRS also encompasses all equipment, including HVAC, monitoring and control, pumps, sluicers, valving, and piping, necessary for a complete waste transfer system.

\subsection{CONSTRAINTS AND ASSUMPTIONS}

\subsection{LEGAL/REGULATORY CONSTRAINTS}

Tanks AX-103 and AN-105 are listed on the hydrogen Watch List; tank C-103 is listed on the organic Watch List. Both categories impose flammable gas requirements on equipment in or around these tanks.

Most existing lines within the A Tank Farm complex are listed as non-compliant. These lines can still be used if they pass a pressure test immediately before use. 


\subsection{TANK FARM OPERATING CONSTRAINTS}

Waste types and mixing/segregation limits are outside the scope of this study and are not considered. Direct transfer of the contents of the SSTs to DST AN-105 without chemical additions is assumed to be an acceptable practice. Necessary chemical additions to the sluice fluid will be made in tank AN-105.

Line pressures, flow rates, Reynold's numbers, $\mathrm{pH}$, viscosity, etc., are extracted from the ISSTRS Statement of Work (SOW) and tank farm Operating Specifications.

\subsection{ASSUMPTIONS}

For the options discussed in this study the following assumptions are made:

- $\quad$ Project W-320 (which includes a pair of encased 4-inch lines directly from tanks $\mathrm{C}-106$ to AY-102) is complete and the C-to-AY Tank Farms transfer system is available for re-use by ISSTRS.

- Conflicts with Project W-314 pipe routing are identified and reconciled early, if required.

- A three-to-one dilution factor is assumed, and tank AN-105 inventory is managed to make space for the total inventory retrieved from the ISSTRS SSTs, including dilution.

- $\quad$ Primary piping leakage from A or AX Tank Farm transfers will be routed to tank AN-105 and will gravity drain. Leakages during C Tank Farm transfers will be allowed to drain back to the originating tank in the $C$ Farm or on to tank AN-105. Valving, jumpers, and retrieval sequence will be used to prevent waste from the A or AX Tank Farms from being routed to a C Farm tank.

Flow calculations included in this study are based on a specific gravity of 1.5 and a viscosity of $30 \mathrm{cps}$, both of which are somewhat high (from Krieg 1996). A specific gravity of 1.5 is comparable to nitric acid or chloroform; a viscosity of $30 \mathrm{cps}$ compares to $10 \mathrm{wt}$ motor oil at $100^{\circ} \mathrm{F}$. Using these numbers leads to high pressure losses and low Reynold's numbers for the given flow rate of $350 \mathrm{gpm}$ through the existing 2-and 3-inch lines. Similar calculations for water are included in Appendix A to bracket the range of possibilities. 


\subsection{DESCRIPTION OF OPTIONS}

\subsection{OPTION 1}

Option 1 would use existing lines, valve pits, diversion boxes, etc. (non-Project W-320 equipment).

Because ISSTRS is using liquid from tank AN-105 as the sluicing fluid, a two-way route between each of the four ISSTRS SSTs and AN-105 is required. Batch processing, using the same pipeline in a back and forth mode, is an unacceptable practice because it would require a liquid inventory build-up in the SSTs. Some existing line routings have been identified, but they would require using AY or AZ Tank Farm valve pits and possibly one of the tanks, as well as Project W-314 piping. This strategy is not routinely acceptable. To illustrate the complexity involved of using the existing infrastructure for ISSTRS, a typical possible routing is illustrated in Figure A-1 in Appendix A. It uses 11 or more pits and at least 28 connections through three farms. Other routings, using existing lines, are possible but are not included here.

All existing supernatant and slurry lines are 3 inches and 2 inches in diameter, respectively. A 2-inch line, flowing at $350 \mathrm{gpm}$, will generate a pressure loss of 170 psi per 100 feet of pipe, or 1,700 psi for a typical thousand foot run between tank farms. Booster pumps, with associated pits and piping, would be required every 100 feet to maintain the required flow rate while staying within reasonable pressure limits. (The W-320 design pressure is 320 psi; see the attached flow calculations.)

Assuming a suitable routing could be found, a 3 -inch line might work, but with essentially no margin (this assumes a design pressure of $320 \mathrm{psi}$, the same as Project W-320). Such a line at $350 \mathrm{gpm}$ would lose about 25.0 psi per 100 feet or 250 psi for a typical thousand foot run. Adding 10 percent for valve and fitting loses, and 180 psi required for nozzle operation, the total pressure required is 455 psi. A single intermediate booster pump, possibly in an existing pump or valve pit, would be required.

Even if a pair of 3-inch lines could be identified, questions regarding RCRA compliance (pipe in a pipe, leak detection) and usability must be answered. Many existing lines, specifically pipe-in-concrete lines, have been declared noncompliant and are not available to ISSTRS without a pre-transfer pressure test. Some of these lines may also be plugged or blanked off due to SST isolation projects in the 1970's and 80's. The cost of upgrading and certifying these lines will exceed the cost of new construction. 


\subsection{OPTION 2}

Option 2 would use a modified Project W-320 system (new inlet and outlet routes) with required changes (relative to routing) to accommodate the ISSTRS tanks.

\subsubsection{Tank Farm}

New pick-up points (stubs) would be used for tanks C-103 and C-105, routed through a small switching valve pit or welded as required for each tank. About $400 \mathrm{ft}$ south of the $\mathrm{C}$ Farm fence, new lines could be welded to Project W-320 system, and the waste could be re-routed from the AY to AN Tank Farm. The waste is then routed up the AN Tank Farm will to a new valve pit (new Valve Pit \# 1 on Drawing SK-2-300469) just inside the west fence of the AN Farm. This new valve pit is a high point in this routing, allowing primary leakages to drain back to the source tank in C Farm or on to tank AN-105. The AN valve pits (241-AN-A and B) would have to be by-passed and the waste routed directly to tank AN-105 because these pits have only 2 - and 3 -inch lines. With proper planning, such a system for $C$ Farm could be used in waste retrieval in the remainder of the tank farm at a later date with only comparatively minor modifications.

\subsubsection{A Tank Farm}

Since all of Project W-320 is north of the A Tank Farm, the piping could be extended from A Farm to the southern end of the W-320 lines. This connection would be welded to the lines and the left over stub to AY Tank Farm would be blanked off. The line could be routed through a second new valve pit (new Valve pit \#2 on Drawing SK-2-300469) to tie in AX Farm. About $200 \mathrm{ft}$ north of new valve pit \#2, new piping would angle away from the W-320 lines to the southwest corner of AN Farm. New valve pit \# 1 would then route the waste directly to tank AN-105. This routing accommodate waste retrieval from the rest of the A Farm tanks at a later date.

\subsubsection{AX Tank Farm}

Because all of Project W-320 is west of the AX Tank Farm, it would be more efficient to lay new piping from the AX Farm to the proposed valve pit \#2. From this point, waste routing is the same as for A Farm. This routing would also accommodate waste retrieval from the rest of the AX Farm tanks at a later date. 


\subsection{OPTION 3}

Option 3 would use the planned Project W-314 system with new or existing inlet and outlet routes. Project W-314 will add new transfer piping and replace selected existing transfer lines between valve pits for the A, AX, AN, AZ, and AW Tank Farms; however, this project will use 2 - and 3 -inch lines. Also, a routing circuit is not available.

\subsection{OPTION 4}

This option proposes all new equipment and routing (an entirely new system, including lines, valve pits, pump pits, diversion boxes, etc.) for each of the three SST farms. It is essentially a variation of Option 2 described above without the goal of re-using the Project W-320

equipment. Three stand alone systems would be required, one between each of the SST farms and the AN Tank Farm. The Initial Retrieval Sequence and Blending Strategy (Penwell et al. 1996) projects a 10 -week period between the retrieval in C-103 and C-105, making it possible to use the same equipment in $\mathrm{C}$ Farm if rapid change-over features are included in the design.

The advantages of Option 4 are the following:

- Two correctly sized and compliant lines between each of the ISSTRS SST farms and tank AN-105.

- Construction around and modifications to the contaminated Project W-320 equipment are avoided.

- Routing to each of the SST farms could be selected to avoid existing contaminated pipework.

The disadvantages are as follows:

- $\quad$ One time, single purpose lines.

- This option is more costly as it requires extensive construction in and around the tank farms including more valve pits and longer pipe runs.

\subsection{OPTION 5}

Option 5 is a collection of seven routing possibilities developed by Westinghouse Hanford Company early in calendar year 1996. These are illustrated on the attached sketches ZCLWSK01 through ZCLWSK07, and discussed in more detail in the next section. 


\subsection{ANALYSIS OF OPTIONS}

\subsection{DISCUSSION OF OPTIONS}

Option 1 is not viable for three reasons. First, a practical, two-way simultaneous transfer route could not be identified, even using other tank farms (e.g., AZ and AY). Second, most of the existing lines are either 2 or 3 inches in diameter, too small to accommodate the required flow rates and Reynold's number without very large pressure losses. Third, the compliance and serviceability of the existing lines is in doubt.

Option 3 is not viable because a routing circuit is not available and it would require the use of 2- and 3-inch lines. In addition, it would not be cost effective to merge ISSTRS requirements with Project W-314 due to the extensive re-design and additional construction that would be required. Finally, planned installation of W-314 lines would not occur in time to support ISSTRS.

Options 2 and 4 are the most reasonable alternatives available to ISSTRS. Option 2 is the recommended choice because more than 800 feet of the necessary piping for ISSTRS is already installed. Option 4 completely new systems would become cost effective only if the W-320 system is not available to ISSTRS.

Option 5, routing and equipment options developed by Westinghouse Hanford Company, are illustrated on sketches ZCLWSK01 through ZCLWSK07 (included in Appendix C).

- $\quad$-01. This option would install new lines from A Farm to AN Farm. It re-uses all of Project W-320 piping and AY-102 as a pass-through tank. All new piping and two new valve pits are inside the fence.

- -02 . This option re-uses all of the Project W-320 system with new piping from A-to-AX-to-AY, and from the midpoint of W-320 to AN Farm, requiring four new valve pits. This routing creates a low point west of AN Farm.

- -03 . This option uses existing lines, operating at $100 \mathrm{gpm}$. The required flow rate for this trade study is $350 \mathrm{gpm}$.

- - 04 . This option uses both existing lines and new 4-inch lines from the 241AX-152 to AN Farm, operating at $100 \mathrm{gpm}$. No new valve pits are required, but the flow rate is too low. New pipe is inside the fence.

- -05 . This option is the same as -02 . 
- -06 . This option uses existing lines routed through the 244-AR Vault and the 241-AX-152 diversion box, with new 4-inch lines to AN Farm. This option requires no new vaive pits, but modifications to the diversion box will be required. Since this option uses existing 2 - and 3 -inch lines, it will operate at $100 \mathrm{gpm}$.

- -07 . This option assumes tank AY-102 is the destination tank.

The only variation of Option 5 that meets the requirements for flow rate and the avoidance of low points is the first (-01). This option is feasible only if passing through tank AY-102 is acceptable. This study assumes this is not acceptable.

Routing new lines around buildings, pits, and other surface obstacles is not complex and is consistent with the preferred zigzag routing used to alleviate thermal stresses on the pipe. However, underground congestion, especially under A Tank Farm, will present some routing problems. The use of shallow burial, with a low drive-over berm for additional shielding, is recommended to allow ISSTRS to avoid most of the existing underground piping without adversely impacting day-to-day tank farm operations.

\subsection{COST ANALYSIS OF OPTION 2}

Five routing configurations of the Option 2 are considered in this analysis ranging from reusing most of the Project W-320 piping to bypassing it altogether. The configurations provide the shortest possible pipe runs and routing to avoid below-grade congestion as much as possible. Estimated costs of the configurations are compared in Table 1. These configurations are illustrated in Figures A-2 through A-5 and Drawing SK-2-300469 (Appendix B) the preferred option.

Cost assumptions used in calculating the estimates are as follows: valve pit, outside tank farm fence, $\$ 150,000$; valve pit, inside tank farm fence, $\$ 450,000$; pipeline, per foot, outside tank farm fence, $\$ 1,000$; pipeline, per foot, inside fence, $\$ 3,000$; and jumpers, each, two per valve pit, $\$ 25,000$.

Pipeline and valve pit estimates assume that excavation and construction within a tank farm fence will cost three times as much as outside the fence because of entry requirements, personnel protection gear, and the greater risk of encountering existing contamination and hot pipes. Distances are estimated on the figures and sketches included in the appendices. 
Table 1. Option 2 Routing Configuration Cost Comparison.

\begin{tabular}{|c|c|c|c|c|c|}
\hline \multirow[b]{2}{*}{ Iten } & \multicolumn{5}{|c|}{ Configuration Routing' } \\
\hline & $\mathrm{SK}-2-300469$ & $\begin{array}{l}\text { Figare } \\
A-2\end{array}$ & $\begin{array}{l}\text { Figure } \\
1-3\end{array}$ & Figure & $\begin{array}{c}\text { Figure: } \\
\text { A-5 }\end{array}$ \\
\hline $\begin{array}{l}\text { Pipeline, inside } \\
\text { fence }^{2}\end{array}$ & $\begin{array}{l}\$ 7,482 \\
\text { (2474 feet) }\end{array}$ & $\begin{array}{l}\$ 10,095 \\
(3,365 \text { feet })\end{array}$ & $\begin{array}{l}\$ 9,075 \\
(3,025 \text { feet })\end{array}$ & $\begin{array}{l}\$ 8,817 \\
(2,939 \text { feet })\end{array}$ & $\begin{array}{l}\$ 9,831 \\
(3,277 \text { feet })\end{array}$ \\
\hline $\begin{array}{l}\text { Pipeline, outside } \\
\text { fence }\end{array}$ & $\begin{array}{l}\$ 1,177 \\
(1,177 \text { feet })\end{array}$ & $\begin{array}{l}\$ 586 \\
(586 \text { feet })\end{array}$ & $\begin{array}{l}\$ 358 \\
\text { (358 feet) }\end{array}$ & $\begin{array}{l}\$ 1,120 \\
(1,120 \text { feet })\end{array}$ & $\begin{array}{l}\$ 1,376 \\
(1,376 \text { feet })\end{array}$ \\
\hline $\begin{array}{l}\text { Valve pit, inside } \\
\text { fence }\end{array}$ & $\$ 450$ & $\$ 450$ & $\$ 450$ & 0 & 0 \\
\hline $\begin{array}{l}\text { Valve pit, } \\
\text { outside fence }\end{array}$ & $\$ 150$ & 0 & 0 & 0 & 0 \\
\hline Jumpers & $\$ 100$ & $\$ 50$ & $\$ 50$ & 0 & 0 \\
\hline Totals & $\$ 9,359$ & $\$ 11,181$ & $\$ 9,933$ & $\$ 9,937$ & $\$ 11,207$ \\
\hline
\end{tabular}

'Dollar amounts in thousands.

${ }^{2}$ Assumes the cost of new piping only. The existing W-320 System is not included in distance and cost calculations. Also assumes each system is "stand alone;" therefore, some piping segments are counted more than once.

\subsection{CONCLUSIONS AND RECOMMENDATIONS}

Option 2 is the recommended choice because it would provide the compliant, appropriately sized lines to and from the tanks within the scope of ISSTRS. It would require less construction and less excavation in potentially contaminated areas than Option 4 and would provide a cost savings by re-using existing equipment. The equipment installed for Option 2 could also be used to retrieve waste from all of the SST farms north of PUREX, as long as routing through the AN Farm is acceptable. Alternatively, future lines could be routed through the proposed new valve pits to service other DST farms, if required. Option 2 would make maximum use of the Project W-320 equipment, and provide a significant cost savings in capital and construction. About one fourth of the required pipelines are already installed. In addition, some of the new excavation would be in areas recently disturbed for Project W-320. The recommended routing for Option 2 is shown on Drawing SK-2-300469 in Appendix B. 


\subsection{REFERENCES}

"Flow of Fluids Through Valves, Fittings, and Pipes," Crane Technical Paper $\# 410$.

Hanlon, B. M., 1996, Waste Tank Summary Report for Month Ending May 31, 1996, WHCEP-0182-99, Westinghouse Hanford Company, Richland, Washington.

Krieg, S. A., 1996, Statement of Work for ISSTRS, Rev. 1, Westinghouse Hanford Company, Richland, Washington.

LATA, 1996, Work Plan for Conceptual Design of ISSTRS, Rev. 1, July , Los Alamos Technical Associates, Richland, Washington.

OSD-T-151-00007, Operating Specifications for the 241-AN, AP, AW, AY, AZ, SY Tank Farms, February 1996, Westinghouse Hanford Company, Richland, Washington.

OSD-T-151-00013, Operating Specifications for Single-Shell Waste Storage Tanks, May 1996, Westinghouse Hanford Company, Richland, Washington.

OSD-T-151-00017, Operating Specifications for Aging-Waste Operations, November 1995, Westinghouse Hanford Company, Richland, Washington.

Penwell, D. L., C. E., Greuard, and R. S. Whittman, 1996, Initial Retrieval Sequence and Blending Strategy, WHC-SD-WM-RPT-229, Rev. 0, Westinghouse Hanford Company, Richland, Washington. 


\section{APPENDIX A}


This page left intentionally blank. 


\section{LIST OF FIGURES}

Figure A-1. Potential Pipeline Routing Using Existing and Proposed Infrastructure

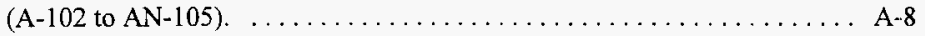

Figure A-2. Routing through Less Congested Area, One New Valve Pit. . . . . . . . . A-9

Figure A-3. Routing with One New Valve Pit, Short Pip Runs and Uses Some of W320.

Figure A-4 Routing Option Independent of W320 No New Valve Pits, Shortest Pipe Runs.

Figure A-5 Routing Option Independent of W320, No New Valve Pits.

\section{LIST OF TABLES}

Table A-1. Tank Summary Information. A-3 


\section{APPENDIX A}

Table A-1. Tank Summary Information.

\begin{tabular}{|c|c|c|c|c|c|}
\hline Tank & $1-102$ & AX-103 & C.103 & C.105 & AN-105 \\
\hline Temperature & $92^{\circ} \mathrm{F}$ & $117^{\circ} \mathrm{F}$ & $117^{\circ} \mathrm{F}$ & $97^{\circ} \mathrm{F}$ & $113^{\circ} \mathrm{F}$ \\
\hline Size (kgal) & 1,000 & 1,000 & 530 & 530 & 1,140 \\
\hline $\begin{array}{l}\text { Watchlist } \\
\text { classification }\end{array}$ & None & $\begin{array}{l}\text { Flammable } \\
\text { Gas } \\
\end{array}$ & Organic & None & \begin{tabular}{|l|} 
Flammable \\
Gas \\
\end{tabular} \\
\hline Sludge (kgal) & 15 & 2 & 62 & 130 & 0 \\
\hline Supernatant (kgal) & 4 & 0 & 133 & 5 & $1,129(5 / 96)$ \\
\hline Saltcake (kgal) & 22 & 110 & 0 & 0 & 0 \\
\hline Waste type & DSSF & $\mathrm{CC}$ & NCPLX & NCPLX & $\mathrm{DN} / \mathrm{PD}$ \\
\hline Risers - Total & 20 & 35 & 10 & 12 & 59 \\
\hline $34^{\prime \prime}$ to $42^{\prime \prime}$ & 1- central & 3 & $\begin{array}{l}1 \\
\left(+126^{\prime \prime}\right)\end{array}$ & ${ }^{2}\left(+126^{\prime \prime}\right)$ & $\begin{array}{l}1 \\
(+242 " \text { non- } \\
\text { functional })\end{array}$ \\
\hline $22 "$ to $32^{\prime \prime}$ & 0 & 0 & 0 & 0 & 2 \\
\hline $12^{\prime \prime}$ to $20^{\prime \prime}$ & 6 & 4 & 4 & 5 & 7 \\
\hline $10^{\prime \prime}$ or less & 13 & 28/1 plug & 4 & 4 & 47 \\
\hline
\end{tabular}

Notes:

DSSF $=$ Double Shell Slurry Feed

$\mathrm{CC}=$ Concentrated Complexant

NCPLX $=$ Non-Complexed

DN/PD $=$ Dilute Non-complex/PUREX TRU Solids

\subsection{CAlCulations}

FOR 2" $\oslash$ Existing Pipe - SCH 40

$$
\begin{aligned}
& \rho \quad=93.5 \mathrm{lb} / \mathrm{ft}^{3}(\mathrm{SpG}=1.5) \\
& \mu \quad=30 \mathrm{cps}=0.0202 \frac{\mathrm{lb}}{\mathrm{ft}^{5}} \\
& \mathrm{~T}=110^{\circ} \mathrm{F} \quad \text { (Avg of } 4 \mathrm{SSTs} \text { ) } \\
& \mathrm{A}_{\mathrm{c}}=0.023 \mathrm{ft}^{2} \quad \mathrm{D}=0.1723 \mathrm{ft} \quad \mathrm{d}=2.067 \mathrm{in} . \\
& Q \quad=350 \mathrm{gpm}
\end{aligned}
$$

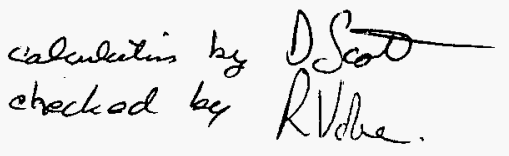


Velocity:

$$
\mathrm{v}=0.408 \mathrm{Q} / \mathrm{d}^{2}=0.408(350) /(2.067)^{2}=33.4 \mathrm{fps}
$$

Reynolds:

$$
\mathrm{R}_{\mathrm{e}}=\frac{\rho v \mathrm{D}}{\mu}=\frac{23.5(33,4) 0.1723}{0.0202} \approx 26,640
$$

Pipe Roughness and Friction

$$
\begin{aligned}
\epsilon / \mathrm{D} & =0.009 \text { (Table A-23, Crane) } \\
f & =0.026 \text { (Table A-24, Crane) }
\end{aligned}
$$

Pressure Loss (Per $100 \mathrm{ft}$ of pipe)

$$
\Delta \mathrm{p}=\frac{\rho f \mathrm{Lv}^{2}}{144 \mathrm{D} 2 \mathrm{~g}}=\frac{23.5(0.026) 100(33.4)^{2}}{144(0.1723) 2(32.2)}=169.7 \mathrm{psi}
$$

OR $\sim 1700 \mathrm{psi}$ for $1000 \mathrm{ft}$ pipe run

$\therefore$ Existing 2 in. lines will not support ISSTRS 
For 3 in. $ø$ existing pipe, $\mathrm{SCH} 40$

$$
\begin{aligned}
& A_{c}=0.0513 \mathrm{ft}^{2} \quad D=0.2557 \mathrm{ft} \quad \mathrm{d}=3.068 \mathrm{in} . \\
& Q \quad=350 \mathrm{gpm}
\end{aligned}
$$

Velocity:

$$
\mathrm{v}=0.408 \mathrm{Q} / \mathrm{d}^{2}=0.408(350) /(3.068)^{2}=15.2 \mathrm{fps}
$$

Reynolds:

$$
\mathrm{R}_{\mathrm{e}}=\frac{\rho v \mathrm{D}}{\mu}=\frac{93.5(15.2) 0.2557}{0.0202}=18,000
$$

Pipe Roughness and Friction

$$
\begin{aligned}
& E / D=0.0006 \\
& f=0.0275 \\
& \text { (Table A-23, Crane) (Table A-24, Crane) }
\end{aligned}
$$

Pressure Loss (Per $100 \mathrm{ft}$ of pipe)

$$
\Delta \mathrm{p}=\frac{\rho f \mathrm{Lv}^{2}}{144 \mathrm{D} 2 \mathrm{~g}}=\frac{93.5(0.0275) 100(15.2)^{2}}{144(0.2557) 2(32.2)} \approx 25 \mathrm{psi} / 100 \mathrm{ft}
$$

OR 250 psi for $1000 \mathrm{ft}$ pipe run

Add $10 \%$ for valve and fitting losses plus 180 psi to operate sluicer nozzle:

$1.1(250)+180=456 \mathrm{psi}=$ minimum booster pump pressure

Compare to W320 design pressure of 320 psi.

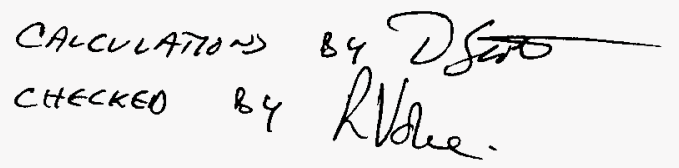


For 4 in. $\oslash$ new line, SCH 40

$$
A_{c} \approx 0.0884 \mathrm{ft}^{2} \quad D=0.3355 \mathrm{ft} \quad \mathrm{d}=4.026 \mathrm{in} .
$$

Velocity:

$$
v \quad=0.408 \mathrm{Q} / \mathrm{d}^{2}=0.408(350) /(6.026)^{2}=8.8 \mathrm{fps}
$$

Reynolds:

$$
\mathrm{R}_{e}=\frac{\rho v D}{\mu}=\frac{23.5(8.8) 0.3355}{0.0202} \approx 13,670
$$

Pipe Roughness and Friction

$$
\begin{aligned}
& \epsilon / \mathrm{D}=0.00045 \quad \text { (Table A-23, Crane) } \\
& f \quad=0.03 \quad \text { (Table A-24, Crane) }
\end{aligned}
$$

Pressure Loss (per $100 \mathrm{ft}$ of pipe)

$$
\Delta \mathrm{p}=\frac{\rho f L v^{2}}{144 \mathrm{D} 2 \mathrm{~g}}=\frac{93.5(0.03) 100(8.8)^{2}}{144(0.3355) 2(32.2)} \approx 7 \mathrm{psi} / 100 \mathrm{ft}
$$

OR 70 psi for $1000 \mathrm{ft}$ pipe run

Add 10\% for valve and fitting losses plus 180 psi to operate sluicer nozzle:

$1.1(70)+180=257 \mathrm{psi}=$ minimum booster pump pressure

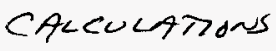
CHECKEO BY
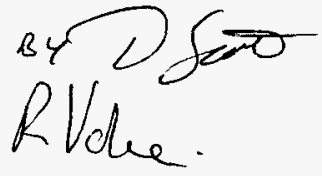
Pressure Drops and $R_{e}$ for Water (at $72{ }^{\circ} \mathrm{F}$ )

\begin{tabular}{l|cccccc|cc} 
& $\mathrm{A}_{\mathrm{c}}$ & $\mathrm{D}$ & $\mathrm{d}$ & $\mathrm{y}$ & $\epsilon / \mathrm{D}$ & \multicolumn{1}{c}{$f$} & \multicolumn{1}{c}{$\mathrm{R}_{\mathrm{e}}$} & $\Delta \mathrm{P}_{100}$ \\
\hline 2 in. $\varnothing$ & 0.0233 & 0.1723 & 2.067 & 33.4 & 0.0009 & 0.02 & 533,500 & $87 . \mathrm{psi}$ \\
3 in. & 0.0513 & 0.2557 & 3.068 & 15.2 & 0.0006 & 0.0185 & 360,300 & 11.2 \\
4 in. & 0.0084 & 0.3355 & 4.026 & 8.8 & 0.0045 & 0.018 & 273,700 & 2.8
\end{tabular}

$$
\begin{aligned}
& \mathrm{Q}=350 \mathrm{gpm} \quad \mu=1 \mathrm{cps}=6.72\left(10^{-4}\right) \frac{\mathrm{lb}}{\mathrm{ft}^{-5}} \\
& \rho \quad=62.3 \mathrm{lb} / f^{\beta}
\end{aligned}
$$

Equations

$$
\begin{aligned}
& \mathrm{v}=0.408 \mathrm{Q} / \mathrm{d}^{2} \\
& \mathrm{R}_{\mathrm{e}}=\frac{\rho \mathrm{\rho D}}{\mu} \\
& \Delta \mathrm{P}_{1003}=\frac{\rho f \mathrm{Lv}^{2}}{144 \mathrm{D} 2 \mathrm{~g}}
\end{aligned}
$$

Friction Factor $(f)$ and relative roughness $(\in / \mathrm{D})$ from Table A-24 and Table A-23, Crane

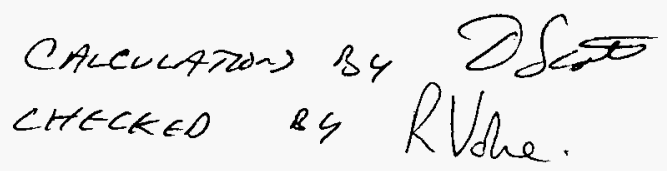




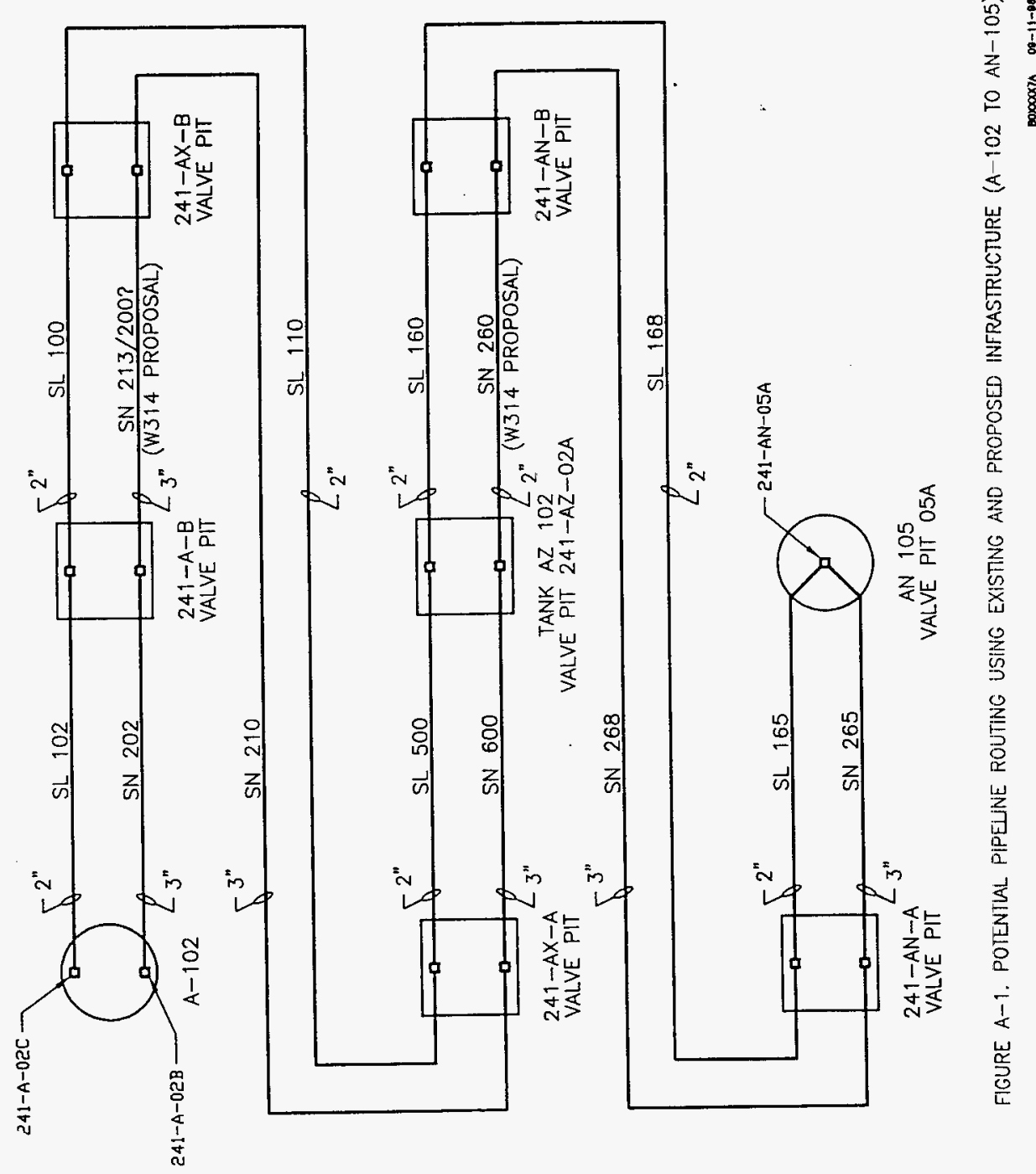




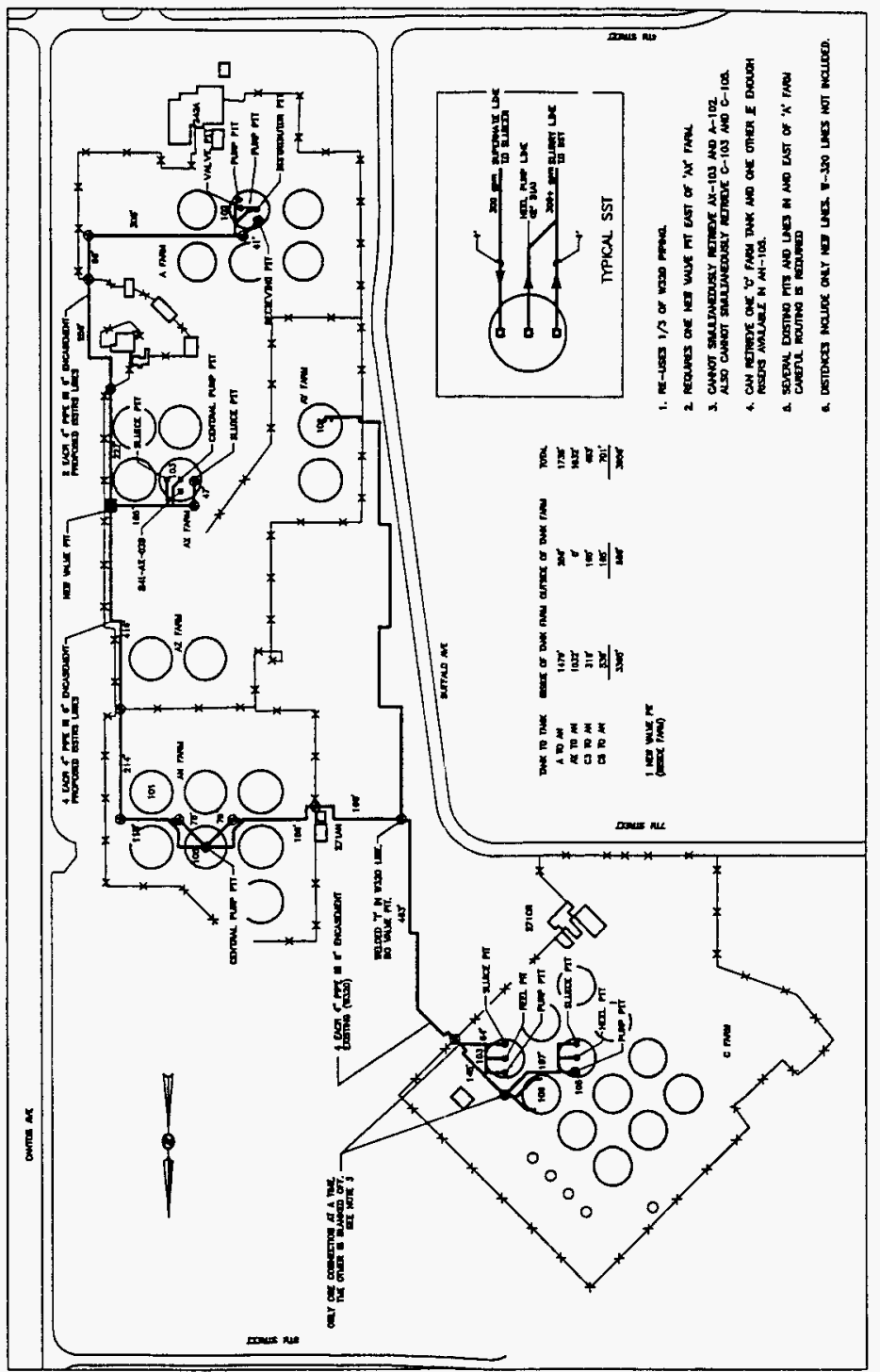

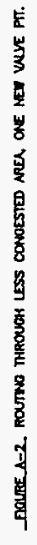




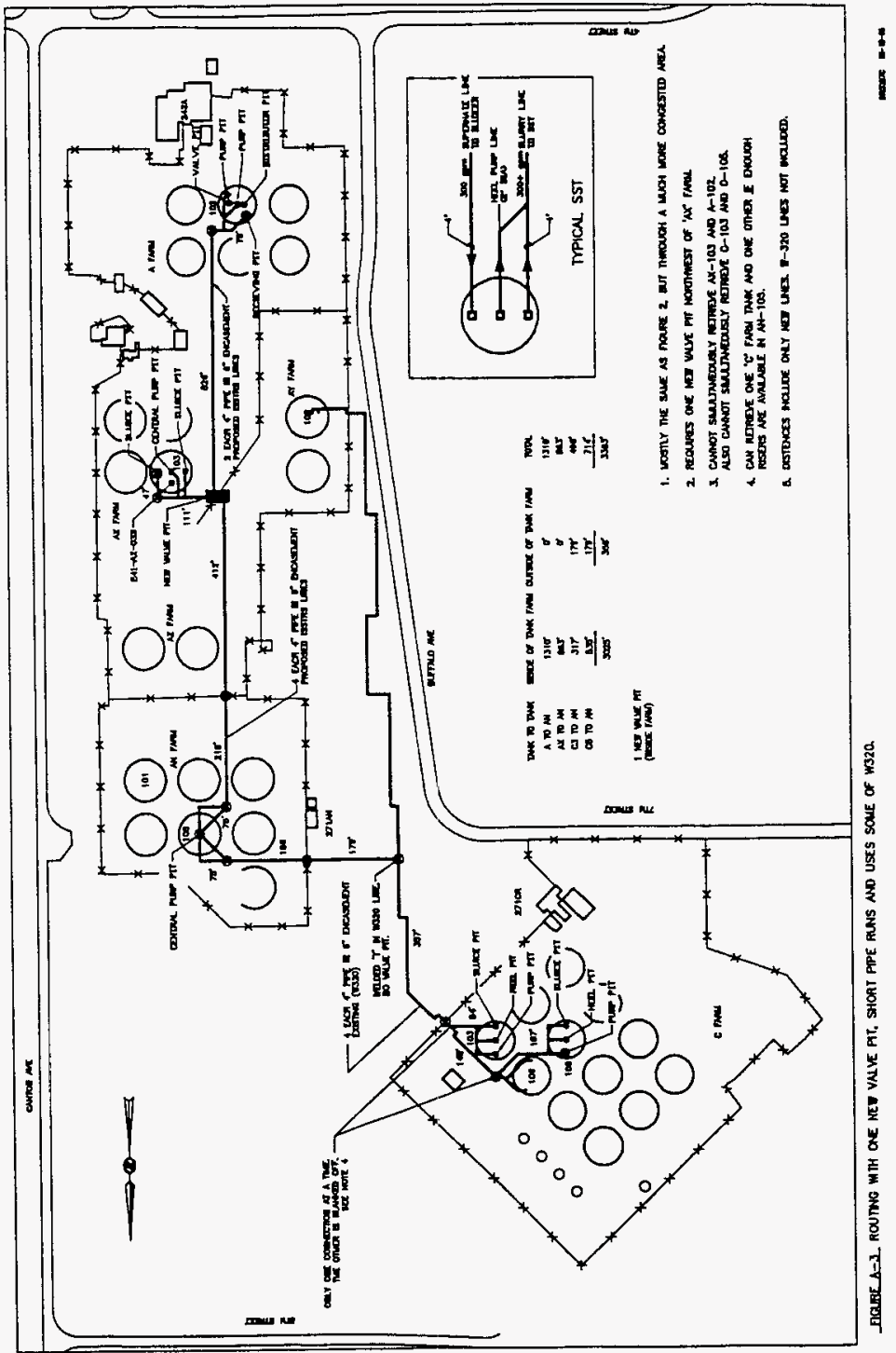




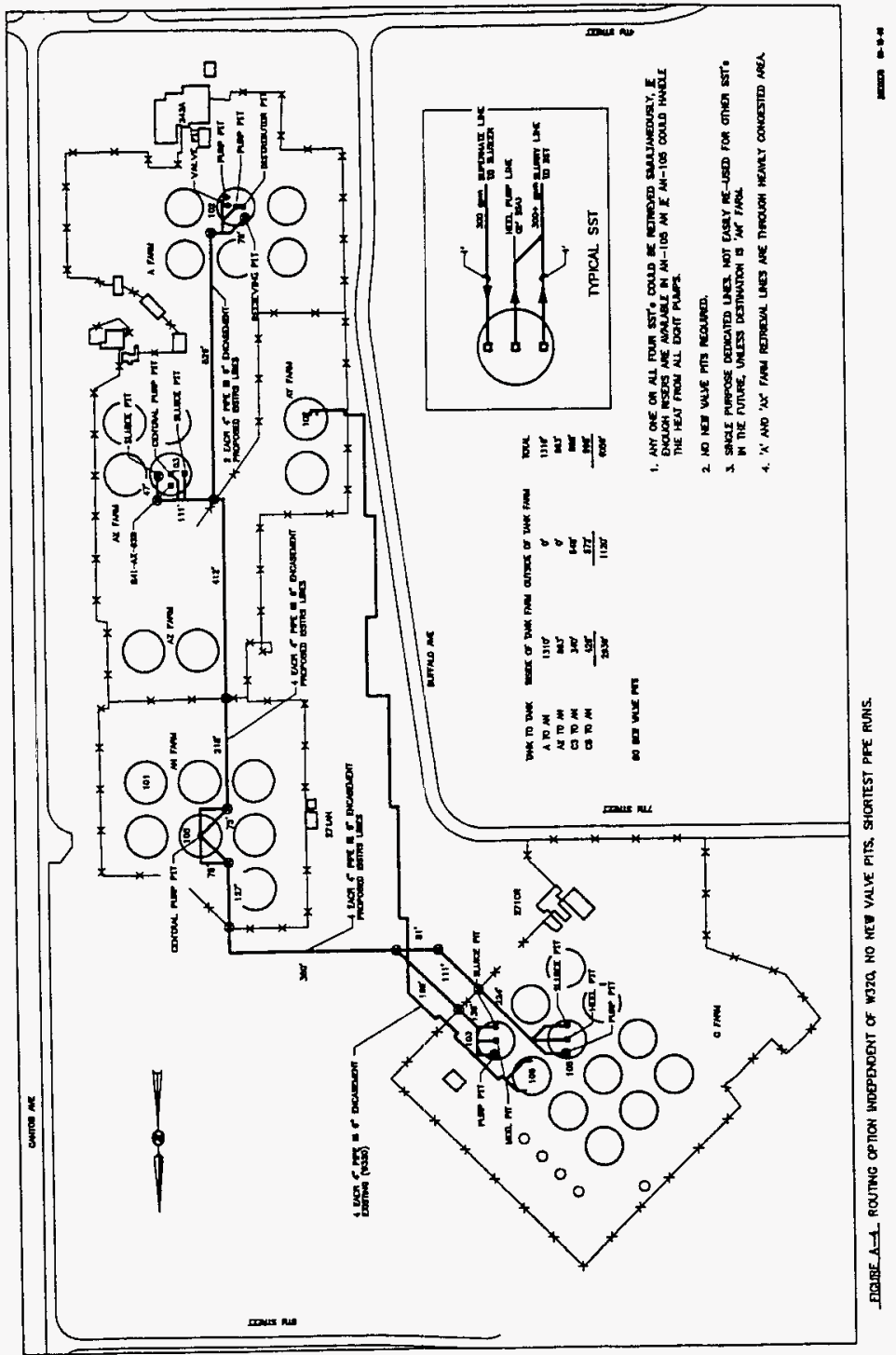


HNF-SD-WM-ES-405 Rev. 0

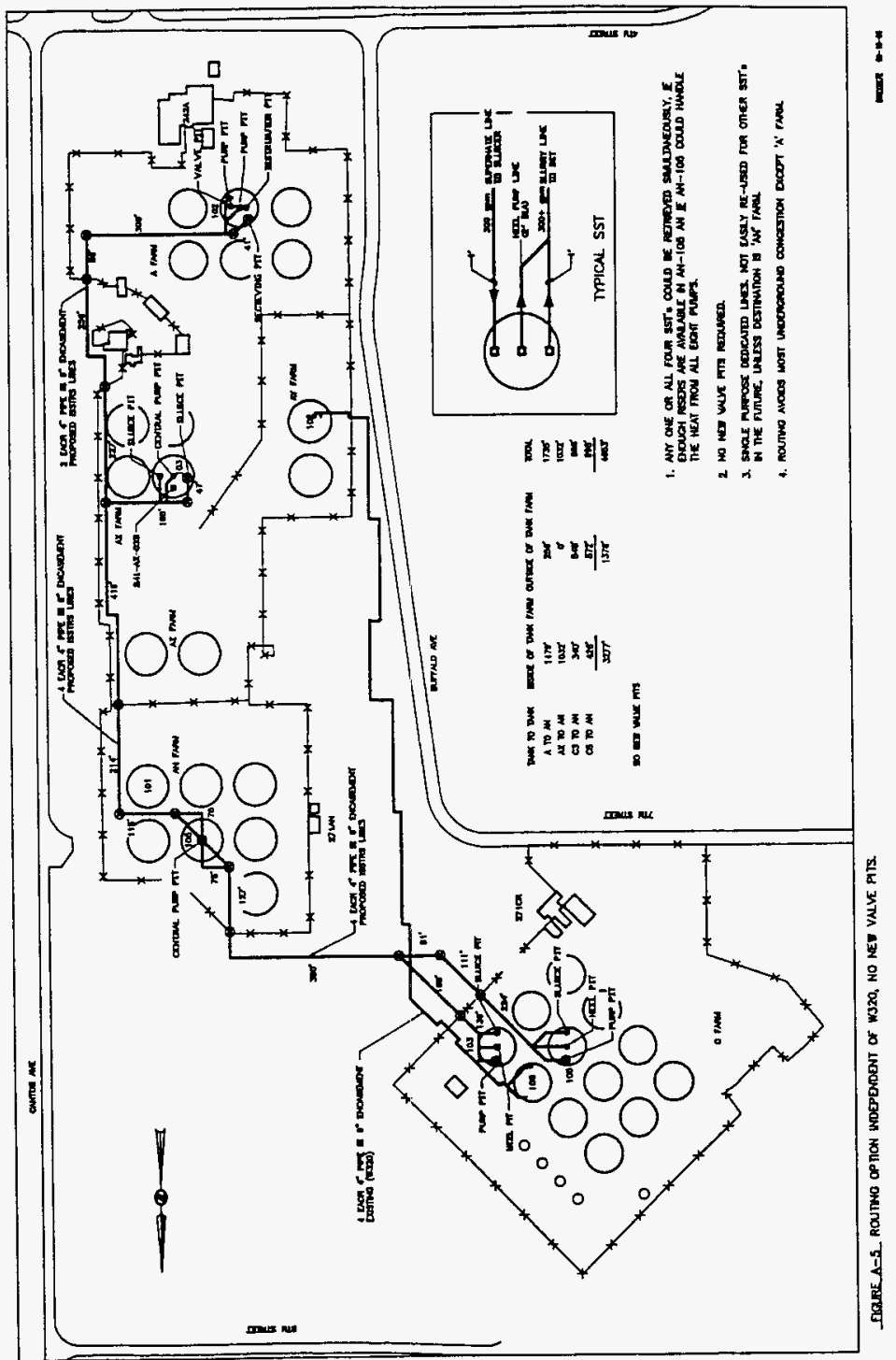


HNF-SD-WM-ES-405 Rev. 0

Review Copy

November 6, 1996

\section{APPENDIX B}


HNF-SD-WM-ES-405 Rev. 0

This page left intentionally blank. 


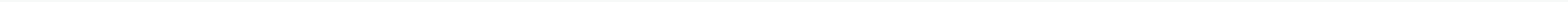


HNF-SD-WM-ES-405 Rev. 0

Review Copy

November 6, 1996

\section{APPENDIX C}


HNF-SD-WM-ES-405

This page left intentionally blank. 


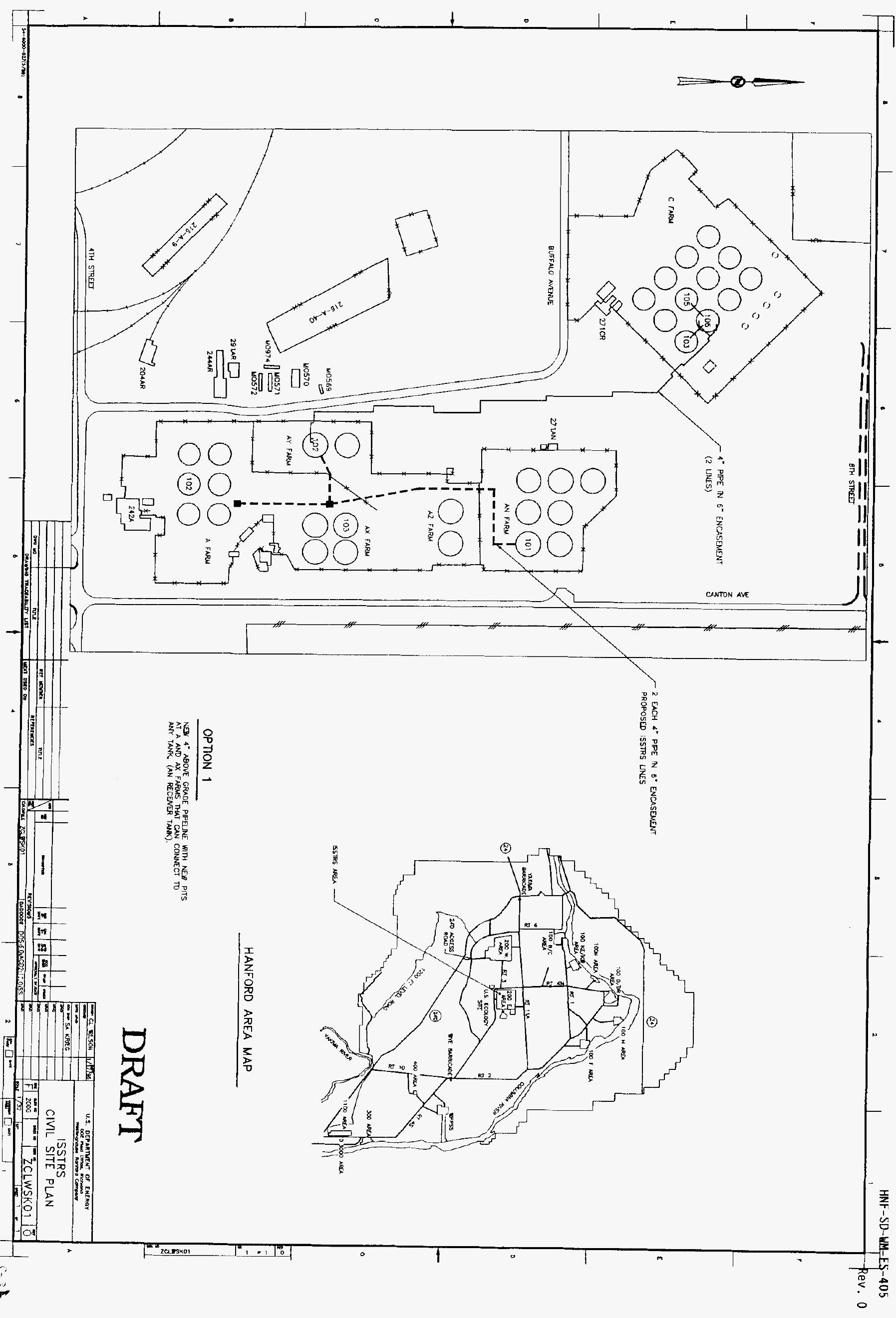




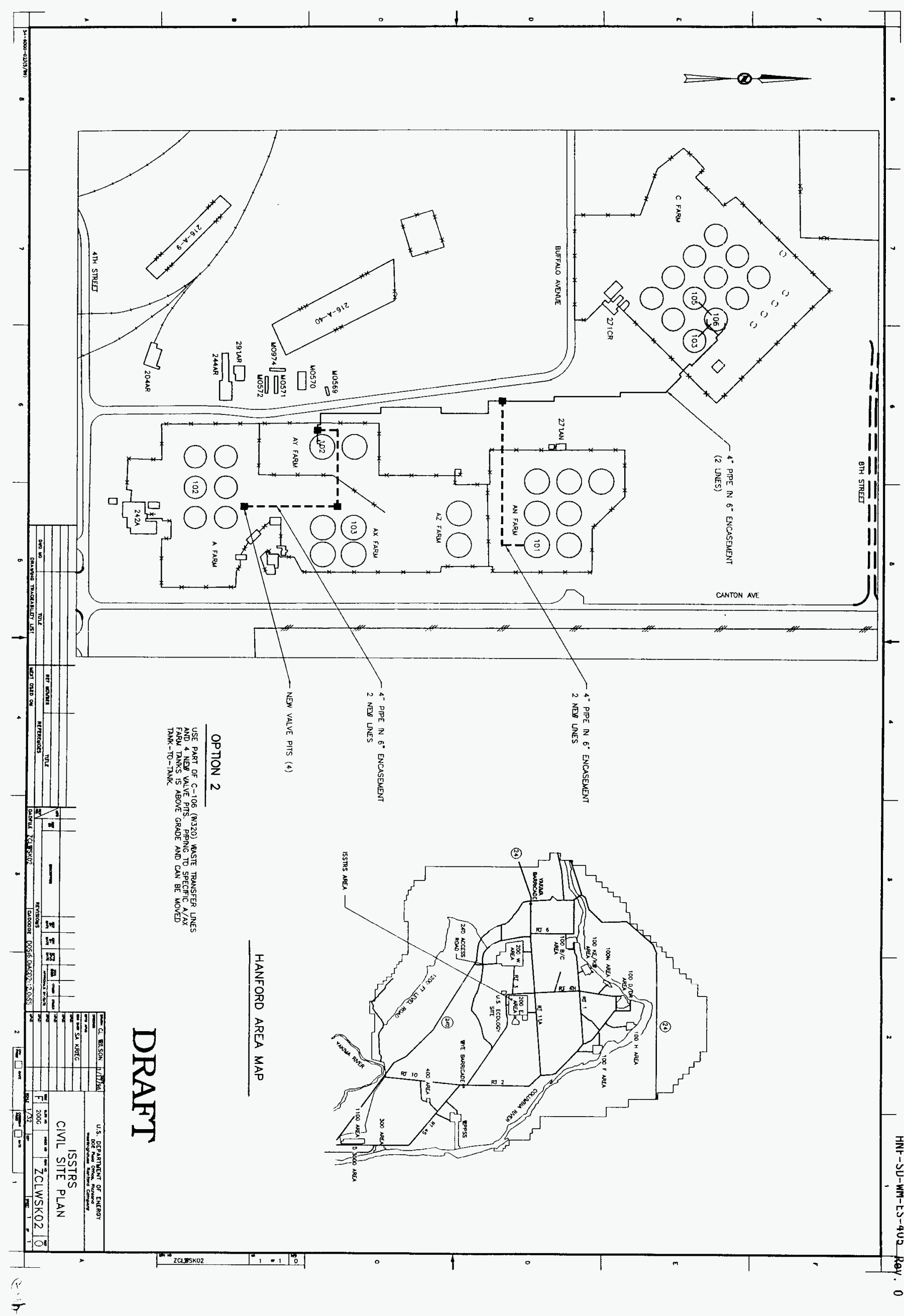




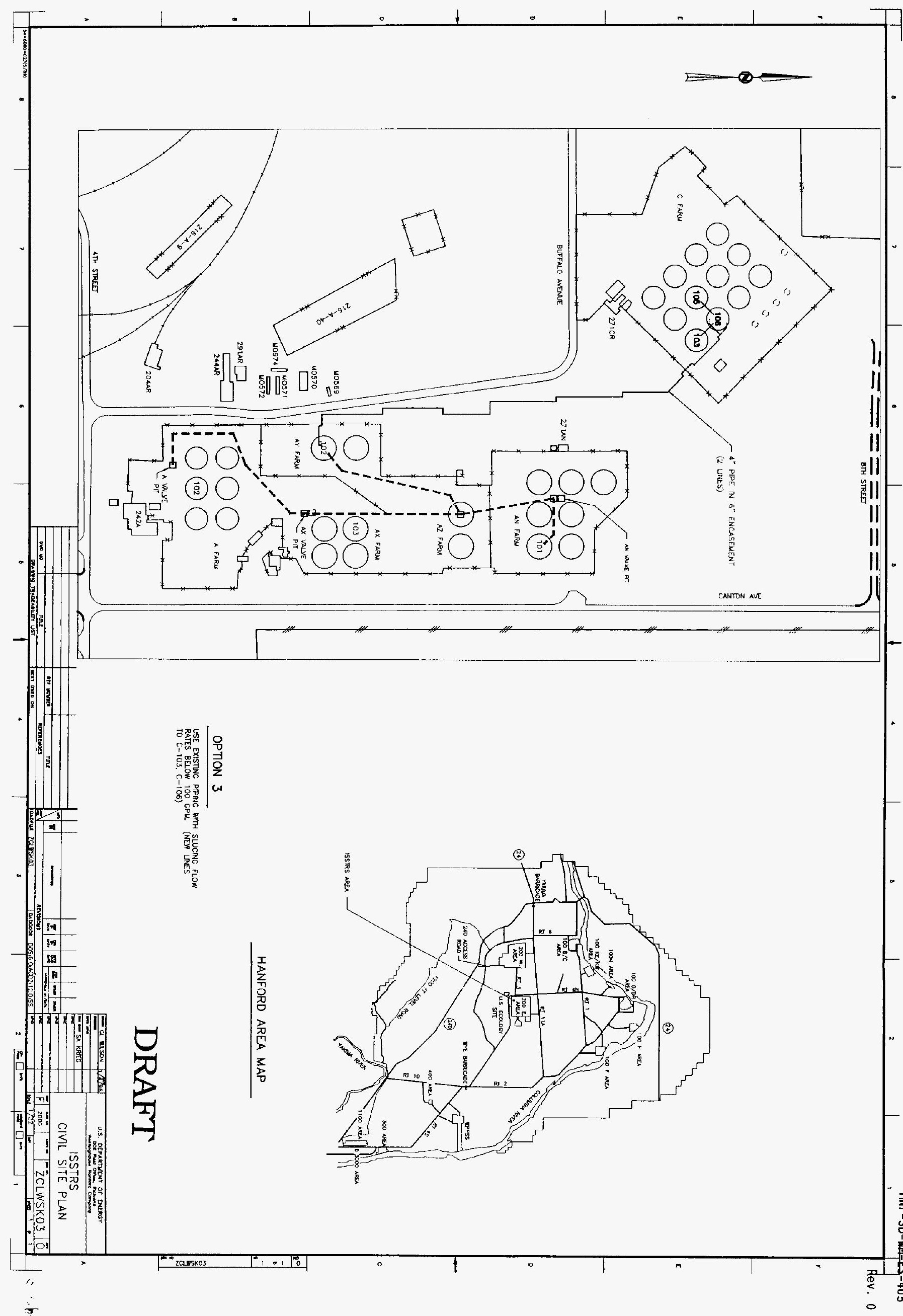




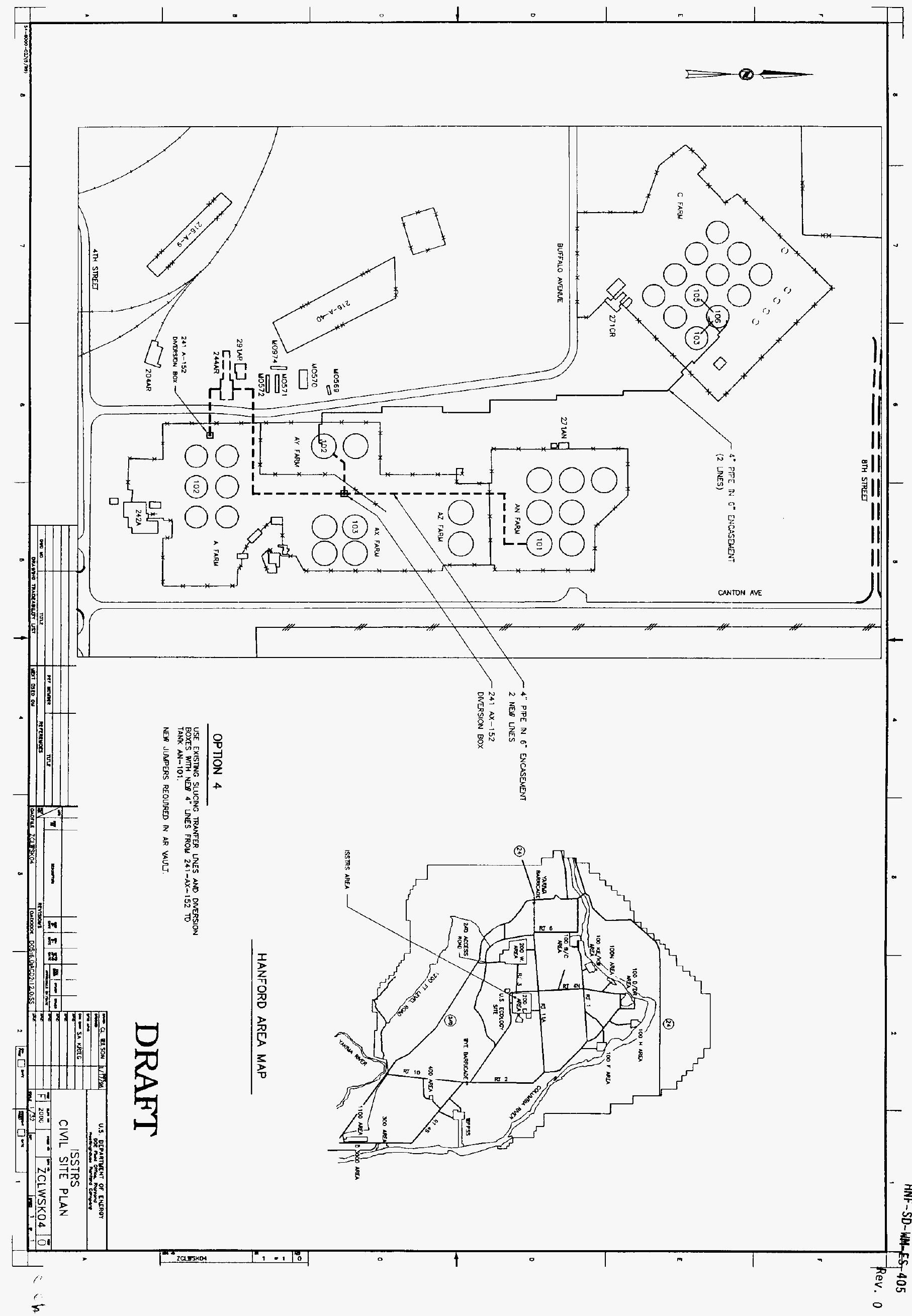




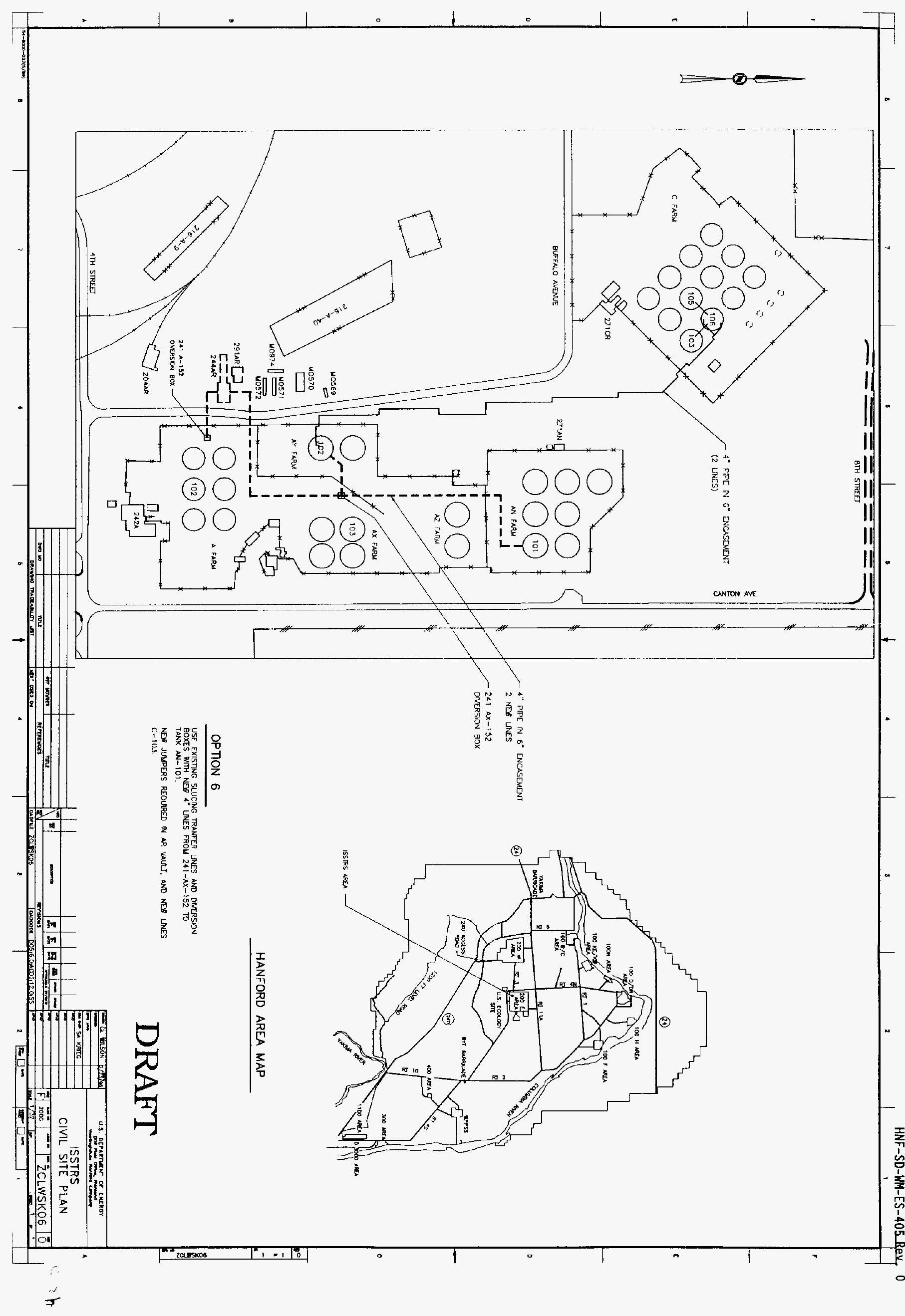




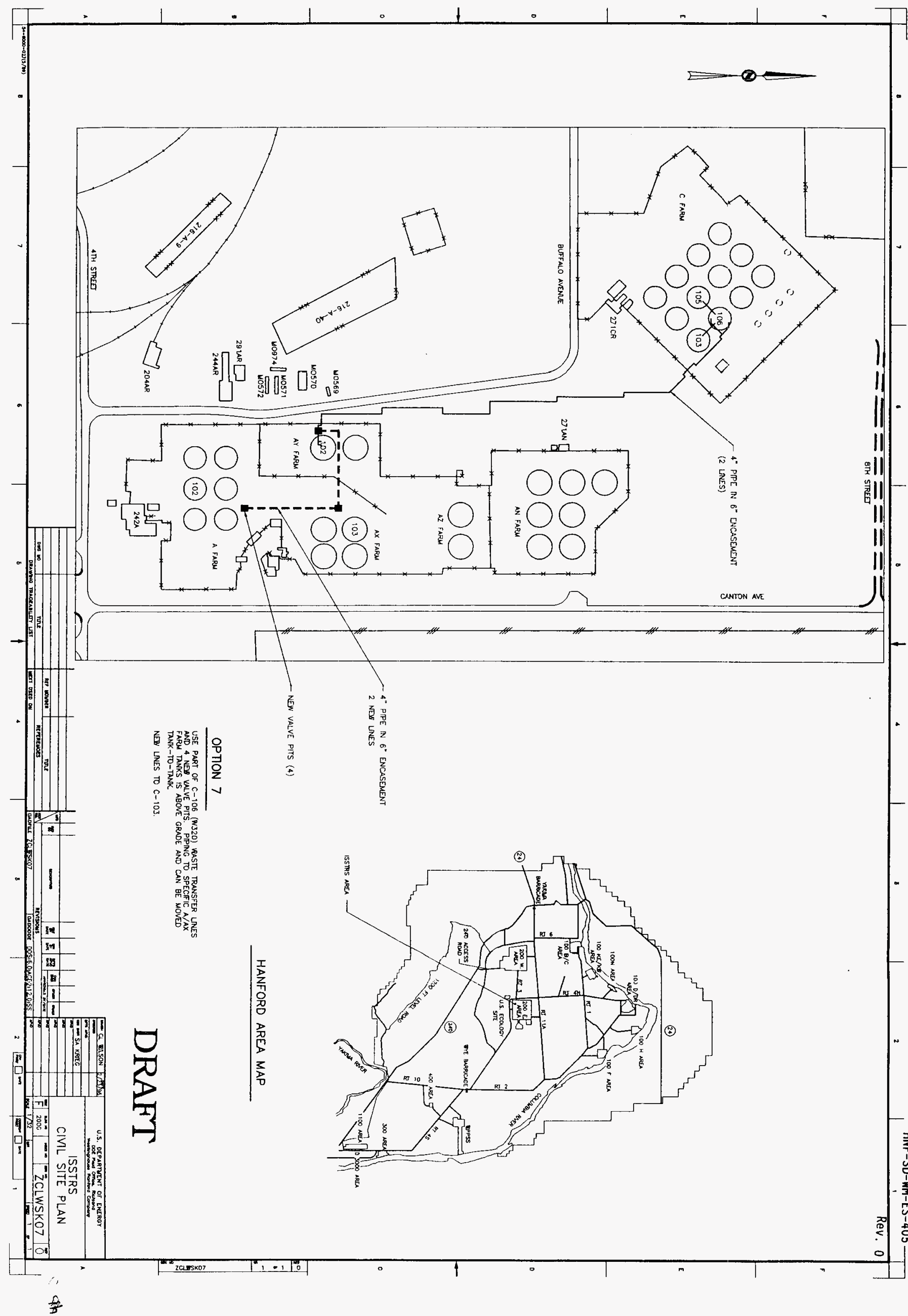




\section{Review Copy}

Prepared By:

LOS ALAMOS TECHNICAL ASSOCIATES, INC.

Richland, WA

Under Purchase Order TJJ-SBW-387700

November 1996 
HNF-SD-WM-ES-405 Rev. 0

Review Copy

November 6, 1996

Approved by:

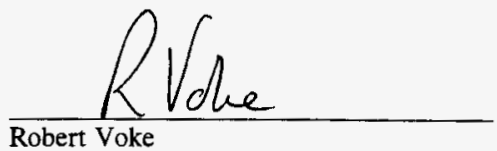

BNFL

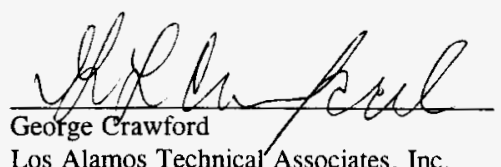

$\frac{11 / 5 / 96}{\text { Date }}$

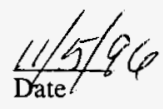


HNF-SD-WM-ES-405 Rev, 0

Review Copy

November 6, 1996

This page left intentionally blank. 


\section{CONTENTS}

1.0 INTRODUCTION $\ldots \ldots \ldots \ldots \ldots \ldots \ldots \ldots \ldots \ldots \ldots \ldots \ldots \ldots \ldots \ldots$

2.0 CONSTRAINTS AND ASSUMPTIONS $\ldots \ldots \ldots \ldots \ldots \ldots \ldots$

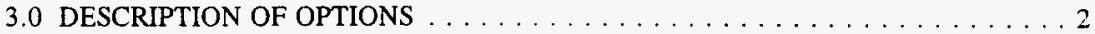

3.1 OPTION 1 - POSITION THE HVAC SYSTEM MIDWAY BETWEEN

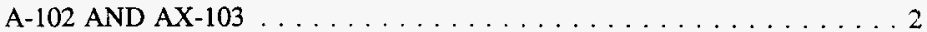

3.2 OPTION 2 - POSITION HVAC SYSTEM AT TANK A-102 . . . . . 3

3.3 OPTION 3 - POSITION HVAC SYSTEMS AT BOTH TANKS A-102

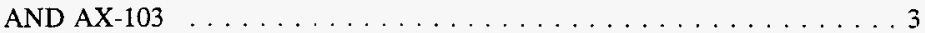

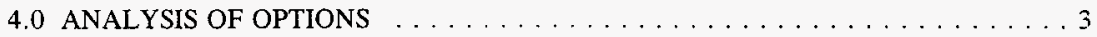

5.0 CONCLUSIONS AND RECOMMENDATIONS $\ldots \ldots \ldots \ldots \ldots \ldots$

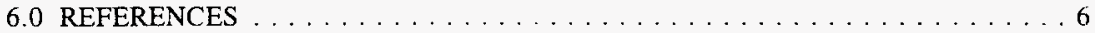

\section{LIST OF TERMS}

HVAC Heating, ventilating, and air conditioning ISSTRS Initial Single-Shell Tank Retrieval System

SST Single-shell tank 
HNF-SD-WM-ES-405 Rev. 0

November 6, 1996

This page left intentionally blank. 


\subsection{INTRODUCTION}

The Initial Single-Shell Tank Retrieval System (ISSTRS) consists of the equipment, hardware, procedures, and systems necessary to retrieve the waste from four Hanford Site single-shell tanks (SSTs). High-level radioactive waste has been stored at the Hanford Site since the early 1940 's as a by-product of processing spent nuclear fuel. Waste volumes in the SSTs vary as does the consistency of the waste (ranging from pumpable liquid, to sludge and hard salt cake).

The overall objective of the ISSTRS Project is to design, fabricate, and install the retrieval systems, waste transfer lines, tank HVAC systems, and infrastructure necessary to begin waste retrieval operations in four SSTs. The conceptual design of the systems and equipment for ISSTRS is based upon the existing Project W-320 (tank C-106) waste retrieval system design. The scope of the ISSTRS Project includes the retrieval of waste from tanks C-103, C-105, A102 , and AX-103 and routing the contents of these tanks to double-shell tank AN-105.

During sluicing operations, the tank ullage space must be kept vented primarily in order to remove heat and to prevent the formation of fog in the tank. The moisture removed from the tank is removed from the offgases by a high-efficiency mist eliminator and other HVAC equipment located in a process building and exhaust skid could service both tanks A-102 and AX-103 at a lower cost than providing separate facilities for each tank.

\subsection{CONSTRAINTS AND ASSUMPTIONS}

The three options discussed in this study are based upon the following assumptions:

- The costs associated with the purchase of the process building/exhaust skid were taken from the Project W-320 cost estimate (KEH 1995).

- The cost of laying new pipe in the tank farms is estimated to be $\$ 3,000$ per foot.

- The cost of running pipe/ducting above ground in the tank farms is estimated at $\$ 2,000$ per foot.

- The cost of process building modifications to add a condensate collection vessel and pump is estimated at $\$ 15,000$.

- The area between the A Tank Farm and the AX Tank Farm is relatively clear and there will be no significant site preparation costs associated with any option: when compared with the other options. 


\subsection{DESCRIPTION OF OPTIONS}

Three options were identified for this study.

- Option 1: Position the HVAC process building and exhaust skid approximately midway between tanks A-102 and AX-103. Option 1 is split into Option 1(a) and Option 1(b). Option 1(a) assumes that all pipework and ducting is run above ground, with the exception of the condensate drain lines, to AX-103. Option 1(b) assumes only the ventilation ducting is run above ground and all the pipework is run below ground level. The issues associated with these options are discussed in Section 3.1 below.

- Option 2: Position the HVAC process building and exhaust skid at A-102 or at $\mathrm{AX}-103$ and run extended pipework from the other tank.

- Option 3: Position HVAC process buildings and exhaust skids at each tank farm.

Each option is described in greater detail below.

\subsection{OPTION 1 - POSITION THE HVAC SYSTEM MIDWAY BETWEEN A-102 ANI AX-103}

The distance between AX-103 and A-102 is approximately 1,000 ft. Hence, there would be the need for approximately $1,000 \mathrm{ft}$ of ventilation ducting. The supports for this ducting would need to be seismically qualified and the duct would have to be routed so traffic patterns around the tank farms are not impacted.

The condensate from the ventilation ducting and the filter units has to be returned to the feed SST. For this to happen, either the process building has to be at a higher elevation than both SSTs (the midpoint between the two tanks is at a lower elevation than A-102) so that it can drain back to the feed tank, or the condensate from A-102 has to be collected in the process building and then pumped back to A-102.

In the first option (Option 1(a)), it would be necessary for the process building to be at least 5 $\mathrm{ft}$ above the existing ground level at the midpoint between the tanks in order for the building to be higher than tank A-102. This arrangement would require all pipework construction to be shielded and seismically qualified. It would also impact traffic patterns between the HVAC facilities and A-102. 
In the second option (Option $1 \mathrm{~b}$ ), the condensate has to be pumped back to tank A-102; hence, the condensate lines could be buried. If the condensate lines are buried and the ventilation duct is run at high level, there will be limited impact to vehicular access around the tanks.

\subsection{OPTION 2 - POSITION HVAC SYSTEM AT TANK A-102}

The issues associated with this option are largely the same as those associated with Option 1. The main difference is: if the process building is positioned near tank A-102, condensation would drain by gravity back to tank $\mathrm{AX}-103$ and $\mathrm{A}-102$ from the process building. Hence, there would be no need to collect condensate and pump it back to the tank.

\subsection{OPTION 3 - POSITION HVAC SYSTEMS AT BOTH TANKS A-102 AND AX-103}

This option would not require long pipe/duct runs within the tank farms and hence would cause least impact on traffic patterns around the tank farms. However, this option would incur the cost of purchasing a second HVAC process building and exhaust skid.

\subsection{ANALYSIS OF OPTIONS}

All of the options discussed above could satisfy the needs of this project in terms of meeting the process requirements. The principal difference between the options is cost, and, to a lesser extent, the impact on traffic patterns around the tank farms. For the purpose of this study a comparison of the costs for each option will be used as a basis for determining the preferred option. The costs for each option and the basis for the estimates are given below.

\section{Option 1(a)}

Process building

Process building modifications

Exhaust system

Above ground piping/duct

Buried piping

Total cost

$\$ 108,600 \quad$ Includes sales tax and warehousing.

$\$ 15,000$ Condensate collection/pumping.

$\$ 207,352$ Includes sales tax and warehousing.

$\$ 2,000,000 \quad(1,000 \mathrm{ft} \times \$ 2,000 / \mathrm{ft})$

$\$ 1.500,000 \quad(500 \mathrm{ft} \times \$ 3,000 / \mathrm{ft})$

$\$ 3,830,952$ 


\section{Option 1(b)}

Process building

Process building modifications

Exhaust system

Above ground piping/duct

Buried piping

Total cost
$\$ 108,600 \quad$ Includes sales tax and warehousing.

$\$ 15,000$ Condensate collection/pumping.

$\$ 207,352$ Includes sales tax and warehousing.

$\$ 2,000,000 \quad(1,000 \mathrm{ft} \times \$ 2,000 / \mathrm{ft})$

$\$ 3.000 .000 \quad(1,000 \mathrm{ft} \times \$ 3,000 / \mathrm{ft})$

\section{Option 2}

Process building

$\$ 108,600 \quad$ Includes sales tax and warehousing.

Exhaust system

$\$ 207,352$

Above ground piping/duct

$\$ 2,000,000$ Includes sales tax and warehousing.

Buried piping

Total cost

$\$ 3.000,000$

$(1,000 \mathrm{ft} \times \$ 2,000 / \mathrm{ft})$

$\$ 5,315,952$

\section{Option 3}

Process building

Exhaust system

Above ground piping/duct

Buried piping

Total cost
$\$ 217,200 \quad$ Includes sales tax and warehousing. $\$ 414,704$ Includes sales tax and warehousing.

$\$ 400,000 \quad(200 \mathrm{ft} \times \$ 2,000 / \mathrm{ft})$

$\$ 600,000 \quad(200 \mathrm{ft} \times \$ 3,000 / \mathrm{ft})$

The estimates for the process building and the exhaust system are taken from the Project W320 cost estimate (KEH 1995). The costs for piping/ducting and process building modifications are based on engineering judgement. However, even if the cost of pipework on the Tank Farms was only $\$ 1,000$ per foot and all piping/ducting in Option 1(a) were run together above ground, Option 3 still is marginally better on cost grounds $(\$ 1,330,952$ for Option 1 and $\$ 1,031,904$ for Option 3). 


\subsection{CONCLUSIONS AND RECOMMENDATIONS}

Option 3 is selected as the preferred alternative on grounds of cost and because it would have the least impact on the traffic patterns in the tank farm area. An additional benefit of this option is that future retrieval projects will be able .0 INTRODUCTION . . . . . . . .

\subsection{REFERENCES}

KEH, 1995, Tank 241-C-106 Sluicing, 90\% Preliminary Estimate, IEST Project Cost Summary, Kaiser Engineers Hanford, Richland, Washington. 


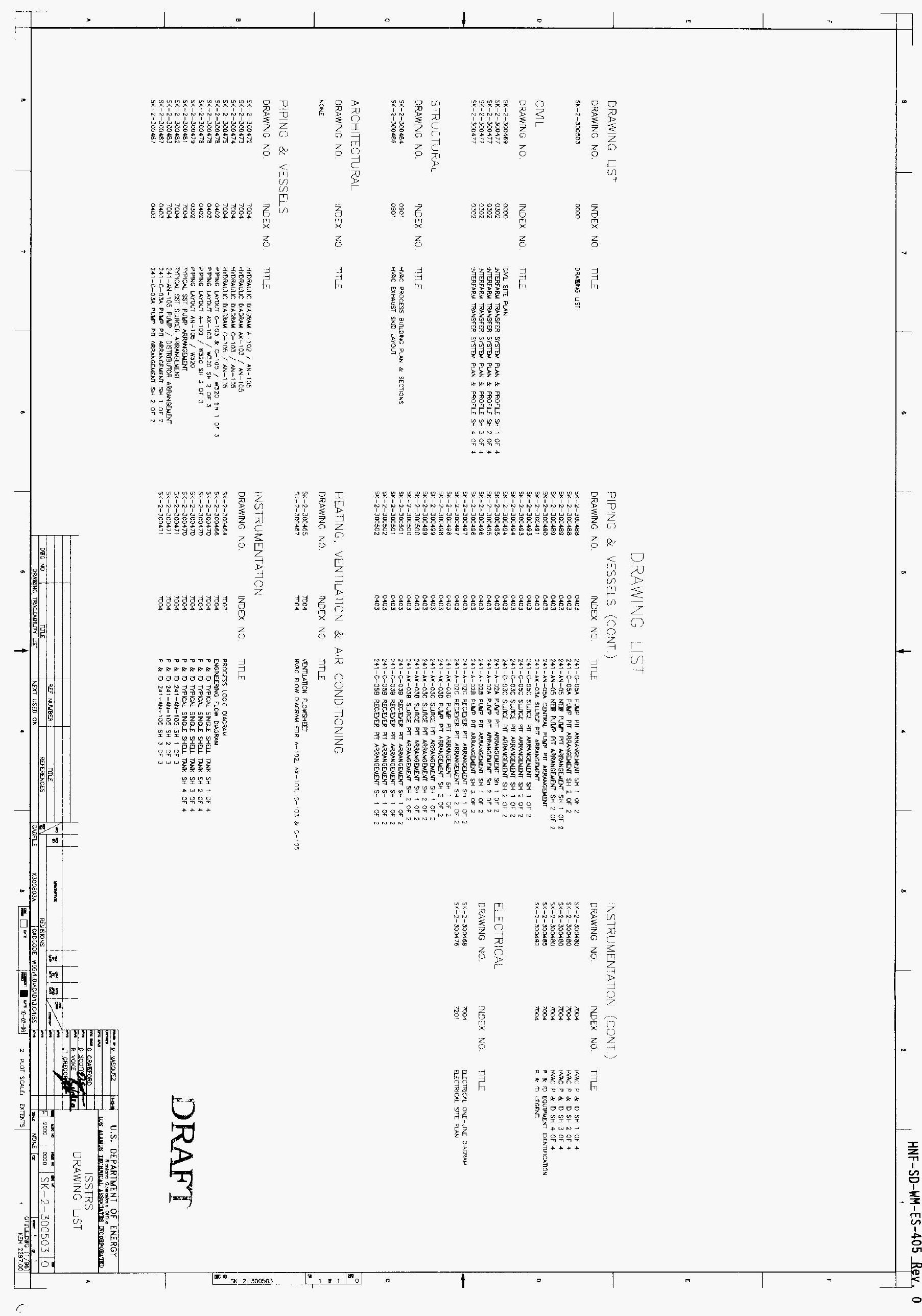




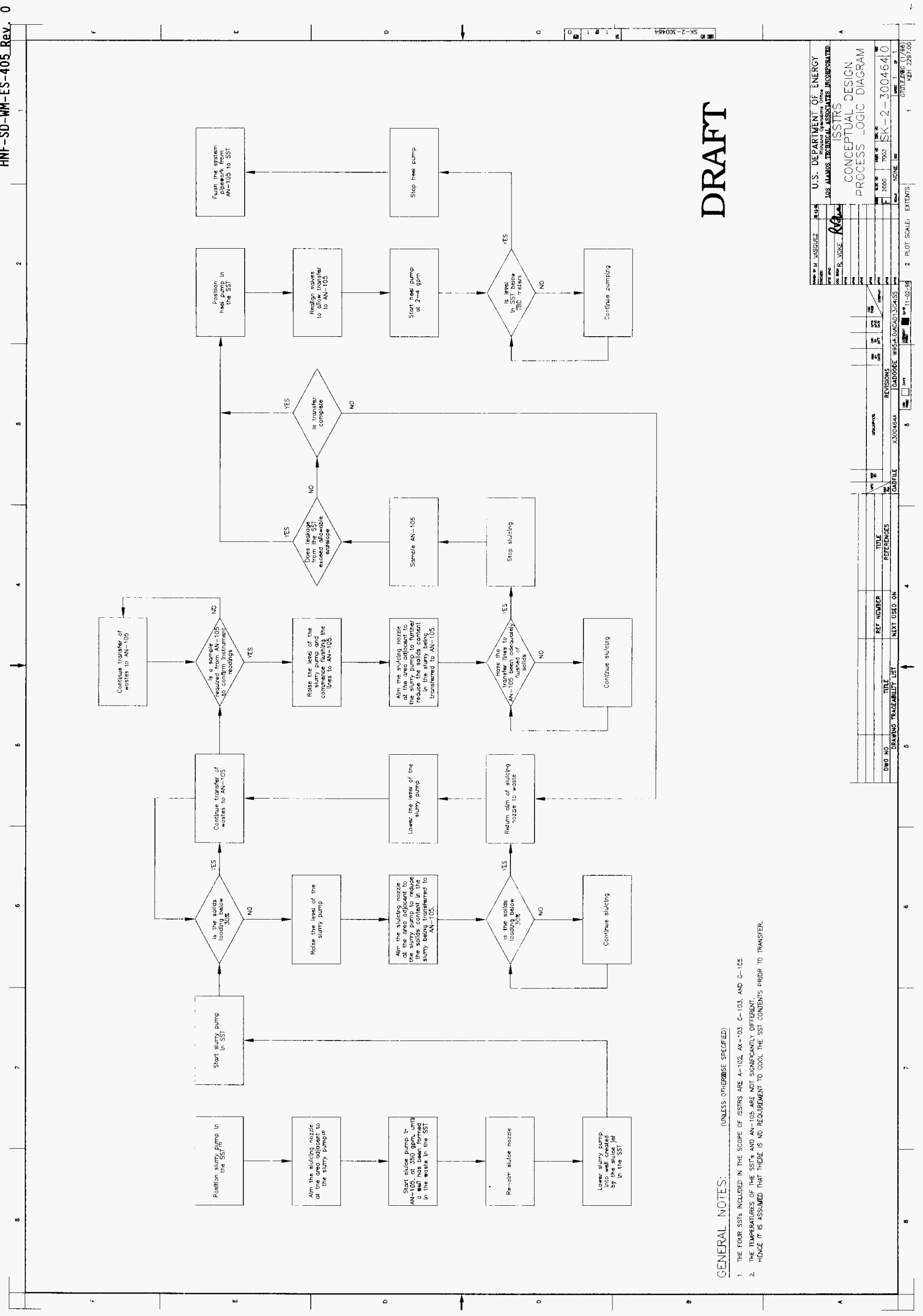




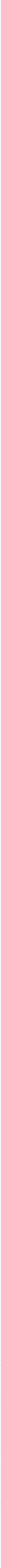




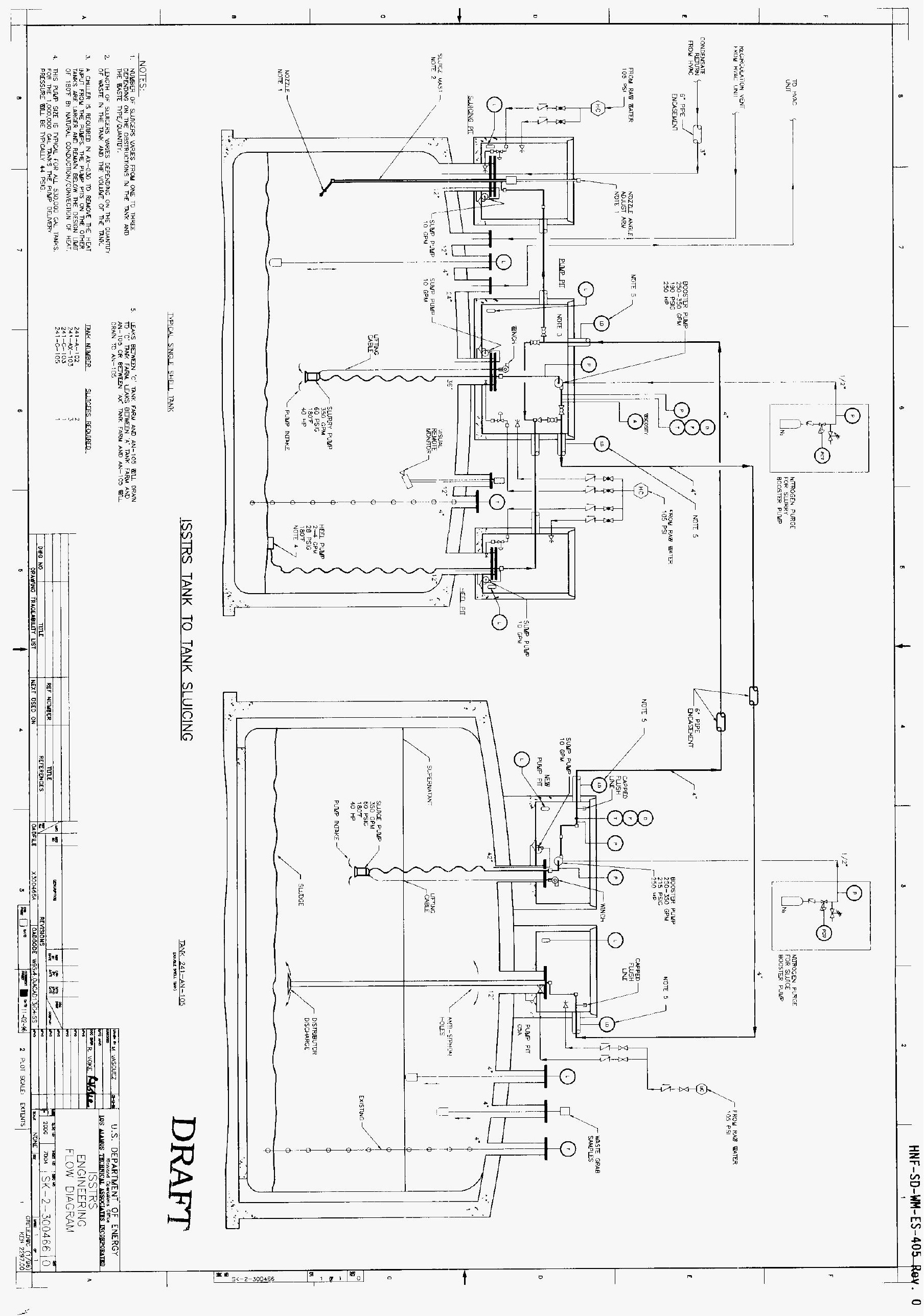




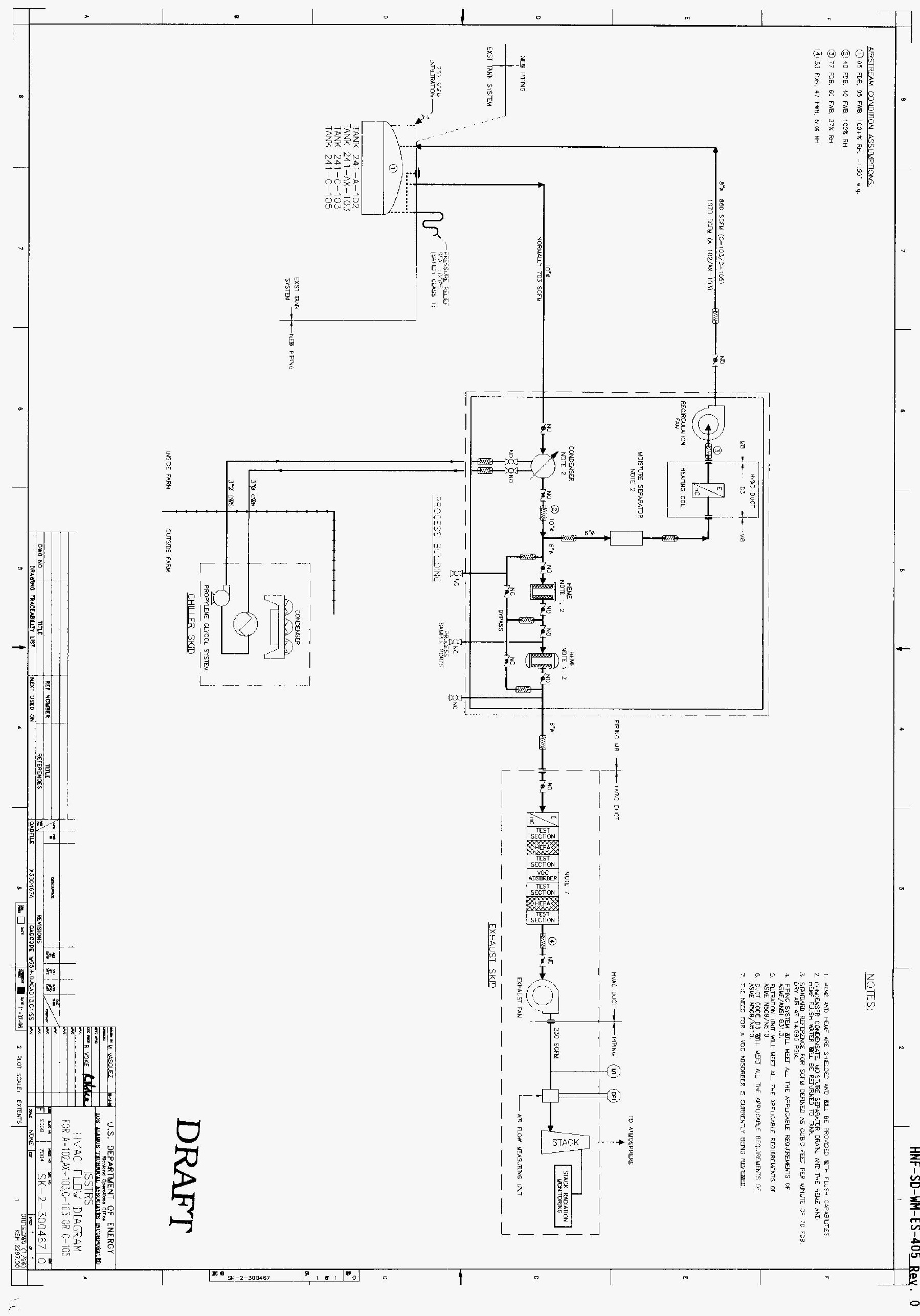




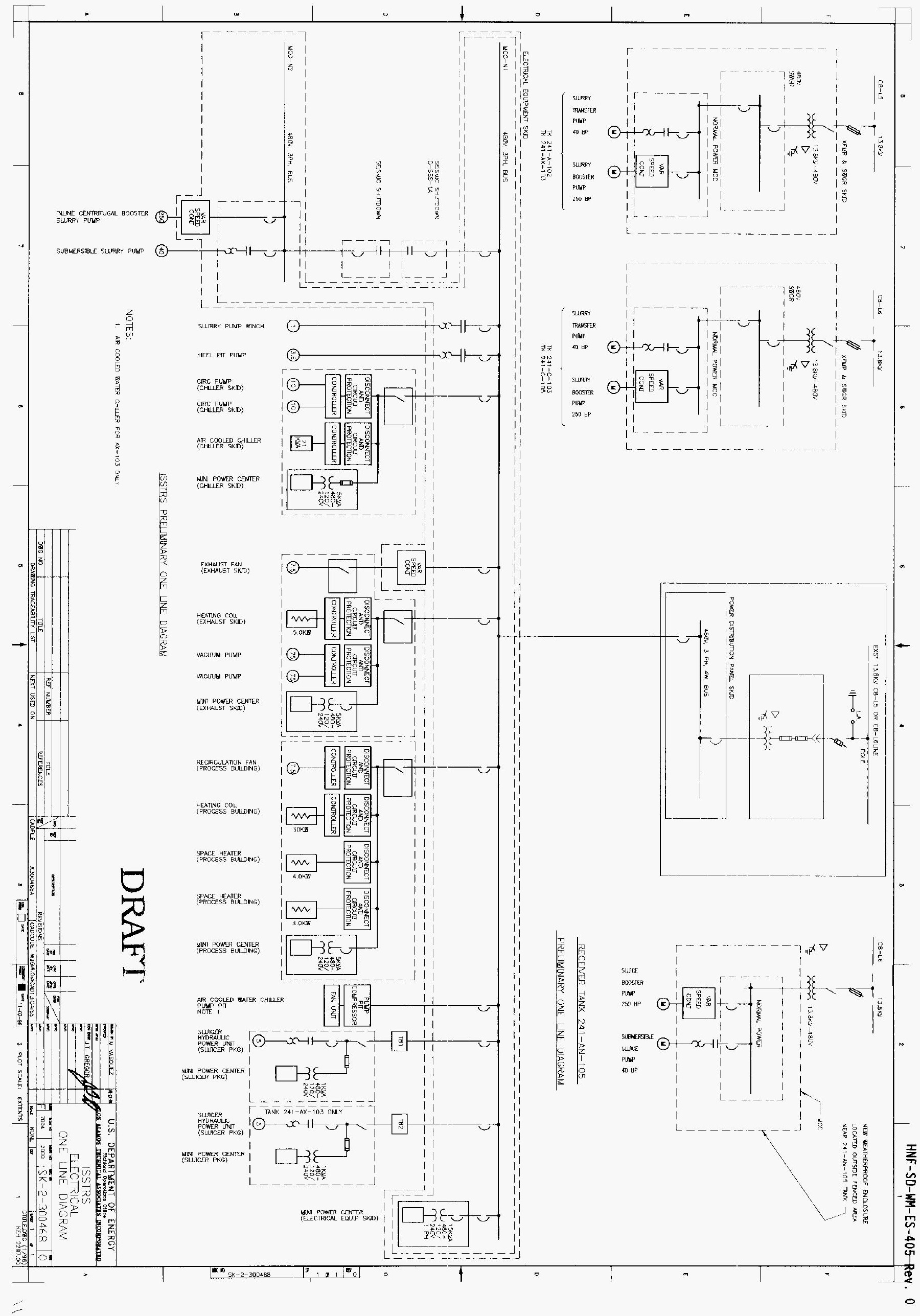




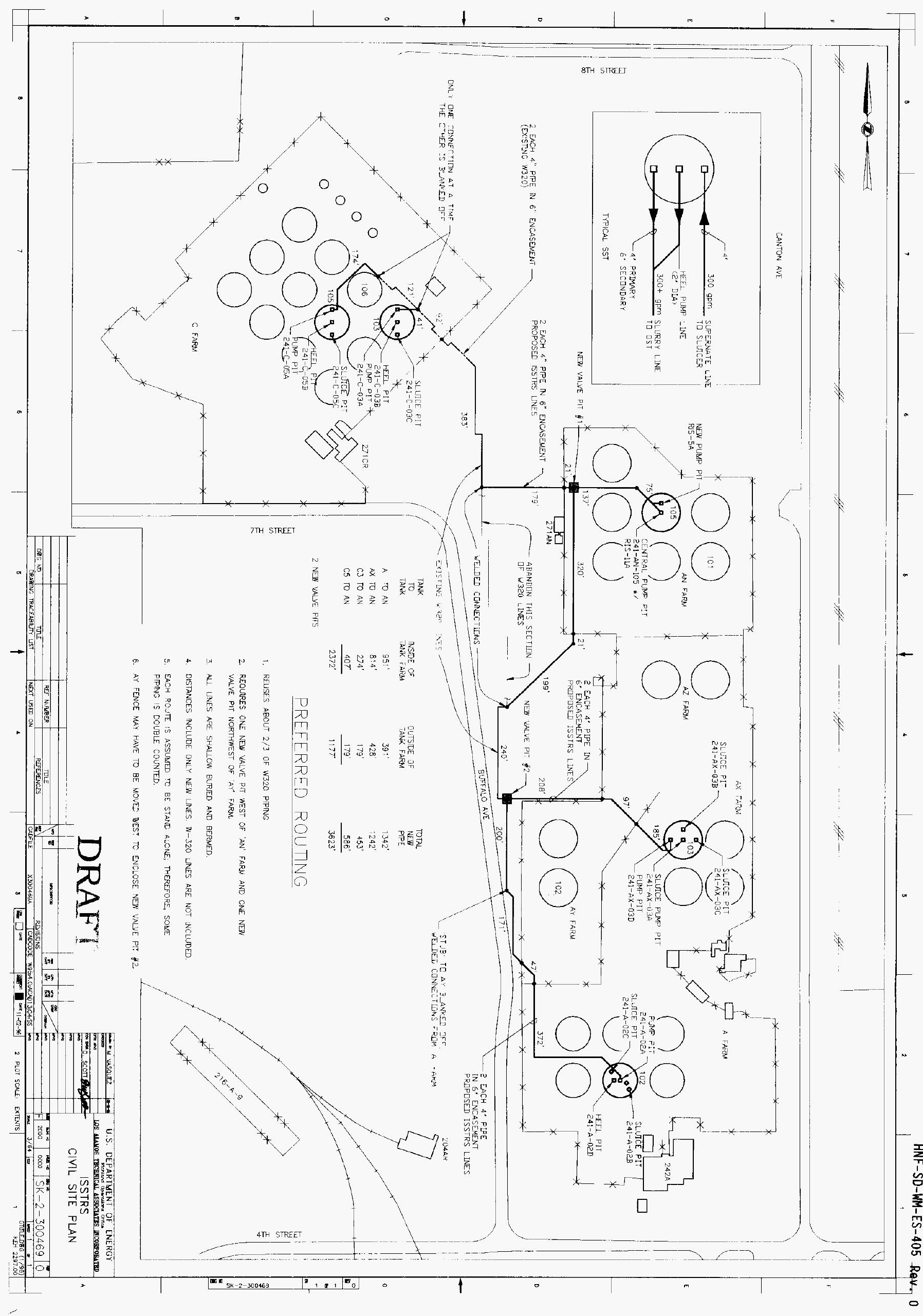




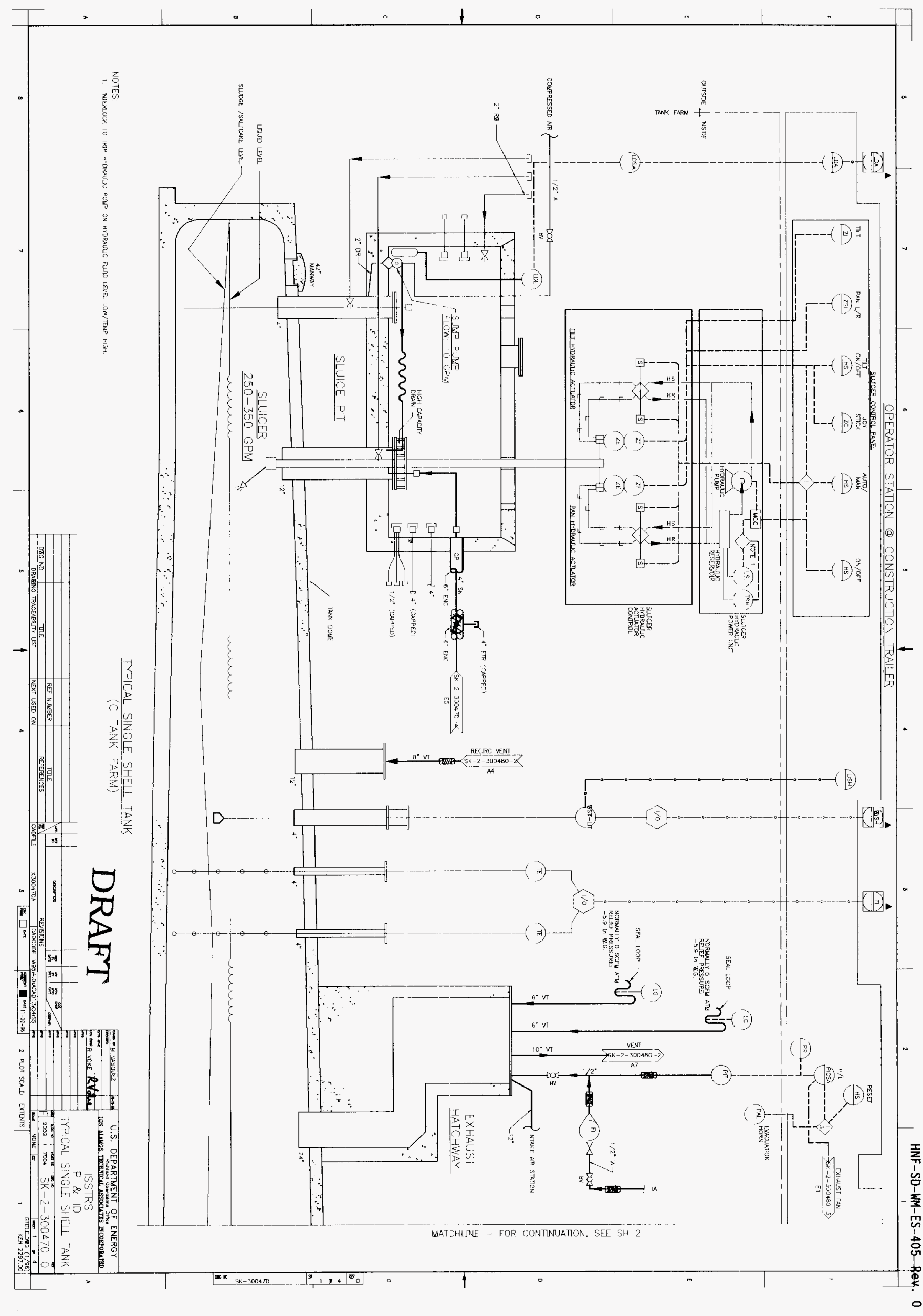




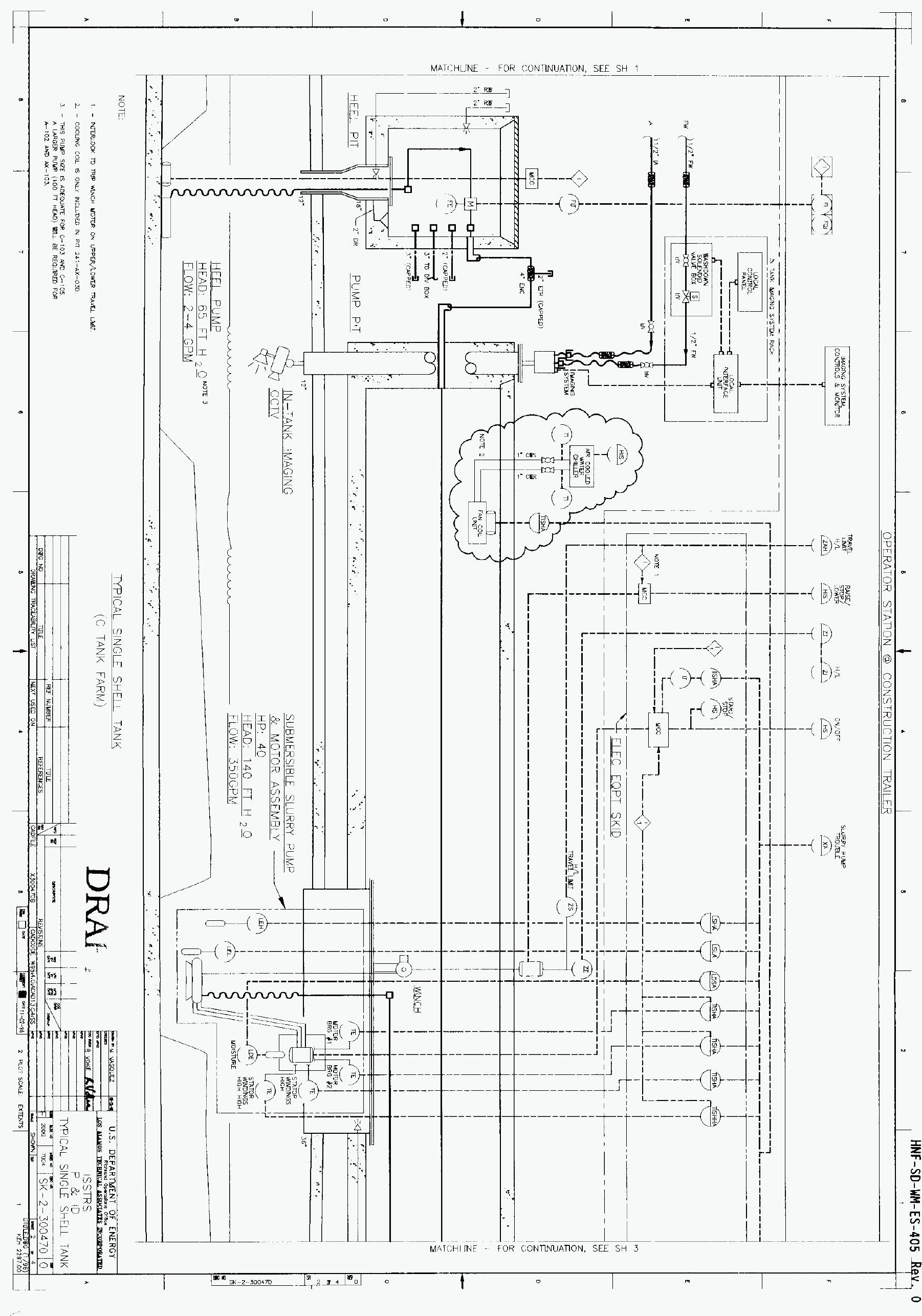




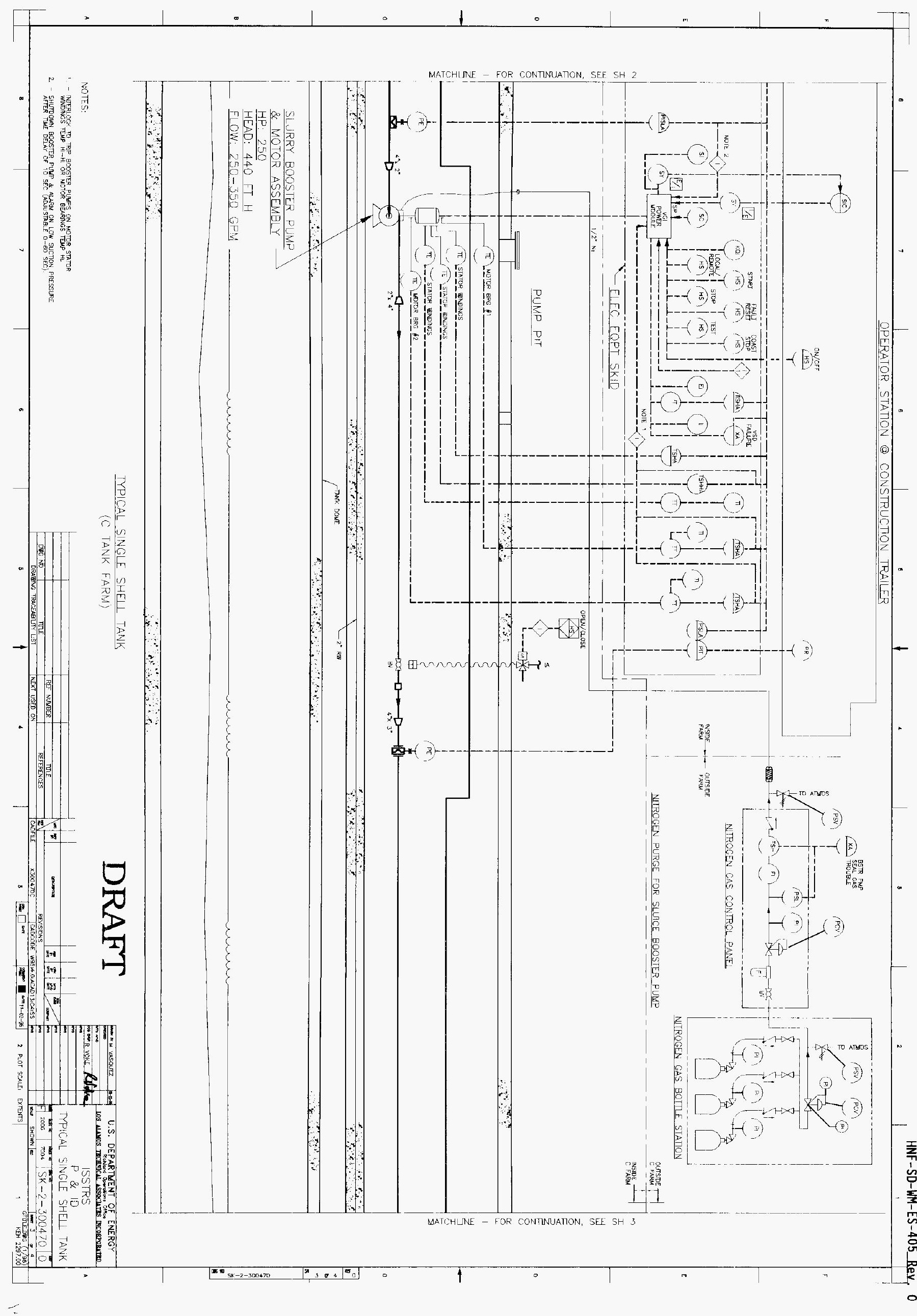




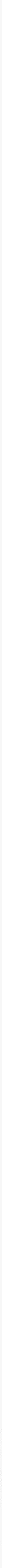




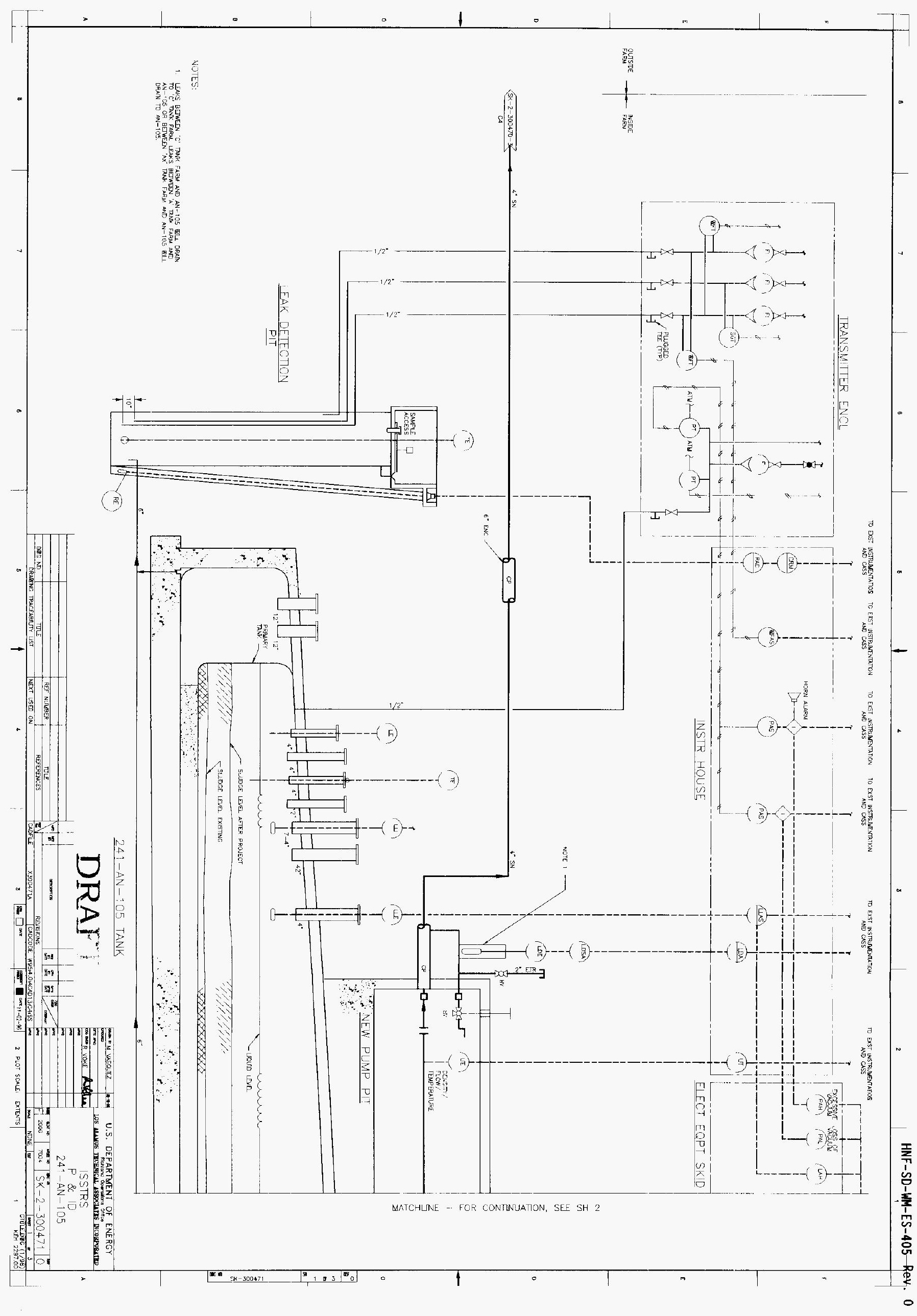




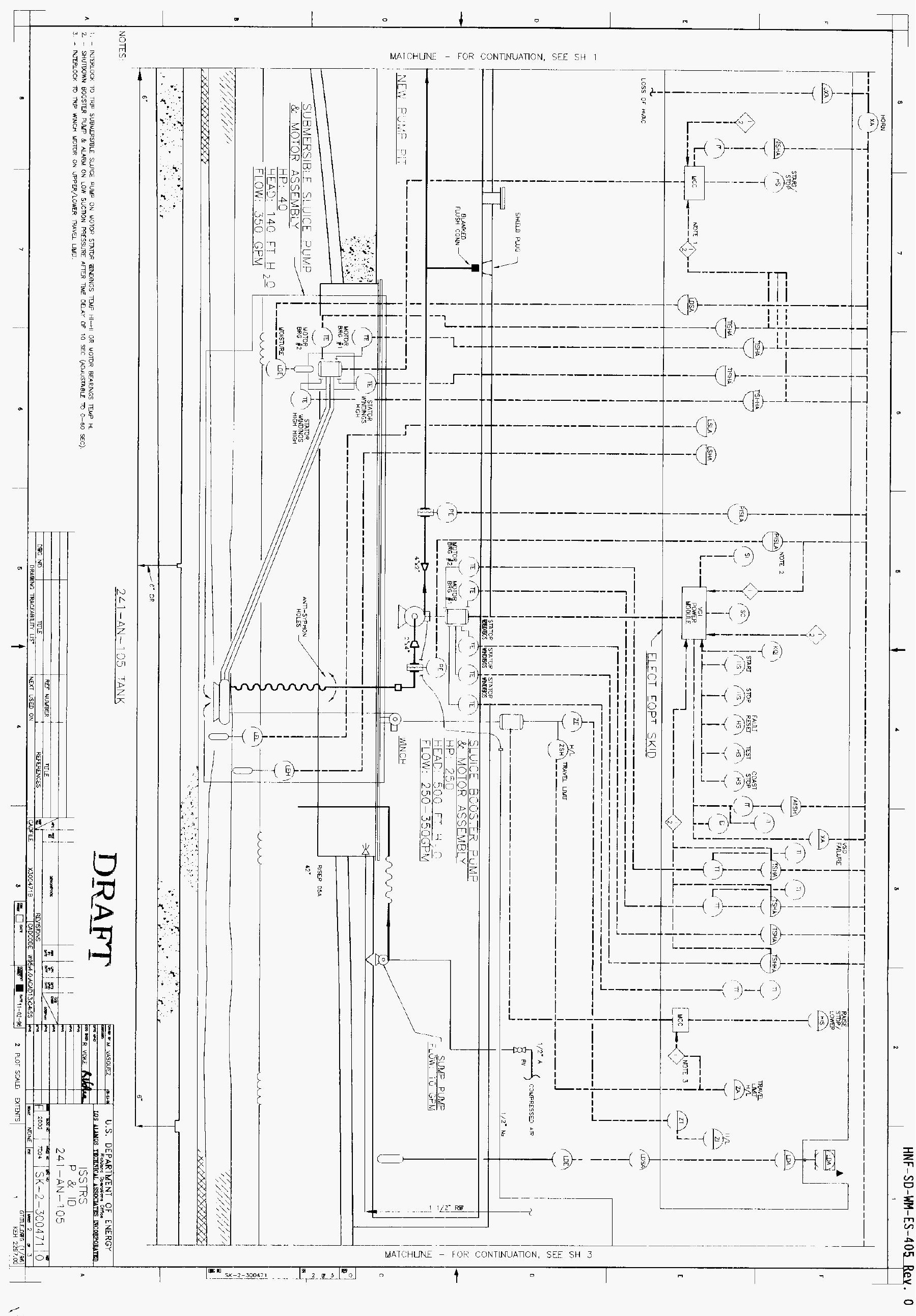




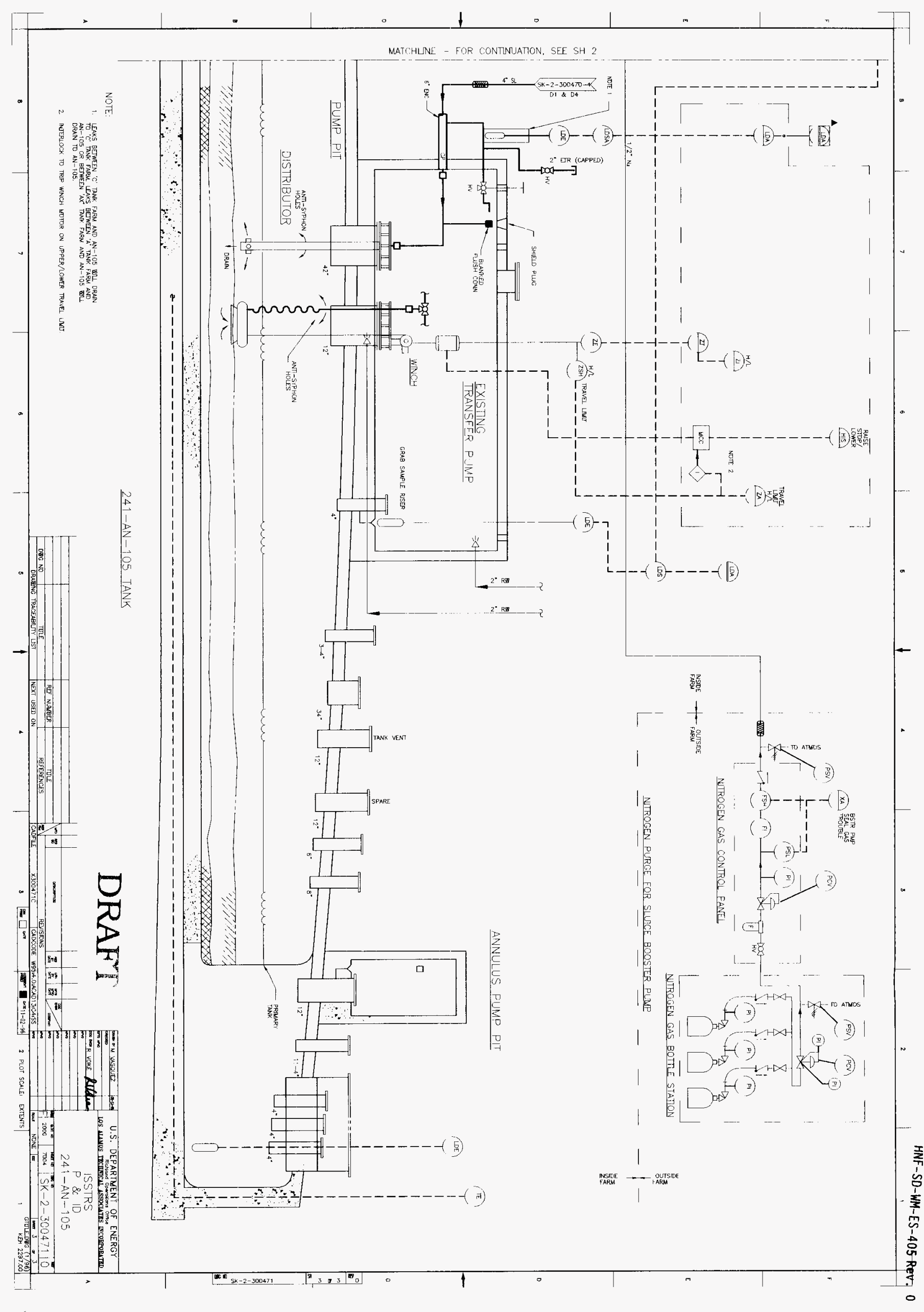




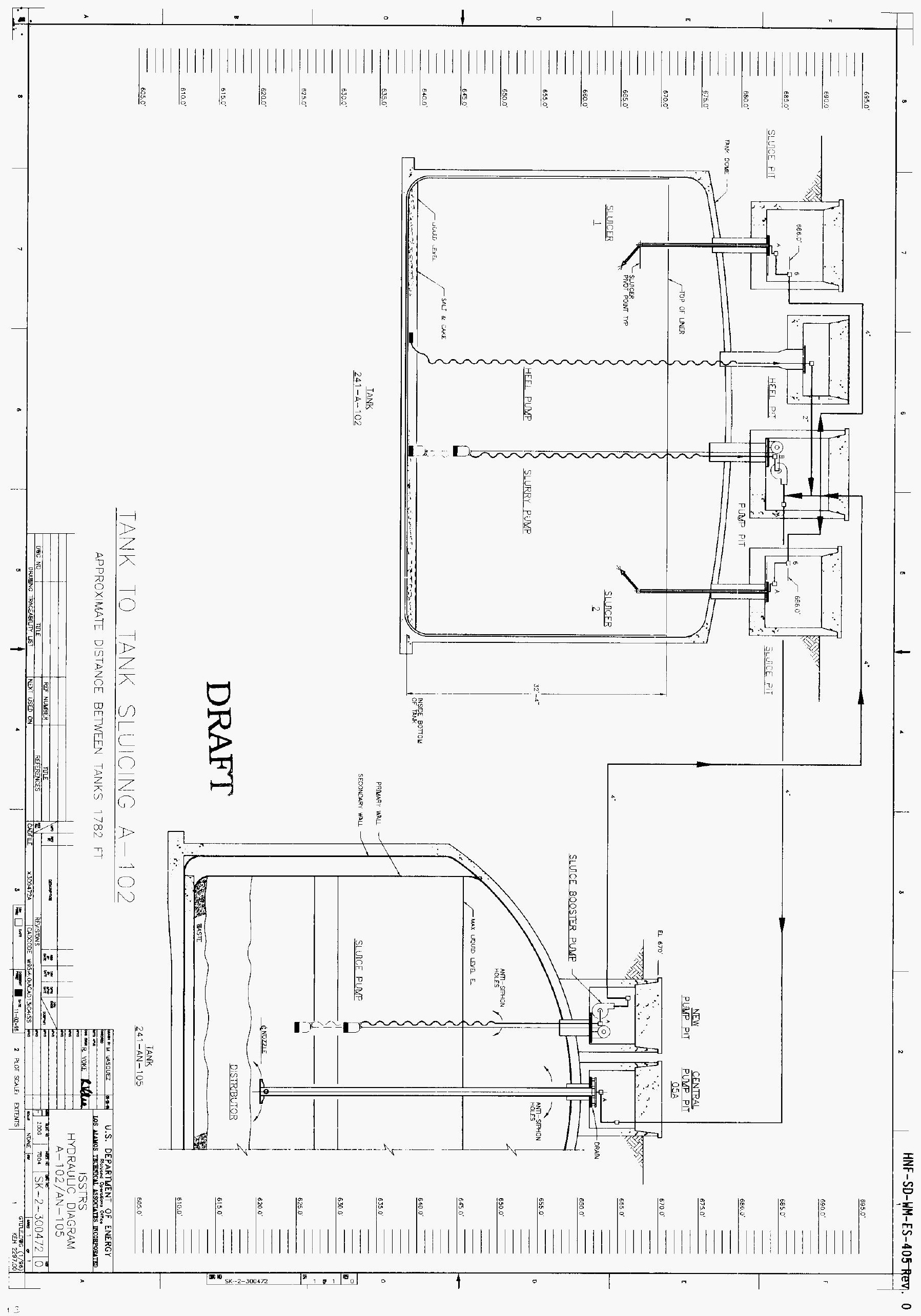




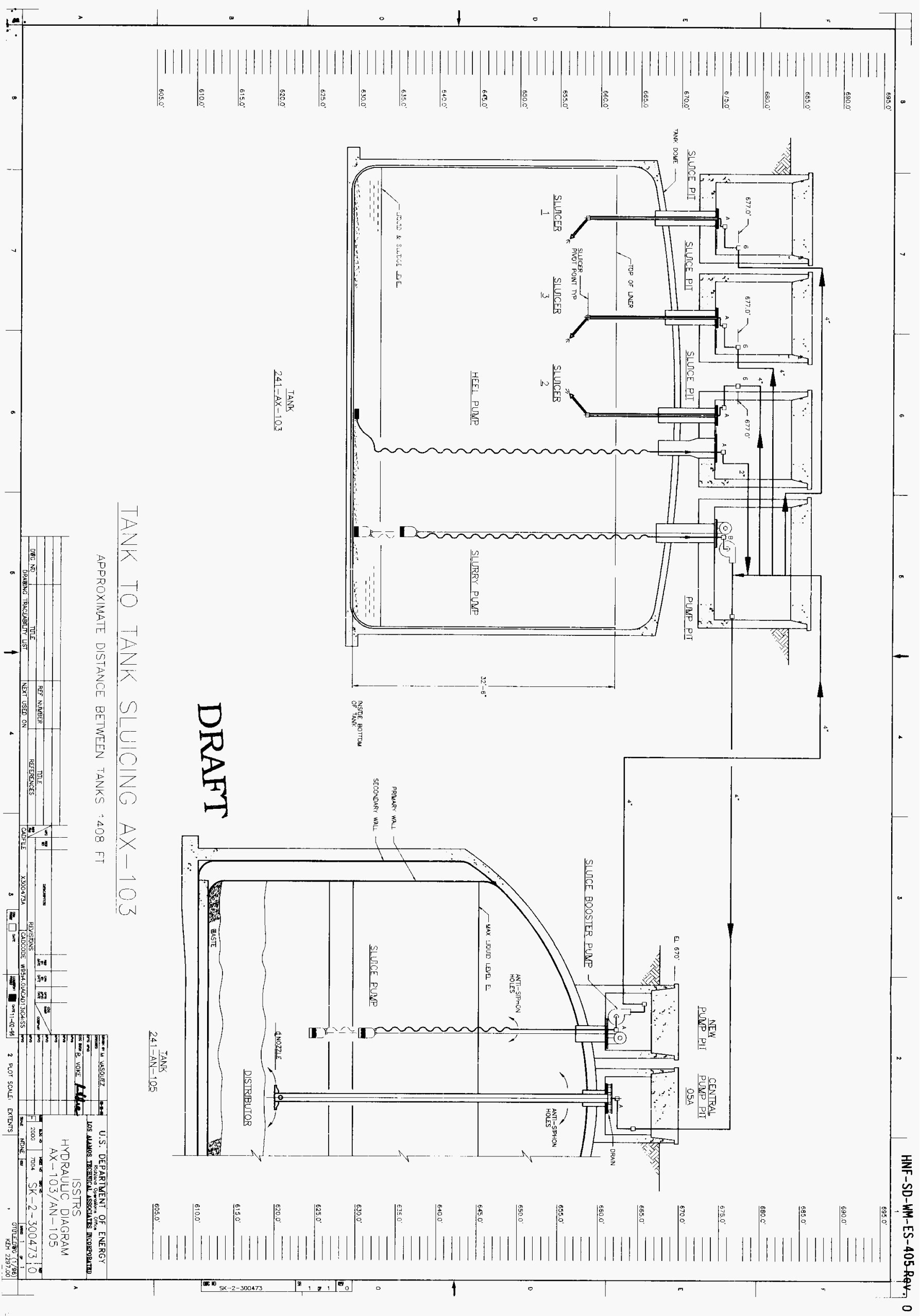




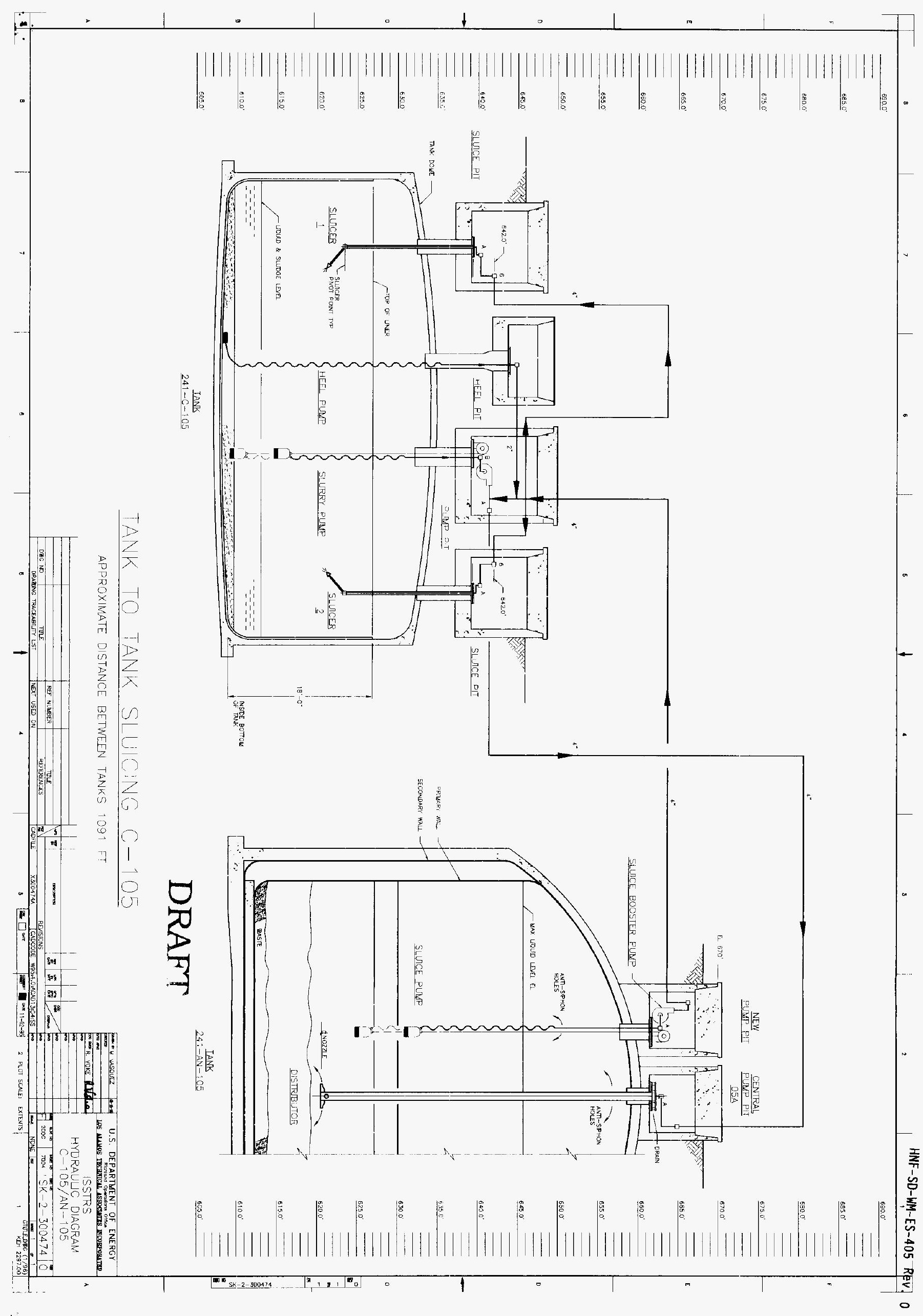




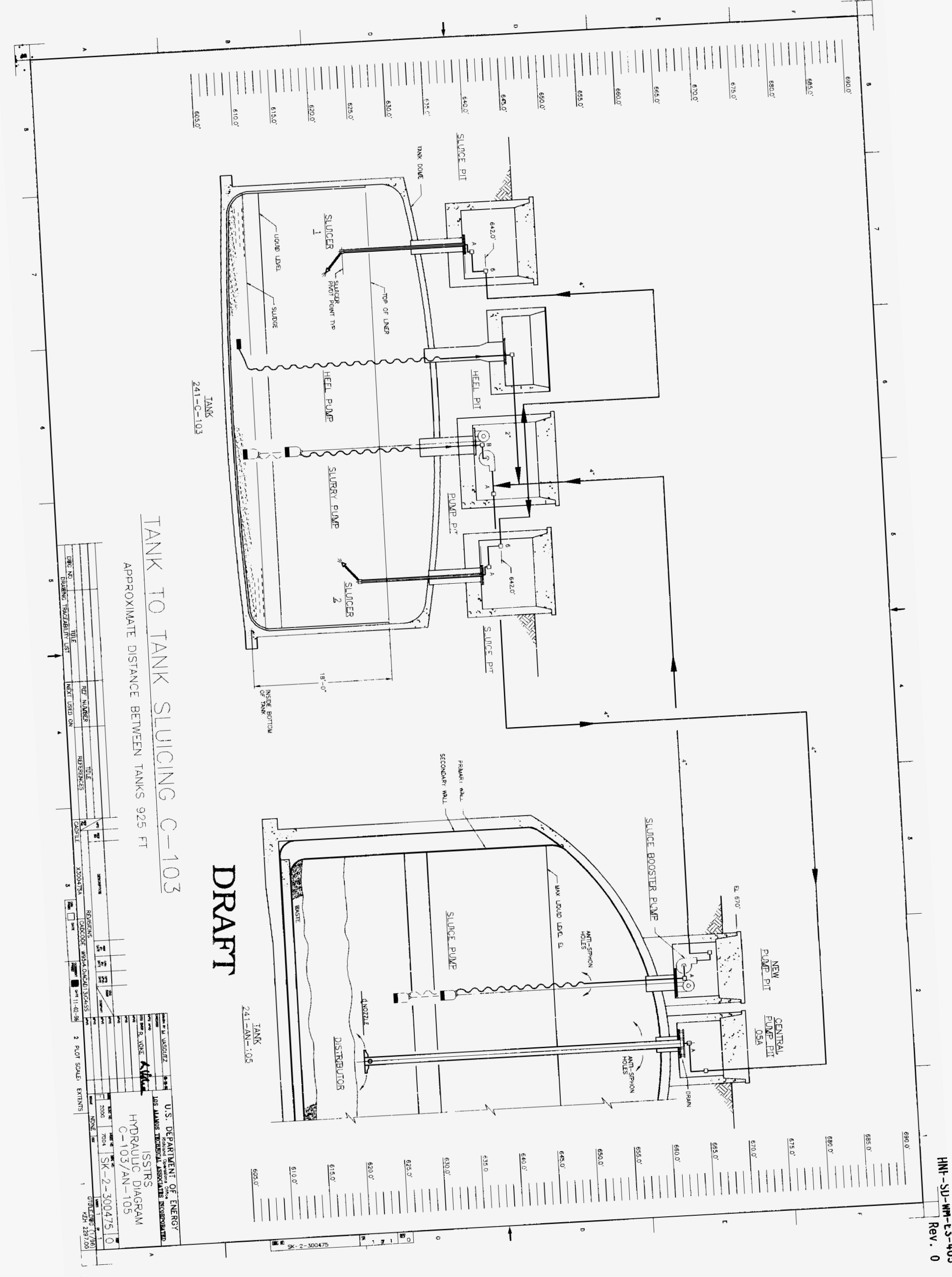




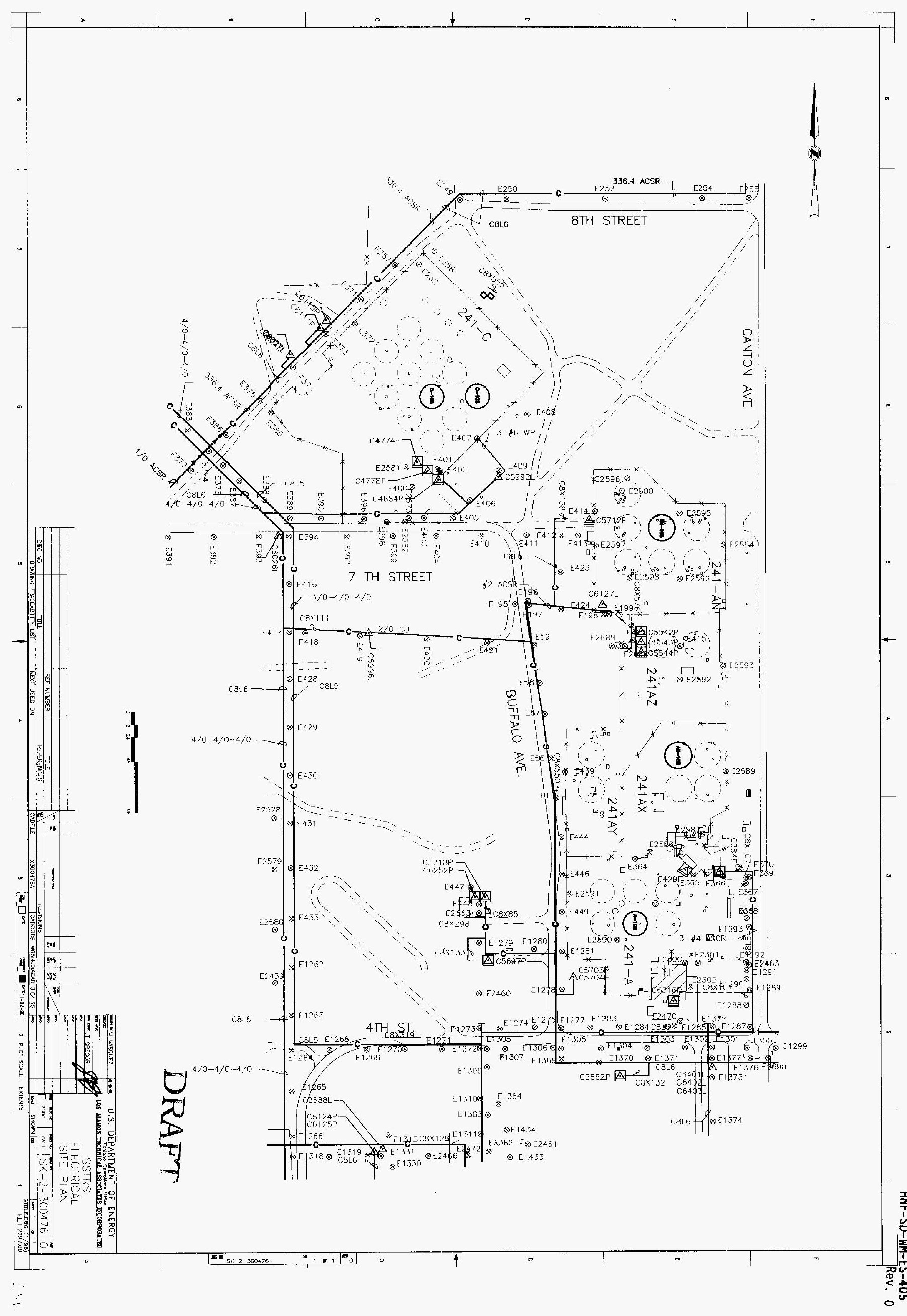




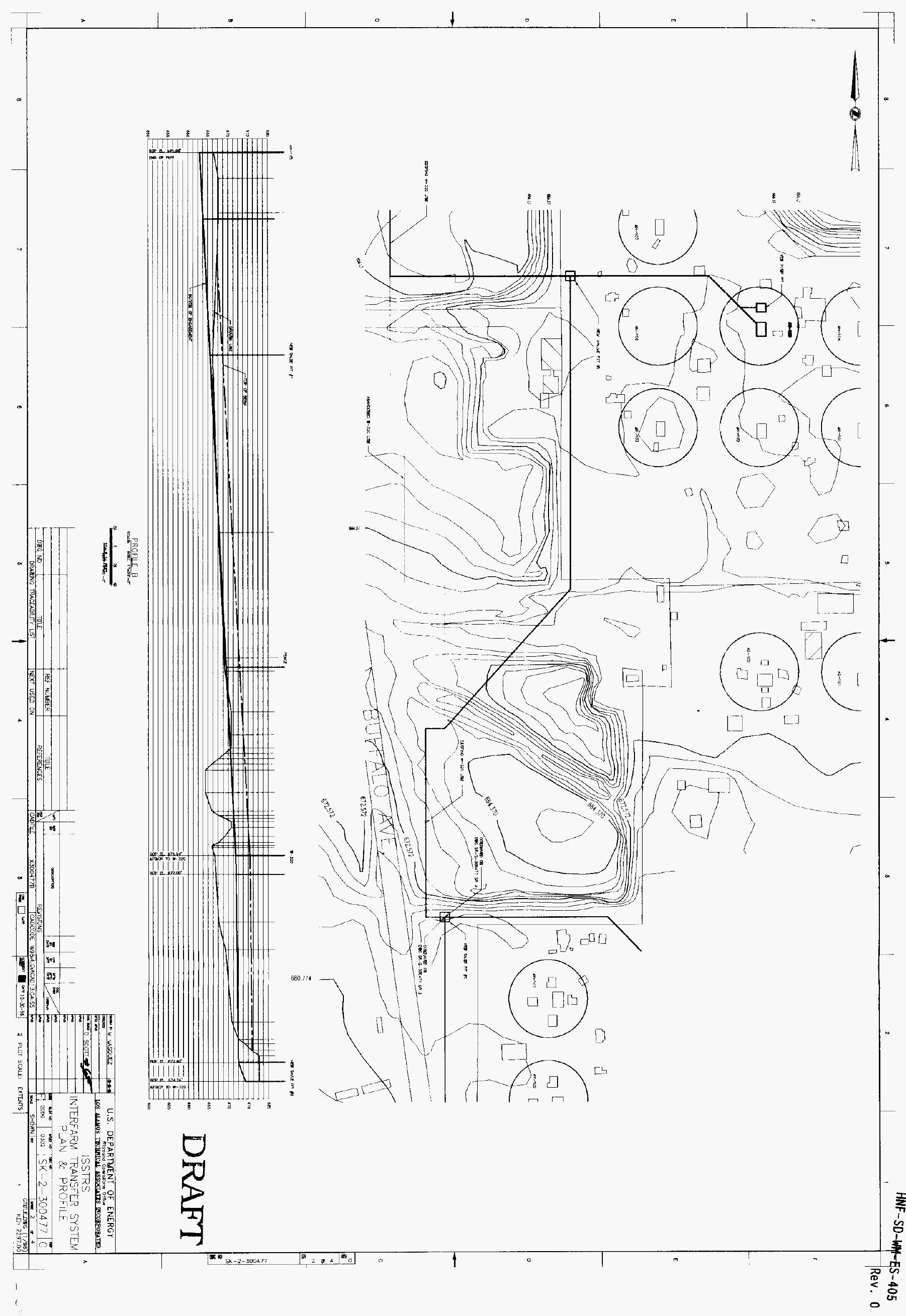




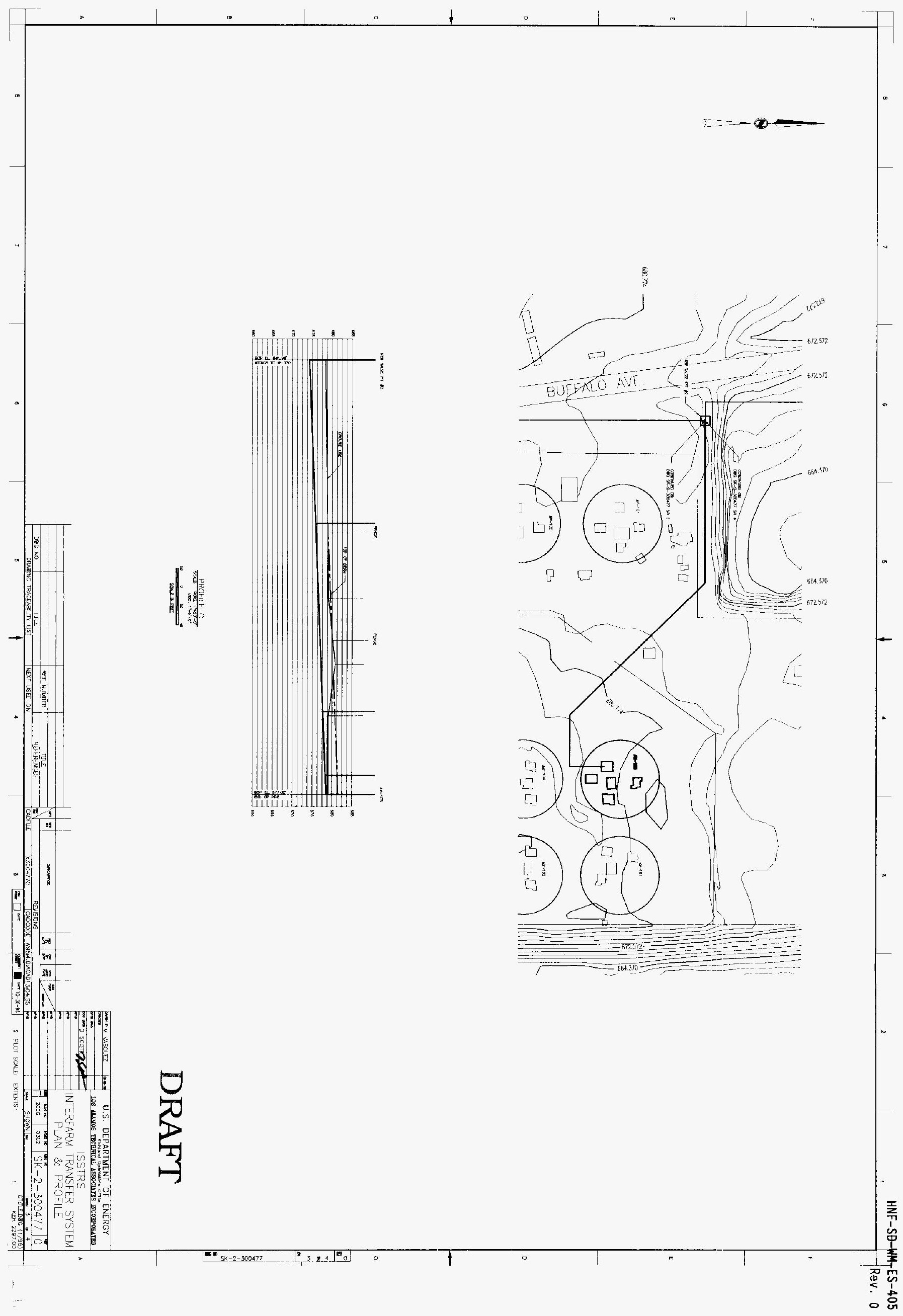




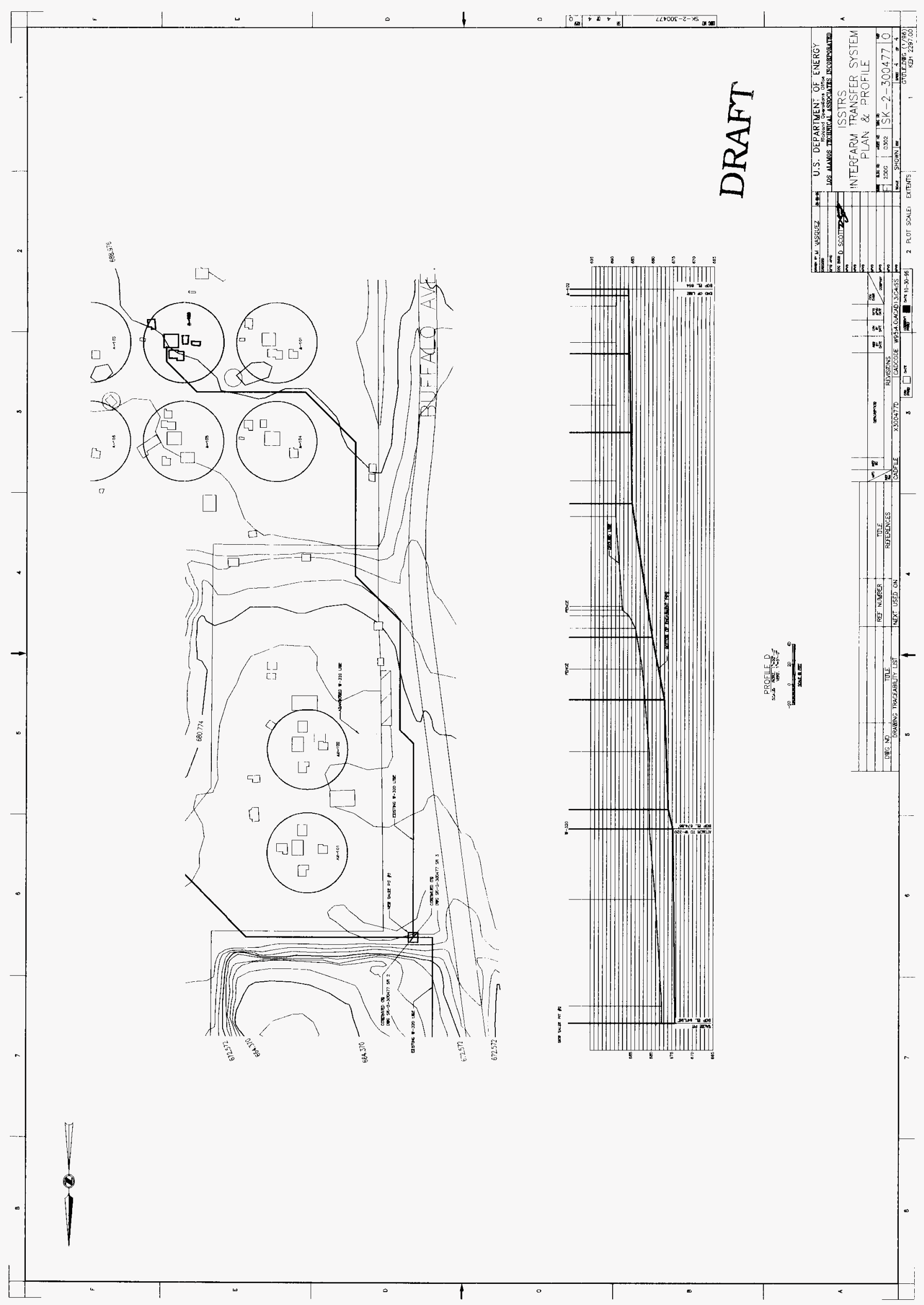




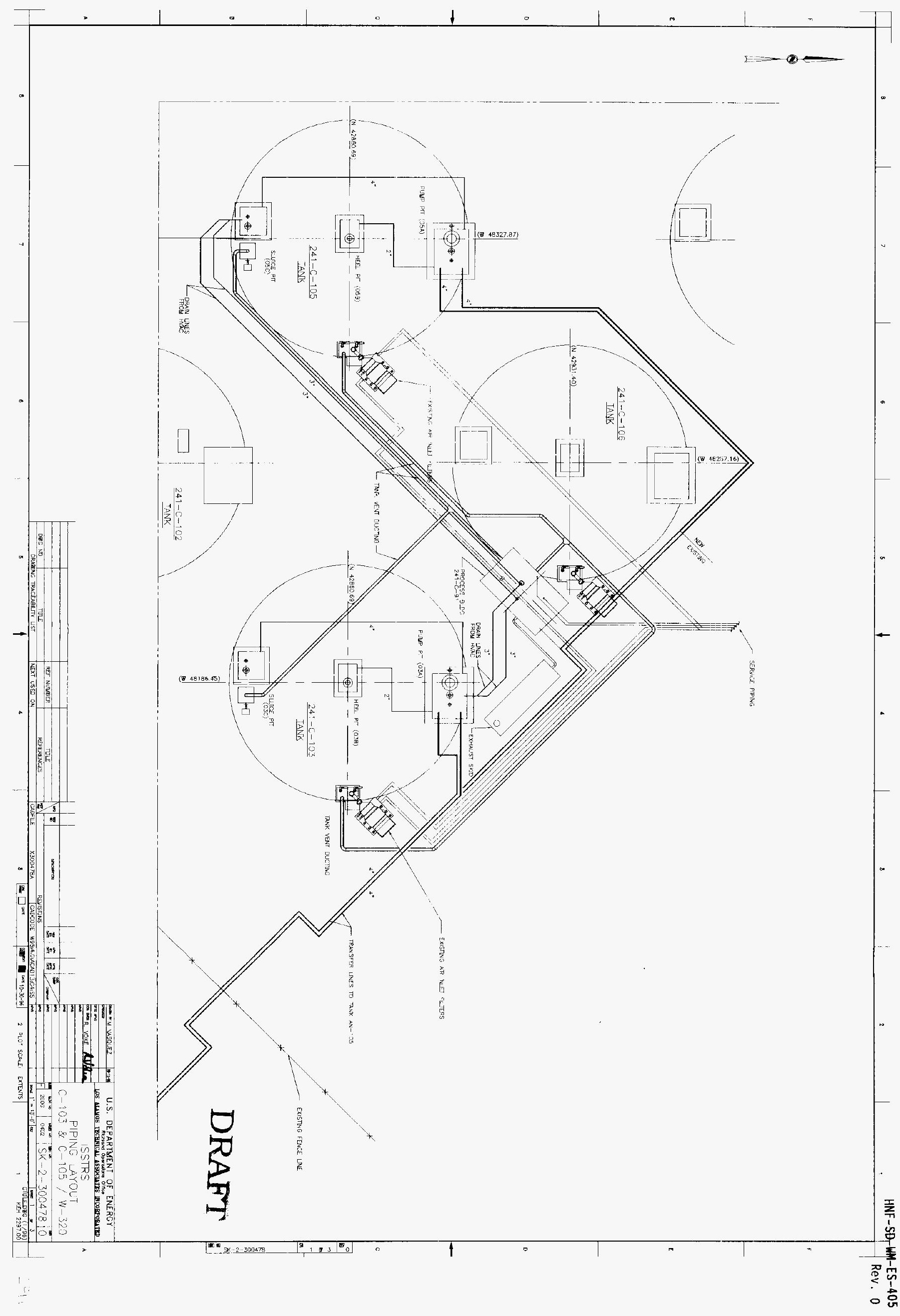




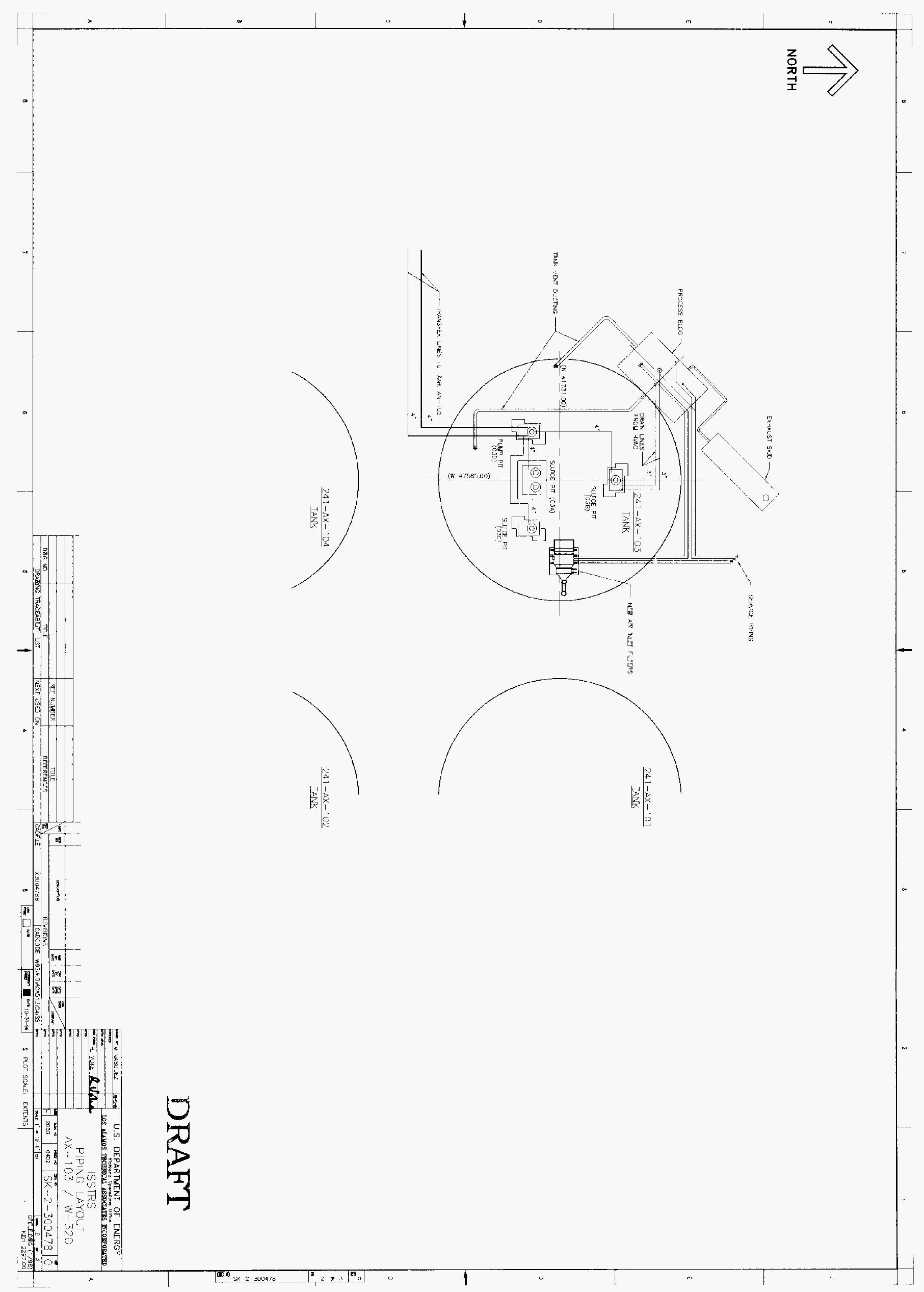




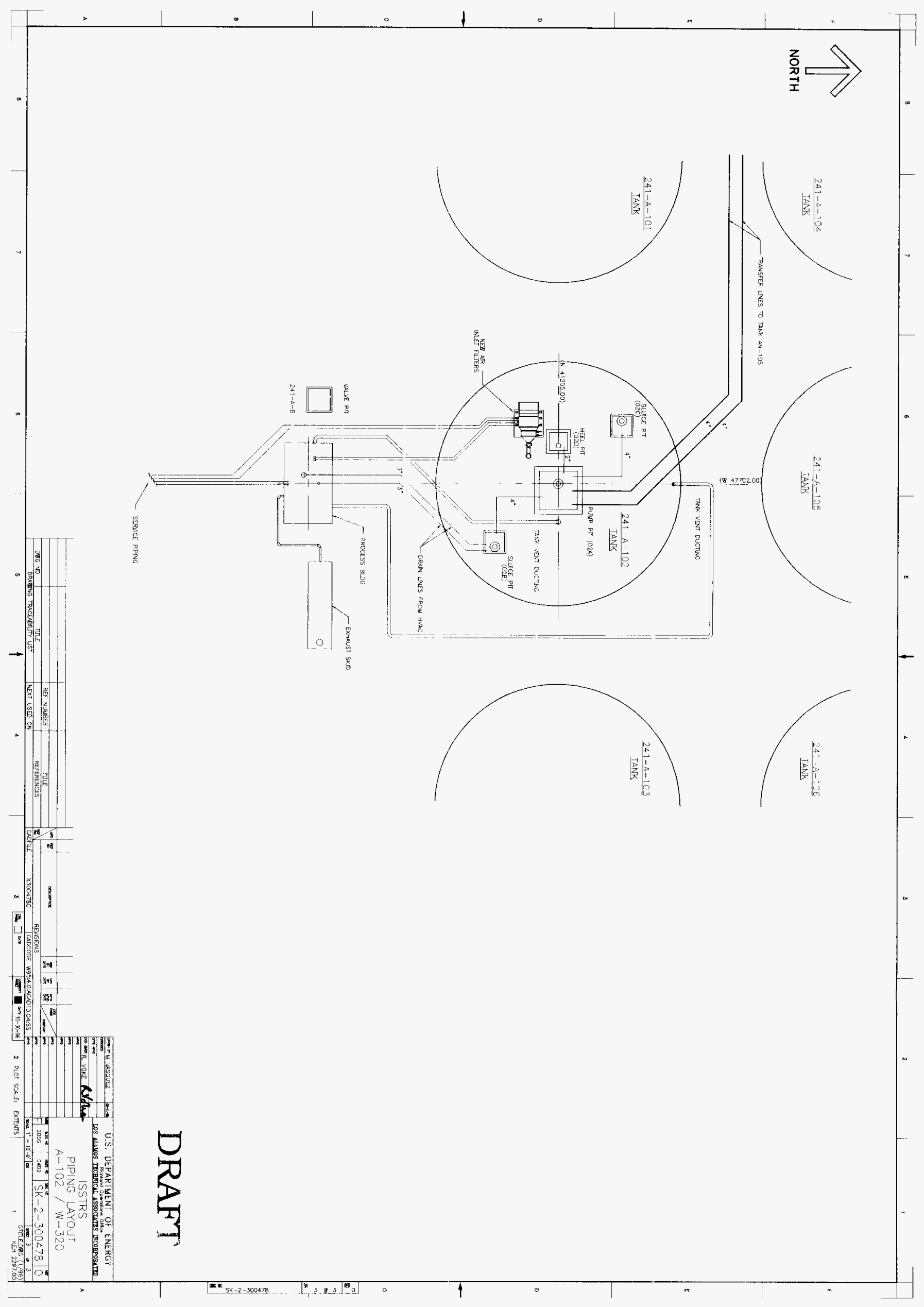




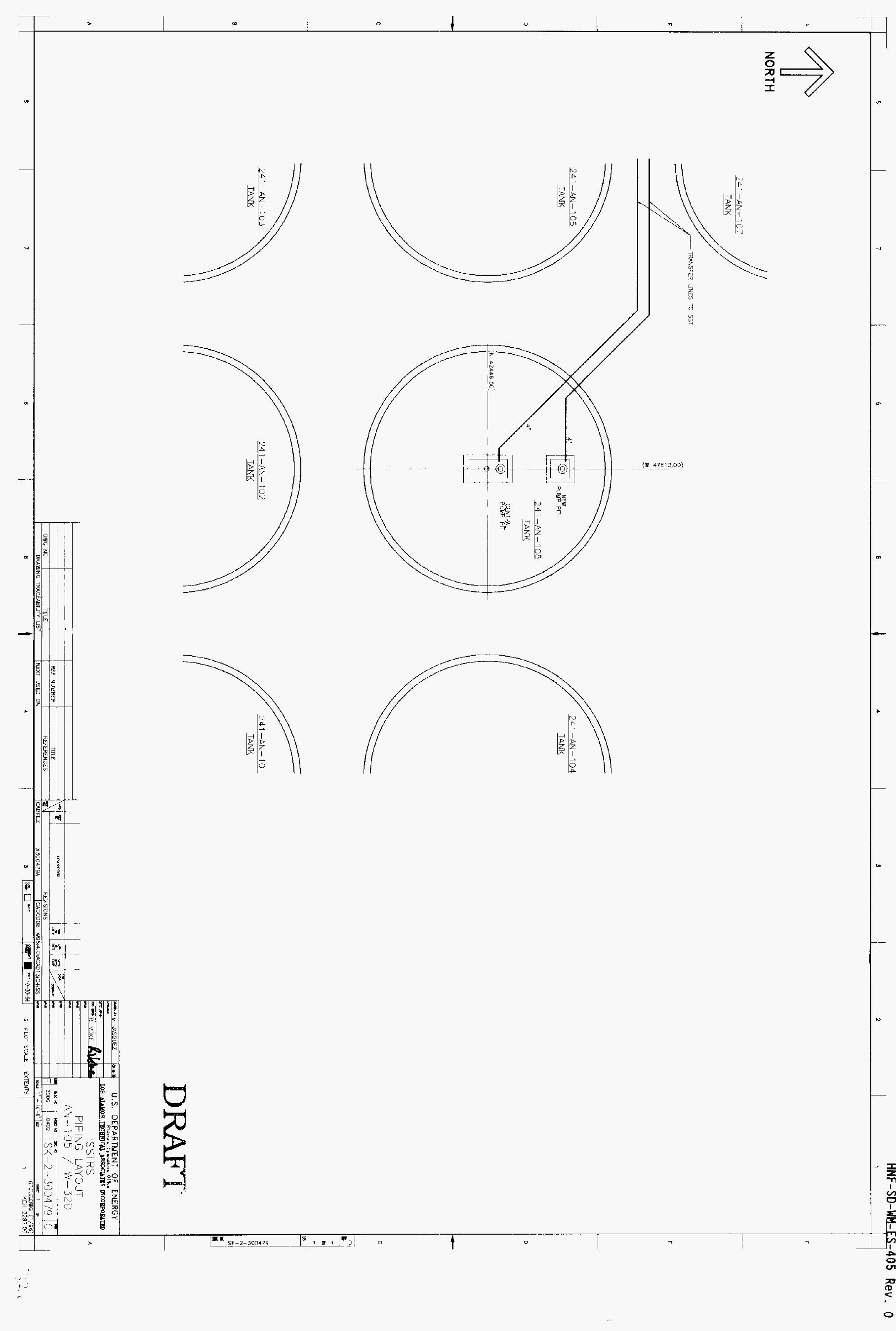




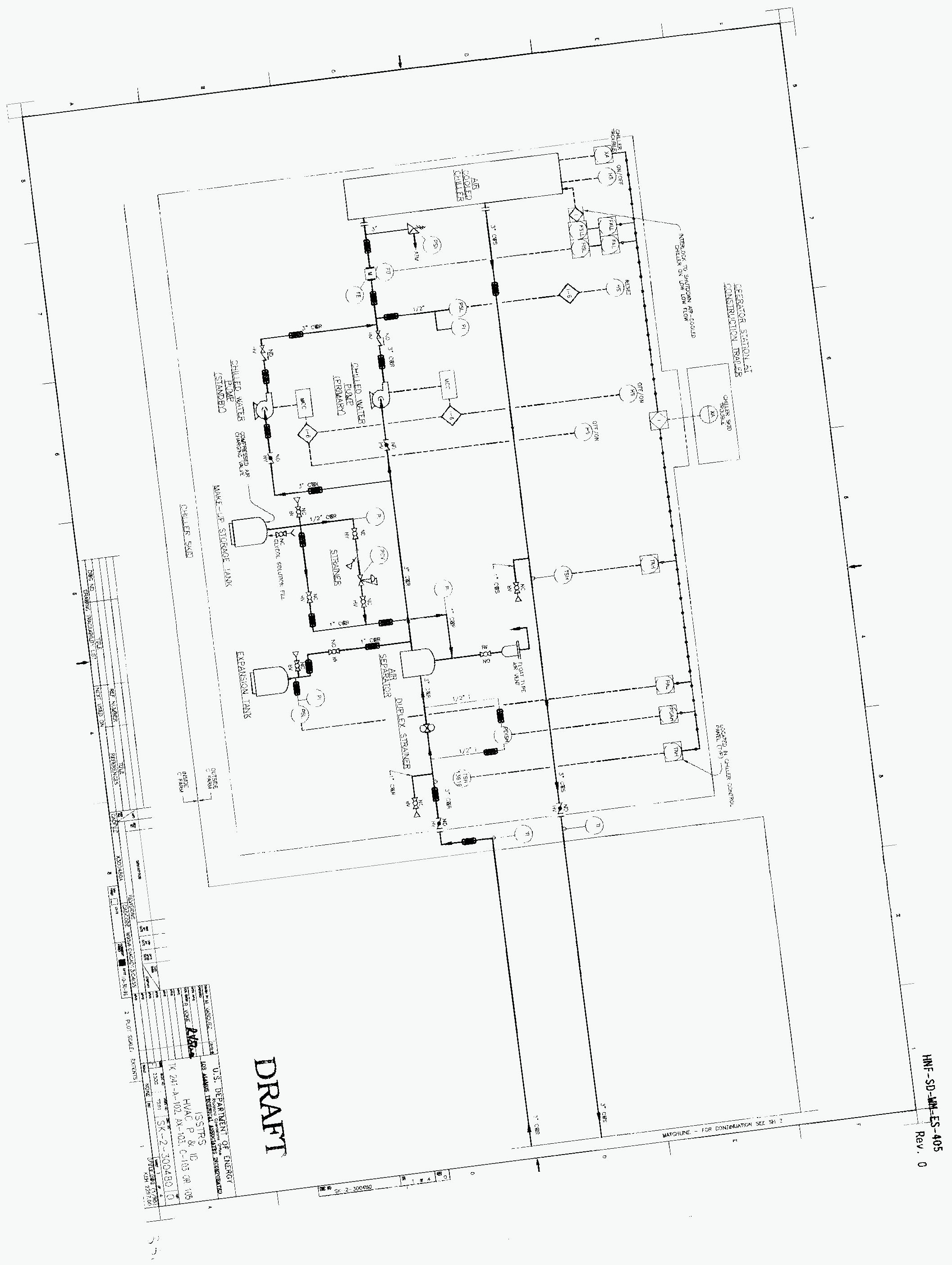




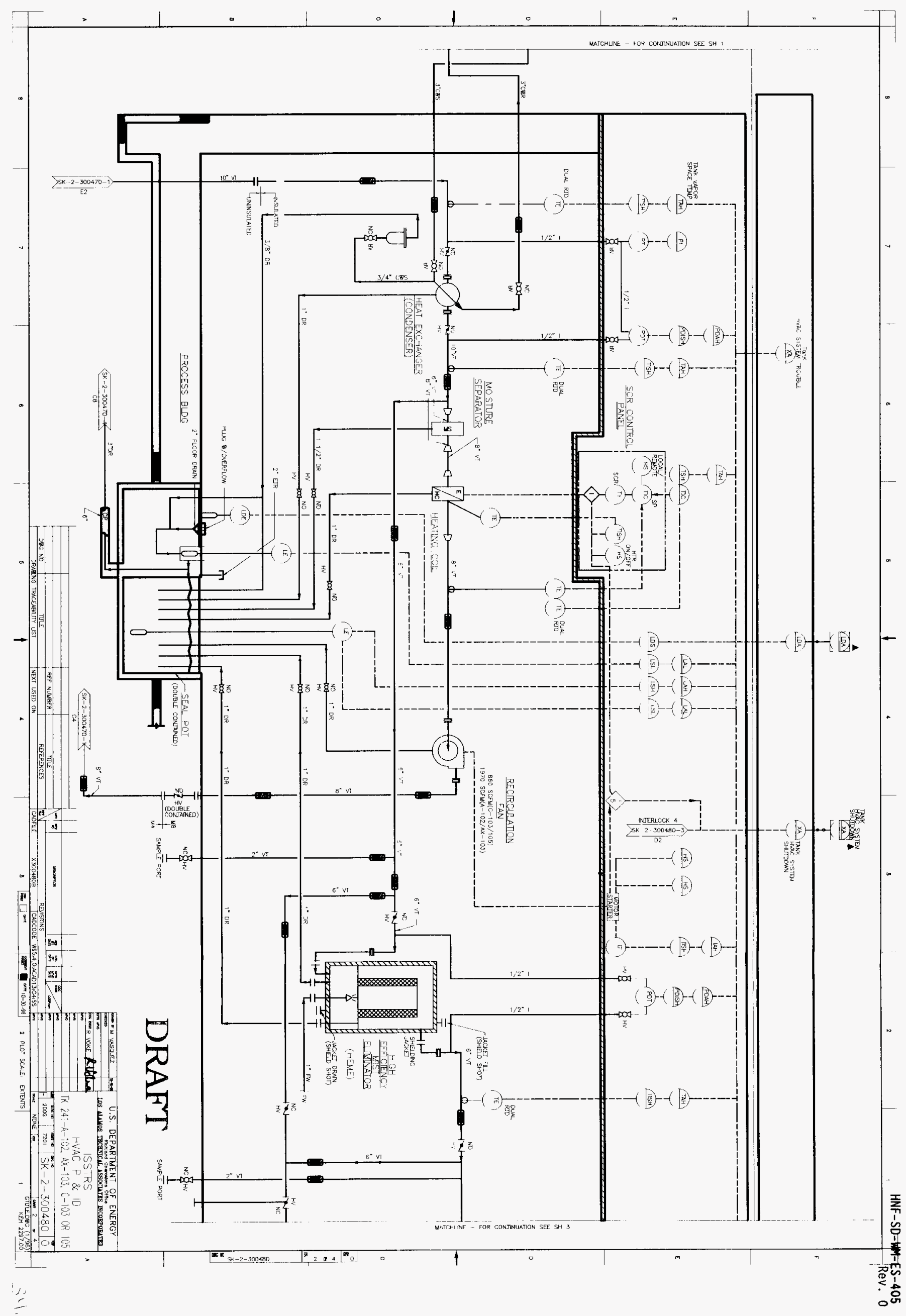




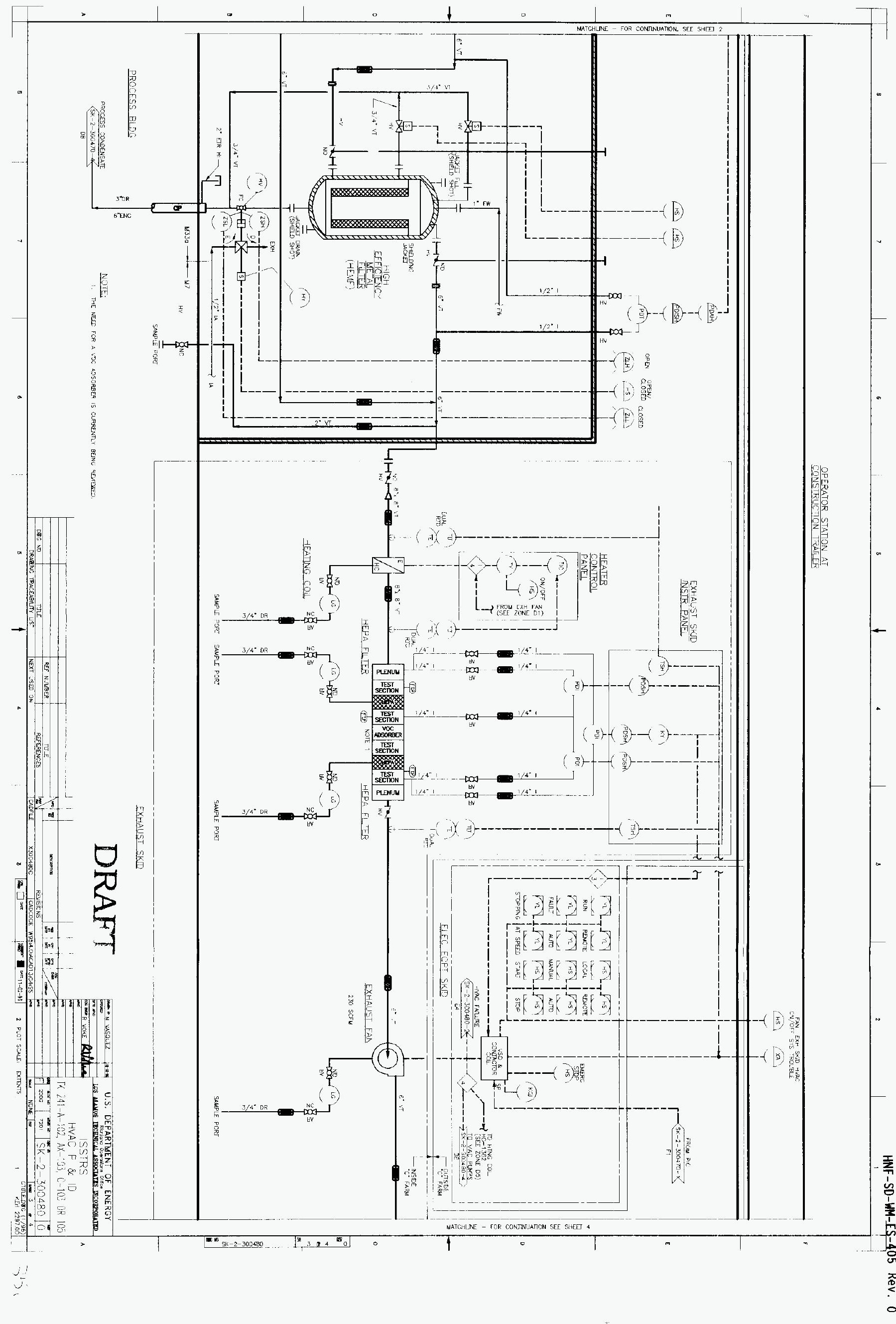




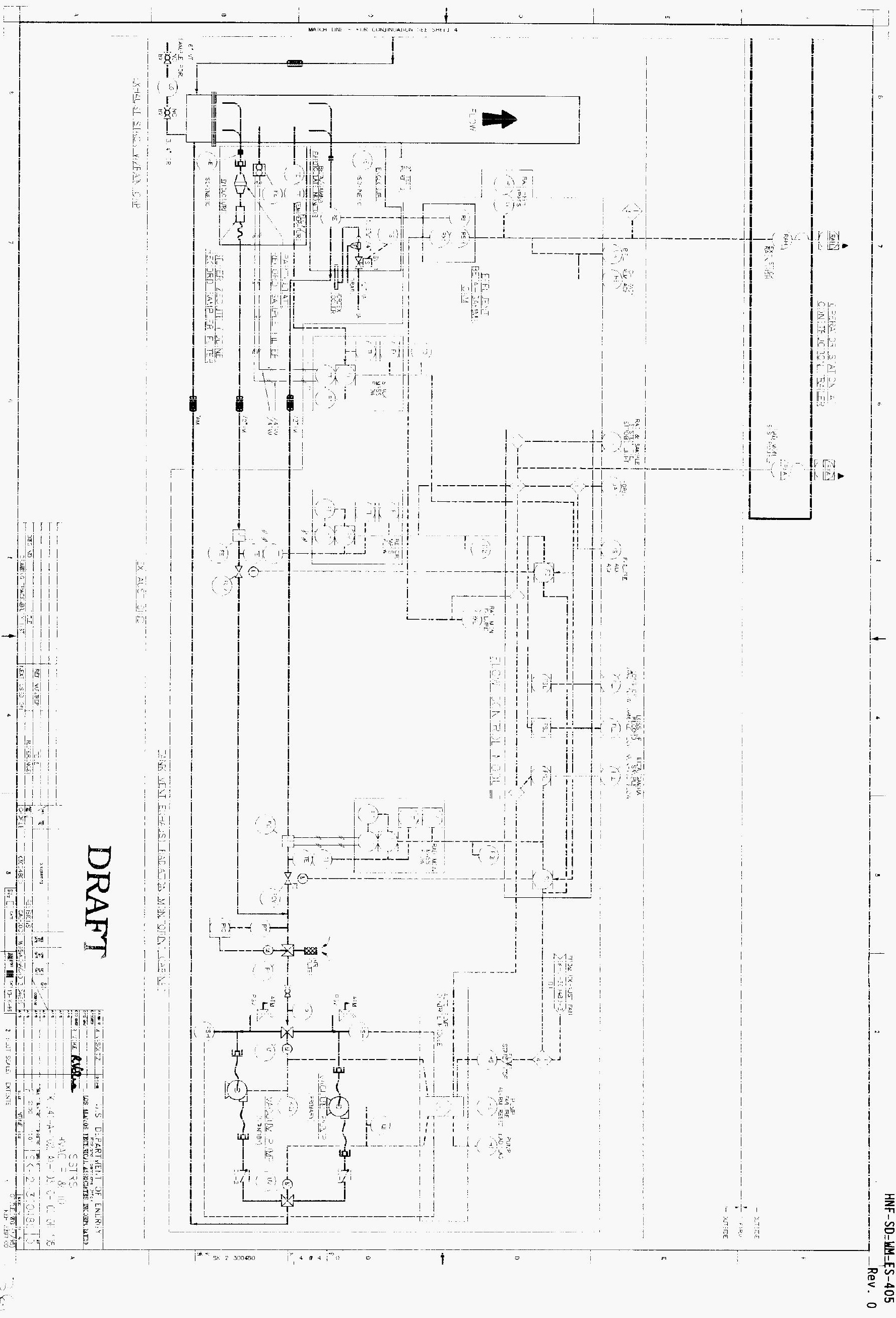




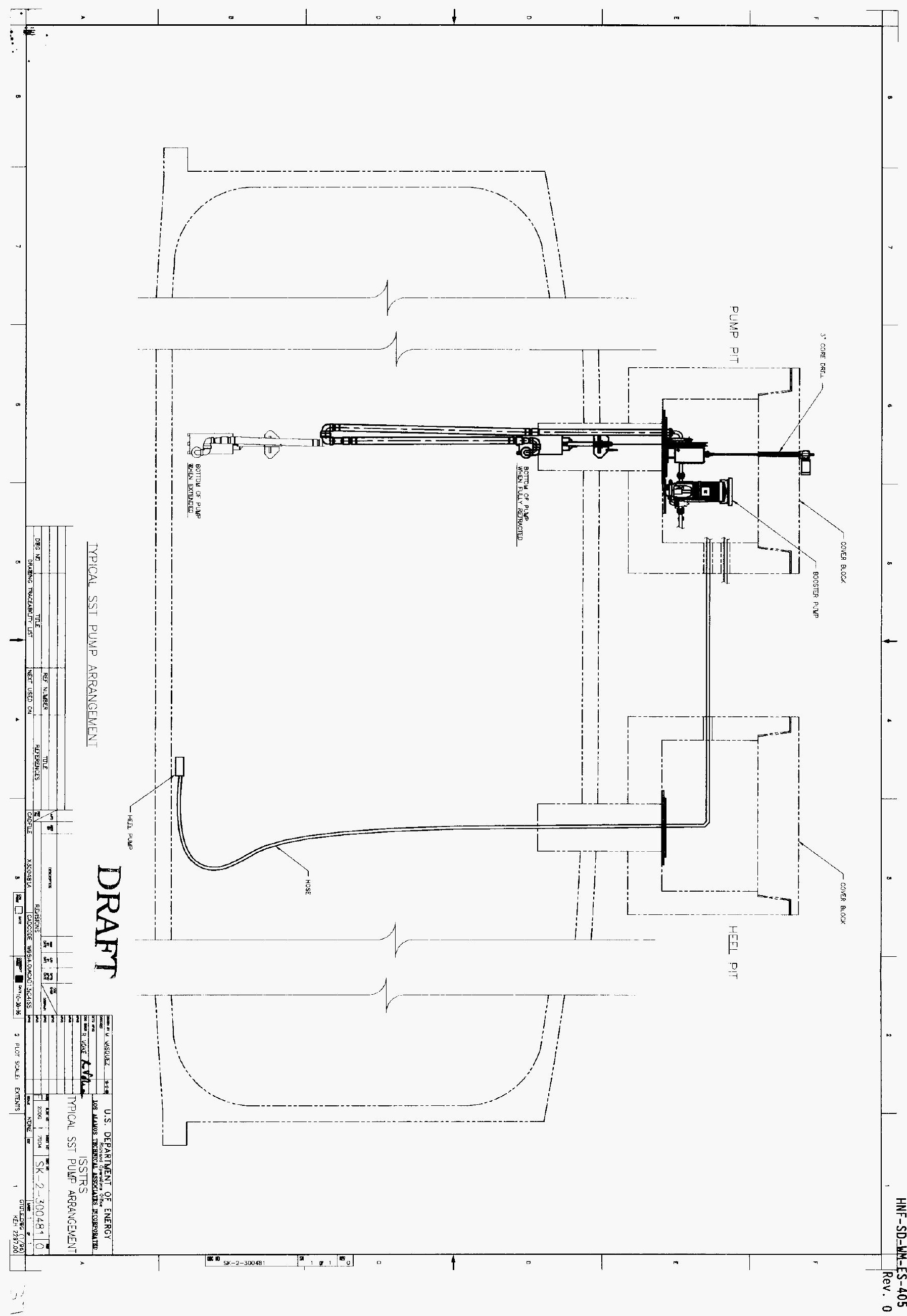




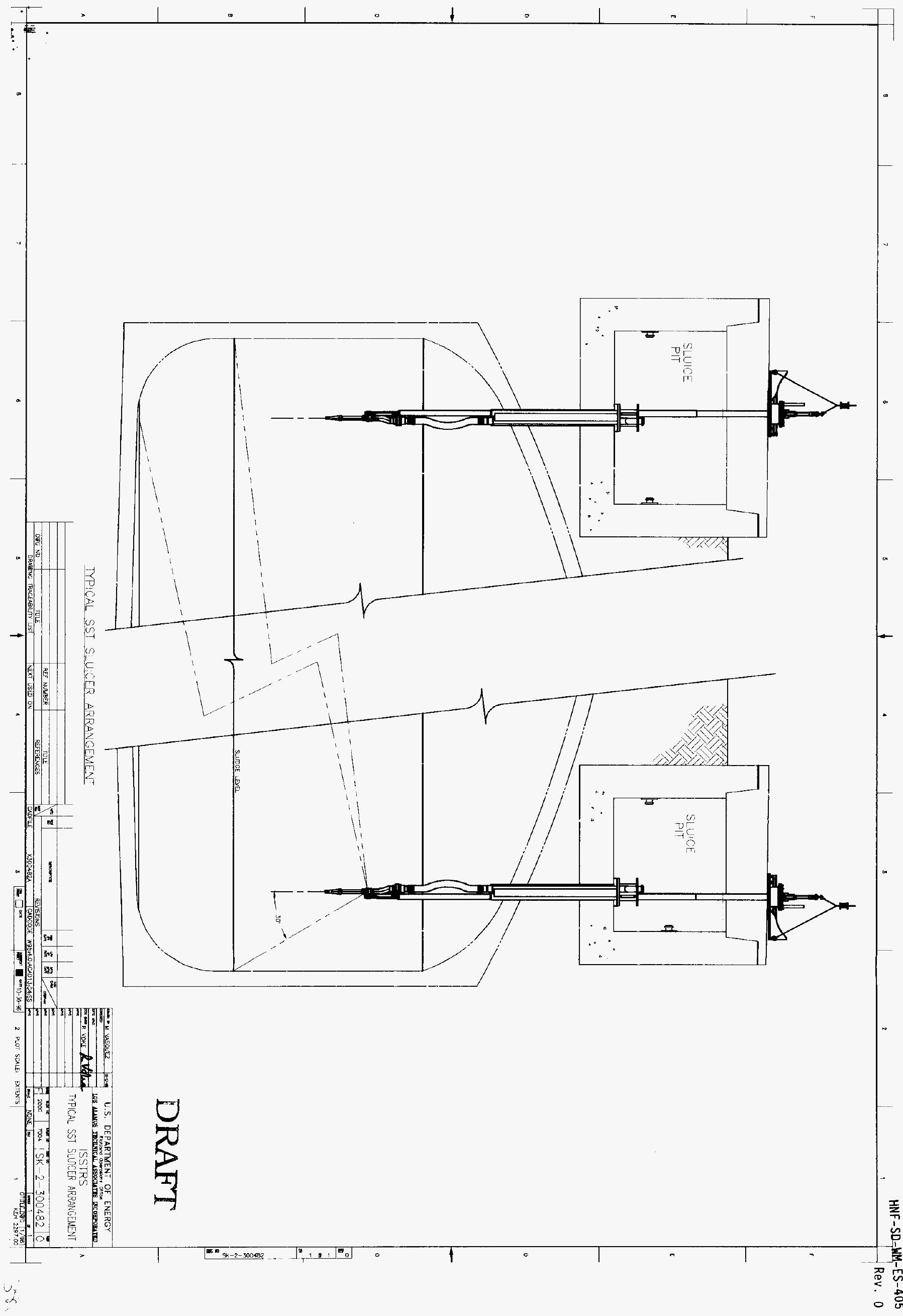




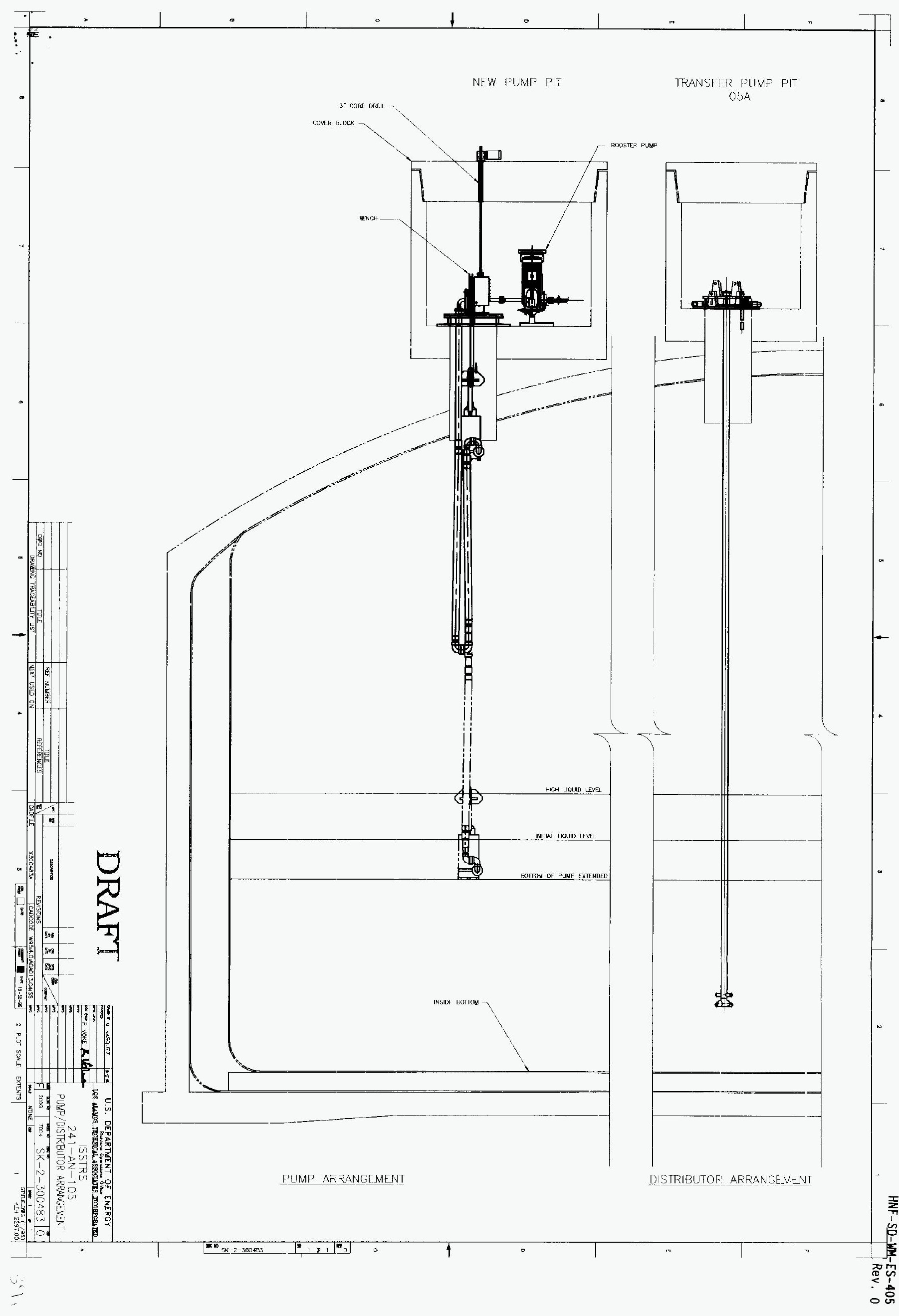



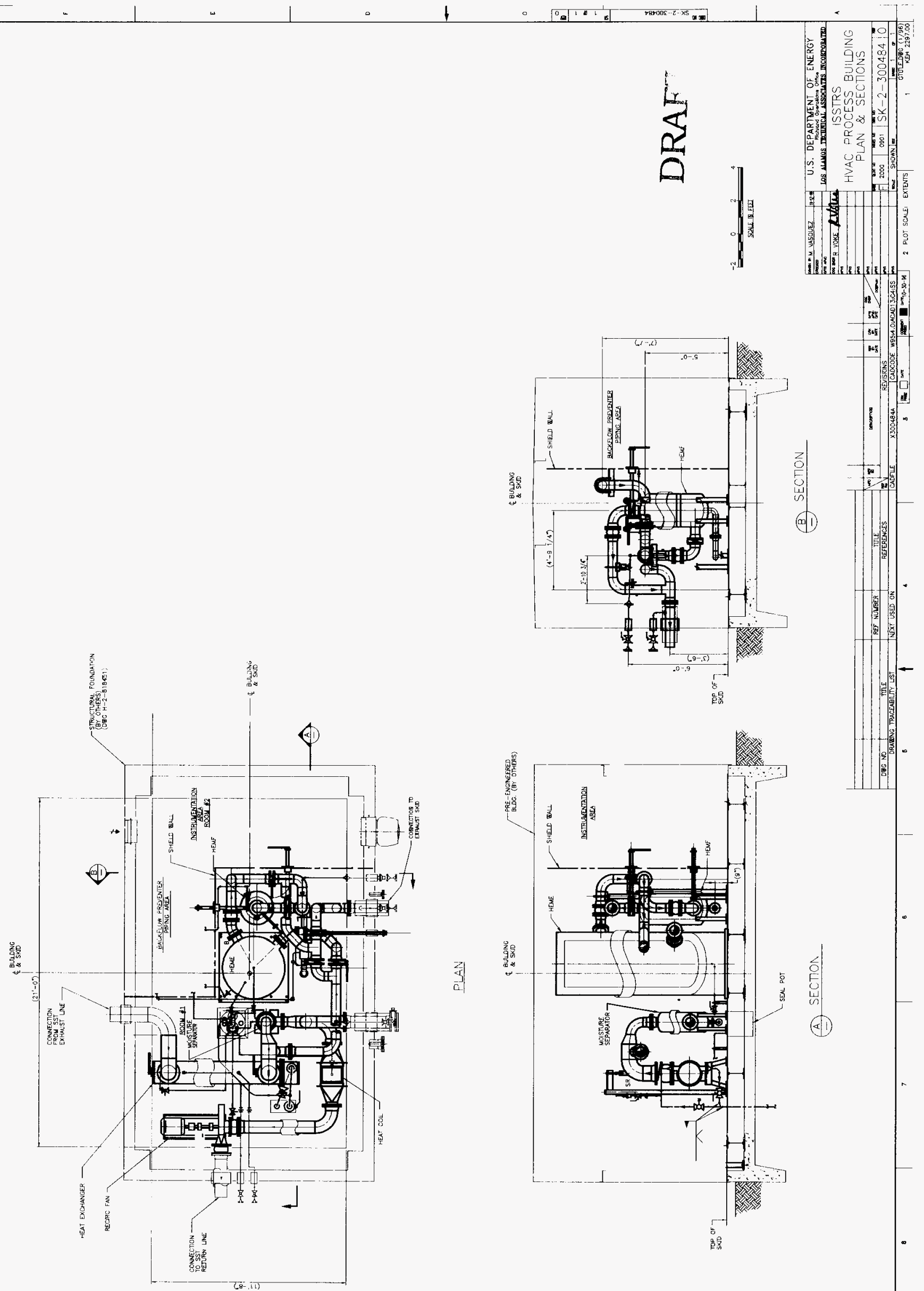

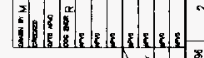
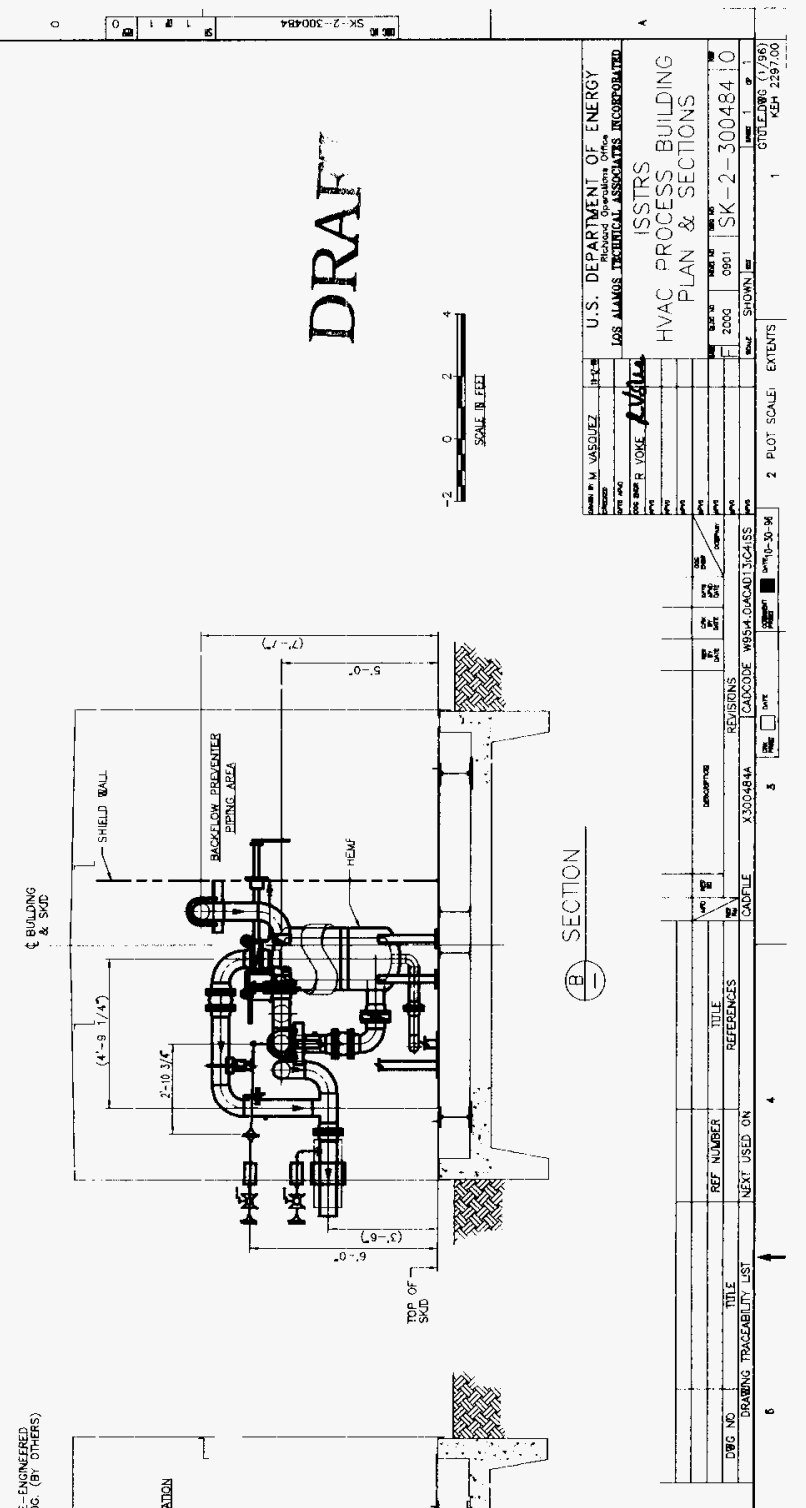

골
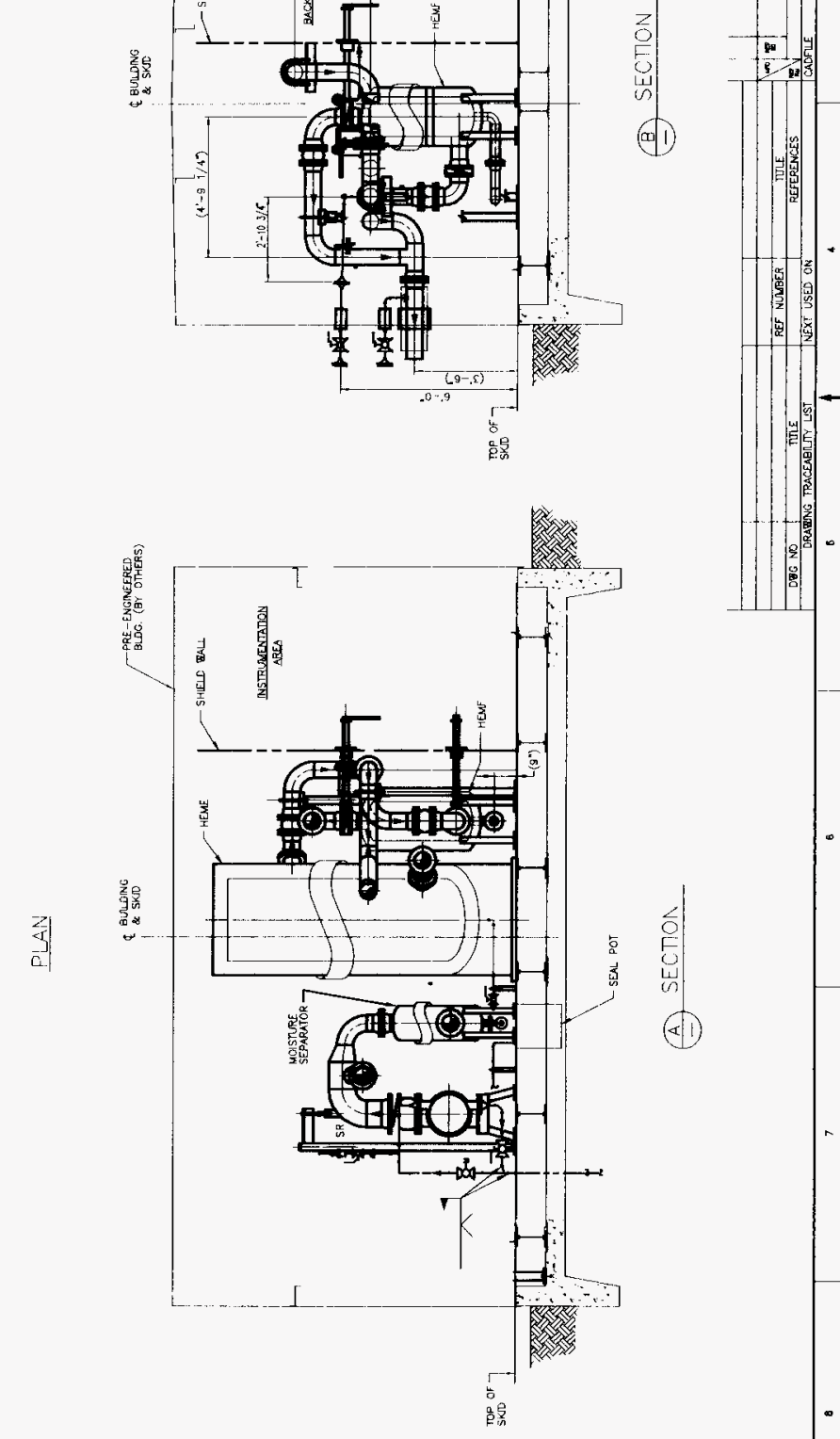


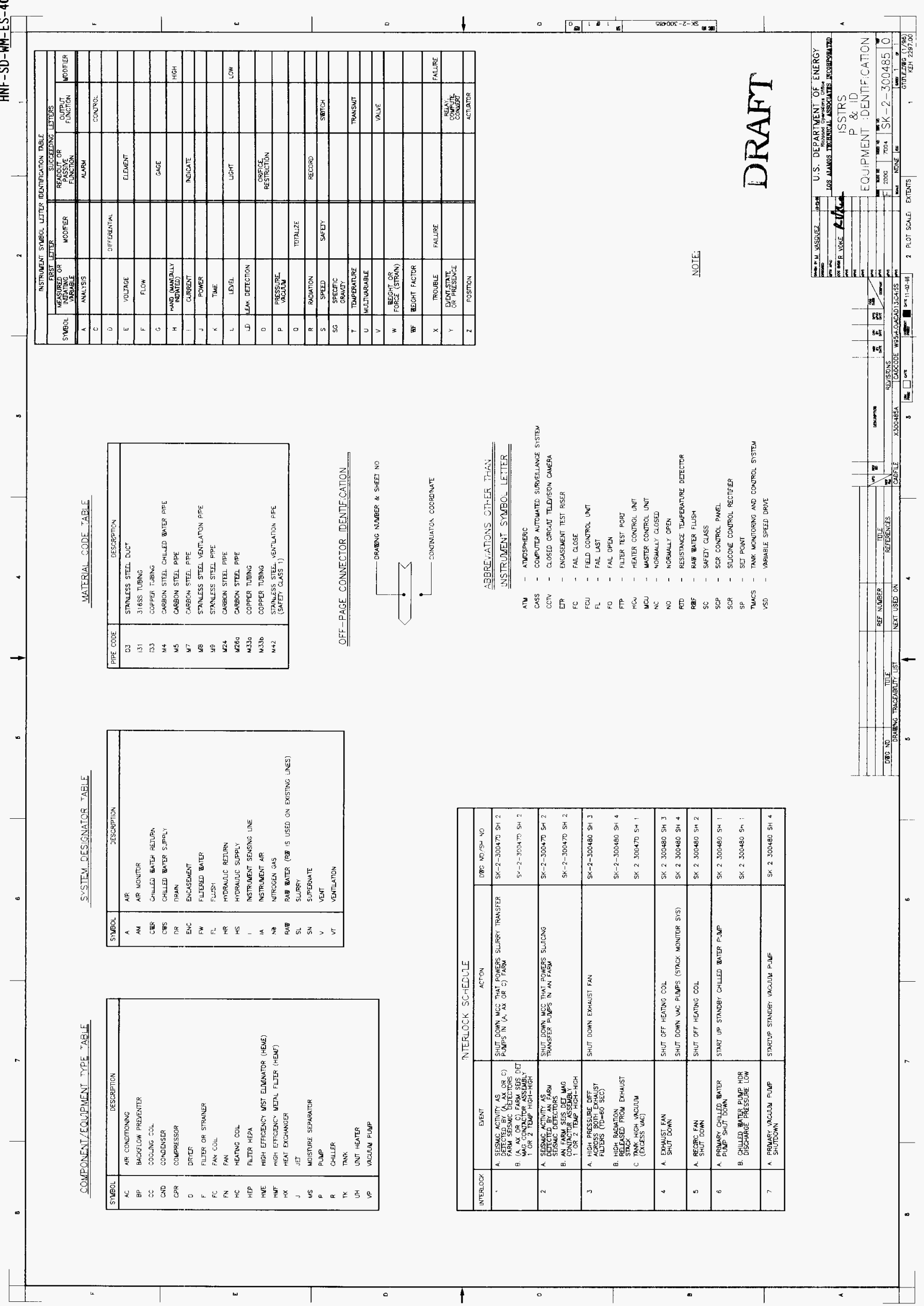


箮高

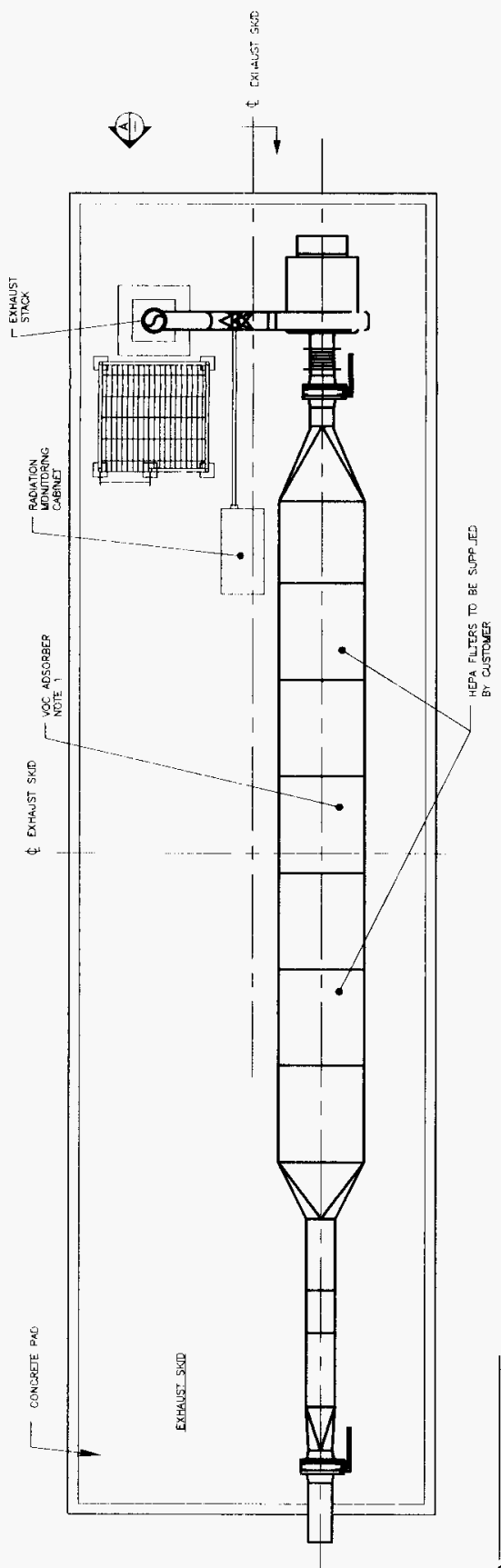

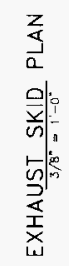
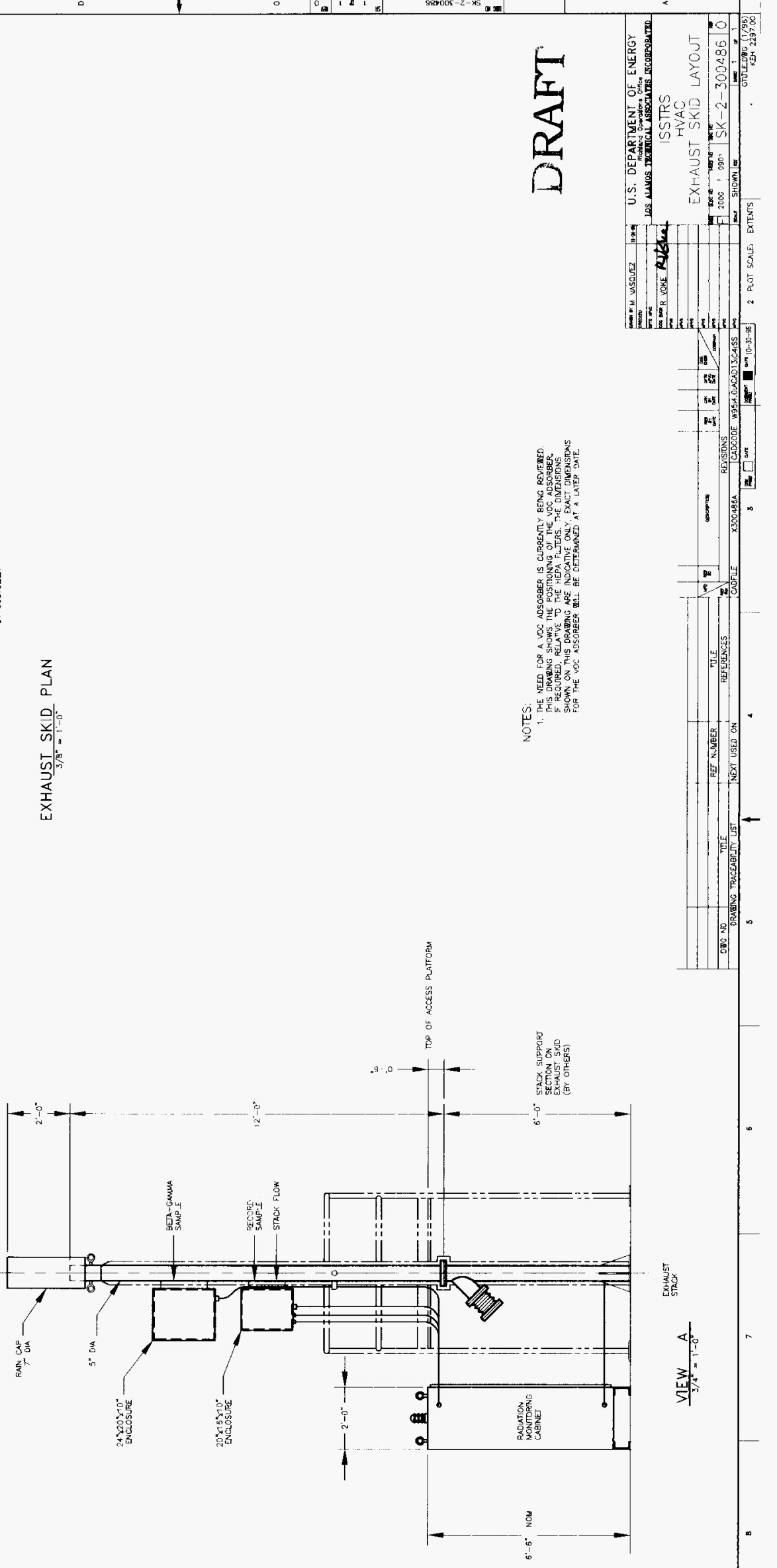

熟慈 


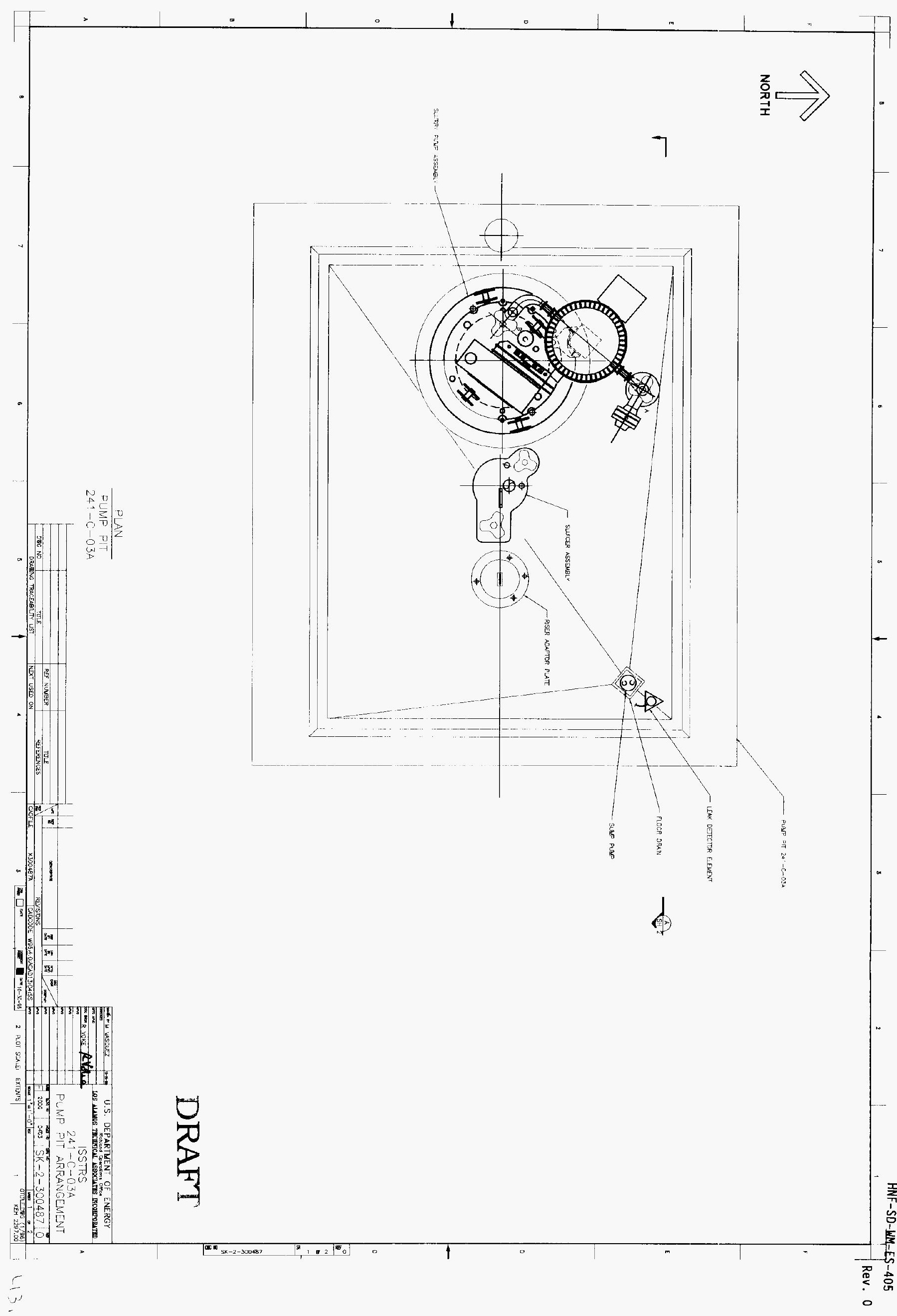




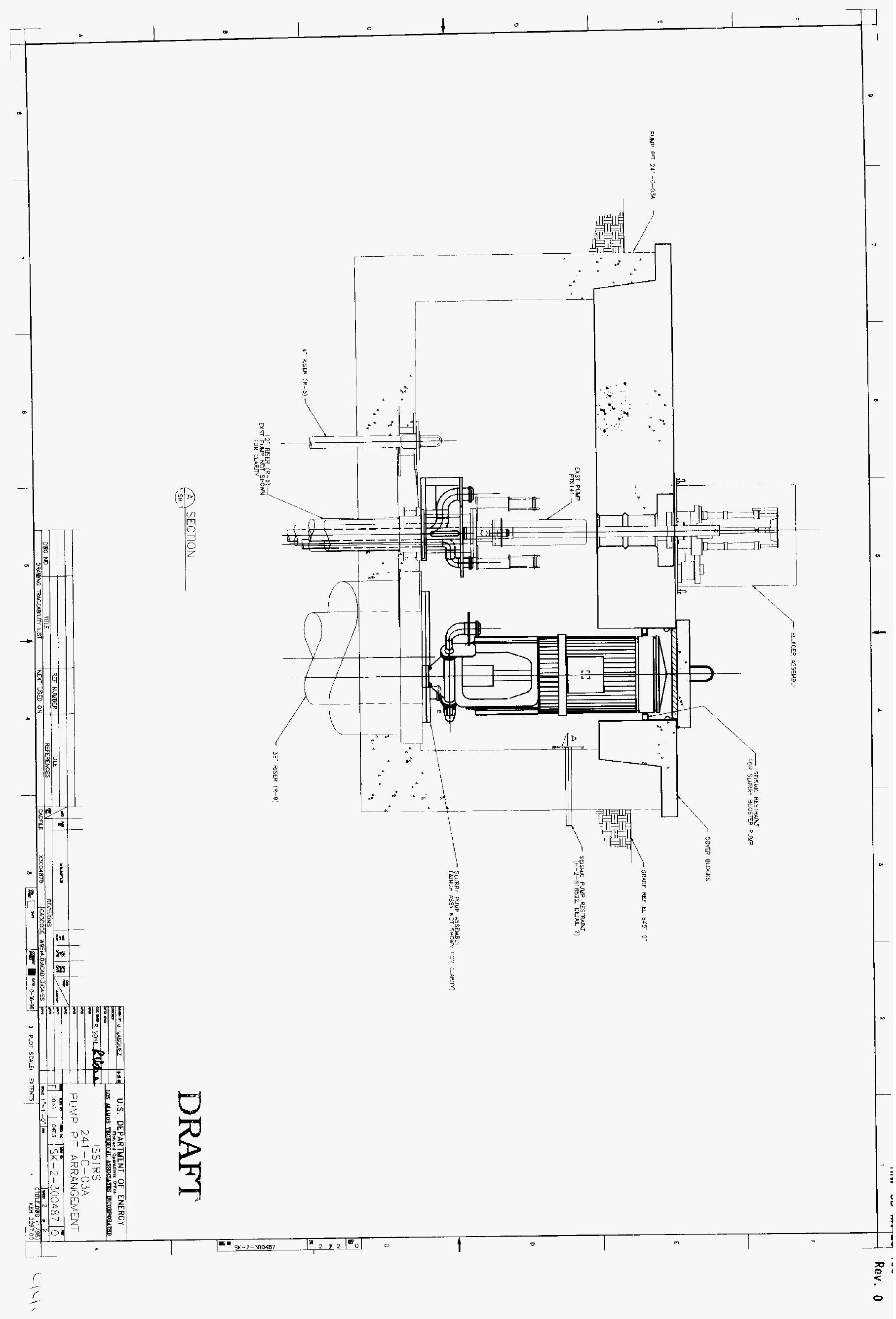




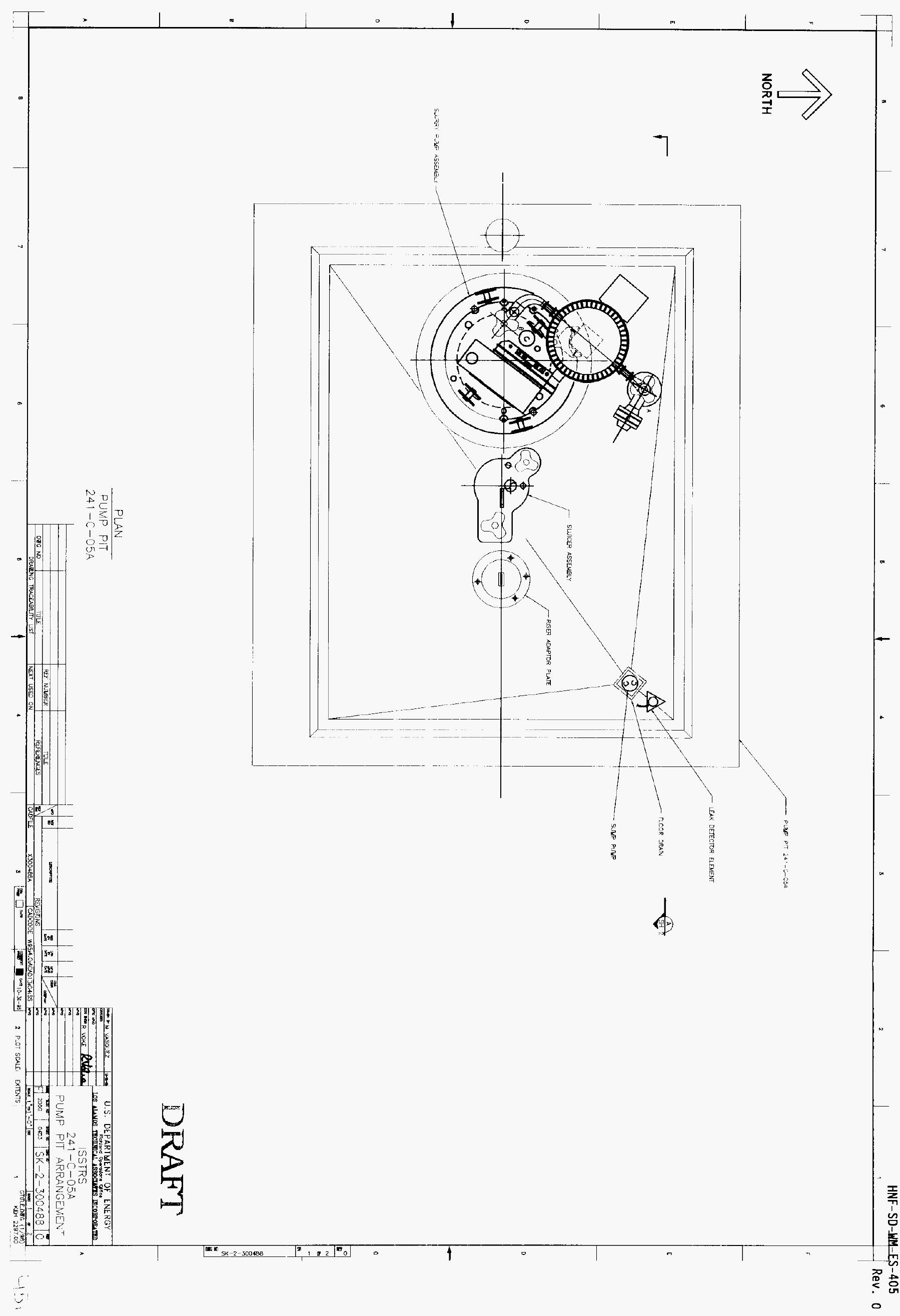




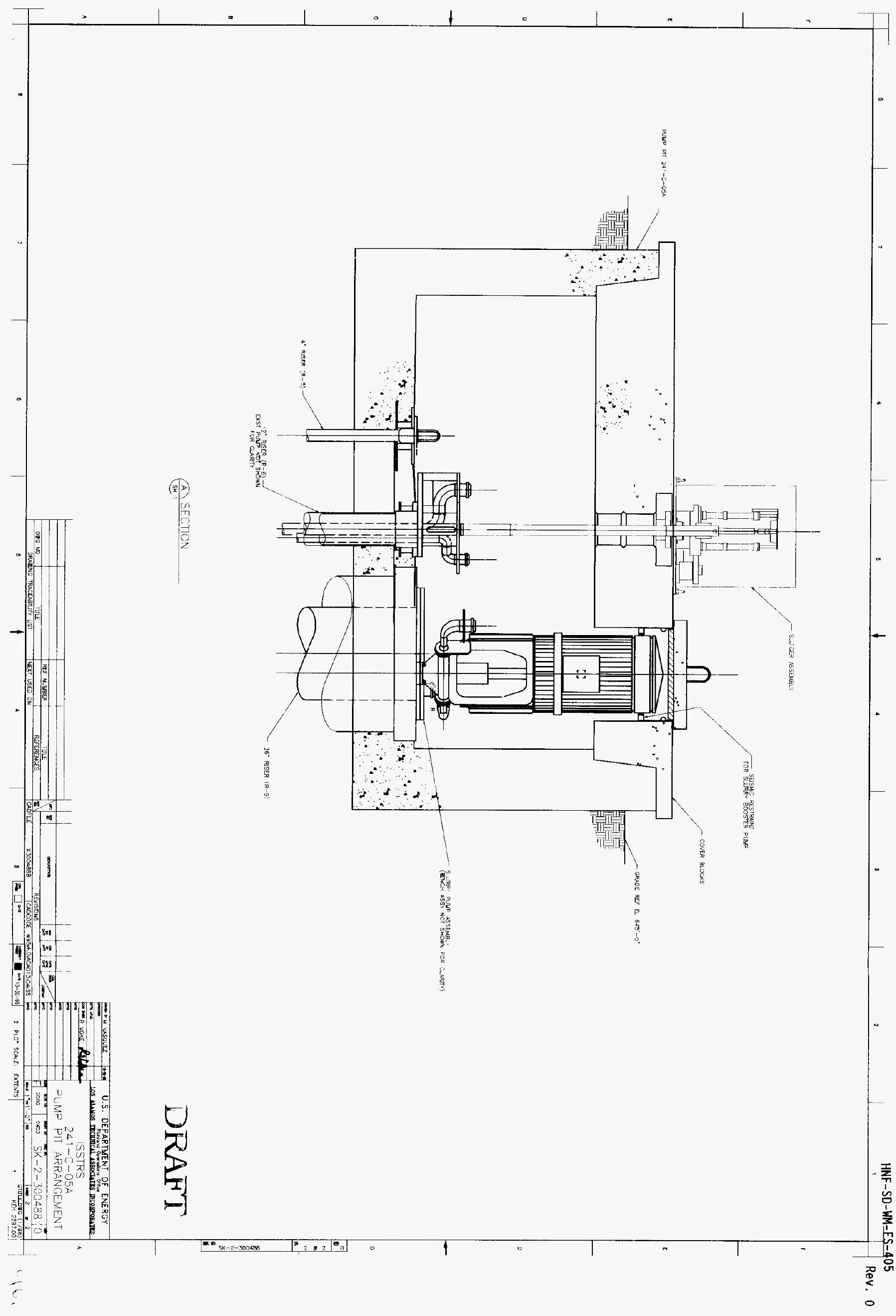




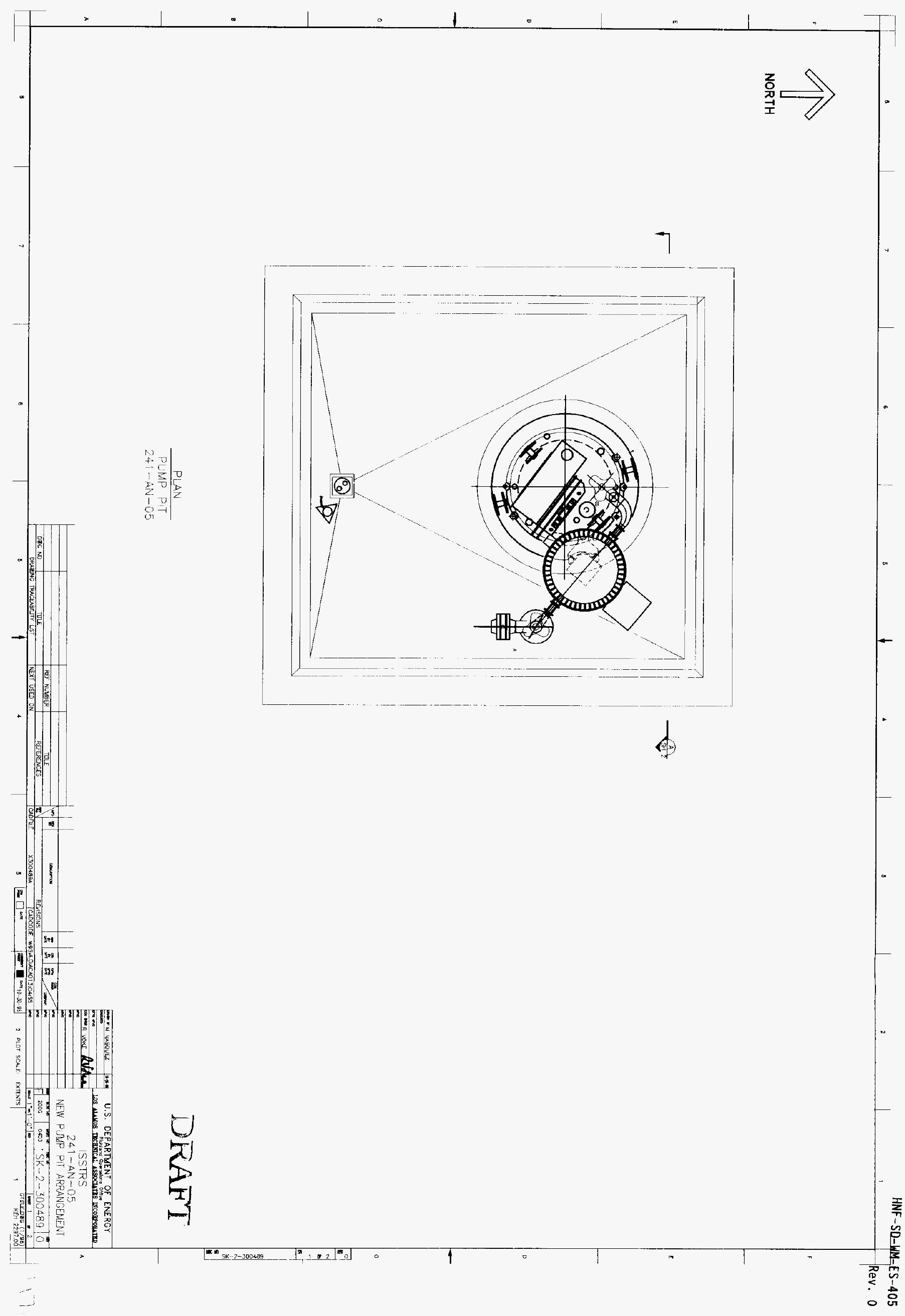




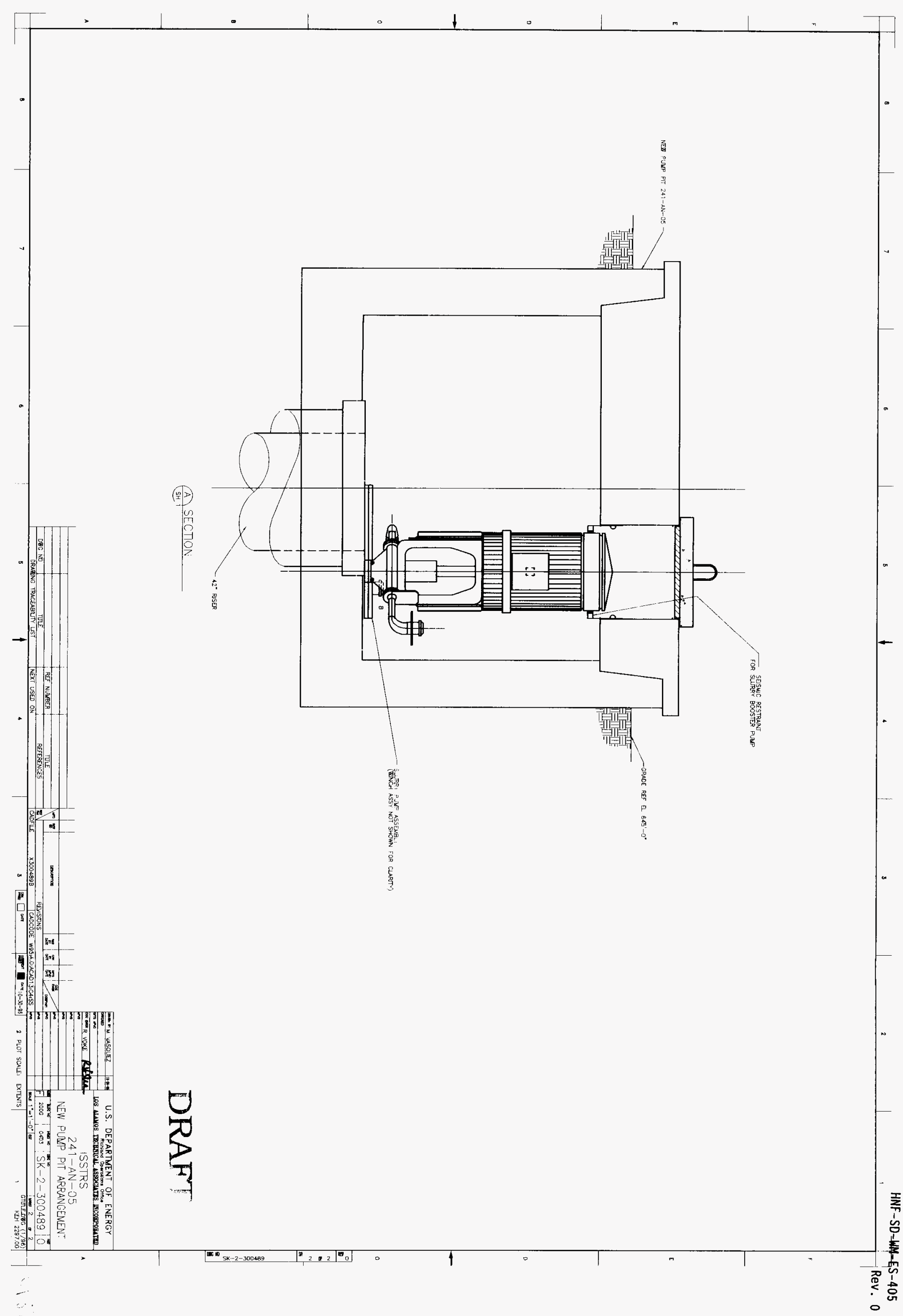




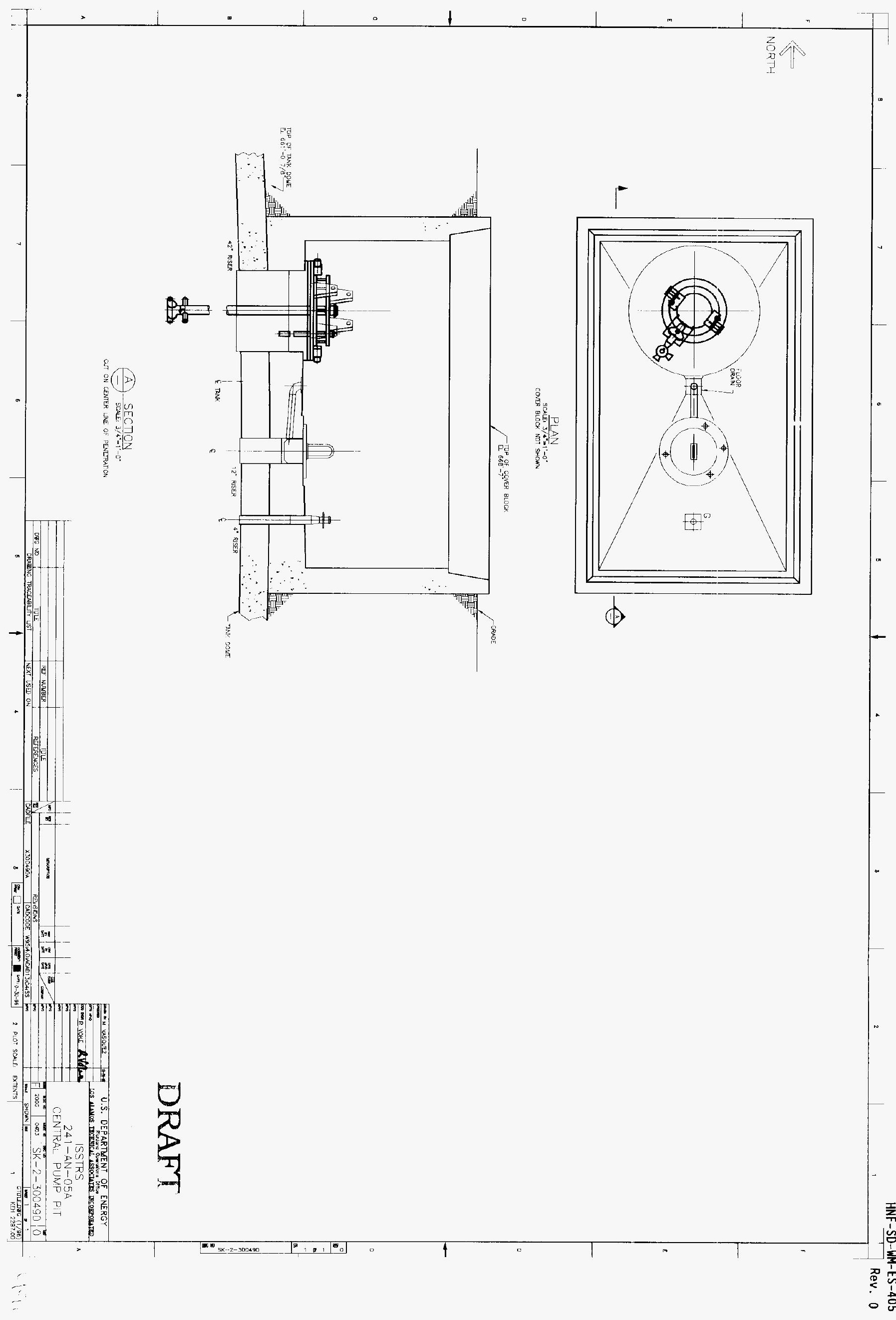




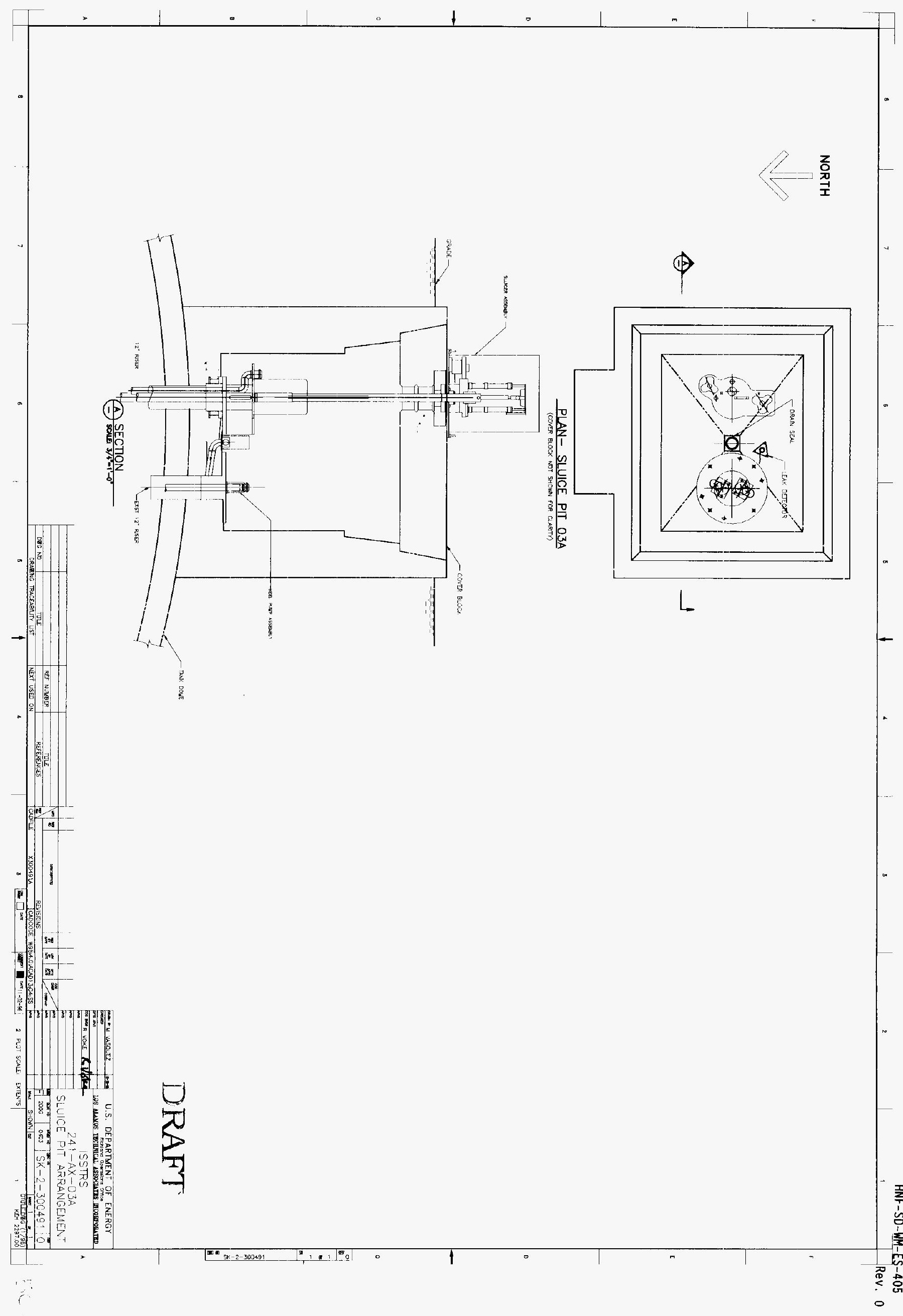




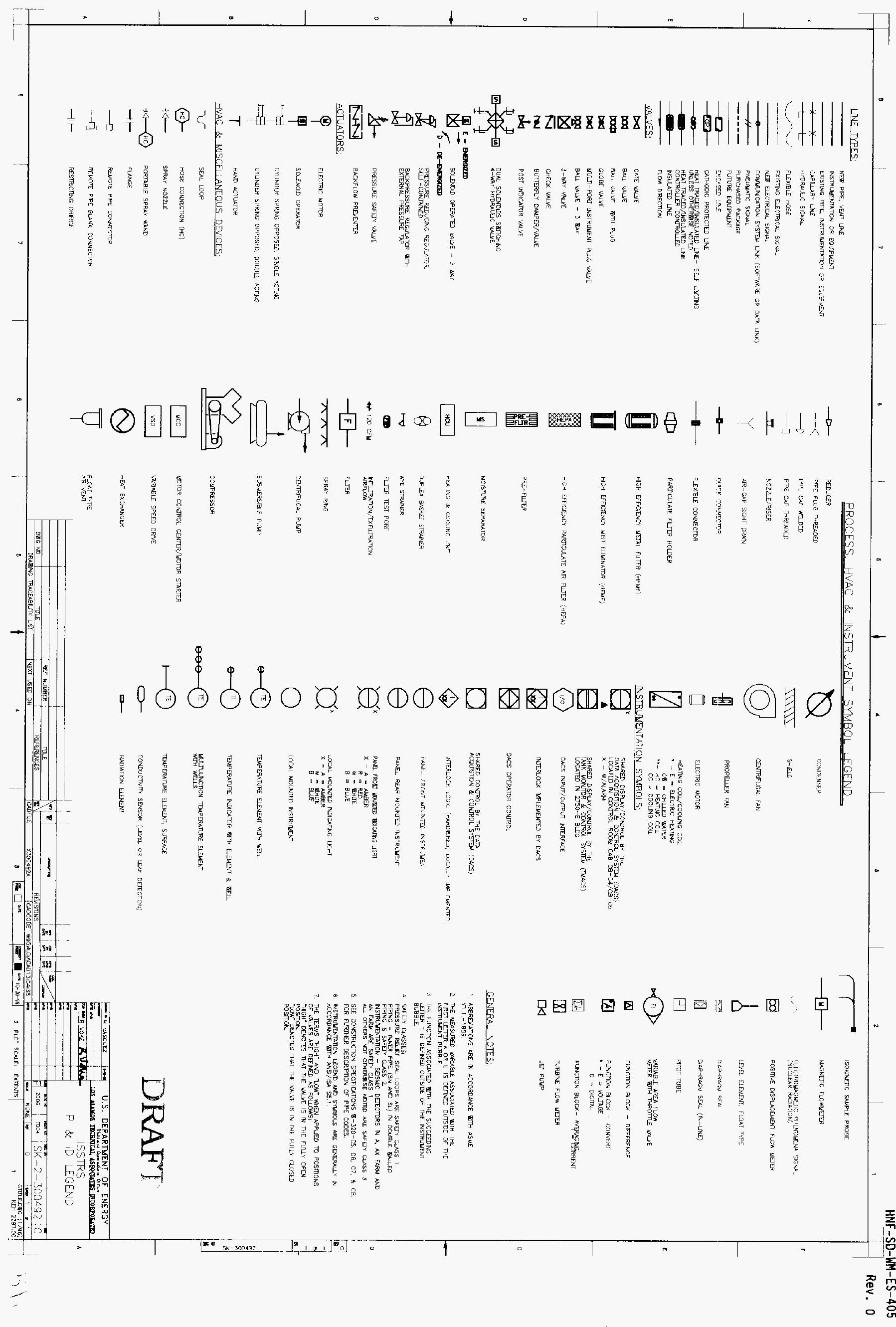




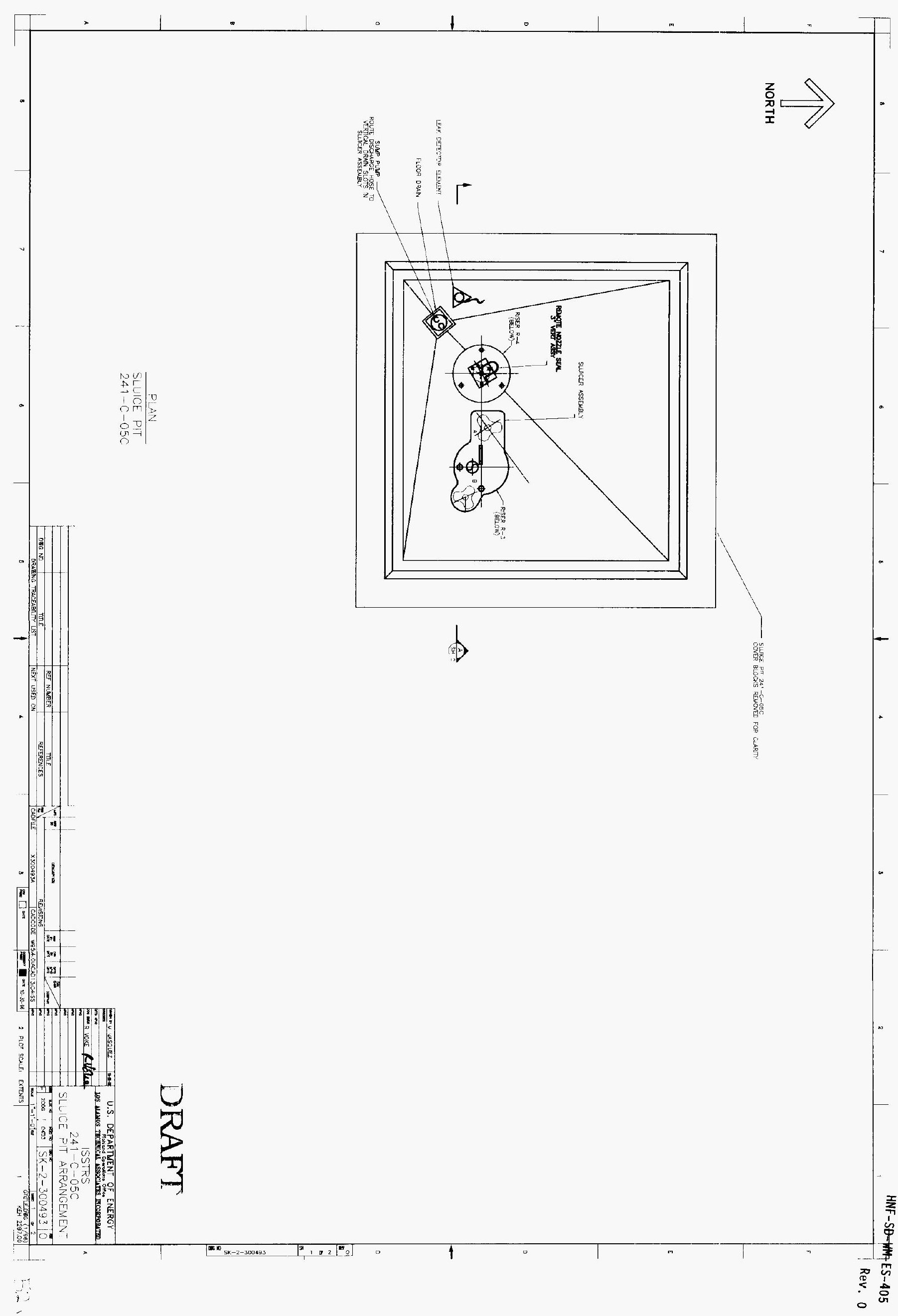




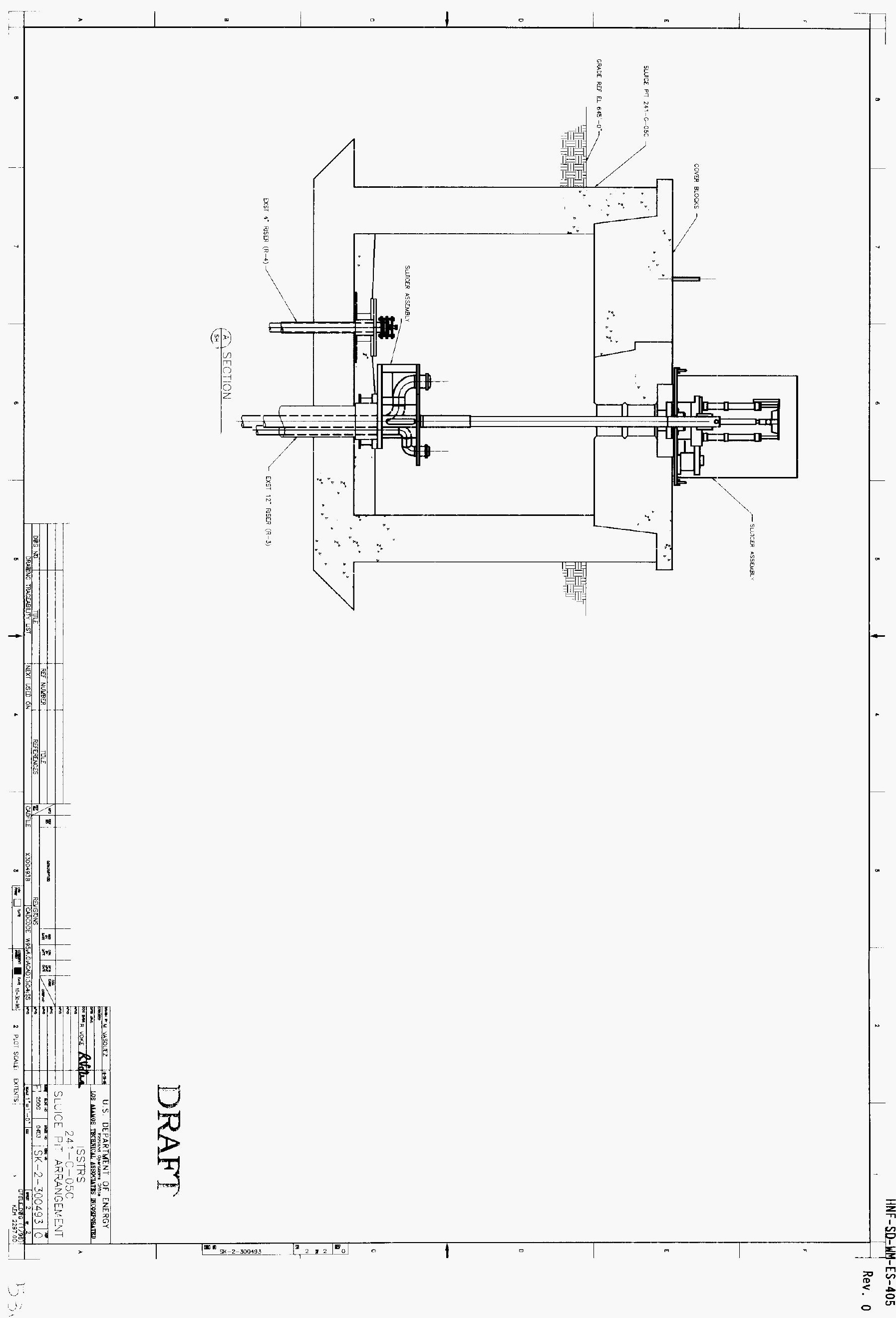




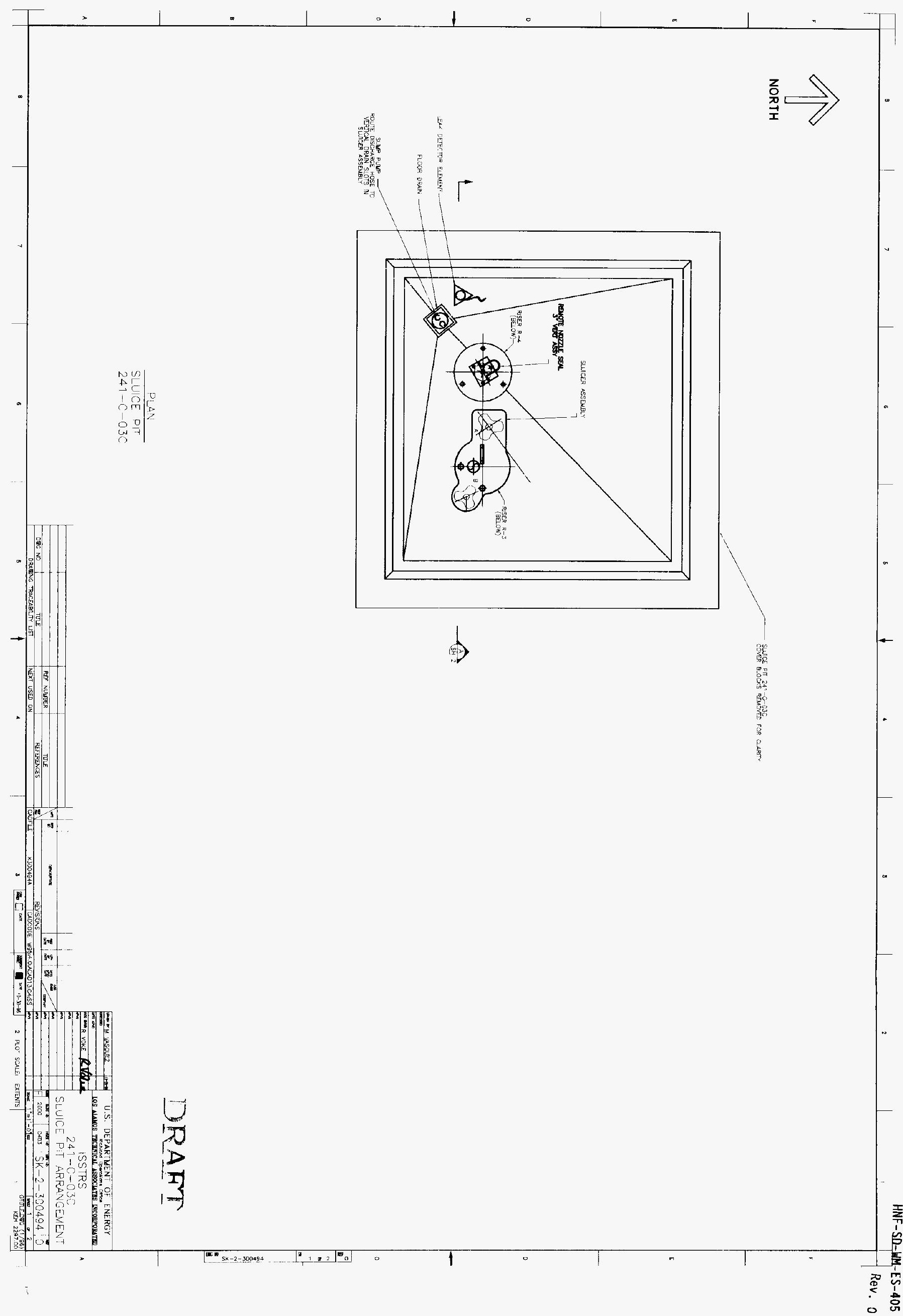




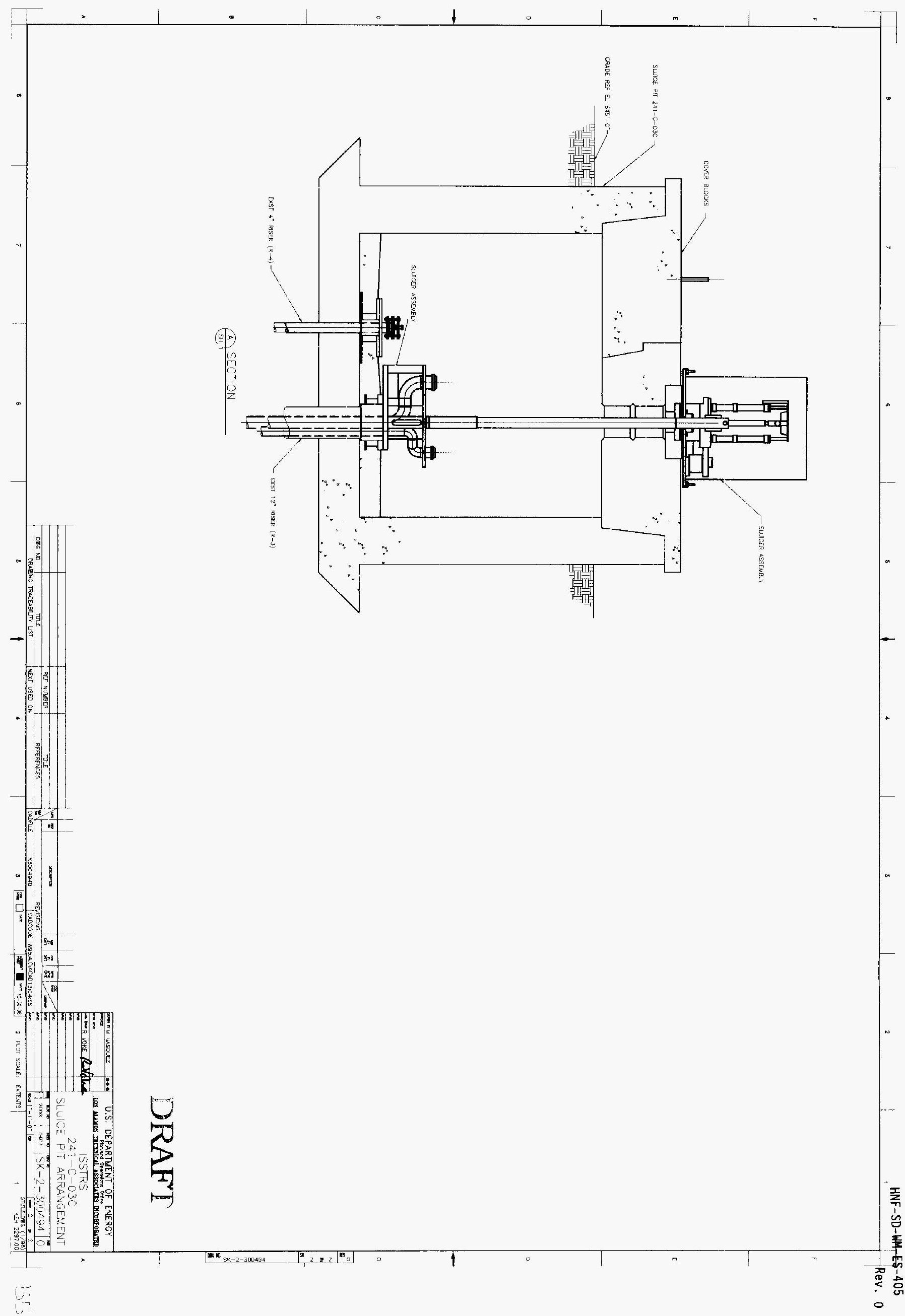




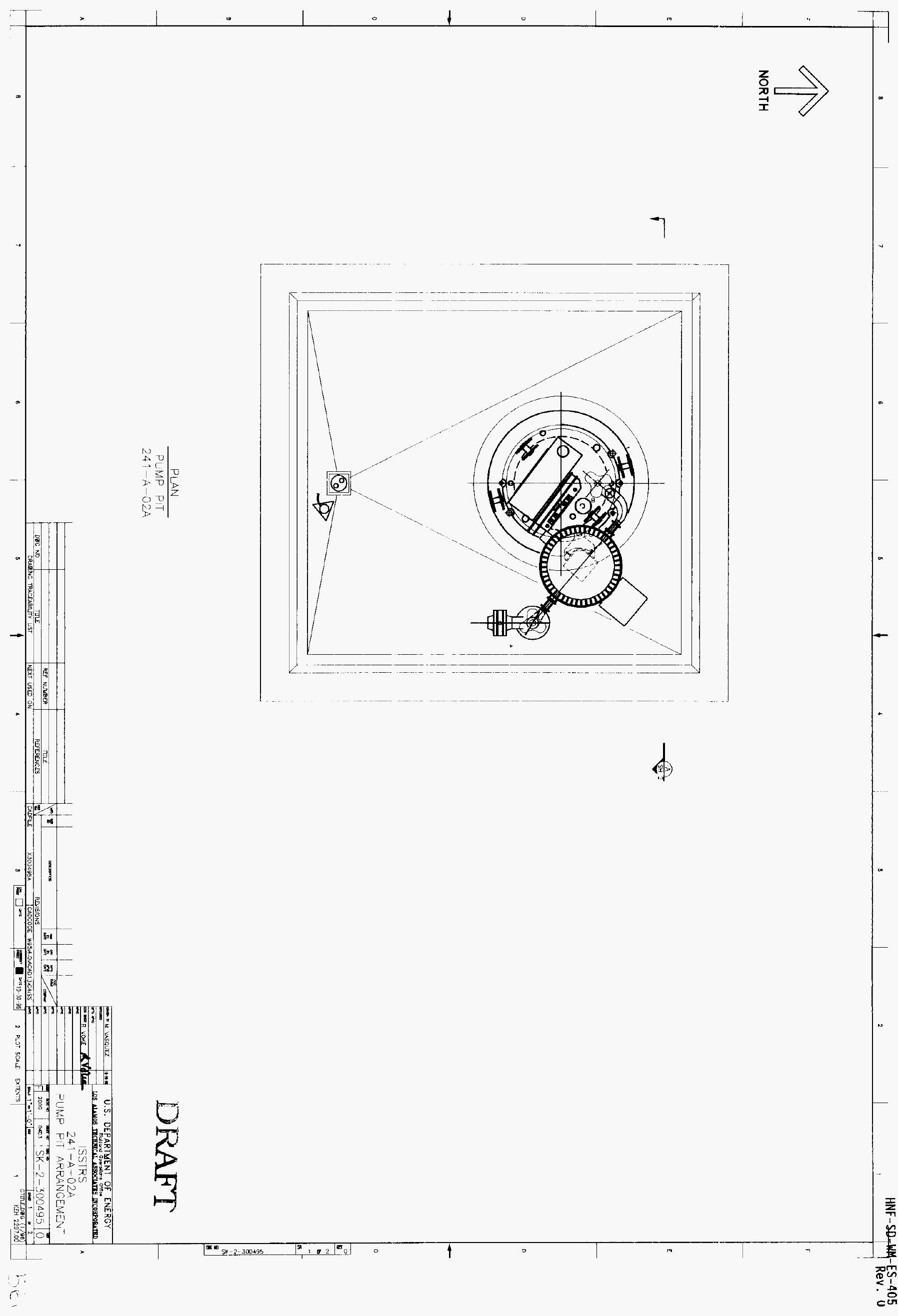




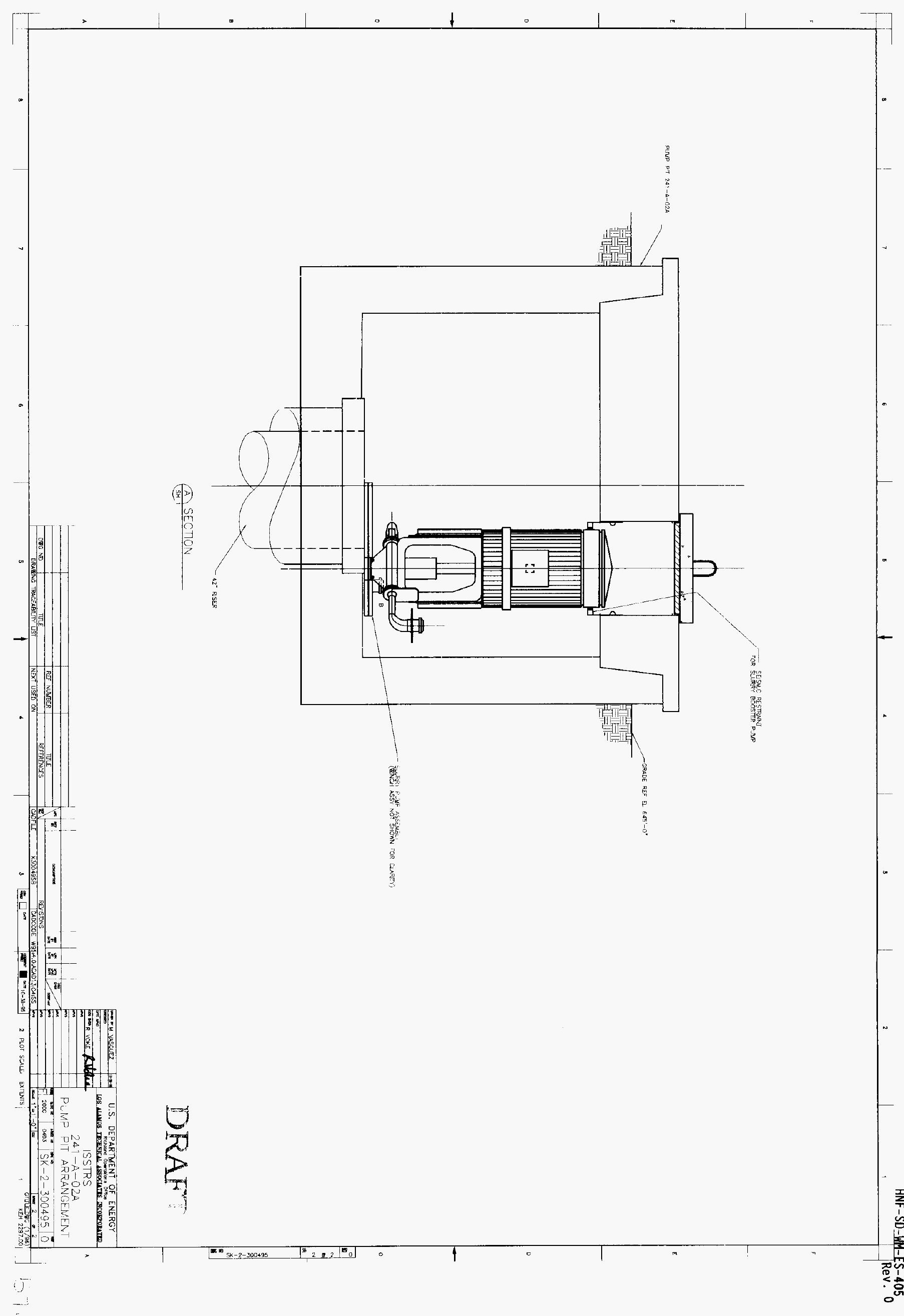




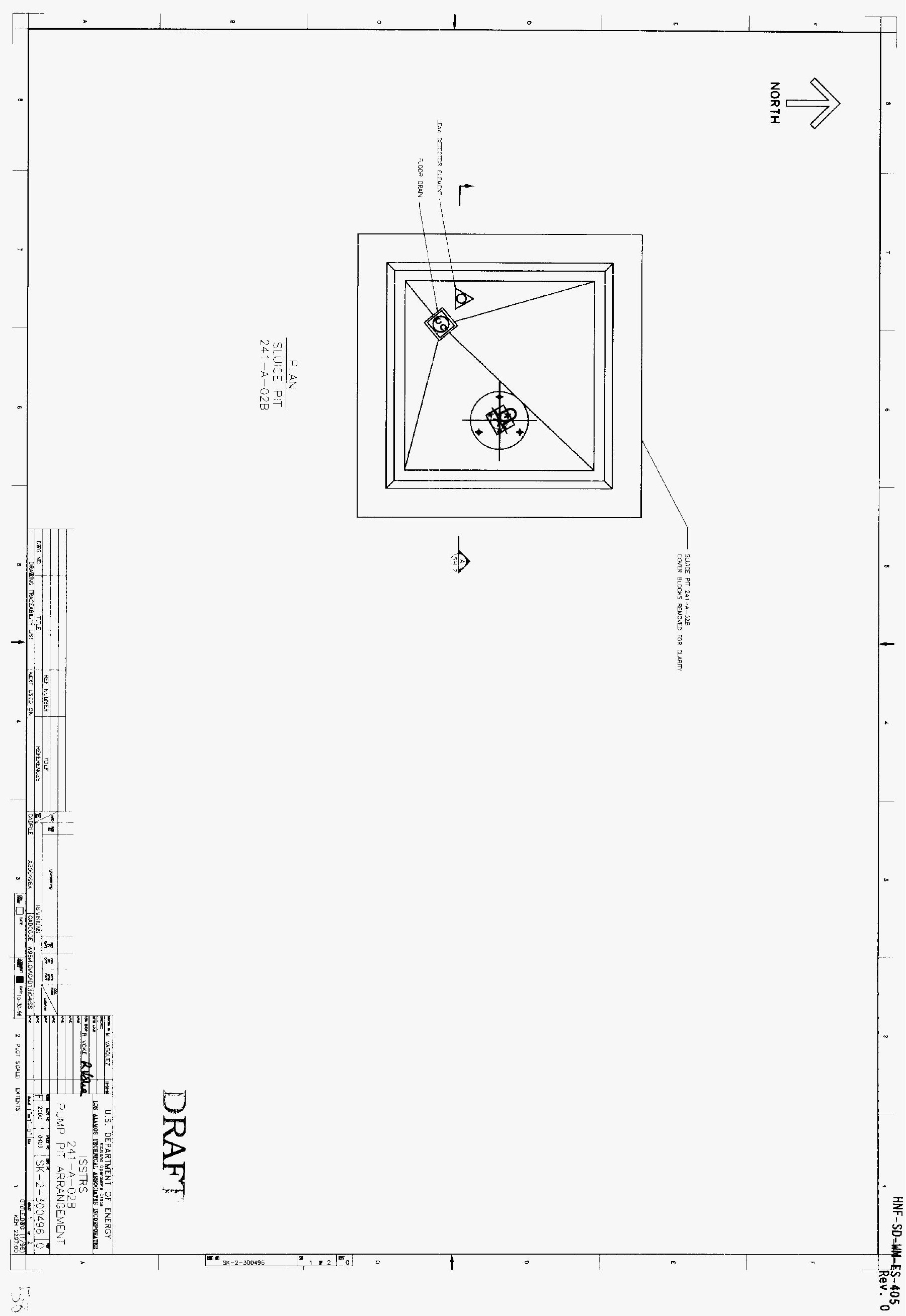




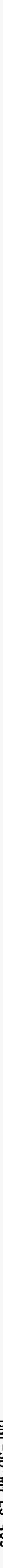




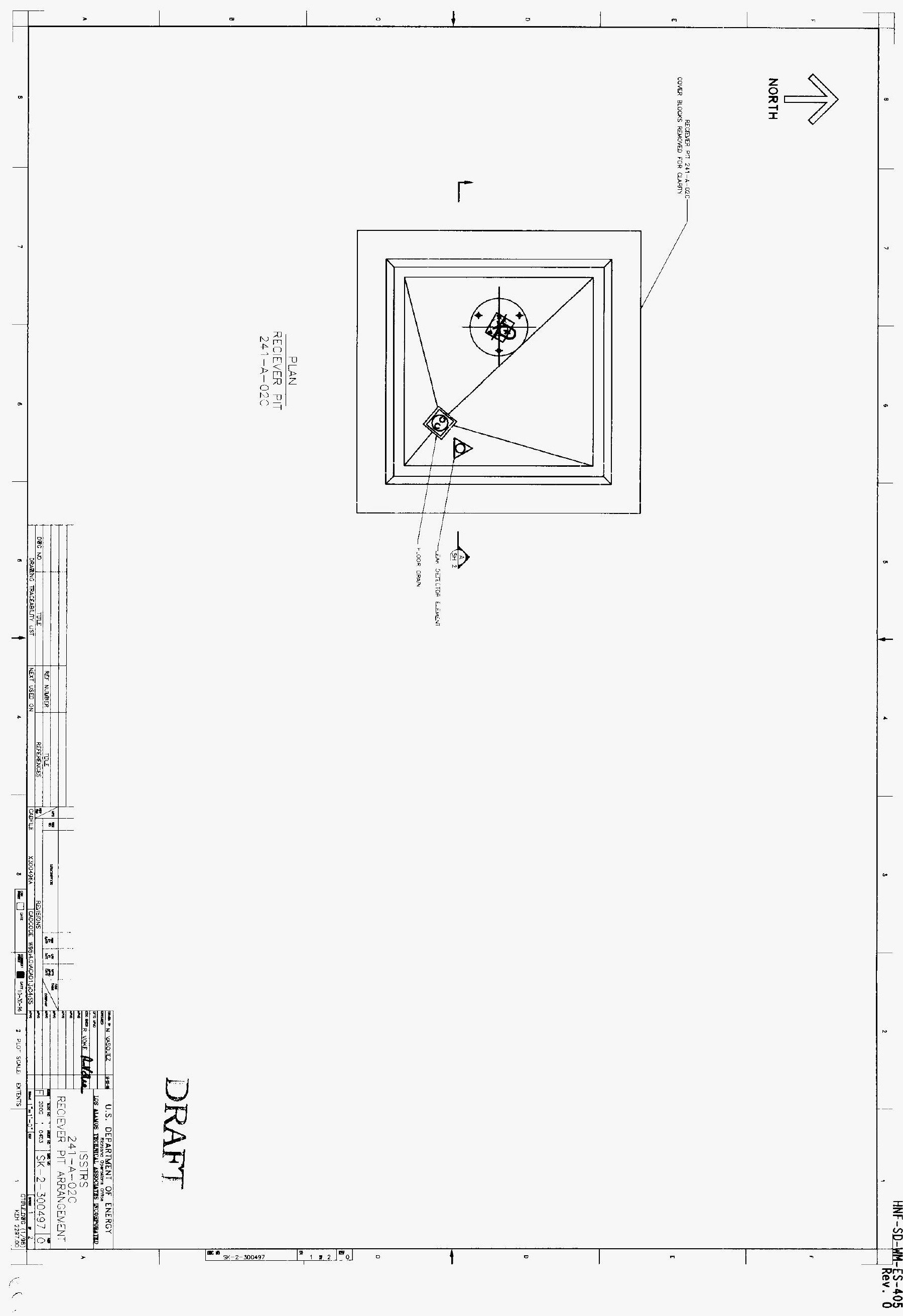




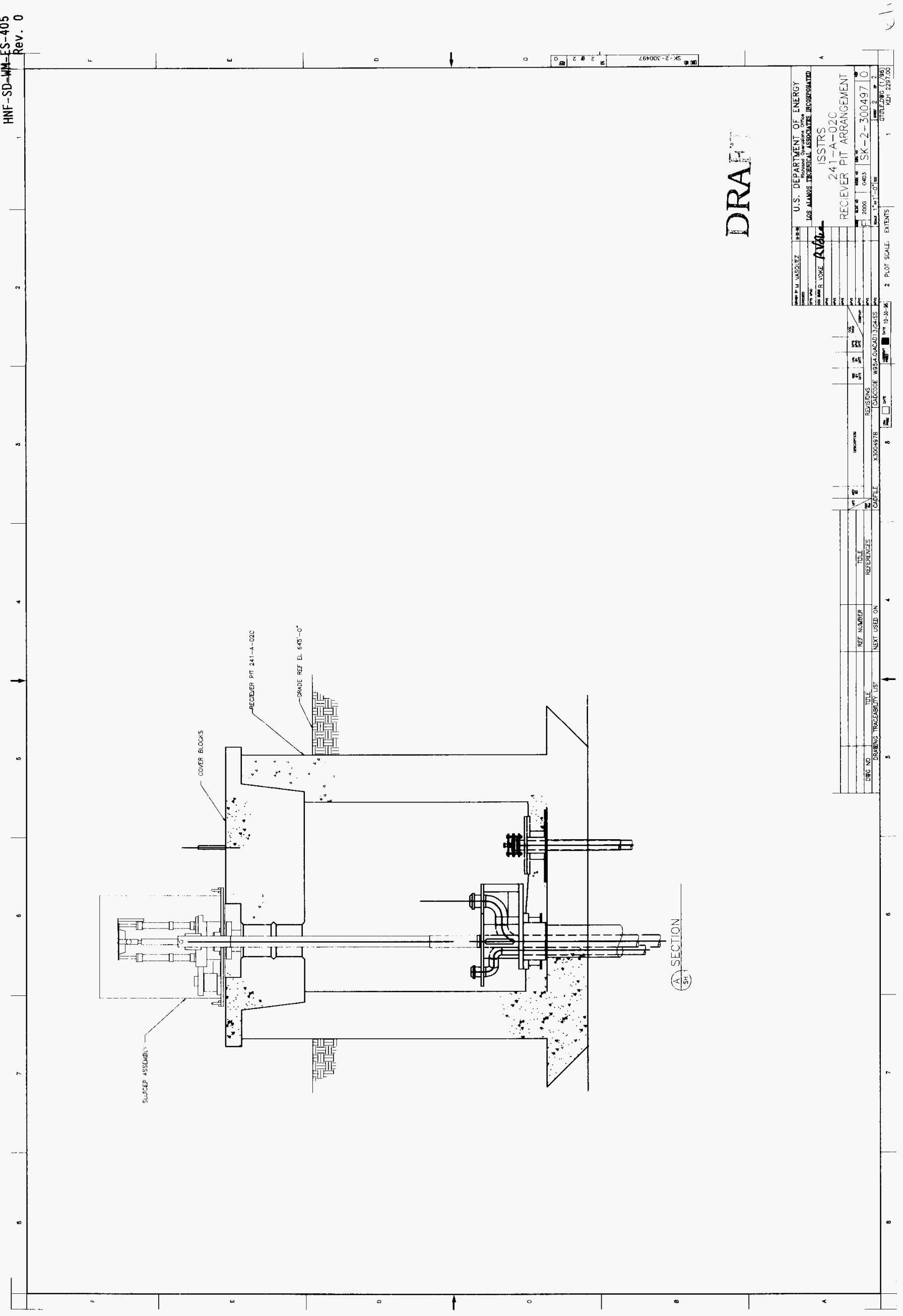




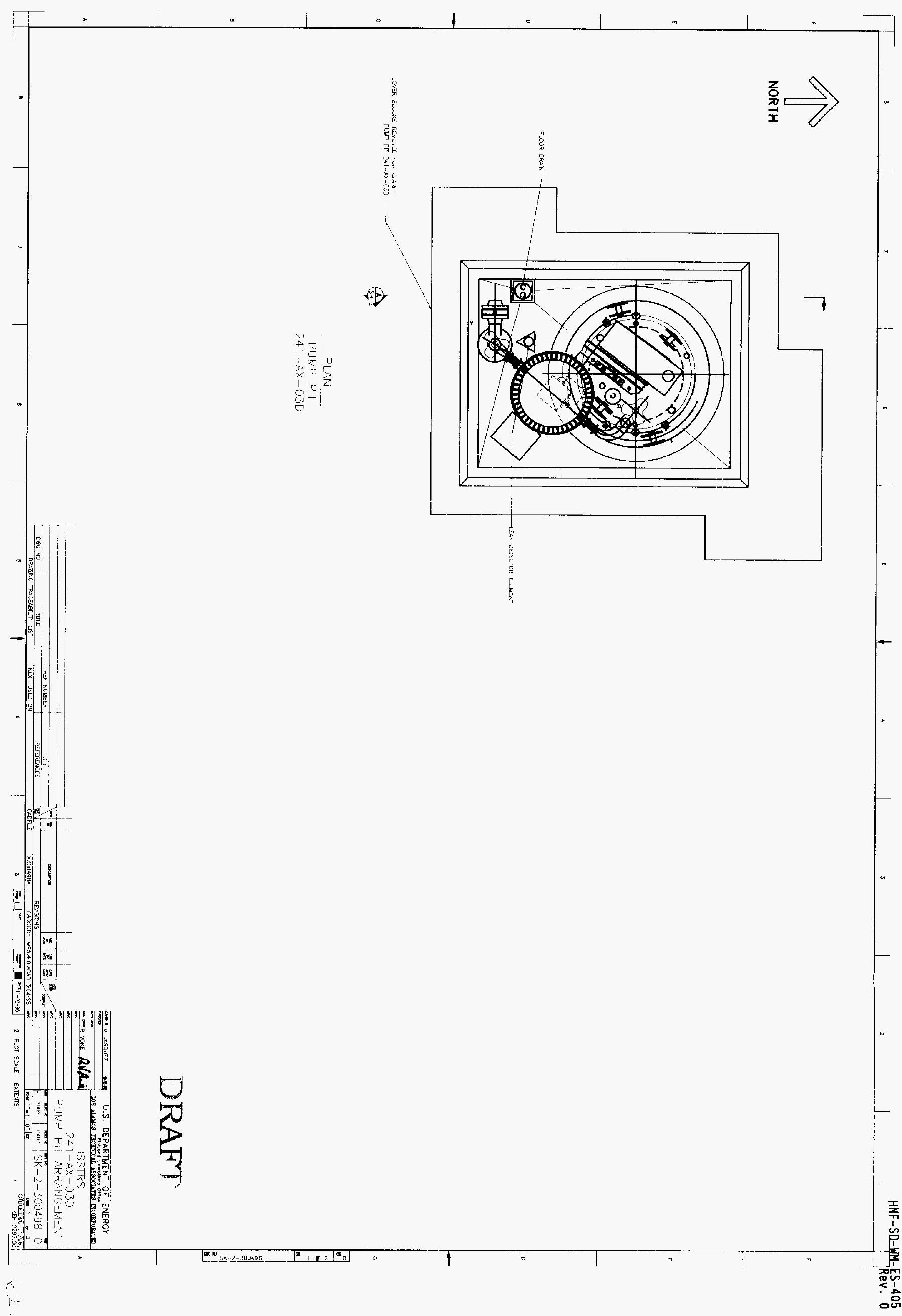




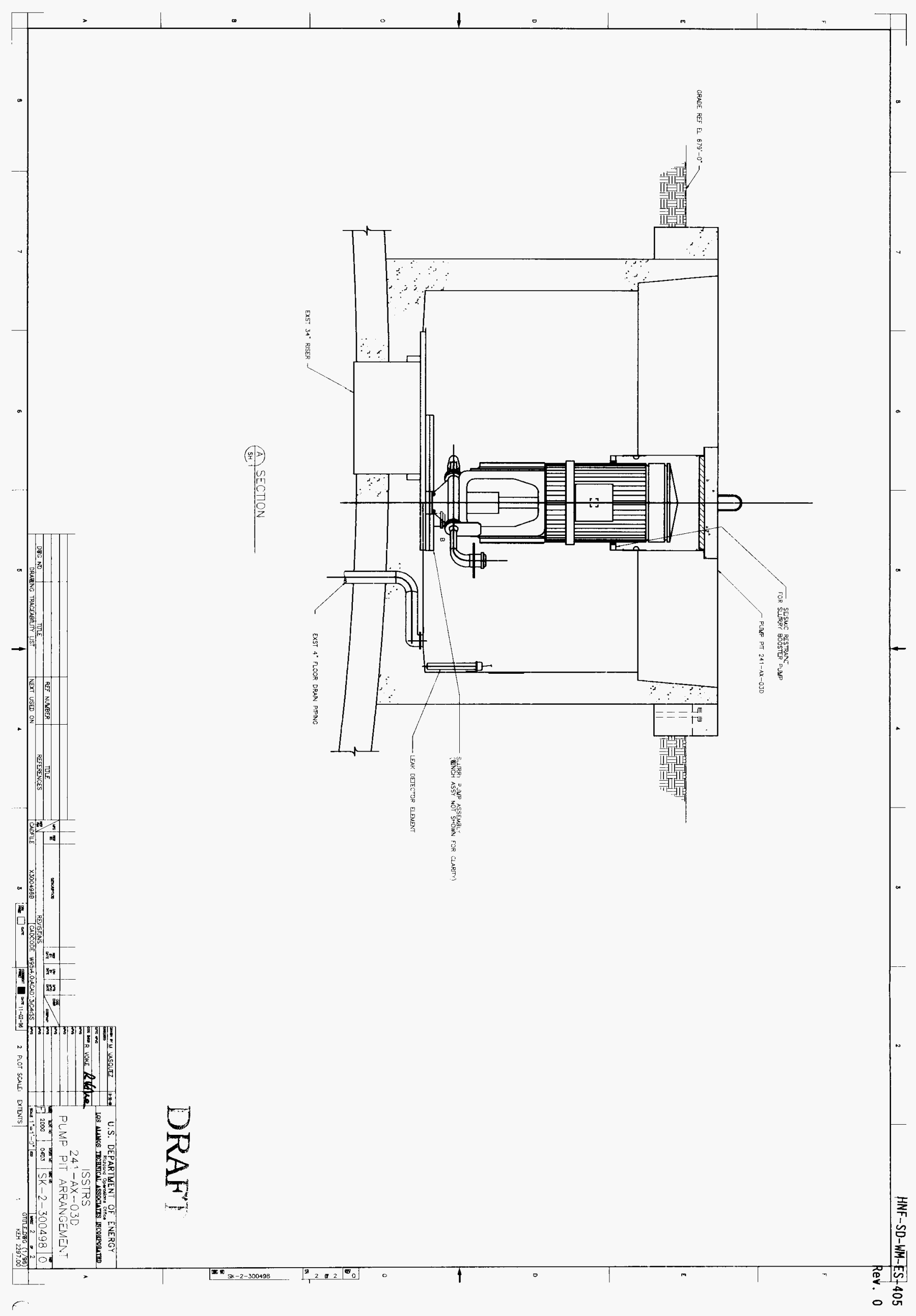




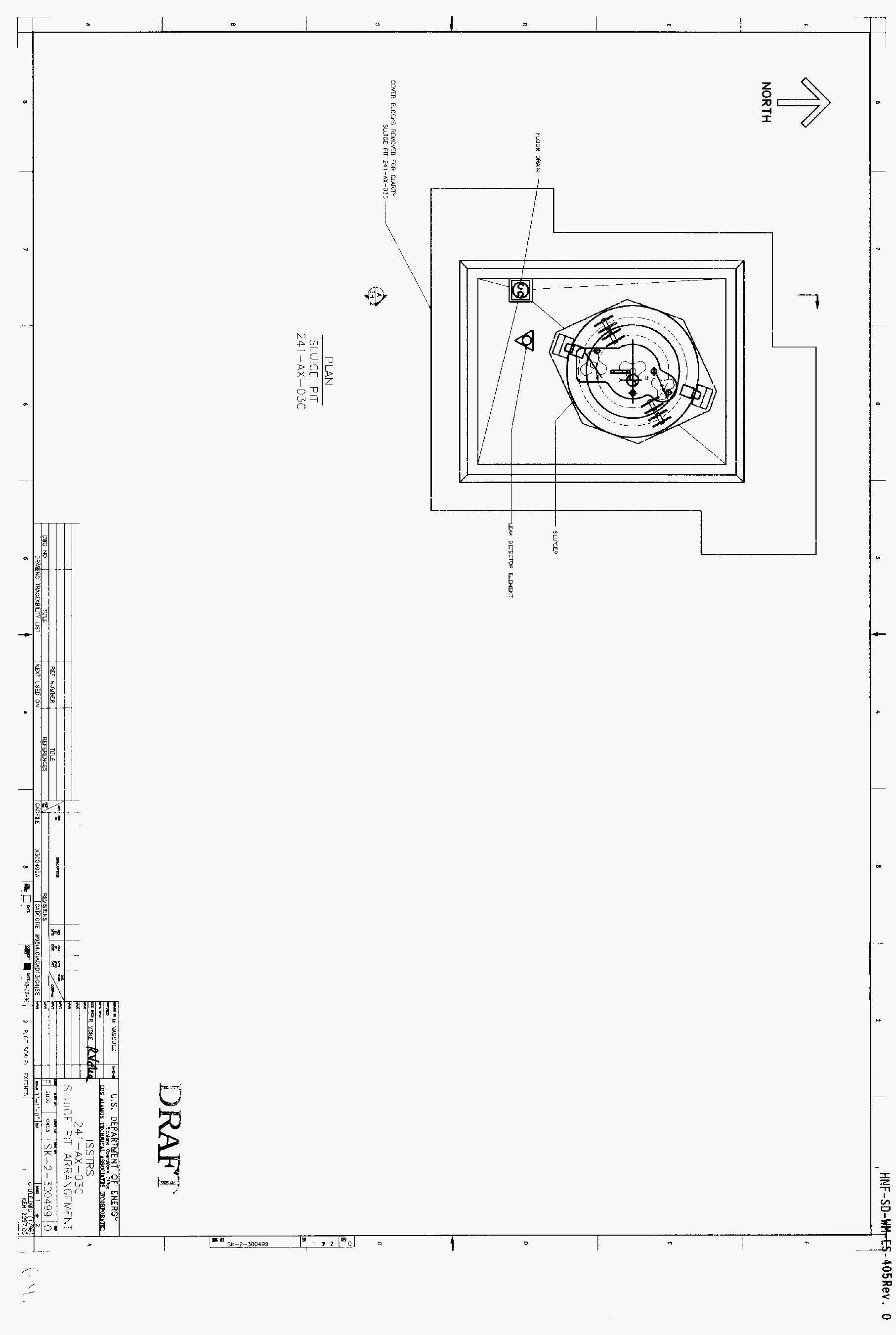




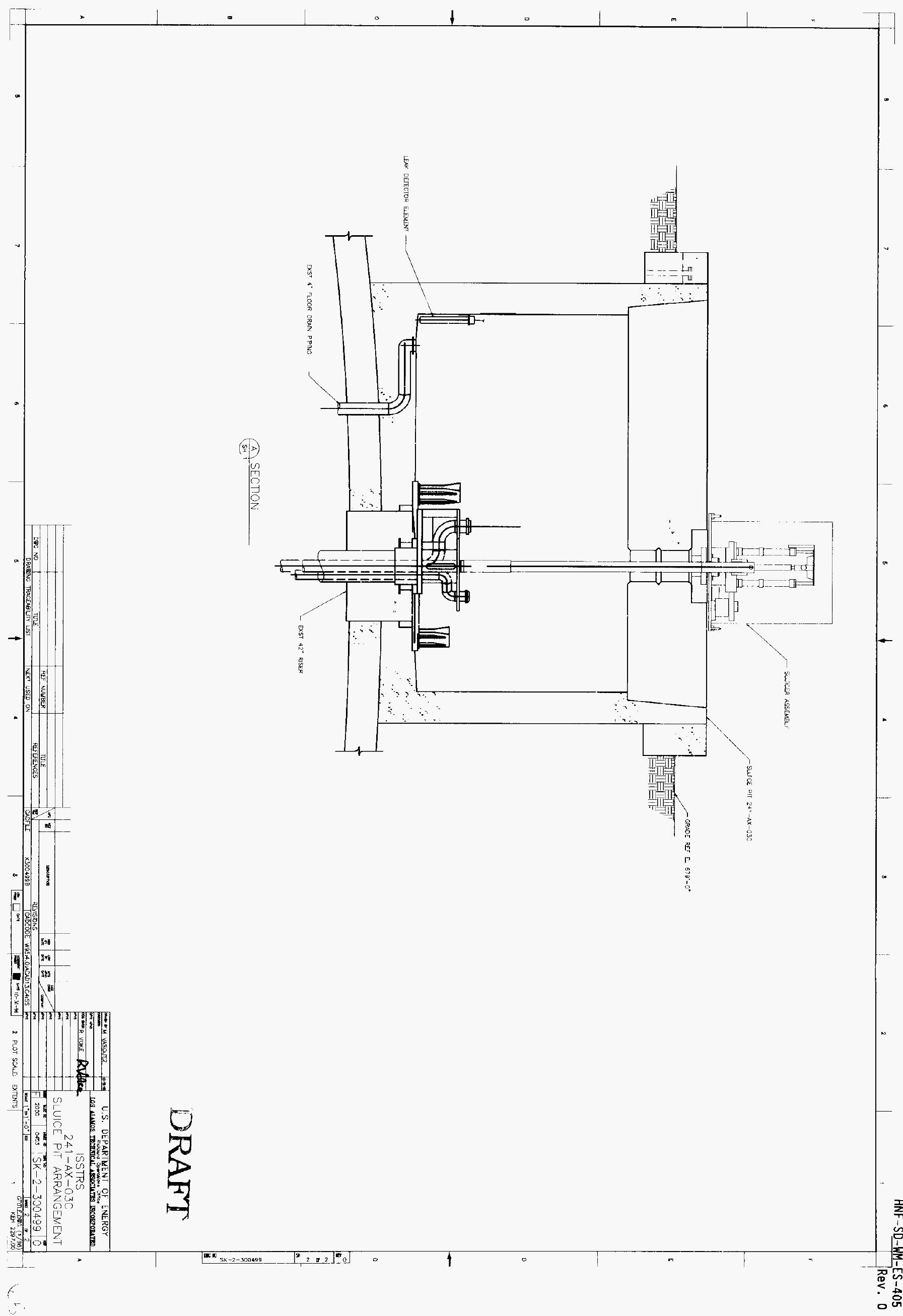




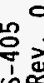

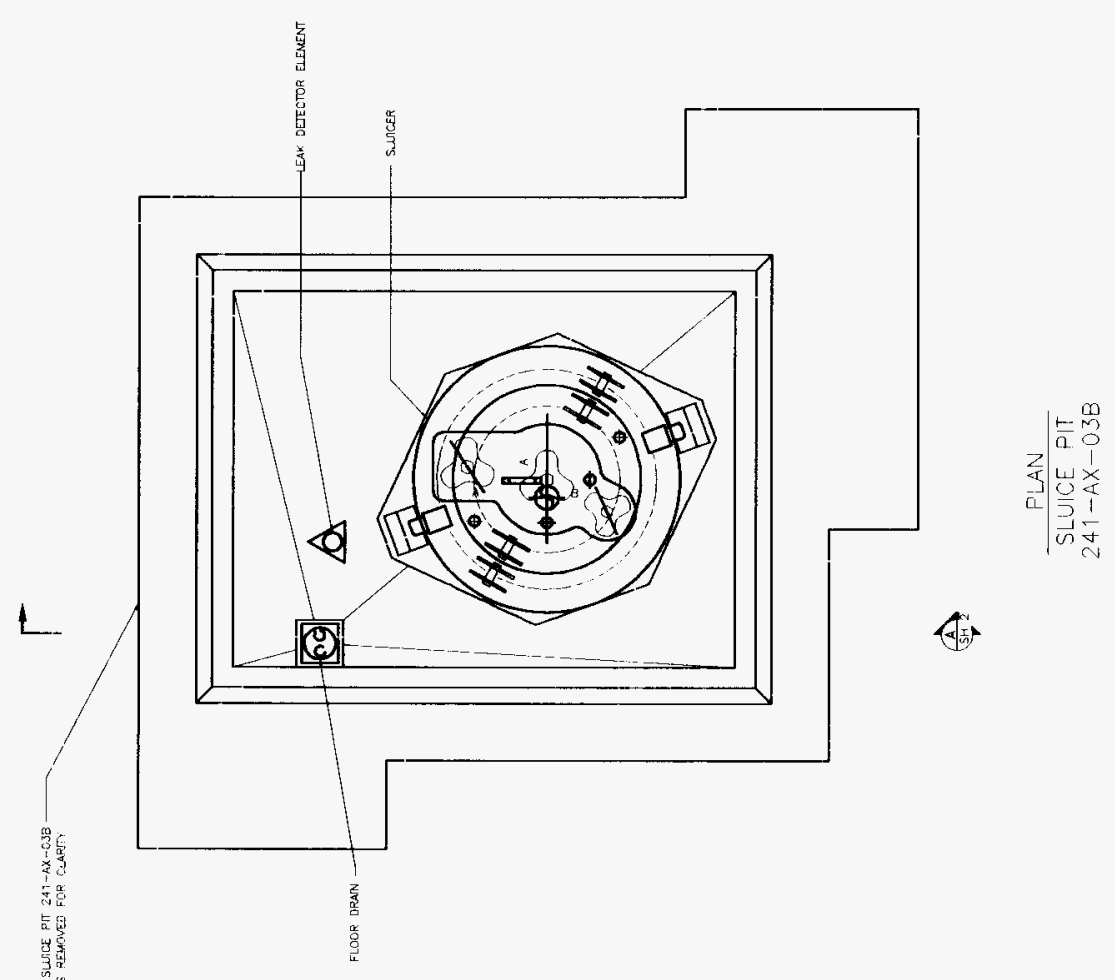



1
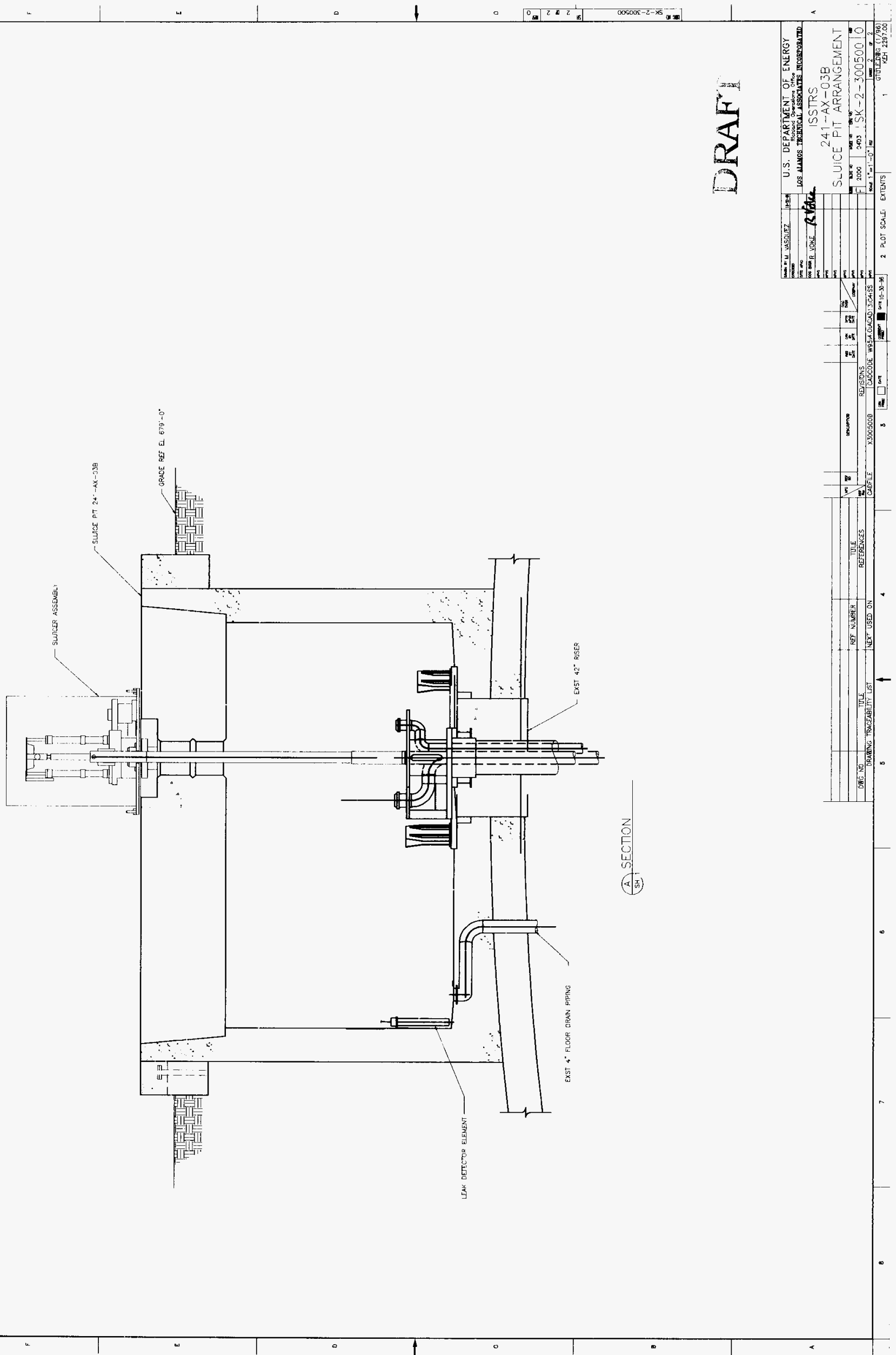


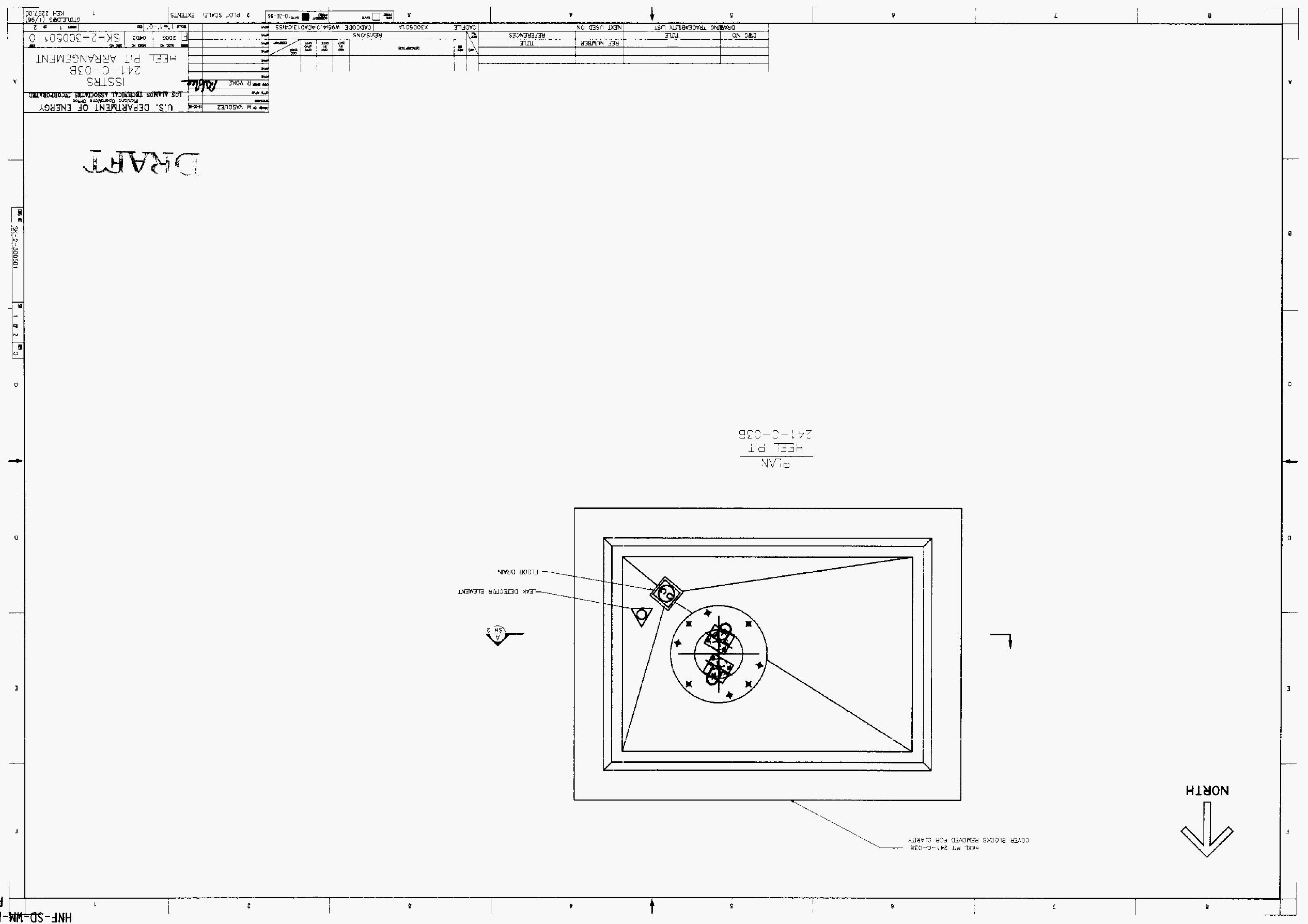




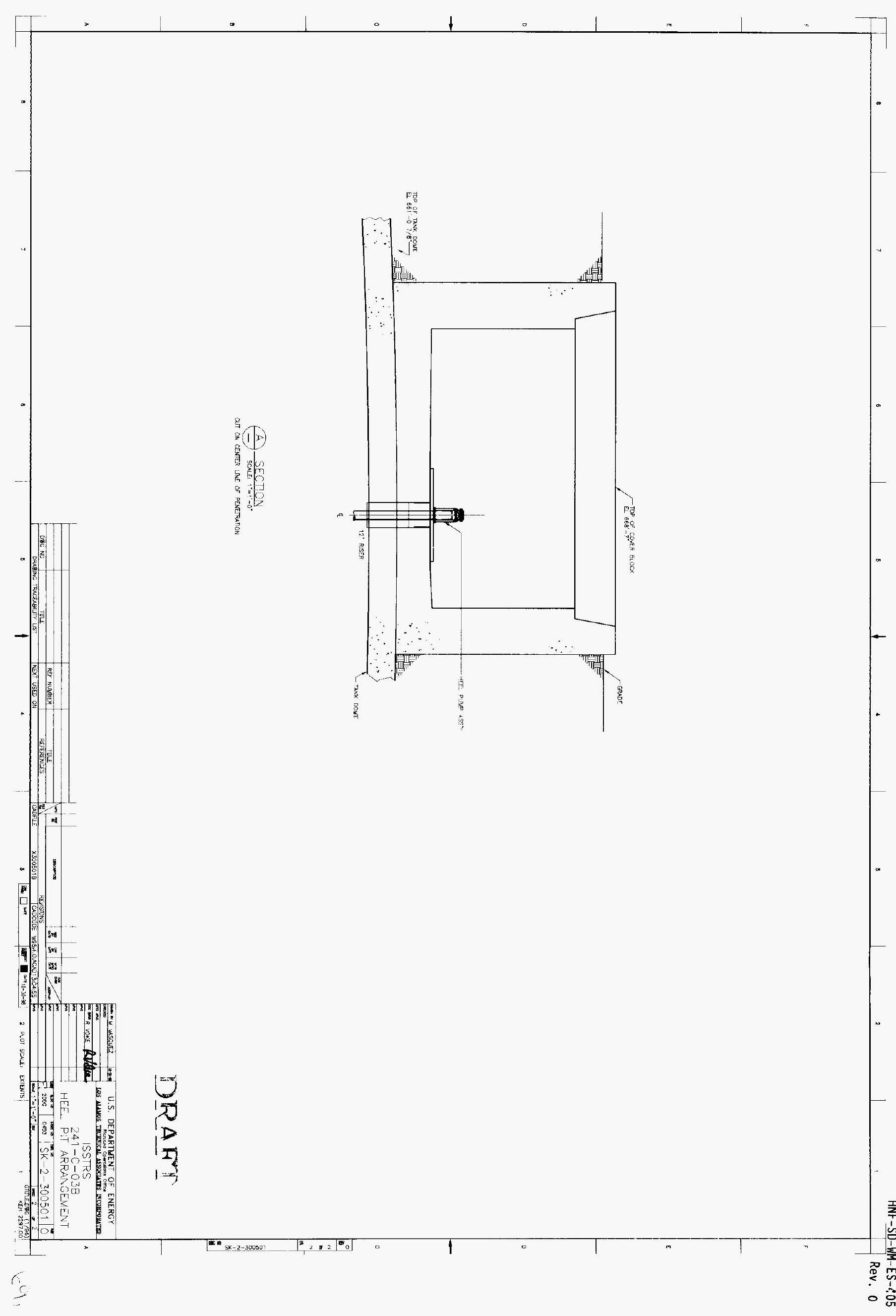




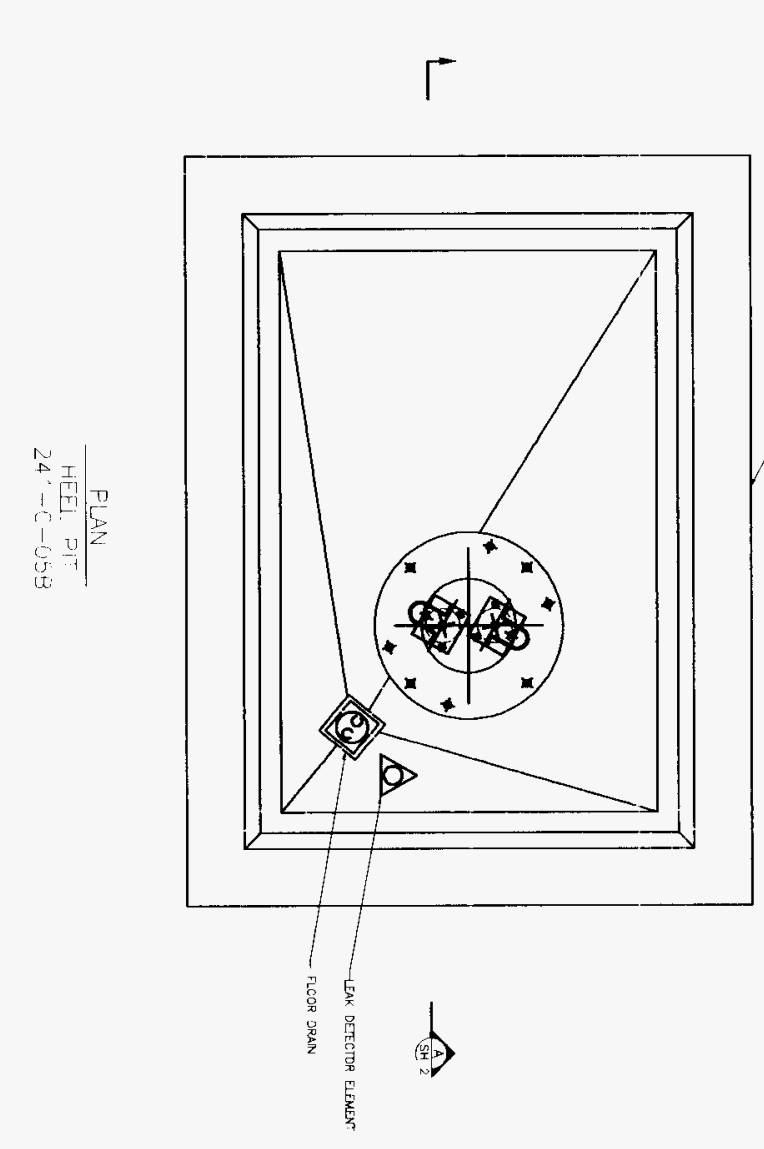

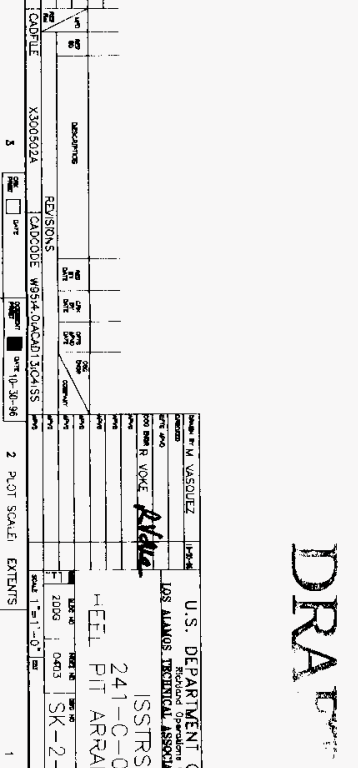

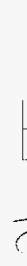




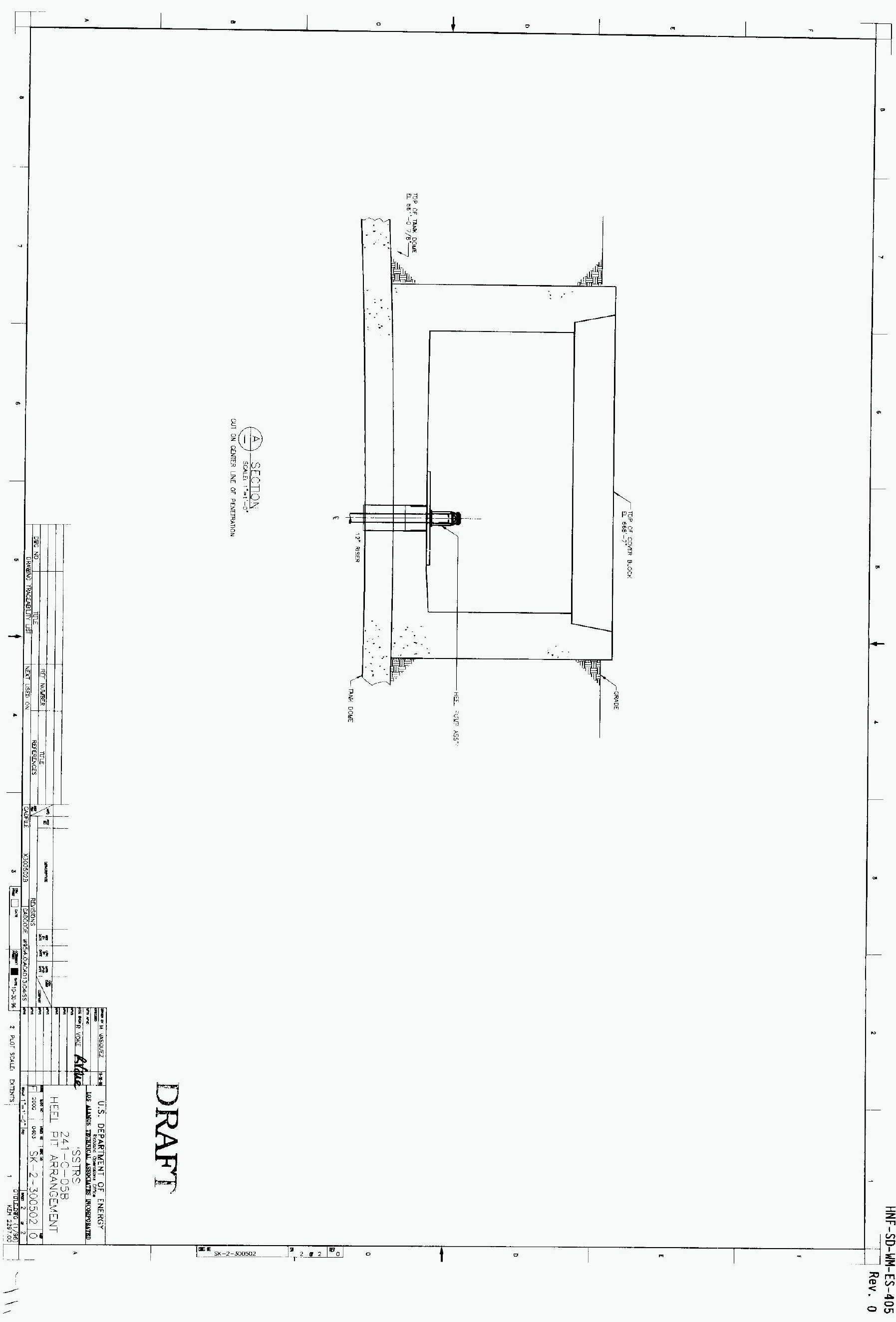

